\title{
Images and Issues
}

The Queensland State Elections of 1963 and 1966

\section{Colin A. Hughes}

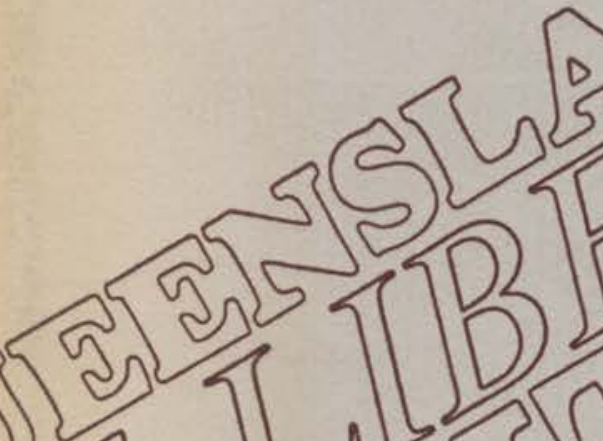


This is the fyttest account of electoral politics in an fustrolizan State yet available. It prondidesdetailed accounts of Strtepartigs und party leaders and of

sampaigymg and candidates at the grass

$D$ roop level throughout the sprawling

5 Stáf of Queensland.

Qu fensland politics have a number of

7 anlque features: the predominance with in the geverning coalition of the Colunn Pafty; the long periods of fabor kule; the heavy weighting of rural electorates; the importance of local developmente as a political issue. The ccountofthe two campaigns in 1963 and 966 is feinforced with a survey of 350 Brisbant loters in 1963, 200 of whom weyere-rented in 1966. Thus, for the folst thine, we haye a study of attitude ebange fver along period of time based 51 sample of Australjan voters. The Book provides anstyers to basic questions abput the apathy, the partisanship, and the amolynt of politicl kndwledge possessed by Australianvoters. It is Essential reading for all politicians and pdlyical parties, and will be of value to journalists and psychologists, political scientists and historians, as well as to general readers interested in politics. 
This book was published by ANU Press between 1965-1991.

This republication is part of the digitisation project being carried out by Scholarly Information Services/Library and ANU Press.

This project aims to make past scholarly works published by The Australian National University available to a global audience under its open-access policy. 
By the same author:

The Papua-New Guinea Elections, 1964 (joint editor). 1965.

The Prime Minister's Policy Speech (with J. S. Western). 1967.

Readings in Australian Government (editor). 1968.

A Handbook of Australian Government and Politics, $1890-1964$ (joint editor). 1968. 


\title{
Images and Issues
}

The Queensland State Elections of 1963 and 1966

\author{
COLIN A. HUGHES
}

Constituency studies by

K. W. Knight and M. N. B. Cribb

Ian $N$. Moles

Jennepher Stevenson 


\section{(C) Colin Anfield Hughes 1969}

This book is copyright. Apart from any fair dealing for the purposes of private study, research, criticism, or review, as permitted under the Copyright Act, no part may be reproduced by any process without written permission. Inquiries should be made to the publisher.

Wholly set up and printed in Australia by Brown Prior Anderson Pty Ltd

Registered in Australia for transmission through the post as a book

SBN 708102670

Library of Congress Catalog Card no. 75-90279

National Library of Australia reg. no. AUS 68-3902 


\section{$\therefore$. wwalking along the street during}

my lanst election, thinking of the

actuaal issues involved, and

compparing them with the vague fog

of jouurnalistic phrases, the halfconscicious impulses of old habit

and nnew suspicion which make up

the attmosphere of electioneering.

Graham Wallas, Human Nature in Politics 


\section{Ciontents}

Preface $\quad \mathbf{x v}$

1 Prelude and Interlude 1

PART I: IMAGES

2. Party Images 23

3. Party Leader Images $\quad 75$

4. Images of the Party Candidates 102

5. Images of the Independent Candidates 143

PART II: ISSUES

6. Statewide Issues $\quad 181$

$\begin{array}{lll}7 & \text { Local Issues } & 237\end{array}$

PART III: THE ELECTORATES

8. Kurilpa and South Brisbane 263

9) Salisbury and Sherwood 276

10) Townsville South 304

$\begin{array}{lr}11 & \text { Townsville North } \\ \end{array}$

Appendixes $\quad 326$

References $\quad 352$

Index of Persons $\quad 353$

Index of Subjects $\quad 361$ 


\section{IIllustrations}

FIGURES

I I Frequency of party image scores 1963

$\therefore 2$ Frequency of party leader image scores 1963 and $1966 \quad 96$

؛3 Kurilpa and South Brisbane 266

4 Voting in Kurilpa and South Brisbane 267

!5 Salisbury and Sherwood 278

16 Voting in Salisbury and Sherwood 279

:7 Townsville South and Townsville North $\quad 316$

i 8 Voting in Townsville South and Townsville North 317

:9 Ashgrove, Baroona, and Ithaca 328

110 Voting in Ashgrove, Baroona, and Ithaca 329

MAPS

Metropolitan electoral districts, Brisbane

Provincial cities and country zones 


\section{Tables}

1.01 Voting and representation 1956-60 11

2.01 Party images $1963 \quad 60$

2.02 Average scores on party images 1963

2.03 Cross-tabulations of party image scores 1963

$\begin{array}{lll}2.04 & \text { Party images } 1966 & 67\end{array}$

2.05 Change in party images 1963-6: reinterviewed group 68

2.06 Average group scores on party images 1963 and $1966 \quad 68$

2.07 Cross-tabulations of party image scores $1966 \quad 69$

2.08 Average party image scores of vote changers 1963-6 71

2.09 Party image scores of occupational groups $1963 \quad 72$

2.10 Party image scores of religious groups $1963 \quad 73$

3.01 Party leader images $1963 \quad 93$

3.02 Party leader images $1966 \quad 95$

3.03 Average scores on party leader images 1963 and $1966 \quad 97$

3.04 Cross-tabulations of party leader image scores 1963 and $1966 \quad 98$

3.05 Partisans, 'cool ones', and deviants in 1963 and $1966 \quad 99$

3.06 Cross-tabulations of party image scores and party leader image scores 1963 and $1966 \quad 99$

3.07 Party leader image scores of occupational groups $1963 \quad 100$

3.08 Party leader image scores of religious groups $1963 \quad 101$

3.09 Party leader image scores of age groups $1963 \quad 101$

4.01 M.L.As.' roles 1963

4.02 M.L.As.' duties $1963 \quad 130$

4.03 M.L.As.' roles 1963: electorate differences 131

4.04 Ranking scores of M.L.As.' roles 1963 
4.05 First priority among M.L.As.' roles 1963

4.06 Identification of M.H.Rs. for the federal electorates of Brisbane and Ryan 1963

4.07 Identification of City Council aldermen $1963 \quad 135$

4.08 Identification of State election candidates $1963 \quad 136$

4.09 Identification of Ministry members $1966 \quad 139$

4.10 Identification of possible Labor Ministry members $1966 \quad 141$

5.01 Readiness to vote for a Liberal candidate in Albert $1963 \quad 165$

6.01 Numbers of registered unemployed in Queensland 1961-3 189

7.01 Opinions of voters in Albert and South Coast on the Jubilee Bridge issue 1963

7.02 Opinions of voters in Toowoomba East on the university college 1963

7.03 Opinions of voters in Toowoomba East on the Government's record on transport regulation 1963

7.04 Votes received in Burdekin in 1960 and 1963

APPENDIX A

A.01 Voting intention of sample compared with actual vote 1963

A.02 Age and religion of sample 1963 and area 1961

A.03 Occupations of sample $1963 \quad 330$

A.04 Occupations and religion of sample $1963 \quad 330$

A.05 Occupations and age of sample 1963

A.06 Completed questionnaires returned 1963 . · 332

A.07 Occupations of persons to whom questionnaire sent and by whom questionnaires were returned 1963

A.08 Characteristics (1963) of original panel and group reinterviewed

A.09 Party leader image scores (1963) of whole panel and reinterviewed group

A.10 Party images 1963 held by whole panel and reinterviewed group 
APPENDIX B Election results, enrolments, and electorate area $1960,1963,1966$

APPENDIX C Independent candidates at State elections 1945-66 


\section{Preface}

A. DDECADE ago, surveying the literature of Australian government and poollitics in company with S. R. Davis, I wondered whether it would erver prove possible to report an Australian federal election on a scale ccomparable with that which the Nuffield College series had provided foor Great Britain. D. W. Rawson's Australia Votes soon undertook exxactly this job for the 1958 federal election, but since then another three national elections have gone unchronicled in Australia and the suspicion revives that the geographic facts of Australian politics ccoupled with the thin scatter of Australian political scientists militate ąggainst such an exercise. Similar problems confront a study of a Queensland state election, involving as it does the activities of just over three-quarters of a million voters spread over two-thirds of a million square miles.

This book began whilst I was a Fellow of the Institute of Advanced Situdies of the Australian National University, and was completed aifter I had returned to the University of Queensland after some years' albsence. It is intended to provide the flavour of Queensland state poollitics and electoral behaviour at two points of time rather than supply a tightly ordered account of two great debates. Whenever prossible parties and candidates have been allowed to speak for themstelves in their own words, but because of the impossibility of personal reeportage over the distances involved, local press accounts have been reelied on for the first seven chapters and, inevitably, some electorates have randomly been given prominence because they are well served b)y their local newspapers. Yet I doubt that too great violence has been dlome to the reality of a Queensland election by this approach. Whilst there are Statewide issues and concerns which affect all voters, there sthould also be something of a Tolstoyan view of the battlefield about at report which tries to approach realism, and the text owes as much tco John Dos Passos as to David Butler.

My debts are indeed substantial. To the Australian National Univerersity and the University of Queensland for the research grants which supported the two surveys of Brisbane voters, and to Mr Roy Morgan of the Australian Gallup Polls and his interviewers who ccomducted them, with some assistance from students of the University of Queensland in 1966. To the editors of various newspapers for permission to quote from their columns: the Brisbane Courier-Mail, TTelegraph and Sunday Mail, the Gold Coast Bulletin, the Toowoomba 
Chronicle, the Maryborough Chronicle, the Bundaberg News-Mail, the Rockhampton Morning Bulletin, the Bowen Independent, the Mackay Daily Mercury, the Townsville Daily Bulletin, the Cairns Post, the Adelaide Advertiser, and the Perth West Australian. To the state secretary of the Liberal Party for permission to quote from the Queensland Liberal. To Mrs Kim Tinnion, Mrs Norma Willis, Miss Maureen Barnes, Miss Anne Doggett and Miss Megan Gayler for typing, and Miss Geraldine O'Connell and Miss Beverley Nagel for research assistance. To the staff of the A.N.U. Press for their forebearance, and Mr Hans Gunther for his skill with maps and graphs. To colleagues at Canberra and Brisbane who were prepared to humour a known eccentricity and talk about Queensland politics, and in particular to the Brisbane and Townsville colleagues who provided the constituency studies. To Queensland candidates who provided campaign literature and explained what they were doing and why. To my wife who did not object to a midden of newspaper clippings, punch cards, and manuscript deposited in her house for an inordinately long time. And, finally, an affirmation: whatever may have become of the principle of ministerial responsibility, I still believe firmly in the principle of an author's responsibility for what he has written.

Brookfield

November 1968 


\section{Prelude and Interlude}

TiHus book takes two slices from the political history of Queensland, at 1 June 1963 and 28 May 1966. the days on which the elections it deesicribes took place. The story really begins some seventy years earlier, when the first Labor members were returned at the 1893 ellection. The infant Labor Party offered forty-six candidates and returned sixteen of them with about 23 per cent of the vote. At one sttroke Labor was established as the second party of the colony, even though it did not claim the official status of Opposition until 1898 and it was very much of a regional party with eleven of its members siitting for pastoral and mining seats in the north and west. The next twenty years were spent by Labor in organising a tightly disciplined prollitical machine based on trade unions and electorate branches in wihich ultimate authority lay with the elected party executive and poarty conference and outside the parliamentary party and in battling frrom its original base in the outback onto the coast and into Brisbane. Im 1899 the Labor Party led by Anderson Dawson held office for a wreek. In 1903 Dawson's successor, W. H. Browne, took the Party into a coalition led by the ex-Speaker, Arthur Morgan, and comprising the olld 'Independent Opposition' and conservatives who had broken with Rioßbert Philp. At the next election Labor and its Morganite allies won a huge victory, with the Labor Party coming close to an absolute majority by itself. However, the current leader, William Kidston, did not press his advantage. In 1906 Morgan retired to the presidency of the: Legislative Council and Kidston became Premier, but with only ome Labor colleague in a cabinet which was overwhelmingly dependent om Labor votes. When Kidston asked the party conference to pledge itts support to his policy at the next election, a majority refused. The prarty split, lost votes and seats, and fell back almost to the position it haad held in 1893. 
A brief period of instability followed, with Kidstonites, Philpites, and Labor approximately equal in strength. After a year an antiLabor coalition was formed, and the remaining uncommitted forces were ground out between the two major parties. Even though the Labor Party lost seats due to the redistribution at the 1912 election, its vote rose to almost half the total. Once again Labor was on the eve of power, but now it had only one opponent and in $T$. J. Ryan and E. G. Theodore it had leaders who were effective in Parliament and outside. At the election on 22 May 1915 Ryan led Labor to a sweeping win-forty-five of seventy-five seats and over half the votes.

It is submitted, although considerations of space do not permit a fuller argument here, that in its years of growth the Queensland branch of the Australian Labor Party-the Queensland Labor Party as its members used to call it before a breakaway faction seized the name and made it official-developed habits which continue to determine its political style. One, the subordination of parliamentarians to the party machine, it shared with Labor in other States. When Premiers and machine clashed, as happened with Theodore in 1923 and V. C. Gair in 1956-7, there does not appear to have been any formal recollection of Kidston and his fate, but the events of 1904-8 so fixed the party's conventional wisdom that the suggestion that the Premier and his cabinet might have moral authority over and above that which the party conferred upon them always produced the same response. Another was a belief in the virtue of outlying areas of the State compared with the settled areas of the south-east, and especially compared with Brisbane. Although this never led the A.L.P. to formal endorsement of separatist schemes for North Queensland and Central Queensland, it did mean that the epithet 'Queen Street government' came as naturally to Labor lips as those of Country Party members. While the growth of the Australian Workers' Union (A.W.U.) to dominance in the A.L.P. organisation and its virtual monopoly of the industrial and political Labor movement in the north and west of the State reinforced this tendency, the style was set before Theodore. In New South Wales and Victoria the history of the Labor Party is of efforts to expand from the capital into the country, fairly successful in the one case and quite unsuccessful in the other; in Queensland the opposite is true. One consequence was that Labor policies were less concerned with the redistribution of wealth around which metropolitan politics revolved, more preoccupied with the development of resources. It may be that successive Labor governments did frustrate the industrialisation of Queensland to protect the A.W.U., dependent as it was on primary industry (Gough et al. 1964: 10), although it is difficult to believe that a few chapters and verses could not be cited if there had been a general and sustained plot. A third habit Queensland Labor inherited from its predecessors: a readiness to tamper 
with the electoral system; although Labor in other States was sometimes inffected, the Queensland case was the most extreme.

The forty years of electoral history following 1915 can be told briiefly. The Labor Party won the next four elections. In 1920 the ne:w Country Party and the old Nationalists pressed hard, polled more vortes, and cut the A.L.P. majority to four seats, but a redistribution resstored party fortunes. In the late 1920s the ministry led by William MicCormack was beset by a number of difficulties, including a major incdustrial dispute with the Australian Railway Union and to a lesser exttent the A.W.U., and the 1929 election turned Labor out and brrought in a Country-National government led by A. E. Moore. Ornce again the Labor Party was driven back into the north and west, where it held eighteen seats, compared with five in Brisbane and four int the south-east of the State. The rebuff was temporary; the Moore gosvernment caught the first blast of the depression and its unsympaathetic administration of relief schemes brought it further odium. Deespite a redistribution and a reduction in the size of the Legislative Asssembly, Labor squeaked back into office in 1932 and began a new terrm which lasted for a quarter of a century.

Over that period long-term demographic trends changed the orriginal base of Labor electoral support. Population in the west remaained static; in the south-east it increased by 50 per cent; in the noorth and in Brisbane it doubled. The northern and western electorates comtinued to provide about 40 per cent of the parliamentary Labor Party, but the relative attrition of this base had to be countered either by attracting support elsewhere or by inflating the value of votes in thiese areas. Both were tried: a majority of seats was won in Brisbane and weightage favoured first the western seats and then the northern omes. Under the notorious 1949 redistribution a vote in the western zomne was worth $2 \frac{1}{2}$ votes in Brisbane, but this was the only occasion on which zonal differences exceeded 2 to 1 . Usually they were less than $1 \frac{11}{22}$ to 1 . Between 1932 and 1957 the proportion of the parliamentary Labor Party representing western and northern electorates remained beetween 35 and 40 per cent, although the two areas had only 24.4 per cennt of the State's enrolment in 1932 and only 21.8 per cent in 1957. TThis substantial bloc within the parliamentary party was given unity through the dominant influence of the A.W.U. in these two areas, an in $f$ fluence which extended to Brisbane as well.

The corollary of the A.L.P.'s dependence on the north and west was the concentration of its opponents in the remaining areas of the Sttate. The 1920 election marked the best effort of the anti-Labor forrces between 1915 and 1929, and it illustrates the regional bias of the two parties: the Country Party won twenty-one seats, eighteen of them in the south-east, and the National Party thirteen seats, ten of them in Birisbane. Their merger in 1924-5 lasted for ten years, but apart from 
the momentary success of 1929 they failed to break out of the southeast-Brisbane area. The 1938 election followed their divorce: the Country Party won thirteen seats, all in the south-east, and the United Australia Party only four, all in Brisbane. Over the years of uneasy union and ineffectual separation the Country and Liberal (as it eventually became) parties worked out an approximate division of the State. The Liberals had a monopoly of Brisbane seats, one-third of the total by the 1940s, and normally contested another fifteen, mainly in or adjacent to the provincial cities-Ipswich, Toowoomba, Rockhampton, Maryborough, Mackay, and Townsville. One wholly rural seat remained Liberal by historical accident: the 1949 redistribution turned the East Toowoomba seat held by Gordon Chalk into a safe Labor seat, and he followed some of his electors into the new electorate of Lockyer, which embraced much of an old Country Party electorate, West Moreton. The Country Party contested the rest of the State. On a few occasions joint Liberal-Country endorsement was given in safe Labor seats, but the ultimate loyalty of these candidates never had to be tested. As the provincial cities were solidly Labor, sufficiently so to permit the incorporation of adjacent rural areas in many cases, the result of this territorial division was that the Liberal Party's parliamentary representation was restricted to Brisbane, with the exception of Chalk.

At the May 1956 elections the Gair government was returned with fifty of the seventy-five Legislative Assembly seats, losing only the marginal country electorate of Mackenzie. The A.L.P. seemed well set for its second quarter-century of uninterrupted rule. Nevertheless, there were certain clouds on the horizon. The March 1953 Labor-inPolitics triennial convention at Rockhampton had reaffirmed the party's approval of the industrial groups, but had also passed a resolution making it the aim of the Labor movement to obtain three weeks' annual leave for workers in the southern part of the State and four weeks for those in the north and west. At the party's federal conference in Hobart in March 1955, five of the six Queensland delegates had supported the right-wing Victorian delegation and ended up boycotting the conference. The State executive, the Queensland Central Executive-invariably abbreviated as Q.C.E.-refused to censure the delegates who had walked out of the conference, but a number of union representatives on the Q.C.E. were critical of the five, who included the Premier, Gair, and the Treasurer and former Deputy Premier, E. J. Walsh. Most significantly, the A.W.U. for the first time in many years aligned itself with the Trades Hall group of unions in hostility to the parliamentary leadership. Caucus expressed its confidence in the Premier and the Treasurer, and there the matter rested for some months. In September 1955 the Q.C.E. had recommended to Caucus that legislation establishing three weeks' annual leave be 
intitroduced, but Cabinet declined to proceed on the ground that State finaances would not permit it, and the Cabinet stand received the unanimoous endorsement of Caucus. The Q.C.E. then directed Caucus to procoed with the legislation, at the same time indicating that endorsemeents for the 1956 election might be affected. A truer picture of the bahlance of power within Caucus was given by the 28-20 vote on 17 Noovember rejecting the instruction. The Q.C.E. asked Caucus to recconsider, but on 22 January 1956 Caucus again rejected the direction, thinis time by 30 to 19 . The Q.C.E. then referred the matter to the Laborin-i-Politics convention meeting at Mackay.

Other events had further inflamed the situation. The Petrov Comminission Report in October 1955 had disturbed those who were concerned about Communist influence in Australia-and the supporters of $f$ the industrial groups were prone to such fears. In January 1956 thie Gair government had declared a state of emergency under the Trransport Act to break a strike by electricity workers. Extensive unnrest in the shearing industry pointed to further industrial troubles ahhead.

When the Mackay convention opened on 28 February an A.W.U.Trrades Hall coalition immediately took command. The Deputy Priremier, Jack Duggan, and a leading back-bencher, Dr Felix Dittmer, werere elected to the new Q.C.E., together with Gair, but a number of Gäair's supporters, including Walsh and the Attorney General, William Pơwer, were defeated. When a Trades Hall delegate moved for three wereeks' annual leave, Gair opposed the resolution, arguing that it would bee unconstitutional so to direct the State government and contrary to the A.L.P. platform which recognised the supremacy of Parliament. Ain amendment which would have required action during the 1956 sesession of the Legislative Assembly was lost, but another amendment (mmoved by an A.W.U. delegate) stating that the Premier should inclilude a pledge for three weeks' annual leave in his policy speech and thhat the necessary legislation should be passed at the first session of the new Parliament was carried 75-58. Cabinet met at once, and the neext day Gair told the convention that his ministry could not accept thhe direction. A committee of the convention then conferred with the Prremier and Deputy Premier, and no further discussion took place. It t was subsequently contended by A.L.P. members that Gair promised the committee that he would implement the direction in 1956, but Gjair denied that he gave any such undertaking. Whatever was said at thhe meeting, the 1956 policy speech and the subsequent Governor's sppeech opening the new Parliament made no mention of three weeks' annnual leave.

In June 1956 T. A. Foley, the Secretary for Mines, resigned from the Cabinet following criticism by a Royal Commissioner of his conduct as Minister for Lands and was expelled from the A.L.P. In 
October another supporter of the Premier, H. R. Gardner, was suspended from the party for criticising the Q.C.E. In December an industrial wing' candidate, Pat Hanlon, won a by-election for his father's old seat of Ithaca. Each of these steps helped to reduce the Premier's support in Caucus. In July 1956 the A.W.U. affiliated to the Trades and Labor Council for the first time in twenty years. Two pieces of Government legislation, the University of Queensland Acts Amendment Bill and the Motor Spirits Distribution Bill, were vigorously attacked by the Opposition and the press for their heavyhanded approach to the problems with which they sought to deal, and did much to alienate moderate goodwill from the Gair government. On 25 September 1956 the Q.C.E. wrote to individual Caucus members asking whether they were prepared to vote for the introduction of the legislation in 1956, but the next day Caucus rejected the idea 28-19. On 28 February 1957 the Q.C.E. on a 52 to 11 vote warned Caucus members that it would deal with refusal to pass the three weeks' annual leave legislation. Caucus then appointed a committee to meet with the Inner Executive of the Q.C.E. On 31 March R. J. J. Bukowski, State Secretary of the A.W.U. and President of the Q.C.E., complained that the government had not informed the Q.C.E. of the contents of the University and Motor Spirits Bills nor given an opportunity to discuss them. Gair denied that the Q.C.E. was usually advised of the government's legislative proposals. The Inner Executive, the standing committee of the Q.C.E., then asked the government to delay the University Bill and repeal the Motor Spirits Bill. Cabinet replied by advising the Administrator to give Royal Assent to the two Bills whilst informing him that it had the confidence of Parliament on the two measures-it being reported that the Administrator had asked for such assurances. The propriety of Duggan's conduct figured in press discussions of the situation: he was reported to have acted against the Premier in the Inner Executive but to have voted with the rest of Cabinet in sending the Bills to the Administrator and confirming that Cabinet still held the confidence of the Assembly, the question being whether the principle of Cabinet solidarity bound its members in the party councils.

On 11 April the full Q.C.E. retreated a little on the Motor Spirits Act by asking the Government not to use certain provisions and to redraft the Act, but the day before the Premier had defied the Executive on the three weeks' leave question. On the 18 th the Q.C.E. by a 35-27 vote carried a motion of no confidence in the Premier and called on him to show cause why he should not be expelled from the Party. (The full text of the resolution may be found in Lack n.d.: 472.) An amendment that all members of Caucus who had voted against introduction of the leave legislation should also be called upon to show cause was defeated. On the 23rd Cabinet met and all members signed a 
deleclaration expressing confidence in the Premier and stating that he wavas only carrying out the decisions of Cabinet. A third clause provided thhat members of Cabinet would consider any action taken against the Prremier to have been taken against each Minister individually; it was erendorsed by all members save Duggan-who had voted against the Q2.C.E.'s resolution on the 18th. (Text, ibid.: 473.) Later that day Cisaucus also declared its support for the Premier on the ground that hee was carrying out its decisions-but the vote in Caucus was 26-21.

$\mathrm{Up}$ to this point of escalation it appears that each side thought the other would back down. The Q.C.E. underestimated the number of GSair's supporters in Cabinet and Caucus; undoubtedly the number wwas increased by the unceremonious way in which Ministers, some of thhem of many years' standing, were treated by representatives of the exextra-parliamentary organs of the Party. On 24 April Gair appeared bbefore the Q.C.E. on six charges-defiance of the Mackay convention dedecision, refusal to accept the Q.C.E. interpretation of convention ddecisions, breach of his party pledge, bringing discredit on the party bby a number of actions, repudiating a pledge given to the convention ccommittee and denying the truthfulness of its report, and organising ththe Cabinet declaration as a challenge to the Q.C.E. (Text, ibid.: 4473-4.) Gair defended himself vigorously, but a motion for his exppulsion was carried 35-30, Duggan voting against it. The Federal EExecutive of the A.L.P. declined to intervene and on the 26th Gair cxalled a meeting of his parliamentary supporters which decided to foform the Queensland Labor Party. A total of twenty-five M.L.A.s joined the Q.L.P., including nine of the ten Ministers. On the 28th Duggan ststated his position in a radio broadcast:

There is only one decision to reach on the matter. Whether you like it or not, whether it is wise or unwise, the course to take is to endorse the official Labor decision. That is where Duggan standsand where every true genuine Labor man stands and will continue to stand. (Ibid.: 477)

TThe phrase 'wise or unwise' in various inaccurate versions was to hhang around Duggan's neck for many years to come. The next day he reresigned his portfolio, and on the 30 th the rump of the A.L.P. Caucus mmet and elected him leader and Dr Dittmer as deputy leader.

The State Parliament was hastily convened, but before it met, exeach of the Labor parties organised vigorously for the inevitable eelection. Only one Brisbane City Council alderman and one federal pparliamentarian chose to follow Gair and his Ministers out of the AA.L.P., but a substantial number of branches in electorates whose Members joined the Q.L.P. broke away from the A.L.P., and Gair rotained the parliamentary leader's special campaign fund estimated tcto contain $£^{5,000}$. When the House met on 11 June it first resolved 
50-23 that Frank (later Sir Francis) Nicklin was still Leader of the Opposition, and then debated the Premier's Appropriation Bill which sought temporary finance for two months. The Bill was defeated 45-25 on the 12th with the A.L.P. voting with the Country and Liberal parties. Gair then resigned and secured a dissolution.

The poll took place on 3 August after a bitter campaign in which the two Labor parties attacked each other and virtually ignored the Country and Liberal parties. One Liberal and three Country Party seats went uncontested, while the poll in Gregory had to be postponed to October when the Q.L.P. Member died after nominations had closed. Generally the Country and Liberal candidates lost votes compared with 1956, 1 or 2 per cent in most electorates but as much as 5-7 per cent in some Brisbane constituencies; only in six electorates for which comparisons can be made between the two elections did their vote increase. One of these was Toowoomba, where it is thought many Q.L.P. supporters, to ensure the defeat of Duggan, voted for the Liberal candidate, M. J. R. Anderson, rather than their own man. Despite the decline in the non-Labor Statewide vote from $45 \cdot 30$ per cent in 1956 to 43.26 in 1957 , the almost equal split in the Labor vote between the A.L.P. (28.89 per cent) and the Q.L.P. (23.39 per cent) ensured the success of a majority of Country and Liberal candidates. The Country Party won eight new seats, two (Balonne and Flinders) from the A.L.P., six-(Mulgrave, Nash, Roma, Somerset, Tablelands, and Gregory-at the delayed election) from the Q.L.P. The Liberal Party won ten new seats, four (Buranda, Kelvin Grove, Mt Gravatt, and Toowoomba) from the A.L.P. and six (Fortitude Valley, Kurilpa, Merthyr, Nundah, Sandgate, and Windsor) from the Q.L.P. The composition of the new Assembly was thus Country Party twenty-four, Liberal Party eighteen, A.L.P. twenty, Q.L.P. eleven, and Independents two. Twenty-five years of Labor rule had ended, with the A.L.P. polling a smaller proportion of the vote and winning fewer seats than at any election since 1907. Even 1929 had not been so disastrous.

On 12 August 1957 Nicklin formed the first non-Labor ministry since 1932. Five of its six Country Party members came from the southeastern corner of the State, the exception being Ernie Evans (Mirani), four of the five Liberal Ministers represented Brisbane electorates, Chalk being the exception. The defeat of both Duggan and Dittmer left the A.L.P. leaderless; Caucus chose Les Wood (North Toowoomba) as leader and Eric Lloyd (Kedron) deputy leader pending the possible return of Duggan to the House at the delayed election in Gregory. When Duggan was defeated again, Wood retained the leadership until his death in March 1958. Jim Donald, secretary of the parliamentary party since 1947, was leader briefly until Duggan won the North Toowoomba seat; Donald promptly resigned and was succeeded by Duggan. While the A.L.P. had lost some of its ablest mem- 
bers at the election, the Q.L.P. with eight former Ministers in its ranks retainned most of its senior men.

More serious for the A.L.P. than its parliamentary weakness was the rapid collapse of the unnatural alliance between the A.W.U. and Trades Hall which had overthrown Gair. Demarcation disputes between the two, and public recriminations between Bukowski and Jack Egerton, the most prominent member of the Trades Hall group, led to the withdrawal of the A.W.U. from the Trades and Labor Council in January 1958. Rivalry between A.W.U. and Trades Hall tickets in the :Senate pre-selection plebescite on 28 June 1958 led to complaints about the use of facsimile ballot papers by A.W.U. members in the plebescite. On 24 July the Q.C.E. on a motion by Egerton censured Bukowski for his action at a federal executive meeting in abstaining on a particular vote. In December 1958 Bukowski attacked a speech by Duggan in which the need for the A.L.P. to recruit well-educated candidates had been emphasised. On 11 December the Q.C.E.'s Christmas party broke up amid ugly scenes between Bukowski and Trades Hall unionists. On 18 December the Q.C.E. voted 49 to 1 to suspend Bukowski as its President. The next day Bukowski charged that the Q.C.E. was riddled with 'sectarianism, Communist influence and inefficiency'. On 30 January 1958 the A.W.U. gave notice of its intention to disaffiliate from the A.L.P. and to withhold its affiliation fees (which accounted for about one-half of the party's regular income) until Bukowski was restored to his party positions: The Q.C.E. left any decision on expelling Bukowski to his local branch, but when he failed to renew his ticket within the requisite period his membership automatically terminated. (The A.W.U. journal subsequently claimed that Bukowski's dues had been tendered, but returned on instructions from the Q.C.E.) The A.L.P., which for many years had been a tenant of the A.W.U., bought its own office building and moved out of Dunstan House. The A.W.U. remained outside the A.L.P. until June 1961, after Bukowski's death, although individual members and officers gave varying amounts of assistance at the 1960 elections. By the time that it reaffiliated the Trades Hall group was firmly in control of the partyfacsimile ballots were abolished at the Brisbane Labor-in-Politics Convention in 1960-and subsequent efforts by A.W.U. delegates to re-establish influence commensurate with the size of their union's membership and its financial and organisational contribution to the A.L.P.'s campaigns proved unsuccessful.

Meanwhile the Country-Liberal coalition set about altering the electoral system. The Electoral Districts Act 1958 abolished the four zones (metropolitan, soutr-eastern, northern, and western) established by the Hanlon government in 1949 to provide heavy weightage for the west, and replaced them with three zones (metropolitan, provincial cities, and country) with smaller differentials. The new dis- 
tribution was published in August 1959, and a slightly amended version was adopted in November. One consequence of the creation of a provincial cities zone was that a number of electorates composed of portions of the larger coastal cities and adjacent country areas disappeared. The Elections Acts Amendment Act 1959 abolished the practice of numbering ballot papers, a point which the government parties had long attacked for infringing the secrecy of the ballot, and increased the period of residence required of electors from one to three months.

At the next general election on 28 May 1960, the Government reaped the benefits of the new distribution and the electoral decline of the Q.L.P. The Country Party with 19.49 per cent of the vote won 32 per cent of the seats, while the Liberal Party with 24.03 per cent of the vote won 26 per cent of the seats. The A.L.P. with 39.89 per cent of the vote had only 33 per cent of the seats, and the Q.L.P. with 12.27 per cent of the vote only 5 per cent of the seats. It would appear that of the 11 per cent of the total vote the Q.L.P. lost between 1957 and 1960 almost all had gone to the A.L.P. In terms of the regional balance of the parties several points need be noted. The Liberal Party added two new seats (Bowen and Rockhampton South) to the two (Lockyer and Toowoomba East) which it held outside Brisbane. Although it still polled 77 per cent of its vote and held 80 per cent of its seats in Brisbane, it was beginning to break out of the metropolitan area. The Q.L.P. lost both of its Brisbane seats, including Gair's. Most of the Q.L.P.-held constituencies had been drastically altered by the redistribution; three of the four seats it won in 1960 were the least affected by boundary changes, and the fourth (Aubigny) was a personal triumph for Les Diplock. Henceforth Q.L.P. parliamentary representation would be dependent on personal followings of its sitting Members in country electorates. All the A.L.P.'s gains came in Brisbane, and for the first time in the Party's history almost half its parliamentary representation (twelve out of twentyfive came from the metropolitan area.

Some indication of the reversion to pre-split voting patterns is provided by Table 1.01. One might have expected the upheaval of 1957 to have enhanced the popularity of the Country and Liberal parties, but their vote in 1960 differed little from their vote in 1956, even though the earlier election was a resounding defeat and the later one a striking victory. Only in the west was there any appreciable gain, but in the south-east there was a decline. Nevertheless the same proportion of the vote meant forty-six seats in 1960 instead of twenty-four in 1956. The phenomenon has two principal explanations. One was a change in boundaries and zonal weightage which no longer advantaged the A.L.P. but now somewhat disadvantaged it. The other was a continued Q.L.P. vote of over 12 per cent. As has already been 
Table 1.01

Voting and representation 1956-60.

$\%$

1956

1957

1960

A.L.P. C.P.Lib, A.L.P. C.P.Lib. Q.L.P. A.L.P. C.P.-Lib. Q.L.P.

\begin{tabular}{|c|c|c|c|c|c|c|c|c|}
\hline \multicolumn{9}{|c|}{ Voting } \\
\hline Brisbane & $52 \cdot 18$ & 45.06 & $32 \cdot 62$ & $43 \cdot 48$ & $22 \cdot 87$ & $41 \cdot 92$ & $44 \cdot 56$ & $13 \cdot 10$ \\
\hline South-east & $48 \cdot 44$ & $51 \cdot 44$ & 23.97 & $48 \cdot 72$ & $21 \cdot 77$ & $36 \cdot 70$ & $46 \cdot 59$ & 11.41 \\
\hline West & 59.99 & $40 \cdot 01$ & 30.97 & $37 \cdot 97$ & $28 \cdot 63$ & $43 \cdot 86$ & $41 \cdot 67$ & 11.05 \\
\hline North & $50 \cdot 89$ & $34 \cdot 72$ & $29 \cdot 63$ & $32 \cdot 10$ & $25 \cdot 39$ & $39 \cdot 78$ & $34 \cdot 34$ & $12 \cdot 68$ \\
\hline \multicolumn{9}{|c|}{ Representation } \\
\hline Brisbane & 71 & 29 & 25 & 67 & 8 & 43 & 57 & - \\
\hline South-east & 50 & 50 & 25 & 61 & 14 & 21 & 66 & 10 \\
\hline West & 90 & 10 & 20 & 50 & 30 & 37 & 63 & - \\
\hline North & 69 & 15 & 38 & 31 & 15 & 31 & 46 & 8 \\
\hline
\end{tabular}

noted, most ex-Q.L.P. voters apparently returned to the A.L.P. whence in the main they had come. Those who remained could be regarded as a harder core whose rate of attrition would be slower and whose antipathy to an unreformed A.L.P. could be counted upon.

In the 1960 election some twenty-two Members were returned on a plurality of the vote. Five of these were Country Party candidates (in Albert, Flinders, Hinchinbrook, Mulgrave, and Roma), and seven Liberals (in Aspley, Bowen, Ithaca, Kurilpa, Rockhampton South, Toowoomba East, and Windsor). Another five were A.L.P. candidates (in Barcoo, Burke, Norman, South Brisbane, and Townsville North), four standing against particularly strong Q.L.P. candidates. Another two Country Party Members (for Burnett and Tablelands) and eight Liberals (for Ashgrove, Chatsworth, Clayfield, Merthyr, Mt Gravatt, Nundah, Wavell, and Yeronga) were returned with between 50 and 55 per cent of the vote, while there were seven A.L.P. Members (for Belmont, Brisbane, Hawthorne, Mackay, Mourilyan, Nudgee, and Sandgate) in a similarly exposed position. The introduction of preferential voting would permit the Q.L.P. vote to be utilised by the Government more effectively, for it would not only be detached from the A.L.P. as it already was under the existing first-past-the-post system but, in appropriate cases, would be counted again for the Government. Experience at federal elections in other. States indicated that 75-80 per cent of Q.L.P. voters could be relied upon to give their second preferences to government candidates. Thus the Country Party and Liberal Members who had been returned without an absolute majority would be insured for the next election, while their colleagues in less marginal seats would be guarded against any swing from the government. In positive terms, the A.L.P. seats held by a plurality 
would be endangered, and, in the event of a swing to the government, those in the 50-55 per cent class could become quite shaky.

In fairness to the Government and its decision to introduce preferential voting it should be added that as this system prevailed at federal elections and in all other mainland States, there were considerable arguments for its introduction in Queensland. Indeed when the Prime Minister first commented on the 1957 election, his remark:

It certainly means that in the State of Queensland electoral reform now becomes not only possible, but certain. I hope that occurs on the fair and objective model of the Commonwealth provisions which have existed now under all parties for many years

was taken to refer to abolition of first-past-the-post voting rather than zonal weightages or blatant gerrymandering (Courier-Mail: 8 August 1957).

The Government's task should have been easy when self-interest and principle pointed in the same direction, but in fact there was considerable reluctance to introduce preferential voting. Early reports (e.g. Courier-Mail: 9 April 1962) suggested that country members of both government parties were sceptical of its advantage lest it produce a multiplicity of candidates and a last minute A.L.P.-Q.L.P. deal for an exchange of preferences. On 29 May 1962 the Courier-Mail reminded the government parties that they had long promised to restore the electors' right to state a second preference and have it counted, and went on:

Queensland is the only Australian State that has its parliamentary elections finally determined by the result of a first count of votes polled. Federal elections have continued to accustom Queensland electors to preferential voting. First past the post can exaggerate the parliamentary strength of a majority party when more than two parties contest an election. Casting and counting of preference votes serve to give minority parties fairer representation in parliament.

On 21 June the State Convention of the Liberal Party urged their parliamentarians to seek introduction of preferential voting during the life of the current Parliament-but in an ill-timed juxtaposition also extended an invitation to the Country Party to merge with the Liberals on any reasonable terms the Country Party might suggest. As many Country Party members feared that preferential voting would bring Liberal candidates into Country Party electorates on the pretext that an exchange of preferences would be mutually beneficial, the double-barrelled threat of takeover by preferences and takeover by merger hardened Country Party resistance to the idea.

At this point Gair entered the domestic dispute-and possibly settled it. Thinking aloud he wondered whether, in the absence of preferential voting, it would be worth the while of the Q.L.P. to con- 
test. the 1963 election 'in force', and added: 'Preference voting gives us something to sell-our preferences.' If it were introduced, Q.L.P. voters would be told to give their preferences to Liberal and Country Party canididates until the A.L.P. stopped 'running around with the Commumists' and restored the right of its parliamentarians to decide the timing of legislation (Sunday Mail: 29 July 1962). On 12 July the Country and Liberal Party organisations had agreed on a 'seat entitlement' for the 1963 election: each would contest thirty-six seats, based on the distribution of candidates in 1960. The two partners also settled another contentious matter by agreeing that J. E. Houghton (who had wom Redcliffe as an Independent in 1960 after losing the Country Party endorsement, and then joined the Liberal Party only to be forced out of it by Country Party disapproval) would be admitted to the Country Party and supported by both parties at the election. With arrangements for 1963 safely settled, the State government appointed a committee of party members to investigate preferential voting-a Mimister and a leading back-bencher from each party (Harold Richter, Rom Camm, Alan (later Sir Alan) Monro, and W. E. Knox). The Conurier-Mail repeated its earlier advice, while Gair accused the government parties of giving precedence to personal interest over principle in failing to act. Accounts of the committee's deliberations suggested that the two Country Party members were opposed to change (Sunday Mail: 30 September 1962), but in a television interview Munro said that there was a 'reasonable prospect' of preferential voting being introduced at once, and the press (Courier-Mail: 24 October 1962) then speculated that there would be a compromise whereby each party would undertake to oppose an independent of their persuasion who tried to poach a partner's seat and contingent; i.e. non-compulsory preferential, voting would be restored. When the matter came before a joint meeting of the two parliamentary parties on 30 October a decision was taken by a secret ballot by two stages: first to change from first-past-the-post, then to introduce compulsory preferential voting. It was reported (Courier-Mail: 1 November 1962) that the Country Party deputy leader, Jack Pizzey, and the Liberal leaders, Munro and T. A. (later Sir Thomas) Hiley, led the supporters of preferential voting, while Evans and Richter led the opposition to it, and that Munro gave asurances that there was no intention of securing an advantage over the Country Party. A later news story added that the vote in favour of change had been 24-21, with seven Country Party members voting with the majority of the Liberals to change and three Liberals voting against. The same story also reported charges that the proxy of a Country Party member known to be opposed to change had been cast in favour of abandoning first-past-the-post (Courier-Mail: 2 November 1962). The State President of the Liberal Party, Alan Hulme, observed that the change should win five more seats for the Govern- 
ment-the five in which the A.L.P. had won with a plurality, although he was not so-indiscreet as to mention the four Q.L.P. seats which were equally vulnerable. Special support was promised to Cec Carey (Albert) and Dr Peter Delamothe (Bowen) whose government seats might be endangered by preferential voting.

To anticipate half of the plot by a few pages, let it be said at once that the 1963 election proved anti-climax-only two seats changed hands. With A.L.P. preferences, the Country Party won Carnarvon, defeated the Q.L.P. leader, Paul Hilton, and halved his party's parliamentary strength. In Tablelands, the A.L.P. candidate won with a clear majority. But elsewhere throughout Queensland sitting Members, including the five Independents, were returned, and where a Member had retired he was replaced by a man of his own party. In the statewide voting patterns, too, there was little change. The Country Party, contesting one seat more than in 1960, raised its share of the vote from 19.49 to 20.31 per cent and held twenty-six seats; the Liberal Party, contesting one seat fewer, dropped from 24.03 to 23.75 per cent with twenty seats. The A.L.P. stood for four more seats (including Burke in which there was no contest), the first time the party had contested every seat in the State, and raised its share of the vote from 39.89 to 43.83 per cent, or only 0.23 per cent less than the government parties combined. Had there been a contest in the safe Labor seat of Burke the margin between Government and Opposition would have been negligible-and yet the A.L.P. in 1963 won only twenty-six seats, only one more than in 1960, whilst the Government managed forty-six on a comparable vote. The Q.L.P. did relatively badly: its four members returned in 1960 had become two by defection and then one by Hilton's defeat; its vote dropped by more than 35,000 , from $12 \cdot 27$ to $7 \cdot 22$ per cent. At both elections there were eighteen Independent candidates; in 1960 they polled $4 \cdot 16$ per cent and three were returned; in 1963 they polled 4.55 per cent and five were returned. Finally, the two minor parties: the Communist Party's six candidates in 1960 managed a thousand votes, 0.14 per cent, and their three candidates in 1963 only five hundred votes, 0.06 per cent; Social Credit's nine candidates in 1963 with almost two thousand votes accounted for 0.25 per cent of the total.

As it was, the implications of preferential voting fell well short of what might have been expected from the 1960 results. In 1960 twenty-two Members were returned on a plurality of the vote; in 1963 only nine Members needed a count of preferences. In only three cases did the preferences change the result from a first-past-the-post count. Two Liberal M.L.As. came from behind to win with Q.L.P. preferences, Dr Delamothe in Bowen and Anderson in Toowoomba East. Two more Liberal seats needed preferences to reach a majority, Nundah and Rockhampton South, and likewise three Country Party seats, Albert, 
Callide, and Carnarvon. Preferences brought A. G. Muller from behind his Country Party opponent to retain Fassifern as an Independent, and the A.L.P. needed preferences for a majority in Townsville North. Neither possibility of preferential voting-enabling the Government to bite deeper into A.L.P. strength or to hang on against a swing to the A.L.P.-eventuated, for there was no significant swing between the main parties, only a modest drift of Q.L.P. votes on the net balance to the A.L.P.

In September 1963 cabinet was enlarged from eleven to thirteen. The Liberal parliamentary party proved Delamothe's supporters right (see p. 116) by electing him to the additional Liberal place, whilst Nicklin appointed Johannes Bjelke-Petersen to the new Country Party position. At its annual conference at the end of July the Country Party rejected another offer of union with the Liberal Party, amid reports that the Liberal Party was organising branches in Country Party seats, especially on the Gold Coast. In March 1964 there emerged within the Liberal parliamentary party a small group of dissidents, led by John Murray, who criticised the Government's excessive domination of parliamentary business and its land policy. Thus for the first time there appeared a small rift in the Government's ranks, turning mainly on electoral competition between the coalition partners but involving also a few policy issues and the appropriate style of parliamentary government. Rumours that the Country Party might, with A.L.P. support, revert to first-past-the-post voting never became a serious possibility, and indeed the only change in electoral matters between our two elections in 1963 and 1966 was a change in legislation permitting hotels to open during polling hours. The change does not seem to have resulted in brighter elections, nor to have inhibited women's attendance at the polls, as used to be feared.

At the end of 1964 relations between the Government and the trade unions began to worsen. There were strikes on the railways and a noisy row when the Trades and Labor Council circularised English trade unions in the metal and building industries warning them about low wages and penal provisions in Queensland, a document which the Premier denounced as 'deliberately calculated to hamper and frustrate the industrial development of Queensland'. However, the main drama developed at Mt Isa, where a radical group of unionists, the Committee for Membership Control, tried to break the A.W.U.'s hold on mining at Mt Isa. A lengthy strike involved hostilities between the A.W.U. and the Brisbane Trades Hall, between left-wing A.L.P. federal parliamentarians and the A.W.U., and briefly between the Queensland Government and a broad sector of Australian trade unions and southern press opinion when the Government brought in stringent police regulations to deal with violence and threats of violence at Mt Isa. No one emerged from the strike with much credit, and the 
Government missed an opportunity to discredit the A.L.P.'s close connection with Trades Hall; even though relations between the A.W.U. and the Trades and Labor Council were further strained, the A.W.U.'s political grudge lay against the federal parliamentary party and not the state.

Relations within the coalition worsened on 2 April 1965 when the Liberal state president, Senator R. D. Sherrington, indicated that Liberal candidates would enter ten or twelve 'three-cornered contests' (strictly a misnomer, because they would almost certainly involve a fourth, D.L.P., candidate) with Country Party candidates at the 1966 election. Nicklin replied that the two parties should fight their common enemy, not each other. When he received a sharp retort from the president of the Young Liberals, who generated most of the pressure for three-cornered contests, to the effect that the Premier was not concerned about the Government being defeated but only with the Country Party becoming the minority partner within it, Nicklin blasted the idea at the Country Party conference as wanted only 'by a few people principally for personal gain'. Worsening inter-party relations did not extend to the cabinet where only one Liberal Minister, Alex Dewar, was suspected of leaning towards the ultraLiberal position. Nicklin sought to confine the contests to seats where there was no sitting government member, and offered to keep Country Party candidates out of Liberal seats if the Liberals would not offer in Albert-the one seat where a sitting Country Party M.L.A. was clearly vulnerable. His pleas were ignored, and the Liberal Party continued to organise branches in electorates around Brisbane and to seek candidates for them, and then ranged further afield by deciding to oppose the pro-Country Party Independent, Arthur Coburn, in Burdekin and to contest the A.L.P.-held seat of Cairns in which the Country Party had recently done well at a by-election. But generally the sniping continued to be confined to relatively junior and young members of the two parties and to occasional interventions by the state presidents; parliamentarians carefully avoided the issue. In October 1965 Muller rejoined the Country Party and increased its caucus strength in joint party meetings by one.

Whatever its domestic problems, the Government's. economic position was good. Serious drought in the west continued, but relief schemes seemed to satisfy most affected parties, and no serious discontent was feared in Country Party electorates in the area. The rapid decline of sugar prices (see p. 225) was a much more serious problem, and the Government became involved in that hardy perennial, parliamentary salaries, when an advisory report suggested an increase of $£ 700$ per annum. The A.L.P. caucus resolved that the amount should be only $£ 23310$ s. to reflect only change in the cost of living, with the balance received by members to be paid to charity or other good 
works. The Q.C.E. endorsed their decision, but when two A.L.P. M.L.As., J. H. Mann and I. Marsden, had minor difficulties with the Q.C.E. about it early in 1966, this was clearly not a cause for the Government to blast Q.C.E. dictation.

Thus at the beginning of the 1966 campaign little had changed since 1963. The A.L.P. had its internal difficulties, and for the first time so had the coalition. But economic development continued at much the same pace. There had been no innovations in government policy in the social services or in the broad pattern of relations between the state and the private sector of the economy. Mineral development in oil, bauxite, and coal had continued on lines well publicised by 1963 . Unemployment no longer appeared a serious problem, but rising prices might be. The defeat of Hilton in 1963 and the retirement of Munro meant that two of the four parties had new leaders, but as the real interest focused on the alternative Premiers, Nicklin or Duggan, this mattered little. The course and the horses were much the same.

Again the election was anti-climax. As in 1963 only two seats changed hands. On the third try, Peter Wood of the A.L.P. won Toowoomba East from the Liberals, but the split in Labor ranks in Hawthorne (pp. 210-12) allowed the Liberal candidate to slip in with 82 per cent of the Q.L.P. second preferences and 58 per cent of Bill Baxter's preferences-which had been augmented by 13 per cent of the Q.L.P. second preferences. Thus the immediate result of the 1966 election was no change in the party strengths in the Legislative Assembly. In terms of total votes, the Country Party with Liberal candidates nibbling away in the three-cornered contests dropped to $19 \cdot 28$ per cent of the total, but kept twenty-seven seats. The Liberal Party with forty-five candidates, more than they had ever offered before, crept up to $25 \cdot 5$ per cent of the total vote, but still had only twenty seats. The A.L.P. held exactly the same share of the vote, 43.83 per cent, and the same total of twenty-six seats. As there were now two uncontested seats, Mackenzie held by the Country Party and Warrego by the A.L.P., no allowance need be made in comparing the Government vote with the A.L.P. The Government had succeeded in increasing its vote 0.72 per cent, and now led the A.L.P. by 0.95 per cent of the vote and twenty-one seats. The Q.L.P. vote continued to slide downwards, but not as badly as in 1963: the absolute drop was less than 6,000 with two fewer candidates offering, and the share of the vote in 19666.25 per cent with one seat held. There were two fewer Independent candidates, but the Independent vote rose again to 4.76 per cent; the four sitting Independent Members were re-elected, Muller having returned to the Country Party before the election. The minor parties performed much as in 1963: the Communists with five candidates reached a thousand votes, 0.14 per cent of the total, and the seven Social Credit 
candidates again just missed two thousand votes, for the same 0.25 per cent.

Despite the development of the three-cornered contests, preferential voting was not much more significant in 1966 than in 1963 . Twelve, instead of nine, Members needed a count of preferences; four, instead of three, came from behind to win. Again only one A.L.P. candidate, Mrs Vi Jordan in Ipswich West, was elected after the distribution of preferences, as against five Liberals, five Country Party Members, and one Independent. The twelve seats may be grouped as seven which resulted from ordinary patterns of inter-party competition and five which came about because of the clash of two government candidates in three-cornered contests. Three Liberal seats, Ithaca, Rockhampton South, and Windsor, were held with Q.L.P. preferences: 71 per cent in Ithaca, 66 per cent in Rockhampton South, and 89 per cent in Windsor. In Chatsworth the distribution of the preferences of a minor Independent candidate were sufficient to hold a normally safe Liberal seat without requiring Q.L.P. preferences. In Hawthorne, as has just been noted, Q.L.P. and Baxter's preferences transferred the seat from the A.L.P. to the Liberals. In Burdekin the Q.L.P. candidate was eliminated first; 58 per cent of his preferences went to the Liberal candidate who consequently overtook the A.L.P. candidate. When the A.L.P. candidate was eliminated next, 63 per cent of his preferences went to the Liberal also, but the drift of preferences, 34 per cent from the Q.L.P. and 37 per cent from the A.L.P., was sufficient to save the seat for Coburn, who had polled $45 \cdot 56$ per cent of first preferences and thus led the Liberal comfortably on the final count.

The other five seats in which preferences were counted were held by the Country Party against Liberal challenges. In two A.L.P. seats three-cornered contests were tried in 1966 without reaching the distribution of preferences. In Port Curtis, Martin Hanson still managed 70 per cent of the vote, and the Country Party candidate outpolled his Liberal colleague three to two. In Cairns a new A.L.P. Member, Ray Jones, who had won the seat at a by-election in February 1965, dropped almost 5 per cent of the vote from the by-election, but was faced with four opponents instead of one; here the Liberal led the Country Party candidate three to two. In the five seats in which 'three-cornered' contests took place-in the event two were fourcornered, two five-cornered, and one six-cornered-and preferences were distributed, the Country Party candidate led on the first preferences in Albert, which was won with 51 per cent of the Q.L.P. preferences and 29 per cent of the A.L.P. preferences, and in Redcliffe, which was won with 65 per cent of the Q.L.P. preferences and 87 per cent of the Liberal preferences. In South Coast the Liberal candidate led on first preferences, but was overtaken by the Country Party candidate who gained 49 per cent of Q.L.P. preferences, 24 per 
cent of the preferences of the Independent, Bernard EIsey, and finally 81 per cent of A.L.P. preferences. In Logan and Murrumba the A.L.P. candidate led on first preferences; in Logan the Country Party won by securing 8 per cent of preferences from the Social Credit candidate, 40 per cent from the Q.L.P., 28 per cent from the Independent, L. J. Storey, and finally 74 per cent from the Liberal; in Murrumba the pattern was fairly similar, with the Country Party Member securing 29 per cent of preferences from the Independent, D. W. Bishop, 69 per cent from the Q.L.P., and finally 78 per cent from the Liberal. In none of these five cases did the appearance of two Government candidates substantially erode the A.L.P. vote, and the later lack of enthusiasm of the Liberal organisation for three-cornered contests suggests a realisation that the experiment was a failure.

The results of the two elections considered in this book suggested the first title proposed for it, No Change. Queensland in the middle 1960s experienced a quite remarkable stability of voting and parliamentary representation, and we must ask why. Behind the hard statistics of the final voting patterns lie the untidy, soft uncertainties of the images and issues which have provided the title finally employed. It is to these images and issues that we must turn. 
I: IMAGES 


\section{Party Images}

IN 1908 Graham Wallas, directing attention to the subject of human nature in politics, introduced the term 'party images'. Starting from the basic human need to make things recognisable and significant, Wallas argued, recognition became attached to certain particular points in the object recognised, and these points thus became symbols of the thing as a whole. Edwardian parties made much of party songs and rosettes, and so Wallas noted first the part these played in establishing party identification, but he went on to comment upon the practice of choosing a party name which held emotional associationsand trying to label one's opponents with a name which induced hostility, and compared it with devices of commercial advertisers who sought to distinguish their brand from the general category of that product:

The party candidate is, at his first appearance, to most of his constituents merely a packet with the name of Liberal or Conservative upon it. That name has associations of colour and music, of traditional habit and affection, which, when once formed, exist independently of the party policy. Unless he bears a party labelunless he is, as the Americans say, a 'regular' candidate-not only will those habits and affections be cut off from him, but he will find it extraordinarily difficult to present himself as a tangible entity to the electors at all. A proportion of the electors, varying greatly at different times and at different places, will vote for the 'regular' nominee of their party without reference to his programme, though to the rest of them, and always to the nominating committee, he must also present a programme which can be identified with the party policy. But, in any case, as long as he is a party candidate, he must remember that it is in that character that he speaks and acts. The party prepossessions and party expectations of his constituents alone make it possible for them to think and feel with him. When he speaks there is between him and 
his audience the party mask, larger and less mobile than his own face, like the mask which enabled actors to be seen and heard in the vast open-air theatres of Greece. If he can no longer act the part with sincerity he must either leave the stage or present himself in the mask of another party. (Wallas 1948: 90-1)

For the next thirty years little attention was paid to the concept of party image, but as studies of electoral behaviour began first in the United States, then in Britain, and later still in Australia, it was taken up as a basic analytic tool. At the same time the extension of advertising techniques into political campaigning, culminating in the employment of advertising agencies to manage campaigns, suggested to some politicians that images could be created in the same way that a new soap powder was marketed-and the suggestion has been bandied about in the political columns of the press. Such an idea is almost certainly mistaken, however, and has been deprecated by the more sophisticated party managers.

One of the closest analyses of the role of images in political campaigning was provided (anonymously, but one may suspect the hand of the State Secretary) in the Queensland Liberal (Vol. V, No. 50, September 1963) shortly after the 1963 elections. It gives not only considerable insight into the Liberal organisation's view of electoral decision-making, but also, after the event, a substantial explanation of the 1963 campaign and, to a lesser extent, of the 1966 campaign. Reporting that surveys had shown that, whilst most people who voted for Labor did so because it was 'the party of the working man', those who voted Liberal did so for a variety of reasons, the article characterised the strategies of both parties:

Thus, whilst the A.L.P. strives to project an image of itself as a body dedicated to advancing the welfare of the little man who is constantly threatened by the insatiable greed of Capitalism, we Liberals project an image of our party as a body dedicated to the proposition of a free society as opposed to the regimentation of socialism.

However, the article went on, party images had to be based on reality or they would rebound to the disadvantage of those who tried to promote a false image, and reality was understood most readily in terms of conflict.

Just as contrast makes for clarity in any picture, so with the matter of a political party's 'image': this will be thrown into sharper relief as the political conflict between major opposing ideologies becomes significant. Thus a party 'image' emerges in precise sharpness not only from communicating what the party is for, but also what it is against.

No other Queensland party has made public its thinking on the bases of electoral decision-making, but similar calculations can be seen 
underlying each party's strategy. Each party seeks to project at least two images, one of itself and one of its principal rival, and to tie each to particulars which provide verisimilitude. Each emphasises the threat which its opponents present as strongly as, if not more than, the benefits which it has brought itself and will bring again. The images which the parties seek to present are related to the arguments which they use in formulating issues and advocating courses of action (see Chapter 6). An image is mainly the deposit of past and present issues upon a voter's political attitudes where they are arranged into a selective, and to varying degrees consistent, pattern. As the voter's perception of those issues will be affected by the way in which they are communicated to him, and the way in which they are adapted to minimise discongruence with the pre-existing pattern, the selectivity may be considerable. It may even cause an external observer to think the image grossly inaccurate.

Parties in their communications to the electorate will consider the images which they believe the voters to have, and select for emphasis issues which have maximum congruence with the favourable elements in their image and with the unfavourable elements in the other party's image. At the same time, by selecting particular issues to emphasise they can be directing the gradual modification of existing images in a way favourable to themselves and unfavourable to their opponents. In the following pages an attempt is made to define, with reasonable brevity, the image which each party sought to present of itself in the two campaigns-together with the image it sought to attach to its rivals. Whenever possible, their own words have been used, and illustrative material chosen from both campaigns, 1963 and 1966.

\section{The Liberal Party}

The image of itself cultivated by the Liberal Party has been the most positive and well thought-out self-image advanced by any of the parties. It embraced four main and inter-related elements: unity, reliability, achievement, and freedom, each of which in a negative form figured in its image of the A.L.P. The first three elements were featured in the standardised blue brochure used in 1963 to introduce each Liberal candidate: unity-'Only the Liberal-Country partnership can offer hope of stable government. Labor can't govern, for it is fragmented on all levels by interlocking feuds and quarrels on personal, sectarian and ideological grounds'; reliability-'The LiberalCountry State Government keeps its word! What it promises, it will do. The record of the past six years abundantly displays this sense of duty, high purpose and real integrity in public office'; achievement'The Liberal-Country State Government has done a good job. In less 
than six years it has brought new hope, new prospects, new achievements for Queensland.' The fourth constituted the party's 1963 election slogan, 'Keep Queensland Free in '63'.

The idea of unity was promoted in 1963 mainly by referring to the Liberal-Country team and then reporting in detail the internal difficulties of the A.L.P. As the Government's term of office to that point had been remarkably free from internal dissension-the minor disagreements over Houghton and the introduction of preferential voting being two exceptions which were short-lived-this could be quite easy. Opening his policy speech, Munro first paid tribute to Nicklin, then continued:

Our two Parties, although completely separate organisations, share many common ideals and objectives and we are completely united in our opposition to Socialism and Communism.

It is a happy augury for the future that we can work well together and are able to carry on our composite Government in such a friendly co-operative spirit.

It is in that spirit of friendly co-operation that I ask you to accept my contribution tonight as an endorsement of the Government policies outlined by Mr Nicklin last Tuesday night and as the second and final section of the full Policy Speech of our Country-Liberal Government.

In 1966 Chalk had to dispose of the three-cornered contests before he could proclaim unity:

Let me stress at the outset that whilst it is true that the two components comprising the Government which has so capably piloted the development of this State over the past nine years, have independent organisations-and we admit differences of opinion, as occur in any good Australian family-we are solidly united in those ideals and principles which tend for the benefit and betterment of Queensland.

In $1966 \mathrm{R}$. N. Bonnett in Townsville North could still call the Liberal Party 'the party whose members fight for the people-not against each other' (Townsville Daily Bulletin: 19 March 1966), but Liberal candidates were more diffident about claiming unity as a leading attribute of their party.

Similarly in the area of reliability the Liberal Party image was strong. In 1963 only K. J. Morris's policy speech promise of 1957 , more jobs than men, hung around the party's neck (see pp. 188-9), and this was whittled down in argument about the real meaning of the unemployment figures. By 1966 it had faded away to one late A.L..P. advertisement in the Mackay district (Daily Mercury (Mackay): 25 May 1966). Liberal advertisements during the 1963 campaign showed Nicklin and Munro, partners in the Liberal-Country State Government', and proclaimed: 'YOU KNOW You can trust these mem'. 
'BUT', they asked, 'Can you trust these men?', pointing to 'Jack Egerton, Trades Hall leader: "Politicians should be told what to do" and 'Jack Duggan, Labor Parliamentary Leader: "Like it or not, wise or unwise, the course is to endorse official Labor decisions".' (Some of the impact of such advertisements may have been lessened by the photographs of Nicklin and Munro used to illustrate them, for both leaders had a most uncharacteristically shifty air; the advertisements in the metropolitan press were hastily altered, but there was insufficient time to catch up with those in the country newspapers.) Another 1963 advertisement repeated a visual effect used in previous campaingns, a huge hammer-and-sickle superimposed on a photograph of the State Parliament House, under the caption: 'Keep the Trades Hall shadow off our Parliament!' By 1966 this advertisement appeared to have outlived its usefulness. The 1963 standard blue leaflet already mentioned made the same point: 'Return a Government that has shown it can get things done. The Liberal-Country State Government has already given greater prospects than it has known in the previous 40 years-let it get on with the good work!'

Reliability and achievement were usually joined together. To quote this leaflet once more:

YOU WILL VOTE LIBERAL BECAUSE . . . with its Country Party partner the Liberal Party has provided Queensland with six years of revolutionary new Government in Queensland.

Revolutionary because it has swept away all the old antibusiness hysteria that characterised the quarter-century of Labor's rule. And because it has introduced a new climate of integrity, trust and unbounded enthusiasm in Queensland's future.

The Liberal-Country Government is sweeping our State from the doldrums of Labor's 'pick-and-shovel' planning into the high excitement of tremendous development and expansion.

Just check the list-

*Oil at Moonie! $£ 37,000,000$ spending on an oil pipeline and Refineries.

* On the Gulf! $£ 45,000,000$ on huge Bauxite development at Weipa and $£ 35,000,000$ for Alumina manufacture at Gladstone.

* In the hinterland! $£ 23,000,000$ on roads to expand beef production, and further spending on brigalow lands.

* North and North-west! $£ 15,000,000$ on bulk sugar handling, $£ 45,000,000$ expansion at Mt Isa, $£ 26,000,000$ on the TownsvilleMt Isa railway.

* Coal and Powerl $£ 14,000,000$ for Callide and Kianga-Moura coal projects, $£ 177,000,000$ for a colossal State power grid.

And these are only some of the great projects not just in the planning stage, but either commenced or firm commitments. YOU WON'T VOTE LABOR BECAUSE . . . all this dazzling prospect could wither and die if a Labor Party, utterly dominated by the Left Wing and committed to Socialism, obtains office. 
One advertisement, widely used in 1963 , employed a map of the State with major developments shown spreading over it, and most pieces of campaign literature managed to fit in a list similar to that just quoted. Three general classes of achievement were mentioned: stimulation of private investment, public works, and maintenance and extension of social services. The first was usually tied to contrasts with the days of Labor government:

The old 'anti-business' attitude, which prior to 1957 pervaded all levels of government in this State, has been completely reversed. Where businessmen from the South and overseas were coldly told to keep out, now every endeavour is made to have new industries and enterprises established in Queensland in preference to other States.

Throughout almost half-a-century Labor regimes deliberately kept Queensland a 'bowyangs' State. They were hostile to business development, discouraged all industrial expansion, and crippled all enterprise with Australia's highest State taxation and Socialist controls. The A.W.U. then dominated Labor, and the A.W.U. was determined there would be no craft unions emerging to challenge its control of the political machine,

So-

Whilst Southern States forged ahead industrially we remained the 'wood-and-water-Joey' for the rest of Australia.

Lists of private investments were usually mixed with public works in individual candidates' leaflets. Thus Dewar produced a list of 'some of the Major Projects now on the way' in which the Amoco refinery and the Collinsville power station, the Comalco smelter and State dams featured side by side, and concluded: 'Two hundred and seventy-four million pounds of positive development. This is only the start.' A Liberal Party leaflet produced a similarly mixed list entitled 'Here is the shape of things already evident and to come', with the comment:

All these, and others, are not 'pie in the sky' proposals. They are solid achievement, involving something like $£ 400,000,000$ capital spending. This is Queensland's 'Vision Splendid' for the future.

In the field of social services this leaflet declared:

Liberals are concerned with people. Labor capitalises on an old and honoured Party name to suggest that it alone is concerned with people and their problems. What are the facts? Practically every important item of social security was introduced by Liberal Governments. Labor over its 40 years of office in Queensland was a vindictive, mean and callous employer. Ask any public servant, any policeman, any teacher of the differences that have occurred since the Liberal-Country Government took office. And when Labor's politicians weep over lack of employment, how genuine are the tears? 
In 1966 the emphasis appears to have shifted slightly from achievement to promise. One widely-used advertisement declared: 'The past record is good, but the future is what matters now.' The State had been guided from the dreamtime of potential to a new era:

Lett's keep things moving! Let's put energy, courage and enthusiasm to work in programmes that look ahead, and maintain and accelerate Queensland's vigorous growth-with stability. It needs action. It needs the ability to think big ... plan big ... and look ahead! (Gold Coast Bulletin: 20 May 1966).

The illustration was of a young man talking into a microphone with the caption: 'Let's meet the challenge of our times', and the slogan 'Vote Liberal for Actionl'

The fourth main element of the Liberal image, freedom, was raised by Munro in the peroration of his policy speech when he quoted the first four paragraphs of the Liberal platform objectives, which include:

\section{An Australian Nation:}

1. Dedicated to political liberty and the freedom and dignity of man.

4. In which an intelligent, free and liberal Australian democracy shall be maintained by:

(a) Parliament controlling the Executive and the Law controlling all;

(b) Independence of the Judiciary;

(c) Freedom of speech, religion and association;

(d) Freedom of citizens to choose their own way of living and of life, subject to the rights of others;

(e) Protecting the people against exploitation;

(f) Looking primarily to the encouragement of individual initiative and enterprise as the dynamic force of progress; and

(g) Developing to the fullest extent a national spirit in Australia.

While most Liberal candidates employed the slogan, 'Keep Queensland Free in '63', few had much to say about it. Freedom figured even less prominently in 1966, though one Liberal candidate, L. E. Storey in Toowoomba East, pointed out that his party

has a policy of advancement and of the furtherment of free enterprise in the individual, which is completely opposed by other ideologies which would if elected to power, take from us in Australia the individual rights of men and women to work as they want, where they want, in a free community. (Toowoomba Chronicle: 28 April 1966)

He went on to list freedom of action, of speech, to change employment, to 'live virtually as we want within our means', and to under- 
take a business as elements of freedom which would be endangered by Labor's policy of nationalisation, even though it was currently being played down.

One aspect of Liberal image-making was defensive: an effort to disabuse voters of the idea that the Liberal Party was opposed to social welfare, employees' interests, and the little man generally. This usually took the form of particularising welfare measures and condemning the Labor record, but one Liberal candidate put it: 'The Liberal Party rejects class distinctions. It is the party for ALL citizens' (Morning Bulletin (Rockhampton): 9 May 1966). Most attention focused on free hospitalisation (see pp. 210-12), but in a number of other areas the Government's record was contrasted with the A.L.P's. In a column supplied to the Telegraph (17 May 1963) Munro observed: 'We have outpaced our Labor predecessors not only in basic development but also in housing, health, education, price stability and social welfare.' After giving particulars of the Government's accomplishments under each subject, he concluded: 'On performance it seems that the socialists who offer themselves as the alternative Government in Queensland could learn a lot from the Country-Liberal Government in the promotion of social welfare.' In 1966 Chalk listed recent concessions in respect of estate duty as evidence of the Government's 'keen appreciation of the family unit and its determination to afford every aid to preserve and assist that unit', and added that there were further proposals under examination 'to give added recognition of the importance of the family unit'. After a long list of physical developments Chalk declared that the Government's policy had been conceived in the best interests of every man, woman and child in every part of this great State':

Our policy is big and broad enough to comprehend in its scope the expanding pattern of primary and secondary industries which pump the lifeblood of the economy and the great enterprises that are the muscles and sinews of a growing industrial giant in this young land.

We are also concerned with the well-being of the individual and the family unit. The achievement of all that is wholesome and desirable in health, education and social welfare weighs just as heavily with us as does the spectacular growth on the skyline of our ports and cities. We pledge ourselves to stand four square on a policy of the greatest good for the greatest number.

Most of the discussion of the Liberal Party by its opponents came from the A.L.P. Q.L.P. candidates can be divided into those who concentrated their attacks on the A.L.P. and completely ignored the Government parties, and a smaller group of those who sought to maintain some show of balance by describing the government as the lesser of two evils, but an evil none the less. The particulars of such criticism usually were that the government parties were dominated 
by business interests and pursued monopolistic policies, that they were doing nothing about unemployment, and that their policy of leaving the unemployment situation to resolve itself by the laws of supply and demand was 'heartless and inhuman' (to cite T. A. Morris, Q.L.P. candidate for Toowoomba West, in Toowoomba Chronicle: 14 May 1963). But in the main the Liberal and Country parties warranted mention only when a Q.L.P. candidate was explaining that his was a party of the centre, situated between monopolism on the right and socialism on the left.

The A.L.P. devoted considerable attention to the government parties, mainly lumping them together except in rural areas where there was an advantage in suggesting that the Liberals were using the Country Party for their own purposes. The hostile image which A.L.P. speakers sought to create for both government parties originally contained four main elements: (i) they were under the control of big business and lacking interest in the common man, two themes which could appear separately but have a close relationship; (ii) they were inefficient; (iii) they were unreliable; (iv) they were careless of State interests. In 1966 a fifth element was added: that they were disunited. Sometimes several of these elements were brought together, as when Lloyd spoke at Rockhampton:

They had sold the soul of Queensland to the big money interests of America and Japan. They were so incompetent that they had to bring in outsiders to make decisions for them. The government of the State was directed by big business interests, not by the people of Queensland. If the national assets continued to be depreciated at the present rate Queensland people would be left with nothing but a heritage of holes in the ground. (Morning Bulletin (Rockhampton): 30 May 1963)

The Government's 'sectionalism' was seen as a fundamental flaw:

Based as it is on pathetic fallacy that attention to one section of the community will bring about a $\mathrm{u}$ holesale increase in the prosperity of every section, the absurd philosophy of the Liberal Party and the political opportunism of the far less vigorous Country Party doomed this Government from its very inception. (Duggan's 1963 policy speech)

Sometimes sectionalism was used to relate business control to Brisbane dominance. Sometimes accusations that the Government was prepared to see an 'unemployment pool' were made, as in a pamphlet used in Windsor:

How doth the Tory crocodile,

Too kind for ruthless rule,

Envisage with a tearful smile

The unemployment pool. 
He bows with sympathetic grief

To 'Economic Laws'

And wrings his sopping handkerchief

And gently licks his jaws.

In his 1963 rural policy speech Duggan illustrated dominance of city interests by the fact that only one of eleven Ministers 'lives more than a comfortable two or three hours drive from Brisbane', with the inevitable result that the Government had lost contact with the people it purported to represent. The substantial financial resources required of candidates for land ballots was often instanced as proof that the Government, and in particular the Liberal Party, had no sympathy for the small man. Attacking failure to act against soaring prices, in 1966 Duggan concluded: 'This is a Government which has one law for the rich and another for the poor.' (Worker: 25 April 1966)

The inefficiency of the Government was often given point in 1963 by quoting from a complaint by the Liberal Premier of Victoria, Henry (later Sir Henry) Bolte, made at the preceding Loan Council meeting. Objecting to special funds being allocated to Queensland, Bolte said that the other States should not be penalised for the 'mistakes and mismanagement' of the Queensland Government (e.g. Duggan's policy speech and Daily Mercury (Mackay): 31 May 1963). Duggan characterised the Government's inefficiency as failure 'to maintain the development and the prosperity of this State' while bringing 'unhappiness and a lessening of the high standards of living that Queenslanders came to expect under a Labor Government'. The two fields in which most charges of inefficiency were levelled were unemployment and high prices, although Duggan himself usually added decline of industrialisation. Anticipating-correctly-the Government's defence against any shortcomings, Duggan stated in his policy speech:

This Government has failed and failed miserably. It cannot now claim that it inherited faults and handicaps from the former Labor Government. It cannot claim that its Ministers have only been a short time in office and plead for more time. It has been in office nearly six years now and it must shoulder its responsibilities.

In 1966 the A.L.P. slogan 'Why accept second best?' was usually documented by accounts of the coalition's poor performance, especially in education, but most of the running for the A.L.P. in regard to the Government's alleged inefficiency was made by E. G. Whitlam, the federal party's deputy leader. At Sarina on 15 May he claimed that federal Parliament would not debate the Queensland Roads Bill because a debate would have exposed the planning incompetence of the Nicklin Government (Daily Mercury (Mackay): 16 May 1966). At Toowoomba Chalk replied that Whitlam's attempt to decry the financial activities of the Government would be as unsuccessful as his recent attempt to unseat the party's federal leader, 
Arthur Calwell, on 27 April; Queensland had been the only State to improve its position under the Commonwealth-States Financial Agreement over the past nine years (Toowoomba Chronicle: 17 May 1966). Continuing his tour of the north, at Proserpine Whitlam charged that Queensland was getting a raw deal on roads but no one in the Government seemed able to fight back (Daily Mercury (Mackay): 17 May 1966). At Redcliffe Chalk explained that Queensland's low allocation was the result of the inertia of previous Labor governments and could be changed only very slowly; the State had done much better in special capital assistance grants than under Labor (Redcliffe Herald: 18 May 1966). Whitlam thought Chalk very sensitive on the subject and pointed out that the State had accepted a lower figure per mile of classified road under the five-year road grants agreement, it received the smallest payment per capita of the four smaller States, and in a number of respects was one down in extracting money from the federal Government (Townsville Daily Bulletin: 19 May 1966). In Cairns he added that the Commonwealth Treasury regarded the Queensland Government as a 'push-over' which could be ignored because it would not fight in its own interest (Cairns Post: 21 May 1966).

In 1966 the Q.L.P. too took a sour view of the Government's efficiency. Diplock in his policy speech declared that the Government was 'confused, frustrated by an internal power struggle . . . which has justifiably incurred the wrath of housewives, workers and farmers, by its sheer incompetence and by its repeated failures to understand, let alone solve, the problems of prices, industry assistance, and the like.' It had totally failed to understand what the Mt Isa strike had been about and was guilty of gross neglect and blunders in its handling of industrial matters.

In his 1960 policy speech (Courier-Mail: 5 May 1960) Duggan had listed fourteen pledges given by the Nicklin-Morris government in its 1957 platform and since repudiated, and in 1963 he repeated the list with the observation: 'There is [a] proverb which says that there are no greater promisors than those who have nothing to give.' Little mention was made of most of these during the campaign, save for creating a 'climate for investment in the future of Queensland' and more jobs than men, although occasionally individual candidates might pick one up-for example Colin Bennett on the failure to introduce a three-member Police Commission (p. 270).

Most 1963 criticism of overseas exploitation of Queensland's resources centred on the oil industry, and the use of Japanese pipes for the Moonie pipeline in particular, and thus involved a Country Party Minister, Evans (see pp. 202-7). By 1966 criticism on this point was wider ranging. Thus the Labor candidate for Burnett referred to bauxite, coal, and iron being exported as raw materials, and claimed: 
There is hardly an acre in the whole of this vast State over which foreign interests do not hold concessions of all mineral rights, and oldtime individual prospectors are only allowed to enter on sufferance dependent upon a reward from the company to reward them for any discoveries they may make. This surrender of our national birthright is gradually being extended to cover all our more profitable industries. A big proportion of Brisbane's bread supply is in the hands of outside capital and the motor industry is also under the control of these un-Australian influences. (NewsMait (Bundaberg): 23 May 1966)

Very little effort was made to indicate that there was disunity within the coalition. Speaking at Biloela in 1963, Duggan listed a number of instances of strain: (i) Hiley's attack on the Secretary of the federal Treasury, and the counter-attack on Hiley by Hulme, the State President of the Liberal Party; (ii) Hulme's dispute with Evans over who had arranged coal sales to Japan; (iii) the selection of John Murray as Liberal candidate for Clayfield; (iv) Houghton's changes of allegiance; (v) the dismissal of Leslie Bury from the federal ministry because he disagreed with John McEwen (leader of the federal Country Party); (vi) the dispute over preferential voting; (vii) Muller's dismissal, which Duggan thought a Liberal victory. If the A.L.P. were not united, said Duggan, the Country Party would 'hurl the minority party from the Government benches' and the Liberal Party would seek to extend into country areas, but as Labor was united Nicklin and Munro had been forced to sink their differences (Telegraph: 28 May 1963). In his policy speech at Gympie he had described the coalition as 'two diametrically opposed factions', and on another occasion supposed they were not a 'happy band') (Northern Miner (Charters Towers): 10 May 1963), but such references by A.L.P. candidates were infrequent. However by 1966 the situation was clearly different. As early as January Duggan was warning that the three-cornered contests proved that the two government parties had different philosophies, and in May his policy speech claimed that such widely divergent views had forced many compromise decisions which were followed by acrimonious exchanges in party rooms. The political marriage of convenience entered into in 1957 was now on the rocks, and there was no more than a temporary truce, save where the three-cornered contests were taking place, dictated by hanging together rather than separately. Relatively few Labor candidates made much of their windfall. In Burke, A. J. Inch asked what could electors expect from a government composed of 'warring factions' and alleged that it had been 'riven by incessant internal struggle since they took power in 1957' (Mt Isa Mail: 12 May 1966), but this was exceptional. Certainly the D.L.P. took up the point, Diplock in his policy speech saying that the government was confused and frustrated by an internal power struggle, and adjectives like 'squabbling' and 'wrangling' were tossed in by 
D.L.P. candidates. But the A.L.P., which should have been delighted to find their opponents in a mire they had regularly occupied themselves since 1957, made little of it, and press comment generally explained that the inter-party conflict, although a threat to the future of the coalition, was still confined to the lower levels of the coalition and did not touch the close co-operation of Nicklin and Chalk.

\section{The Country Party}

The image of itself which the Country Party sought to advance was much simpler than the Liberal Party's self-image, for it had only one element-achievement. Nicklin struck this note in the opening paragraphs of his policy speech and again in the concluding paragraphs:

It is with a profound sense of pride and pleasure, and with a consciousness of tasks performed faithfully and well, that I present to the people of Queensland tonight the first instalment of the Government's policy for the ensuing three years ... Our six years of office have been years of unexampled progress and development that cannot be rivalled in the history of the State. We have been the architects of that progress. The foundations of a stable and flourishing economy that have been laid, guarantee that in our own lifetime Queensland will become the greatest State of the Commonwealth. This is our proud destiny.

The fullest statements of the Government's achievements were provided in two illustrated brochures, each of 160 pages issued by the State Public Relations Bureau on the Premier's authority, entitled 'Achievement: the Country-Liberal Government Reports Progress!' (1963) and simply 'Achievement: Country-Liberal Government' (1966). These brochures were widely circulated by the Country Party during the campaign. Nicklin's foreword to the 1963 brochure gives the same message as his policy speech:

It is with a sense of great satisfaction that I commend to the reader this comprehensive illustrated summary of five years of unparalleled progress and development in Queensland under the administration of the Country-Liberal Government.

The story told here is appropriately entitled Achievement. When the present administration took office in August, 1957, Queensland was widely regarded as the Cinderella State of the Commonwealth. The Government, which I have the honour to lead, brought a new sense of vision, urgency, and purpose to the tasks that confronted it. The leadership and drive which the Government supplied gave new inspiration and incentive to the people of Queensland to work for a common objective-the realisation of the goal of making Queensland in fact as well as in the name the Queen State of the Commonwealth. 
In his 1966 foreword the Premier felt both pleasure and satisfaction, but was otherwise briefer in claiming that the summary 'shows what is attainable under able, energetic and purposeful administration'. It should be noted that the Government Printer also issues regular instalments of the 'Record of the Legislative Acts' of the State Parliament, which provide extremely useful accounts of legislation passed in a Session and incidentally an opportunity for a bit of discreet advertising by the Premier in his foreword-for example the number before both the 1963 and 1966 elections concluded with a reminder to the electors 'to elect representatives who answer to them and them alone', but these publications have a limited circulation. The two principal pieces of Country Party propaganda distributed in 1963 $(70,000$ copies) in one case devoted 90 per cent of its space to a list of particular items, and the other 100 per cent. Individual Country Party candidates followed a similar strategy in their own advertisements in the country press and their personal leaflets. In 1966 the same mixture was provided. There were now one hundred major developments under way, thirty-seven in Brisbane valued at $\$ 321$ million, nineteen in southern Queensland valued at $\$ 175.4$ million, sixteen in central Queensland valued at $\$ 294.9$ million, and twenty-five in north Queensland valued at $\$ 485.9$ million. Large sums were being spent on mineral exploration, which meant that development was achieved at no cost to the taxpayer whilst 'large amounts' were received in royalties (Camm, the Minister for Mines, opening his campaign at North Mackay, Daily Mercury (Mackay): 11 May 1966). In a widely used advertisement the Country Party proclaimed: 'The Country Party under Frank Nicklin has given Queensland a NEW LOOK. NOW the Country Party, in Mr. Nicklin's Policy Speech, pledges to ...' and listed two broad areas and two specific sorts of promise: an increased pace of development through decentralised industry and expanded educational opportunities, assisted hostel accommodation for country children, and the promises made to primary producers during the campaign, the dairy rehabilitation scheme, etc.

Pervading the lists of achievements was a feeling of pride in the State, really a Queensland nationalism, which was noticeably less pronounced in the propaganda of other parties. There was also a deliberate denial of sectionalism; to quote Nicklin's policy speech:

We have demonstrated that we are a government that plans and legislates for the welfare of all of the people of all of the State.

We have striven with a full measure of success to be a government of the people, by the people, for the people. We have not singled out any class or section of the people for preferential treatment over their fellow citizens; we have legislated for the welfare of all without fear or favour of pressure groups, lobbyists, and political log-rollers. 
In 1966 Nicklin's policy speech opened with several references to unity, and went on:

We substituted for a sectional A.L.P. Government of factions, split with conflicting hatreds and intrigues, a Government of strength and dedicated conviction which legislates for all of the people of all of the State, all of the time.

The Country Party candidate for Aubigny, S. Thorn, claimed that aIthough the Country Party emphasised that almost 80 per cent of Australian export income was earned by primary producers and that, for that reason, their prosperity was of pre-eminent importance to the economy, it was also cognisant of the needs of the working man and the businessman (Dalby Herald: 21 May 1963). In Mackay R. E. Eastment denied that the Country Party represented the wealthy farmer and grazier:

The Country Party is a middle of the road party, which stands for a fair deal for everybody, workers, graziers and business men generally. The Country Party believes a sound economy can only be built up by everybody receiving a reasonable return for their labour, not by one section of the community trying to hog every. thing. (Daily Mercury (Mackay): 7 April 1966)

The A.L.P. attack on the Country Party, the negative image of its opponent, closely followed the pattern used against the Liberal Party. The somewhat greater emphasis placed by Country Party candidates on the danger from Communist subversion of the A.L.P. led to rather more frequent suggestions that lack of a positive policy by the Country Party was forcing it into a smear campaign. Thus an A.L.P. advertisement in Mackay warned:

Why: are the Country Party so silent on high prices, high cost of living, unemployment, adequate housing for the people, free hospitalisation, education, yet so loud about Communism???

Because: the Country Party is trying to hide its complete failure to honour its promises made at the last election-and its 6 years of mistakes and mismanagement of the economy of Queensland, behind the 'scare' propaganda of Communism. Even their own have condemned them on their mismanagement. (Ibid.: 1 June 1963)

Occasionally in rural areas A.L.P. candidates claimed that the Liberal Party dominated the coalition, for example, a broadsheet by R. $\mathbf{H}$. Wenham in Warwick in 1963 headed 'Another Take Over: The Liberai Party (The Voice of Combines) takes over Country Party', but rather less use was made of such charges than might have been expected. Often they contrasted the unsatisfactory state of rural industries, which they attributed to lack of planning by the Country Party, with the benefits which Labor had brought in the past, and would bring again, by virtue of its readiness to plan. In Burnett the 
Labor candidate denied that the average primary producer had anything in common with the Liberal Party, which was dominated by big business and totalitarian in outlook (News-Mail (Bundaberg): 23 May 1966). One fighting counter-attack against charges of dictatorship and Communist-influence against the A.L.P. was made by Wenham in his policy speech:

If the opposition wants to call the Q.C.E. dictators, then I am going to ask them who were the boys who framed the policy and dictated it to our Coalition Government, the policy that caused Alf Muller to resign his portfolio from the Government of the day.

I do not know of any more glaring example of dictatorship as in this instance. To every elector in Queensland today it must be known that it was the big land holders and the powerful combines of the West that framed that policy and wielded the stick, and caused that policy to be implemented. These are the boys that are framing the policy of the Liberal-control Government and these are the boys who will enjoy tax reductions as promised by the Premier a few nights ago. These and big controlled combines are the ones running berserk and forcing the small farmer, the small business men and the wage earner back into the age of the peasant. They worship no god; they only worship money, greed and power, the mother, father, sister and brother of Communism. (Warwick Daily News: 17 May 1963)

The A.L.P.

The A.L.P. sought to compose its own image of two main elements, humanitarianism and dynamism. In his 1963 policy speech Duggan gave Labor's pledge 'to achieve social justice and peace and prosperity for all, regardless of class, race or creed' by relieving unemployment, raising standards of living, safeguarding the family, providing a future for children 'in which they have the opportunity and the incentive to live a full, satisfying life', and providing for the aged and sick. One A.L.P. slogan was simply 'Vote A.L.P. in '63', but the other was 'Life is Best with Labor'. One of the biggest A.L.P. advertisements (Sunday Mail: 2 May 1963) showed three housewives in a super-market with the text:

Only Labor will ensure . . Family Security * State Development * Free Hospitals * Benefits for Aged * Equal Pay* Adequate Housing * Full Employment Including jobs for School Leavers * Education from Kindergarten to University,

and a photograph of Duggan with a quotation: 'Every Queensland family has the right to full employment, free hospitalisation, decent housing and a proper education-I give my pledge that under a Labor Government, we shall achieve this-and more' A coloured brochure 
distributed widely presented the identical message. A broadsheet used widely showed a group of men and women of different walks of life, marching in file, with the caption: 'Going somewhere? go with A.L.P. in '63; destination: prosperity, via jobs, education, housing prices.' In a message directed to the women electors of Norman (it included recipes for peanut paste cookies* and oat cakes) Fred Bromley wrote:

Once again, it is our privilege to bring to your attention the high ideals, coupled with absolute honesty, and the never failing desire to raise the living standards for you and your family; these are the real principles which govern every action of the great mass of people who are the natural representatives of the great Australian Labor Party. These representatives are people who know and understand all the problems which every working family have to live with. These are the people who, through their own experiences, understand your hopes, your fears, and feel with you your own private ambitions.

Bromley went on to promise full employment, more education, and good health services under a Labor Government. Advertising for campaign donations the campaign director in Gregory put it simply: 'Labor's cardinal principles are a better standard of living for all' (Western Times (Charelville): 14 April 1966). In Bundaberg M. D. Tallon claimed:

Family Protection is undoubtedly and unquestionably best served by a Labor Government. Labor never fails the breadwinner, the housewife, the mother and her children. Yes . . . a Labor vote is indeed a vote for the family. (News-Mail (Bundaberg): 11 May 1966)

The element of dynamism was provided in part by Duggan himself (see p. 89), partly by the things he promised to do.

It is not enough to talk of our great potential or bandy golden words about the Queen State. Action is required. Performance will be the yardstick-not flowery promises or ballyhoo contained in expensive Government booklets.

Sometimes the past services of the A.L.P. were brought into the picture. Fred Newton, standing for re-election in Belmont, pointed out that on the four occasions since Federation when Australia stood at the cross-roads of destiny-two wars and two depressions-the people voted out the Tories who were in power and put in an A.L.P. government. Duggan in the Gympie half of his 1963 policy speech gave a long list of some of the advances pioneered by A.L.P. governments in areas outside Brisbane with the result that Labor candidates had been elected in many rural constituencies.

Finally the A.L.P. had to try to disabuse voters of the idea that

* In Queensland it is illegal to label peanut butter as such and it must be called peanut paste, a matter of much concern to dairymen. 
it was subject to outside control, and that this control was in the hands of Communists. Duggan dealt with the first allegation in his 1963 policy speech (but ignored it in 1966):

The pattern of the campaign has already revealed that the Government, together with the Press, is endeavouring to poison your minds with the idea that if a Labor Government is elected, we will be subject to irresponsible direction from elements outside Parliament. These charges obviously refer to the A.L.P. Branches and the Trade Unions affiliated with the Labor Party, who are responsible for the formulation of Labor policy every three years.

Every political Party has similar conferences and their policies are fashioned in a similar manner. The Labor Party makes no apology for the fact that its general policy is determined by the rank and file. There could be no more democratic way and it is the responsibility of the elected representatives to use their skill and experience in developing schemes and proposals within the ambit of the policy laid down.

Except on the three weeks' leave issue, there has not, in my memory, been a direction by the Q.C.E. to the Parliamentary Labor Party.

I can give my strong assurance that if elected to power we shall exercise our authority intelligently, with restraint and discretion, as well as an awareness of our responsibilities to the people generally and the State as a whole.

The problem of Communist influence was more difficult, and most candidates ignored it-or charged that it was a trick:

The wise thinking people of the State realise that between the Communist Party and the Australian Labor Party there is an unbridgable gulf. Now you all know the truth. For years Menzies relied on the Communist bogey to cover up his neglect of Queensland. The people woke up to him in the 1961 elections and he is only in office now on Communist preferences. The Country Party is doing the same today. Treat them the same way. (A.L.P. advertisement in Daily Mercury (Mackay): I June 1963)

An alternative approach was to list the A.L.P. policies which differed from the Communist line: loyalty to the Crown, membership of the Commonwealth, support for the United Nations, SEATO and ANZUS, a negotiated settlement in South Vietnam, recognition of mainland China ('in common with all Western governments except the U.S.A.'), opposition to H-bomb testing, according to Peter Wood (Toowoomba Chronicle: 7 May 1966).

Consequently, I am anti-Communist. I oppose Communism in all its insidious forms. (Morning Bulletin (Rockhampton): 3 May 1963)

On tour at Townsville (Townstille Daily Bulletin: 9 May 1963) and Mackay (Daily Mercury: 9 May 1963), Duggan dismissed the old 
Communist bogey as nothing to be afraid of, and unworthy of the Premier. He would repudiate, as would every A.L.P. candidate, any suggestion that the A.L.P. had any connection with, or any belief in the doctrines of, the Communist Party. It was significant that the Communist Party nominated its candidates only in seats the A.L.P. held or could win easily. In Mackay he declared:

We don't want Communist votes, and we don't want to be linked with them in any way regarding their aspirations, ideals or policy .. The great majority of Australians reject Communism as I and the A.L.P. do. It is significant that the three Communist candidates in this election have been nominated in areas where they will damage the Labour Party. I repudiate any suggestion that in our policy or decisions we are influenced in any degree by the Communist Party.

At the end of the campaign Duggan said that he would be disappointed if voters swallowed the sort of advertisement which showed the shadow of the hammer-and-sickle falling on Parliament House, and asked voters to remember that none of the A.L.P.'s political opponents had been able to name one Communist within the A.L.P. Nor could he, for there were none. The bar to Communist parliamentary representation was a 'strong, virile and united Labour Party, dedicated to the needs of all sections of the community, regardless of race or creed, and regardless of income or status' (Toowoomba Chronicle: 31 May 1963).

The hostile image of the A.L.P. propagated by the government parties contained two ingredients, that the parliamentary A.L.P. was dominated by the Q.C.E. which was dominated by Trades Hall which was dominated by Communists, and that the A.L.P. was committed to Socialism which had caused stagnation in the past and would ruin the State in the future. The Q.L.P. image of the A.L.P. conformed in all but the last particular, the Q.L.P. arguing that Labor had not been Socialist in the past but would be if the present leadership retained control of the A.L.P. The government parties also attacked the A.L.P. claim to a monopoly on humanitarianism-it was a fake, and condemned A.L.P. candidates in general, and Duggan in particular, as a lot of wailers and knockers. In 1966 inability to keep its promises was added to the indictment, Nicklin describing the Labor policy speech as a reckless attempt to buy votes without any consideration for the cost of the promises involved, and Chalk as 'meatless, with pie crust promises . . . made in such a way that they could be broken in due course' (Telegraph: 5 May 1966). Extravagant promises to lure the workers' votes could depress industry and return the State to the days of Labor rule when investment capital would not touch Queensland with a forty-foot pole.

Proof of outside control of the parliamentary leadership rested on 
the events of 1957 and Duggan's radio broadcast acknowledgment that in the last resort he would be bound by Q.C.E. rulings. Nicklin in his 1963 policy speech commented:

If he became Premier he would have to carry out the policy dictated to him no matter how illogical, irresponsible, and economically perilous it may be. He will have in the shadows behind him the trigger men and the hatchet men who were the political executioners of Mr Gair.

He will have to do what he is told, or pay the penalty.

The dictators of the policy of the Labor Party-the policy that will be implemented by Labor Governments, whether they be Federal or State,-are men who are not responsible to the voter in any degree whatsoever.

Nicklin explained the immediate significance of outside control in another passage in his speech: Duggan might give an assurance that a Labor government would not socialise the oil industry, but his assurances were worthless-'He is not in a position to give undertakings and assurances for the A.L.P. because he is only the mouthpiece of the real leaders of the A.L.P., the Leftist Q.C.E. inner executive'. Therefore if Labor gained office, Queensland could forget about becoming a commercial oil-producing State. Bjelke-Petersen made the same point in 1966: no Labor candidate was free to carry out any particular policy which might be in the interest of the people, and Whitlam's efforts to get free of his shackles had failed (South Burnett Times (Kingaroy): 25 May 1966); and Chalk reiterated it in his policy speech. While the events of 1957 might have become a little stale in the public's mind by 1963, events at the A.L.P. federal conference at Canberra in March helped freshen them with photographs of the A.L.P. parliamentary leader and deputy leader waiting outside a hotel while the Federal Conference decided the party's stand on an Amercian base at North West Cape. Indeed the Queensland Liberal saw a pattern between the events of that evening and events at the Bundaberg Laborin-Politics convention when the Convention failed to appoint Lloyd to a vacant delegateship despite Duggan's intervention on his behalf:

What does this deliberate campaign of humiliating Labor's Leaders show?

It shows up as an integral part of the Communist plan to weaken and bring into disrepute all phases of our Parliamentary democracy. It is part of the essential 'softening up' process for democracy's overthrow.

That is the long-term aim. But the short-term implication is perhaps even more serious. These recent events prove beyond all shadow of doubt that at any election from now those who vote Labor will not be voting for the Labor men whose names are on the ballot paper. (Vol. V, No. 45, April 1963)

The Country Party took up a statement by the president of the 
United Graziers' Association and publicised it widely with the advice 'Keep the new Queensland safe for your family':

You may not like some of the things which this Government has done, but I urge you again to think deeply just what the alternative is likely to be-a government which runs the risk of being dictated to by a bunch of communists ... (Sunday Truth: 22 May 1966)

The second step in constructing this part of the unfavourable A.L.P. image was to look at the powers behind the parliamentary leadership. Again Nicklin in 1963:

The dominant voice among this undisciplined chorus of voices is that of the Trades Hall oligarchy which exerts a malignant influence over political and industrial Labor out of all proportion to its official standing in the Labor movement. Mark these men well and write them in your books! In this select company where the real left wing leadership of the A.L.P. is to be found, Trades and Labour Council President Mr Jack Egerton, secretary of the Boilermakers' Union and a member of the inner circle of the Q.C.E., is the Big Boss, the would-be 'kingmaker' of Queensland Labor politics. He has made plain his notion that Labor politicians are merely the servants and the mouthpieces of the trade unions-a prophecy of what the people of Queensland may expect if they are unwise enough to elect a Labor Government to power in this State. It will be a government of puppets, a Punch and Judy show manipulated by the left wing controllers of the A.L.P.

Egerton figured in a number of Liberal advertisements, a sinister figure behind Duggan, though in $1966 \mathrm{Dr}$ Delamothe also referred to him as the puppet President of the Trades Hall by grace of Gerry Dawson, the well-known Communist' (Bowen Independent: 20 May 1966). A Country Party advertisement placed in every newspaper in 1963 warned of the choice between government from Parliament House-the Country Party team led by Frank Nicklin is a team of Parliamentary members who are free to think, speak and act in the interests of Queensland, they are not subject to, nor do they accept, outside dictation', with government from Trades Hallwhich ran the Labor Party:

The Parliamentary Labour Party openly accepts dictation from the Trades Hall (wise or unwise, right or wrong). The Trades Hall pro-Communist policies will nationalise the oil and other industries-the Parliamentary Party is impotent to resist (A.L.P. pledge). The Trades Hall dictators are not elected by the people. They are a menace to our way of life and must be kept away from Parliament House, Queensland's seat of Government.

In Gregory Wally Rae contrasted the freedom he had enjoyed to stand up to a Minister in pursuit of his constituents' interests: 
If I had been a member of the Australian Labour Party on the Q'ld Parliamentary benches and had attacked my own Ministers the way I have, I would not be around today. The 'hatchet' men in the back room of the Q.C.E. would have severed my political career.

These men, these 'hatchet men' of the Q.C.E. who we all know have no qualities of manliness as we in the West know them, qualities of hardihood, endurance and tenacity, but are ever willing to beguile and betray, to smash and to destroy in order to wreak their wicked way ... I say to you my friends that the only difference between these men of the Q.C.E. and the Storm Troopers of Adolph Hitler is that these men wear a civilian suit. (Western Times: 26 May 1966)

If the Q.C.E. controlled the parliamentary party, so Trades Hall and its Communist bloc controlled the Q.C.E. Again the Queensland Liberal:

The body controlling the Labor movement in Queensland is the Queensland Central Executive (popularly referred to as the 'Q.C.E.') of the Australian Labor Party. Of its 68 members, no less than 56 are either avowed Communists, known pro-Communists, or fellow-travellers of long standing.

The Trades Hall group has complete and virtually unchallenged domination of the Q.C.E., and this group has nothing but Communists and pro-Communists in all its major positions. Secretary to the Trades and Labor Council is Alec MacDonald, a dedicated and avowed Communist of long standing.

With him are such men as Messrs J. Egerton, F. Nolan, B. Milliner, G. Dawson, J. Daley, W. Fahy, C. Boland, J. Fitzgerald, H. Field, F. MacDonald, E. J. Hansen, T. Millar and others. The weekly Communist newspaper 'Guardian' editorialised on the election of these men in terms of complete satisfaction . . . And above them all towers the figure of F. E. Chamberlain, Federal A.L.P. Secretary, the most powerful Labor figure in Australia today. A Left-wing Socialist from England, Mr Chamberlain controls the Parliamentary wing and makes and breaks Labor Governments with impunity. (Vol. V, No. 46, May 1963)

Most of the men named were members of the Trades Hall executive, and the Q.L.P. used a photograph of an executive meeting (Sunday) Mail and Sunday Truth: 26 May 1963) under the caption: 'Cabinet Meeting? Communist and A.L.P. Members of the Trades Hall executive work together in perfect harmony', and above another: 'These men would rule an A.L.P. government in Queensland'. In 1966 a similar calculation was provided by the Q.L.P. The Q.C.E. was dominated by forty-four left-wing delegates, almost all of whom were on the Trades and Labour Council, which was Communist controlled'Its boss is full-time secretary, Mr A. MacDonald, a Communist. Its policies are quite often straight lift-outs from the Communist Party 
platform.' Q.C.E. delegates from the unions were forced to conform to Trades Hall policies under threat of Communist opposition in union elections.

It is not necessary, then, for the Communist Party to have undercover members in the A.L.P. in order that the A.L.P. be brought under Communist control. It is sufficient that the A.L.P. Parliamentary wing be committed to follow pro-red policies and be under the direction of an outside body which can be trusted to guide the actions of the A.L.P. Caucus or Government along approved lines. (Courier-Mail: 24 May 1966)

Chalk made much the same point in the concluding passage of his policy speech:

There can be no future for you or for Queensland with a Duggan Government puppetted by a leftist group in the Australian Labor Party. The malignant influence of Communism which pollutes our Australian way of life continues to infiltrate through to the Queensland Central Executive of the Labor Party. Alex MacDonald -an openly avowed Communist-a member of the Central Committee of the Communist Party in Australia-remains Secretary of the Queensland Trades and Labor Council. Trade Unions which belong to the Trades and Labor Council are a dominant group on the Queensland Central Executive of the Labor Party and a major influence in framing Australian Labor Party policy.

The consequences of an A.L.P. victory, given such evil influences, were seen in the direst terms. Thus the Speaker, D. E. Nicholson, told a Country Party meeting it was alarming that a small group of men could destroy Queensland's living standards and everything that was being built for the future of the State's children-as had happened already in Cuba, Hungary, and East Germany. Such an influence was already at work in the Moura strike, and the slow and patient encroachment of left-wing influence could be the death of everything Queenslanders enjoyed. They should not lose sight of the fact that they belonged to a highly privileged country with the world's highest standard of living 'and must not allow themselves to be dragged back to the sub-standard level in which opinions and freedom to move and work where they liked, and even their lives, could count for nothing' (Dalby Herald: 8 March 1963). In 1966 the Mt Isa strike was cited as evidence of the dangers of a divided Labor Party and of left-wing control:

It is estimated that the Mt Isa 'strike' cost Townsville about $£ 4,000,000$ in lost trade, unemployment, etc., because it was allowed to drag on, long after all the industrial issues had been settled, mostly in the men's favour, because of the dog-fight between the two Labor Party factions who were struggling for power. Yet these warring factions ask you to believe that they are fit to govern this State. (Townsville Daily Bulletin: 19 March 1966) 
Communist-dominated unions made exorbitant demands for high wages and site allowances to create turmoil, frustrate northern development, and damage the State's economy (Daily Mercury (Mackay): 28 April 1966). Ingeniously, a Country Party advertisement asked why had the A.L.P. and the trade unions opposed the federal government's scheme for adult apprenticeships, and supplied the possible answers that they might resent an opportunity for the unskilled worker to improve his lot or that a shortage of unskilled workers would break their power to disrupt industry and sabotage northern development (ibid.: 24 May 1966). Capitalising on the A.W.U.-Trades Hall bitterness in the north, Dr Delamothe complained that Duggan took so much 'stringing together his promises to the Craft Unions of Brisbane -right or wrong, wise or unwise, the edict of Trades Hall had to be obeyed' that nothing was left for the north. Chalk made a similar point when he claimed that Duggan had to give his rural policy speech at Nambour so that 'the Trades Hall group would neither know much about it or be in the audience when it was delivered' because of the incompatibility of price control over farmers' produce and wage rises for industrial workers.

Q.L.P. proof that the A.L.P. was Communist-controlled rested on two bodies of evidence, official A.L.P. policies which coincided with Communist policies, and statements and actions of individual prominent members of the A.L.P. In respect of policy similarities, the Q.L.P. case ran:

Listed below are the parallel policies of the A.L.P. and Communist Parties. It must be stressed that such 'unity of purpose' never existed prior to the infamous A.L.P. Federal Conference held in Hobart in 1955. These parallel policies did not exist in the A.L.P. when Ben Chifley and John Curtin were leaders.

They have been introduced into the A.L.P. by Communist intrigue through their control of unions affiliated with the A.L.P. . . . The Communists' policies have been designed to bring this country under the heel of international Communism. If A.L.P. policy is nearly the same, it could have the same result. (Standard: 1 May 1963)

The list of policies covered the fields of foreign policy and industrial policy, six in the first and three in the second-recognition of Communist China, support for admission of Communist China to the United Nations, change of SEATO from a military alliance, withdrawal of Australian troops from Malaya, reorganisation of the Australian armed forces for defence and use as a peace-keeping force under the United Nations, establishment of a nuclear weapons-free zone in the Southern Hemisphere, repealing the 'clean ballot' legislation affecting union elections, abolition of the penal clauses in the Arbitration Act, and preventing the industrial groups' work against Communists in the unions. 
In fact, A.L.P. policy was that Australian troops should remain in Malaya only under a treaty between the two countries, but it was never made clear what would happen if, as the Prime Minister contended would happen, Malaya refused to enter into a treaty which would affect her non-aligned position; after the State election an article by the Queensland A.L.P. journal's foreign affairs commentator stated that even if a treaty was concluded 'we cannot agree to defend such a state as Malaysia, particularly against the onslaughts of its own repressed inhabitants' (New Age: 25 September 1963), and this opinion was never repudiated.

The allegations and imputations of actions and statements in 1963 included: (i) a Miner's Union officer, now on the Q.C.E., had been a Communist Party organiser; (ii) an A.L.P. candidate is Brisbane had stood on a unity ticket in a waterside workers' election; (iii) ten State parliamentarians, including Duggan and Lloyd, had made donations to a Peace Committee which was a Communist front; (iv) at least seven unions affiliated to the A.L.P. had Communist officers; (v) Egerton had written in the Building Worker in October, 1959: 'I have seen Socialism growing and developing in Communist China and I wish that Australian workers had the same opportunities as the Chinese'; (vi) Frank Waters had said: 'It is my firm conviction that the Queensland Labor Movement will gain in strength and virility by the affiliation of the Communist Party to the Australian Labor Party', the statement being attributed to the Warwick Daily News usually without a date, but apparently during May 1954; (vii) the Communist Guardian had instructed party members to give second preferences to the A.L.P. in those electorates where Communist candidates offered and first preferences to the A.L.P. in the rest-the point was often made with a photograph of N.S. Khrushchev and the caption 'If Khrushchev had a vote on June lst he would vote A.L.P.'-in 1966 the same point was made in Townsville where Communist preferences were directed to Perc Tucker, and Bonnett took it 'as further proof of my statements that the Communists desire a Socialist Government in power to further their own plans' (Townsville Daily Bulletin: 14 May 1966); (viii) comments about Communist influence on the Queensland branch of the A.L.P. or the Brisbane Trades Hall from Packer publications in Sydney, the Bulletin and the Daily Telegraph, and the A.W.U. journal, the Queensland Worker, usually with the caption 'You don't believe it? Can you disbelieve these expert opinions?'; (ix) Frank Nolan of the Q.C.E. and a delegate to the Federal A.L.P. Conference had been made an honorary member of the Young Pioneers on a visit to Russia in 1959-usually illustrated with a picture of another Young Pioneer (female) hanging the camp sash around Nolan's neck. Most of these items were collected in one leaflet, given very wide distribution, entitled 'Here is Positive Proof of Communist Influence in the Aus- 
tralian Labor Party'. In 1966 the war in Vietnam was added. Australia's independence was threatened as in the $1940 \mathrm{~s}$, but the danger was greater, for the Communists had a ready-made fifth column which the Japanese had lacked. The domino theory was evoked: once the Japanese had occupied Indochina, Thailand capitulated, which led to the fall of Malaya and Singapore, and within three weeks the Japanese had overrun Indonesia and were at Lae and Salamua. Australia would have been conquered but for the United States:

Today the U.S.A. was fighting to defend South Vietnam against aggression by the Communist North. The Australian Government had committed Australian troops to assist Australian allies in Vietnam. The Communists wanted these troops withdrawn, because their aim was to conquer the whole of S.E. Asia, including Australia, as the Japanese had planned to do. The Communists in Australia, by their control of unions, had committed the A.L.P. to withdraw these troops from Vietnam. Every vote for the A.L.P. whether it be in a State or Federal election, was a vote to weaken Australian-American alliance. (J. T. Kane for the federal D.L.P., Evening Advocate (Innisfail): 10 May 1966)

There remained the difficulty that some non-Communists could be seen within the A.L.P. In his 1963 policy speech Hilton explained:

We do not make the exaggerated statement that all members of the A.L.P., either in or out of Parliament, are sympathetic to the Communist Cause. However, it must now be crystal clear to sincere Labor supporters who do not believe in the Marxist concept of society, that the time has arrived for clear thinking and positive action to remove the cancerous growth that has developed in the once great Australian Labor Party.

When Duggan declared that he did not want Communist support, his Q.L.P. opponent in Toowoomba West, retorted:

What would be news was if Mr Duggan took some action to rid the A.L.P. of this embarrassment. When $\mathrm{Mr}$ Duggan begins to actively fight Communist influence in the A.L.P. by demanding the expulsion of those members of the A.L.P. who combine with Communists on unity tickets in union elections, we shall begin to cease to doubt his sincerity. When he takes steps to reinstate the industrial groups to fight Communists on their own battle ground in the trade unions we shall be prepared to admit that his assertion that he does not want the Reds may have real meaning. (Toowoomba Chronicle: 16 May 1963)

Campaigning in Warwick, Virgil Morgan of the federal D.L.P. agreed with Duggan that there were no Communists in any Australian parliament because there was no need to bother when they had no difficulty in finding collaborators in the A.L.P. and were more successful in achieving their objectives that way. In Europe they were less successful in penetrating Christian Democratic parties, and had to run 
candidates of their own (Warwick Daily News: 24 May 1963). Without further documentation the Queensland State branch of the A.L.P. was blamed for the policies of the federal A.L.P. which would isolate Australia from the United States and 'sell us out to a foreign communist power' (Daily Mercury (Mackay): 2 May 1966).

The complaint that the A.L.P. was Socialist was handled in much the same way by the government parties and by the Q.L.P. A statement in the Queensland Liberal (Vol. V, No. 44, March 1963) commenting on the Bundaberg Convention can speak for them both:

The great wounds in Labor's body prove beyond any reasonable doubt that today's Labor Party has very little in common with the party of that name which existed years ago. The people of Queensland were prepared to accept the Socialist policy of the A.L.P. when Governments were led by men like Forgan Smith, Cooper, Hanlon, Gair and others because they were certain that these men weren't Socialists. And events proved the people were right in this belief.

But it's different today.

The Labour Party is now utterly in the hand of coldly calculating professional Socialists, men who see their role as the use of Labor's Socialist platform to pave the way for Communism.

Queensland voters can put aside the comforting old theory that 'Yes, Labor's Socialist, but they won't introduce Socialism.' Today Labor is Socialist and will introduce it as part of the softening-up for the entrance of the grand Communist plan.

The State Secretary of the Country Party, pointing out that all A.L.P. candidates were pledged to support and advocate the socialist objective, explained: 'There was no difference between a socialist state and a Communist state, for they were both totalitarian and aimed at planning all production, which meant the regimentation in the State of every animate being and their production' (Toowoomba Chronicle: 29 January 1963). However there were some disagreements as to just how Socialist past Labor governments had been. Nicklin in his policy speech thought that they had been sufficiently Socialist to have induced economic stagnation:

There was a welter of lip service to development and there was much grandiose planning in the true image of Socialist doctrinaires, but all their 'enterprises of great pith and moment' lost the name of action in a windy wilderness of words.

Not only did Labor Governments fail to bestir themselves to quicken the sluggish tide of development-they effectually discouraged private enterprise from doing so.

In the money markets of the world Queensland was written off as a prospective field for investment. Capital investment and enterprise was frozen out of the Sunshine State by excessive company taxation and the incipient threat of Socialisation, and retreated to southern States where the climate for investment was more hospitable. 
E. G. W. Wood, offering for Logan, recalled his own service with the State Lands Department in those lean years of the Labour regime when the dead hand of Socialism had control' (Beaudesert Times: 13 May 1966). Sometimes the A.L.P.'s socialist record was spelled out in some detail, as by R. A. Armstrong addressing the annual meeting of the Babinda branch of the Country Party:

For many years the A.L.P. has been a socialistic party, pledged to the nationalisation of production, distribution and exchange, which indeed if fully implemented spells total nationalisation or socialism or, in other words, a Government monopoly run by Government employees or even good party supporters appointed for that purpose.

Over the years the A.L.P. politicians and the outside governing body of the party have had mixed feelings on this matter and we in Queensland were early victims of socialism at their hands, and indeed are still paying for it. We had State stations, State butcher shops, State sawmills, State coal mines, State smelters, State copper mines and State hotels, etc., and not long ago we embarked on a further State enterprise with the then British Labour Government -the Peak Downs enterprise.

All of these ventures lost millions of pounds and in addition to depriving the State of moneys needed for such works as schools, hospitals, roads, water conservation and other essential services, did not pay local authority rates, or taxes to general revenue as private enterprise would have done.

Then we remember the Chifley Federal Labour Government's attempt to nationalise the private banking institutions in 1949; so you see, for the last 40 years the A.L.P. from time to time has made attempts to try to put their socialistic policy into practice to the detriment of this State. (Cairns Post: 30 March 1963)

Sometimes it was a matter of a simple appeal: a vote for the Country Party will be a vote against nationalisation and for continued development (A. M. Hodges' advertisement, Gympie Times: 10 May 1966). One old grievance was raised by Hodges at Gympie: a vote for him would be 'a vote against Labour's Stand and Deliver Act, an Act to force the Primary Producers to Produce and Deliver their product, and Labour will decide how, when, where and at what price a commodity may be marketed' (Gympie Times: 12 May 1966). The Act had been passed in 1951 to meet a 'strike' by dairymen to withhold produce in protest against price control. The Labor governments of the past had even painted all government buildings, schools, court houses, police stations, railway stations, the lot, one colour-'stone', whereas the Nicklin Government

decided to add some variety into the appearance of public buildings-in design as well as colour-but it was this very spirit that brought a completely new approach to all matters of government and an air of fresh enthusiasm to all departments, making them 
eager to see Queensland bound ahead. (Country Party advertisement in Daily Mercury (Mackay): 20 May 1966)

Speaking to the Gordonvale branch's annual meeting R. A. Armstrong wondered whether the drift of migrants from Queensland might not be explained by their early recognition of the trend of left-wing influence in the State 'leading back to the darkness of suspicion, control and regimentation' (Cairns Post: 18 April 1963). In 1966 Government spokesmen had convenient ammunition from the difficulties the new Labor Government was experiencing in South Australia, but only John Herbert made use of it, claiming that his Government's prediction that industrial development would grind to a halt if Labor won the election had been justified by trends in South Australia. He cited a survey conducted by the South Australian Chamber of Manufactures which found that investors' confidence had been depressed and not one new industry had been gained by the State since Labor came to power because of increasing costs, worsening industrial relations, and the trend of legislation. The rush of projects to Queensland once Labor had been put out in 1957 made the same point (Telegraph: 27 May 1966). The Q.L.P. perforce denied that the A.L.P. had been Socialist before the split, or that the State had stagnated under the Governments whose lineal descendant it claimed to be. Indeed in 1966 Diplock claimed that 'the fruits of the careful planning of an earlier Queensland with which as a Cabinet Minister I had the honour to be associated, are now being harvested'.

Liberal attacks on the falsity of the A.L.P.'s claim to be the humanitarian party have already been quoted (p. 30). Nicklin added his opinion at Mackay:

But the A.L.P. now stood dismayed that we have unmasked them.

We have exposed the fallacy that they were the only party which had concern for humanitarian services. They cannot match us in the great improvements we have made in the health, medical and education services, housing and the important reforms we have effected in the field of workers' compensation, which was something in which Labour always prided itself. (Cairns Post: 20 May 1963)

They were spelled out in particular electorates with details about local hospitals, local schools, special allowances and arrangements for pensioners. A promise for the future, such as free textbooks in 1966, was irresponsible, Nicklin declared, made careless of 'whether the cost would be $\$ 2$ million or more'.

The complaint that the A.L.P. was a party of wailers and knockers was first made when Duggan replied to the Treasurer's start-of-the-year claim: 'We've never had it so good' with the comment:

The breaking of the drought, lush pastures and record crops are facts for which no political party can claim credit. With an election in the offing, it is to be expected that Queenslanders will be given 
the usual 'razzle-dazzle' about our great potential, return of confidence and the magnificent effort of the Government in accomplishing these things. (Toowoomba Chronicle: 5 January 1963)

and went on to point out that massive Commonwealth finance had been poured into the State, together with the proceeds of the 'booze and betting' legislation. He contrasted Hiley's optimism with the Premier's statement at the Loan Council six months earlier that massive assistance would be necessary to bring Queensland up to the other States. The Queensland Liberal (Vol. V, No. 43, February, 1963) quoted a number of statements about good conditions, then retorted:

In this rousing chorus of faith and enthusiasm there is one discordant note. As might be expected, it comes from a prophet of doom who has a vested interest in disaster and distress.

This is the A.L.P. State Leader (Mr J. Duggan) who sees in this picture of Queensland's great potential and return of confidence nothing but 'razzle-dazzle'. This is the knocker attitude carried to a ridiculous and pathetic extreme, and illustrates the desperate poverty of a party which sees no prospect of winning an election with a buoyant economy and must therefore try every shabby trick to depress, to confuse, to dismay and to disturb.

Labor, irrevocably tied to the left-wing, has a depression complex. It does not want success or growth for Queensland, for eager people with their eyes firmly fixed on a glowing future are poor prospects for socialism's dismal tenets.

Following the world-wide pattern of Communist action, Labor wants to fish in the muddied waters of depression and despair, and its real pattern of action is aimed at wrecking prosperity and sabotaging progress.

In 1966 the sharpest attack on Duggan as a knocker was provided by the Courier-Mail's editorial on his rural policy speech:

An outsider listening to this catalogue of complaints and timid suggestions would not imagine that Queensland is one of the great pastoral and agricultural areas of the world. Queensland is a young and growing giant-not, as this speech would suggest, an elderly Weary Willie needing crutches and medicines. (6 May 1966)

The Q.L.P.

The Q.L.P. as the newest and weakest of the major parties (in the sense of offering a sufficient number of candidates to form a government, alone or in coalition) had the most difficult task in constructing its own image. The first element employed was that it was the most effective party in fighting Communism, the second that it was a middle-of-the-road party, the third that it was the heir to the traditions and achievements of moderate Labor. In rebuttal of an allega- 
tion which was hardly ever made in print the Q.L.P. denied that it was sectarian, i.e. a Catholic party or controlled by the National Civic Council. However, on one fundamental point, the present and future role of the Q.L.P. in the Queensland party system, spokesmen differed and considerable uncertainty appeared.

In his 1963 policy speech Hilton quoted the principles of action incorporated in the Q.L.P. constitution 'since 1957'. The first three were loyalty to the Throne, the maintenance of parliamentary government, and the prevention of the subversion of Parliament by persons not responsible by elections to the people. The fourth was "Active, continuous and unyielding opposition to Communist and any other ideologies which are subversive of, and a threat to, the social, economic, political or Christian way of life of the Australian people'. In an earlier passage he declared:

Our final objective is a united Labor Party, willing to fight on all levels the evil philosophy of Communism and its application to society and also fighting for a just Social Order. We believe without doubt that this evil of Communism is the greatest disturbing factor and the greatest menace to peace in the World of our time. With equal emphasis we believe that the intrigues of the Communist Party have dealt the Australian Labor Party the greatest blows it has ever suffered.

While in federal politics the D.L.P.Q.L.P. often attacked the Menzies government for complacency in the face of the internal and external threat of Communism, in State politics such a charge against the Nicklin government was less meaningful. Owen McGane, Q.L.P. candidate for Bowen, pointed out in a mimeographed open letter to electors in 1963 'No other Party places so much stress on our security nor guards against the infiltration of the Communists in our Society', while in a leaflet in the same campaign he asked:

Do you want a government which permits the Communists to victimise trade unionists and drive them off the job, by refusing to supply the protection of the law? If you do-vote Lib.-C.P.

Do you want Queensland to be run by men who do not encourage genuine anti-communists?

If you do-vote Lib.-C.P.

Contributing a column to the Telegraph (15 May 1963), Hilton remarked that during a recent television interview one of the interviewers had drawn attention to the fact that he, Hilton, had five times brought Communism into the discussion without being asked about it. Such a comment, he remarked, was the sort of thinking that made the Q.L.P. necessary.

The Q.L.P. strategy was stated:

This is the problem:

1. The Menzies and Nicklin Governments are safe while Labor is hopelessly divided. 
2. The A.L.P. must not be allowed to govern while it is subject to Communist control.

This is our solution:

1. Keep the A.L.P. out of office until it throws off Communist control and repudiates Red policies.

2. Press for the re-unification of the non-Communist section of the A.L.P. with the Q.L.P./D.L.P. in a strong Labor Party, which is socially progressive and free of Communist intrigue.

Your Q.L.P. vote will help do this:

1. Bring about the isolation and defeat of Communism.

2. Hasten the re-formation of a great Labor Party.

3. Return strong Labor Government to Office in Queensland and Canberra. (Sunday Truth: 26 May 1963)

Morris put the case for the Q.L.P. as a middle-of-the-road party in Toowoomba West. As the Q.L.P. candidate he was the only one who could state that his party had no dictatorial hold over him and did not have sectional interests; the wage-earner, small businessman, farmer, family man, and housewife were all catered for by the Q.L.P. policy, and such electors were the only people he would have to obey (Toowoomba Chronicle: 13 May 1963, 16 May 1966). At another meeting he set out the Q.L.P. policy of moderation:

A vote for the Q.L.P. tells the moderate A.L.P. forces to jettison Communism and extreme Socialism, and with the Q.L.P. to build the only type of Labour Party that can win a majority in this State. That is: A decent, progressive moderate party in the best traditions of Labour; a party built on democratic rules and procedures; and a party in which are united people of all religions fighting the Communist threat to our freedom.

The Queensland Labour Party is not a Socialist party. We believe in the social utilisation of the nation's resources, and in this we hold firmly and strongly to the true Labour tradition. We declare ourselves against full-scale Socialism, which suppresses individual freedoms, denies the right of private ownership, and aims at concentrating absolute control of ownership, manpower and credit in the hands of the State. (Ibid.: 10 May 1963)

Hilton was horrified when a leading Country Party member called on the Q.L.P. to state where it stood on the 'Red objective' for it had never repudiated it. He observed-with some justification-that such a question must have astounded anyone who had followed State politics over the preceding six years. The platform and constitution of the Q.L.P. and Gair's 1957 and 1960 policy speeches all made it perfectly clear that the Q.L.P. was engaged in absolute opposition to and an unyielding fight against both Communism and the 'Red objective' (Dalby Herald: 16 April 1963; Toowoomba Chronicle: 24 April 1963).

Hilton set out the Q.L.P.'s claim to be a Labor party in his policy speech. The party was composed of men and women who had been 
dedicated to the Labor movement all their lives, who adhered to Labor ideals, believing that Labor's policy and platform should be designed to meet contemporary dangers. The Q.L.P. was always ready to discuss unity of the Labor movement-indeed had sought to do so in 1961. Had those overtures been accepted there would be a federal Labor government in Canberra and 'most of the electors of this State would be impatiently waiting to record their votes for the A.L.P. in the election on the 1st June'. The leaflet, 'Why Vote Q.L.P.?', declared:

Only the Q.L.P.

* is true to traditional Labor policies of social justice.

* is true to traditional Labor policies of no truck with Communism.

* can, with strong electoral support, to which you can contribute by your vote, rebuild a Labor Party fit to govern.

The names of Curtin and Chifley, of Forgan Smith and Hanlon, were frequently mentioned as men whose policies the Q.L.P. still followed.

Hilton in his policy speech denied that the Q.L.P. was sectarian and claimed that it held in its ranks men and women of all religious persuasions:

In a pluralist society such as we have in Australia religious sectarianism should hold no place. The Communists exploit and foster this unbalanced, foolish attitude of mind to the fullest extent. Sectarianism does not harmonise with Christian ideals; it has caused much harm in the past; it can do much damage in the future and it has never achieved any good.

The Party's 1963 'Speakers' Notes' dealt with the problem of the sectarian charge at some length. The Q.L.P. vote was essentially a Labor vote. The present A.L.P. leadership was not interested in resolving the issues which divided the Labor movement, and by using sectarianism against the Q.L.P. were further from power than they had been six years earlier. The 'Notes' quoted extracts from a speech by $\mathbf{R}$. Joshua (a Protestant) to a D.L.P. federal conference: the D.L.P. had adopted a set of principles and appealed to all sections of the community, regardless of religion; many Protestants supported the D.L.P. and 'many more Catholics-but by no means all of them, did so as well'; the N.C.C. had similar objectives and gave the D.L.P. its open support; the A.L.P. accepted affiliation from Communist-controlled unions and admitted Communist sympathisers into its councils-'this scandalous reality is accepted without a tremor by those bitter enemies of the D.L.P. who purport to be shocked by the fact that many members of the National Civic Council are also active and prominent members of the D.L.P.'

The exact political strategy to be followed by the Q.L.P. remained somewhat in doubt in 1963-in 1966 it was hardly raised. Immediately 
the aim was to keep the A.L.P. from office, but differing courses for the longer run were advocated. The Q.L.P. could grow of its own accord, presumably by recruiting A.L.P. voters, and become first the official Opposition and then the Government, or it could hope that the A.L.P. would split again and it could coalesce with the moderates and right-wingers, or the moderates and right-wingers could regain control of the A.L.P. and the two parties merge at that point. This last alternative, however, ran contrary to the short-term interests of the Q.L.P., for it implied that there was a chance of success in staying and fighting in the A.L.P., and so was hardly ever mentioned. Hilton set his sights quite low in his 1963 policy speech:

In this election we do not pose as a Party that is certain to be either the Government or the Official Opposition after the elections. However I, personally, am confident that our representation in the State Parliament will be increased and we will continue to be a virile fighting force in the House. Furthermore, I am confident that support for our Party will greatly increase in the electorates we are contesting. But for the limiting factor of finance we would be contesting many more seats.

By 1966 parliamentary representation was even further reduced and Diplock could only trust the future:

True, I am the only representative in the State Parliament at present, but those whom I lead are men, dedicated to fight on, ignoring defeats and reverses, until we have achieved success. It is not a unique experience for a Political Party to have only small Parliamentary representation-the testing period through which we are passing was experienced by both the present Government Parties.

The party had already been successful in influencing the political thinking of the nation and determining the policies of the major parties, and was doing well in the federal Senate. Some candidates were more optimistic; F. J. Mullins in Toowoomba East declared that the Q.L.P. could form a government and pointed out that the parliamentary leaders were 'men with long and distinguished administrative experience', but on another occasion he said merely that increased Q.L.P. representation would provide a more effective Opposition to keep the Government on its toes, for the A.L.P. in opposition had been 'indecisive, ineffectual and in the doldrums' (ToOwoomba Chronicle: 23 and 20 May 1963).

By and large the Government parties ignored the Q.L.P. during the campaign. In the two electorates where there were sitting Q.L.P. Members, Country Party spokesmen dismissed the Q.L.P. as a political force and argued that its candidates should be regarded as Independents (see p. 147). Duggan was almost as curt. Pointing out that Q.L.P. representation had fallen from eleven to four in 1960, and two of 
these had since defected, he advised voters in his 1963 policy speech that their choice lay between the Coalition or the A.L.P.:

The realities of the political situation are that no other political group or groups, or combination of independents, have any prospect of succeeding. Their entry into the campaign has been largely motivated by a desire to injure the A.L.P., or by acting under a false and misleading political label, to channel votes to the Country-Liberal Party Government by the distribution of their preferences.

Any references to the Q.L.P. were carefully avoided, although at the electorate level inevitably some candidates and their supporters were drawn into exchanges with the Q.L.P. Accusations that the Q.L.P. was a Catholic party were extremely few, one being in a letter to the Toowoomba Chronicle:

Anyone who reads and follows the policies of the political parties can see that the A.L.P. is the only party for the worker. As for the Q.L.P., any country is better without a party which is any way church dominated. (13 May 1963)

Charges that the Q.L.P. was a stooge of the government parties were almost as scarce. One letter-writer in Toowoomba retorted to the local Q.L.P. candidate who had impugned the A.L.P.'s independence:

The Q.L.P. is merely a servant of the Liberal Country Parties. It has no independence, and follows the instructions of its controllers in the Liberal and Country Parties . . . The Q.L.P. is financed by those who finance the Liberal Country Parties; and the Liberal Country Parties are controlled by Australia's largest business interests. (Toowoomba Chronicle: 12 May 1966)

\section{The Communist Party}

Although the Queensland branch of the Communist Party of Australia contested only three seats in 1963, it gave considerable attention to the State election. In 1966 it was much less active. The first shot was a substantial pamphlet, 'What are they doing to Queensland? The record of a guilty government', by the State President, Claude Jones, published a year before the election. It complained of a giveaway of natural resources to overseas monopolies, disregard of the railways, inflation and low wages, racism towards Aborigines and abuse of the civil rights of workers. Reporting to the state committee early in 1963, the party's State Secretary, E. A. Bacon, thought that the Bundaberg convention had 'reflected, to a fair degree, the growing leftward movement of the masses' which was being accelerated by industrial conditions (Qld. Guardian: 27 February 1963). The Communist Party should seek the defeat of the Nicklin government: 
Defeat of this Government would not only help the forward movement of the masses in Queensland. It would have very great national significance, and assist materially in the destruction of the Menzies Government, main centre of reaction in Australia.

Our Party has a big job to do in the forthcoming State election. Only the Communist Party can properly relate the economic problems of the working class, farmers and town middle classes to the key questions of opposing monopoly and fighting for peace. (Ibid.)

Bacon accused the Government of pushing State development in the interest of monopolies, selling State enterprises, whittling down the railways, giving overseas interests control of most of Queensland's natural resources and her few industries. The party's main aim should be to defeat the Nicklin government and return a Labor Government while getting a limited number of Communists into Parliament:

But this does not mean that we support the ALP unconditionally. ALP Parliamentary leaders have studiously avoided criticism of monopoly, their main argument being, in effect, that the ALP could do better in the way of 'attracting capital' to Queensland than the Liberal-Country Party coalition. But we should avoid any form of sectarian approach to the ALP which has the support of wide sections of the working people.

During the campaign the Qld. Guardian concentrated on unemployment and monopolistic exploitation-and the Moura strike while it lasted. Reporting to the State conference, Bacon declared that Communists should not underestimate the unpopularity of the Nicklin government:

Its record on unemployment, its treatment of juvenile delinquents, its treatment of Aborigines, its land policy, its road and rail policies, its role of education, and many other matters, all connected with its pro-monopoly line, have brought it under heavy criticism from many quarters. The ALP can win this election, provided it really gets out and fights around policy, including decisions of the Bundaberg Convention based on working class demands. (Ibid.: 17 April 1963)

The A.L.P. was weak in that it evaded the monopoly question, because most of its leaders believed in capitalism and would fall short unless pushed into action 'by a mighty working class thrust'. The Communist election slogan was: 'For the return of a Labor Government, together with some Communist MLAs.' News stories reported particularly high unemployment in ports affected by bulk handling of sugar. In Hinchinbrook the Communist candidate, G. Bordujenko, spoke of the need to nationalise the Colonial Sugar Refining Company, Mt Isa Mines, and the meat combines (ibid.: 22 May 1963).

After the election the State executive observed that the result was a clear and sharp challenge to the Labor movement, emphasising the basic issue of monopoly and the need 'to unite the workers, and rally 
allies, around working-class programs for the people's welfare'. Thanking those who had worked hard in the Communist campaign, the executive noted that the Party,

as always, was subjected to an unscrupulous news blackout on its policy by the daily press, TV and radio. It was the target of vicious attack through the daily press and other propaganda mediums, with no opportunity to reply through the same mediums. As a result, great numbers of electors were prevented from knowing the truth about Communist policy. (Ibid.: 5 June 1963)

Agarnst the images which the parties sought to create of themselves and their opponents can be set the responses of members of a panel of electors in the Brisbane electorates of Ashgrove, Baroona, and Ithaca. (The method of selection of this panel and information on its members are set out in Appendix A.) Open-ended questions were asked in a mail questionnaire sent in 1963 to a semi-random 1 per cent sample of persons on the electoral rolls of two electorates on the south side of Brisbane: 'Suppose an interstate visitor asked you what the four big parties really stand for, what would you say?' and 'Leaving aside for a moment your own political convictions, could you mention: (a) Anything you like or respect about the Country Party (Liberal Party/ A.L.P./Q.L.P.); (b) Anything in the Country Party (Liberal Party/ A.L.P./Q.L.P.) which you don't like.' A rough content analysis was made of responses to these questions, and twelve items were composed using the salient features. These items were printed on a card which was handed to panel members with the question:

Here are some statements you often hear about the various political parties in the Queensland State Parliament. As I say each of them, would you please say, for instance, whether you think it's true, or not, of the Country Party in Queensland? And the ALP-the Australian Labor Party. As I mention each again, would you please say whether it's true, or not, of the ALP in Queensland? And for the Liberal Party in Queensland-which are true or not? And for the $Q L P$, which is now connected with the DLP-which are true or not?

Members of the panel were divided according to their voting intention determined by their response to the question: 'If the State election were being held today, which party would you like to see win?'. If the first response was undecided or a refusal, they were then invited: 'Would you please mark the paper for the party you're leaning toward at present.' Positive and negative responses to the twelve items relating to the Liberal, A.L.P. and Q.L.P. images in 1963 are set out in Table 2.01.

It appears that most voters had fairly definite opinions about the parties-or at least were prepared to make snap judgments. A.L.P. voters were somewhat more likely to reply 'don't know' to items about 
the Liberal Party (average $15 \cdot 7$ per cent) than about the A.L.P. (average 10.4 per cent), and similarly Liberal voters were more likely to reply 'don't know' about the A.L.P. (average $13 \cdot 3$ per cent) than about the Liberal Party (average 10.8 per cent). Both were more likely to reply 'don't know' about the Q.L.P. than about the other three partiesA.L.P. voters averaged $27 \cdot 5$ per cent and Liberal voters, $29 \cdot 1$ per cent. Indeed 13.4 per cent of A.L.P. voters and 11.5 per cent of Liberal voters answered 'don't know' to all twelve items about the Q.L.P., although with such a long list undoubtedly response set affected the bottom of the list.

Generally, voters saw little difference between the Country Party and the Liberal Party. Liberal voters saw hardly any difference, A.L.P. voters were slightly more likely to give favourable responses to the Country Party, and Q.L.P. voters were even more likely to do so. However, Liberal voters were more likely to distinguish between the coalition parties on the point of which looks after big business than were A.L.P. or Q.L.P. voters: only 46.6 per cent of the Liberal voters thought that the Country Party looked after big business, contrasted with 75.3 per cent of the A.L.P. voters and 75 per cent of Q.L.P. voters. Everyone tended to agree that the Country Party had able leaders more readily than they would agree that the Liberal Party did:

Table 2.01

Party images 1963

$\%$

\begin{tabular}{|c|c|c|c|c|c|c|}
\hline \multicolumn{7}{|c|}{ A.L.P. voting intention $\mathrm{n}=142$} \\
\hline & \multicolumn{2}{|c|}{ Liberal Party } & \multicolumn{2}{|c|}{ A.L.P. } & \multicolumn{2}{|c|}{ Q.L.P. } \\
\hline & Yes & No & Yes & No & Yes & No \\
\hline 1. The ... Party stands for the & & & & & & \\
\hline development of Queensland & $50 \cdot 7$ & $35 \cdot 2$ & $89 \cdot 4$ & 5.6 & 31.0 & $45 \cdot 8$ \\
\hline 2. The... Party is a middle of- & & & & & & \\
\hline the-road party & $31 \cdot 7$ & $49 \cdot 3$ & $33 \cdot 1$ & 50.7 & 38.0 & 34.5 \\
\hline 3. It's one-sided and selfish & $54 \cdot 2$ & 32.4 & $33 \cdot 8$ & $58 \cdot 4$ & $48 \cdot 6$ & $23 \cdot 9$ \\
\hline 4. It keeps its promises & $29 \cdot 6$ & $55 \cdot 6$ & $54 \cdot 9$ & $33 \cdot 8$ & $17 \cdot 6$ & $47 \cdot 9$ \\
\hline 5. The ... Party is too closely & & & & & & \\
\hline attached to one church & $7 \cdot 7$ & $70 \cdot 4$ & $9 \cdot 1$ & 78.9 & $40 \cdot 8$ & $36 \cdot 6$ \\
\hline 6. The ... Party stands for free & & & & & & \\
\hline enterprise & $60 \cdot 6$ & $22 \cdot 6$ & 58.4 & $27 \cdot 5$ & $35 \cdot 2$ & $28 \cdot 9$ \\
\hline 7. Its leaders have the courage & & & & & & \\
\hline of their convictions & $50 \cdot 7$ & $33 \cdot 8$ & $70 \cdot 4$ & $20 \cdot 4$ & $35 \cdot 9$ & $40 \cdot 1$ \\
\hline 8. It will promote full & & & & & & \\
\hline $\begin{array}{l}\text { employment } \\
\text { 9. The ... Party is dominated }\end{array}$ & $26 \cdot 1$ & $59 \cdot 1$ & $73 \cdot 9$ & $14 \cdot 1$ & $28 \cdot 9$ & $38 \cdot 7$ \\
\hline by party bosses & $59 \cdot \mathrm{I}$ & $25 \cdot 3$ & $53 \cdot 5$ & $38 \cdot 7$ & $56 \cdot 3$ & $22 \cdot 5$ \\
\hline 10. It has able leaders & $56 \cdot 3$ & 28.2 & 73.9 & $17 \cdot 6$ & $37 \cdot 3$ & $40 \cdot 8$ \\
\hline 11. It's divided & 32.4 & $54 \cdot 2$ & 50.7 & $42 \cdot 2$ & $43 \cdot 0$ & $34 \cdot 5$ \\
\hline 12. It looks after big business & $79 \cdot 6$ & $6 \cdot 3$ & 26.8 & $59 \cdot \bar{I}$ & 32.4 & 35.9 \\
\hline
\end{tabular}


Table 2.01 continued

\begin{tabular}{|c|c|c|c|c|c|c|}
\hline \multicolumn{7}{|c|}{ Liberal voting intention $\mathrm{n}=148$} \\
\hline & \multicolumn{2}{|c|}{ Liberal Party } & \multicolumn{2}{|c|}{ A.L.P. } & \multicolumn{2}{|c|}{ Q.L.P. } \\
\hline & Yes & No & Yes & No & Yes & No \\
\hline $\begin{array}{l}\text { 1. The ... Party stands for the } \\
\text { development of Queensland }\end{array}$ & $87 \cdot 8$ & $6 \cdot 1$ & $51 \cdot 3$ & $36 \cdot 5$ & $45 \cdot 9$ & $29 \cdot 7$ \\
\hline 2. The ... Party is a middle-of- & & & & & & \\
\hline the-road party & $41 \cdot 2$ & $40 \cdot 0$ & $21 \cdot 6$ & $60 \cdot 1$ & 37.2 & $31 \cdot 1$ \\
\hline 3. It's one-sided and selfish & $26 \cdot 3$ & $64 \cdot 2$ & $65 \cdot 5$ & $23 \cdot 0$ & $51 \cdot 3$ & $24 \cdot 3$ \\
\hline 4. It keeps its promises & $70 \cdot 3$ & $21 \cdot 6$ & $24 \cdot 3$ & $58 \cdot 8$ & $22 \cdot 3$ & $32 \cdot 4$ \\
\hline $\begin{array}{l}\text { 5. The ... Party is too closely } \\
\text { attached to one church }\end{array}$ & 6.8 & 80.4 & 19.6 & 57.4 & 37.8 & 32.4 \\
\hline 6. The ... Party stands for free & & & & & & \\
\hline enterprise & $81 \cdot 1$ & $6 \cdot 1$ & $20 \cdot 3$ & $65 \cdot 5$ & $35 \cdot 1$ & $31 \cdot 1$ \\
\hline $\begin{array}{l}\text { 7. Its leaders have the courage } \\
\text { of their convictions }\end{array}$ & $81 \cdot 1$ & 8.8 & $35 \cdot 1$ & $54 \cdot 0$ & 50.7 & 29.0 \\
\hline 8. It will promote full & & & & & & \\
\hline employment & $66 \cdot 9$ & $24 \cdot 3$ & $48 \cdot 0$ & 39.9 & $46 \cdot 6$ & $28 \cdot 4$ \\
\hline $\begin{array}{l}\text { 9. The ... Party is dominated } \\
\text { by party bosses }\end{array}$ & & & & & $A 0.5$ & 39.4 \\
\hline by party bosses & $23 \cdot 6$ & $64 \cdot 9$ & $86 \cdot 5$ & $6 \cdot 8$ & $\begin{array}{l}40.5 \\
40.5\end{array}$ & $32 \cdot 4$ \\
\hline 10. It has able leaders & $82 \cdot 4$ & $10 \cdot 8$ & 37.8 & $52 \cdot 0$ & $40 \cdot 5$ & $31 \cdot 8$ \\
\hline 11. It's divided & 14.9 & $74 \cdot 3$ & $67 \cdot 6$ & $23 \cdot 0$ & $25 \cdot 7$ & $47 \cdot 3$ \\
\hline 12. It looks after big business & $65 \cdot 5$ & 20.9 & $17 \cdot 6$ & $68 \cdot 2$ & $16 \cdot 9$ & $50 \cdot 0$ \\
\hline
\end{tabular}

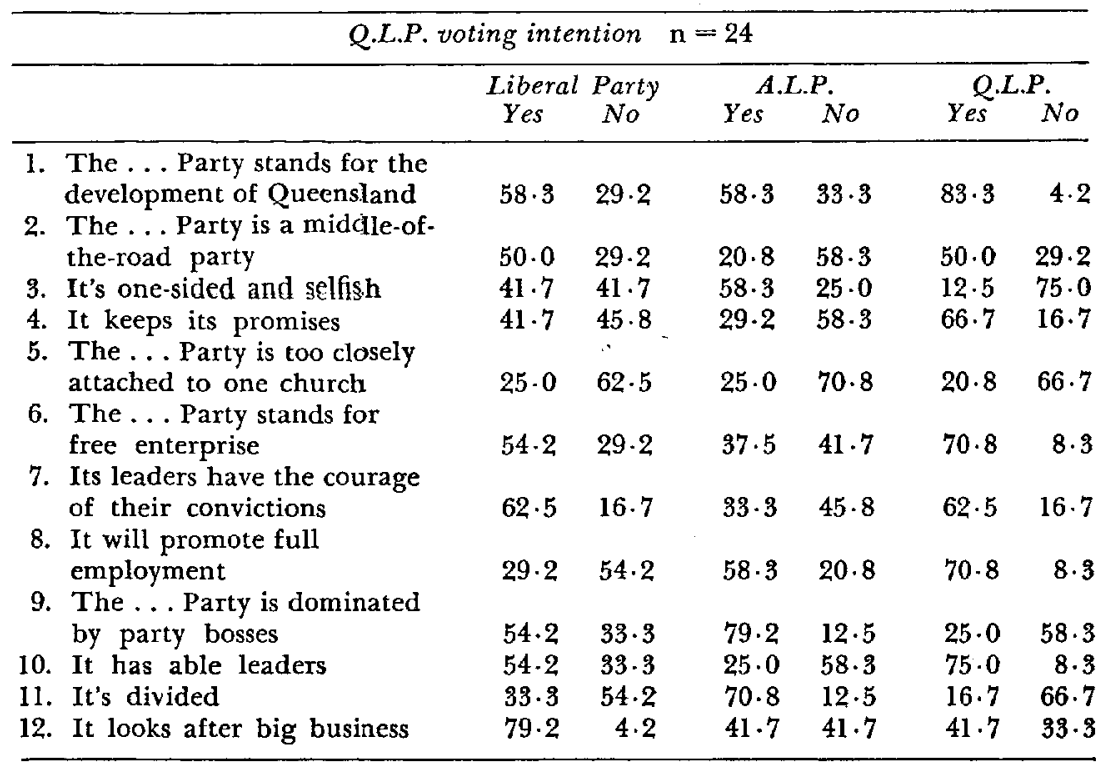


64. 1 per cent of A.L.P. voters, 89.9 per cent of Liberal voters, and 83.3 per cent of Q.L.P. voters thought that the Country Party had able leaders. But, with these minor exceptions, the two coalition parties had remarkably similar images with the voters of all persuasions, and in the remainder of this chapter attention is focused on the Liberal Party and the Country Party is disregarded. When the panel was reinterviewed in 1966 the Country Party was ignored.

Such similarity was not found when comparisons were made between the Liberal Party and the A.L.P. and between either and the Q.L.P., for here partisanship operates strongly. Liberal voters had a favourable image of the coalition parties, A.L.P. voters an unfavourable one. Liberal voters had an unfavourable image of the A.L.P., A.L.P. voters a favourable one. Such a conclusion verges on the platitude: 'People vote for the party they like, and not for the party they don't like' (see Storing 1963: 33-4), but further analysis supplies further conclusions which, if not startling, at least may not be platitudinous. If we examine the Q.L.P. image held by respondents in 1963, A.L.P. voters tended to be more unfavourable than Liberal voters-not unexpectedly-but their hostility focused on certain items and not on others. A.L.P. voters were less likely to see the Q.L.P. standing for development, slightly less likely to see it keeping its promises, less likely to see its leaders having the courage of their convictions, less likely to see it promoting full employment, more likely to see it dominated by bosses, less likely to agree it has able leaders, more likely to see it as divided and looking after big business. But there were only marginal differences about the Q.L.P. being a middle-of-the-road party, about it being one-sided and selfish, about it being too closely attached to one church and standing for free enterprise. Q.L.P. voters had a favourable image of their own party, a fairly favourable one of the Country Party, slightly less so of the Liberal Party, and a strongly unfavourable one of the A.L.P.

Certain items distinguished between parties more sharply than others, items $1,3,4,7,8,9$ and 10 , and these were employed to construct a score which could be used for further analysis. A favourable response series would run: yes, no, yes, yes, yes, no, yes; scoring on such a basis a respondent could have a score of either party ranging from +7 to -7 . The distribution of individual respondents over these scores is shown in Fig. 1 and the average scores in Table 2.02. While the platitude remains that voters tended to give their own party a higher score and their opponents a lower score, distinctions may be drawn. Liberal voters in 1963 were more enthusiastic about their party than A.L.P. voters were about theirs; A.L.P. voters were less critical of the Liberal Party than Liberal voters were of the A.L.P. Indeed the party differential (difference between average scores) for Liberal voters was $5 \cdot 6$, but for A.L.P. voters only $3 \cdot 1$. Neither 
of the main groups of respondents, prospective Liberal and A.L.P. voters, had very strong feelings about the Q.L.P. Liberal voters were slightly more enthusiastic about the Q.L.P. than Q.L.P. voters were about the Liberal Party; Q.L.P. voters were more critical of the A.L.P. than A.L.P. voters were of the Q.L.P. These scores reflect the party system as it then was. Liberal voters and Q.L.P. voters ranked
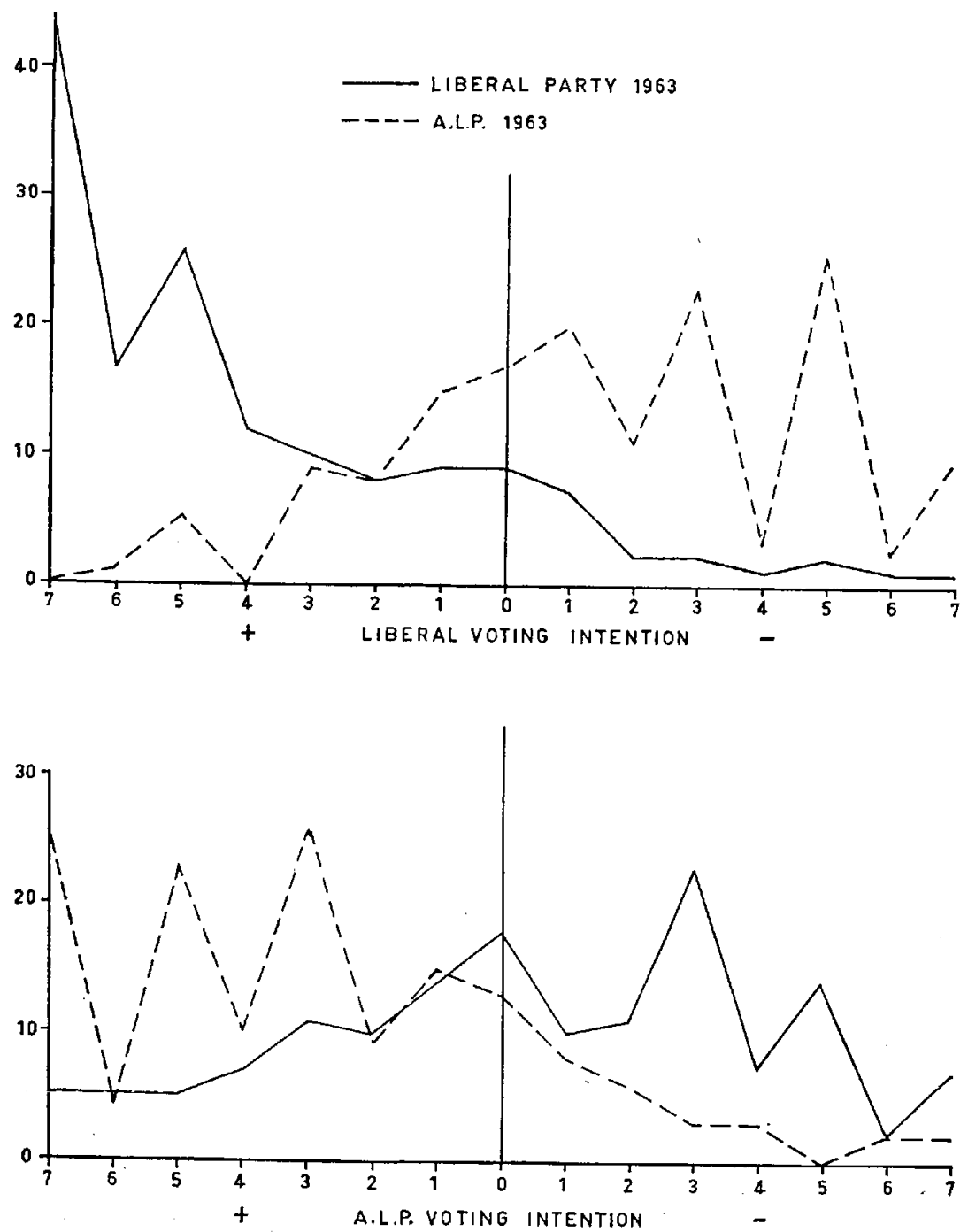

FIG. 1 FREQUENCY OF PARTY IMAGE SCORES 1963 
Table 2.02

Average scores on party images 1963

\begin{tabular}{cccc}
\hline & \multicolumn{3}{c}{ Voting intention } \\
Party & Liberal & A.L.P. & Q.L.P. \\
\hline Liberal & +4.0 & -0.5 & +0.5 \\
A.L.P. & -1.6 & +2.6 & -1.0 \\
Q.L.P. & +0.9 & -0.04 & +2.1 \\
\hline
\end{tabular}

each other's party second to their own, well ahead of the A.L.P.; Liberal voters had an A.L.P.-Q.L.P. party differential of 2.5 and Q.L.P. voters of $1 \cdot 5$. However A.L.P. voters were less likely to distinguish between the Liberal Party and the Q.L.P. with a differential of only 0.5 .

From Fig. 1 one might have expected a distribution of voters over two axes, pro-us to anti-us and pro-them to anti-them, with the greatest concentration in the pro-us, anti-them quadrant, an interesting small minority in the anti-us, pro-them quadrant (A. F. Davies (Davies and Encel 1965: 108) has since dubbed them 'odd balls'), the apolitical and alienated in the anti-us, anti-them quadrant, and the pro-us, prothem quadrant occupied by possessors of what, it was suggested in an earlier presentation of this material, could be called the Cheeryble syndrome. When this distribution is consolidated as a $3 \times 3$ table, the last three categories were infrequent among Liberal and A.L.P. voters. The strongly partisan, pro-us and anti-them (the 'hot ones' to follow Davies) in the cells marked ' $a$ ' in Table 2.03 were relatively small minorities: 16 per cent of the Liberal voters, 13 per cent of the A.L.P. voters. The moderately partisan (the 'mild ones') in the cells marked ' $b$ ' comprised 54 per cent of the Liberals and 26 per cent of the prospective A.L.P. voters. Thus while a total of 70 per cent of the Liberal voters were partisans to some degree, only 39 per cent of A.L.P. voters could be so described. Those who saw little difference between the two parties (the 'cool ones'), marked ' $c$ ', were 23 per cent of the Liberal voters but 43 per cent of the A.L.P. voters. The alienated, anti-us and anti-them, marked 'd', numbered only five, and four of these were Liberal voters. The odd balls, anti-us and pro-them, marked 'e', numbered thirteen: twelve of them were A.L.P. voters, 8 per cent of the total of A.L.P. voters. Finally there are the Cheerybles, some twenty strong, marked ' $f$ ', 4 per cent of Liberal voters and 9 per cent of A.L.P. voters. This distribution indicates that the great majority of voters were partisan or indifferent; very few occupied what could be regarded as deviant positions. However, as Davies points out, the partisanship is 'tepid'.

When respondents' views on the Q.L.P. were checked, variations in the pattern appeared. Liberal voters were less strongly partisan 
Table 2.03

Cross-tabulations of party image scores 1963

Liberal voting intention

\begin{tabular}{|c|c|c|c|}
\hline & & eral & \\
\hline . & +7 to +4 & +3 to -3 & -4 to -7 \\
\hline-7 to -4 & $24^{a}$ & $13^{b}$ & $4^{\mathrm{d}}$ \\
\hline-3 to +3 & $68^{b}$ & $34^{e}$ & 10 \\
\hline+4 to +7 & $6^{x}$ & $0^{\circ}$ & $0^{\circ}$ \\
\hline
\end{tabular}

\begin{tabular}{|c|c|c|c|}
\hline & & eral & \\
\hline & +7 to +4 & +3 to -3 & -4 to -7 \\
\hline : -7 to -4 & 5 & 2 & 0 \\
\hline-3 to +3 & 82 & 35 & 5 \\
\hline$\dot{\alpha}+4$ to +7 & 11 & 10 & 0 \\
\hline
\end{tabular}

\begin{tabular}{|c|c|c|c|}
\hline & \multicolumn{2}{|c|}{ A.L.P. } & \multirow[b]{2}{*}{-4 to -7} \\
\hline & +7 to +4 & to -3 & \\
\hline$\therefore-7$ to -4 & $0^{\mathrm{g}}$ & 4 & $3^{\mathrm{h}}$ \\
\hline-3 to +3 & $4^{k}$ & 83 & 35 \\
\hline$\alpha+4$ to +7 & $2^{j}$ & $16^{k}$ & 3 \\
\hline
\end{tabular}

A.L..P voting intention

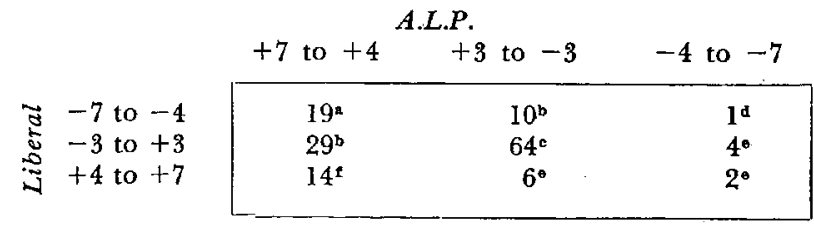

A.L.P.

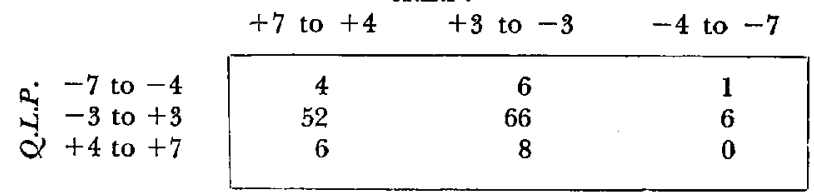

\begin{tabular}{|c|c|c|c|}
\hline & \multicolumn{2}{|c|}{ Liberal } & \multirow[b]{2}{*}{-4 to -7} \\
\hline & +7 to +4 & +3 to -3 & \\
\hline-7 to -4 & $0^{\mathrm{g}}$ & 6 & $5^{h}$ \\
\hline-3 to +3 & $21^{k}$ & 79 & 24 \\
\hline$\dot{\alpha}+4$ to +7 & $1^{\mathrm{J}}$ & $12^{k}$ & 1 \\
\hline
\end{tabular}


against the Q.L.P.: only 3 per cent 'hot' and 60 per cent 'mild'. They were slightly more inclined to be Cheerybles -7 per cent; they were certainly more inclined to be odd balls -10 per cent. A.L.P. voters were slightly more inclined to be Cheerybles-7 per cent; they were against the Liberal Party-only 3 per cent, but they were more inclined to be mildly partisan against it-39 per cent. When the two types of partisanship are added together, however, the differences of each group towards the other two parties are relatively slight: A.L.P. voters 39 per cent where the Liberal Party was involved, 42 per cent where the Q.L.P. was involved: Liberal voters 70 per cent where the A.L.P. was involved, 63 per cent against the Q.L.P. When the attitudes of the two groups to the two other parties are checked, no one is strongly partisan in favour of one and strongly against the other (marked ' $\mathrm{g}$ '); only a handful are strongly against both (marked ' $h$ '), and even fewer are strongly partisan for both (marked ' $j$ '). Only 13 per cent of Liberal voters and 22 per cent of A.L.P. voters are moderately partisan for both (marked ' $k$ ').

These scores may also be combined as $15 \times 15$ tables which give a more detailed picture of the relationship between two party images. Product moment correlations have been calculated for each of the pairs shown collapsed in $3 \times 3$ tables in Table 2.03. For the Liberal voters, scores of the Liberal Party and the A.L.P. have a correlation of 189 , of the Liberal Party and the Q.L.P. of .014, but of the A.L.P. and Q.L.P. of 373. For the A.L.P. voters, the A.L.P. and Liberal Party scores have a negative correlation of -148 , of the A.L.P. and Q.L.P. of $\cdot 059$, but of the Liberal Party and Q.L.P. of 304. Thus there is probably very little relationship, if any, between the favourableness or unfavourableness of a voter's image of his own party and of one of the opposing parties, but a moderately strong relationship between his images of the two parties opposed to his own.

Numbers of Q.L.P. voters were too small to support analysis. However, in view of the supposed high partisanship of Q.L.P. supporters, it might be noted that only two Q.L.P. voters could be termed 'hot' on a comparison of the A.L.P. and Q.L.P., whilst twelve, or half the sample, were 'cool'.

When members of the panel were reinterviewed in 1966 eight of the original twelve items in the party image were used again. Four which had not been particularly helpful were dropped: whether the party was middle-of-the-road, whether it was too closely tied to one church, whether it stood for free enterprise, and whether it looked after big business. Two new items were added which derived from knowledge of the shape the new campaign was taking in one case and recognition of a hardy perennial in the other. Purists may complain that any alteration in the questionnaire can influence responses, but 
it is difficult to see why items which are not highly emotive in a personal way should have any significant effect. If behavioural research is to keep in touch with the real world, which does change, then exercises over time must be liable to modification; the alternative is sterile artificiality. Because of the close similarity between the Liberal and Country party images in 1963 items were not asked about the Country Party in 1966 nor about the Q.L.P., whose political significance appeared to be a declining factor in the State. This greatly reduced the time required for administering the party image portion of the questionnaire.

The new items may be dealt with quickly. Responses are shown in Table 2.04. Almost one-third of Labor voters had doubts about their

Table 2.04

\section{Party images 1966}

$\%$

\begin{tabular}{ccc} 
A.L.P. voting & \multicolumn{2}{c}{ Liberal voting } \\
intention $(\mathrm{n}=82)$ & intention $(\mathrm{n}=100)$
\end{tabular}

A.L.P. image

13. It cannot be relied on where Communists are concerned

14. It will keep prices down

$29 \cdot 3 \quad 46 \cdot 3 \quad 57 \cdot 0 \quad 27 \cdot 0$

Liberal Party image

13. It cannot be relied on where

Communists are concerned

14. It will keep prices down

$70.7 \quad 18.3$

$45 \cdot 0$

$36 \cdot 0$

party on the Communist issue, and another quarter gave a don't know response; only half denied the charge which is so frequently flung at the party they propose voting for. On the other hand, just over a half of Liberal voters trusted their party on the matter. The neat polarity Liberal propaganda has tried to advance is far from accepted even by their own voters. The prices issue showed A.L.P. voters fairly solid in belief in their own party and suspicion of the Liberal Party, but Liberal voters marginally accepting the A.L.P. claim and uncertain of their own party. It is noticeable that 'don't know' responses rise on the items where the record challenges voting intention.

The pattern of the repeated items is more complex. Responses of those members of the panel who were reinterviewed in 1966 are set out in Table 2.05 .

The picture is generally one of stability. There were ninety-six possibilities for change: just on one-half changed by more than $\mathbf{5}$ per cent, but only ten changed by more than 15 per cent. The image of 
Table 2.05

Change in party image 1963-6: reinterviewed group

\begin{tabular}{|c|c|c|c|c|}
\hline \multirow{2}{*}{$\begin{array}{l}\text { Percentage saying } \\
\text { 'Yes' }\end{array}$} & \multicolumn{2}{|c|}{$\begin{array}{c}\text { A.L.P. voting } \\
\text { intention }\end{array}$} & \multicolumn{2}{|c|}{$\begin{array}{l}\text { Liberal voting } \\
\text { intention } \dagger\end{array}$} \\
\hline & $\begin{array}{l}\text { Liberal } \\
\text { image }\end{array}$ & $\begin{array}{l}\text { A.L.P. } \\
\text { image }\end{array}$ & $\begin{array}{l}\text { Liberal } \\
\text { image }\end{array}$ & A.L.P. \\
\hline $\begin{array}{l}\text { 1. The... Party stands for the } \\
\text { development of Qld }\end{array}$ & $-6 \cdot 6$ & -5.6 & +8.4 & $+1 \cdot 7$ \\
\hline 3. It's one-sided and selfish & $+6 \cdot 2$ & $-5 \cdot 7$ & -8.8 & $-11 \cdot 2$ \\
\hline 4. It keeps its promises & $-15 \cdot 6$ & $-1 \cdot 3$ & $+2 \cdot 0$ & $+3 \cdot 2$ \\
\hline $\begin{array}{l}\text { 7. It's leaders have the courage } \\
\text { of their convictions }\end{array}$ & $-15 \cdot 1$ & +5.9 & $+8 \cdot 1$ & $+5 \cdot 9$ \\
\hline $\begin{array}{l}\text { 8. It will promote full } \\
\text { employment }\end{array}$ & $+5 \cdot 9$ & $+5 \cdot 2$ & $+7 \cdot 3$ & $+11 \cdot 6$ \\
\hline $\begin{array}{l}\text { 9. The ... Party is dominated } \\
\text { by party bosses }\end{array}$ & +4.2 & -0.6 & $-5 \cdot 0$ & -0.7 \\
\hline 10. It has able leaders & $-16 \cdot 6$ & $-6 \cdot 0$ & +9.7 & $-7 \cdot 4$ \\
\hline 11. It's divided & $\div 22.4$ & +0.7 & $+31 \cdot 9$ & $+8 \cdot 3$ \\
\hline
\end{tabular}

the Liberal Party held by Labor voters showed the greatest change, and consistently in an unfavourable direction. Its record of keeping promises, its leaders' courage and ability, and its unity, all fell off sharply. Liberal voters, however, held an improved picture of their party on these items save unity, where demonstrably the Liberal Party was not what it was in 1963. There were only minor changes in the image of the Australian Labor Party held by Labor voters, and these seem to be attributable to a longer absence from office. The A.L.P. image held by Liberal voters tended to be slightly improved, save on the ability of its leaders and its unity, the latter being a point A.L.P. voters were showing some uncertainty on also. The effect of change can be shown in Table 2.06. Now there is no distinction between Liberal and A.L.P.

Table 2.06

Average scores on party images 1963 and 1966

\begin{tabular}{lccccc}
\hline & \multicolumn{2}{c}{$\begin{array}{c}\text { Liberal voting } \\
\text { intention }\end{array}$} & \multicolumn{2}{c}{$\begin{array}{c}\text { A.L.P. voting } \\
\text { intention }\end{array}$} \\
\hline & Liberal & A.L.P. & Liberal & A.L.P. \\
Whole group 1963 & +4.0 & -1.6 & -0.5 & +2.6 \\
Reinterviewed 1963 & +3.5 & -1.7 & -0.5 & +2.9 \\
Reinterviewed 1966 & +2.7 & +0.8 & +0.1 & +2.6 \\
\hline
\end{tabular}

voters in their estimations of their own parties, and it is the Liberal voters who are better disposed to their opponents. Both party differentials have been reduced-A.L.P. voters from $3 \cdot 1$ to 2.5 and Liberal voters from $5 \cdot 6$ to 1.9 . 
When the 1966 scores are collapsed and cross-tabulated as in Table 2.03, we get the pattern shown in Table 2.07. The change is

Table 2.07

\section{Cross-tabulations of party image scores 1966}

Liberal voting intention

\begin{tabular}{|c|c|c|c|}
\hline & \multicolumn{3}{|c|}{ Liberal } \\
\hline & +7 to +4 & +3 to -3 & -4 to -7 \\
\hline-7 to -4 & 1 & 2 & 0 \\
\hline-3 to +3 & 22 & 58 & 1 \\
\hline+4 to +7 & 7 & 9 & 0 \\
\hline
\end{tabular}

A.L.P. voting intention

A.L.P.

\begin{tabular}{|c|c|c|c|}
\hline & +7 to +4 & +3 to -3 & -4 to -7 \\
\hline-7 to -4 & 0 & 2 & 0 \\
\hline-3 to +3 & .15 & 56 & 0 \\
\hline+4 to +7 & 4 & 5 & 0 \\
\hline
\end{tabular}

quite remarkable. The 'hot partisans' have almost vanished, down from 16 per cent to 1 per cent among Liberal voters and from 13 per cent to nil among A.L.P. voters. The 'mild partisans' are also much reduced: down from 54 per cent to 24 per cent among Liberals, and from 26 per cent to 21 per cent among Labor voters. Thus the total proportion of partisans has fallen from 70 per cent among Liberals to 25 per cent and from 39 per cent to 21 per cent among Labor voters. The 'cool ones' among. Liberal voters have grown from 23 per cent to 58 per cent and among A.L.P. voters from 43 per cent to 68 per cent. As in 1966, Liberals are more likely to be partisan and less likely to be cool than A.L.P. voters, but the differences are now negligible where they were once pronounced. Deviants are no more common: Cheerybles are slightly more common among Liberals but much less so in the Labor camp; the alienated have disappeared completely; 'odd balls' have risen from one individual to 10 per cent among Liberals, but declined from 8 to 5 per cent among Labor voters. The big shift has been from partisanship into relative neutrality.

Trenaman and McQuail (1961) constructed a similar score for the attitudes of their panel of English (Yorkshire) voters, and found that with a possible range of +5 to -5 . Conservative voters rated their own party $+3 \cdot 1$ and the Labour Party $-1 \cdot 2$, while Labour voters rated their own party $+2 \cdot 7$ and the Conservative Party $+0 \cdot 2$. A comparison with Brisbane 1963 scores raised some interesting possibilities: that Labour/Labor voters in both countries were more open-minded and Conservative/Liberal voters more close-minded (see Rokeach 
1960: 116); that parties in office, as both high-scoring parties were when these surveys were conducted, get extra prestige; that right-wing parties are 'natural' rulers and are so recognised by electors, and so on. Unfortunately the evidence of 1966 challenges all of these hypotheses. Liberal voters changed their opinions more readily. Despite the fact that the Liberal Party had been in office during a period of prosperity, its image suffered. Two gloomy possibilities remain. One is that the image measures represented by these scores are purely artifacts of the questionnaires from which they are developed, and tell us nothing about the realities of electoral attitudes and support. The other is that while political images contain many elements of stability, they also can be drastically affected by short-term trends, as the popularity polls on United States presidents and British prime ministers would suggest. In another three years, or another three months, quite different scores could have been calculated. There is a third possibility, for which there is little hard evidence but to which much of the material presented in this book points, that Queensland politics has been declining from a degree of somewhat feverish partisanship in 1957 into non-partisan apathy, and a fourth, that the A.L.P. is starting a rehabilitation which might eventually take it past the Liberal Party in public estimation and eventually electoral support, but that raises nice problems of how far attitudes such as have been measured by these scores have anything to do with electoral behaviour.

Of the group reinterviewed in 1966, some eighty-nine had said in 1963 that they were likely to vote for the Australian Labor Party and ninety-one had said that they intended to vote for the Liberal Party. But on their intentions for the impending 1966 election, only eighty-two said they would vote for the A.L.P. whilst a hundred indicated that they would vote Liberal. This does not indicate that seven members of this group were switching from Labor to Liberal, and being joined by two others who had previously in 1963 intended to vote Q.L.P., not made up their mind, or refused to say. Rather the first figures indicate only net changes in voting intention within the remaining part of the original panel. Two groups of changers between the major parties can be identified from their responses in 1963 and 1966: seventeen individuals switching from A.L.P. to Liberal and twelve from Liberal to A.L.P. Thus about one-sixth of the reinterviewed group expected to be changing their vote between 1963 and 1966. Do their party image scores give any indication of why they might be changing? Those A.L.P. voters of 1963 who changed (always supposing that both declarations of intention were honoured at the polls, a supposition without which electoral studies would be in sad disrepair) were lacking in partisanship in 1963: their average party differential favouring the A.L.P. was 0.1 against the average for Labor voters of $3 \cdot 4$. In 1966 they were still a little lukewarm among their 
Table 2.08

Average party image scores of tote changers 1963-6

\begin{tabular}{lcccc}
\hline Direction of change & \multicolumn{2}{c}{1963} & \multicolumn{2}{c}{1966} \\
Labor to Liberal & Liberal Pariy & A.L.P. & Liberal Party & A.L.P. \\
\hline Liberal to Labor & +0.7 & +0.8 & +2.2 & +0.9 \\
& +3.8 & -0.7 & +0.7 & +2.5 \\
\hline
\end{tabular}

new friends, with a party differential of 1.3 favouring the Liberal Party whereas all intending Liberal voters averaged 1.9. Those Liberal voters of 1963 who subsequently changed to Labor were much less lacking in partisanship in 1963 than the previous group: they averaged a party differential of 4.5 favouring the Liberal Party whilst all Liberal voters of 1963 reinterviewed in 1966 averaged 5.2; indeed the changers were slightly higher on their Liberal score, and it is the weakness of their negative score on the A.L.P. which reduces the differential. In 1966 they are still a little more partial to their old friends than the total group of A.L.P. voters they have joined, but have much the same score on the A.L.P. Again their party differential is smaller than that of the whole group they have joined, 1.8 against $2 \cdot 5$. Changers start by being less partisan and they appear to stay that way.

It was suggested above that there was a danger that scores employed might be artifacts of the questionnaire. The inter-item phi correlations suggest that this is quite unlikely. Only two items concerning the Liberal Party fail to have at least one phi correlation greater than .400 with at least one other item: it's divided, and it cannot be relied on where Communists are concerned. Four items concerning the A.L.P. fail to have at least one phi correlation greater than .400 with at least one other item: the same two as with the Liberal Party, plus it's one-sided and selfish, and it has able leaders. Most items have a number of strong correlations with other items, for the Liberal Party image, twenty inter-item correlations are greater than 400 , fourteen between 400 and $\cdot 200$, and only eleven below $\cdot 200$, whilst for the A.L.P. image five inter-item correlations are greater than 400 , thirtytwo between $\cdot 400$ and $\cdot 200$, and only five below $\cdot 200$.

The 1963 scores may be used again to test whether there were significant variations among sub-groups of the two main groups of voters, the Liberals and the A.L.P. supporters. A breakdown of each group by occupation is shown in Table 2.09. In terms of party differentials Liberal voters in professional occupations were somewhat less partisan than other Liberals. Among A.L.P. voters the division was between those in white-collar occupations (who were less partisan) and those in manual occupations (who were more partisan), and there was a steady increase in partisanship as one moves along the occupational 
Table 2.09

Party image scores of occupational groups 1963

\begin{tabular}{|c|c|c|c|c|c|c|}
\hline \multirow{2}{*}{ Score for: } & \multirow{2}{*}{$\mathbf{n}$} & \multicolumn{2}{|c|}{ Liberal voting intention } & \multirow{2}{*}{$\mathbf{n}$} & \multicolumn{2}{|c|}{ A.L.P. voting intention } \\
\hline & & Liberal Party & A.L.P. & & Liberal Party & A.L.P. \\
\hline Professionals & 23 & +2.7 & $-1 \cdot 6$ & \multirow{2}{*}{10} & \multirow{2}{*}{$+2 \cdot 2$} & \multirow{2}{*}{$+2 \cdot 3$} \\
\hline $\begin{array}{l}\text { Directors and } \\
\text { managers }\end{array}$ & 23 & +4.9 & $-0 \cdot 8$ & & & \\
\hline $\begin{array}{l}\text { Office and } \\
\text { sales }\end{array}$ & 45 & +4.8 & $-1 \cdot 4$ & 27 & $-1 \cdot 0$ & $+1 \cdot 4$ \\
\hline Skilled workers & 33 & +3.5 & $-1 \cdot 7$ & 37 & -0.1 & +2.8 \\
\hline Semi-skilled & \multirow[b]{2}{*}{18} & \multirow{2}{*}{$+3 \cdot 0$} & \multirow{2}{*}{$-2 \cdot 8$} & 39 & $-1 \cdot 3$ & $+3 \cdot 7$ \\
\hline $\begin{array}{l}\text { Unskilled } \\
\text { workers }\end{array}$ & & & & 23 & -1.3 & +4.0 \\
\hline
\end{tabular}

scale. In both groups the professionals (among A.L.P. voters they account for two-thirds of the combined professionals and directors and managers) departed from the main linear pattern of the group. Among the Liberal voters both parties declined in esteem as one moves from directors and managers to semi-skilled and unskilled workers, although the party differential stayed much the same. Among A.L.P. voters there was little change in rating the Liberal Party apart from the professionals, but the A.L.P. gets progressively higher scores as one moves into the working class. While one might have expected unskilled workers to have a higher opinion of the A.L.P. than office workers, this was the case for A.L.P. voters but not for Liberal voters. The explanation may be that working-class Liberal voters over-compensated in negative partisanship to resist the temptation of a working-class party, although they were unable to resist a class tendency to depreciate the Liberal Party.

The second demographic variable of interest is religion. Table 2.10 sets out the scores for sub-groups of ten or more respondents each.

Among Liberal voters, Catholics and Methodists had a noticeably less favourable image of the Liberal Party than did Anglicans and Presbyterians. It will be recalled that Liberal directors and managers and office and sales workers had higher scores on the Liberal Party image than Liberal professionals or manual workers, and as the former comprised only one-third of Liberal Catholics and Methodists, but half the Liberal Anglicans and two-thirds of the Liberal Presbyterians, occupation and religion appear to be related. Examining the responses of Liberal voters to individual items we find that the Catholics and Methodists were more likely to find the Liberal Party onesided and selfish, less likely to believe it keeps its promises and that 
Table 2.10

Party image scores of religious groups 1963

\begin{tabular}{|c|c|c|c|c|c|c|}
\hline \multirow[b]{2}{*}{ Score for: } & \multirow[b]{2}{*}{$\mathbf{n}$} & \multicolumn{2}{|c|}{ Liberal voting intention } & \multirow[b]{2}{*}{$\mathbf{n}$} & \multicolumn{2}{|c|}{ A.L.P. voting intention } \\
\hline & & $\begin{array}{c}\text { Liberal } \\
\text { Party }\end{array}$ & A.L.P. & & $\begin{array}{c}\text { Liberal } \\
\text { Party }\end{array}$ & A.L.P. \\
\hline Anglicans & 66 & $+4 \cdot 6$ & -1.5 & 39 & +0.4 & +2.7 \\
\hline Catholics & 28 & $+2 \cdot 6$ & $-1 \cdot 8$ & 63 & $-1 \cdot 3$ & $+3 \cdot 2$ \\
\hline Presbyterians & 28 & $+4 \cdot 0$ & $-2 \cdot 2$ & 16 & +0.6 & +2.7 \\
\hline Methodists & 16 & $+2 \cdot 7$ & $-2 \cdot 3$ & * & * & $*$ \\
\hline No religion & * & $*$ & * & 10 & $-1 \cdot 3$ & +0.1 \\
\hline
\end{tabular}

it will promote full employment, and more likely to believe that it is dominated by party bosses. Each of these differences could be attributed to an underlying belief that the Liberal Party is run by and in the interest of a businessmen's establishment, although further research would be necessary to confirm the hypothesis.

Among A.L.P. voters, Catholics were both more favourable to the A.L.P. and critical of the Liberal Party: their party differential was $4 \cdot 5$, compared with $2 \cdot 3$ for the Anglicans and $2 \cdot 1$ for the Presbyterians. The possibility that class, represented by occupation, was at work here also is less certain than among Liberal voters. Manual workers outnumbered white collar workers 3 to 1 among Catholics, but also among Presbyterians and those with no religion while the ratio was almost 2 to 1 among Anglicans. Catholic A.L.P. voters were more likely to see A.L.P. leaders as able and having the courage of their convictions. Some of this might be attributable to Duggan's prestige as a fellow Catholic, or it might be a consequence of a different view of the role of the party leadership in the split. Those Catholics who remained in the A.L.P. might have respected the leadership for resisting what they regarded as an unwarranted attempt to mix religion in politics.

On the point of religion, Catholics generally were less likely to agree that the Q.L.P. is too closely attached to one church. While 39 per cent of Liberal voters agreed with the proposition, only 25 per cent of Liberal Catholics did, and while 39 per cent of A.L.P. voters agreed, only 32 per cent of A.L.P. Catholics did. In the ranks of the Q.L.P. itself only 21 per cent agreed, and only 8 per cent of the Q.L.P. Catholics.

The small number of individuals who were prepared to see parties other than the Q.L.P. too closely attached to one church is puzzling. Liberal Presbyterians and Methodists, and to a lesser degree Liberal Anglicans, were more inclined to say it about the A.L.P. than were 
Liberal Catholics, but there is not a great deal of difference. Nor is it entirely the case that such respondents are just militants who will apply any critical proposition to their opponents: Liberal voters who applied it to their own party had an average score on the Liberal Party image of $+2 \cdot 3$ whereas all Liberal voters averaged $+4 \cdot 0$, and those Liberals who applied it to the A.L.P. had an average score on the A.L.P. image of $-2 \cdot 5$ against the average of all Liberal voters of $-1 \cdot 6$; A.L.P. voters who applied it to their own party had an average score on the A.L.P. image of $-0 \cdot 3$ against an average of $+2 \cdot 6$ for all A.L.P. voters, and those who applied it to the Liberal Party had an average score on the Liberal image of $-0 \cdot 5$, the same as that of all A.L.P. voters. Thus while militancy enters into the matter, it is apparently not the sole explanation. 


\section{Party Leader Images}

WhILE the 1963 and 1966 State elections were a choice between a Country-Liberal coalition government or an Australian Labor Party government, and the choice of seventy-eight Members for the Legislative Assembly to run the parliamentary business of the State and look after the interests of their electors, it was also a choice between two possible Premiers-Nicklin and Duggan. Over the last decade a number of political commentators have claimed that general elections in Britain and Australia, despite their parliamentary form of government, have become popularity contests between rivals for the First Ministership closely resembling the presidential election campaigns of the United States. Whether this is indeed the case in the United Kingdom or the Commonwealth, it is submitted that such a development was not very far advanced in Queensland in 1963 and 1966. Whilst everything that the Premier or the Leader of the Opposition said or did was news, and althrough the policy speech of each provided most of the ammunition of the: campaign debate, there was little of the cult of personality which has long characterised American elections and is beginning to figure in the British.

Again the concept of an image is a convenient analytic tool:

Sometimes a man of exceptional personal force and power of expression is, so to speak, a party-political entity-in himself. He may fashion a permanent and recognisable mask for himself as 'Honest John' or 'The Grand Old Man'. But this can as a rule only be done by those who learn the main condition of their task, the fact that if an individual stateman's intellectual career is to exist for the mass of the present public at all, it must be based either on an obstinate adherence to unchanging opinions or on a development, slow, simple, and consistent. The indifferent and half attentive mind which most men turn towards politics is like a very slow photograph plate. He who wishes to be clearly photographed 
must stand before it in the same attitude for a long time. A bird that flies across the plate leaves no mark. (Wallas 1948: 95-6)

Both party leaders had been long enough in the public eye of Queensland. In 1963 Nicklin had served for sixteen years as Leader of the Opposition and five years as Premier, and for twenty-one years as Leader of the Country Party. Duggan had been a Cabinet Minister for ten years, and leader of the A.L.P. and Leader of the Opposition for almost five years. Both had been sufficiently 'exposed' to produce a clear image-and as is suggested below, both had stood in the same attitude' for a sufficient period to fix it. Certainly there was no significant change between 1963 and 1966. It appears, however, that party members gave less thought to the stimulation of images of their leaders during the campaigns than they gave to the party images. Perhaps they suspected that electors place less emphasis on party leaders than they do on what the party will do for the State or district or on the content of the party program. Or perhaps they regarded the existing images of the two men as more intractable material.

Neither of the rivals for the Premiership of Queensland was born in the State although this was not held against them. Nicklin was born just across the N.S.W. border at Murwillumbah where his father was editor-proprietor of the Tweed Herald, a semi-weekly founded in 1888. He was educated at Highfield College at Turramurra in Sydney, and served with the A.I.F. in France during World War I. As a corporal he won the Military Medal and was mentioned in dispatches, and later he was commissioned. On demobilisation, with some assistance from the Repatriation Department, he purchased a 20-acre pineapple farm sixty miles north of Brisbane where his father had moved. In 1932 he contested and won Country Party pre-selection for the safe seat of Murrumba:

I was only fourth in the primaries, but although I didn't get many first votes I was second choice of nearly everyone. It was a traditionally safe Country Party seat and I got in easily, although the Moore Government went out, and, well, I've been there ever since. (West Australian (Perth): 18 June 1957)

In 1935 he became secretary of the parliamentary Country Party. The union of the parliamentary parties of the Country Party and the United Australia Party in April 1941 as the Country-National Party led to the withdrawal of E. B. Maher as Country Party leader, and on 17 June 1941 the new party elected Nicklin its leader, Maher becoming deputy leader. In 1950 Nicklin sold his farm and moved to the coastal town of Caloundra in his electorate. In 1957 he had been Leader of the Opposition for sixteen years, and although the Country Party under his leadership was still far from electoral success it had managed to avoid the internal dissensions of its earlier years and to retain its solid electoral base in the south-eastern part of the State. 
At the time of the 1957 elections several profiles of Nicklin were published, and these may still be quoted because they capture very nicely his public image as it existed then-and as it remained during ten years as Premier:

Mr Nicklin is, at 61 a tall man with greying hair and a warm, frank face. He is so obviously an honest man that members say that, in Parliament, he has never suffered a personal attack.

$\mathrm{He}$ is not the Opposition's best speaker. His followers say they follow his leadership because they like him, trust him, and because he has lots of common sense.

The criticism made of Mr Nicklin as Opposition leader-even among some of his own friends-has been that he has not been aggressive enough and ruthless enough. They believe now, however, that the qualities he possesses will be much more important in a Premier than any he may have lacked as Opposition leader. (Courier-Mail: 15 June 1957)

Frank Nicklin ... does not conform at any point to the picture of a typical Australian politician and certainly not to the picture which has come out in the last few days of the typical Queensland politician.

He is a quiet, almost shy man. No breath of scandal has touched him. The worst his enemies can find to say about him is that he is ineffectual; he is too much of a gentleman to be a politician. (West Australian (Perth): 18 June 1957)

As a Premier, Frank Nicklin won't be any firebrand. He is neither dynamic nor colourful, but he has engaging frankness and sincerity that will, at any rate, be unusual qualities in the State administrative building.

He is a tall ( $6 \mathrm{ft} .1$ in.) angular man with varied interests and simple tastes. He doesn't drink, doesn't smoke, doesn't swear, yet he's a down-to-earth character who has been gallant in war and determined in peace.

And will this sudden elevation change his simple tastes? Certainly not, sir. He wants to continue picking the best pineapples and pawpaws as judge of tropical fruit for the Great North Coast Show Society. (Advertiser (Adelaide): 5 August 1957)

To the initial image of the simple, unspoiled farmer in politics five years of office added two elements, the effective and popular leader of a united Government and the hard worker familiar with every corner of the State:

The Premier (Mr Nicklin) is his party's and the Government's top card. Even if the rival labor parties came together before next year, they would find Mr Nicklin a formidable obstacle. Mr Nicklin's appeal to the average Queenslander is apparent in every centre he visits. His standing in his own party was evident throughout the four-day conference.

Whenever he spoke he was listened to intently, and his advice on minor or ticklish questions accepted. At no stage did he de- 
liberately attempt to dominate the conference, but his influence was potent. Mr Nicklin can be doggedly firm, but he much prefers the role of benign guide. (Courier-Mail: 18 April 1959)

Back in 1957 we recorded that Mr Nicklin was as humble in his victory as he was gracious in his string of election defeats. Mr Nicklin is still humble-at times even self-effacing-but he is a far shrewder politician than at least he appeared in his hour of triumph five years ago.

Mr Nicklin, the uncertain speaker on occasions, but the sincere, dogged and shrewd fighter, can expect far greater support and loyalty from within the Government than perhaps he has received over the last two years. This trend back to $\mathrm{Mr}$ Nicklin finds vocal expression within the Country Party. It is obvious also in the expressions of a strong body of Liberal opinion. So much so that there is a move in some Liberal quarters for a public statement that Mr Nicklin will remain as Premier, even if the Liberals win more seats than the Country Party at the next election. (Ibid.: 20 June 1962)

The second element can be found in a story datelined Julia Creek:

The Premier (Mr Nicklin) is now known to people here as "Mr Perpetual Motion'. His daily non-stop round of engagements from school inspections in the early morning to civic welcomes in the late afternoon or night have earned him the title.

Shire officials and members of his party have difficulty in keeping up with him. Yesterday he drove along dust choking roads to inspect work on the railways. An American official said: 'That man can move.' Mr Nicklin strode along the line regularly clicking his camera and leaving his staff and other members of the inspection party 'down the track'. On the return to Julia Creek he swung north to inspect the Julia-Creek-Normanton beef road. His party was still trying to quench its thirst from the dusty drive when $\mathrm{Mr}$ Nicklin was changed and ready for his next engagement. (Ibid.: 2 August 1962)

During his ten years of office there was never any suggestion of a wish to replace him, and while the succession to the leadership of the Country Party and therefore presumably the Premiership was clearly in the hands of the deputy leader and Minister of Education, Jack Pizzey, some fifteen years his junior, Pizzey's heart attack in September 1962 had quietened speculation about Nicklin's eventual retirement. When the ebullient Liberal leader and Deputy Premier, K. J. (later Sir Kenneth) Morris, resigned on grounds of ill-health in December 1962, and was succeeded by Munro, the latter's newness and retiring personality left Nicklin all the more alone in the spotlight on the Government side in 1963. In due course Munro retired, and for a brief time the Liberals were led by the Treasurer, Hiley, who had led the Liberals and their predecessors in the Queensland People's Party for a time in the days of opposition. Hiley was probably the ablest of 
the Liberal Ministers of this period and, apart from Morris, who sometimes exuded dynamism but sometimes gave an impression of a bee in a bottle, probably the most newsworthy. However, his selection at this point of time was a tribute for past services, and after a brief spell as Liberal leader and Deputy Premier, he stood down and was succeeded in both posts and as Treasurer by the party's deputy leader, Gordon Chalk, at the end of 1965 in time to prepare for the forthcoming election. Again the novelty of the Liberal leader, and Chalk's fairly phlegmatic public style, meant that Nicklin was the dominant figure in the team. Chalk's firmness in dealing with a Young Liberal resolution asking that he deliver a separate policy speech, instead of a joint second-half to Nicklin's speech, attracted favourable comment. At the opening meeting of his Lockyer campaign committee at Gatton Chalk said that he was insisting on a joint speech, and 'expressed his appreciation that members of the Country Party in Lockyer had, by their attendance at the meeting, indicated their appreciation and support of his efforts' (Queensland Times (Ipswich): 30 March 1966). So far as he was concerned, the parties remained firm friends.

By 1966 Nicklin's age was a possible issue for the campaign. Duggan raised it tentatively at a couple of meetings in North Queensland when he called Cabinet collectively 'a tired, lazy, incompetent lot' and, speaking of the Premier, remarked: 'It's obvious when getting up into the seventies people are not as good as they have been.' He compared the Queensland record unfavourably with Western Australia's and claimed: 'It's no good having old, tired men who aren't doing this sort of thing' (Sunday Mail: 8 May 1966). Nicklin retorted that Duggan's policy was so inept and insubstantial that he was forced to stoop to personal attacks, and defended Queensland's development record. He offered to test their relative fitness over 100 yards, a proposal which was dismissed by Sunday Truth:

Politicians in all camps figure they know already the outcome ... Their guess: A DEAD heat, long before the finishing tape. (15 May 1966)

Dewar as Minister for Industrial Development chimed in, and as a testimonial to his fitness to attract industry to the State offered to race Duggan from Brisbane to Ipswich and give him a mile start (out of twenty-five). But no one else bothered about Nicklin's age during the campaign. Certainly no press reports suggested any flagging of his energy. Thus a week before the poll the Sunday Mail reported:

The Premier (Mr Nicklin) has given the impression throughout his campaign of a man who knows he will win, but who has to put a lot of work into winning. On Friday he completed the first stage of a 5000-mile tour of the north, centre and west, with diversionary visits to the three-cornered trouble spots near Brisbane. Travelling 
by rail, air and road $\mathrm{Mr}$ Nicklin has not spared himself and has shown a vigour that belies his 70 years.

His one concession to comfort and, at the same time the gain of an efficient campaign headquarters, has been the use of his Ministerial rail carriage for part of his Northern tour. When he was not holding meetings he was in almost constant conference with party officials and candidates advising on strategy, changing the course of a campaign. He found time for several afternoon and morning teas with women's organisations, and if there were any cane growers or dairymen around he was every ready for a talk-In his rail carriage, Mr Nicklin usually is the first out of bed. The kettle whistling merrily is a sign that Mr Nicklin is astir. (22 May 1966)

Mr Nicklin's press image being what it was, perhaps it is surprising that any voters agreed to the proposition that he was getting too old for the job (see p. 94).

Unfortunately there are no comparable contemporary sources to quote for Duggan's public image, partly because there are fewer occasions which call for assessment of a Leader of the Opposition, and partly because a prevailing anti-Labor press does not go out of its way to write up its opponents. One exception was provided at the time of the split:

The dreadful secret about Mr John Duggan, Parliamentary Leader of the A.L.P., is that he is an intellectual who plays hi-fi Beethoven in his room at Parliament House ... Mr Duggan, has, at the age of 46, become the 'wild one' of Queensland politics-a figure on whom people cannot agree. After almost universal applause for the brilliant young man of a few years ago there are now catcalls from the pit.

A man of high talents, introspective, ambitious, but not ruthlessly so, cool and intelligent, it is the A.L.P.'s good fortune to be able to present him as its Parliamentary leader. The trouble with $\mathrm{Mr}$ Duggan-if there is a trouble-may be that in his political life he has had success too easily. This contrasts with his youthful life when he had to go to work young, further educate himself at home, and make his own success, which he did, with energy and acumen.

In the Labour Party in Queensland he has undoubtedly deserved his success. But Labour was able to accord it partly because, by its harsh treatment of Parliamentary opposition, in which Mr Duggan has shared, it was always Labour that dished out the gravy. In his $2 l$ years of Parliament ... he has spent only two days-they were three weeks ago-on the Opposition benches and, if the A.L.P. goes into opposition after this election, the experience should enrich him as A.L.P. leader. (Courier-Mail: 5 July 1957)

If Nicklin is the archetypal Country Party leader, Duggan is a classic example of one type of Labor leader, the self-made man. $\mathrm{He}$ was born in Port Augusta, the son of a school teacher, and for a time 
lived at Maree across the border from outback Queensland while his father taught at Birdsville. He was orphaned at 14 , and went to live with an aunt in Toowoomba, starting .work as a grocer's assistant. A voracious reader (probably the best read Member of the Queensland Parliament since Theodore), he soon turned to politics-president of the Toowoomba branch of the A.L.P. at 21, the M.L.A. for Toowoomba at 25. During World War II he served, on leave of absence from the House, as an army officer in New Guinea. In 1947 he entered the Hanlon ministry as Minister for Transport and retained that portfolio until the 1957 split. When Gair became Premier in 1952 he became Deputy Premier. In the 1957 election he was defeated in Toowoomba, and failed to return to the House at the ensuing byelection for Gregory. On the death of Les Wood (who had succeeded him as leader of the parliamentary party) he won the North Toowoomba by-election, and was immediately re-elected to the leadership. The following five years had seen the A.L.P. regain a few seats and some of its electoral support, but the parliamentary party remained weak and Duggan's considerable abilities shone from the lack of competition as well as from their own quality.

The A.L.P. is usually loath to make too much of its leaders, and the experiences of 1957 reinforced this tendency. As Duggan himself put it at that time:

I got into Parliament as an obscure grocer in 1935, and Mr Gair as an obscure railway clerk, only because we were endorsed Labour candidates. There is no place in Australia for the little penny dictators who think they are greater than the machine which created them. (Ibid.: 13 May 1957)

Nevertheless, as the outstanding member of the parliamentary A.L.P. after the split he became the focus of such attention as the press gave the Opposition, most of it turning on the question of his relations with the extra-parliamentary organs of the party. Thus he was described as the strong man of the Brisbane Labor-in-Politics convention of 1960, always successful in getting his way, and the convention itself-in the absence of the A.W.U.-was described as harmonious (ibid.: 3, 6 February 1960). Invited to address the 1961 Trade Union Congress, he was unexpectedly attacked by Egerton who, introducing him to the Congress, declared that Duggan would need no introduction to regular delegates but new ones would not know him, for only Messrs Bromley, Newton, Houston, and Sherrington of the parliamentary A.L.P. attended Trades Hall. Egerton also permitted himself an attack on the A.W.U. Pointing out that in 1960 he and Duggan had agreed that there was a need for a better class of parliamentarian, he said:

I think many of them have not the ability to do the job they are asked to do. The only chance we had of getting a good type was 
while the A.W.U. was not affiliated with the A.L.P. Now that they have bought their way back it will be difficult for decent men to get into Parliament. (Ibid.: 13 October 1961)

This part of his welcoming remarks was passed over, but Duggan denied the charge about his neglect of the unions: he had attended at least three union conferences in the Trades Hall since the last T.U.C. and he spent every Saturday morning at the Toowoomba Trades Hall. Nolan of the A.R.U. added that he could think of at least fourteen M.L.A.s who had been at Trades Hall in the previous year. After an extensive pre-election tour of the State in which he and the state secretary, Jim Keeffe travelled 4,000 miles by car and visited 150 centres in twenty-nine electorates, there were rumours of left-wing dissatisfaction with Duggan's leadership which were promptly repudiated by both the Q.C.E. and Caucus (ibid.: 23 and 26 October 1962).

Difficulties of this sort laid Duggan open to charges that he was subject to dictation by interests outside State Parliament, while the policy statements of others in the Labor movement sometimes saddled him with unwanted responsibilities the avoidance of which produced criticism like that provided by Hilton in a column contributed to the Telegraph on behalf of the Q.L.P. (27 May 1963):

Mr Duggan, the led leader of the Australian 'Labor' Party in Queensland, must be the greatest back-pedaller in the history of the State's politics.

He started back-pedalling in 1957, when he pedalled frantically to desert his mates in the Gair Labor Government; and since then he has continued frenziedly back-pedalling-mostly to get out of the way of bricks dropped by his Trades Hall mates, such as at Bundaberg and on the United States Base issue.

His back-pedalling has been away from people like his party mate, Senator Dittmer, who wants oil socialised, but only after private victims have been let spend their millions finding it.

He has been back-pedalling from his party's decisions at Canberra on the U.S. Base (which talks he attended), because they dangerously affect his election prospects now. He has even already back-pedalled from some of his own policy speech proposals, notably the 'pinching' of State Insurance Office funds to finance house-building.

You may remember that Fred Allen said the penguin flies backward because it hates to see where it's going, and would like to be back where it was. Mr Duggan's so like that! For he lives to take a stand, wise or unwise, and then if necessary retreat from it, right or wrong. These days this is called leadership.

During the two campaigns there were few explicit references to the two leaders and their virtues or defects. Only only one candidate, J. B. Hughes standing for the A.L.P. in Greenslopes in 1963, saw fit to feature his leader in his personal appeal with $5 \frac{1}{2}$ inches of text on Duggan (apparently derived from his biography in Lack's Three 
Decades of Queensland Political History) to $1 \frac{1}{2}$ inches on Hughes. Government speakers sometimes paid brief tributes to their leader. In 1966 the Country Party candidate for Cairns capitalised on his own name: 'The Country Party man is the Nicklin man; the Country Party man is Franzmann' (Cairns Post: 17 May 1966), and in Toowoomba East Alderman J. F. McCafferty used pictures of Nicklin 'Mr Queensland' and himself 'Mr Toowoomba' side by side. At the end of the campaign the main Country Party advertisement (which attracted some comment by listing Chalk among the endorsed Country Party candidates) explained 'why you should vote for Nicklin tomorrow' and said 'Frank Nicklin's Country Party candidates are pledged to . . . .' In view of the extent to which the Government relied on the Premier's popularity, the omission of his image from party advertising is surprising. The Minister for Lands, Alan Fletcher, in 1963 told his Country Party electorate council:

Frank Nicklin is a splendid leader, well informed and practical, and impressive in his knowledge of Queensland. Not many Governors $[s i c]$ are as happy in relationships of Cabinet Ministers to each other and to their Premier. (Toowoomba Chronicle: 8 May 1963)

At another Country Party meeting Fletcher said:

The Government has a top-hole leader in Frank Nicklin-a most effective and informed man with a monumental knowledge of the whole of the State and its problems. The extent of his knowledge of the State is astonishing and his capacity for creating good will and happiness among his colleagues is also inspiring. Not many Governments or Cabinets are as good or as happy as ours is. (Ibid.: 30 April 1963)

By 1966 Fletcher was concluding speeches:

I'm proud to be a Minister under the best Premier we have ever had in Queensland, and to serve in a Cabinet whose Members command by respect and warm regard. (Ibid.: 19 May 1966)

Another Country Party Member, Vin Sullivan, spelled out the difference between the two leaders:

I pay a very high tribute to Frank Nicklin for his grand leadership. No doubt a man with his energy and determination was aware, after so long as Leader of the Opposition, of what would be required of him when eventually he did become Premier.

I have sat in conference with Mr Frank Nicklin and I admired him for the manner in which he patiently sought advice on matters from those who were closely associated with problems. I admired him when he completely rebuked groups within his 'policy making body' endeavouring to insert pressure, reminding them that it is he, and members of his Government, those elected by the people, who will make the decisions. How different from the leader of the Labour Party, Mr J. E. Duggan, who has stated that he will accept 
dictation from his 'policy making body', whether it be 'wise or unwise', 'right or wrong'. (Dalby Herald: 17 May 1963)

Munro opened his 1963 policy speech with a tribute:

Might I say first that I regard it as a great privilege to work with our Premier, the Honourable Frank Nicklin, in the affairs of Government and to be associated with him in the presentation of our Policy statement.

Frank Nicklin has given us inspiring Leadership both in Opposition and in Government and it is a great tribute to his personality that he has so fully retained the confidence and respect of our Queensland people over so long a period.

In 1966 Chalk was much terser: 'It is a great satisfaction to have on this platform the Honourable the Premier-Frank Nicklin-a man who both in times of War and days of Peace, has done so much for Queensland.'

Tributes such as Fletcher's were infrequent and most government candidates were content to acknowledge the services of "Frank Nicklin and his team' in their campaign speeches, while A.L.P. candidates merely commended Duggan for his admirable policy.

Before the elections Nicklin contributed a fortnightly article to the provincial papers entitled 'Personally Speaking'. These articles were usually reports of government work-in-progress or projects for the future, and while they praised his government's achievements they were far from blowing his own horn. As befitting their circulation in country areas, most of them were concerned with the progress of rural industries including mining, but they also concerned industrialisation and workers' compensation. Only one article, 'The Alternative Government' (Bowen Independent: 19 April 1963) under Nicklin's byline appeared during either campaign which deviated from this nonpartisan approach, and this appears not to have been part of the 'Personally Speaking' series. During the 1963 campaign a tour of 3,000 miles by air and rail took him through most of the State, as far north as Cairns and as far west as Charters Towers, Longreach, and Charleville. His campaign speeches involved a refutation that unemployment was nearly as bad as the A.L.P. claimed (at Redcliffe: Morning Bulletin (Rockhampton): 9 May 1963; Cairns: Telegraph: 13 May 1963; and Mackay: Daily Mercury (Mackay): 20 May 1963), predictions that faceless men would control Queensland if the A.L.P. were returned (at Charters Towers (Telegraph): 11 May 1963), attacks on the A.L.P. proposal to use State Government Insurance Office funds for home building (see pp. 208-9), a promise that the railways would employ more rather than fewer men (at Charters Towers: Northern Miner (Charters Towers): 13 May 1963), but in the main they set out the Government's achievements. In an uncharacteristic speech made at Babinda Nicklin denounced the A.L.P. as close to 
Communism with fifty-six of the sixty-eight members of the Q.C.E. proCommunist or fellow-travellers. Declaring that the major issue of the election was whether the people wanted government from Parliament House or Trades Hall, Nicklin claimed:

The left wing union leaders and communist allies now exercise a dominant influence on A.L.P. policy. Mr Duggan might regard communists as jackals squatting in the shadows of Labour's campfire, but the fact remains they are there. (Daily Mercury (Mackay): 16 May 1963)

Referring to Dougherty's attack on A.L.P. parliamentarians as gogetters, lawyers, publicans, and egg-heads (see p. 112), Nicklin added that he forgot to mention 'the subversives, disloyalists, pliant fellow travellers and camp followers who had worked their way into positions of influence at all levels of the A.L.P.' In another account of the speech (Townsville Daily Bulletin: 16 May 1963) he was quoted as giving "the background of some of the people who make up the Labour Party, and influence its policies today'. One candidate had been a member of the Eureka Youth League; two candidates-as well as Duggan, Lloyd and Keeffe-had given donations to the Waterfront Peace Committee and 'the funds collected were used to send Communist Alec Macdonald to the World Peace Conference in Moscow in 1962'; another candidate had been on a unity ticket in a waterfront union election; Waters, a member of the Q.C.E. and the A.L.P. Federal Conference 'deciding on the establishment of an American radio base in Western Australia' as well as being a member of the campaign committee of a Brisbane electorate, had advocated an alliance of the A.L.P. and Communist Party in 1954 and been active in peace organisations; while Nolan, another federal conference delegate, had rejoined the A.L.P. only when his union reaffiliated in 1957. Nicklin supposed that Duggan would say that he was conducting a smear campaign:

It is not a smear campaign. What I am telling you is absolutely true. We have to decide between democratic government and government by the Reds who control the A.L.P. We are a vital outpost in the southern seas, and we have to keep it such and save it from any direction or control by people who have taken complete charge of the A.L.P. in Queensland at present.

At Roma Nicklin produced a photostat copy of a unity ticket for the 1954 Trades Hall committee election in response to a challenge from Waters to say whether he had ever appeared on a unity ticket. According to the Premier the ticket listed Communist unionists along with Waters, Egerton, Milliner and Nolan, and was designed to defeat an effort to dislodge Communists from the Trades Hall executive being made at that time, an attempt which was defeated when those unionists' followers supported the Communist candidates. Nicklin added 
that he could produce other evidence to show the 'share the leadership' arrangement at Trades Hall elections every year between 1958 and 1962 (Western Star (Roma): 24 May 1963).

The attack was uncharacteristic of Nicklin, and occasioned some speculation as to why he had injected the Communist issue into the campaign at this point, for although Country Party organisation propaganda had made much of it, Nicklin had not raised the subject before the Babinda meeting. (An article contributed to the Telegraph's election column 'Leaders Say' on 14 May had warned:

The choice is yours whether that growth is to continue unchecked or whether it is to be stunted by men of limited vision who are the pawns and stooges of a powerful coterie of Leftists and fellow travellers-the type of men who have been described by Harold Laski as 'a secret battalion of paratroopers in Labor's ranks,' whose mission is to break up the Labor movement and impose their own camouflaged party dictatorship.

There is ample proof of their malignant influence as a dominant factor in framing A.L.P. policy. They control the flabby remnants of the Labor Party, whose morale they have undermined and whose strength they have sapped.

But there is reason to believe that the pen was not that of Nicklin but of the Country Party organisation, and the Babinda speech was Nicklin's first personal venture on the Communist issue.) In another hard-hitting speech delivered at Goondiwindi near the end of the campaign Nicklin questioned the appearance of a number of A.L.P. federal Members from other States to campaign in Queensland:

Never since the days of Captain Cook have we had so many explorers descending on Queensland. These southern politicians were like cockatoos on a corn patch, but half of them would not know where Queensland was unless someone pointed it out to them on a map. They came here to tell us how to run Queensland, but when they were members of Federal Parliament they never raised a hand to help us. Now they are trying to sell Socialism to Queenslanders. (Warwick Daily News: 25 May 1963)

At the end of the campaign he again referred to Communist support for the A.L.P. at the election, and pointed out that the Communists were making no bones about wanting Labour to win (Telegraph: 28 May 1963). Nicklin's personal message during the campaign was that his government had done a good job, and in the later stages of the campaign that the A.L.P. was Communist-dominated and Socialistinclined.

In 1966 the campaign was shorter, the shortest campaign Nicklin had ever conducted as Leader of the Opposition or Premier (CourierMail: 19 April 1966). He stole a march on the A.L.P. by a television broadcast, just before Duggan's policy speech, in which he set out Government achievements. After delivering his own policy speech at 
Maroochydore on 9 May, Nicklin campaigned briefly around Brisbane, went north to campaign between Cairns and Mackay, then returned to the south with one swing through some south-western electorates. At Charters Towers he repeated his 1963 dig at A.L.P. federal M.P.s as the greatest influx of explorers since Cook-'Did $\mathrm{Mr}$ Duggan invite them in an endeavour to cover up the weaknesses of the A.L.P. policies or were they directed here by the bosses of the Q.C.E.?'-and got as much press coverage from it as in 1963. At Gordonvale he disclosed that Queensland was seeking a federal subsidy for mineral exploration in the north. Again something in the air at Babinda induced his strongest attack on Duggan; this time it was for endangering sugar price negotiations overseas by making irresponsible statements. The Leader of the Opposition had done more to reduce the value of sugar properties than anything else associated with the industry's current difficulties (Courier-Mail: 16 May 1966). At Roma he made one other uncharacteristic attack when he complained that in the years of A.L.P. dominance western Queensland had been represented by either party hacks or men who were frustrated by their leaders in any effort to secure warranted expenditure in their electorates. On a television panel interview back in Brisbane Nicklin predicted that he would retire before the next general election, indeed would step down in time for Pizzey to settle into the job well before the next election. In 1966 the Premier made less use of Communist and Socialist influences on the A.L.P. and relied more on the government's record.

In the months before the campaigns really started Duggan also had access to a regular column in some of the provincial papers. 'Labour Opinion', in which he dealt with subjects like unemployment, housing, and education. One article in 1963 was devoted to answering Pizzey's attack 'in true Sax Rohmerish style', on the Bundaberg convention. Duggan conceded that there had been tickets at Bundaberg, but there had been tickets at every convention since the first one he attended in 1939, and the government had recently seen some intense lobbying of its own in the Liberal caucus election of Dewar to a vacancy in the ministry and the adoption of preferential voting. The government was relying on abuse and cries of 'Communist-dominated' and 'Red Terror' to conceal its own poor record in unemployment, education, and housing. Duggan observed that Pizzey was 'being groomed for the throne shortly to be vacated by a tiring Premier'. His charge of a takeover of the A.L.P. by leftists made little sense when there had been hardly any change in the composition of the Q.C.E. delegates selected. In 1966 he anticipated government tactics of the previous campaign by warning against government-sponsored advertising listing increases in primary and secondary production, 'centred around the general theme that a dynamic Government has re- 
leased Queensland from the bondage of backwardness'. Duggan declared that some improvements such as the rehabilitation of the Townsville-Mt Isa railway line had been secured on terms unfavourable to Queensland in comparison with railway works in other States, the mineral boom was fortuitous and would have taken place whatever the government in power, Commonwealth aid had been determined by federal election results, population increase had been unsatisfactory, and he dealt with a number of other weak spots in the Government's development record.

Duggan's vote on the North West Cape base in 1963 (in which he voted with the N.S.W., South Australian, and Tasmanian delegations on what was generally, but somewhat inaccurately, reported as a defeat for the left wing) earned him the plaudits of the press. Sunday Truth (24 March 1963) under the headline 'For Labor-and for all-a great service' reported that leftists were determined to remove him from the State leadership, and in another column added: ‘. . He was big enough to see that more than petty party politics was involved. So Jack Duggan went against his mates.' Even so consistently anti-Labor a paper as the Rockhampton Morning Bulletin conceded that 'Duggan's Vote Did Him Good' in the eyes of the public, even if not within his party:

The standing of Mr Duggan, Leader of the State Opposition, has risen in the minds of most people of Queensland as a result of his vote in the Labour Federal Conference . . . but the Leftists in the State Party won't forgive him for it, judging from the bitterness shown since his return from the meeting. They claim he defied the expressed wishes of A.L.P. leaders here and a few of the hotheads are said to have expressed their determination to work for his replacement as leader.

The strong down-the-middle cleavage in the party over the radio station question augurs ill for the Labour Party at the coming State election. Personally Mr Duggan may gain a few votes from his bold, almost heroic action in voting as he did, while his five fellow delegates from Queensland voted the other way, but the result of the conference and the great publicity given to it can only do harm to Labour at the polls. (29 March 1963)

His speech to the Bundaberg convention had won similar backhanded praise from the Morning Bulletin:

Perhaps the best thing to come out of the 1963 Labour-in-Politics Convention was the forthright speech by the State Parliamentary Leader (Mr J. E. Duggan) towards its close, when he said some things that should sink deeply into the consciousness of those to whom they were addressed, and which will earn strong commendation from other quarters....

The content and tone of the speech recalls an earlier J. E. Duggan, the up-and-coming young parliamentarian who seemed des- 
tined to reach the heights not only in Queensland but in national politics. Things have happened to cause him to stumble on his journey. One complaint is that he is too prone to accept dictation, to be pushed around by outside elements which insist that it is the role of the politician to do as he is told.

Submergence of the Queensland Parliamentary Party must have reached its nadir at this convention, what with the deaf ears which greeted the pleas for unity by Federal and State leaders, rejection of the Deputy Leader as a conference delegate, denial of committee appointments to some members and refusal by others to serve.

Someone had to speak out and Mr Duggan has done so with some of his old vigour. It could be a new milestone in his career. $\mathrm{He}$ is too young in years and too strong in ability to suffer eclipse even if there was one to take his place, which may be seriously questioned. (15 February 1963)

His start of the campaign by a 2,200-mile barnstorming tour of northern and western country centres in a small plane added to the image of the dynamic hustling leader (Telegraph: 10 May 1963), and during the tour he unveiled further parts of A.L.P. policy-on Aboriginal welfare, for the tobacco industry, and better medical and dental services for the west. A second trip by plane to visit some centres which bad weather had ruled out on the first tour attracted rather less publicity. In 1966 the emphasis was again on 'The Man of Action' and a rapid, wide-ranging tour. Personal sketches usually mentioned his rapid speech-'very often at about 200 words a minute'-which always impressed journalists. His tour was estimated at 12,000 miles (Evening Advocate (Innisfail): 9 May 1966), but in 1966 the use of a light plane to detour to Mareeba received less attention. One of Duggan's difficulties in 1966 was that as the prices issue visibly crumpled it became more and more difficult to show signs of a large swing sufficient to bring him the seats needed. Whilst the government appeared embarrassed in sugar areas, it was generally agreed that only two seats were likely to be affected, Mirani and Whitsunday. In a television panel interview Duggan claimed that at least sixteen seats would go to Labor, and named twenty possibles. Six of these were in Brisbane (Aspley, Chatsworth, Ithaca, Merthyr, Windsor, and Yeronga) and the rest scattered around the State, seven in the south-east (Bundaberg, Carnarvon, Cooroora, Logan, Murrumba, Redcliffe, and Toowoomba East), three in the west (Balonne, Flinders, and Gregory) and four in the north (Bowen, Cook, Mirani, and Whitsunday). Nicklin was prepared to concede Labor might win one or two, but was only prepared to mention the Liberal-held seat of Ithaca as a possibility. In fact the list of twenty included some which were so implausible that the unlikelihood of a Labor government was suddenly brought home to the more informed spectator. At the end 
of the campaign Duggan tried new tactics: teams of housewives supported by loudspeaker cars holding 200 street meetings on prices on one day in Brisbane, but it was late for that issue.

Late in the 1963 campaign Gair raised again the story that Duggan would lose the leadership after the elections:

This move true to form is inspired by the Communists in the Trades Hall, whose supporters now hold a decisive 2-to-1 majority on the A.L.P.'s Queensland Central Executive. Mr Duggan's days are numbered. He cannot. win the election for the A.L.P. He has served his purpose in persuading non-Communist Labor supporters that it is all right to link with the Communists in the trade unions behind the slogan 'Unite to oust Nicklin'. (Telegraph: 23 May 1963)

The expectation was disappointed. On 13 June Duggan and Lloyd were returned unopposed to the leadership and deputy leadership, and Caucus unanimously passed a resolution congratulating Duggan on his conduct of the campaign. However, after the 1966 election Lloyd was defeated by a left-wing candidate, Jack Houston, for the deputy leadership. In October 1966 Duggan's name was published as an income tax defaulter, and, despite the request of the Caucus that he retain the leadership, he resigned. Houston was elected leader, and another left-winger, Tucker, succeeded him as deputy leader.

Both party leaders did little during the final weeks of campaign. ing to change either their own or their party's image. Nicklin remained 'Honest Frank', the hard-working leader with the interests of the whole State at heart, relying on the record of economic development which had come during his government's terms of office. Duggan remained the bustling and able leader of a disunited and suspect party, trying to sell a program.

As wrTy party images in the preceding chapter, we can set against the public images of the party leaders reported in the newspapers the responses of members of the Brisbane panel of electors. As with the party image survey, pre-testing was conducted in 1963 with a mail questionnaire asking two questions: 'What qualities would you look for in a good political leader, in other words what sort of person would you expect the Premier of Queensland to be?' and 'Suppose an interstate visitor were asking you about your views on the likely head of the next Government of this State, and he invited your candid opinion of both Mr Nicklin and Mr Duggan as political leaders, WHAT WOULD YOU TELL HIM? (a) About Mr Nicklin, (b) About Mr Duggan'. A rough content analysis produced ten items which were printed on a card handed to panel members with the question:

(Here) are some statements often heard about the Premier, $\mathrm{Mr}$ Nicklin, or about the Leader of the Opposition, Mr Duggan. As I 
say each of them, would you please say whether you think it's true or not, firstly of the Premier, Mr Nicklin? And about Mr Duggan. As I mention each again, would you please say whether you think it's true or not of Mr Duggan, the Leader of the Opposition in the State Parliament?

Members of the panel have again to be divided according to their voting intention determined by their response to the question: 'If the State election were being held today, which party would you like to see win?' Their initial responses in 1963 are set out in Table 3.01.

The most obvious thing is the considerable agreement on Nicklin's integrity: he is honest and sincere, and he stands by his principles. Only 1 in 5 of the A.L.P. voters were prepared to gainsay him this. While A.L.P. voters were equally well disposed to Duggan in this respect, almost one-half the Liberal voters questioned his integrity. It would have been interesting to ask why-whether this doubt dates back to the 1957 split, whether it was reinforced by his vote at the Canberra federal conference, or how far it is part of a general hostility to him. There was also a willingness by about two-thirds of A.L.P. voters to concede that Nicklin had a good record of achievement and was interested in the welfare of everybody-a point on which Liberal voters were virtually unanimous. Both groups were much more likely to be uncertain about Duggan's record, and a substantial proportion of A.L.P. voters and half the Liberal voters were prepared to deny him a good record of achievement. Similarly, while only 29 per cent of A.L.P. voters were prepared to deny that Nicklin was interested in the welfare of everybody, almost half the Liberal voters denied that Duggan was.

Two points may be somewhat surprising, and have some importance in relation to generalised political attitudes. A.L.P. voters believed, almost unanimously, that both leaders looked after their own group first, and Liberal voters agreed, almost unanimously about Duggan and two-thirds about Nicklin. The Liberal consensus that Duggan looked after his own first was part of a Liberal general view of the A.L.P. as sectional and selfish, but such a view of Nicklin indicates that some refinements of a sectional-general interest polarisation of images is needed, perhaps in terms of priorities applied; for example Nicklin looked after his own first but in such a way as to pursue a common good, or having satisfied his own group went on to look after other groups while Duggan stopped with his own. Secondly there was a readiness to say that leaders are under the thumb of party bosses. While Liberal near-unanimity about Duggan is not surprising considering the flow of party propaganda and editorial comment to that effect, it is remarkable that 1 in 6 thought it of Nicklin. Again almost 40 per cent of A.L.P. voters thought it of Duggan, but almost 60 per cent of Nicklin. It may be that some A.L.P. voters 
responded to the constant bombardment of their position by charges of bossism with a 'you're another', but it is unlikely that a sufficient number were so emotionally attached to their party to produce the result shown, nor would this explain why so many Liberals saw Nicklin as subject to dictation.

The answers to the open-end questions in the pre-test survey in 1963 had shown a number of Liberal voters critical of Duggan as a knocker, too critical, and always grousing. This was before the campaign attack on him and the A.L.P. along these lines had been opened, and raised the possibility that the constitutional function of a leader of the Opposition might prejudice him with a section of the electorate who thought positively about the happy position of the Sunshine State and resented anyone chipping away at this image, with the further possibility that this might be a factor helping to explain the longevity of State governments which have this group in their pocket-until things go badly wrong, when there is a landslide swing as they shift. However, the majority of A.L.P. voters were prepared to make this criticism of Nicklin, who has eschewed controversy and lambasting the Opposition (say in the manner of Sir Robert Menzies or Sir Thomas Playford) so much that when he made his 'grim-faced speech' at Babinda political inside dopesters wondered why he had panicked. There may be two explanations involved-a resentment against any real or even imagined criticism from the other party, and an apolitical view of party politics generally as unprofitable knocking. The existence of a Liberal bloc that regards Nicklin as too critical would support the latter.

Seven of these ten items were used again in the reinterviews conducted in 1966. Responses are set out in Table 3.02. There were relatively few substantial changes: thirty-six of the eighty-four possible changes exceeded 5 per cent, but only seventeen exceeded 10 per cent, and six 15 per cent. The leaders' images held collectively by the panel were relatively constant. The Liberals' views of Nicklin changed hardly at all, but their view of Duggan became rather more favourable save that in 1966 they were even more likely to think that he criticised too much. They were more likely to find him standing by his principles, interested in the welfare of everybody, and honest and sincere, less likely to think that he looked after his own group first or was under the thumb of party bosses. They were much more uncertain about his record of achievement, as were A.L.P. voters. It should be remembered that these are the same respondents as in 1963, not a new group of voters entering the electorate. Records are wasting assets. Labor voters' views of Duggan had also become more favourable. 'They were less likely to think that he looked after his own group first (if that indeed is a favourable movement for partisans), less likely to believe him under the thumb of party bosses, but 


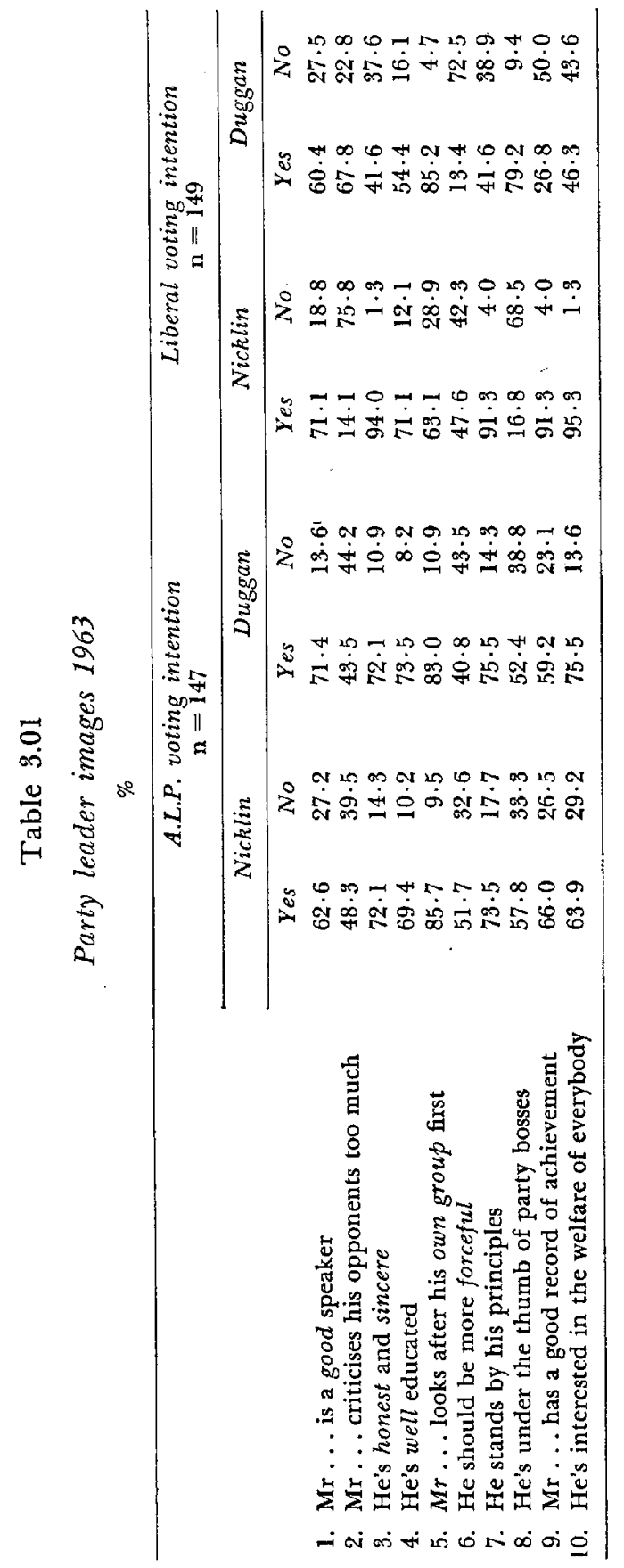


as with the Liberals' views of Nicklin there was relatively little change. The A.L.P. voters' opinions of Nicklin had become distinctly less favourable on some items. More doubted that he was honest and sincere and that he stood by his principles, whilst belief that he was interested in the welfare of everybody had fallen away sharply-from a favourable two to one majority to almost the reverse. Whilst the Labor voters were becoming more partisan, the Liberal voters were becoming less so.

The three new items show a clear distinction between the two men. Liberal voters thought well of their team, but were divided about the A.L.P. team; Labor voters were divided about the government team and only marginally well disposed to their own. Hardly anyone thought Duggan too old, but a quarter of Liberals and half the Labor voters thought Nicklin was. Neither group of voters was likely to think their leader too autocratic and dictatorial, but they were not so certain about their opponents'. The second matter to appear in the pre-test survey in 1963 was that the one criticism which Liberal voters were prepared to make of Nicklin was that he was not forceful enough. This opinion was endorsed by almost half the Liberal voters in the panel and slightly more A.L.P. voters, but whilst a small number of Liberal voters thought Duggan should be more forceful, half the A.L.P. voters thought so. They tended to be more partisan than the average, more likely to give Nicklin a low score (average $-1 \cdot 2$ against -0.3 for all A.L.P. voters in 1963-the scores are explained below), and slightly more likely to give Duggan a high score (average $+2 \cdot 5$ against $+2 \cdot 1$ for all A.L.P. voters in 1963).

It is possible to construct a score on the party leaders' images similar to that used on the party images in the preceding chapter. Using those items which distinguish clearly between the two men in 1963 only ten ( 7 per cent) of Liberal voters were at all critical of 7, 8, 9 and 10 for Duggan. Favourable response series run: no, no, no, yes, yes and no, yes, yes, no, yes, yes respectively. Scoring on this basis a respondent could have a score on his view of Nicklin ranging from +5 to -5 and on Duggan from +6 to -6 . As might have been expected, voters favour their own party leader. Nicklin's greater popularity in 1963 was perhaps not as pronounced as one might have expected from Table 3.01. Admittedly none of the Liberal voters were highly critical ( -4 or worse) in 1963 and only one in 1966, whilst ten ( 7 per cent) Labour voters in 1963 and five (6 per cent) in 1966 were so critical of Duggan, but these are still small minorities. In 1963 only ten ( 7 per cent) of Liberal voters were at all critical of Nicklin and in 1966 the figure was only 9 per cent, whilst twentyfour Labor voters ( 16 per cent) in 1963 and nine ( 11 per cent) in 1966 were critical of Duggan in terms of the score employed here; thus a difference was definitely reduced between the two campaigns. What does 


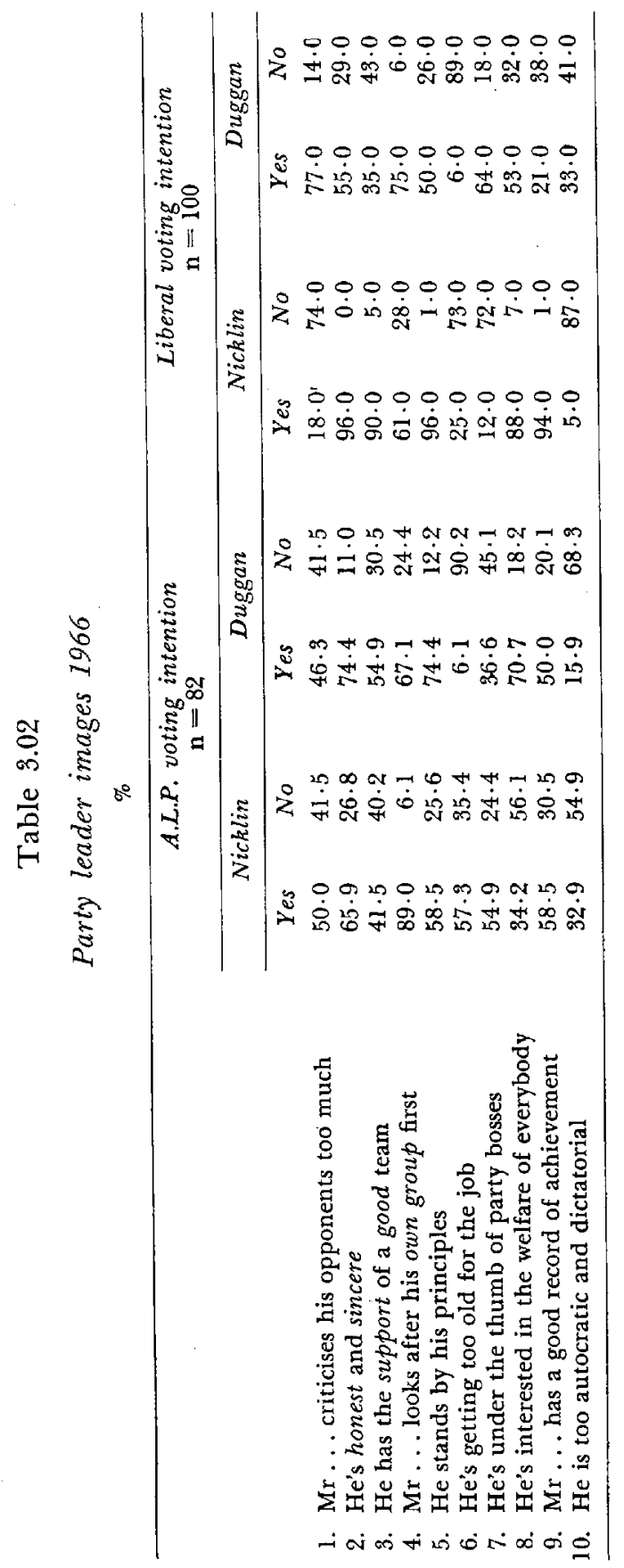


96

IMAGES AND ISSUES
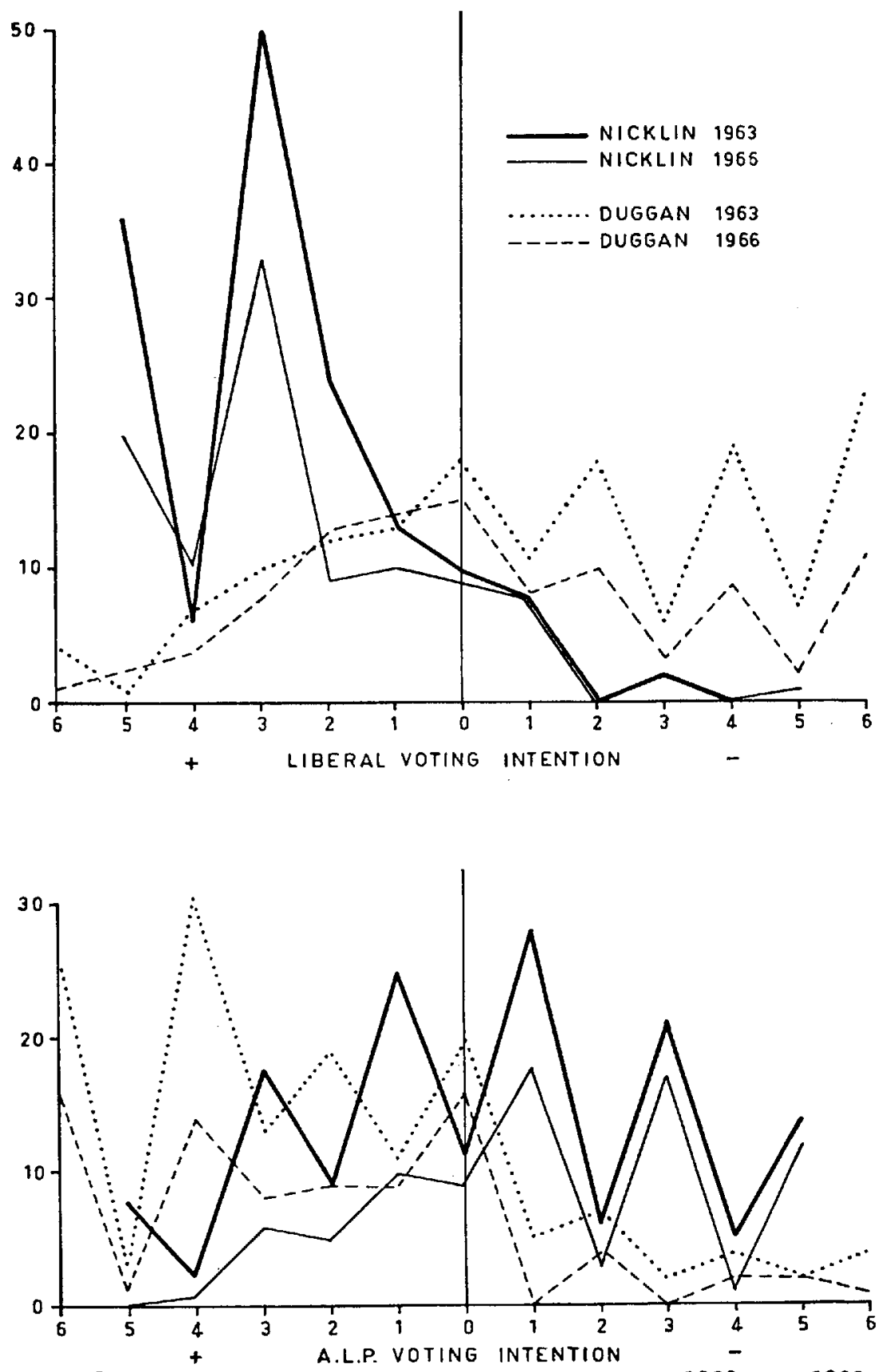

FIG. 2 FREQUENCY OF PARTY LEADER IMAGE SCORES 1963 AND 1966 
stand out is the extent to which Duggan was unpopular with Liberals in 1963 and the extent to which the gap between the two leaders had closed by 1966. In 1963 forty-nine Liberal voters (33 per cent) gave the Leader of the Opposition a score of -4 or lower when only nineteen Labor voters (13 per cent) gave Nicklin a comparable score. In 1966 twenty-two Liberal voters (22 per cent) gave Duggan a score of -4 or lower, and thirteen Labor voters ( 16 per cent) so rated the Premier. In terms of being highly critical, Nicklin still did better with his opponents than Duggan did. However if we consider whether the respondents recorded a negative score at all, then Duggan had been rated negatively by 56 per cent of Liberals in 1963 but this had dropped to 43 per cent in 1966; Nicklin had been rated negatively by 50 per cent of A.L.P. voters in 1963 and this had risen to 62 per cent in 1966. The average scores show little change in evaluation of one's own leader, but a complete reversal of the situation in evaluation of one's opponent. In 1963 Liberal voters appeared strongly hostile to Duggan but Labor voters were only mildly hostile to Nicklin; in 1966 the reverse was true.

Table 3.03

Average scores on party leader images 1963 and 1966

\begin{tabular}{|c|c|c|c|}
\hline Leader & Liberal & $\begin{array}{c}\text { Voting intention } \\
\text { A.L.P. }\end{array}$ & Q.L.P. \\
\hline Nicklin 1963 & +2.7 & -0.3 & +0.5 \\
\hline 1966 & $+2 \cdot 5$ & $-I \cdot 2$ & $+2 \cdot 8$ \\
\hline Duggan 1963 & $-1 \cdot 3$ & $+2 \cdot 1$ & $-1 \cdot 5$ \\
\hline 1966 & -0.5 & $+2 \cdot 1$ & $-1 \cdot 8$ \\
\hline
\end{tabular}

As with party image scores in the preceding chapter, we may distribute party leader image scores on two axes, pro-us to anti-us and pro-them to anti-them (perhaps more accurately pro-our man, etc.), and consolidate these distributions in $3 \times 3$ tables. The result for Liberal and A.L.P. voters appears in Table 3.04. Continuing to use the terminology devised by Davies and employed in Chapter 2 we find that in 1963 the 'hot partisans' were rather more numerous for party leaders than they were for parties-34 per cent of Liberals and 18 per cent of A.L.P. voters. However, 'mild partisans' were correspondingly fewer, 45 per cent and 30 per cent respectively (see p. 64). Thus when the two types of partisan are added together, their totals79 per cent and 48 per cent--were only slightly greater than the figures for party image partisans -70 per cent and 39 per cent. 'Cool ones' were somewhat fewer-16 per cent of Liberals, 29 per cent of A.L.P. voters. There were hardly any alienated in respect of the leader images-no Liberals and only three A.L.P. voters, compared with only four and one on the party images. But now there are eighteen A.L.P. 
Table 3.04

Cross-tabulations of party leader image scores 1963 and 1966

\begin{tabular}{c} 
Liberal voting intention \\
Nicklin \\
\cline { 3 - 5 }
\end{tabular}

Note: the 1966 figures are shown in parentheses.

'odd balls', and twelve Liberal ones, compared with twelve and one, somewhat strange considering the general esteem in which Liberals hold Nicklin and their distrust of Duggan. There were more Liberal Cheerybles, twelve against six, but the same number among the A.L.P. voters.

When the product moment correlations for each group on their 1963 party leader scores are calculated, both are very weak and negative: $\cdot 089$ for the Liberal voters, $\cdot 068$ for A.L.P. voters.

When we come to 1966 the picture has altered in some particulars. The 'hot partisans' are scarcer: down to 17 per cent among Liberals and A.L.P. voters both, halved for the Liberals, but constant for the A.L.P. 'Mild partisans' are as common among Liberals at 44 per cent and rather more common among A.L.P. voters at 39 per cent. Thus the total of partisans has dropped from 79 per cent to 61 per cent among Liberals through the improvement of their opinion of Duggan, and it has risen slightly to 56 per cent among A.L.P. voters through the decline in their opinion of Nicklin. 'Cool ones' are slightly more numerous among Liberals, 23 per cent, and the same among A.L.P. voters at 29 per cent. There are still a few alienated voters, but the 'odd balls' have declined from 8 per cent to 6 per cent among Liberals and much more sharply from 12 per cent to 4 per cent among A.L.P. voters. The movement from partisanship into neutrality is, however, nowhere near so pronounced on the leaders' images as on the party images. A summary of 1963 and 1966 distributions of three basic positions, partisans, 'cool ones' and deviants, is given in Table 3.05. It suggests that, considering the magnitude of change shown, it would be 
Table 3.05

Partisans, 'cool ones', and deviants 1963 and 1966

$\%$

\begin{tabular}{lrrrrrr} 
Voting & \multicolumn{2}{c}{ Partisans } & \multicolumn{2}{c}{ 'Cool ones' } & \multicolumn{2}{c}{ Deviants } \\
intention & 1963 & 1966 & 1963 & 1966 & 1963 & 1966 \\
\hline Party & & & & & & \\
$\quad$ Liberal & 70 & 25 & 23 & 58 & 8 & 17 \\
A.L.P. & 39 & 21 & 43 & 68 & 18 & 10 \\
Leader & & & & & & \\
$\quad$ Liberal & 79 & 61 & 16 & 23 & 16 & 15 \\
A.L.P. & 48 & 56 & 29 & 29 & 18 & 15 \\
\hline
\end{tabular}

Table 3.06

Cross-tabulations of party image scores and party leader image scores 1963 and 1966

Liberal voting intention

Nicklin

\begin{tabular}{|c|c|c|c|}
\hline & +5 to +3 & +2 to -2 & -3 to -5 \\
\hline $\begin{array}{l}\text { Liberal } \\
+7 \text { to }+4 \\
+3 \text { to }-3 \\
-4 \text { to }-7\end{array}$ & $\begin{array}{rr}77 & (20) \\
15 & (44) \\
1 & (0)\end{array}$ & $\begin{array}{rr}23 & (10) \\
27 & (24) \\
4 & (1)\end{array}$ & $\begin{array}{ll}1 & (0) \\
1 & (1) \\
0 & (0)\end{array}$ \\
\hline-4 to -7 & -6 to -3 & $\begin{array}{c}\text { Duggan } \\
-2 \text { to }+2\end{array}$ & +3 to +6 \\
\hline $\begin{array}{l}\text { A.L.P. } \\
-7 \text { to }-4 \\
-3 \text { to }+3 \\
+4 \text { to }+7\end{array}$ & $\begin{array}{rr}26 & (1) \\
29 & (24) \\
0 & (1)\end{array}$ & $\begin{array}{rr}13 & (1) \\
55 & (46) \\
2 & (13)\end{array}$ & $\begin{array}{rr}1 & (1) \\
16 & (11) \\
4 & (2)\end{array}$ \\
\hline & \multicolumn{3}{|c|}{$\begin{array}{l}\text { A.L.P. voting intention } \\
\text { Nicklin }\end{array}$} \\
\hline $\begin{array}{l}\text { Liberal } \\
-7 \text { to }-4 \\
-3 \text { to }+3 \\
+4 \text { to }+7\end{array}$ & $\begin{array}{rr}20 & (2) \\
18 & (26) \\
1 & (2)\end{array}$ & $\begin{array}{rr}10 & (0) \\
56 & (39) \\
9 & (6)\end{array}$ & $\begin{array}{rr}0 & (0) \\
14 & (6) \\
12 & (1)\end{array}$ \\
\hline & +6 to +3 & $\begin{array}{c}\text { Duggan } \\
+2 \text { to }-2\end{array}$ & -3 to -6 \\
\hline $\begin{array}{l}\text { A.L.P. } \\
+7 \text { to }+4 \\
+3 \text { to }-3 \\
-4 \text { to }-7\end{array}$ & $\begin{array}{rr}42 & (7) \\
30 & (30) \\
0 & (0)\end{array}$ & $\begin{array}{rr}18 & (12) \\
35 & (28) \\
4 & (0)\end{array}$ & $\begin{array}{ll}1 & (1) \\
8 & (4) \\
3 & (0)\end{array}$ \\
\hline
\end{tabular}

Note: the 1966 figures are shown in parentheses. 
unwise to regard characterisation as 'partisan' or 'apathetic' based on administration of particular items at a particular point of time as proof of a stable political attitude.

The exercise may be continued for party scores and party leader scores combined, and the resultant $3 \times 3$ tables are set out in Table 3.06. In 1963 there appears to have been a strong relationship between the images held of one's own party and its leader, and of the opposing party and its leader, and the product moment correlations for the 1963 scores corroborate this. For Liberal voters the Nicklin-Liberal 1963 correlation is 447 and the Duggan-A.L.P. correlation is .599; for A.L.P. voters the Duggan-A.L.P. 1963 correlation is 449 and the Nicklin-Liberal correlation 579 . In both cases the relationship of opposing party and party leader images appeared somewhat stronger than that of one's own party and its leader. In 1966 none of the relationships was so strong. For Liberal voters the Nicklin-Liberal 1966 correlation is only 185 and the Duggan-A.L.P. 1966 correlation -283; for A.L.P. voters the Duggan-A.L.P. 1966 correlation is only · 149 and the NicklinLiberal 1966 correlation 425 . Again the relationship of opposing party and party leader images appears stronger than for one's own party and leader, but partisanship does not appear to operate so strongly over both party and leader images as it did in 1963.

We may use the scores again to test whether there were variations among the sub-groups of voters, and begin with occupation:

Table 3.07

Party leader image scores of occupational groups 1963

\begin{tabular}{|c|c|c|c|c|c|c|}
\hline \multirow{2}{*}{ Score for: } & \multicolumn{3}{|c|}{ Liberal voting intention } & \multicolumn{3}{|c|}{ A.L.P. voting intention } \\
\hline & $\mathbf{n}$ & Nicklin & Duggan & $\mathrm{n}$ & Nicklin & Duggan \\
\hline Professional & 23 & $+2 \cdot 4$ & $-1 \cdot 6$ & \multirow[t]{2}{*}{11} & \multirow[t]{2}{*}{+0.5} & \multirow[t]{2}{*}{$+1 \cdot 0$} \\
\hline $\begin{array}{l}\text { Directors and } \\
\text { managers }\end{array}$ & 23 & $+2 \cdot 7$ & -0.8 & & & \\
\hline Office and sales & 45 & $+2 \cdot 7$ & $-1 \cdot 2$ & 27 & -0.7 & +1.7 \\
\hline Skilled workers & 34 & +2.7 & $-1 \cdot 2$ & 39 & -0.1 & +1.7 \\
\hline Semi-skilled & \multirow{2}{*}{19} & \multirow{2}{*}{$+1 \cdot 6$} & \multirow{2}{*}{$-1 \cdot 7$} & 41 & -0.8 & +2.9 \\
\hline Unskilled workers & & & & 22 & -0.4 & $+2 \cdot 5$ \\
\hline
\end{tabular}

Variations are minor. Apart from the semi-skilled and unskilled workers who were less favourable to Nicklin and more unfavourable to Duggan, and the directors and managers who were surprisingly favourable to the A.L.P. leader, Liberals were fairly consistent. Among Labor voters the professionals and businessmen deviated by being more pro-Nicklin and less pro-Duggan than their fellows, while the 
semi-skilled and unskilled workers were conspicuously more proDuggan.

Table 3.08 sets out the scores for the religious sub-groups containing ten or more respondents. The strong partisanship of the Pres-

Table 3.08

Party leader image scores of religious groups 1963

\begin{tabular}{lcccccc}
\hline & \multicolumn{3}{c}{ Liberal voting intention } & \multicolumn{3}{c}{ A.L.P. voting intention } \\
\hline Score for: & $\mathrm{n}$ & Nicklin & Duggan & $\mathrm{n}$ & Nicklin & Duggan \\
Anglicans & 66 & +2.9 & -1.0 & 42 & +0.2 & +1.9 \\
Catholics & 29 & +2.3 & -1.3 & 64 & -0.6 & +2.3 \\
Presbyterians & 28 & +3.1 & -2.6 & 17 & -0.8 & +2.7 \\
Methodists & 16 & +1.4 & -1.1 & $*$ & $*$ & $*$ \\
\hline
\end{tabular}

byterians in each group is striking. Among the Liberals it could be explained by loyalty to Nicklin, but his religious affiliation was very little publicised. It is unclear why this should affect Presbyterial Laborites negatively, and it must remain one of those mysteries tainted with a suspicion that the real explanation is the small number of individuals in that cell of the matrix.

Men tended to be more partisan than women. In 1963 A.L.P. male voters gave Nicklin and Duggan scores of -0.6 and +2.3 respectively, but A.L.P. female voters gave them +0.9 and $+1 \cdot 7$. Liberal male voters gave Nicklin and Duggan scores of $+2 \cdot 8$ and $-\mathrm{I} \cdot 7$ respectively; Liberal female voters gave $+2 \cdot 4$ and $-0 \cdot 9$.

Table 3.09

Party leader image scores of age groups 1963

\begin{tabular}{|c|c|c|c|c|c|c|}
\hline \multirow[b]{2}{*}{ Age group } & \multicolumn{3}{|c|}{ Liberal voting intention } & \multicolumn{3}{|c|}{ A.L.P. voting intention } \\
\hline & $\mathrm{n}$ & Nicklin & Duggan & $\mathbf{n}$ & Nicklin & Duggan \\
\hline $21-30$ & 20 & $+2 \cdot 0$ & -1.6 & 16 & +0.4 & $+1 \cdot 6$ \\
\hline $31-40$ & 29 & $+2 \cdot 7$ & -0.1 & 22 & -0.8 & $+2 \cdot 9$ \\
\hline $41-50$ & 30 & $+2 \cdot 3$ & -0.9 & 31 & -0.8 & $+1 \cdot 7$ \\
\hline $51-60$ & 23 & $+2 \cdot 4$ & $-2 \cdot 1$ & 34 & +0.5 & $+1 \cdot 3$ \\
\hline $61+$ & 46 & $+3 \cdot 1$ & $-1 \cdot 6$ & 44 & -0.7 & $+2 \cdot 7$ \\
\hline
\end{tabular}

No clear pattern emerged to distinguish between age groups. But then there is no obvious reason why age groups should have differed significantly in their views on party leaders in a situation in which the age of neither was a political factor, there being no suggestion in 1963 that either was too old or too young for the job.

Finally it may be added that Q.L.P. voters gave Nicklin a score of +1.5 and Duggan $-1 \cdot 5$, thus being a little more critical of Duggan than were Liberal voters $(-1 \cdot 3)$, and much better disposed to Nicklin than were A.L.P. voters $(-0 \cdot 3)$. 


\section{Images of the Party Candidates}

TODAY the principal contribution of the great majority of candidates is to expound their party's record and its policies for the future. The leader's policy speech is chopped into bite-size morsels and retailed in the candidates' street-corner speeches, hand-outs to the local press, newspaper advertisements, and leaflets. However, the candidates' selection of items from the text of the speech appears to have little relation to the social and economic characteristics of individual constituencies save in those constituencies which form a class such as sugar districts or 'the West'. Certainly some Country and Liberal candidates recount at length the present Government's record of public works and economic development in each electorate, and opposition candidates provide a counterpoint of what A.L.P. governments had done before 1957, but promises for anticipated action are seldom explored in localised detail. Thus what might have been expected to be an important function of candidates in developing and applying generalised future party policy to their own electorates remains relativeiy undeveloped. Opening the Country Party campaign in Callide in 1963, Vin Jones observed that most of his listeners would have read or heard the Government's policy contained in the leaders' speeches, and therefore he did not propose to traverse the items in any detail save when they affected the Callide electorate, but he could assure his listeners that he fully supported the planks in the platform and would use all his strength to have them implemented (Morning Bulletin (Rockhampton): 14 May 1963). This was an exceptional instance, and the reasons for the general failure are not immediately obvious. It may be that many candidates lacked the ability or the training to translate the program contained in the printed or mimeographed copies of the leader's speech into local benefits, or it may be that uncertainty as to the way in which statewide policies will have to be 
administered in the future makes it difficult, if not impossible, to say what impact they will have on the individual electorate. But in addition to expounding general party policy the candidates try to 'sell' themselves as past and/or prospective Members of the Legislative Assembly, and it is to this aspect of the general election-the formulation of candidates' images by themselves and occasionally by their rivals-that this chapter and the next are addressed.

There is no study of the way in which Australian parliamentarians think about themselves and their work comparable to the research reported by Wahlke et al. for four state legislatures of the United States of America in The Legislative System (1964). Until comparable work is done in Australia, the possibility must always be borne in mind that the public image of themselves and their duties which candidates hold out to their constituents may differ from private assessments of themselves and, for those who get elected, of their colleagues in the State Parliament. Thus a candidate may publicly emphasise his independence of mind, when he believes that party regularity is the proper style. What follows has been gleaned mainly from the Queensland press-principally the country press, for the metropolitan dailies have little space in which to report individual candidates-and from campaign literature. Against this material is set the responses of the Brisbane and provincial cities' panel members in 1963 to questions eliciting their opinions on the duties of Members. Neither body of data can be regarded as complete or conclusive evidence on the subject. Relatively few constituency contests are reported by their local papers in sufficient detail to capture the full flavour of what the candidates had been saying. Many reports are provided by the candidates, and may be reports of what they wished they had said; however, these will have wider dissemination than the words actually spoken in the main street. Many constituencies are not reported at all. Thus any typology advanced is subject to extension by the identification of unreported types, and to modification by the compilation of a more complete record. It is obviously impossible to make any estimate as to the frequency with which any type occurs in this election, or to say whether patterns of frequencies are stable or changing. At the electors' level, the Brisbane panel represents only three of the twentyeight electoral districts in the metropolitan zone, and it may be, for example, that voters in the new outer suburbs would have given somewhat different responses. Readers are warned elsewhere of the deficiencies of the data obtained from the mail questionnaires (Appendix A, p. 332), and whilst the patterns which emerge from this data are plausible they must be advanced more tentatively than in comparable discussion of Brisbane data. Furthermore, the two panels purport to reveal the politics of only metropolitan and provincial city electorates (strictly speaking Albert and South Coast are 'country' 
electorates), and so exclude almost half the electoral districts of the State. It may well be that a survey in the truly rural constituencies would reveal a substantially different pattern.

The Legislative System divides the roles legislators may choose to play into two main categories: purposive, which operate mainly within the legislature itself, and representational, which depend on the relation between the legislator and his constituents. In the first category Wahlke et al. (ch. 11) have the ritualist who concentrates on parliamentary procedures rather than goals, the tribune who is the advocate or defender of popular demands, the inventor who discovers new issues (and, presumably, solutions), and the broker who mediates between the pressures of a pluralist society. Elsewhere (ch. 9) they also identify subject matter experts who probably comprise a fifth purposive role sub-category. Their definitions derive from the American constitutional and party-political system, and not all of these roles can be easily identified, or have comparable significance, in the Australian system of cabinet and parliamentary government. In the second category, representational roles, they identify (ch. 12) principally the trustee who claims the right to follow his own conscience, the delegate who believes himself obliged to consult his constituents and to follow their directions even when they run counter to his own opinion, and the politico who tries to combine the two roles, perhaps by regarding himself as a delegate in parochial matters and a trustee in others. Two subsidiary classifications of representational roles concern the legislator as servant-errand-boy, communicator, or mentor-and the legislator in relation to pressure groups-facilitator, resister, or neutral. These categories are more immediately applicable to the Australian scene than those Wahlke et al. use for purposive roles, but again there are qualifications.

A parliamentary system, particularly as it is worked in Australia, gives little weight to the ritualist, the expert in parliamentary procedures, certainly nothing comparable with a congressional system where the manipulation of procedures is widely publicised political activity and evidence of a member's ability to look after his district. Parliamentary performance hardly matters; in Bulimba the campaign director for the A.L.P. Member, Houston, in a letter forming part of the candidate's 'personal appeal' leaflet pointed out: 'As a debater in Parliament he is most capable and has on many occasions been complimented by friends and opponents alike for his constructive debating.' Apart from this and the composer of some A.L.P. advertisements in Bundaberg who billed Hanlon as 'recognised as one of the most able and logical debaters in Parliament' and Duggan as 'recognised as the finest orator in the House' (News-Mail (Bundaberg): 16, 17 April 1963), no one paid any attention to such skills. In 1966 one new Member (Jones) reported that in the year that he had been in 
the House he had spoken 'at length' eleven times and asked ninety-five questions (Cairns Post: 20 May 1966), but this was again exceptional. More representative of the assessment of performance on the floor of Parliament was Carey's 1963 defence against complaints that he never spoke: he got on with the job in the places where things got done (see pp. 164-5).

The role of the inventor is greatly curtailed by the virtual monopoly of legislation by cabinet and the bureaucracy, and the sources of legislation are almost invariably found in the departments or in party policy formulated for an election and put forward first by the leader (see Davies 1958: 154-61). Occasionally a Minister may acquire a reputation for particular advances, like Pizzey as Minister for Education:

The Minister for Education (Mr Pizzey), who has sponsored the spread of secondary education, has shown himself to be a dynamic force. He has advanced the cause of higher education at a remarkable rate since taking office, and the future will show that he has thought along the right lines. (Morning Bulletin (Rockhampton): 10 January 1963)

Even more occasionally this may be translated into the Minister's electorate, as when the Vice-Chancellor of the University of Queensland at the opening of the first high school at Childers in the Minister's electorate referred to Mr Pizzey's 'untiring efforts' on behalf of education and predicted that 'the last few years will be known as the PizzeyWatkin era of secondary education in this State' (Maryborough Chronicle: 1 April 1963). Hiley in his 'personal appeal' leaflet referred in some detail to his achievements as Treasurer:

Under his guidance, expenditure from all funds has expanded greatly, allowing the Government to expand its work programme, increase its services and, at the same time, greatly improve salaries and pensions to its employees .. His skilful management of State finances had meant an increase in employment by the Government and a complete absence of those mass dismissals which characterised Labor's control. For six consecutive years Crown employees have enjoyed steady employment opportunity.

The leaflet went on to specify 'a number of important reforms' Hiley had instituted: guaranteed assistance to building societies, low deposit purchase of Housing Commission homes, new house designs, and shark meshing for surfing beaches. Dr Noble in his 'personal appeal' also listed a number of innovations in health services which had taken place during his term as Minister for Health under the heading 'What your Member has done for Queensland'. In his 'personal appeal' one Liberal backbencher, Ray Smith, a barrister by profession, was able to refer with pride to his part in introducing the nominal defendant for 
running down cases, but there were few with anything so specific to their credit. Gaven claimed credit in a campaign leaflet for an amendment to the Land Act of 1962 which gave an appeal against sharp increases in rent on Crown leases of residential blocks. Sam Ramsden, the Liberal member for Merthyr, claimed credit in his 'personal appeal' leaflet for getting an Air Pollution Council set up and for the introduction of pedestrian-controlled traffic lights at school crossings, and referred to his proposals for traffic tunnels under the Brisbane River.

One of the rare instances of a candidate proposing to be an innovator came from Anderson, speaking with the authority of a former Mayor. In view of the protracted discussions between the City Council and the Department of Local Government over the Toowoomba Town Plan, if returned to Parliament he would at once advocate establishment of a master planning authority for the State to separate planning from other local government functions. Such a body might work closely with the Main Roads Department in its road plan (Toowoomba Chronicle: 21 May 1963). Another promise, for innovation came from Chalk, when opening his campaign at Gatton. He and the Minister for Public Works, H. H. Richter (their electorates of Lockyer and Somerset being particularly concerned with potato and onion growing) were concerned at the quantity of produce being condemned at the Roma (Brisbane) markets, by which time producers were liable for bags, picking-over charges, and rail freight, as well as loss of the produce. When returned they would, during the first session of parliament, have the Marketing Act amended to provide for inspection before produce was railed. Normally candidates were content to promise to work within the existing framework of legislation and administration, to get the district some of whatever was going, but not to suggest new benefits which the State might provide. Nor were they prepared to provide new diagnoses of society's ills. An Independent might get a bit off the beaten track, but endorsed party candidates saw the same problems and proposed the same remedies as their party leaders had done in the policy speeches.

Similarly the back-bencher's role of broker is minor compared with that of cabinet and bureaucracy, and, as is indicated below in connection with representational roles and pressure groups, the quantity and quality of pressure group activity in Australia differs sharply from the United States. Most of the situations in which brokerage appeared appropriate involved rivalry between different geographic centres-where an alumina plant, or a university college, or an abattoir would be located. Here it is possible for the local Member to champion his electorate all out, and he will be expected to do so. It is the Cabinet or an individual Minister who must act as broker, and this will be done circumspectly. Thus Nicklin replied to a request that he 
support Dr Delamothe's request for an investigation of Bowen as an alumina plant site:

While my colleagues and I are, of course, most anxious to do something which will help the development of Bowen and the stabilisation of the economy of its district, we must take into account the fact that, under the Comalco Agreement, the Commonwealth Aluminium Corporation Pty. Ltd. is required to spend millions of pounds in Queensland on the Weipa project during the next few years. Manufacture of aluminium is a highly competitive industry with over-supply on world and Australian markets forecast, so it is essential that it be manufactured at the least possible cost if the Weipa project is to survive and grow. For this reason, it would be unwise to interfere with the right of the Company to locate the Alumina Refinery where costs are lowest. However the Government has required the company to investigate all likely sites in Queensland. . . (Bowen Independent: 22. February 1963)

The Premier promised that Bowen's natural advantages would be kept in mind, and Dr Delamothe's submission would be discussed with the Minister for Mines.

The tribune's image in Queensland is developed mainly by the independent candidates, claiming to be able to battle for the local interest free from party restraints, and in the idea of fearless or vigorous representation. In the last resort he should be prepared to defy his party. Wharton in Burnett claimed: 'He's positive in thought and action-sometimes out of step with the Government but never out of step with the people of Burnett' (News-Mail (Bundaberg): 26 May 1966), and Lonergan pledged that if the Government tried to close the railway workshops at Charters Towers: 'I would fight the move tooth and nail in the party room and on the floor of the House, and if I failed would not hesitate to resign from the Government' (Northern Miner (Charters Towers): 25 May 1966). One debate turning on the style appropriate to a tribune in 1963 concerned the A.L.P. member for Maryborough, Horrie Davies. As soon as it was known that the Country Party was offering the local Mayor, Alderman Hunter, against him, the Maryborough Chronicle commented:

[The voters] would have to picture him as a more vigorous advocate for Maryborough than Mr Davies is, and has been. To do only that may not impose undue stress on the imagination. (24 April 1963)

Opening his campaign Alderman R. A. Hunter made the same point. H. J. Davies had failed to prevent removal of certain divisional headquarters from Maryborough to Bundaberg when Labor was in office:

I fail to remember any forthright, last-ditch stand by my A.L.P. opponent to prevent their removal. Indeed, I fail to remember any- 
thing of a substantial nature that my opponent has gained for our city as the sole result of tenacious and out-spoken advocacy. I go further. I say, in all gentleness, Maryborough is entitled to have expected more-much more-from its members. (Ibid.: 14 May 1963)

It was time for Maryborough to vote selfishly, for a candidate who would be part of the Government and who would put Maryborough's case forcefully. The city had achieved nothing with the incumbent under a Labor government-what would he do with a non-Labor government? Alderman Hunter declared that he himself possessed 'the overriding compulsion to drive to the limit of his capacity for the advancement of the city'.

Davies replied that the electors could judge his services to the city, but he had never spared himself and was available for interviews at all times. Government supporters were

disappointed that he had not made representations on matters of local concern in a noisy, vociferous way with a banging of drums and blare of trumpets, for they realised that such conduct would have resulted in his failure to represent all the electors well. They would sooner see the city suffer so long as it resulted in his defeat and thus the defeat of the A.L.P. in this electorate. (Ibid.: 16 Mày 1963)

As a result of his representations the electorate had received as large a share of State money as any, a claim which Davies subsequently repeated in his advertisements.

A somewhat similar campaign was conducted against the A.L.P. member for Mackay, Fred Graham, during the last weeks of the campaign. His Country Party opponent, John Matson, began it by observing that Graham was trying to fight the election 'with the usual vague statements that have characterised his efforts over the years'. A few days later this was more specific:

Let us have a look at Mr Graham's achievements, which he claims entitles him to your vote on June 1. Has he built any roads, bridges, dams? No. Has he put forward any schemes to help his fellows, such as hospitals, schools, universities, etc.? No. Has he contributed any advice which led to better running of the railways? No. Has he done anything to advance agriculture, horticulture or pastoral pursuits? No. Has he done anything for aviation, better aerodromes, better flying facilities, etc.? No again. Has he put forward any plan to secure Mackay against its seasonal flooding problem? No, but he has endeavoured to stomp heavily on those who have, and got his toes burnt in the attempt.

Frankly, electors, Mr Graham in 20 years as representative of Mackay has done nothing that any office girl could not do. (Daily Mercury (Mackay): 22 May 1963) 
Rather than wealth, Graham produced illth:

Mackay depends almost entirely on the products of the Mirani and Whitsunday Electorates for its basic economy. Mirani and Whitsunday are both Country Party seats and much of the good done by Ernie Evans and Ron Camm in Parliament is counterbalanced by Mackay's Member being in the Opposition. (Ibid.: 20 May 1963)

The campaign spilled into the classifieds: 'It's time for a change. Mackay needs active representation in State Parliament. Not silent tongues.' Graham counter-attacked to charge that during the past three years no Housing Commission homes had been built in Mackay while a number had been built in Whitsunday to help Camm, but his advertisements generally spoke only of his twenty years of 'honest, effective representation' without going into details.

A comparable case against a Government Member was made against the Member for Warwick, D. W. Cory, by his A.L.P. opponent in 1966 , charging that he had failed to act promptly to secure drought relief money when it was available and secured only one-quarter of the sum sought (Warwick Daily News: 26 March 1966). Cory replied that the money had been made available to harder-hit shires farther west; as soon as Warwick became eligible he had been in touch with the City Council and the Co-ordinator-General of Works, and he had attended one meeting in company with the delegation from an adjacent shire though he had not been able to go with the Warwick delegation (ibid.: 2 April 1966).

Last among the purposive roles defined in The Legislative System is the expert. However, when candidates or their supporters mention what knowledge they require of a good Member it is the knowledge that comes from experience. Country Party propaganda was particularly likely to make this point-E. J. Beardmore, M.L.A. for Balonne, 'the practical member with the knowhow for a country electorate' (Western Star (Roma): 10 May 1963), Wharton, M.L.A. for Burnett for his 'close practical knowledge of Primary Industry and their marketing boards' (News-Mail (Bundaberg): 10 May 1963; Maryborough Chronicle: 11 May 1963), Turner, candidate for Warrego, 'a man ... who is familiar with all aspects of life in the west' (Western Times (Charleville): 30 May 1963). E. G. Wood in Logan had 'proved his ability to get things done, especially in Local Government':

As Chairman of the Redland Shire for the past six years, he has headed rapid and sound road development, started a Shire-wide water reticulation scheme, and maintained sound finances. Past experience as a State Land Commissioner in dairying, grazing, sugar, forestry and residential areas ideally fits him to direct his energy, enthusiasm and experience in ably representing Logan ... Elect a member who gets things done. . . . Beaudesert Times: 29 April 1966) 
The Liberal candidates for the two Gold Coast seats, Harley and H. G. Winders, admitted that they lacked practical rural experience and would call on the advice and practical knowledge of their rural electors (Gold Coast Bulletin: 4 March 1966), but then the rural electors were little more than 10 per cent of the total. M. R. Thew, the A.L.P. candidate for Roma in 1966 reported that he had written all over the world for information on natural gas and its uses, and had offered the Town Council an economic survey on gas reticulation' $\mathrm{He}$ is on your side by deeds as well as words and research into oil and gas prices!' (Western Star (Roma): 13 May 1966)

A distinction was sometimes drawn between the 'practical men' and, by implication, the ideologues and politicians. Thus the chairman of the Balonne Electorate Council of the Country Party wrote to the Western Star: 21 May 1963:

Promises alone will not find jobs for the workers. We must have legislators with the practical knowledge of the Nicklin Government to legislate for the development of our primary industry, the backbone of our export earnings and great adjuster of our economy ... [The Nicklin Government] have shown over the past six years they have the Know-how to encourage the primary producer to give of his best for his own and the State's benefit. Never in the history of the Labour's long term of office about 40 years have they shown they have the Know-how to develop and get the export earnings so necessary to keep our standard of living so high. They have always lacked practical men and have never known how to gain and get proper knowledge of industry.

A subsequent letter from the same writer revealed that Russ Hall, the A.L.P. candidate for Balonne, was 'not even a member of the Australian Workers' Union and is in fact a member of the Federated Ironworkers Union which has disaffliated from the A.L.P.':

Mr Hall's knowledge of the requirements of country dwellers gained through a brief experience of employment at a country sawmill could hardly give him the necessary qualifications to represent a rural and grazing area. (Ibid.: 24 May 1963)

Contrast the claim of the A.L.P. candidate for Gregory in 1966:

Before becoming an official of the Australian Workers' Union I had a wide experience in industry as a shophand-butcher, meatworker in the export trade, as a ship's fireman, in road and bridge construction, sewerage construction, miner, building, and in all phases of the sugar industry. For the past 12 years $I$ have been an executive officer on the Union, and for seven years have been District Secretary of the Western District at Longreach. In this period I have visited every area of the district. (Queensland Country Life: 5 May 1966).

A Country Party advertisement for Mirani, Mackay, and Whitsunday in 1963 pointed out: 
Sugar is the mainstay of this vast district . . To get the best out of this happy position [the bright future of the sugar industry] it is important that you have in State Parliament men with wide knowledge of the sugar industry ... Mr Ernie Evans, who is Minister for Development, Mines, Main Roads and Electricity, has had wide experience of the sugar industry as a grower and mill director of many years standing, and the same applies to $\mathrm{Mr}$ Camm, who is chairman of directors of Proserpine Mill, and also a cane grower supplying Proserpine Mill. Mr John Matson, the candidate for Mackay, has also had a lot of experience in the industry, both as a sugar grower and as a member of the Racecourse Mill Suppliers' Committee. (Daily Mercury (Mackay): 3 May 1963)

The topic was taken up in Row's 'personal appeal' leaflet in Hinchinbrook as well; he pointed out that his family had been canegrowers in the district since 1906, he had owned a cane farm since 1926, and had been associated with canegrowers' organisations for twenty-eight years. A rare tribute was paid by a veteran A.L.P. Member, Jim Donald, in supporting Peter Wood for Toowoomba East, when he referred to the latter's experience of overseas study of parliamentary procedure and Labour Party organisation in England and concluded: 'With this experience, and the considerable experience he had already gained in Australian politics, both theoretical and practical, Mr Wood has the qualifications to make a first-rate member of Parliament.' (Toowoomba Chronicle: 9 May 1966)

Academic qualifications were rarely mentioned, but then few candidates possessed them. Pizzey modestly did not mention his degrees, including an honorary LL.D., at home in Isis, though once they were picked up in 1966 by his hosts in Flinders publicising a meeting. The A.L.P. candidate for Lockyer, Jim Keim, in an advertisement setting out some of the A.L.P.'s educational policies, was described as 'an expert in the field of Education-he holds a Bachelor of Arts and Bachelor of Education-he is Headteacher of Granchester State School' (Queensland Times (Ipswich) and Toowoomba Chronicle: 29 May 1963), but this was the only one of his advertisements which mentioned the degrees, apart from one $8^{\prime \prime} \times 16^{\prime \prime}$ on the eve of poll in which he was characterised as 'a teacher and scholar . . . to this man you entrust your children-why not your electorate?' (Toowoomba Chronicle: 31 May 1963), and again his degrees were mentioned. Alderman Pilbeam's biggest advertisement in 1963 set out his accounting qualifications (Morning Bulletin (Rockhampton): 15 May 1963), but then it set out absolutely everything about him; usually his advertisements emphasised his administrative and organising experience (e.g. ibid.: 16 May 1963). One Q.L.P. candidate, Higham, mentioned his university courses in economics, political science, and public administration (Evening Advocate (Innisfail): 8 March 1963; Cairns Post: 24 April 1963). The 'personal appeal' leaflet of A. G. V. Hall in Fassifern in 
1963 mentioned: 'In his ambition to improve himself, three years ago he did Economics I at the Queensland University', and that of $O$. W. Brunner, the Liberal candidate for Wynnum that he had the University's certificate of education and was proceeding to an Arts degree. Peter Wood in 1966 had 'studied Political Science with High Distinction at the University of Queensland [and is] widely read in politics, economics, sociology, education'. Few candidates even recognised the need for expertise or hard work to make up for it. Wood was an exception, no doubt influenced by his background as a teacher-and his father's example:

To you, and to the electors in Toowoomba East I would say this. I believe that the duties of a member of Parliament are such that to be done properly a member must give his full attention to Parliamentary affairs. There are two aspects of his job. Firstly he must give his attention to legislation, and that comes before Parliament. To be able to give an informed speech, he must spend many hours in research and study, and take time preparing speeches which should make a valuable contribution to the debate. Secondly, he must make himself available to his constituents at all times and do all he can to resolve their difficulties. (Toowoomba Chronicle: 22 March 1963)

The prevailing A.L.P. style has always been that parliamentarians should be representative of their constituents because they resemble them. In March 1963, speaking in Melbourne, Calwell called for more grass-roots parliamentarians representing trade unions and farmers, and his point was taken up in Sydney by the federal secretary of the A.W.U., T. Dougherty. Dougherty condemned existing pre-selection practices for getting the wrong men into Parliament; the A.L.P.'s ranks were now filled with 'go-getters, legal experts, publicans and egg-heads' (Age (Melbourne): 12 March 1963). Whilst he conceded that the Labor Party needed professional men, particularly those with university degrees, the position had become unbalanced in recent years:

The party today is not producing the Andrew Fishers, Forgan Smiths or John Curtins, because the honest-to-goodness working man is being pushed aside by go-getters and self-seekers.

That afternoon Milliner as President of the Q.C.E. defended the Queensland branch: none of its politicians were go-getters or eggheads just because it retained pre-selection plebiscites (Telegraph: 12 March 1963), in fact only two of its M.L.A.s were graduates. The Telegraph deplored Dougherty's view, pointing out that the A.L.P. did not have a monopoly of go-getters and some very good politicians had come from the ranks of the publicans:

That leaves only the lawyers and the egg-heads-and what's wrong with them? It's common knowledge that there's prejudice against 
them in the Labor Party ... but it's better surely to have men of learning in Parliament than no-hopers in bowyangs.

As the point is one of some importance, the writer might add his own opinion that, in Queensland at least, whilst there is undoubtedly some prejudice against egg-heads or intellectuals among A.L.P. branch members, such influence on the pre-selection process is slight. What does keep down the number of candidates with tertiary education, whether they be professionals or intellectuals, is the convention of local residence for candidates. As egg-head employment is concentrated in Brisbane and is relatively well paid, most potential candidates in this class live in a few safe Liberal seats, and if they are to win preselection in marginal or safe Labor seats they must appear not only as egg-heads but also carpet-baggers. Because Brisbane contains only 36 per cent of the State's electoral districts, the university graduates' geographic concentration counts against them.

It has already been argued that the differences between a parliamentary and a congressional system have left some of the purposive roles identified in the United States quite undeveloped in Australia. One of the basic elements of the parliamentary system, however, is the concentration of power in the hands of Ministers, and a moderate amount of attention was paid to the role of Minister in the campaigns. Ministers usually come from safe seats, and safe seats tend to be reported less fully; all but one in 1963 and two in 1966 of the Liberal Ministers came from Brisbane electorates, and therefore were hardly reported at all. Thus it may be that the following examples are slanted by their selection from rural electorates, but in so far as they go to emphasise a pattern exhibited elsewhere, this caution may be unnecessary.

In Warwick, Otto Madsen, the sitting Country Party Member and Minister for Agriculture since 1957, had been in poor health since the preceding October, and the Warwick Daily News speculated (27 March 1963) that he would not be a candidate for Cabinet if the Nicklin Government was returned. Madsen promptly replied that he was not contemplating retiring and that he expected to resume office shortlyhe returned to work on 16 April and declared that there was no reason why he should not stand again for Cabinet after the elections. On 27 April Madsen advertised that he would be in attendance at his local office that weekend for the first time in seven months. His campaign was brief: it opened in Warwick on 24 May-the advertisements (e.g. ibid.: 18 May 1963) described Madsen as 'Minister for Agriculture and Forestry', and at the first meeting he declared:

Since my election as State Parliamentary representative for the Warwick electorate in 1947, it has been my practice to make myself available to the people $I$ represent by attending regularly at a Warwick office, and thereby providing a service rendering every assistance possible on problems of both business and a personal nature. 
Even after attaining Cabinet selection, which naturally threw greater responsibility on to me and demanded much of my time, I still kept faith with electors and their families by continuing to be available and endeavouring to assist them with their difficulties. . . .

Since my entry into Parliament, I feel that I can justly claim that I have been able to secure considerable benefits for the Warwick electorate, and I believe there is ample evidence to support this contention. In this regard, my selection to Cabinet has further assisted by [my?] representation and I believe the whole of the electorate has consequently benefited ... You will, of course, realise that as a Minister, I have had a responsibility to the whole State, and $I$ and my Parliamentary colleagues have endeavoured to plan and legislate for the welfare of all the people, throughout the whole of the State. No single person, or section of the community, or particular area of the State, has been singled out for preferential treatment, and all matters coming before Cabinet are dealt with honestly and fairly without fear or favour to any other authority. (Ibid.: 25 May 1963)

Madsen had a difficult path to walk. On the one hand it may be a good thing to have the local Member become a Minister, but it may mean that he will have to spend much more time in Brisbane, especially during the months when Parliament is not sitting, than he otherwise would have done, and thus be unavailable to constituents. Some Ministers even move to live in Brisbane. Again, the sitting Member will wish to suggest that his electorate has benefited from his membership of Cabinet, but he cannot go too far lest it appear that he has abused his office and responsibilities. However, it is expected that Ministers will look after their own electorates particularly well: Lonergan could list his achievements with pride and say "when making the comparison with that of Labor please remember this Electorate was previously represented by a Labor Minister' (Townsville Daily Bulletin: 18 May 1966), and the same point was made by the former M.L.A. for Tablelands, Gilmore (Tablelands Advertiser (Mareeba): 18 May 1966).

This problem arose also in Mirani, the electorate of the Minister for Mines and Main Roads, Ernie Evans, and was introduced by the A.L.P. candidate, G. Moody, opening his campaign at Finch Hatton. Moody accused the Minister of having climbed the ladder of success within his party at the expense of attention to the needs of the people of Mirani. Despite Evans's six years as Minister for Main Roads the people of Finch Hatton and nearby centres still lacked an all-weather road to Mackay (Daily Mercury (Mackay): 22 April 1963). The Country Party campaign director, R. E. Eastment, replied the next day with a general demurrer: the Labor government had neglected roads more than twenty-five miles out of Brisbane, and spending on main roads had risen by nearly $£^{30}$ million in Evans's five years of office 
compared with Labor's last five years, but nothing about Mirani. However, Evans was soon reported (Telegraph: 3 May 1963) to be casting a Minister's mantle over Ron Camm, the sitting Member for Whitsunday; declaring that the next Parliament would be his last, Evans added that Camm would succeed him in the Cabinet. In a letter to the electors of Whitsunday which appeared as an advertisement, Evans was more discreet:

I know you will re-elect Ron Camm . . . I can tell you he is one of the most capable members in the Country Party. $\mathrm{He}$ is real Cabinet material. (Daily Mercury (Mackay): 14 May 1963)

Presiding over a special meeting of Country Party branches to plan Chalk's 1963 campaign, C. W. Harch observed that 'tangible evidence of his success as a Cabinet Minister was to be seen throughout the electorate' (Queensland Times (Ipswich): 15 March 1963). Chalk replied modestly that his efforts at all times had been in the interests of the electorate and the State generally. Opening his campaign at Gatton he listed public works undertaken in the Lockyer electorate and specified:

The widening of the Laidley-Plainland Road, the building of the Chalk-By-Pass bitumen strip from Gatton to Forest Hill and the provision of the money to connect Murphy's Creek with Toowoomba through the Crow's Nest Shire-all free grants to the councilsare clear proof of what has been achieved since $I$ have been Minister for Transport. (Ibid.: 24 May 1963)

As a Cabinet Minister I am at the seat of Government, and since it is an accepted fact that the Nicklin Government will be returned, the Lockyer electorate cannot afford to throw away the opportunity of having a representative at such a level. (Toowoomba Chronicle: 24 May 1963)

In 1966 Chalk was a little more direct:

As Treasurer of this State, and provided you return me as your Member-I believe I can retain my present portfolio-I consider I am in a very influential position to assist the industries of the Lockyer electorate. (Ibid.: 21 May 1966)

In adjacent Somerset, advertisements for the Minister for Public Works and Local Government, Harold Richter, proclaimed 'For Cabinet Voice-Richter is Your Choice' (Queensland Times (Ipswich): 22 May 1963) and noted that 'his colleagues in the progressive Nicklin Government have elevated him to Cabinet Rank' (ibid.: 30 May 1963). In Isis, however, Pizzey's advertisements described him merely as 'Your Country Party M.L.A.' and only at the end of the campaign did he say:

I submit, sincerely and quite humbly, that my experience as Member and Minister fits me for responsible stewardship. (Maryborough Chronicle: 30 May 1963) 
In Bowen Dr Delamothe was reputed to be in the running for Cabinet rank if the Liberals added another Minister from outside Brisbane. Visiting the electorate, Hiley merely praised Dr Delamothe 'as an able, hard-working Member, shrewd enough to get in early on Government spending, busy, active, and intelligent' (Bowen Independent: 31 May 1963), but the Bowen Independent went a bit further:

Dr Delamothe's achievements in winning Government expenditure in the electorate have been phenomenal, and the attention he has paid to the needs of his electors is alone a good argument for his return. In addition, his chances of eventual promotion to Cabinet rank would seem bright.

This prophecy proved correct. Dr Delamothe was soon Minister for Justice, and three years later was supported by an advertisement signed by the Premier and the Deputy Premier (apparently the only case of this being done, but then he was the only Minister with a really marginal seat):

It would not be possible to get anyone more capable or conscientious than Peter Delamothe, the Liberal Member who has represented you so ably for the past six years. It is indicative of the calibre of the man that he had been a member for only three years when his Parliamentary colleagues selected him for appointment to Cabinet rank.

Since 1963, he has justified their faith in him as a Member of Cabinet in the same efficient and praiseworthy manner as he has served the people of Bowen Electorate as their Parliamentary Representative. As Minister for Justice and Attorney-General he has been in the forefront of the Government's policy formulation which has led to the tremendous development and expansion taking place throughout Queensland today. (Townswille Daily Bulletin: 20 May 1966)

Thus, it was argued, a Minister was the best sort of Member. However, being a Minister held its dangers. A Minister's administrative acts could bring down the wrath of some group or individual. The campaign against Chalk by the Transport Operators Association is reported elsewhere (pp. 252-3), and in Yeronga the Minister of Health, Dr Noble, was attacked in a roneoed pamphlet distributed by a John Daly of Mulgildie for the condition of children committed to State institutions (Sunday Truth: 5 May 1963). Daly's allegations about conditions in the Westbrook farm home for boys in 1961 had led to a Commission of Inquiry which revealed some disquieting practices, but the impact of the pamphlet in Yeronga appears to have been negligibile.

Turning now to the representational roles candidates might assume, again we must use Wahlke's definitions with care. The distinctions between delegate and trustee roles were very much to the fore in the 1957 split (Hughes 1957) and have been the subject of partisan debate ever since. From the early days of the Labor Party in Austra- 
lia its acceptance of the principles of the pledge and caucus solidarity have been attacked by the anti-Labor parties, even though those parties steadily became more intolerant of dissidents within their own ranks and have often adopted the institutional arrangements devised by the Labor movement to ensure party regularity. Nevertheless the A.L.P. chooses to emphasise the delegate role, the Liberal and Country parties the trustee role, while the Q.L.P. defends an intermediate position, somewhat resembling one of the politico roles defined in The Legislative System but directly attributable to the anomalous situation in which Gair and his colleagues found themselves in 1957, defending their independence as to timing but with a lifetime of acceptance of A.L.P. doctrine on record. Again these definitions provided by Wahlke and his colleagues relate to the loose, undisciplined American party system, and much of the Australian delegate-trustee debate takes place within assumptions as to party voting which would be totally unacceptable in the United States. The real defence of the trustee position comes from the independent candidates, and they put their case at sufficient length to warrant its consideration in a separate chapter (ch. 5). Most of the argument about representational roles during the campaign revolved around attacks by Government and Q.L.P. candidates on the A.L.P. for the subservience of its parliamentary members to 'outside dictation'; the caucus principle entered only when raised by Independents. Because the debate raged in virtually all electorates it is necessary to select a few and follow the development of the debate there. In the three electorates of the Mackay district (Mackay, Mirani, and Whitsunday) the debate was opened in 1963 with a Country Party advertisement which reviewed the arguments of 1957. Gair had said that for the Labor-in-Politics convention to direct the Government on the timing or implementation of a convention decision was unconstitutional. The Constitution provided that Parliament was supreme, but that supremacy and the principle of responsible government would be destroyed if 'the decisions of any Party in Parliament become subject to review by an outside body other than an electorate'. Egerton had replied that Convention would not presume to direct the government but would presume to direct the parliamentary representatives of the A.L.P., for there was no other body with a right to do so. The disagreement led to the split in the Labor Party and its defeat. The advertisement concluded:

The Party is still split on the question of outside interference. Responsible members of Parliament wiil not tolerate orders from outside and rightly so. If they did, Parliament would become merely a rubber stamp for the policies of the Trades Hall and Australia would be under Communist control in no time at all. (Daily Mercury (Mackay): 25 April 1963)

This was the first of a series of advertisements on the Communist 
threat (ibid.: 27, 29 April, 1, 2 May 1963), but interposed was one (30 April 1963) which reproduced the A.L.P. candidate's pledge and observed:

Electors will note that whilst a Labor Party candidate agrees that he is not a Communist, he does agree to be controlled in everything he does by the Queensland Central Executive, the majority of whose members are Left Wing.

A few days later Evans commented sadly about the A.L.P. candidate for Mirani:

I have known Mr Moody for some years, and know him to be an honest, upright man, whose endeavours to advance the cause of Mackay and District are too well known to need re-telling. What a pity his considerable ability will be severely handicapped by Left Wing Q.C.E. directions, should he manage to win the State seat of Mirani. (Ibid.: 6 May 1963)

Other advertisements (e.g. see p. 231) kept hammering at the points that A.L.P. policy promises could not be trusted because they were subject to instant change upon direction by the Q.C.E. and that final policy decisions lay with a left wing body-'To let Labor in is to build your future on shifting sand. Shifting at the whim of the Q.C.E.' (ibid.: 16 May 1963). When Graham apparently promised that the A.L.P. would not let Communism take over because its members lived and brought up their children in the State, Matson agreed:

This is a fair enough statement, and I feel that the Member for Mackay is honest in the expression of his opinion on this matter. However, the most important aspect of this matter is the fact that the Member for Mackay will have no say because he will not be making the decisions ... I point out that the unfortunate position is if Labour were elected to govern this State, the decision of Parliament would be usurped by a body not answerable to the people. (Ibid.: 20 May 1963)

The A.L.P. took the view that the Country Party, devoid of policy, was running a smear campaign on the Communist issue and did not reply on the question of outside dictation. Similar exchanges can be found taking place in almost every electorate of the State in 1963, Government and Q.L.P. candidates charging that A.L.P. parliamentarians could not be trusted because they accepted outside dictationwhich proposition enabled them to go on to left wing and Communist influence on the extra-parliamentary organs of the A.L.P., the A.L.P. candidates remaining silent. However, few took the pure Burkean view that the election was not a contract of employment between constituents and Member, an exception being Hall, standing for the Country Party in Fassifern:

As a candidate and one who has never been in Parliament, I will 
not make any specific promises to electors, for I have had sufficient experience in Local Government, on commodity and hospital boards, in co-operatives and farmers' organisations to know the fallacy of such promises. (Queensland Times (Ipswich): 14 May 1963)

More typical was a speech by Hodges to the Mary Valley branch of the Country Party, reported by the Gympie Times (7 May 1963):

Mr Hodges went on to indicate how his opposition would, if elected, impose upon the people many things contrary to the expressed wishes of the people. He said that if they had A.L.P. representation, children from Kandanga would not have been given the opportunity to attend the Gympie School, the school of their choice -because his opponent has stated that he would not have listened to their request for transportation but would have established a High School at Kandanga, irrespective of what they requested. Such was not true representation the people of the electorate desired. They realised they had to elect a man who would endeavour to assist them, and represent their wishes, and who was answerable to them every three years, and not answerable to the Trades Hall junta over whom they had no control.

Alternatively, government candidates could emphasise that party reins lay more lightly on them. Gaven distributed a leaflet in South Coast which stated:

Eric Gaven has proved himself an able and fearless Champion for the South Coast, recognised by political friends and opponents alike as a sincere and trusted representative of the people. Although a strong Country Party man, he has never heistated to speak against the decisions of the Government if his constituents were adversely affected; it is a fact that his forthright expressions of opinion in the Parliament have brought outright expressions of surprise and admiration from all Parties.

Immediately relevant to the supposed wish of electors to keep their Member answerable is their desire to have him available, the Member as errand-boy or communicator. By communicator Wahlke et al. meant being available to constituents, answering mail, and so on, and clearly Queensland candidates think this is a meaningful activity. It can be a demanding business. The Member for Flinders, Lonergan, reported putting over 36,000 miles on his speedometer in the previous fourteen months (Townsville Daily Bulletin: 18 May 1966). The Member for Mirani, Newbery, reported: '. . . apart from interviews and other meetings, my inward and outward mail during the year exceeded 20,000 articles, and the great bulk of this mail matter was on behalf of the electors' and that he had to employ as many as five assistants (Daily Mercury (Mackay): 21 May 1966). A member should live in his electorate. Lonergan reported to the electors of Flinders that in 1957 he had promised to live in the electorate and had done so (Townsville 
Daily Bulletin: 15 May 1963). His A.L.P. opponent C. Rattray, also 'pledged himself to live in Charters Towers' (Northern Miner (Charters Towers): 31 May 1963). A letter complaining about the unemployment rate in Bundaberg asked:

Could it be that our member of Parliament, Mr E. J. Walsh, is too far distant to appreciate the situation and has lost that intimate feeling which any M.P. should have for his city? (News-Mail (Bundaberg): 22 April 1963)

Walsh lives in the Brisbane suburb of Annerley. His opponent, Tallon, in contrast was 'one who will reside in Bundaberg' (NewsMail (Bundaberg): 3, 7 May 1963). W. M. Ewan, the Country Party M.L.A. for Roma, wrote in his 'personal appeal' leaflet in 1963:

As your Representative I feel a personal responsibility for the progress and the happiness of everyone in our Electorate. No one can serve you who does not know your problems, and no one can know your problems who has not worked with you, worked for you, and lived the life we all live here.

For 38 years I have lived in the Maranoa and, until I disposed of my hard-earned property to devote all my time to your interests, I toiled as you toil, I faced the difficulties that you encounter, and I learned how unfortunate an electorate can be with a poor Parliamentary Representative.

As you know, I live with my family in Roma, the centre of the Electorate, which helps me, by constant travelling, to cover our territory, and to meet personally as many as possible of the good people I represent.

That is my constant object-to talk with my electors, to discuss with them at first hand all those things where I may be able to offer help, guidance or advice.

In South Coast the call 'Vote Liberal/Vote Local/Vote Winders' was expanded:

The man who lives in the area, works for the area, knows the area and its problems and its requirements. He lives in the area, works for the area ... Compare his record of community service with that of other candidates ... (Gold Coast Bulletin: 27 April 1966)

In Fassifern Alf Muller's final three of ten reasons, the first seven of which spelled VOTE FOR, were:

Assets in the district, and will be affected by adverse legislation just as other land-owners will be.

Lived all his life in Fassifern, and knows its every requirement.

Fassifern's interests at heart, and stands for all sections of the community alike. (Queensland Times (Ipswich): 24 May 1966)

Even in Brisbane, where few electorates have a real identity, George Georgouras, standing for Windsor, described himself as 'the only candidate who lives in the electorate' (Sunday Truth: 26 May 1963), although this had overtones of the sitting Member's unsuccessful at- 
tempt to shift to the next-door and safer seat. Murray, contesting the safe Liberal seat of Clayfield, still chose to move to the electorate and begin a complete house-to-house personal canvass (Telegraph: 18 January 1963). Living in the electorate is partly a matter of convenience, but it is also a matter of sentiment. Thus Rae in Gregory:

I have been out here in the West for the greater part of my life. In all truth I can say that I know it and the people who inhabit this region better than most. I know the hardships, frustrations and disappointments for I have experienced them all and felt the deep sense of defeat in what I thought was a hard and pitiless country, but somehow I have felt too there is kindness in this country, bountiful if one has the spirit and the courage to rise above the adversities. (Western Times (Charleville): 26 May 1966)

In addition to living in the electorate, the Member should be 'easily approachable at all times' (cf. Adair, Cairns Post: 11 May 1963). Thus Hedley Scriven in Ipswich East promised: 'If elected I will not only be available to electors every second Saturday at the Trades Hall, but at any time day or night' (Queensland Times: 11 May 1963). Morris, standing for the Q.L.P. in Toowoomba West, promised to visit every home in the electorate at least once every three years. German promised to open an office in Rockhampton North, and Rattray that 'at regular periods will hold public meetings in the electorate to advise the electors of what I have done in Parliament, what the Government are doing and to receive from electors their wishes for representation in Parliament' (Northern Miner (Charters Towers): 27 May 1963). The long shadow of Tom Aikens was cast over Flinders by such a promise. The report that Col. Bennett was available only between 4.30 and 6.00 p.m. (see p. 272) was taken up in Toowoomba by A. Dietz, defending Anderson against the complaint that he had held two jobs as M.L.A. and Mayor. Anderson's office was open all the time, whereas Bennett's hours were most inconvenient for a mother with children. What was the A.L.P. doing about that? (Toowoomba Chronicle: 18 May 1963). In Toowoomba East in 1966 both A.L.P. and Liberal candidates promised full-time representation in opposition to Alderman McCafferty of the Country Party who was attempting three jobs -Mayor, businessman, and M.L.A. (ibid.: 5 May 1966). Alderman McCafferty was unabashed: his business and local government experience made him appreciate what was requried (ibid.: 14 May 1966) and his advertisements repeated the message: 'The best qualified. The most accomplished. Better versed in Local Government. Has more influential contacts.'

However, there might be times when full-time representation was not wanted. When the Country Party candidate for Aubigny in 1963, Alderman Thorn, promised to put a manager into his business so that he could devote all his time to parliamentary duties, the sitting Q.L.P. 
member, Diplock, offered to resign his post with the Dalby firm of Napier Brothers Ltd. The irony of the offer was devastating, for a considerable factor in Diplock's retention and consolidation of the seat was his part in saving the firm from ruin. At the end of the financial year in June 1962 the company showed a loss of $£ 212,000$, equivalent to almost one-half its paid-up capital. The directors were prepared to accept a take-over bid from Toowoomba Foundry; had the bid been accepted it was presumed that the Dalby works would close, throwing 175 men out of work and dealing a heavy blow to the town's economy. A group of local shareholders opposed the move, four directors resigned and were replaced, and Diplock became Chairman. In less than six months the company was back on a profitable basis, and 5 s. shares which had been down to $6 \mathrm{~d}$. had risen to $2 \mathrm{~s}$. 9d. to 3s. A Brisbane paper observed:

... The Board has done a grand job, the responsibility undertaken by chairman Mr Les Diplock being most unenviable. He stepped in when the company was going through its blackest hour, and had he failed, Napier Bros.-and a large part of the Dalby township-would have died. That obviously would have ruined $\mathrm{Mr}$ Diplock's political career. Well aware of the risk he was taking, Mr Diplock (aided by his co-directors) has come through with flying colours. (Sunday Truth: 21 April 1963)

At a Q.L.P. branch meeting Diplock was congratulated by the branch president. The Australian people liked a chap who took risks if the result was worthwhile, and the majority of Dalby people would admire Diplock for what he had done for the town. The member replied in appropriately modest terms:

It was not a one-man job, but the efforts of a wonderful teamdirectors, management, white collar workers and a team of fellows who really know the meaning of the term 'yakka'. We are all on one ship, and we are all determined that she's going to keep floating. I am very happy to be associated with the whole outfit. (Dalby Herald: 3 May 1963)

Alderman Thorn could point out that the two Dalby firms in which he was interested employed sixty-one persons, nearly all married and home-owners (ibid.: 14 May 1963), but this lacked the drama of Napier's battle back. Diplock, speaking in Dalby, agreed with the thought of full-time representation, but wondered if its reiteration meant that Thorn was trying to call attention to the fact that he (Diplock) was chairman of Napiers. He was prepared to leave it to the electors to decide whether or not he had devoted 100 per cent of his time to his job, meaning seven days and seven nights a weekwhich he had done, even though it meant giving up his sport on Sundays. He had not looked for the chairmanship of Napiers, but accepted it in the interests of the town because of the economic tragedy 
which would have resulted had the company failed (Toowoomba Chronicle: 23 May 1963; Dalby Herald: 24 May 1963). Thereafter Diplock's advertisements added 'the salvation of Napier of Dalby is the result of his leadership' (Dalby Herald: 24 May 1963), and at the end of the campaign he flatly attacked the Government for its unsympathetic treatment of Napiers. He had pointed out to the Premier and his Ministers the hardship that the closing of Napiers would cause Dalby, but the Government had progressively withdrawn the railway section, even though the company had offered to continue the work with very little financial benefit to maintain employment. Two days before the 1960 election, the Country Party candidate, Sparkes (as a result of the redistribution of 1960 Sparkes, the M.L.A. for Aubigny, and Diplock, the M.L.A. for Condamine, had been thrown into one electorate; Sparkes lost), had announced a contract for $£ 15,000$ worth of repair work in the following financial year, but that was the last order from the Government. As a result of the cessation of railway work, 140 men had lost their jobs and could not be absorbed in other parts of the works. In the award of contracts to build 500 railway waggons Napiers had been passed over, although they could have competed had the requirements not been stacked against them. The Government was not prepared to give people engaged in industry in rural areas an even break.

The second theme to emerge from the contest between Thorn and Diplock was the role of errand-boy. (The third, the problems of the independent Member, is discussed in ch. 5.) Diplock, dealing with the question of an Independent's efficiency at a meeting at Bowenville, stated that there were many instances of his getting the results after Country Party organisation had failed. A typical example was when the Rosalie Shire Council sent a deputation to Brisbane to secure $£ 15,000$ for roadworks and got nothing. Certain councillors then insisted on another deputation, led by Diplock, which secured not $£ 15,000$, but $£ 25,000$ (ibid.: 21 May 1963). Alderman Thorn replied that such a statement was incorrect. He had been in touch with the Shire Council chairman, W. F. Kajewski, who had denied that his Council ever needed anyone to fight its battles.

His council had merely given Mr Diplock the courtesy of putting the case to the department by virtue of the fact that he was their representative in the district. When their member was asked to introduce a deputation or to make representations on behalf of any matter, it was purely a courtesy which every council extended to its representative in Parliament, irrespective of any political views on either side. This is the normal procedure in every portion of the State, and every council practises and expects that routine service from its sitting representatives. For $\mathrm{Mr}$ Diplock to capitalize on that situation and claim credit for any successful representation gives a very wrong impression indeed. (Ibid.: 24 May 1963) 
The same number of the Dalby Herald contained another tactical error on Alderman Thorn's part. To counter a Diplock advertisement in the previous number advancing the merits of 'Diplockium . . . the proven stimulant . . . containing all the vitamins essential to growth and development ... Dosage: Regular applications of my formulaconstant visits to all parts of the Electorate and personal interest in the affairs of all the people', a Thorn advertisement advised calling in a doctor and sacking the medicine man 'with his meaningless weekly visits, his cheapjack pills. . . ' Now Diplock prided himself on his regular tours of Aubigny, carefully advertised in the local press in advance, and they had been the subject of frequent congratulations at his earlier meetings, as when the chairman of his Bowenville meeting observed:

Mr Diplock has visited us regularly, almost weekly, since he became our member. This is something we have never had before, and probably would not have if Mr Diplock were not our member. We of this area have no doubt about the election. (Ibid.: 21 May 1963)

Diplock answered the advertisement with one of his own directed to the residents of all the smaller centres in the electorate. Thorn had called his weekly visits 'meaningless':

Meaningless to most Politicians, because they mean travel and much follow-up work. But, are they meaningless to You and Your District? Are they meaningless to the hundreds of people who have benefited from them? (Toowoomba Chronicle: 27 May 1963)

Thorn had indicated the sort of representation he would provide, and it was up to the electors to choose which they wanted. In a speech at Cooyar, Diplock dealt with the subject of the Rosalie Shire deputation. He agreed that there was no need for him to fight the shire councillors' battles for them; he merely assisted as was his job. The facts of the deputation were as he had stated: a Council deputation had been invited to accompany the deputation, they saw the Minister in his bedroom at Parliament House, and in less than twenty minutes they had secured $£ 25,000$. Kajewski could be excused for leading Thorn astray on the matter because, although he had been appointed a member of the deputation, 'he either forgot the deputation, or was otherwise engaged, and did not arrive to take part in the proceedings, and we just had to do the best we could without his valuable assistance' (ibid.). At a meeting at Goombungee three Rosalie Shire councillors supported Diplock's account as correct. One of them reported the opinion of the late Shire Chairman of Diplock:

I just know how highly our late chairman, Mr S. Plant, thought of him. One of the last things that he said was, 'Vic, he certainly does the job. The occasion was received the $£ 25,000$ was one of the few 
times we really got the money. On other occasions we had promises of favourable consideration.' (Ibid.: 29 May 1963)

In his final press release Alderman Thorn promised to be at the electors' disposal 100 per cent of the time by reason of putting a manager into his business, and added: 'You will see me often, for I will regularly visit all parts of the electorate, and you will always be able to come to me with your knotty problems and your grouches.' He dismissed Diplock with the comment: 'He offers you nothing because he has nothing to offer except a little personal attention which you will get from me anyway' (Dalby Herald: 31 May 1963). This election must have been the first time on record when a Country Party candidate attacked an opponent for regular visits to his constituents. Presumably it will be the last.

The usual form of errand-boy activity is of a polite approach to the appropriate authority. Thus Dr Delamothe to the Minister for Lands:

Enclosed is a newspaper cutting which has probably been brought to your notice. I desire to press the claims of the Bowen River district for growing irrigated cotton. I understand that this facet is under consideration in the proposed plans for the Bowen River Dam and I feel sure that your advisers will agree with my submissions and this would perhaps be the time to consider a wider field of irrigation in the area than has yet been envisaged. (Bowen Independent: 14 June 1963)

Occasionally a more acid note is appropriate; thus Dr Delamothe to the Treasurer, as minister responsible for harbours:

According to reports in the Northern press, it is proposed to cease exports of bagged sugar from the Port of Cairns. Instead, sugar is to be bagged and exported from Townsville. This would appear to be a good illustration of the Biblical quotation 'To him that hath shall be given.' Townsville already has large exports of $M t$ Isa products and beef as well as bulk sugar, and its Harbour Board prospers thereby. In this case, the sugar to be bagged has to be brought a minimum of 70 odd miles to Townsville.

Sugar is produced in quantity at Proserpine, about 40 odd miles from Bowen-a Port Ianguished for want of trade. Would you be so obliging as to secure from the Sugar Board the full story so that the claims of Bowen may, with your assistance, be adequately presented. (Ibid.: 29 March 1963)

Rarest of all is the outburst-Peter Byrne, Labor M.L.A. for Mourilyan, to the Minister for Transport:

You are aware of my repeated references to the urgent need of improvement to the railway stations at Innisfail and Tully, and you have wiped them off with various excusses [sic] ... If you are not prepared to do something to remedy this state of affairs then a 
public meeting will certainly be called. (Evening Advocate (Innisfail): 2 May 1963)

Errands can be run to authorities other than the State Government. Thus Carey claimed credit for attacking the Federal Government and replacing an antiquated post office in Southport: 'It brought on my head strong personal criticisms from the Postmaster-General, $\mathrm{Mr}$ Hulme, but it also brought immediate action' (Gold Coast Bulletin: 18 March 1966).

The third of The Legislative System's roles for the legislator as servant was that of mentor, educating his constituents on the problems of the day. Obviously a Member taking on such a task would have to proceed carefully, and an election campaign may well not be the best time to begin. Still it appears that most candidates were content to state and re-state party policy. Only Peter Wood apparently devoted some campaign speeches to explaining such topics as democracy and State finances to his listeners, but the explanation may be that with over a hundred street-corner meetings scheduled, a man of Wood's ability would have gone mad delivering the same speech a hundred times and relapsed into pedagogy in self-defence. The failure of $\mathrm{V}$. Robb's meeting of all candidates at Ipswich suggests that the voters might not feel much of a need for education in things political.

Finally we may look at what candidates had to say about themselves in relation to pressure groups, as facilitators, resisters, or neutrals. All parties claimed to rise above sectionalism, that is favouring one group over another, save that most in country towns and districts were happy to keep Brisbane in its place. Similarly the candidates were averse to attaching themselves to any one group or to making promises to any group. Obviously as communicators or errand boys they would be available to any individual or group who claimed their services, but they would not be committed to anything but the widest possible public interest. The independent M.L.A. for Burdekin, Coburn, identified himself specifically as a facilitator by listing among the things he stood for: 'A close liaison between the Member of Parliament and the representatives of the Sugar Cane Growers' Organisations so that the best interests of those who derive a livelihood from the industry may be served' (Townsville Daily Bulletin: 13 May 1963). Wharton reported that he had spent considerable time in assisting cane growers in his electorate to secure additional representation on the Queensland Cane Growers executive, and dealt with cabinet to that effect: 'When the industry says exactly what it wants, my Government and I will not be found wanting in meeting these wishes' (News-Mail (Bundaberg): 14 May 1966). Sullivan of Condamine declared that his contacts with many primary producer organisations assisted him in making decisions on the problems of their various industries (Toowoomba Chronicle: 12 May 1966). Hodges in 
Gympie reported similar close association with the dairymen. The problem of reconciling party and district loyalties, as well as personal interest, presented itself to Anderson at the opening meeting of the campaign in Toowoomba at which he was scheduled to speak after Chalk, the Minister whose transport policies he had often attacked publicly.

There have been some occasions possibly when some of my statements, particularly in relation to transport legislation in Queensland, would convey the impression to some people that I was not very loyal to my Party. Let me hasten to assure you that I am dedicated to the ideals of Liberalism ... I reassure you tonight that I will play my part to ensure that we preserve this liberty by winning the next State election.

Transport legislation certainly has been of a controversial nature since our Government assumed office. In this regard, I make no apology for my outspoken comments on some aspects of this legislation. It must be remembered that I have a duty to my constituents and when we consider that Toowoomba is regarded as the home of the road transport industry in Queensland, you can well appreciate my desire to make representations on behalf of more than 600 employees in the Transport Workers' Union in this city.

Admittedly, my own business has suffered too because of certain aspects of this legislation but I would not like you to gain the impression that I selfishly approached the subject because I was being affected. I may mention at this point that my firm reorganised its operations and where formerly we conducted an extensive business in Queensland we have now turned our main force of operations to the sou thern States with gratifying results.

Notwithstanding what I have already said regarding transport legislation, we are all very grateful indeed for the clear and comprehensive manner in which Mr Chalk outlined the Government's attitude to road-rail transport. (Toowoomba Chronicle: 25 March 1963: omission in original)

The related problem of the broker was illustrated by Chalk, dealing with Keim's remarks on the need for price control:

The Nicklin Government is pledged to find new markets for primary production, but unfortunately for Mr Keim, Mr Duggan had pledged the A.L.P. in a radio broadcast to the workers of Brisbane on Sunday evening last, to a return of price control so that 'the workers will be able to obtain butter, eggs, potatoes, and onions at the cheapest possible price'. Mr Keim cannot hunt with the Trades Hall A.L.P. group and at the same time run along with the primary producers. No primary proudcer can on this occasion vote for Mr Keim since by doing so he will be signing away his freedom. (Ibid.: 31 May 1963)

As reported in the press, candidates spent most of their time expounding party policy for the State as a whole. When they spoke of themselves their main duties were seen to be two, being good 'fruit. 
pickers' on behalf of their electorates in the allocation of public works expenditure and being accessible to their constituents. On behalf of Nev Hewitt, the Country Party M.L.A. for Mackenzie, it was claimed:

He is best known for his warm-hearted approach to the problems of the individual. He is indeed a reliable friend. (Morning Bulletin (Rockhampton): 31 May 1963)

The amount of self-sacrifice expected of a Member gained a degree of prominence in 1966 because of the recent increase in parliamentary salaries. The A.L.P. had opposed the amount of the increase, and at least two members ran into some difficulties with the Q.C.E. for refusing to return part of the increase or place it in a special fund for charitable constituency use (see p. 17). In Carnarvon McKechnie reported that he had placed his net gain from the increase in a special bank account to be 'allotted by me where $I$ consider it will do the most good in my own electorate'; if he had returned it, the amount would have gone back into Consolidated Revenue and would have benefited electorates whose A.L.P. Members were accepting the increase (Warwick Daily News: 13 April 1966). At this point we might turn to the electors to see what expectations they had of the candidates.

Both Brisbane and provincial city panels were asked forced choice questions in 1963 to discover their role expectations of Members of the Legislative Assembly. They were asked what they wanted the man they elected to the State Parliament to do most: (a) his work in Parliament, look after electors' problems, or both equally; (b) be loyal to his party, do what he thinks best, or it depends; (c) work hard as an M.L.A., be a leader in local affairs, or both equally; (d) vote as the people who put him there say, vote as he thinks best, or it depends. They were then asked to choose the most important duty of the man they vote for, and to rank the others in order of importance: look after the district, support his leader, see that his party's program is carried out, and look after the State as a whole.

Responses to the first question suggest remarkable uniformity of opinions.

In Brisbane, A.L.P. and Q.L.P. voters were more likely to prefer errand boy to parliamentarian than were Liberal voters. In the provincial cities A.L.P. and government supporters did not differ, though both groups tended to respond with an equal rating more often than in Brisbane. Brisbane panel members emphasised work as an M.L.A. rather than as a local leader, provincial cities panel members were more ready to endorse both, although (apart from the little group of Q.L.P. supporters in Brisbane whose numbers are too small to attribute much significance to the point) in both Brisbane and the provincial cities only one voter in ten regarded local leadership as 
Table 4.01

M.L.As.' Roles 1963 $\%$

\begin{tabular}{lrrrrr}
\hline & \multicolumn{3}{c}{ Brisbane panel } & \multicolumn{2}{c}{ Provincial cities panel } \\
\cline { 2 - 7 } & \multicolumn{3}{c}{ Voting intention: } & \multicolumn{2}{c}{ Voting intention: } \\
& A.L.P. & Lib. & Q.L.P. & A.L.P. & Govt. \\
& $(\mathrm{n}=149)$ & $(\mathrm{n}=149)$ & $(\mathrm{n}=24)$ & $(\mathrm{n}=99)$ & $(\mathrm{n}=132)$ \\
\hline Work in parliament & 23 & 28 & 25 & 13 & 10 \\
Look after electors' problems & 45 & 37 & 42 & 30 & 23 \\
Both equally & 32 & 36 & 33 & 58 & 67 \\
Work hard as M.L.A. & 64 & 66 & 50 & 51 & 36 \\
Be a leader in local affairs & 12 & 10 & 25 & 9 & 12 \\
Both equally & 24 & 24 & 25 & 40 & 52 \\
Be loyal to his party & 45 & 38 & 35 & 43 & 20 \\
Do what he thinks best & 48 & 50 & 57 & 44 & 60 \\
It depends & 7 & 12 & 9 & 13 & 20 \\
Vote as the people who & & & & & \\
$\quad$ put him there say & 49 & 26 & 35 & 36 & 24 \\
Vote as he thinks best & 44 & 64 & 52 & 49 & 56 \\
It depends & 7 & 11 & 13 & 14 & 20 \\
\hline
\end{tabular}

more important. In the choice between party loyalty and independence of judgment there was less difference between A.L.P. voters on the one hand and Liberals and the Q.L.P. on the other than one might have expected. In the provincial cities panel the government supporters were more sharply distinguished from A.L.P. supporters on this point. Finally there was a difference between A.L.P. and Liberal supporters in Brisbane and A.L.P. supporters and government supporters in the provincial cities on whether the M.L.A. is a delegate or a trustee, but less difference than could have been expected. Almost as many Labor voters in Brisbane endorsed the heretical trustee theory as the official delegate view, and in the provincial cities panel the larger group supported the trustee theory. On the other hand a quarter of Liberal or government supporters in each panel endorsed the delègate theory. The Q.L.P. supporters occupied a middle position, indicating that the official views of the party have not been uniformly accepted by its supporters. These two last items have been cross-tabulated in Table 4.02. Thus among A.L.P. supporters barely one-quarter (27 per cent) were sound on the point that the M.L.A. is a delegate loyal to his party, while among Liberal and Q.L.P. supporters less than half (38 and 39 per cent respectively) agreed with their parties' official view that he is a trustee with independent judgment. On the other hand; more than a quarter (29 per cent) of A.L.P. supporters adhered to their opponents' view of the M.L.As.' roles, while among Liberal and Q.L.P. supporters rather fewer (12 and 17 per cent respectively) were squarely in heresy. It need hardly be added that party practice does 
Table 4.02

M.L.As.' duties 1963: party loyalty/independence; delegate/trustee

\begin{tabular}{lccc}
\hline Voting Intention & Delegate & Trustee & It depends \\
\hline A.L.P. $(n=147)$ & & & \\
$\quad$ Party loyalty & 27 & 14 & 3 \\
$\quad$ Independent judgment & 18 & 29 & 1 \\
$\quad$ It depends & 4 & 1 & 2 \\
L.iberal $(n=147)$ & & & \\
$\quad$ Party loyalty & 12 & 20 & 5 \\
$\quad$ Independent judgment & 10 & 7 & 2 \\
$\quad$ It depends & 3 & & 3 \\
Q.L.P. $(n=23)$ & & 9 & 9 \\
Party loyalty & 17 & 39 & 0 \\
Independent judgment & 17 & 4 & 4 \\
$\quad$ It depends & 0 & & \\
\hline
\end{tabular}

not always conform to party doctrine, and Liberal parliamentarians are only marginally more likely to speak or vote against their party than are A.L.P. members, but since 1957 so much has been made of the supposed difference in Queensland that the lack of consensus in each camp is surprising.

One of the reasons for asking these questions concerning electors' role expectations was to see whether individual electorates had local points of view. It may be that over the years a member like Tom Aikens may shape electorate opinion on what an M.L.A. should be like. Unfortunately in each of the three Brisbane electorates from which our panel was drawn the sitting member was relatively new. S. D. Tooth (Ashgrove) was elected only in 1957, and the electoral boundaries were substantially altered in 1960 when Kelvin Grove became Ashgrove. Hanlon (Baroona) and R. L. Windsor (Ithaca) were returned for their present electorates only in 1960, although Hanlon retained part of his old electorate (Ithaca) for which he was first elected in 1956. In the metropolitan areas where electorates are artificial creations it is particularly hard for an M.L.A. to impress his style, or even his identity, on the electorate, and in any event none of these gentlemen has the strong individualistic style of an Aikens or a Barnes (see p. 143). However, each of the electorates represents a class of electorate, Ashgrove the safe Liberal seat, Baroona the safe A.L.P. seat, Ithaca the marginal, and if there were any widely held electoral opinion on the style appropriate to the Member for such a seat, it might have been reflected in the answers. No such pattern appeared. A few tentative suggestions may be made. Labor voters in Baroona were more concerned with the Member looking after their interests, but Liberal voters were less likely to be so. Is this a consequence of the seat being safe for the A.L.P., a working class district in which the 
Table 4.03

M.L.As.' roles 1963: $\underset{\%}{\text { electorate differences }}$

\begin{tabular}{|c|c|c|c|c|c|c|}
\hline & \multicolumn{3}{|c|}{ Voting intention: } & \multicolumn{3}{|c|}{ Voting intention: } \\
\hline & $\begin{array}{l}\text { Ashgrove } \\
(\mathrm{n}=27)(\mathrm{r}\end{array}$ & $\begin{array}{c}\text { A.L.P. } \\
\text { Baroona } \\
\mathrm{a}=75)(\mathrm{n}\end{array}$ & $\begin{array}{l}\text { Ithaca } \\
=47)\end{array}$ & $\begin{array}{r}\text { Ashgrove } \\
(\mathrm{n}=59)\end{array}$ & $\begin{array}{c}\text { Liberal } \\
\text { Baroona } \\
(\mathrm{n}=\mathbf{3 1})\end{array}$ & $\begin{array}{l}\text { Ithaca } \\
(\mathbf{n}=59)\end{array}$ \\
\hline $\begin{array}{l}\text { Work in parliament } \\
\text { Look after electors' }\end{array}$ & 19 & 15 & 39 & 26 & 27 & 29 \\
\hline $\begin{array}{l}\text { problems } \\
\text { Both equally }\end{array}$ & $\begin{array}{l}35 \\
46\end{array}$ & $\begin{array}{l}51 \\
34\end{array}$ & $\begin{array}{l}39 \\
22\end{array}$ & $\begin{array}{l}44 \\
30\end{array}$ & $\begin{array}{l}27 \\
47\end{array}$ & $\begin{array}{l}35 \\
36\end{array}$ \\
\hline $\begin{array}{l}\text { Work hard as M.L.A. } \\
\text { Be a leader in local }\end{array}$ & 63 & 65 & 62 & 63 & 63 & 69 \\
\hline $\begin{array}{l}\text { affairs } \\
\text { Both equally }\end{array}$ & $\begin{array}{l}11 \\
26\end{array}$ & $\begin{array}{l}12 \\
23\end{array}$ & $\begin{array}{l}11 \\
27\end{array}$ & $\begin{array}{l}10 \\
26\end{array}$ & $\begin{array}{r}3 \\
93\end{array}$ & $\begin{array}{l}14 \\
17\end{array}$ \\
\hline $\begin{array}{l}\text { Be loyal to his party } \\
\text { Do what he thinks best } \\
\text { It depends }\end{array}$ & $\begin{array}{r}54 \\
38 \\
8\end{array}$ & $\begin{array}{l}44 \\
45 \\
11\end{array}$ & $\begin{array}{r}40 \\
57 \\
2\end{array}$ & $\begin{array}{l}41 \\
43 \\
16\end{array}$ & $\begin{array}{l}33 \\
50 \\
17\end{array}$ & $\begin{array}{r}37 \\
58 \\
5\end{array}$ \\
\hline $\begin{array}{l}\text { Vote as the people who } \\
\text { put him there say } \\
\text { Vote as he thinks best } \\
\text { It depends }\end{array}$ & $\begin{array}{r}56 \\
41 \\
4\end{array}$ & $\begin{array}{l}43 \\
45 \\
12\end{array}$ & $\begin{array}{r}55 \\
45 \\
0\end{array}$ & $\begin{array}{l}19 \\
70 \\
12\end{array}$ & $\begin{array}{l}27 \\
53 \\
20\end{array}$ & $\begin{array}{r}32 \\
63 \\
5\end{array}$ \\
\hline
\end{tabular}

errand-boy function is an important one, coupled with the reputed unwillingness of voters to approach a Member of another party? Labor voters in Ashgrove emphasised party loyalty and the delegate role compared with the other two electorates. Is this an illustration of the doctrinaire character of electoral permanent minorities? Liberal voters in Ashgrove were the strongest supporters of the trustee rolebut they were least likely to emphasise independent judgment. These are minor, and suspect, conclusions. What is certain is that very little variation occurs over the three electorates.

One might go on to ask whether social class is likely to influence role expectation. We can take occupation as the index of social class, and divide each group of party supporters into (i) professionals and businessmen, (ii) office and sales workers, and (iii) manual workers, as the broad categories which are most likely to be meaningful. The answer is that any such influence is marginal if it exists at all. Liberal manual workers placed slightly more emphasis on looking after electors' problems (42 per cent, against 35 per cent for professional and businessmen and 25 per cent for office and sales workers), and manual workers supporting both A.L.P. and Liberals placed less emphasis on parliamentary duties (21 per cent among A.L.P. supporters, against 36 per cent for professional and businessmen and 31 per cent for office and sales workers; 24 per cent among Liberal supporters, 
against 35 per cent for professional and businessmen and 29 per cent for office and sales workers).

It is also possible that sex could affect role expectation, so the party supporters of the 1963 panel were re-divided into men and women. Again differences within each group of party supporters are slight. In all cases women were more ready to emphasise local leadership and looking after electors' problems, and this might have been expected. Among Labor supporters the majority of men emphasised party loyalty ( 51 per cent) and the delegate role ( 57 per cent), but the majority of women emphasised independence of judgment (53 per cent) and the trustee role ( 50 per cent). But among Liberal supporters men were slightly more likely to emphasise independence of judgment and the trustee role than were women. The point appears to be that the men in each group adhered more closely to the party point of view, perhaps because they were better informed on what it was.

On the second question, determining the priorities of roles, again there was a striking uniformity of opinion. Ranking may be shown most conveniently by scoring four points for a lst place, three for 2nd place, two for 3rd place and one for 4th place. Thus if a role was ranked 1st by every member of a group it would have a score of four; if ranked last by all members, a score of one. Table 4.04 shows the results for both Brisbane and provincial cities groups. In Brisbane, for all groups, looking after the State as a whole had top priority, supporting the leader lowest. Both A.L.P. and Q.L.P. voters ranked district ahead of program for second place; Liberals reversed this order. It may seem surprising that Liberal voters should appear more program-orientated than Labor voters, but in terms of scores there was little difference. The significant difference is in district-orientation, where both A.L.P. and Q.L.P. voters showed higher scores. This supports political folklore to the effect that Labor Members are usually more zealous in looking after their constituents' parochial interests at the drains and pensions level. In the provincial cities

Table 4.04

Ranking scores of M.L.As.' roles 1963

\begin{tabular}{lcccc}
\hline Brisbane panel & District & Leader & Program & State \\
Voting intention: & & & & \\
A.L.P. $(n=149)$ & 2.6 & 2.0 & 2.3 & $3 \cdot 1$ \\
Liberal $(n=149)$ & $2 \cdot 1$ & 2.0 & 2.4 & 3.4 \\
Q.L.P. $(n=24)$ & 2.7 & 1.9 & 2.2 & 3.0 \\
Provincial city panel & & & & \\
Voting intention: & & & & \\
A.L.P. $(n=90)$ & 2.7 & 2.3 & 2.6 & 2.6 \\
Government $(n=125)$ & 3.0 & 2.0 & 2.4 & 2.7 \\
\hline
\end{tabular}


panel, the district claimed top priority with both groups, while support for the leader was again bottom. Again this is what one might have expected, although the extent to which implementation of the party program had overtaken looking after the interests of the State as a whole is more novel.

The different patterns between Brisbane and the provincial cities may be illustrated by comparing the proportions of the panels ranking the district or the State first in Table 4.05.

Table 4.05

First priority among M.L.As.' roles 1963 $\%$

\begin{tabular}{ccc}
\hline $\begin{array}{c}\text { Brisbane panel } \\
\text { Voting intention: }\end{array}$ & District & State \\
A.L.P. $(n=149)$ & & \\
Liberal $(n=149)$ & 28 & 54 \\
Q.L.P. $(n=24)$ & 13 & 66 \\
Provincial panel & 33 & 42 \\
Voting intention: & & \\
A.L.P. $(n=90)$ & 30 & 34 \\
Government $(n=125)$ & 40 & 35 \\
\hline
\end{tabular}

Within each voting intention group it does not appear that social background affected role expectation. Two characteristics which could reasonably have been expected to be influential were sex and class, but neither showed any deviation from the group pattern.

Occupational groups are numerically inadequate for firm conclusions; but it does seem that in Brisbane manual workers might have been slightly inclined to rate program and State lower than whitecollar groups, and to rate district higher. The pattern did not appear among members of the provincial cities panel, and this casts further doubt on the validity of the proposition. Among Government supporters in the provincial cities panel, farmers scored the highest ranking for State, a finding that runs so contrary to general belief as to challenge the representativeness of the panel.

We may also ask how far individual voters recognised individual candidates, or indeed individual members of the political system, on the hypothesis that minimal recognition of the role player's name or his party label is a preliminary and necessary step to role evaluation. In 1963 members of the Brisbane panel were asked several questions to ascertain their familiarity with elected representatives:

5. Can you remember the name of your member in Federal Parliament? What is it?

6. Do you know which political party he belongs to? Which is it?

8. Can you remember your Alderman's name? What is it? 
9. Do you know which political party he belongs to? Which is it?

11. Can you remember the name of the present Lord Mayor of Brisbane? What is it? Do you know which political party he belongs to?

13. Do you happen to know the names of any of the men standing for election in this district, for the State election on the 1st of June? Which ones do you know the names of?

14. A man standing for Parliament, of course, is either supported by a political party, or is an independent. Supposing you did not know which parties the candidates at the coming State election belonged to, do you feel you'd then know enough about those candidates to be able to choose between them?

It had been intended to compile an index of political figure recognition from responses to questions 5, 6, 8, 9, 11, and 13, but as almost all respondents were able to identify the Lord Mayor, Alderman Clem Jones (95 per cent), and his party, the A.L.P. (87 per cent), question 11 was not included. It might be added that at the following Brisbane City Council election in 1964 Alderman Jones was returned for a second term with 64 per cent of the vote, an increase of 14 per cent over his 1961 poll. Minor party candidates stood in Baroona (Communist) and Ithaca (Social Credit), but so very few respondents were able to identify them that they were excluded from the calculation.

With these modifications to the original plan it was possible to obtain maximum score of seven by correctly identifying the federal M.H.R. and his party, the City Council alderman and his party, and naming the candidates of the three major parties standing at the current State election. Responses are tabulated in Tables 4.06, 4.07 and 4.08 .

Table 4.06

Identification of M.H.Rs. for the federal electorates of Brisbane and Ryan 1963

\begin{tabular}{|c|c|c|c|c|}
\hline \multirow{2}{*}{ Electorates } & \multicolumn{4}{|c|}{ Voting intention: } \\
\hline & A.L.P. & Liberal & Q.L.P. & None \\
\hline \multicolumn{5}{|c|}{ Brisbane (Cross, A.L.P) } \\
\hline \multicolumn{5}{|c|}{ Name } \\
\hline Yes & 21 & 6 & $\mathbf{l}$ & 0 \\
\hline No & 85 & 58 & 12 & 12 \\
\hline \multicolumn{5}{|l|}{ Party } \\
\hline Yes & 49 & 13 & 3 & 1 \\
\hline No & 57 & 51 & 10 & 11 \\
\hline \multicolumn{5}{|c|}{ Ryan (Drury, Liberal) } \\
\hline \multicolumn{5}{|c|}{ Name } \\
\hline Yes & 8 & 29 & 2 & 6 \\
\hline No & 34 & 58 & 9 & 7 \\
\hline \multicolumn{5}{|l|}{ Party } \\
\hline Yes & 17 & 54 & 5 & 8 \\
\hline No & 25 & 33 & 6 & 5 \\
\hline
\end{tabular}


Table 4.07

Identification of City Council aldermen 1963

\begin{tabular}{|c|c|c|c|c|}
\hline \multirow{2}{*}{ Wards } & \multicolumn{4}{|c|}{ Voting intention: } \\
\hline & A.L.P. & Liberal & Q.L.P. & None \\
\hline \multicolumn{5}{|c|}{ Ashgrove (Mead, C.M.O.) } \\
\hline \multicolumn{5}{|c|}{ Name } \\
\hline Yes & 0 & 5 & $\mathbf{0}$ & 3 \\
\hline No & 28 & 54 & 6 & 9 \\
\hline \multicolumn{5}{|l|}{ Party } \\
\hline Yes & 6 & 22 & 2 & 4 \\
\hline No & 22 & 37 & 4 & 8 \\
\hline \multicolumn{5}{|c|}{ Baroona (Marshall, A.L.P.) } \\
\hline \multicolumn{5}{|c|}{ Name } \\
\hline Yes & 15 & 1 & 3 & 0 \\
\hline No & 60 & 30 & 8 & 7 \\
\hline \multicolumn{5}{|l|}{ Party } \\
\hline Yes & 29 & 6 & 3 & 2 \\
\hline No & 46 & 25 & 8 & 5 \\
\hline \multicolumn{5}{|c|}{ Ithaca (Buchan, A.L.P.) } \\
\hline \multicolumn{5}{|l|}{ Name } \\
\hline Yes & 22 & 22 & 3 & 2 \\
\hline No & 24 & 38 & 4 & 5 \\
\hline \multicolumn{5}{|l|}{ Party } \\
\hline Yes & 26 & 25 & 3 & 4 \\
\hline No & 20 & 35 & 4 & 3 \\
\hline
\end{tabular}

While the low rate of identification was not unexpected (see Rawson 1961: 180), certain additional conclusions can be drawn from these data. It would appear that partisanship aids identification: invariably a political figure was more likely to be remembered by his supporters than by his opponents. Respondents found it easier to identify a man's party than his name, but not very much easier; some of this difference may be explained by shrewd deduction from the known character of the constituency, but in a safe Labor ward like Baroona it is surprising to find that two-thirds of the respondents were not aware that their alderman was A.L.P., which suggests that any band waggon effect in safe electorates is severely limited.

Cross had been M.H.R. for Brisbane for only eighteen months when the 1963 survey was conducted, and the fact that only 14 per cent of the electorate were able to remember his name may be explained by novelty-certainly several thought that George Lawson, M.H.R. 1931-61, was still there. However, Drury had been M.H.R. for Ryan since 1949, almost fourteen years, and only 29 per cent could name him. Both Cross and Drury were modest back-benchers unlikely to make the headlines of the metropolitan press, but the name of as colourful a veteran as Les Haylen could be recalled by fewer than 
Table 4.08

Identification of State election candidates 1963

\begin{tabular}{|c|c|c|c|c|}
\hline \multirow{2}{*}{ Electorates and Candidates } & \multicolumn{4}{|c|}{ Voting intention: } \\
\hline & A.L.P. & Liberal & Q.L.P. & None \\
\hline \multicolumn{5}{|l|}{ Ashgrove } \\
\hline \multicolumn{5}{|l|}{ Tooth (Liberal)* } \\
\hline Yes & 19 & 46 & 4 & 7 \\
\hline No & 9 & 13 & 2 & 5 \\
\hline \multicolumn{5}{|l|}{ Kearney (A.L.P.) } \\
\hline Yes & 22 & 31 & 5 & 4 \\
\hline No & 6 & 28 & 1 & 8 \\
\hline \multicolumn{5}{|l|}{ Cook (Q.L.P.) } \\
\hline Yes & 6 & 14 & 5 & 5 \\
\hline No & 22 & 45 & 1 & 7 \\
\hline \multicolumn{5}{|l|}{ Baroona } \\
\hline \multicolumn{5}{|l|}{ Miss Stanton (Liberal) } \\
\hline Yes & 10 & 5 & 1 & 0 \\
\hline No & 65 & 26 & 10 & 7 \\
\hline \multicolumn{5}{|l|}{ Hanlon (A.L.P.)* } \\
\hline Yes & 47 & 12 & 5 & 2 \\
\hline No & 28 & 19 & 6 & 5 \\
\hline \multicolumn{5}{|l|}{ Garsen (Q.L.P.) } \\
\hline Yes & 6 & 2 & 1 & 0 \\
\hline No & 69 & 29 & 10 & 7 \\
\hline \multicolumn{5}{|l|}{ Englart (Communist) } \\
\hline Yes & 9 & 3 & 0 & 1 \\
\hline No & 66 & 28 & 11 & 6 \\
\hline \multicolumn{5}{|l|}{ Ithaca } \\
\hline \multicolumn{5}{|l|}{ Windsor (Lib.) } \\
\hline Y Yes & 15 & 38 & 3. & 2 \\
\hline No & 31 & 22 & 4 & 5 \\
\hline \multicolumn{5}{|l|}{ Clifford (A.L.P.) } \\
\hline Yes & 21 & 15 & 2 & 0 \\
\hline No & 25 & 45 & 5 & 7 \\
\hline \multicolumn{5}{|l|}{ Ashe (Q.L.P.) } \\
\hline Yes & 9 & 10 & 2 & 0 \\
\hline No & 37 & 50 & $\mathbf{5}$ & 7 \\
\hline \multicolumn{5}{|l|}{ Tannock (Social Credit) } \\
\hline Yes & 4 & 4 & 1 & 0 \\
\hline No & 42 & 56 & 6 & 7 \\
\hline
\end{tabular}

* Sitting M.L.A.

half the respondents in a panel in his electorate of Parkes in Sydney (ibid.: 169-70). Lest it be thought that federal electorates are too large and federal politics too remote to attract the attention of the average voter, rates of identification for aldermen are equally bad. Barely 6 per cent of Ashgrove respondents knew their Alderman Mead, and more named each of the former aldermen who had represented different parts of the constituency before 1961 than could recall him. This last phenomenon, it is suggested, might be called the Fomushka- 
Fimishka effect after the aged couple in Virgin. Soil-or else the Lucifer Yokum effect by reason of that character's periodic inquiries after President Coolidge. Alderman Mead lost C.M.O. endorsement for the 1964 City Council elections, and it may be that his term was too short and his style too unobtrusive to have made any impact on his electors, but we are left with the cases of Alderman Marshall, representing Baroona since 1955 and regarded in political circles as one of the more conscientious servants of the needs of his constituents, and Alderman Buchan, whose personal following it was thought had enabled him to hold Ithaca when Windsor won the constituency for the Legislative Assembly. Barely 20 per cent in Baroona could name Alderman Marshall, and only 41 per cent in Ithaca recalled Alderman Buchan. These figures contrast sharply with the overwhelming majority able to name the Lord Mayor, Alderman Jones, and lead to the suspicion that the average voter concentrates his attention on the men at the top-the Mayor, the Prime Minister, the Premier, and the Leader of the Opposition (see p. 93), and in an economy of effort disregards the spear-carriers of Parliament and City Council save as they support a party.

Few scored six or seven correct identifications: only eighteen members of the whole panel. On the other hand, sixty-three were unable to make one correct identification and another seventy-four made only one correct identification out of the possible seven. On average Liberal supporters made 2.4 correct identifications, A.L.P. and Q.L.P. supporters $2 \cdot 2$, and those with no party voting intention 1.9. When these figures are rearranged by sex, class, age, and electorate, greater differences appear. Men made 2.5 correct identifications, women only $2 \cdot 1$. The highest scores were made by office and sales workers $(2 \cdot 8)$ and the lowest by unskilled workers $(1 \cdot 6)$. Those in the 21-30 age group had the lowest score (1.9), but other age groups showed no consistent pattern. Some of the results : were expected: women know less about politics than men; those under 30 know, perhaps care, less. But the sicores of professional and businessmen (both $2 \cdot 1)$ were lower than skilled workers $(2 \cdot 4)$ and semi-skilled workers (2.3). Each group in Baroona scored lower than its counterpart in the other two electorates.

The same phenomenon appeared in response to the question:

12a. It's only ... days to the State election. How much difference do you feel it will make to Queensland which party wins that election-a great deal of difference-a little difference-or hardly any difference at all.

Apart from the don't knows who were lower in correct identifications $(1 \cdot 5)$, there does not appear to have been any relationship between estimate of the significance of the election and identification of politi- 
cal figures. It might be noted that fewer respondents in Baroona $(37 \cdot 1$ per cent) believe that the election matters a great deal than in Ashgrove ( 50 per cent) and Ithaca ( 47.5 per cent), and so the deviant performance of Baroona already noted may reflect apathy among other factors, although it is impossible to establish this on the data available.

In reply to the question whether they thought they could vote for candidates without the guidance of a party label, only 31 per cent of A.L.P. voters and 28 per cent of Liberal voters thought that they could. In the case of A.L.P. voters their answer had nothing to do with their identification score for political figures: 30 per cent of those with scores of 3 to 7 thought they could vote without a party label, 31 per cent of those with scores of 0 to 2 . If we divide the panel into those who could identify all three major party candidates, or only two, one, or none at all, those who could identify all the candidates are usually the most sceptical about their ability to vote without the party label being attached to candidates. Excluding the don't knows, 24 per cent of those who correctly identify three candidates, 40 per cent of those who identify two (which usually means not knowing the Q.L.P.), 36 per cent of those who identify only one (which usually means the candidate who will be supported), and 23 per cent of those unable to identify any candidate thought that they would be ready to vote if candidates did not bear party labels.

At the same time as they were being asked to identify political figures in 1963, respondents were asked questions designed to ascertain their views on the party system generally:

4. Some people say that if you vote for a particular party at a State election, you should also vote for the same party at Federal elections and City Council elections. Do you agree-or disagree-with that view? What's your chief reason for feeling that way?

10. Which do you think would be better for the City of Brisbanefor Aldermen to belong to political parties-OR-for Aldermen to be independents, with no party labels?

Thirty-five per cent of Liberal voters and 52 per cent of A.L.P. voters thought that it was best to vote a solid ticket, and the more partisan they were, the more likely they were to think so: 41 per cent of the Liberals with a Liberal Party image score of +5 to +7 agreed with the solid ticket, but none of the small group with scores of -2 or lower; 73 per cent of A.L.P. voters with an A.L.P. image score of +5 to +7 agreed with the solid ticket, only 31 per cent with scores of -2 or lower. Those who favoured the solid ticket justified this view in terms of loyalty to a group, the better working of the party or governmental system, the similarity of interest or policy of one party at different levels, or-speaking in very general terms-the merits of consistency. 
Those who were opposed to regular voting believed that voters should decide on the man, or the party record, or the party policy, or on consideration of their or the district's interest, or argued that different levels of government had different spheres in which to operate or that they secured different interests, or defended open mindedness in general terms. Very few offered the justification beloved of those explaining variations in federal and state voting patterns, that some sort of political equilibrium was maintained by split ticket voting. For the City Council, only 36 per cent of A.L.P. voters, 24 per cent of Liberal voters, and 17 per cent of Q.L.P. voters favoured party aldermen. Thus whilst voters recognise their dependence on the party system to cast their obligatory votes, in principle they are by no means firmly wedded to it.

In 1966 it was decided to pursue another aspect of the political system and inquire how far voters recognised individual members of a ministerial team, either in office or in embryo among the Opposition. Accordingly respondents being reinterviewed were asked:

11a. The next question is to find out if people know any of the members of the State Government. Can you name any of the Ministers in Mr Nicklin's Cabinet? Any others?

b. Do you happen to know what ministry Mr... holds?

c. Is he a Liberal member, or Country Party member?

12. Can you name any members of the A.L.P. who are likely to become Ministers, if the Labor Party wins the election and Mr Duggan becomes Premier?

The responses concerning the Nicklin Ministry are set out in Table 4.09 .

Table 4.09

Identification of Ministry members 1966

\begin{tabular}{llcccc}
\hline \multicolumn{1}{c}{ Minister } & \multicolumn{1}{c}{ Poritfolio } & Party & Named & $\begin{array}{c}\text { Portfolio } \\
\text { correct }\end{array}$ & $\begin{array}{c}\text { Party } \\
\text { correct }\end{array}$ \\
\hline Chalk & Treasury & Lib. & 107 & 29 & 67 \\
Pizzey & Education & C.P. & 64 & 59 & 21 \\
Tooth & Health & Lib. & 58 & 46 & 50 \\
Dewar & Industrial development & Lib. & 33 & 13 & 25 \\
Delamothe & Justice & Lib. & 22 & 10 & 9 \\
Herbert & Labour and industry & Lib. & 21 & 11 & 18 \\
Knox & Transport & Lib. & 15 & 13 & 14 \\
Fletcher & Lands & C.P. & 13 & 7 & 10 \\
Bjelke-Petersen & Works and housing & C.P. & 11 & 9 & 8 \\
Richter & Local government & & & & \\
& and conservation & C.P. & 9 & 5 & 9 \\
Camm & Mines and main roads & C.P. & 8 & 5 & 8 \\
Row & Primary industry & C.P. & 6 & 3 & 3 \\
\hline
\end{tabular}

There were 199 reinterviews. Thus only six Ministers are known to 10 per cent or more of the sample. Chalk, the Liberal leader and 
Deputy Premier, was known to just over half the sample, though barely 15 per cent knew that he was now Treasurer, which might be thought the second most important ministerial post. Barely one-third knew that he was a Liberal, though perhaps had the question been put, 'Who is the leader of the Liberal Party in Queensland?', it would have triggered better recall of Chalk. However, he had been leader for about six months, and factual details of political images may take time to precipitate. Just under a third of the sample mentioned Pizzey; almost all of them knew he was Minister of Education, a post of some prominence in local affairs, but only 10 per cent connected him with the Country Party even though he had. been its deputy leader for more than a decade and Nicklin's heir apparent for the leadership. Three times as many respondents knew Chalk's party as knew Pizzey's, but twice as many knew Pizzey's portfolio as knew Chalk's; Pizzey was known as a Minister of Education, Chalk as a Liberal.

The prominence of Tooth is to be explained by the contribution of his electors in Ashgrove to the total score. Forty-one of his fiftyeight mentions were in Ashgrove, thirty-three of the correct identifications of his portfolio and thirty-eight of the correct identifications of his party. Outside Ashgrove Tooth was just another Liberal Minister, on a par with Herbert and Knox. Dewar and Dr Delamothe are in a slightly different class to Herbert and Knox. The latter are known to few who do not know either their portfolio or their party or both-in other words, the political buffs who could name the great majority of the cabinet and have a considerable amount of political information. Dewar's greater prominence might be explained by his position as deputy leader of the Liberal Party, but Dr Delamothe's is a little mysterious as, apart from Chalk, he was the one Minister with an electorate outside Brisbane. The Country Party Ministers shade off into near anonymity. Perhaps a reverse pattern would appear in country electorates where their portfolios matter more.

The pattern of responses to the inquiry about a possible Labor cabinet discloses even less information held by the sample.

Only half the persons named were in fact eligible for a Labor cabinet if one could have been formed. Five men who had broken with the A.L.P. were included-Baxter, Foley, Gair, Power, and Walsh, only two of whom, Baxter and Walsh, were actually standing in 1966, whilst Foley and Power had retired from political life and Gair had been translated to the Senate. The list may be compared with the Caucus executive actually elected after the 1966 election-and after Lloyd had been defeated for the deputy leadership by Houston: Duggan, Houston, Davies, Donald, Hanlon, Newton, O'Donnell, Sherrington, Tucker. Apart from Duggan, whose name was given in the question anyway, only Hanlon of the members of the Caucus executive re- 
Table 4.10

Identification of possible Labor Ministry members 1966

\begin{tabular}{lrllllll}
\hline \multicolumn{2}{c}{$\begin{array}{c}\text { Candidates at } \\
\text { 1966 election }\end{array}$} & \multicolumn{2}{c}{$\begin{array}{c}\text { Federal } \\
\text { parliamentarians }\end{array}$} & & $\begin{array}{c}\text { City } \\
\text { Council }\end{array}$ & & \multicolumn{2}{c}{$\begin{array}{c}\text { Other } \\
\text { ineligibles }\end{array}$} \\
\hline Hanlon & 41 & Patterson & 6 & Buchan & 2 & Baxter & 2 \\
Lloyd & 26 & Cairns & 1 & Harvey & 1 & Walsh & 2 \\
Mann & 15 & Coutts & 1 & Marshall & 1 & Foley & 1 \\
Bennett & 7 & Cross & 1 & Trezona & 1 & Gair & 1 \\
Gill* & 5 & Dittmer & 1 & & & Marsden & 1 \\
Hudson* & 4 & & & & & Munro & 1 \\
Davies & 1 & & & & Nolan & 1 \\
Dean & 1 & & & & & O'Neill & 1 \\
Fordyce & 1 & & & & & & \\
Gorman* & 1 & & & & & & \\
Graham & 1 & & & & & & \\
Hanson & 1 & & & & & & \\
Houston & 1 & & & & & & \\
Inch & 1 & & & & & & \\
Newton & 1 & & & & & & \\
O'Donnell & 1 & & & & & & \\
Wallis-Smith & 1 & & & & & & \\
\hline
\end{tabular}

* Not a sitting Member

ceived more than one mention. Four other members, Davies, Houston, Newton, and O'Donnell, each received one mention, but three others were not mentioned: Tucker, who was soon to become deputy leader of the Party; Donald, a veteran secretary of the parliamentary party; and Sherrington. Only four members of the parliamentary party were known to any significant number of respondents: the deputy leader, Lloyd; Hanlon, M.L.A. for one of the electorates sampled and for most of another (Ithaca) 1956-60, and a good constituency nurse; Mann, ex-Speaker, Member for the adjacent electorate of Brisbane for about thirty years, and a colourful figure; and Bennett, with a political reputation as A.L.P. leader in the City Council before he entered the Legislative Assembly, whose practice as a barrister and disputes with the Police Commissioner kept him on the front pages of the metropolitan newspapers. R. T. Gill and S. C. Hudson were known only in the electorates where they were campaigning; they had succeeded in making themselves known as having a Labor label to a few people. Only Hanlon and Lloyd were thought of by more than 10 per cent of the sample.

On this evidence it is difficult to argue that the parliamentary system is perceived by Brisbane voters, and one is tempted to widen this and say by Queensland voters and perhaps even by Australian voters, as the competition of teams of identifiable political figures. Behind the leaders, literally the two men at the top, are a few shadowy figures 
and then a grey blur. Respondents were ready to evaluate the parties, and more than 80 per cent to say yea or nay to the proposition that the leader had the support of a good team, but it is hard to place much reliance on their judgment on that point. Whilst it is difficult for an Opposition front-bencher at the State level to make political news, with parliamentary reports brief and usually well short of the front page, Ministers can claim the eye and ear of the public, at least opening new public works and at most disclosing new policies. The great majority of the population seem able to ignore them entirely. 


\section{Images of the Independent Candidates}

INDEPENDENT candidates are a regular feature of Australian elections, but their lack of success in winning seats has tended to push them out of sight in electoral studies. If one looks only at the post-war years, the period since the Liberal Party was re-formed from the fragments of the United Australia Party, it would appear that Independents are both numerous and, on occasion, able to poll something more than a comic vote (see Appendix C). In Victoria they seem to be a vanishing breed, but elsewhere their numbers are holding firm, and in Queensland their vote in the four most recent elections was consistently better than it had been in the preceding four elections.

Although it usually has relatively fewer independent candidates than New South Wales, South Australia, or Western Australia, Queensland has as many, if not more, independent Members of Parliament. Two of them in particular, J. F. 'Bombshell' Barnes, the 'Andrew Fisher Labor' Member for Bundaberg from 1941 to 1950 (Lack n.d.: 680-8), and Tom Aikens, Hermit Park Australian Labor and North Queensland Labor Party Member for Mundingburra (and now Townsville South) since 1944 , by obstreperous conduct within the Legislative Assembly and parochial loyalty outside it, have made the presence of independent Members felt. The abolition of contingent voting in 1942 enabled a number of independent candidates to slip in. In 1944 Barnes held his seat with only 40 per cent of the vote (his brother held Cairns comfortably with 65.65 per cent of the vote, opposed only by the A.L.P.), and G. H. Marriott, who had been expelled from the A.L.P., retained Bulimba as an Independent Labor candidate with 41.84 per cent of the vote. Aikens won Mundingburra with only 35.57 per cent of the vote from A.L.P., Q.P.P., Independent Labor, and independent candidates, and F. B. Paterson won Bowen for the Communist Party with 44.41 per cent of the vote. In 1947 
L. J. Barnes's vote (as 'King O'Malley Labor') slumped to 28.84 per cent in Cairns, and the seat returned to the A.L.P., but the three other independent Members retained their seats: Aikens narrowly with 39.60 per cent of the vote, 'Bombshell' Barnes with 40.39 per cent, Marriott with 42.78 per cent, and Paterson with 39.34 per cent. In 1950 boundaries had been altered: Marriott's vote went down to 28.97 per cent in Bulimba, in Bundaberg Barnes could manage only 29.63 per cent, and, in the new electorate of Whitsunday, Paterson just $12 \cdot 70$ per cent. Bulimba and Bundaberg reverted to the A.L.P., while Whitsunday went to the Country Party. However, Aikens retained Mundingburra with 42.57 per cent against A.L.P. and Liberal opponents, and his independent opponent of the two previous elections, Arthur Coburn, won the new seat of Burdekin with an absolute majority (52.45 per cent of the vote) against A.L.P. and Communist candidates. These two retained their seats at subsequent elections with absolute majorities: in 1953 Coburn managed 58.03 per cent against only the A.L.P., Aikens 52.53 per cent against A.L.P. and Liberal candidates. In 1956 Coburn went up to 63.92 per cent against A.L.P. and Communist candidates, and Aikens to 77.86 per cent with only the A.L.P. against him. In 1957 the appearance of a Q.L.P. candidate cut into Coburn's vote, which dropped to 51.99 per cent but left the seat safe, while Aikens's vote remaining a thumping 75.09 per cent against the A.L.P. with an independent candidate thrown in.

In 1960 the position became more complicated. The decline of the Q.L.P. as a political force in the State meant that those Q.L.P. members who retained their seats did so mainly because of personal popularity. The Party's statewide vote dropped from 15.49 per cent to 5.26 per cent and its eleven seats became four. Redistribution destroyed the personal followings of some sitting Q.L.P. members, and only Diplock survived a drastic change in his electorate boundaries. In Cook Adair retained the seat with $39 \cdot 18$ per cent of the vote, and with the Country Party candidate bottom of the poll was in a good position for the future. In Bundaberg Walsh, with 40.54 per cent of the vote, was only sixteen votes ahead of the A.L.P. candidate; whilst a Liberal was third, it was uncertain whether Bundaberg inclined naturally to the A.L.P. or to independency as it had done with Barnes. In Carnarvon Hilton had 41.27 per cent of the vote, but the A.L.P. was third, behind the Country Party, which augured ill for Hilton if preferential voting were introduced, and in Aubigny Diplock with $45 \cdot 89$ per cent was in a similar position, although somewhat closer to an absolute majority. Of the two sitting Independents, Coburn held Burdekin with 50.71 per cent of the vote, and Aikens retained Townsville South (as Mundingburra has become) with 66.85 per cent against only an A.L.P. opponent.

In 1961 the Q.L.P. finally faced up to the ambiguity of its rela- 
tionship with the D.L.P. in other States. A visit to Brisbane by the D.L.P. federal president, Robert Joshua, at the invitation of George Cook, precipitated matters. Cook declared that about July the Q.L.P. would virtually become a state branch of the D.L.P., but Hilton as parliamentary leader said that the 'original idea' when the state convention had met in January had been to approach both A.L.P. and D.L.P. with a view to reconciliation. Adair, who had seconded Hilton's motion in January, declared that his immediate reaction was to resign from the Q.L.P., but he would wait until he had consulted the other parliamentary members, and Walsh stated that he had made no definite decision as to what he would do in the event of a merger, nor would he without consulting the Bundaberg branch of the Q.L.P. (Courier-Mail: 2 May 1961). Later that month the Q.L.P. central council invited the federal executive of the D.L.P. to confer to determine the extent of association of the two parties. Walsh declined to comment, but Adair observed that he was certain the decision would affect his membership of the Q.L.P. for he held no allegiance whatsoever for the D.L.P. (ibid.: 18 May 1961). However nothing further happened for a year, when after rumours that he would allow his Q.L.P. membership to lapse, Walsh in the House unexpectedly referred to a time 'when I was associated with the Queensland Labor Party'; Hilton subsequently said outside the House that Walsh had never formally resigned, and had continued using the Party room, but the next day Gair stated that Walsh had not renewed his membership in January, and had not campaigned for the Q.L.P. candidate in Wide Bay or the Q.L.P. Senate team in the December 1961 federal election. Gair found it clifficult to believe that union with D.L.P. was the reason for Walsh's cleparture, and observed tartly that Walsh began to lose interest in the Q.L.P. when he nearly lost Bundaberg in 1960 (ibid.: 7 and $8 \mathrm{May}$ 1962). A fortnight later Adair declared that he would contest Cook as an Independent in 1963 because he objected to any liaison between the Q.I.P. and the D.L.P. In November the merger was agreed; the Q.L.P. would become a state branch of the D.L.P. but would continue to contest State elections under its old name. The Courier-Mail commented:

Had it allowed its identity as a State party to be wholly merged in the Democratic Labor Party it would not have improved its prospects. The D.L.P. was born of acute sectarian controversy which split Labor in Victoria, and some Queenslanders would shy off its 'ticket' in the politics of their own State. (6 November 1962)

The immediate consequence of the move was that the Q.L.P.'s parliamentary strength was halved, and the Legislative Assembly acquired two more independent Members.

A fifth appeared when Alf Muller, Member for Fassifern since 1935, left the Country Party in 1960. Muller had been Minister for 
Lands and Irrigation since 1957; following the May 1960 general election there was every reason to expect him to return to that portfolio. However, despite his re-election to the ministry by the parliamentary Country Party on 7 June, Muller broke with the party when the Premier asked him to accept another portfolio because he had been listed as a tax defaulter. In a statement to the Legislative Assernbly Muller complained that his administration of the Lands Department had been under pressure from interests which sought preferential treatment and used the Country Party executive to press him. He announced that he would thereafter sit as an Independent Country Party Member, and pledged himself 'to help the Country Party to take bearings afresh and to bring the party back to its time-honoured principles from which it has departed because of the domination of narrowing interests'. In subsequent debates the Premier and the Treasurer denied that there had been any improper pressure brought to bear on Muller as Minister for Lands, and there the matter rested for almost a year. Muller criticised a number of government decisions in the fields of transport and land policy, and at the end of August 1961 he resigned from his local branch of the Country Party and thereafter sat as an Independent.

Of the five independent Members in 1963 only Aikens was certain to hold his seat against all comers. Coburn was dependent upon the support through preferences or non-intervention of the government parties, although as he consistently voted with them there was little reason for them to intervene if there was a chance that this could throw the seat to the A.L.P. It was not at all certain how Muller could do against an endorsed Country Party candidate, although he could probably count on A.L.P. preferences if he could remain ahead of the A.L.P. candidate. The former Q.L.P. members, Adair and Walsh, were dependent upon the government parties for support; and if there was any drift of preferences from government supporters they would be in difficulties. The two who had remained in the party were in an even worse position: their seats could be won by the Country Party, and the A.L.P. was quite prepared to see that they were.

In 1966 there were fewer problems in prediction. The relative ease with which Aikens, Adair, and Walsh had held their seats in 1963 suggested that in similar circumstances they could win in 1966. Despite the intervention of a Liberal candidate, Coburn seemed fairly safe in Burdekin for he could count on Liberal preferences if he missed an absolute majority. Muller had since rejoined the Country Party, but there was a new independent M.L.A. in Bill Baxter of Hawthorne, who had broken with the A.L.P. The dispute had broken out just before the 1966 campaign began, when complaints against Baxter were heard by the Q.C.E. and his endorsement to re-contest Hawthorne was withdrawn, reportedly with the approval of his local elec- 
torate council. Baxter had been a Member for thirteen years and the seat had been marginal since the redistribution in which Baxter had taken the less attractive part of his old constituency. Almost certainly the 1966 contest would be decided on preferences and thus was open between Baxter, the Liberal candidate, and the new A.L.P. candidate, T. S. Burton, with whom Baxter had a well publicised row. Diplock was the only surviving Q.L.P. Member, but his win in 1963 indicated that he would be very hard to shift.

The fullest debate concerning the effectiveness of independent Members came in Aubigny in 1963 where Diplock was fighting off a strong Country Party candidate, Somer Thorn. (Thorn was an alderman of the Dalby Town Council, topping the poll at the last election, and a substantial local businessman. His grandfather, William, had been the Member for Aubigny for twenty-one years commencing in 1893 and an influential politician on the Darling Downs, and, as the secretary of the Goombungee branch of the Country Party pointed out (Dalby Herald: 7 May 1963), had been responsible for securing the Goombungee-Harden railway, whilst William's father, Robert, had represented the district in the 1860 s.) In February at the Q.L.P. branch meeting in Dalby following rumours that Diplock was moving to Brisbane to live, Diplock referred to road development, commended Ernie Evans, the responsible Minister, for being very fair and generous so far as Aubigny was concerned, and added that Evans had always acted when Diplock put appropriate cases before him (ibid.: 5 February 1963). This passed unnoticed, but as the campaign developed Thorn turned to the subject. Benefits had come to Aubigny during the Nicklin government's term of office because of the innate fairness of that government; the coalition had never broken its promise to meet obvious needs irrespective of the party representation of the electorate. If he were elected he could provide 'a clear and vital voice in the government of this State', an active voice in the party room without which the electorate would lack 'full representation' but which could secure the things that the electorate had long been denied. Although it had lacked a voice in the Government, Aubigny's needs had not suffered unduly,

but that was due to the acknowledged fairness of the Nicklin Government. Nevertheless, the needs of the electorate could have been much more fully met with a voice in the party room-the place where so many things were threshed out and basic recommendations made before they went to Cabinet for ultimate approval. With a full and clear voice there pleading Aubigny's cause and putting its case directly before the party and the Ministers the benefits the electorate had obtained could have been increased manyfold. (Toowoomba Chronicle: 24 April 1963)

In the party room he could command dozens of ears at once, rather 
than one at a time. At the same time Alderman Thorn documented the fairness of the Nicklin government by releasing the breakdown of Public Works Department spending in the electorate from 1 July 1957 to 31 January 1963 . The total was $£ 358,465$, and items ranged from $£ 80,603$ for the Dalby High School to $£^{3}$ for the Mother and Child Welfare centre in Dalby, covering schools, police stations, and government officers' residences and offices (Dalby Herald: 26 April 1963). Diplock thanked him politely and asked for the figures on road construction. The full blast came a few days later:

Whether or not the electors are going to swallow this line of twaddle remains to be seen. I was rather amused to learn that a change of candidates 'would enable someone to command dozens of ears at the one time in the Party Room'. This is a novice politician's dream, and after all, dreams of greatness are really exhilarating. I am afraid that I will still have to remain modest and be like little Tommy Tucker-I shall just pull out a plum every now and again; appeal to-not command-a big ear once in a while, and I am sure Aubigny will not continue to progress as it has done during the past three years. (Ibid.: 3 May 1963)

Three federal parliamentarians came to Alderman Thorn's aid. At a Country Party rally in Bowenville Senator Harrie Wade, the Minister for Health, said that, whether we liked it or not, the party system prevailed and we had to live with it. It entailed extreme limitations on the Independent in politics for, whilst we would vigorously uphold his right to be heard, it would have to be asked 'Who did he speak for?' Senator Wade added that the independent Senator (Senator R. J. D. Turnbull) had recently been complaining that he had not been informed of any of the goings-on in the House; as a member of the Government Alderman Thorn would know what was going on, he would be able to bring forward the views, desires, and needs of his electors and have the backing of his colleagues. A Country Party back-bencher, W. J. Brimblecome, added that it was vital for electors to have their say in the party room: most decisions were taken there and in many cases the debates in Parliament were only formalities. It was rare for amendments to be made to any legislation before the House (ibid.: 7 May 1965). A Country Party supporter ridiculed the

Tommy Tucker picture in a letter to the editor:

True, he is just like little Tommy Tucker-but he doesn't reach out and pick the plums. He just sits meekly and patiently outside the door where the 'big business' is done, the true merits of every part of the State are assessed, and, when the Tucker area's merited share of works is determined, the door opens, they pat dear little Tommy on the head, and give him the message that a plum has fallen ... Because they haven't one of their own men inside that all important room, sharing and planning for the best all-round 
use of the money available, the 'big ears' inside have to fall back on little Tommy Tucker to run their messages. (Ibid.: 7 May 1963)

A. G. E. Lawrie, State President of the Country Party, added his own analogy: a father was more likely to listen to and agree with a proposition put by his own son than one brought by 'another boy'. As one of the family, Thorn would have the ready ear of the head of the family, and would be able to ask for and hasten the fall of the bigger plums needed by Aubigny (ibid.: 14 May 1963).

A fortnight before election day Evans wrote to the Toowoomba Chronicle and Dalby Herald (17 May 1963) complaining that Diplock had been saying that his personal friendship with the Minister should influence Country Party supporters to vote for him. Evans agreed that he was friendly with Diplock but declared that he was politically opposed to him, and went on:

I have administered my departments without any discrimination towards any electorate, or against it, because of the political complexion of its representative in Parliament. The electorate of Aubigny has received every consideration from the departments under my jurisdiction. That is reasonable because the result of the last election gave conclusive proof that almost half of the people of Aubigny supported the Country Party. In Government, the Country Party caters for all of the people; particularly for the little people who are not strong enough to fight for themselves. There is no obligation on any person who approaches me for assistance to tell me which party he voted for, because it makes no difference to me. I help anyone who is in need of help and this is how it should be.

However, I must warn the electors of Aubigny that a Country Party Member will have much more influence in all matters pertaining to the welfare of the electorate, because he will be wearing the guernsey of the Party in power. Proposed legislation is, in the first instance, recommended to Cabinet by the Minister concerned. It then goes from Cabinet to the Parliamentary Party meeting, where rank-and-file Members have every opportunity of submitting their views on the effect the legislation, if implemented, will have in relation to the problems and difficulties of their own electorates. On many occasions alterations have been made to proposed legislation at the instigation of individual Members who have pointed out some particular problem that would be consequent on its implementation.

The next day Diplock denied that he had ever sought Country Party votes on the basis of his friendship with Evans-he valued that friendship too much to use it politically. He believed that Ministers respected their oaths, and that Evans had administered his own department fairly. However, he had voted with the Government on occasion (something which Evans had said he could not remember), and if returned would continue to consider measures on their merits. Diplock scored 
nicely off the party line on two points. After he had spoken against a particular bill (to restrict barristers from other States practising in Queensland) many Country Party members had congratulated him on the speech and sought to have the bill amended, but they were voted down in the party room. Again, if the Country Party's claims were true, it would be as logical to say that the Minister and his col. leagues had accepted their salaries for a long time without being any use to their electorates, for they had certainly spent a long time in opposition.

Evans dropped out of the argument, which continued briskly. At a meeting at Cooyar Diplock charged that farmers in the area had been told by Thorn's supporters that the availability of funds for electricity extensions to country areas would depend on Thorn's election; if Diplock were re-elected there would be no money. He had phoned the Commissioner for Electricity, who said the statement was fantastic and unthinkable (Toowoomba Chronicle: 27 May 1963). On the eve of poll one Thorn advertisement carried the 'Medicine Man' gag to its ridiculous conclusion:

New true-heart plain-talk chief, Summer [sic] Thorn, open new pow-wow season, June 2, alongside big do-good wolf chiefs, senior braves, who work help all reservations. Own reservation pow-wow every moon. All-time work reservations whole prairie inside big palaver house, Brisbane.

True-heart Chief Summer Thorn say: 'Me no give all-bull allbluff rumour pow-wow. Me give fact all time. Me say totem pole give power. No totem pole no power no meaning. You vote me I help all my people.' (Ibid.: 31 May 1963)

Another pursued the Tommy Tucker metaphor, juxtaposing an empty box labelled 'This Member Stands Out: Out on his own in the cold! Out beyond the garden gate where no plum trees grow! Out there patiently waiting, waiting, waiting-for a hand-out!' with a picture of Thorn labelled "This Member Will Sit Inside: In with the full team of Country Party gardeners! In the garden where the plum trees grow and fruit! In with the Aubigny basket in his hand and picking the big plums himself!' (Dalby Herald: 31 May 1963).

In a tabloid facsimile, 'Aubigny Clarion', distributed on the eve of poll, Thorn had his final word on the weekly visits:

It may perhaps be personally gratifying that your member answers your letters promptly, sends you a note of condolence, or comes often to chat with you about your hopes and fears and even gives you some little assistance in putting them before the Government. Somer Thorn will do that, too, and he will sit inside where things are done.

You will see your new member regularly but not, perhaps, as frequently as your present member. Remember that Mr. Thorn, in the House and in the Party Room, will be doing by his presence 
for you there a great deal more than the little weekly visits of your present member. And remember, too, that this weekly call is only possible because of his political futility insofar as his presence or absence in the House had no impact whatever on the course of the State's development.

These visits may be comforting and flattering but remember they are meaningless because he is powerless.

At the poll Diplock's share of the vote rose from $45 \cdot 89$ per cent (1960) to 52.42 per cent. Thorn with 34.05 per cent was well below Sparkes's 42.92 per cent at the previous election. The A.L.P. candidate, B. W. Strachan, increased his vote slightly-from $11 \cdot 19$ per cent to 13.52 per cent. In Dalby, which provides almost 45 per cent of the electorate vote, there was very little change; Dalby was the home of both leading candidates, and it had had some years of Diplock's services in which to grow accustomed to them. In the rest of the electorate, which knew Diplock only from 1960, there was a pronounced swing to him of between 15 and 20 per cent. At almost every polling booth outside Dalby Diplock cut deeply into the Country Party vote, proof positive of the importance of his personal impact on the smaller towns and hamlets in the three years in which they had been in his electorate.

In 1966 the campaign in Aubigny was much more subdued. The Country Party candidate, John Corfe, as chairman of Jondaryan Shire Council, was well known in the eastern part of the electorate but would have problems eroding Diplock's support in Dalby. The A.L.P. candidate, Peter Fitzpatrick, a young law clerk of Dalby, was certain to finish third. The first press report suggesting that Corfe's supporters would claim that he represents the powerful Government party, with all the advantages which that holds' was quickly met by a letter from a Diplock supporter pointing out that the Minister for Housing, Bjelke-Petersen, on a recent visit had commended Diplock and said that he got more for his constituency than government Members got for theirs, and itemising some recent achievements (Toowoomba Chronicle: 7 May 1966). A Corfe man replied that his candidate had already made it clear that there would be no personal attacks during the campaign, but it was no belittlement of Diplock to point out that the cake that he distributed in Aubigny had been mixed and baked by the Country Party 'which, in its wisdom, lent a sympathetic ear to the requests and recommendations of a member like $\mathrm{Mr}$. Diplock representing the worthy causes of the electorate' (ibid.: 11 May 1966). Diplock's advertisements were restrained: make certain of getting value, the same personal service and the same progress, as in the previous six years. One of his supporters, F. M. Lobwein, shifted his ground to get in some sharp blows at the Government's neglect of a dairy industry, an issue which the A.L.P. took up also, but Diplock continued quietly, saying nothing to exacerbate feelings, for example Nicklin's concessions to dairymen were a start but not enough. The A.L.P. candidate chal- 
lenged Diplock to a debate, pointed out that he hardly ever voted in the House-eight out of seventy-one divisions in the previous Parliament, and offered out-of-state politicians and a jazz concert, none of them tactics likely to make much of an impact in Aubigny. There were rumours of a dispute between Brisbane and the Dalby A.L.P. over the direction of A.L.P. preferences, with the local branch resisting a second preference to Diplock; Fitzpatrick's advertisements left it up to the voters to decide, and late in the campaign the Q.C.E. reversed its decision in deference to local opinion, and then Diplock moved quickly to advise: 'If you must give A.L.P. (Labor) your No. 1; protect yourselves, give Les No. 2'. The election results continued the trend shown in 1963. Diplock's share rose again, to 56.29 per cent, mainly at the expense of the Country Party which slipped further to 31.07 . The A.L.P. vote declined slightly to $12 \cdot 64$ per cent. Diplock would retire from Aubigny only when he wanted to.

The decision for the two sitting Q.L.P. Members in 1963 had been difficult. They could hardly discard the party label completely, yet the examples of Adair and Walsh clearly suggested that it might be a liability. In the end each had taken a slightly different emphasis, Diplock, only Deputy Leader, emphasised independence. Hilton, perhaps befitting his position as Parliamentary Leader, emphasised party.

As soon as Hilton announced that his health had improved and he would stand again for Carnarvon, and added that he was highly gratified at the numerous requests and inquiries he had received 'from Labour supporters throughout Carnarvon, also from many old friends" (Warwick Daily News: 22 February 1963), the endorsed A.L.P. candidate, D. G. T. Grow attacked his failure to mention the Q.L.P. Would the campaign be like Hilton's 1960 how-to-vote card with 'Labor Party' in large letters at the top and 'Queensland Labor Party' in small letters at the bottom (Stanthorpe Border Post: 28 February 1963)? Hilton gave a dignified reply.

As announced in the Press this week it will by my honour and privilege to lead a very substantial number of Queensland Party [sic] candidates in the forthcoming elections. It is true that our political representation is now small but that does not deter us from continuing a good and honest fight for the principles to which we are pledged.

Whilst Mr. Adair and Mr. Walsh have considered their independent role the best under the circumstances that prevail a very cordial relationship exists between these gentlemen and myself and they are very pleased that I am able to enter the fray. (Ibid.: $\mathbf{5}$ March 1963)

He went on to inquire what party Gow had belonged to under the Curtin and Chifley governments, for he had not been in the A.L.P., and the subject occupied both gentlemen for some weeks. In May all 
three candidates addressed themselves to the problem of what Hilton could do for Carnarvon. A.L.P. advertisements warned that the Q.L.P. was fading away, and the choice was between the two recognised parties. Hilton's referred to his experience, and his eve-of-poll advertisement compared the policies of the three parties but concluded: '. . I I respectfully and humbly submit that my long period of representation of Carnarvon electorate has been one of earnest, faithful and successful service' (Warwick Daily News: 30 May 1963). However, the advertisements for McKechnie, for the Country Party, opened the Pizzey line: if he were returned it would give the electors a vote within the Government to vote for Carnarvon's interests (Stanthorpe Border Post: 23 May 1963). Another warned:

It is no coincidence but real fact that those electorates which had the good sense to switch from Iabour representation in the past six years to the Country Party's sounder development have gained considerably because this Party protects the interests of people who live and work in country districts (Warwick Daily News: 25 May 1963)

This became more pointed in a joint advertisement for Balonne and Carnarvon electors which pointed out that since Balonne had switched from Labor it had smashed all records for capital works of different sorts, and declared that Country Party policy could do the same for Carnarvon, but McKechnie's campaign generally made less of Hilton's lack of effectiveness than did other Country Party candidates running against an Independent.

Jack Bethel, the A.L.P. candidate for Cook, opened his $1963 \mathrm{cam}$ paign without reference to Adair-his speech at Edmonton was a straight exposition of his Party's case against the Government's economic record (Cairns Post: 9 May 1963), and his advertisements merely listed his local meetings and solicited votes. In 1966 in his opening speech he followed the same approach with an attack on government neglect of the sugar industry (ibid.: 14 May 1966). Adair's first advertisement in 1963 introduced the Independent's problem quietly:

Electors of Cook vote 1 ADAIR, H. A. (Bunny)

(1) $\mathrm{He}$ is the hardest fighter for the North-and the most fearless

(2) He gets the best results

(3) Ten years in politics have not changed him. He has the common touch

(4) He and his family have always resided in the Cook Electorate

(5) Easily approachable at all times

(6) A true representative for everyone Bunny Adair represents all sections of his electorate equally and well, irrespective of who you are or what you are. There's no discrimination with this man. (Ibid.: 11 May 1963)

Later versions of the same advertisement (e.g. 15 May 1963) inserted 
'Your Independent Member' below ADAIR, H. A., and in 1966 the label was used from the beginning. At a meeting at Freshwater, his own area, Adair challenged claims being made by his opponents that his position as an Independent would react against him in Parliament by quoting a statement made by Evans in the House that the Member for Cook received more money for his electorate than any other Member of the House, but normally his reported speeches dealt with his efforts on behalf of the electorate-permission for the swimming baths at Edmonton, road works, the Thursday Island water supply and the like, while Bethel, as reported in the press, continued to ignore Adair's partyless state. Adair did introduce a new advertisement which he used again in 1966:

Electors of Cook

Bunny Adair, your Independent Member, has PROVED that he can do MORE for YOU irrespective of what Party is in power. He has the EXPERIENCE, the ABILITY and DRIVE to represent you well, Keep the Far North's Most ACTIVE Member in Parliament. (Ibid.: 23 May 1963 and 14 May 1966)

but it was late in the day before Bethel began to be described in his advertisements as 'The Candidate who can give you better representation as a Government Member' (ibid.: 22 May 1963). At the last minute Adair varied his advertisements to read:

Don't Let COOK Slip Like CAIRNS! An AMATEUR Left Wing A.L.P. Representative against a Liberal-Country Party Government can get you NOTHING! Bunny Adair, your Independent Member, has PROVED that he can do MORE for YOU \&cc. (Ibid.: 30 May 1963)

Bethel's next advertisement came too quickly to have been a direct riposte:

Electors of Cook the Australian Labor Party are proud to present their Candidate Jack Bethel who has a PARTY and a POLICY. Jack sticks to the middle of the road. He does not hop from party to party. Because he is a member of the Australian Labor Party and can present his policy knowing full well that the policy of the A.L.P. will be carried out. On June Ist Vote for the Candidate who can give you Better Representation as a Member of an A.L.P. Government. Remember-A vote for an Independent is a vote wasted. (Ibid.: 31 May 1963)

However, Adair had also addressed himself to the point by adding two lines of type to his advertisement of the previous day: "Bunny Adair is NOT tied to any Party and has a FREE Voice for you in Parliament' (ibid.). In the polling day number of the Cairns Post Bethel repeated his advertisement of the previous day, but Adair asked simply: 'Independent Electors of Cook: Vote for a Man of Principle'. He had a fairly easy win with $54 \cdot 74$ per cent of the vote. 
In 1966 Bethel opened softly with the observation that it was time for a change and that he was 'the man who can do more for you'. Adair launched his campaign with a promise to press for a road linking Cooktown to Bloomfield and Daintree and an increase in the maximum loan from the Agricultural Bank, whilst his advertisements reiterated the themes of fearless, hard-fighting for the North and results such as 'One Million for School Buildings alone', a common touch and residence in the electorate. Bethel ignored him and ran against the Government, save to describe himself as 'the only Candidate in Cook with a Party and Policy of Guarantees-not Promises' and late in the day as "the Man the Liberal Country Parties will not oppose', with a plea to vote for the party with a policy-'Independents play a Useless Role in Government' (ibid.: 26 May 1966).

There was one exception to this mutual avoidance, a good row over a pamphlet in Torres Strait Islander dialects. In 1966 there were approximately 2,500 newly-enfranchised Torres Strait Islanders and considerable attention was given to the contest in the rest of the State both because of the novelty and because the growth in the electorate could easily overturn Adair's 1963 majority of 800 . The pamphlet was issued by Bethel, and supposedly set out Labor policy including equal pay for Islanders; it was thought that as sitting Member and a prospector in their area Adair started with a lead among the new voters. Adair soon complained that the pamphlet was misleading in that it claimed that W. J. Fulton, the A.L.P. federal Member for the area, secured all repatriation benefits for returned servicemen, and that Bethel was a Senator in Brisbane and head of the railways union, and had already arranged for equal pay on railway construction on which many Islanders were engaged. Adair issued his own pamphlet 'correcting' the Labor document (Courier-Mail: 18 May 1966). Bethel denied the accusation: the pamphlet had said to vote for him as a State Member and had called him a railway union 'big man' which he was entitled to as a union secretary-in which capacity he had worked for equal pay just as Fulton as federal Member had worked for repatriation benefits for Islander ex-servicemen (Cairns Post: 25 May). Thirty new polling places were set up to handle the increased electorate and its new distribution. A minority of these showed a conspicuously lopsided division of the vote, two going solidly to Adair and five to Bethel, but the majority divided as any other polling place in the electorate might have done. Despite the increase of about 2,500 in the total vote, Adair's share rose by less than one-half of 1 per cent, indicating that Cook had absorbed its new electors with a minimum of upset.

Adair's fellow, Walsh, had had a closer shave in Bundaberg in 1960. As soon as it was known that the Government would not offer a candidate in 1963 the News-Mail speculated: 
Mr Walsh, despite that near defeat of three years ago, is unlikely to have lost any ground. His political acumen is conceded even by his opponents, and there are few people in the electorate who will not agree that he has been a first-class representative for Bundaberg. His chief difficulty will be to convince electors that, as an Independent, he can continue to do the job which he achieved with such success when he was a Minister in the former Labour Government. Under the Q.L.P. banner his political career was almost obliterated; he himself probably concluded that as Independent his prospects must be brighter than they were in 1960. (27 April 1963)

The A.L.P. promptly opened its attack on Walsh with an advertisement warning that Matt Tallon was the only 'Labor candidate' for Bundaberg. Showing unusual charity to the Q.L.P., which Walsh had recently left, it went on:

The present member, by declaring himself a 'straight forward independent' has finally and completely severed his connection with the Labor movement and thereby forfeits all claims to a Labor vote. (Ibid.: 29 April 1963)

Voters were reminded that the incumbent had twice 'repudiated the tickets on which you elected him', whilst Tallon offered someone who would always live in Bundaberg, representation with real political influence which an Independent could not provide, and stability instead of indecision. Bundaberg was too important to be outside the ranks of those who governed or could govern; once it had tolerated such a situation, but had subsequently rejected it. At a street meeting Tallon declared that party government, although not faultless, was here to stay. Independents received merely the crumbs because they could not hope to form governments which had the final say on the allocation of funds. Invitations to vote for the 'only Labor candidate' became the 'only Party candidate'.

Walsh did not open his campaign officially, and when he eventually spoke he concentrated on the issue of 1957-whether there should be outside dictation to Parliament on the implementation of party policy. He paused only to characterise the arguments against an independent Member as 'personal':

One would think that if I were defeated the endorsed A.L.P. candidate would become the Government, and that his influence would bring about the magic reforms put forward by the A.L.P. (Ibid.: 18 May 1963)

His advertisements turned on the slogan: "There is no substitute for experience':

A Candidate who learned the Hard Way

From-a Station Hand, a Labourer, a Scrubfeller, a Canecutter, a Navvy, a Farmer 
To-A Member of Parliament for 25 years, a Cabinet. Minister for 14 years

Administered the-Lands Department for 4 years, Railways Department for 3 years, the Treasury Department for nearly six years Bundaberg electors have benefited from Ted Walsh's experience and will continue to do so while he is Member. (Ibid.: 22 May 1963)

Duggan on a visit to Bundaberg quoted Pizzey's Southport speech against Alderman Harley and said that it had to be taken as authoritative evidence that a Country Party government would ignore independent Members. There was a strong possibility of the A.L.P. being the next government, and Tallon was the only candidate who could be in any government, whilst at worst members of the official Opposition received greater recognition from the Government than did Independents (ibid.: 20 May 1963). However, a Walsh supporter wrote to the editor declaring that the services Walsh had given had improved after the Nicklin government came into power and had become even better in the last Parliament, and in an eve-of-poll full page advertisement Walsh supplied a list of civic improvements under the heading 'Ted Walsh's name, as Member for Bundaberg, is linked with . . . a number of promises for the future, and a reminder of his twenty-five years of experience in handling electors' problems. He retained the seat with 53.46 per cent of the vote.

In 1966 the A.L.P. changed their emphasis to positive advice that 'the only sure, positive and effective vote for a Labor Government' was a vote for Tallon, and called for a change of the Government. The election of Tallon was the only effective vote against the Liberals. In his opening speech Tallon concentrated on policy matters, and allowed himself only one dig at Walsh with a promise to continue living in the electorate (ibid.: 17 May 1966). Thereafter his advertisements included invitations to 'be with the strength' and warnings that 'any member of parliament may exercise his right of free speech, but the hard, cold and irrefutable facts are that only Governments, backed by strong parliamentary majorities can possibly govern for your welfare', but Walsh was ignored. When Walsh finally weighed in, it was with a record of achievement as a candidate:

Who has been identified with Bundaberg's spectacular progress for the past (16) sixteen years.

Who will continue to support in the future any proposal to encourage sound development in Bundaberg and District.

Who understands the problems of family life and has given valuable advice and assistance to hundreds of families.

Who does not make 'hollow or shallow' promises. (Ibid.: 19 May 1966)

This was his only message until the eve of polling when it was spelled out in larger type and slightly different words, with the addition that 
four new school sites had been approved (ibid.: 26 May 1966). The final A.L.P. advertisement warned: 'All Bundaberg knows that the election of a sympathetic and interested government is more important than the political career of any individual. ... The electorate had risen by 900 , but Walsh's share of the vote altered by 0.02 per centupwards.

In Fassifern the Country Party campaign to unseat Muller was based on the merits of their candidate, Councillor A. G. V. Hall, a 45-year-old farmer, member of the Moreton Shire Council for ten years and its chairman since 1962, and an active member and officeholder in local authority and farming bodies, and on the proposition that a generation of voters was coming on who had short memories of Muller's services within the Country Party. Muller explained his candidacy in a release and advertisement which stated that he was standing as Independent Country Party:

The fact that I have declined Country Party Endorsement does not in any way alter my political view. In soliciting your support may I ask that you judge me on my record of service, both as a private Member and as a Minister. If, in your opinion, I deserve the treatment that was given me, then your duty is clear to vote against me. If, on the other hand, you feel that my years of service merit something better than shabby treatment, then I respectfully appeal for your support. (Queensland Times (Ipswich): 30 April 1963; Fassifern Guardian (Boonah): I May 1963; Beaudesert Times: 3 May 1963)

Muller went on to refer to his twenty-five years of work for the Country Party, including three as Minister, but added that as an Independent Country Party member he could say things on issues then outstanding in the Country Party-the small amount of money being spent on water resources, the excessive size of brigalow blocks, and the lack of financial assistance for young men, and declared that he had opposed Sunday opening and the gambling shops. Muller promised that he would not treat a confidence motion lightly, and would use his vote, not for revenge, but in the interest of the electors. It was his confirmed opinion that, with his experience and knowledge of parliamentary practice and of the various State departments, the electors' interests would not be prejudiced by his Independent Country status, and indeed the people of Queensland as a whole would gain. A fortnight later, following local flood damage, he said that irrespective of who was elected he would fight for necessary action to implement control schemes.

Councillor Hall had opened his campaign on 10 May with an attack on the A.L.P. and praise for the Nicklin government's record, without mentioning Muller. However, Pizzey came to Fassifern, supporting Councillor Hall, and made his usual attack on the ineffectiveness of an Independent: 
He cannot attend party meetings. A resolution may come from a country branch to the Electorate Council, from there to the Central Council, thence to the Party committee, then to the Party, and if it is thought desirable, legislation is framed and discussed. It is a case of a lone voice against a concerted team. When a team is working the Government has to take notice, even if it does not take action. (Beaudesert Times: 17 May 1963)

Pizzey conceded that Muller had done much for Fassifern in education, roads, electricity, hospitals, dams and irrigation, but the point was that he was no longer a member of the Government. Muller had given great service and was respected in all walks of life, but it was now essential that Fassifern look to its own future, that it analyse the benefits which could accrue from a government Member against the 'lost cause' of an Independent (Queensland Times (Ipswich): 14 May 1963). Any reply by Muller went unnoticed by the local papers.

At the poll Muller received only 33.46 per cent of the first preferences, slightly behind Councillor Hall with 35.49 per cent, but well ahead of the Q.L.P. with 5.47 per cent and the A.L.P. with 25.57 per cent. More than half the Q.L.P. preferences went to Councillor Hall, but 86 per cent of the A.L.P. preferences went to Muller, who held the seat with 57.73 per cent of the vote on the third count. In 1966 Muller polled 63.95 per cent of the total vote against A.L.P., D.L.P., and Social Credit candidates, a loss of 7 per cent on his and Councillor Hall's combined total of 1963.

In Townsville South there must have seemed little point in attacking Aikens for his independence in view of the way he paraded it, and it was left to Aikens himself to start the argument in 1963 with an advertisement:

Don't replace a freeman, and a fighter like 'Townsville Tom' with an A.L.P. Party Hack, who is pledged to always speak and vote as he is instructed by his Brisbane Back-room Party Bosses. (Townsville Daily Bulletin: 30 March 1963; the same issue contains a $13 \times 6 \frac{1}{2}$ " advertisement in support of Aikens reprinting his biographical sketch from Lack's Three Decades of Queensland Political History, pp. 615-16, which includes some of his better exchanges with the former Speaker, Mann.)

Trower replied:

My opponent at the coming election, the self-styled 'Townsville Tom' has seen fit to refer to me as an A.L.P. PARTY HACK. No offence is taken. In the first place I am proud to be a member of the Australian Labor Party from whose stable many thoroughbreds have emerged. This party stands for social justice and which can and WILL form a Government, as different to a one-man party which at the most optimistic can only have nuisance value-like toothache. As regards being a 'hack' if my opponent means workhorse, then I'll be in that too, and promise the electors of Towns- 
ville South that, if they have confidence in me on June 1 , no horse will work harder than I on their behalf. (Ibid.: 20 April 1963)

In other advertisements Aikens related Townsville's industrial growth to his status as an Independent, free to work with and support any organisation rather than waste his time in political sham-fighting and faction bickering. His freedom had been equally valuable in securing government housing. In 1966 other accomplishments were set out: high school, swamp reclamation, secondary industry. But the principal claim for support rested on his hatred 'of political humbug and hypocrisy', and regularity of service:

Tom doesn't just bob up at election time-he is on the job, watching your interests, and telling you the WHOLE TRUTH, all the time. (Ibid.: 30 April 1966)

Tom Aikens doesn't wait for any special event, to let the people of Townsville see him. He is here all the time ... Tom's famous bike is not just a 'gimmick'. He rides it so that the people can see him, and pull him up to talk to him.... (Ibid.: 2 May 1966)

Tom doesn't suddenly appear at election time, carrying a briefcase, and looking like a Count. $\mathrm{He}$ is here on the job all the time. (Ibid.: 4 May 1966.)

Tom doesn't need a flock of Southern politicians to fly up-at your expense-with their brain in neutral and their tongue in top gearto help him with his election campaign. He can stand on his own feet, and fight his own fights. (Ibid.: 11 May 1966)

In 1963 Aikens was returned comfortably with $60 \cdot 16$ per cent of the vote. In 1966 his share had risen to 63.21 per cent.

In Burdekin Coburn seemed safe enough in 1963 with no Government candidate in the field. The first evidence of his campaign is an advertisement in the Townsville Daily Bulletin (13 May 1963) which reported 'Electors of Burdekin, Arthur Coburn, Independent candidate, stands for' followed by a list of some twenty-three items starting with 'a fair deal for North Queensland' and ending with 'the fundamental right to think and act as conscience dictates', the intervening items ranging from the highly specific-a cannery at Ayr and new nurses' quarters at the Ayr hospital, to the highly generalised-the full development of the potentialities of the electorate and 'provision of homes under the most satisfactory terms possible for all persons requiring them'. The same day an advertisement in the Innisfail Evening Advocate listed the benefits he had secured in the past three years, and concluded 'Keep the Good work going, Keep the money flowing'. Coburn cast his net widely: among the good things that have been done while Arthur Coburn has been your representative in Parliament' were many which primarily benefited other parts of the State, such as a youth hospital and geriatrics unit in Brisbane-although there was a proviso that such were planned for Townsville as well, or were spread evenly over the State (Townsville Daily Bulletin: 15 May 1963). 
Subsequent advertisements specified public works in the Burdekin electorate, but others continued to list statewide benefits, 'some of the great important things that have been done for Queensland while Arthur Coburn has been your Member' (ibid.: 27 May 1963). Only on the eve of poll did Coburn depart from such lists:

Electors of Burdekin! Tomorrow you will make your choice. You may have a Member who has had thirteen years experience as your Parliamentary Representative or one entirely without such experience. Arthur Coburn has lived in Ayr for 46 years and represented Burdekin faithfully and well for the past 13 years. $\mathrm{He}$ is always available to serve his constituents. For courteous and prompt service by a Member who always lives among you-Vote for Arthur Coburn. (Ibid.: 31 May 1963)

The 1963 campaign in Burdekin went unreported in the Townsville and Ayr papers so it is impossible to say what was said on the hustings, but judging from their advertisements Coburn did not emphasise his Independent status, nor did his A.L.P. opponent, T. Niven, attack him for it. One large advertisement (Advocate (Ayr): 24 May 1963) did warn 'Don't Follow a One-Man Band-Join the Full A.L.P. Orchestra', but generally the A.L.P. ran a quiet campaign in Burdekin and Coburn's status passed unnoticed. He polled $56 \cdot 17$ per cent of the vote.

In 1966 the situation was changed. A Liberal candidate, S. J. Pearce, stood, as well as the usual A.L.P. and Q.L.P. candidates--and a certain piquancy was added by the fact that both the Liberal and A.L.P. candidates were Coburn's former pupils (Telegraph: 6 May 1966). Coburn began the campaign with his customary autobiographical advertisement and then went over to lengthy lists of policies and achievements (Townsville Daily Bulletin: 10, 12, 14 May 1966). The first of his policies was a dam on the Burdekin at Burdekin Falls, and in a subsequent advertisement (ibid.: 18 May 1966) he pointed out that he had been the first parliamentarian to advocate it-in 1944. This was a response to inclusion in Chalk's policy speech of a promise to investigate the feasibility of such a dam scheme and Pearce's effort to claim credit for the idea for the Liberals. Coburn commented amiably:

You're late, Gordon-very late. But nonetheless we're glad that you've arrived. Competent eminent Government experts, after comprehensive investigations, have endorsed Arthur Coburn's opinions. Return the champion of the Burdekin Dam scheme to Parliament ...

Pearce claimed that as a Liberal branch member in three years he had secured Liberal State Council endorsement, Liberal convention blessing, and now inclusion of the dam in the Liberal policy speech, whilst the 'Independent member has had sixteen years in Parliament and has achieved nothing' (ibid.). Coburn retaliated by quoting a resolution of the Ayr branch of the Country Party not to enter the contest after 
consideration of his 'excellent service', nor to support the Liberal candidate. Thereafter Coburn continued calmly setting out developments in education around the State and public works in the electorate, whilst Pearce pointed out that only government Members would draft sugar legislation and discuss the Burdekin Dam and quoted Nicklin's call to all Queenslanders to vote for endorsed government candidates which 'did not mean Mr. Coburn, who has refused to join the Government' (ibid.: 27 May 1966). Pearce polled 19.43 per cent of the vote, but drew barely half of it from Coburn, the rest coming in equal shares from the A.L.P. and the D.L.P. Coburn with 45.46 per cent was lying well; the D.L.P. candidate was eliminated first and the majority of his preferences went to Pearce, putting him ahead of the A.L.P. candidate whose preferences also favoured Pearce by almost two to one. Nevertheless in the two counts Coburn picked up almost another thousand votes to win with 58.53 per cent of the final count.

Apart from the sitting independent (and Q.L.P.) Members, only two independent candidates were given a serious chance of winning in these two elections: the Mayor of Gold Coast, Alderman Harley, in Albert in 1963, and the Mayor of Ipswich, Alderman Finimore, in Ipswich West in 1966, both because of unusual circumstances in the electorate. In 1960 Harley had polled 36.44 per cent of the vote, and lost narrowly to the Country Party candidate, Carey, with 39.58 per cent. There was no reason to expect that Carey had greatly increased his vote or that Harley had lost his in the ensuing three years, and so the key question in 1963 became the distribution of A.L.P. preferences. In 1960 the A.L.P. candidate had polled 22.39 per cent of the primary vote, sufficient to determine the result had there been preferential voting at that time. Although Harley was reported to have been considered for endorsement by the A.L.P. for the federal seat of McPherson in 1961-and claimed that he had been offered it for the next federal election if he would withdraw from the Albert contest-the Southport branch of the A.L.P. sought and obtained Q.C.E. permission to give second preferences to Carey on the ground that Labor principles were opposed to one man holding two jobs-as Harley would do as Mayor and M.L.A. Just before the election a prominent A.L.P. member in the electorate, Harold Evans, wrote to the Gold Coast Bulletin (22 May 1963) pointing out that with the two jobs Harley would receive almost $£ 6,000$ a year plus allowances, and reminding readers that the A.L.P. had always been firm on the point, expelling the Lord Mayor of Brisbane, Frank Roberts, when he insisted on holding a seat in the Legislative Assembly as well. The Country Party reciprocated by promising its second preferences to the A.L.P. candidate, Ulrick-although in the absence of a landslide swing to Labor it was inevitable that Ulrick's preferences would be the ones distributed. Perhaps the Country Party acted in the belief that the gesture would 
keep Labor preferences solid behind the how-to-vote card and in favour of Carey.

Alderman Harley bore up bravely:

I wish to sincerely thank Mr Carey and Mr Ulrick for their actions in cementing my success at the elections on June 1. Neither the Country Party nor the A.L.P. supporters will accept without question the alliance entered into. The decision that they have made will mean a considerable increase in my primary vote from both C.P. and Labor supporters showing their objection to such an alliance. (Ibid.: 3 May 1963)

In an advertisement entitled 'Who's Fooling Who?' (ibid.: 8 May 1963) the claim of a swing to Harley was repeated, with the warning that jealousy of the South Coast by the Nicklin government lay behind the all-out effort to defeat the local Mayor, whilst Carey's silent acceptance of the Government's policy of ignoring the South Coast made him the "ideal "dummy" member for Albert to suit the Government's policy'. On the other hand, if A.L.P. members accepted this deal, they could be responsible for saving the Nicklin government in a close finish.

Carey defended the Country Party's action at his opening meeting, but from a fairly personal point of view:

With three candidates in this field it does not matter where my preferences go. If my preferences are counted in a three man field I will be out anyway. The Labor Party paid us the greatest compliment of all times when they allocated their preferences to the Country Party. (Ibid.: 10 May 1963)

Supporting Carey, Pizzey made the point that Albert needed to retain a voice in the Government, for an Independent was a lost cause with no access to party discussions and, therefore, unable to make any contribution to policy-making decisions. Pizzey observed that it was essential that the interests of Albert be protected by a voice of strength and capacity that was 'with the strength'.

Harley's next advertisement (ibid.) repeated that the deal was backfiring because voters wanted a 'fair go'. The Mayor had been persecuted by 'a series of attacks aimed at undermining his personal standing and dignity of office just to satisfy the appetite of an antagonistic government'. His business had been 'pushed off' the waterfront at Government direction, during the Royal Visit to the Gold Coast 'this district's first citizens-the Mayor and his lady-pushed into the background' (i.e. presented to the Queen after the Minister for Local Government and the two local M.L.As.), and there had been 'a neverending parade of political "hogwash"' in the press from Ministers seeking to ridicule the Mayor. In another advertisement (ibid.: 15 May 1963) Harley reported a 40 per cent drop in Country Party membership in the electorate over the previous three years because of the 
party's treatment of the Mayor and its introduction of T.A.B. As for Pizzey's intervention, Harley asked, did the Minister admit that he distinguished between electorates on their Members' affiliations? Why had not the Government opposed Coburn and Aikens at the previous three elections? Pizzey was condemning his own party for taking no interest in the people of their electorates.

The Mayor was promptly attacked from both sides. Eric Lloyd at Ulrick's opening meeting said that Harley's record was one of continuous quarrels with people who tried to help the Gold Coast. The Australian Labor Party believed that Independents could not give effective representation. Ulrick characterised Harley as wanting to be a one-man show all the time, and predicted that he would get into a brawl with whatever government might be elected. The chairman of the Albert Electorate Council of the Country Party declared that party membership was rising. Carey defended Pizzey by pointing out that, except in the case of Coburn, who invariably supported the Government, every 'genuine and serious Independent candidate' was being opposed by one of the government parties, a reply which either overlooked Aikens or perhaps credited the North Queensland Labor Party with more status than its part in the 1963 campaign warranted.

A letter by 'Independent' (ibid.: 17 May 1963) distinguished between the two local Country Party M.L.As. Gaven 'who is independent in all but name ... who has the moral courage to express his views on the floor of the House, if, in his wisdom, the Party's action or proposed action will be to the detriment of the people he represents ... [who] has fought the battles of his people in direct opposition to party policy on more occasions than I can remember' was contrasted with $\mathrm{Mr}$ Carey, 'the real party man, the good boy who always toes the party line irrespective of its effect on the people, and because of this is of little real use to us ... He is a true party man who refuses to embarrass the Government by asking questions.'

Harley opened his first campaign meeting dramatically. Hanging his head he invited the audience: 'Take a good look at me. I am the unacceptable candidate.' On the two jobs point he explained:

As Mayor I spend more time in Brisbane than Parliament is in session each year getting in doors to Ministers. If elected it will be much easier for the Mayor of the Gold Coast to get through these doors. It is a fact that when Mayors are Members of Parliament they are getting the plums. (Ibid.: 22 May 1963)

In an advertisement (ibid.) he complained that Carey admitted that he had not spoken during the term of the present Parliament. Carey retorted that this was 'half facts and distortions'. He had spoken in the Address-in-reply debates and had done

perhaps more than my share of talking on subjects of interest and importance to my area in our own joint party meetings. Thinking 
people will know this is the place where legislation and the laws of our State are really made. (Ibid.: 24 May 1963)

In addition, he had served on several party committees and on one allparty committee examining third party insurance. In an anti-Harley editorial the Gold Coast Bulletin commented (22 May 1963):

In all fairness, surely it must be admitted that a member does not actually have to be sitting in Parliament House to be serving his electorate. There are a thousand and one things OUTSIDE Parliament that can keep a conscientious member busy in the service of his electorate. There are all sorts of requests and formalities and chores from voting citizens; a wide variety of demands to be put to Government departments; social, charity and public services to be rendered. None but the stubborn would deny that an enthusiastic member capably, honestly and constantly serving his electorate is a very busy man.

The distribution of votes on 1 June differed little from 1960. Ulrick's vote was down slightly to $21 \cdot 46$ per cent, Carey's was up to 44.39 per cent, and Harley's down to $34 \cdot 15$ per cent. On the distribution of preferences a bare majority of Labor voters followed the A.L.P. how-to-vote ticket: 54 per cent gave their second preference to Carey, and 46 per cent to Harley, but it was sufficient to ensure the return of the Country Party regular with 55.93 per cent of the vote on the second count.

This distribution of votes may exaggerate the 'normal' support for an independent candidate. In a mail questionnaire sent to a 1 per cent sample of Albert voters the question was asked: 'If a Liberal Party candidate were standing this time, would you rather vote for him?', alternative answers of 'yes', 'no', and 'it would depend' being checked. The responses are given in Table 5.01 .

Table $\mathbf{5 . 0 1}$

Readiness to vote for a Liberal candidate in Albert 1963

$\%$

\begin{tabular}{cccc}
\hline & \multicolumn{3}{c}{ Intending to vote: } \\
\cline { 2 - 4 } & $\begin{array}{c}\text { A.L.P. } \\
(\mathbf{n}=15)\end{array}$ & $\begin{array}{c}\text { Country } \\
(\mathbf{n}=33)\end{array}$ & $\begin{array}{c}\text { Independent } \\
(\mathbf{n}=18)\end{array}$ \\
\hline Readiness to vote Liberal & & & \\
Yes & 0 & 42 & 28 \\
No & 87 & 21 & 50 \\
It would depend & 13 & 36 & 22 \\
\hline
\end{tabular}

For all the reasons set out in Appendix A, conclusions derived from these questionnaires must be regarded with considerable caution, but it would appear that Harley received a substantial part of his vote from frustrated Liberals-as did Carey. The point was taken by the 
Liberal Party, which proceeded first to organise branches in the Gold Coast area for the first time-by May 1965 there were four Liberal and two Young Liberal branches in the area-and then to call for nominations for Albert and South Coast (where Gaven had announced his retirement) for the 1966 election. In the meantime Alderman Harley had joined the Liberal Party, and at the 1965 Young Liberals convention in Southport (Courier-Mail: 3 May 1965) repeated his attacks on Nicklin for warning against the Communist-dominated A.L.P. and then asking Albert voters to give their second preferences to that party. In September 1965 Harley was endorsed as Liberal candidate for Albert. On the face of it, he should have been able to hold his independent voters and attract some of the frustrated Liberals away from Carey. In fact all three major candidates lost ground slightly with the appearance of a Q.L.P. candidate. Carey dropped to 41.72 per cent and Harley to 33.26 per cent. A bare majority of Q.L.P. preferences went to Carey, and he then secured a leakage of almost 30 per cent of A.L.P. preferences to win with 50.22 per cent of the final count after some days of cliff hanging.

Ipswich West is naturally a Labor seat, and the retiring member, Marsden, had won with 63.78 per cent in 1963. However, when a woman, Mrs Vi Jordan, won the A.L.P. pre-selection, its future became uncertain. No woman had sat in the Queensland Legislative Assembly since the first and only woman M.L.A. was defeated in 1932, and although Mrs Jordan had five years service as an alderman and longer experience in party posts, it was thought that a woman might not be able to carry a solid industrial seat. The intervention of the Mayor of Ipswich increased this possibility. Alderman Finimore had been Mayor since 1949, and an ex-Labor Independent in a solidly Labor city, and his personal popularity and wide connections plus Liberal and Q.L.P. preferences made him an attractive candidate. With the slogan 'friendly, forceful Finimore', the Mayor concentrated on local issues, especially land valuations for which he advocated a local independent appeal board, and his independence of Q.C.E. and big business interests, with some passing references to his sex:

If you would have a local Member who meets and answers you as Man to Man, who does not blindly bind himself to Caucus, and hide behind the decisions made by other men; if you would have a MAN to represent you, and not a section of a party plan who represents a group and power beyond you; then vote for J. T. Finimore-HE'S JUST YOUR MAN! (Queensland Times (Ipswich): 11 May 1966)

Mrs Jordan emphasised party policy and that she was the endorsed Labor candidate. Finimore had a number of policies: education, equal pay, improved train services, expansion of local industry, and full use of the local railway workshops, but the predominant emphasis of his 
campaign was on independence. The Liberal candidate, Alderman A. Whybird, added a claim that he was the only candidate who would be a member of the Government and therefore able to get things done, but it was unlikely that he could finish ahead of either Mrs Jordan or the Mayor. In one advertisement the Mayor explained why he was independent:

I believe that it is imperative to stop the trend towards party rule by cabinets, by means of disciplined party members. The only 'way to protect our Parliamentary Democracy from this trend is to have a body of bold Independent Members ... I require an independent voice to speak and fight on your behalf without control or censorship of any party-responsible only to you, my fellow citizens. (Ibid.: 25 May 1966)

Late in the day Mrs Jordan replied to Alderman Finimore: 'Only a party can give you an effective voice in Parliament.' Her victory was a narrow one. On first preferences she led Alderman Finimore 47.50 per cent to 31.66 per cent, but he received the majority of Q.L.P. preferences and almost 85 per cent of Liberal preferences. On the final count Mrs Jordan led with only 50.87 per cent, a margin of barely 200 votes. Unfortunately, it is impossible to say how many votes she lost to an Independent and how many votes she lost to a man.

Two other candidates in 1966 could have been given an outside chance of winning. Baxter as a sitting Member could claim personal support for past services to the electorate and a sympathy vote as a man 'stood over' by the Q.C.E. However, the absence of any issue of principle in his loss of endorsement and the limited sense of local identity in an inner suburban electorate such as Hawthorne reduced the effect either factor could have. The contest in a metropolitan electorate rarely produces a story warranting space in the Courier-Mail, Telegraph, or Sunday papers, and after the initial cryptic accounts of Baxter's break with the party nothing was heard from the mass media. Direct observation in the area would have permitted some account of how the campaign developed, whether the case for and against independence was developed, but this was not possible. The results suggest a slight drift of votes from Q.L.P. and Liberals to Baxter who could still manage only $14 \cdot 69$ per cent. The Labor candidate, Burton, held four-fifths of the old Labor vote, but it was not enough Eighty per cent of the Q.L.P. preferences and almost 60 per cent of Baxter's preferences brought the Liberal candidate, W. B. Kaus, from behind to win the seat-the one Government gain in the whole election.

In Cairns a real estate agent, Colin Penridge, might have been able to combine local issues and the intervention of Liberal and Country party candidates to carry a normally Labor seat-64.82 per cent so in 1963. Cairns had gone independent before. Penridge ran an expensive campaign in the advertising columns of the Cairns Post and on radio 
to promote a varied program for local development of which reclamation of the mudflats along the Cairns waterfront and the provision of safe swimming there were the most remarkable element and his plans for a town hall to cost $\$ 3$ million his favourite project. His criticisms of the Government's record in education paralleled Labor's (Cairns Post: 27 April; Sunday Truth: 1 May 1966), though his request for the next northern Queensland university for Cairns suggests unfamiliarity with the frustrations of Rockhampton and Toowoomba. In his later advertisements Penridge tried to associate himself with the three other Independents 'fighting for the North Queensland towns in their electorates and ... re-elected every time'-Aikens, Coburn, and Adair: "United they stand for North Queensland. Divided they fight for their electors, who keep putting them back, so they must be doing a good job.' Whilst this might seem to have limited appeal, Penridge with 16.48 per cent of the vote polled almost as well as the Liberal candidate with 18.00 per cent and ahead of the Country Party candidate with 12.54 per cent. The A.L.P. vote dropped to 51.34 per cent.

A somewhat similar phenomenon was the candidacy of Bernie Elsey in South Coast in 1966. At one stage it had seemed possible that despite Alderman Harley's adoption by the Liberal Party both Gold Coast seats would have independent candidates, but Vic Kearney, the possible starter in Albert, eventually dropped out and became Elsey's campaign manager instead. Kearney, an ex-A.W.U. organiser, had been the A.L.P. federal Member for Cunningham, New South Wales, for three terms until 1963 when he retired and moved to Queensland. After filling the columns of the Gold Coast Bulletin in the early months of 1966, Kearney dropped out to work for Elsey, a longer-term resident of the Gold Coast. Elsey had been well known as hotel proprietor and advocate of brighter tourism; his campaign concerned his ideas for promoting tourism and, admitting that he had no chance of carrying the seat, using the direction of his preferences to further that cause (Gold Coast Bulletin: 30 March 1966). The direction of his preferences should be determined by public advice solicited through the columns of the Bulletin, and by late April Elsey reported having had over a hundred letters and phone calls proffering advice, although his advertisements simply suggested 'obtain Government support for tourist industry' by voting for him, and his speeches merely promised not to be 'muzzled by party leaders and political axe-grinding'. Eventually Elsey indicated that his preferences should go to the Liberal candidate, Alderman Winders, although it was reported that Councillor Hinze, the Country Party candidate, had topped his public opinion poll; the result was a complicated 5, 1, 3, 4, 2 sequence. Elsey polled only $7 \cdot 17$ per cent-disappointing, perhaps, considering how well known he was; understandable considering the close rivalry 
between Liberal and Country party candidates in the electorate. Even though 56 per cent of his preferences went to Alderman Winders, A.L.P. preferences went much more solidly to the Country Party candidate, who won.

The remaining candidates fall into two main groups, two or three in 1963 who could be classed as 'Independent Country Party', a type which occurs at most Australian state elections, plus one in 1966, and the rest 'true Independents' advancing a particular policy item or two as a form of protest but with little chance of success-in fact none of them polled 10 per cent of the total vote in their electorates.

A variant on the Country Party expellee is the Country Party dissident standing in protest over some policy or action of the party. Presumably because of the good standing of the Country Party in rural areas in 1963 and the general respect given its leaders within the party, there were only two candidates of this sort. On 25 April P. B. Edwards announced that he would contest Barambah against the sitting Country Party member, Bjelke-Petersen. Edwards was made of the stuff from which Country Party candidates are cut: a member of the party since 1928, he had lived all his life in Kingaroy apart from five and a half years in the R.A.A.F., was President of the Kingaroy Chamber of Commerce, had played an important part in forming the South Burnett Vegetable Oil Growers Committee of which he was then secretary, had been oil growers' representative on the Queensland Grain Growers' Association, and for eight years had managed the Poultry Farmers' Cooperative Society-but resigned the post to contest the elections. He was also on the Kingaroy R.S.L. Club Committee. But despite his years in the Country Party, he now resigned and declared that he would not rejoin the party until its policies were altered. His campaign began with attacks on the Government's agricultural policy for its effect on the Burnett district. Unsympathetic treatment of the peanut industry had cost $£^{3}$ million since 1959, and neglect of dairying a further sum. In an advertisement (South Burnett Times (Kingaroy): 2 May 1963) he charged that government policies were creating chaos in the rural industries of the area. Opening his campaign formally at a meeting at Woorrolin, he complained that BjelkePetersen was letting the district down for aggressive representation; if the rate of deterioration continued for another three years, 20 per cent of South Burnett farmers and dairymen would go broke. The Country Party was the party of small and medium farmers, but-farmers were being forced into larger and larger units. In later statements he criticised the brigalow scheme as influenced by the big graziers, and, closer to home, complained about the action of woolgrowers' and graziers' associations in opposing the Peanut Marketing Board, the Cotton Board, the Vegetable Oil Committee, and the Queensland Grain Growers' Association at recent Tariff Board hearings. The Govern- 
ment had failed to support soya bean growing, and there were rising imports of vegetable oils. The Commonwealth Government and the Tariff Board had forced South Burnett into becoming the poorest area in Australia: Christmas sales were down at Kingaroy compared with previous years, and the electorate's enrolment had fallen since 1960 , certain evidence that it was going backwards. In a final appeal, in which he described himself as 'Independent Country Party', Edwards called on voters to 'support his protest':

The Country Party seems to have lost sight of the basic principle around which the Party was built-"That a fair share of the National Wealth to Primary Producers in turn gives security to commerce, trade and workers alike.' The unemployment problem will never be solved until rural prosperity is regained. (Ibid.: 9 May 1963)

Much of Edwards's campaign paralleled that of the A.L.P. candidate, W. A. A. Weir, who spoke in similar terms of neglect and stagnation in the rural industries of the area. Bjelke-Petersen replied to his detractors in an advertisement:

I have been accused of doing nothing to get Secondary Industries to the Barambah Electorate. As the Government we sponsored to the extent of $£ 75,000$ the establishment of the South Burnett abattoirs. The Finance Section of the Secondary Industries Department of the Government has offered finance for expansion of industries already established in our district. As is well known, I have made every endeavour to get one of the big peanut processing industries to the South Burnett, and also carried out negotiations with Quaker Oats Corporation, United States, re processing our maize in this area. How can I be accused of doing nothing? (Ibid.: 23 May 1963)

In another advertisement he called attention to the $£ 13.4$ million spent on electorate roads in six years of the Nicklin government, twice what had been spent under the last six years of a Labor government. However Bjelke-Petersen's cornucopia does seem to have been somewhat limited in comparison with the other government members', and the closure of the Goomeri cheese factory a fortnight before the election must have been a further embarrassment.

In 1960 there had been a Q.L.P. candidate in Barambah who had polled 14.18 per cent of the vote. In 1963 Weir's vote rose slightly by 4.09 per cent to 25.40 per cent, while Bjelke-Petersen's fell by 2.60 per cent to 62.90 per cent. Edwards polled only 11.69 per cent of the total vote, and the distribution of his votes was strikingly similar to that of the Q.L.P. candidate in 1960. It would appear that his campaign had limited appeal to regular Country Party voters.

The second independent candidate who had left the Country Party to stand in 1963 was Alf O'Rourke in Callide. He had been a member of the Banana Shire Council for twelve years and its president for 
three terms, having lived in the electorate since 1937, first as a selector on the Dawson River and then as a grazier at Thangool. O'Rourke was a member of the Capricornia Regional Electricity Board, a member of the selection committee for the brigalow development, deputy chairman of the Banana Hospitals Board, and patron of the Callide Valley Show Society and many sporting organisations. His policy announced in an advertisement (Central Telegraph (Biloela): 2 May 1963; Morning Bulletin (Rockhampton): 14 May 1963) was 'the promise of an active and vigorous Parliamentary representation to ensure that the Callide Electorate benefits from' a lengthy list of local improvements of roads, power, abattoirs, and port facilities, hospitals, irrigation and water conservation schemes, ending with: 'Freedom to vote independently'. Two later advertisements called for support 'if you are fed up with broken promises and plans', and advised voters: 'Parliament should be like a beehive-throw out the drones. Vote for a workerl', but no other reports of O'Rourke's campaign appeared in the Morning Bulletin, which gave extensive coverage to the campaigns of the A.L.P., Country, and Q.L.P. candidates in Callide. The Central Telegraph casts some light on O'Rourke's candidacy: he had been a member of the Country Party since his youth, but had now resigned (24 April 1963). When the endorsed Country Party candidate, Vin Jones, delivered his policy speech at Biloela, he warned that an Independent would be merely a messenger-boy, carrying messages for his electorate. A heckler asked: 'Would you call Aikens a messenger boy?' and Jones replied:

Mr Aikens is very loyal to his electorate, but without access to the Party deliberations and participation in the committees that stand behind each Minister, he can do little more than carry messages from his electorate to Parliament. (Central Telegraph (Biloela): 16 May 1963)

Pizzey, attending a meeting at Goovigen called to press for bitumen on a stretch of the Burnett Highway, warned that no independent candidate who had opposed an endorsed candidate would be admitted to the Country Party after the election.

In his policy speech O'Rourke pointed out that Townsville and Bundaberg had been represented by Independents for years. If he held the balance of power, this would be the strongest representation the electorate could obtain. He went on to criticise Jones's representation:

I consider that I can give the Electorate better representation than it has had in the past. Many people will see more of their present sitting Member in the weeks ahead than they have seen of him in the past few years. That the Government is concerned at his indifferent representation is evidenced by the fact that, at this Election, he is being assisted by Senior Cabinet Ministers. They will no doubt take full credit for development work in the area provided by private enterprise and hard working property owners. It 
should not be difficult for them to promise a greater measure of public works in the area in the future for comparatively little has been done during their six years of office. (Ibid.: 23 May 1963)

O'Rourke concluded by asking the voters for either their first or second preferences. Certainly there were local grievances, such as the State Government's decision not to build a district abattoir-which one Banana Shire councillor attributed to political pressure by Alderman Pilbeam, the Mayor and Liberal M.L.A. for Rockhampton whose Lakes Creek works would benefit (ibid.: 14 February 1963), and led to a meeting attended by Pizzey, Jones, Country Party members from the Callide and Mackenzie electorates, the State President of the Country Party, Lawrie, and the chairman of the Rockhampton District Abattoir Board, after which Pizzey undertook to convey certain suggestions on the allocation of facilities at Rockhampton to State Cabinet (Morning Bulletin (Rockhampton): 11 April 1963). In his policy speech Jones retailed public works in the electorate over the previous six years, and concluded:

There is no doubt that on June 1 the Nicklin Government will be returned and only a member of the Government can best represent Callide. (Ibid.: 14 May 1963)

Fletcher, speaking at Biloela in support of Jones, added the standard warning:

A Labour member can only give you a divided loyalty and an independent has no say anywhere and almost disfranchises his electorate. He has no part in organised Government or organised opposition. $\mathrm{Mr}$ Jones has given good and loyal service in the past and it's unthinkable that Callide should do other than vote in his support. (Ibid.: 23 May 1963)

Callide in 1960 had been contested by only A.L.P. and Country Party candidates, and Jones had had an easy win with 62.32 per cent of the vote. In 1963, with O'Rourke and a Q.L.P. candidate, Mrs Green, in the field, he failed to secure an absolute majority: Jones 45.45 per cent, Coombs (A.L.P.) 31.84 per cent, O'Rourke 17.26 per cent, and Mrs. Green 5.47 per cent. O'Rourke received a quarter of the Q.L.P. preferences, and when his own preferences were allocated 70.53 per cent of them went to Jones, who thus had 61.54 per cent of the vote on the third count, indicating a minimal drift to the A.L.P. Most of O'Rourke's votes came from Biloela, where he polled 40 per cent of the vote, and Thangool, where he had 38 per cent-in both centres a plurality of the vote. It would appear that his candidacy benefited from local dissatisfactions and local personal support, and not any widespread opposition to the Country Party or Jones.

In 1966, despite the problems of the sugar and dairying industries, there was only one Independent Country Party candidate, J. L. Rasmussen in Somerset, pledged to 'independent representation in 
dairying, railways, rural problems'. His policy speech developed these themes: an immediate subsidy to butter and cheese producers whose incomes were below the basic wage; an immediate start on water storage works in the area; assistance with reafforestation; development of a local coalfield; a drought relief scheme parallel to public servants' superannuation, assisted by Government subsidy, and payable on drought or retirement; closer attention to education to reduce the failure rate (Queensland Times (Ipswich): 25 May 1966). $\mathrm{He}$ attacked the Country Party Government for trying to fob responsibility for dairymen's problems onto the federal government when it knew that Canberra would underwrite expenditure:

Our Country Party Government has chosen rather to stand aside and watch hundreds of staunch supporters-dairymen-pack up and leave the industry because no assistance was forthcoming. And all this time Government planners were withholding this assistance to use as an election plum.

As an Independent Member he would support any legislation for the benefit of Somerset and Queensland, whether it came from the coalition, the A.L.P. or his fellow independents. In 1963 there had been only Country Party and A.L.P. candidates in Somerset, whereas in 1966 Rasmussen and a Q.L.P. candidate offered as well. However, the Country Party vote fell hardly at all: from 60.14 per cent to 59.92 per cent. Rasmussen's 4.49 per cent and the Q.L.P.'s 3.23 per cent came almost entirely out of A.L.P. support.

On the borderline of the 'true Independents' were two candidates, T. J. Chapman in Cooroora in 1963 and L. J. Storey in Logan in 1966. Chapman described himself as a 'Progressive Liberal' in his one advertisement (Maroochydore Advertiser: 8 May 1963) located for this study. Its heading, 'Worried About Valuations?', suggests one grievance Chapman may have sought to remedy. D. A. Low, the sitting Country Party M.L.A., described himself as the endorsed Country Party candidate in his advertisements, suggesting that Chapman's appeal may have been along 'Independent Country Party' lines, but there is no further evidence in support of this. The Gympie Times, which had moderate coverage of the A.L.P. and Country Party campaigns in Cooroora, says nothing about Chapman. Chapman polled 6.93 per cent of the vote (mainly from one centre, Nambour) in a safe Country Party seat and left Low still with more than 60 per cent. Storey called himself 'the independent candidate who stands for democratic principles', but again his campaign is not caught by the local press. He managed 8.34 per cent of the vote, doing particularly well in the Waterford-Kingston area where his family had long lived, and in a situation where Liberal, Country, A.L.P., Q.L.P., and Social Credit candidates were offering this was a respectable vote.

In nearby Redcliffe where the Mayor, Alderman Houghton, had 
been elected in 1960 as an Independent (he polled 41.96 per cent of the vote, against 24.82 per cent for the Country Party candidate, his nearest rival), but was now standing for the Country Party after a brief flirtation with the Liberals, there were two independent candidates in 1963, E. J. Pritchard and E. A. Sykes. Pritchard had opened a hardware store in Redcliffe six years previously, and had become President of the Scarborough Progress Association and of the Combined Peninsula Progress Associations (which cover the Redcliffe area), and a VicePresident of the Redcliffe Peninsula Chamber of Commerce. Sykes, now retired, had lived in the Redcliffe Peninsula since 1930, had served a term on the Redcliffe Town Council and, like Pritchard, been active in the Progress Association field. The Redcliffe Herald noted that he was writing a book on social problems and his policy statement as reported by the Herald and contained in a leaflet he distributed suggests that social credit ideas influenced his views:

Ladies and gentlemen, with the powers of the Commonwealth to issue all money to cover the cost of Government and semi-Government instrumentalities free of interest and, if necessary, not to require the repayment of the principal, the present Government policy of incurring debt can only be described as criminal irrespon. sibility and unconstitutional ... The debt of this country has been imposed by an act of treason and it is my intention to have it exposed. (Redcliffe Herald: 16 May 1963)

Sykes complained also of party selection of candidates and compulsory voting; party-endorsed candidates did not represent the people who elected them but the parties that chose them.

Pritchard promised not to join a party and to hold a monthly meeting to discuss matters with his constituents; his policy planks were mainly local: reduced royalties to help sawmilling, a survey for a local harbour, taking tolls off the Hornibrook Highway linking Redcliffe to Brisbane or building a more direct bridge in its place, and containing the whole town of Redcliffe within one electoral district (ibid.). His policy statement, reprinted as a leaflet, stated:

In seeking your vote I would point out my position if elected by you would be to represent all peoples, irrespective of party politics. The first function of your Representative should be to be in constant contact with the people; this can only be done in working with all Organisations, irrespective of Political Beliefs.

When the Combined Peninsula Progress Associations sent a circular letter to all candidates in Redcliffe and Murrumba asking for their stand on ten points, nine of local interest and the tenth whether a conference of Commonwealth, State, and Local governments should consider direct allocation of federal funds to local authorities, Pritchard replied satisfactorily on all ten, Sykes on the first nine but in favour of returning financial powers to the States on the tenth. F. X. 
O'Mara, an independent candidate for Murrumba in 1963 but formerly with the Q.L.P., answered satisfactorily on some items and promised to investigate the rest. No replies were received from the other candidates, and the second release concluded: 'We, the Combined Peninsula Progress Associations, ask, "Are These Candidates Worth a Vote?"' (Redcliffe Herald: 23, 30 May 1967). Few electors answered negatively: O'Mara polled 0.72 per cent of the vote, a random scatter through the district; Pritchard, a fairly well known citizen of Redcliffe, one would have thought, managed $3 \cdot 16$ per cent of that vote, and Sykes only 0.84 per cent.

The candidacy of $\mathrm{J}$. P. Dwyer in Lockyer in 1963 will be discussed later (pp. 252-3), and its interest comes from the intervention of a pressure group on his behalf, not from any contribution he made to the style of Independent.

In 1966 there was an Independent Labor candidate, Doug Wood, offering in Ipswich East, as safe a seat for the A.L.P. as Ipswich West and, instead of the uncertainty of a woman candidate, with a wellentrenched unionist member. Wood's campaign began with a 'time for a change', but soon concentrated on municipal affairs. Like Alderman Finimore he was bothered about rates, though unlike the Mayor he was critical of the A.L.P.-controlled Council which 'has caused hardships never suffered before by any other city in Queensland'. If elected, Wood promised to act as an ombudsman between the ratepayers of Ipswich and the State Government. Industry, education, valuations, prices, all needed action, and Wood offered a few specifics such as pensioners' rebates on motor car insurance and registration, improvement of the miners' pension scheme by taxes on the industry, and removal of control of sewerage from local authorities when they proved ineffective, together with some generalities:

That citizens of Ipswich are respected and treated as individuals and not compelled and be controlled in their ways of thinking, and requests, by a political party controlled by Left Wing elements.

To be a determined fighter, to put back into the Labour movement what has been lost through the years of party decay.

To follow the true principles of Labour as established by our forefathers. (Queensland Times (Ipswich): 20 May 1966)

His final advertisement pointed out that the sitting Member was now past seventy. Would his successor meet with the voters' approval, did they want a party controlled by left-wing elements? Wood polled 7.06 per cent, much better than the Q.L.P. and Social Credit candidates. combined had managed in 1963, but the A.L.P. vote fell by less than 2 per cent.

More colourful cases come from central and north Queensland where there were four minor independent candidates in 1963. In 
Rockhampton South, Brian Dillon, a real estate agent and merchant, stood. Dillon had lived in Rockhampton twenty-one years. He polled 0.77 per cent of the vote. The only report on his campaign appeared in the Morning Bulletin's column, 'Topics of the Day', and read:

Although I am not in his electorate Mr Dillon very kindly supplied me with two copies of his election manifesto. It contains five or six lines and is printed on a slip of paper about the size of one of Charlie Davidson's postage stamps. (25 May 1963)

The columnist compared Dillon's modest effort with the 58-point program advanced by Thomas Pinkstone Kelly, the 'Democrat' candidate for Port Curtis. (To assess Dillon's campaign on the written word is demonstrably unfair, however: this writer, having had an opportunity to hear him as heckler in a federal by-election, considers that Dillon has one of the most powerful voices he has heard in some years of listening to politicians.) Kelly had been the hardy perennial of politics in the Rockhampton district, standing for Rockhampton in 1953 (227 votes), 1956 ( 66 votes), and 1957 (9 votes). In $1960 \mathrm{Mr}$ Kelly did not offer, perhaps having projected the curve of his previous ventures, and in 1963 he removed to adjacent Port Curtis to start afresh. Unfortunately the Morning Bulletin (25 May 1963) chose to condense Kelly's program, and it is necessary to rely on their account. Apparently, far from abashed by events in Rockhampton, he attributed that city's recent advance after a hundred years of stagnation to the 52-point program he had advanced in the old Rockhampton electorate. One group of points related to the industrialisation of Curtis Island by establishing the alumina plant there rather than at Gladstone, and building shipyards, a boot factory, fertiliser works, an oil refinery, a sugar refinery, steelworks, an asbestos plant, wool stores, a wool selling centre and woolscour, cement works, foodstuff processing including a condensed milk factory, a pineapple chutney and jam factory, paper mills, and a soap factory. Kelly declared that if his plans were carried out, and if he were elected he would see that they were, Curtis Island would become another Manhattan. Whilst Curtis Island was being made into the industrial heart of the Port Curtis electorate, Gladstone should become its cultural centre with a teachers' training college, the Central Queensland University, an agricultural college, and a theological college (as a check to juvenile delinquency). It might be observed that Kelly seemed the roads-and-bridges Member grown to Ruwenzorian proportions. Port Curtis voters, with only A.L.P. and Q.L.P. candidates as alternatives, rallied to him more readily than had the Rockhampton electors in the fifties; he polled 370 votes, 4.39 per cent of the total, and more than he had obtained in the three earlier tries combined.

In Townsville North A. F. Reeves came forward at the last moment as an independent candidate. His first contribution to the campaign 
was a $3 \frac{1}{4} " \times 23 \frac{1}{2}$ " advertisement (Townsville Daily Bulletin: 23 May 1963) beginning:

I nominated as an Independent so that the citizens of Townsville who do not believe in party politics could declare as such. I am not a party stooge for any political party, and my campaign expenses will be mine.

The advertisement told the story of Reeves's aviation experiences with QANTAS before the war and in the war, and then attacked preferential voting as 'the most misused and misunderstood system of all our Democratic procedures' because second and subsequent preferences were distributed only when the first choice had been eliminated. However, Reeves then carefully explained how a valid vote should be marked (with one misprint) for each of the party candidates offering, and enjoined voters to "vote intelligently, according to the dictates of your own heart'. A second advertisement (ibid.: 25 May 1963) shifted the attack somewhat:

Preferential voting DEMANDS citizens to cast votes to candidates they have ABSOLUTELY NO DESIRE TO SUPPORT. Citizens are compelled to vote in FEAR of being fined if they fail to do so.

And, two days later, sadly:

It is better by far to have representation by a lone Democrat than good representation within a dictator government. Vote 1 REEVES, A. F. Your number 2 vote is likely to be allocated for I fear my primary votes will be so low as to eliminate me first. I SHOULD TOP THE POLL but the apathy of the public with regard to the affairs of the State is, to say the least, DISGRACEFUL. Out of $\mathbf{5 0}$ people interviewed, 20 could not tell me the names of the candidates standing. COMPULSORY VOTING SHOULD BE ABOLISHED, people who do not vote intelligently are a menace to society. (Ibid.: 27 May 1963)

Finally, the next day he attacked the Government for introducing preferential voting without a mandate, and the A.L.P. for not opposing the legislation on that ground-'had they done so the Government would have had to withdraw it and either hold a referendum or make it a plank of their Parties' Policy at this election'-and called on voters to register their objection by voting for him. Some $66(0.51$ per cent) did

Only one other candidate has left a record in the Queensland press, Mrs G. E. M. O'Sullivan in Toowoomba East in 1966. Mrs O'Sullivan declared that she would not hold meetings or give advice on preferences: 'I am independent in every sense of the word.' A series of advertisements made 'a special appeal to the housewife, the wage-earner and the pensioner' and referred to industry, housing, aboriginals, nursing, education, and police. She polled 58 votes $(0 \cdot 42$ per cent). However, there were a number of other individuals whose candidacies 
have sunk without a trace. In 1963 Dino Bertoldo, a hotel-keeper of Cairns, intervened in Tablelands; his vote of 3.21 per cent appears to have come mainly from disgruntled tobacco-growers. At that election R. W. G. Burrows, the Liberal candidate in 1960, stood as an Independent in Kedron, Lloyd's seat, and managed 4.83 per cent with the benefit of the donkey vote-which Bertoldo had also benefited from. In 1966 there were two more Independents standing in Brisbane: D. J. Wallace in Chatsworth (4.26 per cent) and D. S. Fulton in Wavell ( 0.36 per cent), and one in Murrumba, D. W. Bishop, who polled 2.59 per cent. But what they fought for never reached the press and a wider audience. 


\section{I : ISSUES}




\section{Statewide Issues}

Most of the visible and audible activity of an election campaign is about 'issues'. Candidates and party activists make speeches, distribute printed material, and produce television or radio advertisements. Very occasionally they knock at doors and say something to the householders who answer. Sometimes these political 'communications' or 'messages' are about the party leaders or the party candidates, but most often they are about 'issues'.

Each and every government decision, real, potential, or prospective, can involve an 'issue'. Berelson et al. have defined issues as 'statements that allege differences between the contending parties or candidates with reference to such matters as domestic and international policy, the nature of a party's support, or the capabilities of the nominees' (1954: 182), matters which provide the content of political debate. They are 'the points in question', as the Concise Oxford Dictionary has it, in the election. Thus an issue is an item of information available to the rational voter in determining how he will vote. It may be a policy promised for the future, it may be an action taken by the government in the past, it may be a social or economic problem about which it is thought the government should take or should have taken action. It may be some matter relating to a candidate or a party which may be relevant to the ability of the party to create benefits for some part or the whole of the electorate. 'Policies' in the Australian context often means promises of future courses of government action, but in what follows it is used to mean any course of government action.

One question which must be asked is when a subject becomes, or ceases to be, an 'issue'. Berelson et al. (207-12) have postulated a lifehistory pattern for issues, moving 'through various phases-from rejection at first through sharp partisan disagreement to near-unanimous acceptance at the end, perhaps a generation later', and kept moving 
not only by agitation but also by the underlying historical trends which have engendered them. The critical point in an issue's life-history is the

political 'gateway'-through which an endless succession of social proposals have passed, are passing, and will pass. The issues are disputed only during the time they remain at the point of legislative or electoral decision, when the issue 'hangs in the balance'. Before that they are not at the level of popular visibility. After that they are accomplished facts and out of controversy in a historically brief time.

To the extent that the division into two parties is achieved with the aid of issues, the cleavage will turn around those proposals that are near, just approaching or just passing, the critical gateway phase of precarious balance between acceptance or rejection. Thus it is important to know not only what issues are in the political arena during a campaign but what issues are at the most critical phase of partisan disagreement at that point of time.

Each policy speech produces a few issues which never get off the ground; they are repeated only by the conscientious or unimaginative candidates who parrot the policy speech in their own campaigns, and are ignored by editors and writers of letters to the editors. These are the issues which are not yet in the gateway, and it is one of the dangers of public opinion sampling that questions about such issues may generate false pictures of a substantial opinion which has been generated only by the questioning. On the other hand each policy speech will make reference to issues which are past the gateway, sometimes to report the party's role in pushing them through, sometimes to condemn the other party's past opposition to them, sometimes to lay claim to such merit by association as may be derived by incorporating settled policies into the party image.

Berelson et al. postulate that those issues which are nearest to the gateway are most likely to provide the symbols for partisan cleavage,

the subjects of sharpest disagreement between parties and the points of greatest rallying power within each party. They become what the disagreement is about-the content of the debate between polar political positions. In this sense, a sequence of longrange agreements representing the 'trend of the times' is formed, paradoxically enough, by a sequence of short-range disagreements around which parties polarize and elections are in part decided.

The authors themselves warn that their model is over-simplified, by assuming a 'typical' election in a sequence of similar elections and a historical trend underlying the sequence, and by neglecting feed-back whereby the character of the trend and the nature of cleavage is affected by the election results. There is a further danger in the model in that it supposes the parties seek, or at least do not resist, the development of cleavage, whereas it may well be that at least one of the 
parties has opted for an issue-matching strategy, that is to be as much like its opponent as possible save in one vital respect-in which it is better, indeed that the prevailing political style emphasises consensus rather than cleavage. Again, the model needs to be more sophisticated to distinguish between situations in which the disagreement between the parties consists in agreement that there is a problem and disagreement about its solution and those in which there is no agreement on whether there is a problem at all. In the first both parties are likely to emphasise cleavage, in the second they may but one could emphasise consensus. It should not be thought, however, that the model is appropriate only to policies: such a subject as Communist infiltration of the A.L.P. fits readily to it.

Several typologies of issues have been suggested, but the one which appears to have found the most general acceptance was that also provided by Berelson $e t$ al. (184-5) in their distinction between 'position issues' and 'style issues'. The differences are that whilst position issues seek to appeal to relatively direct self-interest, typically through matters of money and material power, with direct, objective, tangible gains for a successful group, style issues seek to appeal to selfexpression 'of a rather indirect, projective kind', typically through matters of style, taste, or way of life, so as to achieve indirect, subjective or symbolic gratifications for the successful group. It is not so certain that two other distinctions they draw from American experience are very helpful in Australia: that position issues oppose classes, geographical sections, and other economic organisations, and have a long-range time reference, while style issues oppose religious or ethnic groups, city against country, or personality types, and have a shortrange time reference, being more topical than position issues. Style issues are more easily created by propaganda; position issues tend to develop from socio-economic conditions, but perhaps are stronger because 'economic conditions call them forth with such cogency', whereas style issues become important only when position issues recede. The 'Big Issues' are those which combine position and style aspects. Berelson and his fellow authors cite the French Revolution and the slavery issue in the United States as 'Big Issues', but it might be more appropriate to elevate such social cataclysms to a class of 'Very Big Issues', and treat, say, depressions in which the competing parties differed sharply on ideological questions as 'Big Issues'. In any event, there was nothing approaching a 'Big Issue' in Queensland in 1963 or 1966, although we shall see some attempts to wed position and style aspects in a single issue.

A second typology is suggested by the efforts of Campbell et al. (1960: 222-3) to assign interview respondents to four levels of conceptualisation. These levels may also be regarded as the levels on which parties and candidates hold out issues to the electors. They are Level 
$\mathrm{A}$ in which issues are abstracted so as to be primarily ideological in character, Level $B$ which contains issues that are relatively concrete and designed to deal with short-term group interests, Level $\mathbf{C}$ on which the issues relate to the 'goodness' or 'badness' of the times or the parties, and Level D in which issues are, in the authors' opinion, nonpolitical, for example, the personal characteristics of the candidates or matters of individual corruption. This last class or level is unsatisfactory for our purposes, partly because in this book candidates are considered apart from issues, and partly because it prejudges much about the models of the political system prevailing in public opinion.

Having such typologies in mind may help in sorting out the constituent issues for the operation of a rational model of voter decisionmaking. One of the great difficulties in such an exercise is that one issue may shade over into a neighbour, for example, union demands may be represented as a consequence of Communist influence or retrenchment of employees as the result of big business influence. One or more large issues may overlap a smaller, more particular one, for example location of a university college in Toowoomba can be examined as an issue in its own right or as an aspect of the Government's record on education or on decentralisation. Campbell and Cooper (1956: 11) appear on the verge of distinguishing between 'issues' and 'issue areas', between questions such as 'Would Senator McCarthy's support for a candidate make you more/less likely to vote for that candidate?' and others such as 'What were the best/worst things the Republicans have done in office?' or 'Has Eisenhower been as good a president as you had expected or have you been disappointed?' The distinction seems a useful one, but, alas, it cannot operate tidily. Here issue area has been used to mean something broader than issue, for example union relations and the Moura strike (pp. 198-202), decentralisation and the Toowoomba University College (pp. 244-9).

As was said earlier, issues are items of information available to rational voters in determining how they will vote. Rational is used in the sense defined by Anthony Downs (1957: 6)

A rational man is one who behaves as follows: (1) he can always make a decision when confronted with a range of alternatives; (2) he ranks all the alternatives facing him in order of his preference in such a way that each is either preferred to, indifferent to, or inferior to each other; (3) his preference ranking is transitive; (4) he always chooses from among the possible alternatives that which ranks highest in his preference ordering; and (5) he always makes the same decision each time he is confronted with the same alternatives.

He excludes non-political goals from this model, thereby making a drastic departure from reality (Downs, of course, is well aware of this 
and concedes (p. 7) 'empirical studies are almost unanimous in their conclusion that adjustments in primary groups is far more crucial to nearly every individual than more remote considerations of economic or political welfare', his example being the man who wishes to vote for party A on political grounds but votes for party B because his wife will be ill-tempered if he does not).

His model assumes for its governmental elements that every government seeks to maximise its electoral support at periodic elections, that its primary goal is re-election, and that each party out of power seeks election to the Treasury benches as its primary goal. Its fundamental hypothesis derives from a self-interest axiom: "parties formulate policies in order to win elections, rather than to win elections in order to formulate policies' (ibid: 28). This he defends on the ground that few individuals pursue their social functions for their own sake but rather for private motives, social functions being usually by-products and private ambitions the ends of human action, quoting Schumpeter's observation that legislation and administrative measures are produced incidentally to the struggle for power and office, much as production is incidental to the making of profits. In the real world to which we will return in a moment this is crucial to understanding the relationship of the parliamentary party to its extra-parliamentary party and syndicates.

Such a model is relevant to descriptive political science of the sort generally practised in preparing this study of the 1963 and 1966 State elections in two ways: it proposes a single hypothesis to explain government decision-making and party behaviour, and it tells what behaviour could be expected if men behaved 'rationally'. The first, through empirical testing, may; lead to non-obvious conclusions, the second can show where men behave rationally and irrationally, and how they deviate from rationality in the latter.

In applying the: model to rational voting, Downs starts from the fact that all voters, receive benefits from government activity; these benefits are their utility income. (They may indeed receive benefits without being aware of them, and much of the parties' activity is directed to making them aware.) Thus utility income is measured over two periods: the period up to polling day $(t)$ and the period to follow polling day $(t+1)$. Downs's $t$ period may more conveniently be divided into two periods: $t$ when the present government has been in power, and $t-1$ when the opposition was last in power. As, in Queensland, this takes us back to 1932, that should suffice. Each rational voter will vote for the party which be believes will provide him with the higher utility income over $t+1$; to decide this he compares the expected utility incomes each party would produce for him. He has to calculate these, however, and this involves depreciating what each party promises to do over $t+1$ to what he thinks they will actually do. He can 
examine what the party in power did over the period $t$, which is the soundest basis for what it will do over $t+1$, there being good reasons to expect continuity (ibid.: ch. 7). It would be irrational to compare the $t$ performance of one party with the $t+1$ possible performance of another, because for valid comparisons the two performances must take place under the same conditions, that is over the same period, and so he must compare what the party in power did over $t$ with what the other parties would have done over $t$ had they been in power. This permits comparison of one real utility income with one hypothetical one, rather than of two hypothetical utility incomes. Thus the principal element in electoral decisions will be the size of current party differential, that is the difference between his real (government party generated) and his hypothetical (opposition party potential) utility incomes over $t$. It would also be irrational, however, to ignore the future, and so our rational voter applies two modifiers: (i) the trend factor which allows for any trend in events over $t$, for example the government has improved steadily; (ii) performance ratings. Downs argues that performance ratings will operate only when the voter sees no difference between the parties over $t$, and in the strictest formulation of the model, supposing that each voter has perfect information, this would be so. However, it is suggested, once uncertainty of information is admitted to the model, performance ratings become a valuable modifier whether or not a difference is seen over $t$.

Let us now apply this model to the recent experience of Queensland electors. In the first place Australian election campaigns are given a spurious unity for the $t+1$ period by the leaders' policy speeches, which correspond to the party manifestoes of Great Britain. Here are contracts which the parties offer the electorate as to what they will do if elected, and generally they are honoured (Barrett 1959). However, the policy speeches are often also assessments of the government's record over $t$, sometimes of parties' records over $t-1$ periods, and even attempts to supply trend factor assessments or performance ratings. The leader's statement is expounded and explained by the candidates of his party to their constituencies, and matters which are of local relevance may be brought out or added. Political life goes on during a campaign, the Government must continue to make decisions, and new alternatives are open to the competing parties. Party leaders and candidates have an opportunity to introduce new subjects and thereby shape the campaign to the new realities of the political situation.

But when we turn to a real world in which electoral decisionmaking is as much, or more, influenced by images which have been as greatly affected by irrational factors as it is by rational calculation of the sort outlined by Downs, a new dimension is introduced. No longer does the rational voter seek the maximum information and weigh 
utility incomes without prejudice. Rather he seeks the minimum of information necessary to appraise a pre-existing image and determine whether it is still valid for his purpose-which is to discharge a civic obligation under penalty of a fine. Images acquired over $t-1$ and $t$ affect the assessment of promises for $t+1$. No longer does the rational party seek to maximise its voters by the content and quality of its performance and promises alone, but it is selective in their presentation and also provides an equally selective account of its opponent's performance and promises.

Underlying the electoral strategies of the A.L.P. and the Liberal Party (to deal only with two of the major parties) were certain assumptions about voting decisions. One interpretation was of a very simple model. A government by definition had a majority of electoral support, and so long as things-in particular the economy-were going fairly well there would be no reason for electors to change their habits of previous elections. Thus governments lose elections, oppositions don't win them. This did not mean that oppositions need not do anything; they had to hold themselves ready to point out the government's mistakes and indicate how they would have done better, but they could not turn out a government unless things began to go wrong. Another interpretation concentrated more on the marginal voter. It supposed that a gradual federalisation of State politics was taking place, and that federal issues were more generalised and ideological, that is style rather than position. State governments had little room for manoeuvre, and in particular the only means of increasing revenue under their own control was increase by indirect taxation, which was highly unpopular; therefore there was little scope for initiative in devising new policies. The first school of thought characterises the A.L.P. strategy and also that of the Liberal parliamentary leadership, the second that of the Liberal Party organisation. The first is based on a modified view of the rational voter, the second emphasises the irrational and the image, although each contains aspects of both approaches.

It would be possible to provide a detailed comparison of each party's policy speech or speeches, to compare items in the same field, and to report the way in which each was carried to the constituencies by the party leaders on tour and by the local candidates. To such a body of material could then be added those issues which developed during the campaign, or had been floating around before but failed to warrant mention in the policy speeches, and their subsequent presentation to the voters. Such an exercise would inflate the size of this study and tax the patience of the reader. Instead, half a dozen issues from 1963 and three from 1966 have been selected for consideration in some detail, and in the next chapter other issues which developed in a local rather than a statewide context are similarly reported. One of the 
1963 half dozen, employment, was widely regarded as potentially the most important issue in the campaign, the one sign that things were going badly sufficient to turn the Nicklin government out. Another, relations with the trade unions, is a classic theme-and in the material on the Moura strike is a case study of an issue arising during the campaign. A third also involves the unions-the importation of Japanese pipes to build the Moonie pipeline. The fourth arose from a proposal for more housing finance in Duggan's policy speech, one of the few specific proposals to be discussed on a statewide basis. The fifth, free hospitalisation, is a recurrent theme peculiar to Queensland State politics, while the sixth, drink and gambling, has been one of the staples of Australian politics; both now appear to have little mileage left in them. Two of the three selected from 1966 had figured to a certain extent in 1963. In the earlier election Duggan's wish to restore price control had been a relatively minor issue, but in 1966 inflation and price control dominated the A.L.P. campaign. In 1969 there had been talk about the state of the dairying industry, but in 1966 increasing difficulties and the Dawson federal by-election (Hughes 1966) gave dairying much greater prominence. Finally, the sugar industry, which had been booming in 1963, was in the midst of a slump in 1966 . Each of the issues has been chosen partly because good documentation was available. Many other issues of considerable importance or interest have had to be set aside. In 1963 alone we could have added the comparison of the Labor record in school building with that of the Nicklin government, the question whether the Government was providing enough teachers for the future, land policy in the brigalow belt development, and profits and losses of the Railways Department. The list if not endless at least is distressingly long. However, to examine any issues in some detail selection has been necessary, and these nine must stand for all their fellows left unchronicled and unsung.

\section{Unemployment 1963}

One of the most prominent issues of the campaign was the relatively high rate of unemployment prevailing in Queensland. It was generally believed that this had caused a substantial swing against the Menzies government at the December 1961 federal elections, and although the numbers of registered unemployed had fallen somewhat since then, they remained substantial.

To make matters worse, the A.L.P. could make accusations of broken promises for, in his 1957 policy speech, the ebullient Liberal leader, K. J. Morris had declared:

Given the development that we are determined to see it won't be 
Table 6.01

Numbers of registered unemployed in Queensland 1961-3

\begin{tabular}{|c|c|c|c|c|c|c|c|}
\hline 27 & Oct. & 1961 & $\mathrm{I} 6,986$ & 31 & Aug. & 1962 & 13,040 \\
\hline 1 & Dec. & 1961 & 19,973 & 28 & Sep. & 1962 & 11,993 \\
\hline 29 & Dec. & 1961 & 25,799 & 2 & Nov. & 1962 & 12,924 \\
\hline 2 & Feb. & 1962 & 30,426 & 30 & Nov. & 1962 & 16,661 \\
\hline 2 & Mar. & 1962 & 26,312 & 28 & Dec. & 1962 & 24,585 \\
\hline 30 & Mar. & 1962 & 24,290 & $l$ & Feb. & 1963 & 26,646 \\
\hline 27 & Apr. & 1962 & 22,761 & 1 & Mar. & 1963 & 22,560 \\
\hline I & Jun. & 1962 & 19,363 & 29 & Mar. & 1963 & 19,777 \\
\hline 29 & Jun. & 1962 & 16,284 & 26 & Apr. & 1963 & 19,433 \\
\hline 27 & Jul. & 1962 & 14,195 & 31 & May & 1963 & 14,682 \\
\hline
\end{tabular}

a matter of finding jobs for men, but finding all the men for all the jobs. (Courier-Mail: 3 July 1957)

The Liberal Party was genuinely embarrassed about this in 1963, and more concerned about the promise than about the actual figures. The latter they could obfuscate with qualifications, but there was little they could do about the former save say that the happy day was just around the corner.

1963 opened with the Premier announcing the State Government's new plans to combat off-season unemployment prior to the reopening of the sugar and meat seasons. $£ 500,000$ would be spent by the Main Roads, Forestry, and Works Departments and the Housing Commission, in addition to the $f 1$ million already committed to the new bulk sugar terminal at Cairns and extensions to the Mackay terminal. The proposals were welcomed as 'a realistic approach' by the Townsville Daily Bulletin (10 January 1963) and a wise discharge of the Government's responsibilities by the Toowoomba Chronicle (10 January 1963), but most quarters waited anxiously for the December unemployment figures (which would reflect the first wave of schoolleavers registering for employment-22,500 teenagers had left school in December) and for the Commonwealth Government's annual consultation of business and financial leaders on the state of the economy due in mid-February. When they came on 14 January, the figures produced headlines. National unemployment was again over the 100,000 total-the generally accepted hallmark for electoral troublehaving gone up 20,000 since November. Queensland, with 4.1 per cent of its work force unemployed, was significantly above the national average of 2.4 per cent. The federal Minister of Labour attributed the general rise to the number of school-leavers, and 'an abnormally high level' of unemployment in Queensland to the late finish of the sugar harvest. The increase of 7,900 in Queensland was spread over the whole State, but was particularly pronounced in the sugar townsCairns 692 (224 in November), Ayr 519 (159), Mackay 547 (159) and 
Bundaberg 862 (246). In Brisbane the number of registered unemployed was 4,502 instead of 3,188 in November.

The first attack on the Government's record came from Lloyd, who accused the State Government of 'improper' use of $f^{7}$ million in Commonwealth grants over the preceding twelve months to reduce accumulated deficits instead of getting on with eliminating unemployment. However, the Queensland press generally looked to the Commonwealth Government for further action by new incentives before the next federal budget due in August (Telegraph: 15 January 1963; News-Mail (Bundaberg): 16 January 1963) although the Toowoomba Chronicle (16 January 1963) thought that both Commonwealth and State Governments should provide more funds for local authorities. The Government's supporters saw little cause for anxiety. Thus the Rockhampton Morning Bulletin:

While there is no cause for joy in the unemployment figures released this week ... there is also little reason for them to be used as a political lash for the time-honoured pastime of Governmentscourging. Even though more than 100,000 were registered for employment at the end of December, this figure is considerably lower than might have been expected a year ago, and is not nearly so bad as it appears at first glance . . . Nobody who cares to think about the problems of employment on a national scale can imagine that with one sweep of a fairy wand a Government can undo the cumulative effect of a heady boom followed by a period of readjustment. The only real recovery can be a steady one, aimed at all sections of the economy. (18 January 1963)

The Gympie Times (19 January) warned against inflationary measures being taken, and cited unions' demands for a 35-hour week as evidence of lack of responsibility in dealing with the unemployment problem.

The first step taken by the State Government was to provide places for school-leavers in industry by relaxing apprenticeship conditions, permitting employers more apprentices than prescribed by the apprenticeship regulations and stating that apprenticeship authorities were prepared 'to listen to any proposition' which might lead to the employment of more young people. The Minister for Labour and Industry, commenting on the December unemployment figures, observed that 70 per cent of the increase was in the towns affected by seasonal unemployment, the figure of 4.1 per cent was still down 0.4 per cent from the previous December notwithstanding a large increase in the number of school-leavers, and in view of the general improvement in the State economy a more rapid recovery could be expected. Dewar also introduced a point which figured in subsequent Government defences of their unemployment record: seasonal workers enjoyed higher rates of pay to compensate for their seasonal unemployment (Maryborough Chronicle: 16 January 1963). On 16 January the Minister for Works released details of a special works program costing $£ 157,000$ 
designed to relieve unemployment through the building industry; emphasis was to be placed on a number of small works rather than a smaller number of large works, the additional planning of which would delay action.

On 15 January, the same day that Dewar had announced relaxed apprenticeship conditions, a letter from the Minister for Transport to the secretary of the Amalgamated Engineering Union, Jack Devereux, was released. In it Chalk advised that the Railways Department would take on only fifty-one apprentices in 1963, sixteen fewer than in 1962; of these, thirty-five would be at Ipswich, and the rest at Rockhampton, Townsville, and Cairns. Devereux promptly complained that the Government was failing in its responsibility to the people, especially in North Queensland where the railway workshops trained skilled tradesmen for industry generally. Egerton, speaking as secretary of the Boilermaker's Society, condemned the changes in apprenticeship conditions as meaning little: for many years employers had been allowed to employ more apprentices than the regulations provided for, but many had not taken on even their regular quota. He advocated improved training facilities, a revised syllabus, daylight training, and higher wages for both apprentices and tradesmen as an inducement for youths to enter apprenticeships (Telegraph: 16 January 1963). The first meeting of the Queensland Trades and Labor Council on 16 January decided to call a special statewide meeting on unemployment together with a series of meetings in country centres, to ask the A.C.T.U. to initiate a national campaign for full employment, to ask Nicklin to receive a deputation to hear the unions' proposals for solving the unemployment problem with special emphasis on the difficulties of school-leavers and apprentices, and to back the State Government in obtaining a special $£ 20$ million grant for unemployment relief from the Commonwealth.

In contrast with the unions' dissatisfaction, the Government's measures received a good press. The Queensland Times (17 January 1963) hailed the apprenticeship proposals as 'a welcome plan' and warned that 'party politics should not enter into discussion of this important subject'. The Townstille Daily Bulletin thought that the $£ 157,000$ building program would 'greatly refresh' the building industry and commended the Government:

The Nicklin Government has never been lacking when there is a chance to keep any industry moving. It appears to have its fingers on the pulse of public demand, irrespective of where the need may be. (18 January 1963)

The same number of the Daily Bulletin reported the efforts of a number of local employers to increase their intake of apprentices, although the figures given for the number of applications suggested the 
magnitude of the problem: five employers had thirty-six vacancies and 250 applications.

During January a series of press reports featured unemployment stories: demonstrators around the office of the Minister for Health and Home Affairs in Brisbane, queues of applicants for one or two jobs in provincial cities, and local authorities laying off men because of insufficient funds. In its February industrial report the Queensland Employers' Federation criticised the Government for not calling a conference on junior unemployment. The Telegraph (24 January 1963) warned that unemployment would be a major issue at the election, whatever happened from good rain and increased public spending, and the January unemployment figures announced on 18 February brought the proportion of the State work force registered for employment to 4.4 per cent, 1.8 per cent above the national average. The State Government had approved new expenditure of $£ 450,000$ in January, and in February it deployed the additional funds rapidly through the provincial cities which were the hardest hit areas. Press grumbling for a day or two after the January figures were announced changed to happy reports of money trickling down to the local authorities. A Brisbane despatch in the Cairns Post summed it up:

The big new works programme will have a marked effect on the coming elections, despite any claims by the Opposition that the money is being spent in an effort by the Government to gain kudos. Work is real, criticism is only froth, and would not provide a starving man with a crust of bread.

Mr Duggan and his men will have to do something much more than indulge in criticism if they are to have a chance of even cutting into the Government's present majority. (1 March 1963)

On 6 March the Telegraph reported on a public opinion survey which it had conducted in Brisbane and ten country cities and towns. (The Telegraph did not disclose the size of the sample but said that its members were 'from nearly 100 walks of life'.) The survey found that unemployment rather than left-wing control of the A.L.P. would be the key issue, and that there had been a drop of 6 per cent in support for the Government parties since the previous October when seasonal employment was near its peak. The Telegraph's four polls showed the following percentages:

\begin{tabular}{lcccc}
\hline & April & July & October & February \\
\hline Government parties & 39 & $45 \cdot 0$ & $50 \cdot 7$ & 44.2 \\
A.L.P. & 45 & $46 \cdot 7$ & $43 \cdot 2$ & 44.8 \\
Q.L.P. and undecided & 16 & $8 \cdot 3$ & $6 \cdot 1$ & $11 \cdot 0$ \\
\hline
\end{tabular}

However, as the Telegraph pointed out, with 44 per cent of the primary votes the Government was certain of re-election, especially under 
preferential voting, and the improvement in employment in May and early June would also improve its position. Indeed hundreds of meat workers were already returning to their seasonal employment in provincial meatworks at Townsville, Gladstone, and Bowen.

It was only at this stage that the Australian Labor Party and the unions moved to the attack in a big way. A conference of 120 northern trade unionists at Townsville (Townsville Daily Bulletin: 11 March 1963) condemned the Government for failing to plan and provide employment, particularly for juniors, and accused it of hoarding money from 1962 for a pre-election splash. The unionists called for an immediate Commonwealth grant, and the 35-hour week and threeweeks annual leave as parts of a policy of full employment. Duggan then intervened with a major speech at a public meeting in the Ipswich Trades Hall convened to protest against unemployment but more immediately triggered off by the dismissal of seventy miners from the West Moreton coal field. Duggan declared that in his opinion:

The cancer of unemployment will be the predominant factor to be considered at the forthcoming State election. The test of good Government is not to succeed in the art of 'ballyhoo' or to engage in character smears and assassination, but to promote the development of the State and the well-being of its people. (Queensland Times (Ipswich): 13 March 1963)

His attack on the Government centred on two features of the unemployment situation-the rise in the proportion of the work force unemployed from 1.4 per cent when Labor left office in 1957 to 4.4 per cent in January, and the fact that 40 per cent of the unemployed were under the age of 21 . The work force in factories had actually fallen by 200 in the five years of the Nicklin government, which was failing to plan ahead for automation for the re-training of redundant workers.

The figures for February showed some improvement. The State total fell to $3 \cdot 8$ per cent of the work force against a national average of 2.2 per cent. The Telegraph's government roundsman reported (19 March) that the Government was hopeful that another 10,000 would be in jobs by July, by which time the State figure would be near the national average. It appeared that the unemployment pattern was running two months ahead of that of 1962, that is February's figures equalled those of April 1962; the full impact of Commonwealth assistance had not been felt; less than half the registered juniors were school-leavers; the Government was receiving reports of prospective labour shortages in the sugar and tobacco fields of North Queensland, and of tradesmen everywhere. The press reaction varied. Most agreed with the Government that things were getting better, the Telegraph (19 March 1963) remained critical of the Commonwealth Government and the Bundaberg News-Mail (20 March 1963) doubted that 
the State Government could find much comfort in figures which suggested that a hard core of unemployment remained. Nicklin (Queensland Times (Ipswich): 20 March 1963) found encouragement in a drop in what was usually one of the worst months, and the next day the secretary of the Queensland Employers' Federation declared the picture was of potential labour shortage rather than unemployment (ibid.: $21 \mathrm{March}$ ) and was corroborated by the Country Party member for Condamine, Sullivan, who reported that farmers on the Western Downs were unable to get casual labour except at weekends.

A Country Party hand-out which appeared as a statement by various candidates, including Claude Wharton, member for Burnett (Maryborough Chronicle: 28 March 1963), and Michael Turner, candidate for Warrego (Western Star (Roma): 29 March 1963), complained that the A.L.P. argument on unemployment contained flaws, and the actual unemployment figures had been exaggerated "by the left-wing Labor Party to embarrass the Nicklin Government'. A high proportion of the unemployed were seasonal workers whose type of employment had been taken into consideration by the Arbitration Court in fixing wage rates. Many of the juniors were untrained, and if some of the 800-1,000 married women were deducted 'the number requiring employment would be relatively small and would exist whichever government was in power'.

The March figures showed further improvement, down to $3 \cdot 3$ per cent against a national average of 2 per cent. The Courier-Mail (18 April) warned that the Queensland figure was inflated by 'resting' seasonal workers, but the Telegraph (18 April) found no cause to be 'unduly jubilant' yet. Continued reports of employment-generating projects by local authorities were now mixed with statements about labour shortages. Thus the president of the Employers' Association of Central Queensland in his annual report referred to the scarcity of skilled tradesmen and the dangers of union demands for higher margins and other benefits. The secretary of the Queensland Cane Growers' Council reported (Cairns Post: 4 May 1963) that the belated arrival of cane cutters was causing anxiety in North Queensland. The Bowen Independent (10 May 1963) stated that 'a comprehensive survey' of school-leavers in the Bowen electorate found only ten of the 162 with Junior passes still unemployed, and a concerted effort by employers would quickly absorb them.

Certain A.L.P. candidates by now had warmed to their task over unemployment, and Russ Hall, candidate for Balonne, provides one of the most elaborate cases (Western Star (Roma): 30 April and 8 May 1963). The Premier had waited until the peak of seasonal unemployment had passed before he dared announce the election date. Queensland was particularly prone to seasonal unemployment and under Labor governments public works and local authority projects took 
up much of the slack. However the 'Liberal Government' had neglected this, and seasonal unemployment had grown every year:

The callous indifference of the Liberal Party which now dominates the Government of Queensland, to the plight of the unemployed should never be seen in a civilised community.

Some 7,000 of the unemployed were under twenty-one, 37 per cent of the total, and another 3,000 had been sent back to school by their parents because no jobs were offering. Unless something drastic were done, these 10,000 would be joined by another 25,000 school-leavers at the end of 1963. The Government's own apprenticeship policy was a sorry example to private employers, and those who had finished their apprenticeships were often dismissed or offered sub-standard jobs at the end of their courses. In Toowoomba, Peter Wood, the candidate for Toowoomba East, queried the relationship between juvenile delinquency and the high rate of juvenile unemployment (Toowoomba Chronicle: 7 May 1963).

The April figures provided small comfort for the Government. Queensland's proportion fell to $3 \cdot 2$ per cent against a constant 2 per cent national average. The Telegraph snapped:

No one can be satisfied with this unhappy situation or with rather vague claims that something will turn up soon to effect a remedy. Queenslanders will be looking for a dramatic recovery to match the Premier's promise that in six months there will be more jobs than applicants. (14 May 1963)

Nevertheless, its government roundsman repeated that the Government was still hopeful of having 10,000 more in jobs by the end of June and the State proportion down to the national average. Eight thousand men would be required within a fortnight for the start of the sugar season, and another thousand at the meatworks. Nicklin added that the A.L.P. was still trying to make an issue out of unemployment because it was its last and only hope of winning votes, even though Labor governments had never in their long years of office ever achieved 'literal full employment'.

A minor stir was created when a report to the Presbyterian Church's State Assembly said that prospective migrants had been advised that they could not find employment in Queensland, and some had been assisted to settle in other States. The Queensland Employers' Federation secretary, J. R. James, declared that whilst the Church's interest in the State's economic problems was to be commended, its attitude was far from helpful: the State needed migrants urgently. The Minister for Labour and Industry, Dewar, declared that he was convinced that by the end of July the unemployment rate would be below 2 per cent and there would be a shortage of skilled labour; by August the figure would be 'something like' the number when Labor left 
office despite the great increase in the number of school-leavers since then. The Minister went on to explain the slow industrial development of the State by the atmosphere which Labor governments had created and which had lasted for the first four or five years of the present government. The Government had 'killed the dead, dying socialist atmosphere Labor created in this State', and Queensland was on the verge of the greatest industrial revolution Australia had ever known (Telegraph: 20 May 1963). On this prophetic note the cam. paign debate about unemployment came to an end.

A voter seeking to compare the Government's performance in coping with unemployment with the A.L.P.'s hypothetical performance would have a number of preliminary questions to answer. Is dealing with unemployment a responsibility of the Federal Government or of the State Government? How substantial has unemployment been, that is how much significance can he give to the actual numbers of registered unemployed? What weight should he give to seasonal fluctuations in normal unemployment rates? Is a higher rate in Queensland indicative of poor government performance or does it depend upon the structure of the Queensland economy? Although rationally he should compare the Government's real performance with the Opposition's hypothetical performance, A.L.P. candidates ask him rather to compare the Government at $t$ and the A.L.P. at $t-1$, and Dewar suggested that it was Labor's performance over $t-1$ which had caused any Government failures at $t$. Voters would be likely to assess the problem and the Government's policies from highly specific news stories of the number of applicants for a particular job or the allocation of funds for a specific relief project. Very rarely, a candidate might provide a reasoned statement which could be used on the rational model: Russ Hall did in Balonne, and so did the Country Party candidates who adopted the Party's handout. Specific policies might be introduced by sources other than the parties: Egerton made a number of suggestions for dealing with juvenile unemployment through the apprenticeship system but he was speaking on behalf of the Trades and Labour Council rather than as a member of the inner executive of the Q.C.E. The rational voter would have his job cut out for him.

\section{Relations with the unions 1963}

A perennial position issue area in Australian elections must be the satisfaction of the current demands of the trade unions. As the Australian Labor Party is permanently committed to the syndical satisfaction of the labour movement, its problem is to advance this interest without being identified in the mind of the general public with over- 
satisfaction of the unions' demands. As the Liberal Party chooses to identify itself with a 'national' interest, it has to balance such recognition of trade union demands as are compatible with such an interest without thereby antagonising those business and financial interests, the employers, which provide its principal financial support and sit in its councils. The Country Party has the easiest task of the three, for its commitment is to the syndical satisfaction of a geographic section in which organised labour is a relatively small minority. Thus the Downs model fails us at once: for the Liberal Party and the A.L.P. we have to introduce the interest of the extra-parliamentary party and the syndicate whose concerns are not with maximising votes, and in the Country Party we have a party which seeks to maximise its votes in only part of the electorate. We shall see how these modifications affect rationality as we proceed. Three particular issues were prominent during the 1963 election campaign: three-weeks annual leave, a 35-hour week, and the Moura strike.

On 4 December 1962 a meeting of union shop-stewards and jobstewards in Brisbane launched a campaign for increased margins, the 35-hour week, and three-weeks annual leave in 1963. The campaign produced hostile reactions, but the Telegraph (14 January 1963) suspected that the 35 -hour week would prove tempting election bait. On 25 January an application for three-weeks leave for 250,000 State award employees was filed on behalf of the Amalgamated Society of Carpenters and Joiners and all unions affiliated to the Trades and Labor Council. Arguments advanced in the application were that the Commonwealth Conciliation and Arbitration Commission was to hear a similar application for Federal award employees on 5 February, that workers were entitled to a greater share of increased productivity, and that extra leave was desirable in the interests of production and of employees' health and their need for more time with their families and social obligations in view of the increasing tension and complexity of society. As in the previous November the Liberal Party State Council had endorsed the principle of three-weeks leave but left its implementation to the State Industrial Conciliation and Arbitration Commission, it was unlikely that the State Government would intervene. On 9 April the State Industrial Commission granted rises to 10,000 public servants and 8,500 teachers retrospective to 1 January, and on 10 April 2,600 non-commissioned policemen and 1,500 hospital employees received similar rises. Annual increases ranged from $£ 250$ to $£ 50$ for public servants, $£ 175$ to $£ 20$ for teachers, and $£^{74}$ to $£^{15}$ for policemen. On 18 April the Commonwealth Commission awarded three-weeks annual leave and 10 per cent margins rise to the $1 \frac{1}{2}$ million workers covered by Federal awards. On 26 April the basic wage for Queensland rose by 2s. for males and 1s. 6d. for females. The tide was clearly running in the direction of the unions' 
demands. The employers chose to oppose the three-weeks leave application, but the unions, heartened by the Federal award, filed for 10 per cent margins increase as well. The case came before the State Commission on 20 May, when the Crown advocate told the Commission that the State Government, speaking as an employer, was prepared to see the extra leave granted-two-thirds of State employees already had it, anyway. The Commission promptly granted the request.

The Maryborough Chronicle commented:

Mr Gair, listening in, may have winced at some mental picture of Mr Duggan as Premier standing, as it were, on some body nearly bowed and undeniably bloodied while he introduced the legislation which had made and shattered their respective political careers.

Grateful now Mr Gair may be that this is illusion; despondent Mr Duggan may be that his armoury has lost a formidable weapon; and happy the Liberal-Country Party Coalition must be that the State Industrial Commission has taken it out of everybody's hands. (22 May 1963)

In Berelson's terms, the three-weeks leave issue had passed through the gateway. Its dangers to the Government were avoided by the institutional situation in which the decision was taken by a non-partisan body. To a considerable extent Duggan, who for reasons of party history was bound to pursue the issue vigorously, was saved from reopening the wounds of 1957 and becoming directly embroiled with employers who were opposed to the increased benefits. One of his opponents warned against any attempt by the A.L.P. to claim credit for the issue's successful passage:

As the present leave decision has come at the time of a State election campaign when the Australian Labour Party is exploring desperately every avenue to bolster its polling platform, it can be expected that this conclusion will be allied to the clamour the party made six years ago, to foist legislation to achieve this result on to the electorate by by-passing accepted industrial channels . . . If the finalisation of this matter has any message for the electors of the campaign it is that Queenslanders stand for the democratic processes of arbitration and conciliation as the only safeguard to the democratic way of life. They should think carefully on June 1 before they pass this over to a party under Left wing control. (Daily Mercury (Mackay): 22 May 1963)

A position issue much more in the gateway was the Moura strike, and its style issue aspect of Communist influence in unions gave it additional prominence. On 21 January eighty members of the Queensland Colliery Employees' Union, the Amalgamated Engineering Union and the Federated Engine Drivers and Firemen's Association, struck at the open-cast coal mine at Moura in Central Queensland. The first strike of twenty-four hours was on the ground that non-union labour had loaded wagons at the weekend, and on 22 February (Townstille 
Daily Bulletin: 26 February 1963) the men went out again, this time demanding wage increases and a site allowance of $£ 12$ 12s. a week. The press report said that 'it was officially stated today' that such increases would mean that the man who presently got $£ 16$ 10s. for washing out the bathrooms would receive $£ 42$ 3s. weekly. The Trades and Labor Council president, Egerton, declared that open-cut miners were not covered by the Queensland award; Evans, Minister for Mines, stated that they were covered by a Federal award, but was contradicted by the Colliery Employees' Union secretary, Cyril Vickers. The seriousness of the matter was foreshadowed by a Morning Bulletin headline on 28 February: BITTER STRUGGLE EXPECTED IN MOURA DISPUTE.

The Queensland Coal Owners' Association obtained a back-to-work order from the Coal Reference Board chairman at a hearing in which the owners charged that the strike was designed to protect underground miners elsewhere, and the union spokesman, Devereux of the Engineers, denied that it was part of an organised attempt to stop production at Moura, and declared it arose in protest against conditions at the mine. A meeting of the strikers decided almost unanimously to disregard the order, and an appeal was lodged. Evans charged that the Communist-controlled Miners' Federation was trying to help its New South Wales members by forcing Queensland out of a coal export trade and had secured the help of the left-wing Trades and Labor Council to lead Kianga-Moura miners by the nose (Queensland Times (Ipswich): 9 March). The Q.L.P. promptly echoed the charge of Communist influence (Morning Bulletin (Rockhampton): 7 March).

Senior trade unionists converged on Moura, and their spokesman issued (Morning Bulletin (Rockhampton): 11 March 1963) a long list of grievances which made skilful use of trade union suspicion of the introduction of new techniques by American companies and the legitimate complaints of isolated industrial communities, the sort of mixture which, complicated by A.W.U.-Trade Hall rivalry, produced the Mt Isa strike in 1964-5. The Colliery Employees' Union executive challenged Evans to visit Moura and see conditions for himself. The Minister replied that he was not going to fall for 'any Communistinspired three-card trick', the same tactics as had been used unsuccessfully in the dispute which had eventually closed the Collinsville state mine. The people of Queensland would not be misled by the claim of union leaders that it was a genuine fight over conditions that motivated the strike, and their performance at the Bundaberg Convention had shown what Queenslanders could expect from these men if they achieved power. The Miners' Federation was determined to save the bacon of miners in uneconomical mines in New South Wales by destroying Queensland exports. In trying to trap him into 
speaking the unionists sought to short-circuit the arbitration system which their Communist bosses wished to destroy. Neither he nor the company had any power to determine the unions' claims for wages and conditions, which were determined by industrial law and awards, and many of the matters involved should be decided by industry-wide arbitration.

Vickers for the Q.C.E.U. (Telegraph: 12 March 1963) denied the charge that the strike was designed to aid New South Wales miners and that there was Communist influence-he was a member of the A.L.P., the union president, Tom Millar was a Communist, and the vice-president, Richard James, belonged to no party. The unsatisfactory conditions had been raised before the introduction of a huge dragline had raised the question of productivity. Vickers still hoped that the Minister would accept the unions' bona fide challenge to inspect conditions. The Minister replied at once that conditions at the mine were a matter for the Banana Shire health inspector, and working conditions were a matter for the industrial inspector. He again asserted that the stoppage was Communist-inspired and quoted Common Cause, the N.S.W. miners' journal, in proof.

It might appear that Evans was trying to have the best of both worlds, denying ministerial responsibility whilst scoring off the Communist connections of the unions and by proxy the A.L.P., but such a suspicion would have to be considered with the long-held belief of members of the Queensland Government and of Queensland employers that there was a Communist-inspired conspiracy to frustrate Queensland development. Evans continued to fish in troubled waters when, addressing the annual conference of the Australian Sugar Producers' Association, he went out of his way to praise the A.W.U., a law-abiding union dedicated to arbitration, which he contrasted with the leftwing unions trying to stop open-cut mining and to get men $£ 4210 \mathrm{~s}$. $0 \mathrm{~d}$. a week for sweeping out a bathroom. Duggan joined the fray at this point to complain that the Minister had acted 'with unseeming haste to present the employers' case': the A.L.P. had supported the Moura open-cut scheme in the Parliamentary debate and supported arbitration whilst the Government interfered with it, as when it removed the Court's power to increase lead bonus payments while providing power to reduce them (another matter which was to figure in the $\mathrm{Mt}$. Isa strike).

Up to this point it appeared that matters were running in favour of the employers and the Government. However, on 15 March the Courier-Mail's leading political reporter wrote of his visit to Moura under the heading: MOURA TOWNSHIP IS JUST A SORDID SLUM. He found conditions a disgrace to Banana Shire and the State, and described the plight of one family in the same terms as the unions had used. 
The same number of the paper also reported Evans's reply to Duggan. He, the Minister, had not been defending the employers but the people of Queensland and the law-abiding workers of Moura, but it was clear that Duggan was backing the attitudes of Millar, Macdonald 'and others of their calibre' (both being prominent Com. munists). The next day he repeated that living conditions were a matter for Banana Shire and the unions. He agreed that accommodation was not up to standard and declared he would not protect companies or individuals which did not conform to health regulations, but the matter was not one for him (Morning Bulletin (Rockhampton): 16 March 1963). Duggan protested against Evans's recent disposition to take any criticism as Communist-inspired, and observed that the union representatives had expressed their views more mildly than the Minister had when he had been a militant union representative (Queensland Times (Ipswich): 16 March 1963).

The first hearings began before Mr Justice Gallagher of the Coal Industry Tribunal in Sydney on 21 March. The men were ordered to resume work on $29 \mathrm{March}$, refused, and an anti-strike clause was added to the award to protect overseas trade. Mr Justice Gallagher added that accommodation was undoubtedly bad and fell below the standards to be expected even in a remote spot in Central Queensland, although he found the charge that the employer had been impervious to or completely neglectful of the need for adequate accommodation to be false, misleading, and without foundation. Charges that the strike was part of a Communist plot continued. Thus 'A Live Unionist' wrote to the Maryborough Chronicle (3 April 1963) that a 'full-time industrial strategist of the Communist Party' had visited Queensland several weeks before the strike started to bring a plan of action for a series of political strikes designed to strengthen Communist influence in industrial matters, and the Queensland Employers' Federation secretary, J. R. James, charged (Queensland Times (Ipswich): 6 April 1963) that the Moura dispute was the start of a general campaign by the Trades and Labour Council under the influence of a small but influential section of its disputes committee to bypass arbitration. On 8 April the men voted to return to work. The Banana Shire council decided to give miners living in temporary accommodation three months in which to find permanent accommodation, on the advice of the council's health inspector that standards were below those of a permanent camp.

Hearings of the employees' claims began again before the Coal Industry Tribunal on 17 April. On 18 April Mr Justice Gallagher spoke sharply about conditions. It was an absolutely monstrous state of affairs for 1963. The project should not have been started without proper arrangements for employees' accommodation, and he directed that photographs produced in evidence be given to the press. Whilst he 
doubted whether it lay in his power to make an order about accommodation, he 'would not expect any company with any decency to condone such a situation' (Morning Bulletin (Rockhampton): 19 April 1963). The next day, awarding a site allowance of $f 1$ as an interim measure, he described existing living conditions as "nauseating, revolting and degrading'. On 20 April the Morning Bulletin reported that the Treasurer had authorised the Housing Commission to proceed immediately to build six houses at Moura. It added that Hiley had visited Moura before Christmas 1962, and had been told, on the basis of questionnaires distributed by the company, that the men preferred to live at Biloela where there were facilities; accordingly the Housing Commission had let contracts for twenty-two houses at Biloela during the first three months of 1963.

Here the matter was dropped. The Morning Bulletin editorial (22 April 1963) merely reported Mr Justice Gallagher's comments on conditions. On the one hand the Minister for Mines' view that the strike was a put-up job had been discredited by the Tribunal's findings and the press reports and photographs. On the other hand the taint of Communist unionists was so dangerous to the A.L.P. that Duggan was probably wise to leave it alone. The charge of a leftwing plan to reverse a settled policy and scrap arbitration was a potent one; ever since the defeat of the Bruce-Page government in 1929 (Carboch 1958), reports of attempts to tamper with arbitration are thought likely to inflame the electorate-and not only that part of it whose working conditions are regulated by arbitral awards.

This was an issue with an extremely short life. Its contribution to the electoral decision would have been to reinforce party images: Government supporters' ideas of greedy unionists, Communist influence and forces outside Queensland operating on the A.L.P., and A.L.P. supporters' ideas of a Government impervious to the needs of the workers. The Government denied that it could offer a policy at all, the A.L.P. certainly did not say what it would have done.

\section{Moonie pipes 1963}

Development of the Moonie oil field near Roma was one of the brightest jewels in the Country-Liberal government's crown-both the government 1963 brochure, 'Achievement' and Nicklin's 1962 Christmas cards bore pictures of an oil rig. In September 1962 the Union Oil Company announced that it would build a pipeline from the Moonie field to Brisbane at a cost estimated between $£^{5}$ million and £8 million, and on 18 January 1963 Ampol Petroleum announced that it was shifting a refinery which it had intended to build in Queensland from Port Alma near Rockhampton to Brisbane because of the location of the pipeline. Evans predicted that oil would be flowing 
through the pipeline by the end of 1963. Even the Mayor of Rockhampton, Alderman Pilbeam, bit bravely on the bullet: once the pipeline was decided there was no other possible site for a refinery, and he remained confident of the future of Rockhampton and Port Alma'Something else will turn up. Our turn will come' (Morning Bulletin (Rockhampton): 19 January 1963). The only grumbling came from grain growers who sought protection against the disturbances of oil exploration-and they received short shrift from their central council and from Evans, who said that the rights of graziers and farmers were amply protected by legislation.

On 4 February the resident manager of Union Oil Development confirmed that it was expected that the pipeline would be completed by the end of the year, and added that he did not expect any mechanical or engineering difficulties from the job. Local papers waxed ecstatic:

Improved techniques and better equipment will cut the cost of the pipeline construction, as well as the time involved, but it will still be a big-scale enterprise, and will provide more employment and be a useful investment in the State ... While all concerned are plotting the course, Queensland, secure now in its new and priceless possession, views with confidence what is probably the brightest horizon in its century of history. (Toowoomba Chronicle: 6 February 1963)

Here is the boost the State has been waiting for. It should not be long before the Cinderella days are little more than a memory. The State's hopes extend far beyond the royalties the Government will receive. Of even greater importance is the stimulus to other industries. This could be the start of Queensland's golden era. We inust be ready to make the most of it. (Telegraph: 7 February 1963)

Evans, returning from a private trip to Japan, remarked casually that Japanese interests were anxious to win the contract to supply the pipes for the pipeline. His words were noted by Alderman McCafferty, the A.L.P. Mayor of Toowoomba, who suggested that so historic an occasion as Australia's discovery of its first oil field warranted Australian-made steel in the pipes; overseas experience had shown that the firms which were associated with the early stages of pipeline building usually obtain subsequent contracts, and as there was a high labour content in steel pipes the award of the contract in Australia would help with unemployment (Toowoomba Chronicle: 6 February 1963). Evans had also said that 10,000 tons of steel pipe would be needed, and Australian firms could not manufacture the 10 -inch size required. Egerton, speaking as secretary of the Boilermakers Society, reported that at least two Brisbane firms were prepared to install the necessary equipment to do the job (Telegraph: 6 February 1963), and the Telegraph named two companies prepared to tender. In due course the Trades and Labor Council decided to protest to the Premier against 
material being secured outside Queensland and ask that Evans be withdrawn from further negotiations about the pipeline (Morning Bulletin (Rockhampton): 8 February 1963). The next week Evans, visiting Cairns, defended his stand. The pipes could not be produced in Australia, and whilst he would be happy to see new equipment installed, they had to get on with the job and finish it that year (Cairns Post: 11 February 1963).

Oil excitement grew in mid-February when Ampol announced that it would raise the capital for its new refinery within Australia, and while the company had no commitment to Moonie it was 'naturally logical' to assume a Queensland refinery would refine Moonie oil. Evans predicted a petro-chemical plant would follow the refinery, and a few days later Amoco announced that it was raising its projected Brisbane refinery's capacity by two-thirds. This brought refinery capacity in Brisbane ahead of pipeline capacity and almost double Queensland current consumption. Amid the heady talk of tens of thousands of barrels per day Labor leaders continued to worry about the pipes. Calwell, McDonald and the A.L.P. Central Campaign Committee all expressed disquiet, and were answered by Dewar: the discovery of oil had changed the whole atmosphere of secondary industry in Queensland overnight. Before World War II the A.W.U.dominated A.L.P. had had a vested interest in keeping secondary industry out because it feared craft unions would try to take over the party, but in 1963 projects totalling $£ 230$ million would be started in the State. In the past Queensland had been a dumping ground for southern manufacturers, but a buy-Queensland campaign was about to be launched. Turning to the pipeline question, Dewar explained that the pipes amounted to only 20 per cent of the cost of the pipeline, and there was still plenty of scope for Queensland interests to be served, particularly in terms of labour. The pipeline agreement had given the builders freedom to contract where they wished, and they were buying their steel from the cheapest source (Telegraph: 3 April 1963; Courier-Mail: 4 April 1963).

When it was reported that a Japanese ship had left with the first shipment of pipes, Union Oil Development disclosed the background of the contract. Bechtel Corporation, which was building the pipeline, had modified specifications to make it possible for Australian manufacturers to tender, and tenders had been solicited from possible Australian suppliers as well as several overseas firms. However, Australian suppliers had been amongst the highest tenderers by more than 40 per cent and had been able to supply only a portion of the pipe required and this not fully in accordance with specifications. The company spokesman concluded:

Every effort has been made to implement our company's policy in giving preferential treatment to Australian manufacturers and 
suppliers, when their prices are competitive and delivery dates in accordance with production schedules. (Queensland Times (Ipswich): 6 April 1963)

Meanwhile Duggan had gingerly entered the argument by commenting that it was significant that the Government had not yet made a statement on the question. Conceding that the company had a right to make its own decisions, he thought it was still within the Government's power to provide 'a substantial measure of preference' for Australian and Queensland firms-and it should have done so (Courier-Mail: 4 April 1963). Duggan had made his observations on the same day that Dewar defended the Government, and the Government added nothing to the explanation provided by Union Oil Development.

The first shipment of Japanese pipes arrived on the Wakatoku Maru on 15 April, and the night before the ship was due to dock Nicklin appealed to unionists not to do anything which would delay the pipeline project. Reminding Queenslanders that Japan was now Queensland's biggest market for wool and Queensland had to purchase goods in return, he said:

It is unfortunate that Queensland marufacturers did not win the contract to supply the pipes. But we must be sensible about it. The pipelines will be laid by Queenslanders and when completed it will be of incalculable benefit to the State. Anyone foolish enough to stop or delay the project will not get much public sympathy. (Courier-Mail: 15 April 1963)

The president of the Queensland Employers' Federation, Peter Bell, was more suspicious: Communists at Trades Hall were determined to block the pipeline. If they succeeded they would go on to defeat other development schemes such as the brigalow belt and the oil refineries, but, 'it is not the true Labor men who are trying to block the pipeline'. If Queensland did not buy goods from Japan, the Japanese would turn to synthetics instead of wool (ibid.). However, despite rumblings from the Waterside Workers Federation national secretary and Brisbane branch president and from Egerton, McDonald and Whitlam, unionists confined themselves to a lunchtime protest meeting which asked for an inquiry. When a delegation sought to meet Nicklin he declined to see them, and replied by letter that at his request the Bechtel Corporation had invited quotations from Australian suppliers but these had been unsatisfactory. A fuller statement was provided by the Commonwealth Minister for National Development, Senator William Spooner, passing through Brisbane en route to Weipa. The company had invited quotations from Australian companies and modified the specifications to give them every chance. Nevertheless no Australian tenderer was able to provide the whole pipeline; indeed the two companies who tendered could not in combination, and one of 
them could not provide the proper lengths of pipe and so would have increased costs considerably. Speed was important in getting the field into production, and the company concerned was spending $£^{3}$ million a year in exploration and should be encouraged. Japan was buying three million tons of coal from Australia, thereby providing employment for 2,000-3,000 miners:

We need to buy what we can from Japan if we are to expect to sell to Japan. The Japanese supplier won this contract in circumstances in which Australian companies could not supply and in the face of world competition. It would be bad luck for Australia if the Japanese steel industry thought this irresponsible criticism of the Moonie pipeline contract represented the views of Australia. (Courier-Mail: 18 April 1963)

There the matter rested in Queensland. The Toowoomba Chronicle charged that an attempt was being made to make political capital and industrial unrest out of the issue (18 April 1963), but no such activity was evident. A few candidates grumbled at street-corner meetings, but the general desire to get the oil flowing and to avoid frightening would-be investors made the issue too hot for the A.L.P. In Canberra the Federal Treasurer took a swipe at Whitlam for encouraging militant trade unionists and worrying the Japanese. Evans and Egerton squabbled over how many Australian companies had tendered and how much labour would have to be imported to build the pipeline. Sunday Truth (21 April 1963) seized on the statement that Japanese pipe was cheaper to proclaim that 'Australian workmen are not going to give up a decent way of life to live in tar-paper shacks and eat boiled rice . . 2 , and subsequently complained (28 April 1963) that the A.L.P. was more interested in political tactics than in opposing the free trade principle involved in the importation which would threaten Queensland's future. Later still the same journalist (12 May 1963) attacked the quality of the Japanese pipes, and apropos of Spooner's and Evans's statements explained that the claim that the 'required' size of pipes could not be made in Queensland merely meant that Queensland pipes were in shorter lengths and thus required more welding and were more expensive. He flatly denied the argument that Australian pipes could not have been delivered in time.

Another line of thought was opened up in Rockhampton when a prominent member of the A.L.P., Dr Doug. Everingham, pointed to 'conflicting statements' as to why Australian pipes were unsuitable and asked why delivery had to be so prompt. The Morning Bulletin (22 April 1963) replied that 'the main essential was to get the [Moonie] field developed as quickly as possible so that Queensland could enjoy one of its most important natural resources which had been sought for so long'. Would Dr Everingham delay this while the inquiry 
on the contract went on? More ingeniously the Q.L.P. candidate for Callide, Mrs N. H. Green, asked:

The category of oil pipes Japan is selling to Australia are at present in demand by Russia for the expansion of her oil industry. The U.S.S.R. is currently seeking to obtain supply oil pipeline material from Japan [sic]. Could the Trades Hall leaders have in mind that they would assist Russia's chances of extending her oil industry by obtaining a supply of oil pipes originally scheduled for Australia's development? (Ibid.: 25 April 1963)

Here was one of the few issues on which, albeit gradually, what appears to have been all the facts were disclosed to the public. As with the Moura strike the A.L.P. was hampered by having to avoid too close an identification with the militant unions, and even more than at Moura to avoid appearing to be the party that would shoot the Santa Claus of development. Any suggestion of hampering the development of the oil field at Moonie was politically dangerous, and the fact that the Employers' Federation and the Queensland Chamber of Manufactures (Sunday Truth: 17 April 1963) stood up to be counted on the side of the Government made it difficult for the unions to claim to speak for the interest of Queensland industry as a whole. Here again what was basically a position issue was clouded by style aspects-foreign exploitation on one side, Communist influence on the other.

\section{Housing and the State Government Insurance Office 1963}

The demand for more and cheaper housing is a perennial issue in Australian politics, and the State Government scored the first point by announcing early in January 1963 that as a result of the State's improved finances an extra $£ 343,000$ was to be spent on a further 400 Housing Commission homes in the first half of the year. The fact that new houses were to be built in twenty-nine country centres as well as four Brisbane suburbs came in for special praise. In February the Treasurer added a further $£ 350,000$ from the new Loan Council allocations designed, in part, to reduce unemployment.

Munro gave the Government's policy on housing in his policy speech, and claimed that the number of houses completed each year had increased over Labor's last year of office, in recent years by onethird more. His Government had supported the co-operative building societies, whereas Labor had not, and now proposed to extend its guarantee to societies formed to provide finance for the purchase of existing houses. It would also extend the list of hard consumer goods items covered by Housing Commission finance to refrigerators and washing machines "provided that such appliances are made in Queens- 
land', and increase the maximum advance limit from $£ 3,500$ to cover those items.

Duggan's housing program was much more elaborate: (i) Housing Commission interest rates to be reduced from $5 \frac{1}{4}$ per cent to $4 \frac{3}{4}$ per cent and, if the Commonwealth Bond rate fell, to $4 \frac{1}{4}$ per cent; (ii) empower the Housing Commission to give 95 per cent loans; (iii) 'utilise the resources of the State Government Insurance Office to provide the initial finance for the purchase of approved houses', at as low a rate of interest as possible, probably $4 \frac{3}{4}$ per cent; (iv) permit the purchase of State rental homes by tenants of an approved period of rental on no deposit; (v) investigate Crown land in urban areas for subdivision and development; (vi) provide more houses for rental rather than sale; (vii) seek the establishment of a rental rebate system for tenants drawing unemployment or sickness benefits; (viii) seek a Commonwealth subsidy for cheaper rentals for pensioners in State houses or flats; (ix) institute a survey of housing needs in every town and city; ( $x$ ) insist on the armed services having only their quota of housing.

The A.L.P. denounced the Government's offer of assistance with refrigerators and washing machines as a sham because no firm in Queensland then manufactured these items, but most inter-party arguments centred around Duggan's scheme to employ S.G.I.O. funds for housing. Speaking at Ingham on 11 May Nicklin denounced the idea of a 'bare-faced raid' on policy-holders' funds because the low rates proposed by Duggan could deprive policy-holders of bonuses built up over the years and would reduce the value of the policies as these 'raids' continued:

It was bad enough raiding Government funds, but it was completely reprehensible to raid funds belonging to someone else ... This is one of the most disgraceful actions of its kind ever attempted by any political party and a repudiation of the rights of policyholders. (Morning Bulletin (Rockhampton): 13 May 1963)

It would also deprive shire councils of this source of funds and thus mean 'fewer amenities for the people'.

Nicklin was promptly answered by Lloyd, who said that the Premier was guilty of amazing ignorance ("typical of the form of government suffered by Queensland during the last six years') of the activities of the State Government Insurance Office, which had lent $f 1$ million to co-operative societies for housing at 5 per cent. The A.L.P. had no intention of using S.G.I.O. funds in place of Housing Commission funds, but would expand its activities into the home purchasing field at current Commonwealth Bond interest rates (Toowoomba Chronicle: 13 May 1963). Duggan added that Nicklin's attack confirmed the suspicion that he was suffering from 'election jitters'. Lloyd had already answered the charge, but it should also be 
remembered that the State Government Insurance Office was a creation of a Labor government and had been opposed by members of the present government. Duggan said that the A.L.P. believed that it could finance its housing policy without recourse to S.G.I.O. funds, but 'any investment that might flow from that institution for housing would be used with a full realisation of the need to help thousands of people without impairing the financial stability of the organisation' (Daily Mercury (Mackay): 14 May 1963).

Nicklin answered that the reference to the loans to co-operative societies was a red herring to distract attention from a dangerous proposal: to use S.G.I.O. funds at a lower interest rate than it cost the Office to secure them (Telegraph: 14 May 1963). This had definitely been stated in Duggan's policy speech 'and no amount of shuffling and evasion by experts of Mr Lloyd's calibre could controvert the facts'.

Up to this point honours seemed to be with the A.L.P., and the editorial comment of the News-Mail agreed that Duggan had struck a sensitive spot as evidenced by the wildness of Nicklin's reaction (15 May 1963). In his next speech at Innisfail Nicklin contented himself with denying there was a shortage of Housing Commission homes for rent, but a day later at Home Hill he returned to the subject to inquire what existing lending activities of the S.G.I.O. would have to be curtailed to provide housing funds. Duggan had a partial answer when, in the closing days of the campaign, he challenged the Premier to disclose the facts behind an S.G.I.O. loan of $£ 100,000$ to build a block of doctors' offices in Brisbane and charged that signature of the agreement had been delayed to avoid publicity before polling day (Toowoomba Chronicle: 29 May 1963). The Treasurer replied that the loan was indeed a good investment which would bring the S.G.I.O. a lot of new insurance business. The Labor governments of the past had never used a penny of S.G.I.O. funds for housing, but under the present Government $£ 850,000$ had gone into housing-but at the rate of interest currently being charged by the savings banks and other lenders.

The matter could have been represented as a position issue, a choice between the needs of the consumers of cheap housing and the interests of the insured of the S.G.I.O. No one cared to be so explicit. Each side pictured the question as one of management of existing policies. No Liberal suggested that the S.G.I.O. was an example of socialism competing with private enterprise, or denied that cheap housing was a good thing, although it might be added that some years later the president of the Brisbane Chamber of Commerce denounced the State Government for creeping socialism and cited favouritism to the S.G.I.O. in the field of workers' compensation insurance as one example (Courier-Mail: 24 May 1967). No A.L.P. spokesman hinted 
that the needs of the houseless were more pressing than the needs of the holders of insurance policies. Each suggested style points on the periphery of the question. Nicklin thought that the suggestion showed the irresponsibility of the Opposition-and its readiness to be free with other people's money. Duggan pointed to the Government's lack of initiative and readiness to place profits, even of a State enterprise, above considerations of social welfare.

\section{Free hospitalisation 1963}

From time immemorial Labor speakers have warned that the return of a non-Labor government imperils existing social welfare schemes. As J. H. Mann put it in 1957 to a rally of unionists:

I want you to go out and walk your boots off to see that those who oppose Labour at the next election-those who are out to wreck Labour-be not returned to power. I want to warn you that your long service leave is in jeopardy, your extra sick leave is in jeopardy, your two smokos are in jeopardy, and I would say that even your 40-hour week is in jeopardy. (Courier-Mail: 13 May 1957)

In particular ever since Hanlon had introduced free hospitalisation, the A.L.P. had warned that its departure from office would mean an attack on the benefit. Thus in 1957 Duggan in his policy speech on 4 July promised to maintain it and added: 'We cannot trust our political opponents to continue free hospitalisation' (ibid.: 5 July 1957)-even though Morris the night before in his policy speech had proposed an eleven-point program of improvements to the service. In 1960 Duggan claimed that the Government had been afraid to make any open attacks on the system, but a number of innovations were undermining it, such as the 'sub-intermediate patient' category by which a patient was given facilities at nine guineas a week on subscribing to a hospital benefits fund but was 'no better off than free public patients' (ibid.: 5 May 1960). In his policy speech Nicklin reported that free hospitalisation had been available all through his Government's term of office, and pledged that it would continue to be available in the future (ibid.: 6 May 1960), and Morris repeated the pledge and promised that the system would be improved and extended' (ibid.: 12 May 1960), claiming that the number of public beds had increased in the previous three years. When 1963 rolled around, Duggan once again raised the subject, but this time only to say:

Labor takes credit for introducing its free hospitalisation policy, and will do everything possible to maintain and extend the benefits which have been enjoyed by the people over the years.

Munro had much more to say in his policy speech: 
Because of our advanced policy on health and hospital services, Queensland has become an object of envy and admiration by other States of the Commonwealth. We have expanded and improved hospital and health services far beyond the limited vision of our predecessors in office.

The Labor Party has persistently endeavoured to implant in the mind of the public the notion that it is our intention to abolish free hospitalisation. This, of course, is quite false.

Not only have we retained free hospital treatment both for inpatients and outpatients as an integral part of our policy but at the same time we have provided increased facilities for those patients who prefer intermediate or private hospital accommodation, with treatment by the doctor of their choice.

Upon our return to office we will continue to maintain, expand and improve the free public hospital system. We are proud of the fact that we are the only Australian government which has been able to maintain its public beds free of cost to its people. In this connection, only recently the Labor Government of New South Wales increased its hospital fees in public wards to $£ 3$ per day, or $f^{21}$ per week.

By way of contrast, in Queensland hospital treatment in public wards is entirely free and beds are immediately available. There is no waiting list of admission to public wards in Queensland as is the rule in other States.

At last the shoe was on the other foot and the suggestion was that Labor governments were the threat to free hospitalisation.

The federal Minister for Repatriation, Swartz, took up the refrain in Toowoomba.

In health, our State Liberal-Country Government has shown an example in many aspects to the rest of the world. Our free hospital services have been expanded and improved; they are the envy of the Commonwealth and the Western world. (Toowoomba Chronicle: 20 May 1963)

Duggan's own first speech in Toowoomba had referred tangentially to health matters: he complained that a cornerstone laying for a new surgical block had been scheduled for mid-week as a Government stunt to get it in before polling day (ibid.: 1 May 1963). As the day approached, argument turned not on free hospitalisation but on the standard of medical services in country areas. There were warm exchanges between Anderson and Duggan as to which party was entitled to credit for the state of hospital facilities in Toowoomba and Munro, Swartz, a Liberal alderman, H. J. Scott, and Wood joined in (ibid., $20,23,25,28,29,30$ May 1963), but they argued within the framework of a free hospitalisation service to which all were committed. In 1966 an A.L.P. advertisement soliciting campaign funds in the west mentioned free hospitalisation as an amenity which had been 'almost abolished' by an autocratic and dictatorial government (Western 
Times (Charleville): 14 April 1966), but this was an old activist's reflex twitch.

The belated demise of free hospitalisation as an issue suggests that the party defending itself on an issue past the gateway may go on in the past rather longer than the party which first raised the issue. The Liberal Party with a settled policy on its hands made a virtue of not trying to reverse it, but also began to exploit the position issue aspects of its administration.

\section{Drink and gambling 1963}

Style issues frequently arise in the fields of drink and gambling legislation, and in Australia there have been many elections in which the battles between the temperance societies and the churches on the one hand and the licensed victuallers and breweries on the other have provided most of the headlines, and a very substantial proportion of the campaign expenses. In South Australia 1938 would have been a vintage year in this respect. In 1963 in Queensland drink and gambling issues appeared in two connections. First, the Country and Liberal parties which in Opposition had vigorously attacked the A.L.P. for its concessions to drinking and gambling had, in office, considerably altered their opinions. One of its friends warned (Telegraph: 5 February 1963) that the Government was in danger of becoming known as a booze and betting government because it had made it easier to drink and was receiving $£ 1$ million a year in betting taxes. Second, the Government had recently established the Totalisator Agency Board which ran betting shops throughout the State; by February there were fifty-three agencies operating and the gross turnover had been more than $£^{2}$ million in just under six months, with 5 per cent of the turnover going into general revenue.

T.A.B. agencies had incurred some unpopularity in the north and west of the State where the availability of licensed betting shops was thought to have curtailed attendances at race meetings, and the operation of a statewide betting agency was suspected of sending money out of country areas into Brisbane. There was speculation that T.A.B. would prove an electoral liability for the Government (Gympie Times: 5 January 1963; Morning Bulletin (Rockhampton): 7 February 1963), and the A.L.P. moved quickly to capitalise upon the possibility. A Caucus sub-committee (composed of two Members for western electorates, J. J. Dufficy and E. C. O'Donnell, and two from Brisbane, Hanlon and Bromley) was reported to be investigating the T.A.B., and Duggan observed that the Government was subordinating the interests of racing to the collection of revenue. Hiley snapped back that the Government was not encouraging gambling and Duggan's statement was 'the voice of the people who waxed fat on illicit bookmaking 
for a generation'. The chairman of the Totalisator Agency Board, A. Sakzewski, declared that extension of its agencies to country areas had not had a detrimental effect on attendance at provincial race meetings. The Caucus committee recommended to the Bundaberg Convention that T.A.B. agencies be restricted to Brisbane and thickly populated country areas, and off-course bookmakers be permitted to operate in northern and western districts. It complained that the Treasurer was not consulting the people about extension of T.A.B. agencies to their centres, and contrasted the A.L.P. legislation of 1954, which had made the licensing of off-course bookmakers a matter of local option.

Evidence that Government members were far from happy with their situation was provided by an election meeting at Longreach (Telegraph: 13 May 1963), where a T.A.B. agency was about to open: the local Member, Rae, said that he had hoped that the Government would delay introducing T.A.B. to country areas until its effects had been studied in some suitable test area, and the Minister for Mines, Evans, supporting him at the meeting, suggested that extension of agencies should be considered by a party meeting, presumably the parliamentary party, and one should not have been taken to Longreach unless it had been requested by the local racing clubs.

Rather less was heard about drink during the campaign: there was one rumour (Morning Bulletin (Rockhampton): 7 February 1963) that the Government would extend Sunday drinking to the entire State whereas it was presently permitted only outside a fortymile radius of Brisbane, but the Deputy Premier, Munro, denied (Telegraph: 16 March 1963) that the Government planned any major changes in the liquor laws either before or after the elections.

In his policy speech Duggan devoted some time to both subjects, accusing Nicklin of a 'monumental about-face . . . because the Government, after four successive deficits in four years of office, was desperate for revenue-a desperation that overrode the moral convictions so firmly stated in 1954 by every leading figure in the Government today' in introducing T.A.B., and of being 'responsible to a large measure, for the additional trade in beer and in liberalising the access of teenagers to liquor'. An A.L.P. government would 'inherit this Nicklin Government creation of a mushrooming organisation which is establishing betting agencies "willy nilly" in a rush for revenue, regardless of its side effects'; it would call a halt to the opening of new agencies until all the ramifications of the matter had been considered, and the A.L.P. would not allow revenue considerations to dominate its thinking. Having referred to the discrimination against drinking in Brisbane compared with country centres, and disregard of the wishes of local residents in the siting of a new hotel at Inala, Duggan promised rather vaguely: 'We shall examine the whole liquor question.' Munro said nothing about betting and drink, but did report the Government's 
record in the treatment of alcoholism as an aspect of its health record.

Apart from the specific proposals for keeping T.A.B. out of the north and west, the A.L.P. asked voters to trust it. Peter Wood at a Toowoomba meeting accused the Government of having socialised gambling by licensing 160 off-course bookmakers since 1961 and opening nearly seventy betting shops without consulting the people. In 1956 and again in 1960 Nicklin had pledged his opposition to offcourse betting as a social evil, but after four successive budgetary deficits he had legislated for it.

With Labour Government in power, Queensland people could rest assured that it would act in their best interests. It would not sacrifice principles in the search for finance, and it would find a solution to the betting and liquor problems which would consider the views of all. (Toowoomba Chronicle: 6 May 1963)

Duggan's Q.L.P. opponent in Toowoomba West, T. A. Morris, doubted such altruism; in his view, A.L.P. candidates 'forced into a corner on the vital issues of Trades Hall sectional government and Communist influence, have no new policies to offer except the substitution of S.P. bookies for T.A.B. agencies' (Toowoomba Chronicle: 30 May 1963). Such a suggestion would be popular neither with the 'many ordinary working people' who liked a five-shilling bet nor with those opposed to betting on religious grounds.

However, the pressure groups which could have concentrated criticism on the Government were silent. The temperance societies are a pale shadow of their pre-World War I selves, and the churches cautious of entering campaign politics. One clergyman on the eve of poll wrote a letter to his local editor (Maryborough Chronicle: 30 May 1963) expressing the hope that the elected representatives would act on the twin evils of drink and gambling, but after the election the Telegraph (14 June 1963) could point to the increased votes of Rae (Gregory) and Lonergan (Flinders) as proof that the T.A.B. had not been a live issue after all.

At this election a normally prolific issue area produced very little. A more generalised difference between Government and Opposition had disappeared when the present Government achieved power. Now their disagreement concerned only a matter of administration, the form of off-course betting to be permitted in certain parts of the State, and this disagreement concerned a fairly specific position issue. With some disagreement on the point in the government party, the A.L.P. were unable to start a dialogue. The strongest exchanges were that each party, by changing its policy, was being hypocritical or unprincipled. Perhaps liberalisation of gambling and drinking is through the gateway; perhaps these issue areas are merely quiescent. 


\section{Price control 1966}

In 1966 price rises played a role in Labor strategy comparable to that of unemployment in 1963. It was an issue close to the hearts of trade unionists; it affected the small man more than the big man; the party's solution conformed to traditional policies. In a press release at the beginning of the year Duggan attacked the recent salary rises for M.L.As. at a time when wage earners were not receiving wage justice and the man on the land was hit by drought.

During the eight years that the Nicklin Government has been in power, the cost of living in Queensland has risen to a greater extent than any other State. The Government has refused to deal with these spiralling prices and, in addition, through its advocate to the Industrial Court, has virtually frozen the basic wage until June this year. (Worker: 3 January 1966)

Labor would unfreeze the basic wage, restore quarterly cost of living adjustments, and deal rigorously with cost increases.

The Labor case was augmented by price adjustments which had accompanied the introduction of decimal currency with $£ 1=\$ 2$. Halving the face value of the national currency gave an immediate credibility to complaints about galloping prices, and Labor candidates were soon talking of 'a sharp increase' in the cost of living; by midMarch the Courier-Mail commented that in Brisbane

there is a lot of dissatisfaction ... over rises in costs of many items in the family budget with the introduction of the decimal system, although the Government has earned good marks by keeping railway fares down, which is in such marked contrast to the heavy increases the Labour controlled council made in bus and tram fares (18 March 1966)

and Labor spokesmen were starting to itemise grocery increases at street-corner meetings (Sunday Truth: 20 March 1966). The Minister for Labour as the responsible minister for prices charged the A.L.P. with political hypocrisy because of the bus and tram fares, and contrasted the Government's decision to keep rail fares fixed with great gains in traffic as a result. More ingeniously, Herbert warned that price control would force prices up by causing manufacturers to shift their marketing efforts to uncontrolled States and creating shortages of the goods in Queensland. His views were echoed by a spokesman for the Brisbane Chamber of Commerce, who said that price control had never proved effective in the past, and in one State alone would be chaotic. Between 1956 and 1959 prices had risen fastest in two capital cities with price control, Brisbane and Adelaide. The Queensland Retailers' Association president added that price rises since December had been negligible: four out of seventy basic items of clothing and household goods had risen, and two of them by one cent only. Later 
still the Chamber of Manufactures reported a survey which concluded that there had been an increase in manufacturers' prices because of the changeover to decimal currency, and the Retailers produced a more extensive one covering 483 items which showed a minute increase. Decontrolled commodities had risen by less than 1 per cent per annum, and grocery lines still subject to price control had risen much more rapidly than the decontrolled-26.3 per cent against $1 \cdot 5$ per cent (Courier-Mail: 30 April 1966).

The Government front was far from solid, however. Pro-Government newspapers like the Rockhampton Morning Bulletin declared that no one could deny that there had been a price rise in the first quarter of 1966 and supposed that it could be an electoral danger, whilst the Bundaberg News-Mail attributed the fact that most protest meetings on prices had been organised by local Trades and Labour Councils to public apathy rather than absence of dissatisfaction with the situation. Much closer to home, the Liberal convention meeting in Brisbane rejected an urgency motion moved by the Women's Council president, Mrs N. J. Wheeler, asking that prices be frozen at their pre-decimal conversion level but carried an amendment moved by Chalk asking the State Government to make an immediate investigation of increases. During the debate phrases like 'blatant profiteering' and 'cynical increases' were used, and one Liberal M.L.A. said in horror that he had to prick himself to make himself believe that he was at a Liberal meeting. Mrs Wheeler warned that 'everyone is expressing concern at the price spiral' and referred to a number of specific increases in the prices of meat, eggs, milk, and bread. Herbert as the responsible Minister warned that if her motion were carried it would have to be enforced at a much wider level than the Labor Party had ever tried and would only drive scarce goods across the border. Her motion had also sought an investigation of increases by the Prices Commissioner to be concluded within thirteen weeks, after which only justified increases would be permitted, and Dewar pointed out that this would have the implication that nothing would be done after the election, which was 'political dynamite' worse than doing nothing at all. Chalk agreed with him, and gave an undertaking that Cabinet would investigate immediately and come up with a decision (Courier-Mail: 25 March 1966). The Government then instructed the State Prices Commissioner, D. H. Pluckrose, to prepare a report within a fortnight.

Worst amongst the Government's unhelpful friends was J. R. James, acting as industrial advocate of the Queensland Employers' Federation, who opposed the unions' basic wage application. James doubted if the retail price rises reflected in the consumer index had resulted in an appreciable reduction in the standard of living and went on: 
The prudent housewife had ample opportunity to offset food price increases by substituting cheaper for dearer foodstuffs, and curtailment of expenditure on luxury items such as cigarettes, tobacco, and beer, could easily prove beneficial rather than detrimental to the consumer's health. (Courier-Mail: 1 April 1966)

This brought Mrs Gabrielle Horan into the debate with the rhetorical question:

Why should people have to live on scraps and poor quality foods in a land of abundance? Someone ought to remind Mr. James that we are no longer in the dim ages when the working man was a slave existing on scraps from his master's table. (Maryborough Chronicle: 1 April 1966)

Even before it reached State Gabinet there were anticipations that the Pluckrose report would find that higher transport charges and higher prices for beer, tobacco, and petrol were primarily responsible for any rise in the cost of living (Sunday Mail: 10 April 1966). The News-Mail (14 April 1966) thought that Duggan's language may have been too strong, but it also felt that any government claim that previous protesters had been mistaken could not be sustained: 'Cabinet members may be assured ... that a householder's shopping list provides a much more conclusive argument than a theoretical list of prices.' The Sunday Mail (17 April 1966) agreed, and felt that Cabinet had done itself 'powerful harm' by flying in the face of housewives' convictions as to what had happened. The Queensland Housewives' Association and the A.L.P. both set about compiling lists of price rises to refute the Pluckrose report, and the Trades and Labour Council's basic wage case advocate, Dawson, asked Nicklin for Pluckrose's terms of reference, his methods, and a list of the organisations he consulted, plus a copy of the report.

Opening the A.L.P. campaign in Ithaca, Duggan claimed that the Government was insulting the intelligence of the average person by talking about prices 'evening out'. He had checked with a retailer recently and on a list of 230 items 111 had increased, 60 had decreased fractionally, and the rest were unchanged. Broadcasting in Mt Isa, Inch accused Pluckrose of securing' his information 'from the representatives of concerns who would be more likely to conceal evidence of rising costs' and blamed the steep rises on the removal of Labor's controls (Mt Isa Mail: 22 April 1966). However, the Labor campaign soon had a second setback. The March consumer price index released on 22 April showed a rise of 1.4 points and the Commonwealth Statistician attributed most of this to rises in tram and bus fares and newspaper prices; food and groceries had risen only 0.4 of a point. Business interests cheered the news, and the Premier declared that the Pluckrose report had been confirmed:

As there has been no public controversy in the other States, there 
is no doubt that the A.L.P. and the industrial unions in Queensland are using the matter purely for political reasons. (CourierMail: 23 April 1966)

Disbelief lingered with some: Mrs Horan thought that something must be radically wrong because 'everything has gone up', and the Trades and Labor Council secretary held that the index obviously did not provide a correct measure. The News-Mail conceded that it was proven that price increases had been moderate, but it was still the case that Queensland had had a sharper increase than any other State and wondered how sound the index was in the face of so much genuine conviction on the part of housewives (26 April 1966). However, the syndicated 'Brisbane Letter' (e.g. Morning Bulletin (Rockhampton): 28 April 1966) found the Government vindicated.

Although the A.L.P. was apparently on shaky ground, Duggan predictably featured cost-of-living concessions in his policy speech, and claimed that a Labor victory must flow from families' growing resentment against rising prices. Queensland had gone from being the State with the lowest cost of living to being the one with the fastest rise. Labor would restore the quarterly basic wage adjustment to keep pace with the cost of living, unfreeze the basic wage, and link the basic wage to the consumer price index. Between 1949 and 1957 the cost of living had risen less in Brisbane than in any other capital city, and the Brisbane index was 5.4 per cent below the Australian average.

Consider the situations for which the Nicklin Government stands indicted:

The removal of legislative price control on essential commodities, which has resulted in the growth of private price agreements and collusive tendering;

The impact that the emergence of false and misleading packaging and advertising is having on the prices of goods and services;

The growth of unsatisfactory trading practices, particularly in the marketing of electrical appliances, which feature grossly inflated prices and phoney discounts;

The influx of goods manufactured outside the State;

Profiteering which has followed in the wake of the conversion to decimal currency;

Unchecked rises in commodity prices following the introduction of State and Federal Budgets;

The rejection by the Government of the advice tendered by its Prices Advisory Board to retain price control on essential commodities;

Failure of Government policy to regulate commodity prices by healthy competition.

The Government had not acted to use the powers it had, and voters 
should not be fobbed off with promises of monthly price reviews. A Labor government would restore effective price control.

The policy promptly called down the Government's wrath. Nicklin warned that it would return Queensland to controls and bureaucracy, and Chalk thought that it would bring back the days when investment capital 'would not touch Queensland with a 40 foot pole'. Nicklin pointed out that Duggan was not promising a return to price control as it had previously been known in the State by legislatively recontrolling the hundreds of items which had been freed by the present Government-and incidentally conceding that the old system was a failure-but a new form of price control through a standards institute. On television Chalk promised that the Government would not introduce price control, for under price control the State had stagnated because capital did not come. 'Price control is blackmail, and not fair.' James believed pegging prices and increasing wages would force industry to other States. In the electorates $\mathrm{H}$. A. McKechnie in Carnarvon calculated that the last nine years of Labor government had seen a price rise of 81 per cent, whereas the present Government over an equivalent period had kept rises to 20 per cent, and C. G. Leavy, Duggan's Liberal opponent in Toowoomba West, argued that price control under Labor had made Queensland the lowest wage State by keeping down the price of items affecting the basic wage whilst the present Government had brought wages up to the level of other States. After some reflection James added that Duggan's claim that the cost of living in Queensland was 4 per cent higher than the Australian average was misleading: each index measured movement in its own city; indexes were not comparable as to level. One of the more elaborate refutations was provided by T. G. Newbery at a Country Party branch meeting at Sarina. The A.L.P. campaign for restoration of price control was based on a fallacy. The greatest annual rise in prices in the previous ten years had been in 1956, the last year of price control, 6.5 per cent, greatly above the highest annual increase in the term of the Nicklin government, 4.9 per cent. In the last five years of Labor government total index increase had been 22.5 per cent, double the $11 \cdot 1$ per cent of the last five years and almost double any five years of Nicklin government. The Government did not deny that there had been price rises recently but declared that they were not confined to Queensland, and the A.L.P. was hypocritical to complain when the fare increases of its city administration was the greatest single factor pushing up the cost of living for the family man (Daily Mercury (Mackay): 7 May 1966).

More statistics were brought in to the debate by Whitlam when he visited Ipswich: prices had risen more and wages less in Queensland than any other State. Over an unspecified period prices had risen 26.3 per cent in Queensland against 19.7 per cent in Australia, but 
incomes had gone up only 59 per cent as against the Australian average of 68 per cent. Mrs Jordan, on whose behalf he was speaking, commented on the situation of spiralling prices and pegged wages:

We have all suffered less purchasing power and those on fixed pensions and those in the lower income groups have endured much hardship. The ostrich-like acts of the Government in trying to whitewash the frauds which were perpetrated under the guise of decimal currency have fooled few people. Every family has been the 'bunny' in this Government's efforts to lower the standards of the workers. (Queensland Times (Ipswich): 10 May 1966)

Lloyd campaigning in Carnarvon explained what Labor policy on price control really meant: it was directed against profiteering and unscrupulous trade practices which had been allowed to spring up over the past nine years, and it did not intend harsh and restrictive controls on honest business. He referred to a matter of particular grievance in fruit-growing areas, the cost of cartons kept high by monopolistic arrangements, and argued that 'fair and just Government intervention is necessary to prevent this form of price control' (Stanthorpe Border Post: 10 May 1966).

Few Labor candidates developed a line of their own. In Bowen a series of advertisements for $\mathrm{J}$. A. Gralton retailed the story of the Liberal convention's concern with increases and blamed abolition of the quarterly adjustment in the basic wage to the cost of living in 1961 as well as refusal to reintroduce price control for a growing gap between wages and prices (Bowen Independent: 15 April, 6, 20 and 27 May 1966). In Townsville South A. J. Trower illustrated advertisements with pictures of a shopping basket of groceries and asked: 'Mrs. Housewife-you are the best judge. Can you in fact save anything today from your housekeeping money?' (Townsville Daily Bulletin: 26 April, 9 May 1966). Another Trower advertisement pictured a T-bone steak and bottle of sauce and warned: 'We all enjoy a little luxury now and then. Soaring prices have almost placed meat in that category for the average family, yet it need not be' (ibid.: 16 May 1966). The best effort to translate the statewide problem to local circumstances was made by G. Burns in Gregory when he reported that he had conducted a survey of food and clothing items and found that the cost of living had risen 27 per cent in the past two years in Longreach whilst wages had risen only $10 \frac{1}{2}$ per cent; in outlying areas of the electorate prices would be even higher (Western Times (Charleville): 19 May 1966 ).

Following Nicklin's policy speech Lloyd pointed out that it contained no promise of action against spiralling prices. Nicklin, however, had moved to the attack. Beginning with a meeting in Logan he repeatedly warned primary producers, and dairymen in particular, that price-control would be a threat to their prices. Duggan and the 
A.L.P. had allied themselves to a Communist-inspired campaign run by the Trades and Labor Council which had 'viciously attacked' the prices of essential commodities including butter, eggs, bread, milk, bacon, and meat. The backroom boys at Trades Hall could not care less about the welfare of primary producers and it was 'guineas to gooseberries' that they would be well represented on Duggan's projected consumers' council. Any price reduction would hit the primary producers who would bear the brunt of price-slashing (Courier-Mail: 12 May 1966). In the hands of some Country Party men this became even stronger. Thus the chairman of the Balonne electorate council warned that price controls would plunge Queensland 'back to the black market era with all its vices and rackets designed to restrict progress as his (Mr Duggan's) Left Wing Trades' Hall friends have been organising over the years with wanton strikes directed at the heart of our development programme ...' (Goondiwindi Argus: 19 May 1966). In Mackay a Country Party advertisement answered the housewife's question 'When will prices cease to rise?' with 'the true answer': '. . when the A.L.P. ceases to align itself with the disruptive elements blackmailing the State, the nation and YOU personally by sabotage of the economy with threats of and actual strike action', citing the Mt Isa strike as an example (Daily Mercury: 21 May 1966). Not all Government candidates backed him. Muller at a joint Fassifern-Logan meeting referred to 'the present inflationary trend with higher living costs and higher wages, higher and higher production costs' but thought it pointed to the need to place confidence in men and women who are prepared to accept their responsibility for the welfare of the State and are not prepared to submit to the dictates and demands made by irresponsible self-constituted pressure groups' (Beaudesert Times: 13 May 1966). However Chalk took up the theme at Laidley. Duggan advocated pegging prices but not wages; thus the prices of items essential to the man on the land would rise with spiralling wage costs and shorter hours. Farmers would have to work longer hours for returns pegged to fixed prices, and anyone who supported the Labor line would be 'putting a rope around his own neck' (Courier Mail: 18 May 1966). In Tablelands, T. V. Gilmore quoted the Tasmanian Attorney-General as saying that no State could legislate for price control on its own and predicted that price control in Queensland would mean a decline in the quality of goods as prime produce went across the border to southern markets where there was no control (Tablelands Advertiser (Mareeba): 25 May 1966).

An interim report on the progress of the campaign in 'Brisbane Letter' (e.g. Morning Bulletin (Rockhampton): 12 May 1966) thought that the Labor policy was failing to make the impression hoped for:

Labour undoubtedly made a mistake by making such a hullabulloo over alleged price rises so early in the campaign, before it started in 
fact. The price bomb was thrown into the ring too soon and appears to be turning out a squib.

There is no real feeling here that the reintroduction of price fixing would be a good move. Competition in the retail business has become so fierce that price fixing instead of reducing costs could actually increase them.

Many housewives fear that if prices were fixed their beloved specials, a sort of sporting affair that appeals to their bargainhunting instincts, might be wiped out.

Most press reports still thought there was some mileage in the issue. Mackay housewives were described as calling out 'Good on you, Jack; give 'em curry; prices are right up' to Duggan at a meeting in front of the Town Hall (Courier-Mail: 13 May 1966), and Duggan told them that the suggestion that those who advocated price reforms were Communists was an insult to every housewife. The charge was an attempt to divert attention from the Government's failure to act (Daily Mercury: 13 May 1966). At Bundaberg Duggan read a letter from the North Rockhampton A.L.P. women's branch to Pluckrose, asking for a list of the items which had been reduced in price, and from Pluckrose's reply that he was bound by an oath of secrecy taken when he became Prices Commissioner. The oath had been designed to permit access to company books to check on profiteering, and the stand was ridiculous. The Government was using Pluckrose as a shield to conceal its own inactivity (Sunday Mail: 15 May 1966). Back in Toowoomba Duggan thought that as Queensland was now the State with the highest living costs, 5.4 per cent above the Australian average, retail sales were becoming sluggish and firms were already retrenching staff.

As on so many issues, the Q.L.P. was forced into a middle-of-theroad position. In his policy speech Diplock advocated a judicial tribunal to investigate reforming the basic wage. Linking the basic wage to prices had proved futile and would price Australia out of export markets, and it should depend rather on national productivity. As productivity rose, unit prices should be forced down. However, there had been alarming price rises in recent months which demanded urgent government action, and a Q.L.P. government would act at once to stabilise prices and 'restore a basis of justice in assessing price variations for essential food and clothing items'. Price controls would be imposed on goods essential to day-to-day living. In the hands of Q.L.P. candidates like T. Morris this became typically a denunciation of both major parties:

The Country-Liberal Party Government in Queensland is as incompetent in its handling of prices, wages and industrial matters as the A.L.P. is insincere. (Toowoomba Chronicle: 16 May 1966)

The A.L.P. leaders appear to have divided their attack on prices. Whilst Duggan expounded the statistics of Queensland's inflation, 
Lloyd emphasised the sinister interests at work. At Redcliffe he distinguished between the retailers, who were not to blame, and the producers, who received little more than they obtained nine years before, and 'the percentage man who was making the money'. As Queensland paid more for goods imported from other States, locally produced goods should be sold at lower prices; legislation would control cases where the middleman was profiteering (Redcliffe Herald: 18 May 1966). Peter Byrne made the same point in Mourilyan. The Government had refused time for a debate on price increases in 1965 because they would have been shown to be to blame. Labor had no quarrel with efficient management and reasonable profits, but objected to excessive profits by unfair and undesirable practices. Whilst Labor had to fight for betterment of working conditions through the industrial courts, big business determined prices around the conference table. As the Country-Liberal government was not game to tackle unfair practices, Labor must do it (Evening Advocate (Innisfail): 18 May 1966).

A sudden turn to the debate came on 18 May when the State Industrial Commission handed down its decision on the State basic wage case. The male rate was increased by $\$ 1.30$ to $\$ 32.70$ and the female rate by $\$ 1$ to $\$ 24.55$. As the last increase in the previous September had been for only 50 cents, and the hearing had been granted despite a declaration by the Commission on the previous increase that no further claims would be entertained before 1 July 1966, the so-called basic wage freeze, wage-earners had cause to be cheered. Some 240,000 male wage-earners and 82,000 women benefited from the increase. The increase was attacked by employers' spokesmen, who inevitably had resisted any upward movement, and received grudging approval from the Trades and Labor Council which had sought \$4.30. Dawson called for price control and a realistic measure of the cost of living, but welcomed the restoration of adjusting the basic wage to the consumer price index. Among the politicians, Chalk thought that the decision must be regarded as fair because the wage increase was in keeping with rising costs as evidenced by the Commonwealth consumer index, whilst Duggan believed that it confirmed the A.L.P. claim that prices had risen (Courier-Mail: 19 May 1966). The A.L.P.'s best response came in an advertisement for the candidate in Burnett, A. T. Craig, which warned that without price control wage increases are lost (Maryborough Chronicle: 20 May 1966), subsequently echoed by Duggan (Courier-Mail: 24 May 1966). In Bundaberg Tallon called the basic wage increase 'a political stunt' and reminded readers that the Government had stopped quarterly cost of living adjustments only eight months before (News Mail: 24 May 1966). At this stage of the campaign the A.L.P. was suddenly reinforced by its Lord Mayor of Brisbane, Alderman Jones, at a street corner meeting in Chatsworth. 
The City Council had been forced to raise its fares, that prime element in the consumer price index rise, because the State government had refused to subsidise school children's fares which were a responsibility of the State rather than the city. Other cost increases such as wages had contributed to the fare rise, but the children's subsidy had been the main factor (Telegraph: 21 May 1966).

This was the last substantial contribution to the debate. In the closing week of the campaign party spokesmen repeated earlier lines. The Morning Bulletin's comment summarised the position:

The A.L.P. had bad luck with what looked like an election winner -price increases following the shift to decimal currency. First of all the mine was exploded too soon. Then the basic wage rise killed it stone dead. (21 May 1966)

Duggan continued to claim that prices were one of the important issues of the campaign, and Lloyd seized on a comment by Nicklin on television about certain housewives ranting around the country about prices as further evidence that the Premier was rattled by the prices question. In Brisbane the A.L.P.'s women's organisation planned a massive series of street corner meetings to urge price control (Telegraph: 23 May 1966). At the last minute Duggan disclosed that a secret meeting had decided that the price of pork and veal would rise 3 cents per pound after the election (Courier-Mail: 26 May 1966).

As with unemployment, the biggest issue of 1963, price control as the biggest issue of 1966 taxed our rational voter. Should he believe the evidence of interested experts like spokesmen for the Brisbane Chamber of Commerce, the Queensland Retailers' Association, and the Queensland Chamber of Manufactures and apparently disinterested experts like the Commonwealth Statistician and Pluckrose or should he believe the press and the housewives? What had happened to prices? If he concluded that there had been an excessive rise in prices, then he was offered a fairly clear choice, for Duggan said his policy would deal with the problem and all his opponents said that such a policy would only worsen the situation. Some A.L.P. spokesmen, like Lloyd, added some style overtones to an apparently position issue by distinguishing between honest businessmen and unscrupulous profiteers, and the Government countered by claiming that the Communists had created the issue. Duggan introduced the comparison of $t-1$ and $t$ price rises, and a few Government members sought to answer him on it, but no one tried to predict what a Labor government would have done between 1957 and 1966. Finally, in the closing days of the campaign the voter would have to decide how far an increase in the basic wage would compensate him for such price increases as might have occurred. Most of the discussion concentrated on a relatively small part of the $t$ period, the months since decimal currency had been introduced, and the Government complained that 
most of the responsibility for what had happened in this time lay with the Labor-controlled Brisbane City Council.

\section{The sugar industry 1966}

The most important event for the 1966 debate on the problems of the sugar industry, which accounts for about one-half of the gross value of the State's agricultural production, had occurred almost three years previously. On 28 October 1963 Cabinet received the report of a committee of experts presided over by $\mathrm{Mr}$ Justice Gibbs. It had recommended a great expansion of the industry by the addition of 150,000 acres of new land, of which 64,000 acres should go to about 1,000 new cane growers. The expansion would raise sugar production by $1965-6$ to $2 \cdot 2$ million tons, an increase of 0.4 million tons, and would involve capital outlay of more than $£ 50$ million. This would be an even greater expansion than that of 1949-53, which had raised sugar production by 0.3 million tons and cost $£ 30$ million in new land and equipment and $£ 20$ million in increased crushing facilities (Courier-Mail: 30 October 1963). A detailed account of the elaborate administration of the sugar industry may be found in every Queensland Year Book, but the substance is contained in one sentence which regularly appears there: 'Subject to the agreement with the Commonwealth Government regarding the price in the Australian market, the Queensland Government controls sugar production.' Ownership of all sugar output is vested in the Government, which fixes 'mill peaks' for domestic consumption and basic exports. Thus the decision to accept the Gibbs report, expand existing holdings, and admit new growers to the industry was the Government's.

Unfortunately 1963 was a bad year in which to make a decision of this sort. The average export price rose sharply from just under $\mathcal{f} 41$ per ton in 1962 to over $£ 65$ per ton in 1963 , and the volume of sugar exported had risen sharply in the preceding year. Thus the value of sugar production went from $f 63$ million in 1961 to $f^{84}$ million in 1962 and $£ 105$ million in 1963, and the Government's hopes for the industry rose with it. As the international sugar market adjusted to the political isolation of Cuba the inflated prices of 1963 fell away rapidly, and only one-third of production is taken by the protected domestic market in which fixed prices actually advanced slowly. The average export price dropped in 1964 to under $£ 42$ and by 1965 it had fallen to under $£ 34$, reflecting a fall in the free market from $£ 38$ (1964) to $£ 21$ (1965). Thus the value of production slumped from its record high of $£ 105$ million in 1963 to $£^{88}$ million in 1964 and under $\mathscr{L}^{80}$ million in 1965. Industry problems were aggravated by drought in 1964 and 1965, so that total sugar production which had risen by 0.2 million tons in $1963-4$ remained static in 
1964-5 and barely 0.1 million tons above the 1962 record. Thus whilst 1965 had set a new record of production, performance was 11 per cent below the mill peaks prescribed, and in the hardest hit area, the Isis district around Bundaberg, production was only 17 per cent of peak. Even milling was affected by the water shortage.

A member of the Sugar Board addressing the annual meeting of the Queensland Cane Growers' Council could point with pride to the expansion of bulk sugar handling facilities in the ports and the promise of a good season with 2.2 million tons of sugar, but he had to warn that expansion had been into sales dependent on the world market price-as the Gibbs report had clearly stated. Improvement could come either by outlets at agreed prices above the world market price, as had been provided by the Commonwealth Sugar Agreement and more recent arrangements with the United States, or by an increase in the world price through international agreement or the operation of market forces. By the end of the year 'a lot more will be known on the likely outcome' of the review of the International Sugar Agreement (Townswille Daily Bulletin: 8 March 1966).

This was a long way off, however, and at its meeting in Ayr the State Cabinet decided to make a submission to the Federal Government for assistance to those growers who were being hit by levies required by the sugar mills which were themselves in financial difficulties (ibid.: 5 April 1966). With such prospects, it was not surprising that when the Country Party member for Mulgrave, R. A. Armstrong, met a delegation of cane farmers to hear their complaint that the Government and the public failed to understand their problems, he invited industry leaders to approach the Government with a plan to assist farmers. Nicklin's campaign itinerary to Mulgrave and Whitsunday, but not Hinchinbrook, suggested that he was confident of J. A. Row's ability to hold the latter seat (Courier-Mail: 19 April 1966), but Camm in Cairns expressed concern at the strain on the industry caused by overseas prices. He reported that an investigation of the financial requirements of the sugar mills had been completed and Cabinet awaited the committee's report (Cairns Post: 20 April 1966). Late in April the Commonwealth Government announced a loan of $\$ 1.7$ million to necessitous cane growers who were liable to pay levies to certain mills. The chairman of the Mackay District Cane Growers' Executive promptly paid tribute to the assistance of the Premier and Cabinet in securing this assistance, but another member of the Executive and the A.L.P. candidate for Mirani, G. R. H. Creber, said that low-interest loans were not a complete answer for they did not help growers outside co-operative mill areas and they would still have to be paid back. He thought the Government should investigate some form of stabilisation or price support for sugar sold outside the negotiated price markets (Daily Mercury (Mackay): 29 April 1966). The 
A.L.P.'s state secretary lumped the sugar assistance with the Pluckrose report as belated action on the eve of the election.

Making his first tour through the sugar areas, Duggan declared that the swing to Labor was even bigger than at the Dawson byelection. The industry was in chaos, and the expansion of the industry under the present Government had been a débâcle. Despite warnings to go slowly, the Government had 'projected the industry recklessly into this expansion'. Nicklin's overseas trip to negotiate prices had been an abject failure, and in actual money prices growers were getting less for cane than in the depression years 1929-32. Thousands were out of work in the sugar belt (Courier-Mail: 10 May 1966). He was backed by Byrne, who blamed mismanagement by both Federal and State governments, and charged that the affairs of the industry were beyond the capacity of present Ministers. The Cane Growers' Council had advocated a cautious approach, but it was alleged in some quarters that the Council did not have the complete confidence of the Government. The Gibbs committee had recommended expansion, but had all the relevant information been placed before it? There had been the possibility of curtailment of exports if Britain joined the Common Market, and this was still in prospect. Had the Nicklin government followed the Hanlon government's policy of securing contracts first and then permitting expansion, this would not have happened. Growers were now paying the price in falling farm values, restricted credit, and rising costs, and new growers in particular would be lucky to survive. Byrne attributed the recent Commonwealth assistance to the efforts of Dr Rex Patterson, but it was far from adequate and would have to be repaid. Typifying the unhappy state of affairs was the sale of the co-operative mill at Gin Gin (actually Wallaville) for $£ 150,000$ when it was worth ten times that amount, and the Government had legislated to make it easier for co-operative growers to divest themselves of their property in the interests of banks and proprietary millers (Evening Advocate (Innisfail): 10 May 1966). Creber, opening his campaign at Eton, attacked the State Government's drought and frost relief scheme because it was tied to tonnage rather than sugar content and thus less effective than it should have been, and repeated his call for a stabilisation scheme.

For the Government the Minister for Primary Industry, Row, continued optimistic:

We are going through a bad phase when the whole picture is overshadowed by an uneconomic world price. This position must have a sobering effect on the producers, but it is not a cause for extreme pessimism as to the future. It is a time for consolidation, when the best use should be made of the most suitable varieties, etc. If these things are done, all money spent on production will be spent wisely. Then, should a quota-type International Sugar Agreement come 
into being, our production will be such as to justify a quota which

bears true relationship to our capacity. (Cairns Post: 11 May 1966)

The Country Party member for Mirani, Newbery, answered the Labor promise of a stabilisation scheme. He favoured the idea but it was easier said than done; it was under consideration at the moment. He nominated another candidate for the kudos of the Commonwealth aid, himself:

My outspoken resentment towards the imposition of levies on growers already in financial straits obviously made an impression on both the Premier and several Cabinet ministers because within a short time the Queensland Government had submitted a proposition to the Federal Treasury. ... (Daily Mercury (Mackay): 11 May 1966)

In the Commonwealth Parliament John McEwen, leader of the Federal Country Party, assured Dr Patterson that the Commonwealth Government was sparing no effort to secure a better price for sugar. It would consider a stabilisation plan if the industry made a proposal, but in fact industry affairs for many years had been run on what was substantially a stabilisation plan.

Speaking at Innisfail, Duggan claimed that farm values had fallen by a quarter almost overnight. The basis of the sugar industry had been stability and intelligent planning, and this had been overturned by the Government's unwise expansion which had most of the responsibility for the industry's present plight (Evening Advocate: 12 May 1966). Creber replied to Newbery's approval of a stabilisation scheme by pointing out that the Country Party had rubbished Dr Patterson when he advocated it. For the Government, G. A. Wharton in Burnett repeated McEwen: 'When the industry says exactly what it wants, my Government and $I$ will not be found wanting in meeting these wishes' (News-Mail (Bundaberg): 14 May 1966). Chalk in Ayr said that the scheme for assisting co-operative mill growers was a combined effort by the State Government and banks, and had the blessing of the Commonwealth Government as well, and repeated the invitation to the industry to come up with a scheme.

One of the more elaborate analyses of the sugar problem came from the Q.L.P. candidate for Whitsunday, B. J. Lewis. There had been general agreement on expansion in 1964 and on the principle of new assignments. However, the Government had erred in the allocation of peaks, for the Gibbs committee had concentrated on lifting quotas in northern areas even though some of the mills there had never exceeded their peaks and did not appear likely to reach them. The Government should have known the committee had failed to recognise the claims of central Queensland growers. The answer was not a stabilisation scheme utilising a general subsidy but generous loans (Daily Mercury (Mackay): 14 May 1966). The Q.L.P. candidate 
for Mourilyan, G. A. Higham, echoed the Q.L.P. policy: long-term, low-interest loans to co-operative mills; the Commonwealth Government to release more credit to the trading banks for extended loans to growers engaged on expansion; a Commonwealth bounty on sugar exports to spread the burden over the entire community. The exQ.L.P. independent, Adair, in Cook, promised to seek an increase in the maximum loan from the State Agricultural Bank to $\$ 24,000$ to give new growers a hand; many were carrying on only by taking outside employment.

In Cook, J. J. Bethel for the A.L.P. repeated Duggan's comments, and went on to examine the world market situation. The Government had sought to base an expansion to $2 \cdot 2$ million tons with only $1 \cdot 1$ million tons guaranteed a satisfactory price and the balance at the world market price, which currently ranged between $\$ 35$ and $\$ 48$. If an international sugar agreement was reached, Australia might still find it difficult to justify a quota large enough to cover expansion because of inadequate performance due to flood, drought, and frost having curtailed production (Cairns Post: 14 May 1966). In the Bundaberg area, which had been particularly hard hit by the drought, Duggan and the local candidate, Tallon, attacked the Government's record on irrigation. However Nicklin's policy speech promise of action on the Kolan River irrigation scheme--an approach to the Commonwealth Government for money if the report on the scheme was favourableled the chairman of the Bundaberg Irrigation Committee to express its appreciation of what the chairman said were not 'piecrust' promises.

Once again Nicklin had the inside track. His first move was to bring out the 'knocker' label. In a speech at Babinda he blamed Duggan for being primarily responsible for lower farm values.

Mr Duggan has been going all around the north crying blue ruin about the sugar industry and saying it is down and out. Everything we say about the sugar industry here is noted and carried to the other side of the world. Statements such as Mr Duggan is making are not to the benefit of negotiations taking place for the betterment of the industry. (Maryborough Chronicle: 16 May 1966)

The sugar industry was too valuable and important to be made a political football, and overseas negotiations were involved enough without someone throwing a spanner in the works. The Government favoured co-operation with the industry, and had met the last two specific requests for finanical assistance to certain mills and levy relief for growers. An industry working party had been discussing the situation and the Government would be ready to hear them as soon as they were finished. His second move came the following day at Cairns when he announced a number of concessions. Drought relief would be based on sugar content rather than tonnage of cane. The drought 
year of 1964 would be omitted from calculation of average annual production. The interest-free period for advances would be extended by a year to 30 June 1967 , so that interest payments at $3 \frac{1}{2}$ per cent would be payable only then. Nicklin defended expansion: volume of production would have an important bearing on Australia's bargaining strength. These alterations were in response to a submission by the Cane Growers' Council on anomalies in existing arrangements.

In these difficult times there may be doubt in some minds as to the wisdom of the recent sugar industry expansion. It is time I think to put that decision in its proper perspective. The committee which investigated expansion comprised responsible and knowledgeable men, who had support of expert advisers fully representative of the industry. Practically the whole of the evidence was strongly in support of expansion in these circumstances and in a situation of world sugar shortage Government approval of the committee's recommendations was justified. Rejection of the report would have encountered severe criticism. The industry and the Government therefore are jointly and irrevocably committed to the extent of expansion that has taken place. (Cairns Post: 17 May 1966)

The first point was promptly taken up in the Daily Mercury (17 May 1966): such a vital industry should not become 'a political plaything'. The problem caused by adverse seasonal conditions and depressed world prices could hardly be blamed on the State Government, and the prosperity of earlier years should be sufficient to carry the industry, except for some special cases, through the current difficulties. Opening the Country Party campaign in Mourilyan, A. L. Martinuzzi asked why the A.L.P. had not moved a motion of no confidence if it had been opposed to expansion, and repeated the charge that wild statements were damaging the industry. Referring to the Gin Gin mill, he observed that the mill at least would stay open, whereas when the Mt Bauple mill had got into difficulties in 1950 the Labor government had allowed it to close and growers had to send their cane to another mill. Supporting him, Camm defended the decision to expand and predicted it would still prove of ultimate benefit to the industry. His tour of sugar areas from Mackay to Mossman convinced him that there was no unanimity within the industry on what steps should be taken, nor had any detailed submission for assistance been made to the Government (Evening Advocate (Innisfail): 18 May 1966). Further along the coast at Cairns Camm added that if the Gibbs committee recommendations had not been accepted, there might have been demands to produce sugar from other areas of Queensland and even other States. As it was the major expansion had been within the areas of mills already operating. Speaking at Gin Gin, the Country Party member, Wharton, gave a different account of the sale of the mill. The State Government had provided finance to keep the mill going to the end of the crushing season, but when growers decided not 
to pay levies the bank closed the mill. The growers then agreed to pay levies to Bingera mill, and the bank accepted Bingera's tender for the mill which was the only one which would have kept the mill open. The Government required the new owner to spend further money on the mill and to keep it open, and growers were given relief on their levies for it as if it were a co-operative mill (News-Mail (Bundaberg): 23 May 1966).

In his rural policy speech Duggan advocated investigation of a shorter crushing season. This was interpreted by several Country Party and Q.L.P. candidates as abandoning the mill workers to even longer layoffs. A more drastic attack on the A.L.P. came in Country Party advertisements which appeared the day before polling:

Free enterprise has created the NEW Queensland. Remember every A.L.P. Candidate is bound by oath to: Nationalise the sugar industry. 'Small producers through nationalisation may be bound hand and foot'-LENIN, Founder of Communist Russia.

Its timing prevented any debate on this startling proposition, but it might be fair to observe that small producers in the sugar industry are pretty well bound without nationalisation. The closest to a Marxist note in the A.L.P. campaign was provided by the candidate for Mulgrave, S. J. Dalton, who wondered whether the expansion had been designed to create a sugar monopoly by forcing all the small growers out (Cairns Post: 27 May 1966). Probably more effective than either debating point was the announcement by the Minister for Primary Industry on 24 May that sugar producers would receive $\$ 86.58$ a ton 94 net titre for the 1965 crop, $\$ 1.33$ higher than the amount estimated in March. As $\$ 78$ had already been paid out in advances, a further $\$ 8.58$ remained to be paid. On the Queensland average sugar content, this would mean about 80 cents per ton more than had been expected. Winding up his tour at St George in Balonne, Nicklin said that he was convinced his Government would be returned and reassured because the political climate in sugar and dairying areas had improved noticeably.

Here at last we have a real situation which conforms to Downs's model. The Government argued that the decision to expand sugar production over $t$ had been the right one to assure Australia's claims in any subsequent international agreement; the A.L.P. contended that the Hanlon policy not to expand without an assured market had been more appropriate although there was some question of whether this alternative had been made clear at the time. The side issue of the Gin Gin mill did not develop comparably, for whilst the Opposition said the Government had been wrong, they did not say what they would have done to save the mill. For $t+1$ the picture is less clear. The A.L.P. favoured a stabilisation scheme; the Government would wait to know what the industry wanted. Trades Hall unions are not 
involved in the sugar industry and the A.W.U. could hardly be represented as a Communist front. It took the imaginative leap of introducing Lenin to import a style element, and the Opposition was equally restricted in an industry of small growers. It might be said that estimating the future development of the international sugar market was a demanding task for the average Queensland voter, but most commentators expected the issue to be significant only in the sugar-growing electorates where in the last three years the local press provided a great deal of information on the subject.

\section{The dairying industry 1966}

Although the value of dairy produce in Queensland is generally about two-fifths that of sugar (and with the addition of the closely associated pig-raising industry would still be less than three-fifths), dairy farmers outnumber cane growers by more than two to one. Queensland produces over 95 per cent of Australia's sugar but it has fewer than one-quarter of Australia's dairy cows and produces only one-sixth of Australia's milk. The last two statistics point to one of the problems which make the Queensland dairymen the most embattled of their breed: milk production per cow is the lowest in the country and barely two-thirds of the national average. While the number of dairy cows has been growing steadily in other States, it has been declining in Queensland and there has been a steady exodus of farmers from the industry and a more modest fall in the number of dairy factories. In 1965 the State Government appointed a committee chaired by the Minister for Primary Industry to examine the state of the dairying industry. Its report, the first ingredient in the campaign debate of 1966, was featured in a story in Sunday Truth (13 March 1966), which called it 'dynamite' because it was costly and involved the Premier in a choice between dairymen who would want it fully implemented and the Liberal Party which wanted more money for secondary industry. The article went on to describe discontent in the dairying industry where the number of dairy farmers had fallen by almost half in ten years (from 25,000 to 13,000) and a recent report by the Commonwealth Bureau of Agricultural Economics had found the average net income to be under $\$ 40$ per week for a capital investment of $\$ 30,000$. In marginal and drought-affected areas many dairy farmers had a net income of less than $\$ 1,000$ a year. Both statistics of population decline and low incomes figure prominently in subsequent argument. In the House of Representatives the member for Wide Bay in a debate on the New Zealand trade agreement charged that the report would not be released until after the State election because it was not favourable to the State Government. Nicklin replied that the report had been received and was being studied by departmental officers; it would be released when the Government had 
studied its full implications, which involved the expenditure of 'a considerable sum of money' (Courier-Mail: 16 March 1966). The most vigorous debate took place in the Warwick electorate and the theme of the suppressed report was promptly taken up by the A.L.P. candidate, Alderman E. T. Barrett, who asked whether publication was being withheld because the report advocated the same land policies as Duggan had been advocating (Warwick Daily News: 15 March 1966). The A.L.P. candidate for Murrumba, Norm Kruger, describing himself as a dairy farmer, wrote to Queensland Country Life (14 April 1966) accusing the Government of playing for time until after the elections 'and then we will all be powerless' and demanding release of the report and action on it. At a meeting in Lowood in Somerset, D. J. Sherrington, a Brisbane M.L.A., declared that the Government was suspected of not wanting to save the dairy industry but wanted its producers to switch to beef cattle. He was supported by the member for Barcoo, O'Donnell, who added that most dairy farmers were too small for beef (Queensland Times (Ipswich): 28 April 1966). Opening the A.L.P. campaign in Mulgrave, Dalton asked why the State Agricultural Bank or the Commonwealth Bank did not provide more aid for equipment purchases by dairy farmers and accused the State Government of failing to make a firm approach to the Commonwealth Government to influence the free trade agreement with New Zealand (which had figured prominently in the Dawson campaign) (Cairns Post: 4 May 1966).

In a telecast before his policy speech Nicklin promised to sustain the sugar industry and to give the dairy industry 'a real lift' towards stability. His promises were welcomed by the president of the United Graziers' Association, who referred to the freeholding and drought relief items and the president of the Queensland Dairymen's Organisation, who pointed out that many items mentioned by Nicklin had been suggested by the Q.D.O. State Council to the dairy industry advisory committee. Action such as the Premier now promised should assist Queensland dairy farmers to overcome some of the problems which made dairy production more difficult than in other States, but some immediate assistance would also be necessary (Courier-Mail: 11 May 1966). The promises to sugar and dairying figured prominently in an advertisement placed in provincial papers immediately after the speech (e.g. Townsville Daily Bulletin, Maryborough Chronicle, Warwick Daily News: 11 May 1966), together with decentralisation, education, and hostel assistance for country children. Press comment was favourable without being effusive: the Townsville Daily Bulletin called the dairying proposals 'realistic measures' and the Rockhampton Morning Bulletin spoke of 'serious attention' requiring the dairy farmer to show some self-help. Only Queensland Country Life, the U.G.A. journal, let its head go to the point of talking of a possible 'rebirth of an industry' (12 May 1966). 
At Innisfail, Duggan warned that both long-range planning and immediate assistance were needed. Labor policy was opposed to large aggregations of freehold land (though it is not clear from the context whether Duggan was speaking of aggregation in dairying or in grazing) and would achieve a standard of living for dairy farmers comparable with that of other sections of the community (Evening Advocate (Innisfail): 12 May 1966). Internal disputes within the Q.D.O., particularly on the Darling Downs, were reported in the press, but did not become involved in the campaign. When the advisory committee report appeared Duggan stated that he had been approached by a deputation of five dairymen who had a petition bearing the signatures of some 1,600 dairy farmers to express their shock and disappointment with the report's findings. He added that the deputation had previously tried to see Nicklin but the Premier would not spare them fifteen minutes of his time (Courier-Mail: 19 May 1966). Nicklin replied at once that this splinter group within the Q.D.O. was not the voice of the industry; his Government dealt with the properly-elected representatives of State industries and his door was always open to them (Morning Bulletin (Rockhampton): 20 May 1966). Correspondence between members of this group, the Save the Dairying Industry Committee, and their opponents occupied considerable space in the columns of the Toowoomba Chronicle, but it was never directly concerned with the election and some of the rebels' supporters expressed the hope that the Country Party would win the election. A Warwick journalist subsequently reported that some Q.D.O. branch officials had advised dairymen 'to take ballot box action' against the Government before the advisory committee report appeared, but believed that antiGovernment feelings had been mollified by subsequent developments (Telegraph: 25 May 1966). On the eve of polling the most energetic of the rebel correspondents, F. M. Lobwein, claimed that the Q.D.O., 'while it may not be blameless', could not change Government policy:

... Only the dairymen themselves can do this at the ballot box. Election results is the only language politicians understand. (Toowoomba Chronicle: 27 May 1966)

Certainly Labor candidates in dairying electorates, for example, W. R. Prisgrove in Callide (Morning Bulletin (Rockhampton): 17 May 1966), J. L. S. van der Lelie in Somerset (Queensland Times (Ipswich): 17 May 1966), J. J. Keim in Lockyer (ibid.: 18 May 1966), N. H. Hasemann in Barambah (South Burnett Times (Kingaroy): 18 May 1966), D. M. O'Brien in Fassifern (Beaudesert Times: 20 May 1966), belaboured the Government on the declining number of dairy farmers and claimed that the Labor policy was better, but their criticism appeared to lack bite. Q.L.P. candidates in dairying electorates, for example, Mrs N. A. Grulke in Somerset (Queensland Times (Ipswich): 17 May 1966) and Diplock in Aubigny (Toowoomba Chronicle: 25 May 1966), attacked both the Government's neglect and the A.L.P. 
proposal of subsidies; the real problems were drought, which should be dealt with by schemes to help the individual farmer prepare for drought and by ensuring a fair income by means of a tribunal to investigate production costs and ensure an adequate return and by better marketing. Diplock doubted that pasture improvement would help outside the high rainfall areas, and sensibly pointed out that if pasture improvement meant higher production then it would involve further diversion to the unprofitable overseas market. He promised that he would continue to press the Government to break the Brisbane Milk Board's monopoly of distribution in the metropolitan area.

At Atherton Nicklin gave some more details of the pasture improvement scheme and augmented his promises. The Government would establish teams of experts in each of the State's eight dairying districts, consisting of four specialist officers and extension officers. Selected farms would be assisted with a special farm management service. The farm water supply scheme would be extended with deferred payments, and advances would be made for equipment purchases. The Primary Industries Department would extend its regional development services. Immediate assistance was warranted by the declining number of dairy farmers and cattle (Courier-Mail: 18 May 1966). At the same time Chalk, as acting Premier whilst Nicklin was on the road, released the report of the dairy industry advisory committee. It had blamed poor nutrition for much of the Queensland industry's difficulties and advocated the pasture improvement already promised by the Premier in his policy speech, a strengthening of advisory services, and an extension of the farm water supply scheme (ibid:). Thus the Government was on record with immediate action for all these recommendations. One proposal which was not acted upon at once was that an assessment should be made of farm size necessary for a reasonable farm income to guide aggregation either for dairying or conversion to other agricultural activities, with special funds being made available for consolidation. This would have been too sensitive to adopt at this time. At Atherton Nicklin also encouraged the Country Party candidates for Tablelands and Mulgrave by predicting that if local dairy farmers took advantage of the Government's measures the district 'should improve out of sight' and be in a position to meet the demands of growth in North Queensland. In Laidley Chalk said that he was convinced that the net income of dairy farmers would be substantially improved. Again the Q.D.O., this time through its secretary, gave its blessings to the announcement.

Duggan's counter-attack was concerned more with the timing of the proposals than their substance. They were belated handouts which were cynical moves designed to save Government politicians rather than help the industries concerned, and pointed to the fact that the Government had no overall co-ordinated approach (ibid.). The pub- 
lication and implementation of the report took the sting out of Labor accusations that the Premier was afraid to release it 'because his Liberal-dominated Government is not prepared to carry out its recommendations' (Barrett in Warwick, Warwick Daily News: 18 May 1966) and candidates, for example Prisgrove in Callide (Morning Bulletin (Rockhampton): 20 May 1966) were left with only the rhetorical question of why he had waited so long to act. Hasemann on the day after did claim that the Government was not game 'to release the full report' before the election lest it suffer 'a total eclipse' and forecast that it would disclose that 3,000 dairy farmers had left the industry in the previous two years (South Burnett Times (Kingaroy): 25 May 1966) but the point was not taken up elsewhere. In Aubigny P. G. Fitzpatrick (Toowoomba Chronicle: 21 May 1966) suggested that the proposals were 'aimed at aggregation of farms at the expense of the financially weak' when no one could prove that aggregation was the answer until all alternatives of research and land use had been tried. The News-Mail (20 May 1966) conceded that Duggan might be right in claiming that some dairy farmers were dissatisfied with the report, but considering that $\$ 1.5$ million was to be spent their resentment might be misplaced. Inevitably one Government candidate, J. E. Corfe in Aubigny, expressed regret at 'the shabby practice of trying to make a political football out of the industry for the purpose of gaining votes for any particular party or candidate' (Toowoomba Chronicle: 24 May 1966). Equally inevitably he got the reply from one of the rebels that the industry had been a political football for years (ibid.: 26 May 1966).

The Government's sack was still not empty, however. On the Tuesday before the election Chalk announced that drought relief loans up to $\$ 600$ at $3 \frac{1}{2}$ per cent for five years to assist with fodder crops would be made available to dairy farmers who had not previously received assistance. The loans would be made by the Agricultural Bank (Courier-Mail: 25 May 1966).

The debate about the sugar industry had taken place without substantial reference to the Cane Growers' Council, but disagreements within the Queensland Dairymen's Organisation and its leaders' endorsement of various government schemes for assistance during the campaign brought this interest group fairly prominently into the election. Nevertheless, this natural ally of the Country Party managed to remain clear of the main fight. Disagreement focused on the $t+1$ period and whether the Government's immediate remedies were to be preferred to the A.L.P.'s long-range and much vaguer proposals. One suspects that both sides found themselves baffled by the intractability of the problem, but the Government at least had available to it the means for some short-term alleviation. Increased production through improved pastures could hardly be regarded as a long-term solution. 


\section{Local Issues}

By and large the issues in both the 1963 and the 1966 elections were statewide issues, broad policy questions which in the future would affect most of the State or at least large areas of it, together with the records of the Country-Liberal government and its Labor predecessor as custodians of the State's interest in the past. Certainly many local matters were mentioned in the campaigns, matters relevant to only one electorate or a part of an electorate: the state of local roads; public works sought for or received by the electorate; private projects for development in the district. But these occasioned little debate. A sitting Member might say that he had secured more of something than his predecessor of the other party, and this might be denied, but the local matters on which anything of a dialogue developed were few and far between. Five of them are reported below in some detail to give an indication of the way in which such issues unfold during an election campaign and become involved in it. All five come from the 1963 campaign, which was much more productive of such issues, but there were some comparable issues in 1966 such as the barrage at Rockhampton or the parks on islands in the Nerang River and coastal erosion at Gold Coast. Some others from 1963 such as the possibility of a new abbatoir at Rockhampton and the location of the main airport at Toowoomba might have been added, but these five should suffice to show how local issues can erupt into State politics or State politics seize upon local issues.

\section{The Jubilee Bridge in Gold Coast}

The city of Gold Coast consists of the formerly separate towns of Southport, Surfers Paradise, and a series of smaller resort centres stretching down the coast to the New South Wales border at Coolan- 
gatta, a prime example of ribbon development along the beach and the Pacific Highway. Immediately south of Southport, which forms the northern part of the city, in 1963 the Highway crossed the narrow Nerang River on the wooden, two-lane Jubilee Bridge, named to commemorate the jubilee of George V. Upstream the river swings out towards the coast forcing the land into a thin isthmus connecting the first land south of the Bridge, Main Beach, with Surfers Paradise and points south. Erosion of this isthmus, Narrow Neck, was a perpetual danger to the Highway, and as the Jubilee Bridge became more decrepit and Narrow Neck eroded, plans were prepared for a new bridge upstream, bearing four lanes commensurate with the city's growing traffic, to enter the heart of Surfers Paradise south of Narrow Neck. The principal unpleasant consequence of such a change would be to leave Main Beach and its small shopping centre an isolated backwater off the Highway.* In February 1962 the Department of Main Roads proposed to the Gold Coast City Council that a new four-lane bridge be built at a cost of $£ 526,000$, of which the Council should provide $£ 250,000$. The Council queried its share of the cost, the underpass works suggested for each end of the bridge, and whether four lanes were really necessary. There the matter rested for a year.

On 2 March 1963 Ernie Evans, the Minister for Main Roads, announced that a new design for a replacement bridge would soon be offered to the Council by officers of his department. At the Bundaberg Labor-in-Politics convention the Coolangatta branch of the A.L.P. had tabled a resolution calling for action to replace the Jubilee Bridge, but it was another of its motions, to redivide the city to attach Southport to adjacent Albert Shire, that attracted most attention, and Evans's announcement was more likely a consequence of departmental routine than a response to Labor pressure. The Mayor of Gold Coast, Alderman Ern Harley, who was expected to stand as an Independent candidate for the Albert constituency comprising Southport, promptly reminded the public that the Council had asked for details of a traffic survey which had been undertaken to ascertain whether four lanes were necessary. On the 18th a new urgency was provided when two planks on the old bridge broke away during heavy rain, and the Brisbane Telegraph (20 March 1963) was moved to demand urgent action.

On the 20th Evans was reported to have disclosed that the new plans called for the upstream crossing because a four-lane highway was required and this could not be built over Narrow Neck. The State Government would continue to maintain the Highway over Narrow Neck as a gazetted highway, and the old Jubilee Bridge could

* A handsome aerial colour photograph of the area at this time may be found in The National Geographic Magazine, Vol. 124, No. 3 (September 1963), p. 372. 
be left as a link between Southport and Main Beach. The plan, the Minister declared, was the result of detailed inquiry and would be part of a co-ordinated plan in the interest of local residents and visitors. Whilst the Government wanted the Council to co-operate, it would make an independent decision if necessary, and Evans added that both local M.L.As. were co-operating fully with his Department in the proposals being discussed (Courier-Mail: 21 March 1963). The next day he made a further statement about the exact location of the new bridge, and also dealt with Alderman Harley's comment on the first announcement to the effect that the Council would give its full co-operation but had been waiting since February 1962 for a concrete proposal. On the contrary, the Minister said, when last the Department had submitted proposals to the Council, the Council had waited some months before considering them, then had asked for information which entailed a traffic survey. When this was available the Government had acted (ibid.: 22 March 1963).

On 22 March the Gold Coast Bulletin rounded on the Minister for reviving the 'moth-eaten' idea of a new bridge site and claiming that a four-lane highway could not be built over Narrow Neck. Only a year before his Department had submitted a proposal along the lines now rejected to the Council.

Obviously the question can now be asked: Did the Government do this knowing that the Council would reject it and possibly leave the civic body open to public charges of procrastination? It would be very hard to convince the public that the whole thing does not reek with political manoeuvring and civic blame-laying.

Observing sadly that taik of the inadequacy of the Jubilee Bridge started in 1928, the editorial observed with some justice that the issue had become so befuddled that the public had long since given up trying to blame anyone.

One of the two local M.L.As., Eric Gaven, whose constituency of South Coast embraced Gold Coast south of the Nerang, promptly declared his opposition to the scheme.

It will hurt too many people. I will not be on side with the Main Roads Minister, Mr Evans, on this issue. I don't represent the Main Roads Department of the Minister. I represent the people of Gold Coast. I'm not an engineer. But I know the area. I know the people and I know their needs. I will not hesitate to fight against my own Government for my people. (Gold Coast Bulletin: 27 March 1963)

The new site could take ten years to complete, and Gaven offered elaborate suggestions of his own for utilising the old route. These Evans, no mean controversialist, found 'quite unsound' and proof 'that a little knowledge is a dangerous thing as far as some people are concerned'. For the next few days the Minister and the Member lambasted each other in the columns of the Brisbane and Gold Coast press. 
Gaven warned that the Minister's assurance that he would leave the existing bridge 'could be so much eyewash', and his scheme would be the immediate ruination of Main Beach and could ultimately affect Southport. Evans defended the new scheme, not as his own plan but as a Main Roads Plan 'approved by the Co-ordinator-General, the Departments of Lands and Harbours and Marine, and finally State Cabinet'; it would protect Narrow Neck but without prohibitively expensive resumption such as was implicit in Gaven's plan for a fourlane highway along Narrow Neck.

Despite the Minister's defence, the Gold Coast United Progress Associations Council to which nineteen local bodies belonged gave its support to Gaven and the old site. On 1 April details of the new scheme were disclosed at a meeting of Gold Coast Councillors with officials of the Department of Main Roads. Both local M.L.As. endorsed the old site, but it was Gaven who made most of the running. First he presented the Minister with a petition signed by 400 residents of Main Beach, which lay in his electorate, then he appeared before the Gold Coast Chambers of Commerce which subsequently decided to protest against the scheme as wasting several hundred thousand pounds and bringing the State Government into competition with private land developers. (One consequence of the new route would be that one arm of the Nerang behind Narrow Neck could be filled in and the new land subdivided for sale. Proponents of the Department's scheme argued that this alone could save Narrow Neck from eventually being cut through by the river, with the complete isolation of Main Beach.) Gaven explained that the decision had never come before the Country Party parliamentary party but was a Cabinet act. Evans was reported as saying 'We are not going to hold up progress for petty politics or for an election'. Gaven was equally adamant: 'I will not stand for the steam-roller tactics they are using' (Sunday Mail: 14 April 1963).

At this point the two Country Party M.L.As. parted company. Cec Carey's first response had been to ask that Departmental officers be sent down to investigate cases of hardship which would result from the new route. He then called a meeting of some sixty-six Southport businessmen and property-owners to discuss the matter. The meeting canvassed the merits of the scheme, including the possibility that the State Government might build an expressway further inland and bypass Surfers Paradise entirely, for it was already committed to the first stage of an interstate highway which bypassed most of the Gold Coast, and endorsed it 60-6 (Courier-Mail: 27 March 1963). Carey explained that he had sought guidance from his constituents on the issue, and expressed his belief that the Government was prepared to do whatever was best. He also reported that the Minister had promised to keep the Jubilee Bridge going until the new bridge was finished, 
and then to redeck and repair it so as to make it usable for another ten to fifteen years and present it to the City Council at no cost. Under the new scheme the Council would pay only $£ 182,000$ of the cost of $£ 779,400$, and if there were no footways on the bridge its share would drop to $£ 112,000$, instead of the $£ 250,000$ suggested in 1962 . As to the first promise, the State Government could hardly let traffic across the Nerang stop entirely, and as to the second, Alderman Harley had already told the I April meeting with Main Roads officials that the Council was not interested in accepting responsibility for the maintenance of a wooden bridge.

The other interested parties promptly dissociated themselves from Carey's meeting. Both Harley and Gaven objected to a decision taken by a collection of Carey's invitees instead of at an open meeting. Gaven added that he had received 'shoddy and shabby' treatment from the Government in not being consulted over the new scheme, and described himself as 'the label on a tin of jam-always on the outside'. The president of the Main Beach Development Association called an open meeting at which 200 people, having heard Gaven charge that the new bridge was ' $a$ wildcat scheme, conceived in indecent haste, with no regard for the number of people who would be hurt' (Telegraph: 19 April 1963), voted unanimously to have the bridge rebuilt on the sane site. The A.L.P. candidate for Albert, E. F. J. Ulrick, chimed in with a letter advising acceptance of the rehabilitated Jubilee Bridge. He concluded that the episode proved voters could not trust the Government.

However, when the Gold Coast Council met on 17 April it voted 7-2 to accept the advice of its works committee and agree to the new bridge together with one footway. Alderman Harley was unable to record his opposing vote in the absence of a tie. The Council, again on its committee's advice, rejected the offer of a rehabilitated Jubilee Bridge and demanded that the Department of Main Roads remain responsible for erosion control at Narrow Neck. Carey, thus reinforced, declared that he would seek implementation of the new scheme, and defended his meeting as representative, for some of the people invited were personally unknown to him. A meeting of 400 called by the Surfers Paradise Chamber of Commerce to hear the Commissioner for Main Roads, the permanent head of Evans's department, heckled him vigorously, but the tide was beginning to turn. The Gold Coast Bulletin decided that common sense had prevailed, and dismissed the continued obstinacy of the Main Beach Development Association with the statistic that only 2 per cent of the traffic over the Jubilee Bridge stopped at Main Beach. The Surfers Paradise Chamber of Commerce voted 23-14 to reverse its earlier opposition to the scheme, and the Southport Chamber of Commerce voted unanimously in favour of it-and retention of the old bridge. 
Later in the campaign there were a few references to the bridge, but the new site was accepted as a fait accompli. Thus Gaven told a meeting of 200 at Surfers Paradise that resumptions for the new bridge would affect a large number of developed properties, and the meeting passed a resolution asking that no action be taken until further investigations were made. The parish priest, Father J. N. Shannon, added that Surfers Paradise would be sandwiched between two speedways under the Government's plan and virtually ruined as a holiday resort. On the other side, Carey thought that the Council had acted too hastily in rejecting the old bridge, and promised his first campaign meeting that he would appeal to the Minister to retain it. Survey work began in May. The last words in the campaign came from the A.L.P.: Mrs. I. G. Weir, the candidate for South Coast, complained that $£ 800,000$ was being spent to satisfy Carey's ego because he had promised a new bridge in the 1960 campaign, instead of which one had been built to Bribie Island north of Brisbane, and Duggan stated that the route for the new bridge had been selected with a careless disregard for cost.

The views of members of the provincial cities panel drawn from Albert and South Coast were elicited by a forced choice question: 'Do you think that the State Government has been in the wrong in its actions over the Jubilee Bridge?' As numbers of respondents were small and differences between the two constituencies minor, totals for both were combined in Table 7.01. It appears that Alderman Harley's supporters were as likely to support the State Government as those prepared to vote for either Carey or Gaven; it may be that most of them were basically Liberal voters rather than true Independents. Labor voters were much more likely to condemn the Government out of hand, and to deny its good intentions. However, about the same proportion of each group was prepared to look to the local M.L.A. for action in such situations: Among Country Party voters in Albert, where Carey played it very cool, 24 per cent mentioned the Member's role and in South Coast, where Gaven played it very hot, 32 per cent did so. In Albert, where Carey was converted to the Government's view, 21 per cent thought the Government had made the right decision, but in South Coast, where Gaven remained unconvinced, only 9 per cent thought so.

Those respondents (14 per cent in Albert and 9 per cent in South Coast) who availed themselves of the opportunity to use their own words mainly either restated one of the forced choice propositions, condemned the Government's scheme 'on engineering grounds', stated the need for a new bridge, or agreed that it would cause some localised hardship. Very few provided comments with some political overtone. A builder observed: 'No matter which Government or Party does anything it is always criticised by someone but I believe it makes things 
Table 7.01

Opinions of voters in Albert and South Coast on the Jubilee Bridge issue 1963

$\%$

\begin{tabular}{lcccc}
\hline & \multicolumn{4}{c}{ Voting intention: } \\
\cline { 2 - 6 } & $\begin{array}{c}\text { A.L.P. } \\
(\mathrm{n}=35)\end{array}$ & $\begin{array}{c}\text { Country } \\
(\mathrm{n}=78)\end{array}$ & $\begin{array}{c}\text { In- } \\
(\mathrm{n}=18)\end{array}$ & $\begin{array}{c}\text { Q.L.P.† } \\
(\mathrm{n}=4)\end{array}$ \\
\hline $\begin{array}{l}\text { They have been completely in the wrong } \\
\text { They had to make a difficult decision } \\
\text { and cannot be blamed for it }\end{array}$ & 31 & 8 & 11 & 25 \\
$\begin{array}{l}\text { They made the right decision and criticism } \\
\text { of it is just an attempt to make political } \\
\text { capital against the Government }\end{array}$ & 14 & 24 & 33 & 25 \\
$\begin{array}{l}\text { I cannot judge their decision but I believe } \\
\text { that the Government acted with good } \\
\text { intentions }\end{array}$ & 11 & 14 & 0 & 25 \\
$\begin{array}{l}\text { We should have a local representative in } \\
\text { Parliament prepared to speak and vote } \\
\text { against mistaken policies such as this }\end{array}$ & 26 & 37 & 45 & 25 \\
\hline
\end{tabular}

\section{* Albert only † South Coast only}

Note: Percentages may add to more or Iess than 100 because other answers might be given or more than one of the forced choice alternatives marked.

all the better for that criticism.' Several criticised the conflict between the two local Members and between the State Government and the City Council. Perhaps the most representative opinion is that of a working widow, who might be classed as a pure Independent: she had voted for Alderman Harley in 1960 and planned to do so again without being interested in a Liberal candidate: 'There has been so much controversy about the bridge that we are foxed. What is best for the coast as a whole is my opinion.'

Short of withdrawing his support from the Government there was little more that Gaven could have done for his Main Beach constituents. He had polled 86 per cent of the votes at the Main Beach polling booth in 1960, and he polled 86 per cent again in 1963. Across the Nerang in Southport the three local polling booths showed a definite swing to Carey: 43 per cent of the vote in 1963 as against 36 per cent in 1960. The A.L.P. vote dropped from 24 per cent to 22 per cent, and Alderman Harley's vote fell from 39 per cent to 35 per cent. There was a general swing to Carey in the electorate as a whole, but it was under 5 per cent, whilst at three Southport booths it was 7 per cent. Neither sitting Member appears to have suffered for his views, even though they were substantially opposed. 


\section{University colleges for Rockhampton and Toowoomba}

One local issue can be studied in two separate areas comprising four electorates in 1963. For some years prior to the election both Rockhampton and Toowoomba had sought establishment of university colleges of the University of Queensland, and their appetite had been whetted by the appearance of the first such college at Townsville in 1961. Each city had an active and influential University Development Association formed to press the University and the State Government to get on with the job, and in each city a large site had been set aside by the City Council for its university. Again, in 1963 each city contained a marginal Liberal seat-Toowoomba East, retained by the former Mayor, Anderson, with $47 \cdot 17$ per cent of the vote, and Rockhampton South, held by the current Mayor, Alderman Pilbeam, with only $41 \cdot 12$ per cent of the vote. This latter figure somewhat overstated Alderman Pilbeam's danger, for the seat had previously belonged to a Q.L.P. Member, H. R. Gardner, and part of his 30.96 per cent of the 1960 vote would undoubtedly drift towards the Liberal candidate as the Q.L.P. vote declined.

On 31 December 1962 Pizzey as Minister of Education reviewed the State Government's record in education and found that the greatest building expansion on record was well under way, but he made no mention of any new university college. In January a succession of Government press releases and editorials proclaimed a new era of education. In Rockhampton and Toowoomba provision of local university colleges seemed the obvious culmination of an improved educational system, particularly as Townsville enrolments grew. On 12 February the Bundaberg Labor-in-Politics convention adopted a resolution, moved by Duggan, advocating establishment of university colleges on the Darling Downs and at Rockhampton. As the finance would have to be provided by the Federal Government, the resolution was referred to the federal A.L.P. for its consideration. Peter Wood, the A.L.P. candidate for Toowoomba East, promptly wrote to the Toowoomba Chronicle to point out that the decision on the university college would depend on which party won the election. The chairman of the Darling Downs University Establishment Association reported its pleasure at the decision and thanked 'our local Member' for moving the resolution. A number of newspapers commented favourably on the A.L.P.'s move, one of the few events at Bundaberg that received a good press, and even the Morning Bulletin (14 February 1963) found it 'a favourable development, if only to the extent of putting the other side on its toes and engendering a spirit of competition'. The paper also attacked the argument that provincial centres cost more per student than expansion of the St Lucia campus in Brisbane as 'shortsighted, and not in accord with the broad and imaginative sweep of the new secondary education scheme'. 
The other side did not rise to the bait. Fletcher, Minister for Lands and M.L.A. for the seat of Cunningham near Toowoomba, stated that the Country-Liberal Government remained the pioneer of regional university education about which Labor had done nothing during its long term of office, and claimed that the Government still said 'that the success of Townsville University College would lead to provision of a similar facility at Rockhampton and that this could be followed by a third at Toowoomba' (Toowoomba Chronicle: 23 February 1963). Wood found his reply too vague, his Party's attitude 'characteristic-a lot of talk, but no action', and declared that Toowoomba people would not accept having to wait behind Rockhampton. The debate developed in the columns of the Chronicle. 'Thinking Voter' came to Fletcher's aid by conceding that Central Queensland had stronger claims for development and pointing out that there was a Labor government in office in New South Wales where quotas had been imposed on university admissions. Pizzey questioned Wood's claim that a Labor government had never turned away students, when for almost forty years it had favoured industrial areas at the expense of the country in the provision of secondary schools. Imposition of quotas at the University of Melbourne and a prediction by the University of Queensland's Vice-Chancellor that this might be necessary at St Lucia by 1965 gave urgency to the argument for expansion, but a number of letter-writers complained that the Association, or Wood, or the A.L.P., were turning 'such a worthwhile project' into 'a political football'. Only one correspondent threatened direct action when, after conceding that Pizzey was 'the best Minister for Education we have ever had', he asked Government candidates to state plainly whether the Government was going to build a second university in Brisbane or would 'many thousands of us . . . voting for our children' have to vote Labor.

On 15 March Pizzey provided a cold douche for both cities by warning that any date for establishing a second university in Queensland was conjectural. No action could be taken by the State Government until the report of the Commonwealth's committee on tertiary education was available and that would probably not be for some months. (The Martin Committee's report was released in 1965, and recommended that the second university be established in Brisbane. Rockhampton and Toowoomba were awarded high-level technical colleges which evolved into colleges of advanced education with shifts in Commonwealth policy.) This closed down the debate in Rockhampton until the election campaign entered its final stages in May, but in Toowoomba the argument continued unabated. Letters to the editor urged spectators to get off the fence and help the Association, but one reported a visit to the Premier at which, after pointing out the problems of money and staff any new foundation would have, 
Nicklin had given an assurance that a university would be established 'the moment the Government can see its way clear to bring it into being, and keep it functioning' and that no government could do more than his was prepared to do (ibid.: 18 March 1963).

On 21 March Toowoomba received another rebuff. The Executive Council approved expenditure of $£ 82,500$ for the first stage of a new Inebriates' Institute to be built at Wacol on the Brisbane-Ipswich boundary, replacing the old institution in the small town of Marburg between Ipswich and Toowoomba. The A.L.P. Mayor of Toowoomba, McCafferty, grumbled that no consideration had been given to pressing Toowoomba's claims for this 'industry', and found it unfortunate that those in a position to press Toowoomba's claims were either indifferent or else prepared to accept 'Queen Street type of Government'. If this was an indication of their readiness to push Toowoomba 'an ideal site for this type of institution, what chance had the city of getting a university?' (ibid.: 23 March 1963). Peter Wood, opening his campaign formally, dealt with those who objected to the issue becoming a political football by claiming that the Government's Townsville decision in 1960 had been political, and went on to say that inevitably the building of such colleges would be political issues and only by this happening would a college be built in Toowoomba.

Pizzey, as the principal and often sole Government spokesman on the matter, took his stand on the need for Federal - Government approval. Whilst Toowoomba's claims would never be overlooked, the Australian Universities Commission would have to be satisfied, and the Government would break their fiduciary trust to undertake such a venture without A.U.C. backing. Duggan answered that the Minister for Education had encouraged the people of the area to form a committee by saying that the Government would help those who helped themselves. The people of the Darling Downs had responded magnificently and now they were getting evasive replies. The Minister had not waited for the A.U.C. when funds were made available to start Townsville University College. Duggan then restated Labor policy fully:

It will be the intention of the Labour Party, if returned as a Government, to immediately initiate discussions with the Commonwealth Government for the provision of loan allocations and subsidised financial assistance for the construction of University College facilities at both Rockhampton and Toowoomba. If the Commonwealth refuses to help the Labour Party will go ahead itself with such funds as it can command. (Ibid.: 28 March 1963)

The Minister, apart from passing shots at Labor's record, for example, in failing to get. University or professional recognition for diploma courses at the technical colleges or neglecting secondary education, could only restate his reliance on the financial problem and say that it 
was useless for the Leader of the Opposition to say that he would seek special federal assistance for that would be given only according to a national policy which was then under review. He correctly foreshadowed that the Commonwealth might decide against subsidies for university colleges and in favour of technical colleges in provincial centres, in which case Labor would have to find $£ l$ million each for Rockhampton and Toowoomba university colleges at the same time as aid for technical colleges had been ruled out because all the tertiary students were in the university colleges. Would Duggan split the enrolment between two institutions at each centre, and would the Commonwealth be prepared to subsidise technical colleges on such a basis? If not the $£ 2$ million would have to come out of other educational needs. Pizzey counselled patience.

Duggan came back at once. The Minister was now disclosing prerequisites which had not been revealed before. Had they applied to Townsville? The potential of the subject was now about worked out, but letters continued to accuse the Government of evading its responsibilities and of delaying an announcement that the second university would be in Brisbane until after the election. The Association picked its path carefully. A combined meeting of Liberal branches was postponed so as not to clash with the launching of 'Project University', a fund-raising and membership drive, and the chairman of the Darling Downs Area of the Liberal Party commended the move for the university college. The Association remained carefully non-partisan. A morning tea was arranged by Mesdames McCafferty, Duggan, Chalk, Swartz, and Anderson, and at the opening of the 'Project' McCafferty and Anderson spoke, while letters were read from Chalk, Fletcher, Swartz, and Duggan. Warnings against partisan politics continued:

Plato or Aristotle could start a university single-handed, merely by discoursing in a public place to all who would listen; but in this day and age we need the active support of all political parties, State and Federal, and we shall not get it by playing them off against one another. (Ibid.: 25 April 1963)

The Association continued to make the general case for a university in a population centre of Toowoomba's size. But A.L.P. advertisements proclaimed that Labor "will establish a university college in Toowoomba' (ibid.: 11 May 1963), and Wood and Duggan continued to contrast the Government's expedition for Townsville in 1960 with its reluctance because of the A.U.C. in 1963. At the end of the campaign Wood proclaimed: 'While this coalition is in power Toowoomba people will never see a University College in their city . . ' (ibid.: 30 May 1963). Only then was Anderson moved to reply by accusing Labor of irresponsibility in saying that it would act regardless of the Martin Committee's report. 
In Rockhampton the Minister of Education's warning that the A.L.P. could not implement its promise until the extent and form of Federal aid were known may have prevented the issue coming to the fore, or perhaps it was the coincidence of the Darling Downs University Establishment Association's campaign which stirred Toowoomba. The first step in Rockhampton was an A.L.P. advertisement which promised 'a University at Rockhampton', and this was followed by a statement by the Labor candidate for Rockhampton South, C. W. White, that it would cost $£^{5}$ million and place emphasis in its teaching on tropical agriculture and science to train the personnel to develop the North as well as swelling the population and increasing the purchasing power of Rockhampton (Morning Bulletin: 3 and 14 May 1963). A rider for the tropical emphasis had been added to Duggan's motion at the Bundaberg Labor-in-Politics convention, apparently in response to a decision of the North Queensland Local Government Association meeting at Mareeba a few days before to ask the State Government for an agricultural college in North Queensland and facilities for a degree in agricultural science specialising in tropical agriculture. For the Liberals, Alderman Pilbeam's advertisements claimed 'he wants to fight for . . . a Central Queensland University', and in their policy speeches he and the Liberal candidate for Rockhampton North, P. M. German, pledged their support for the university college. When the Liberal leader spoke in their support, however, he dwelt on the Government's assistance for high schools and technical schools without mentioning the university college, an omission the Morning Bulletin regretted. Thereafter while A.L.P. candidates repeated that their party was pledged to the construction in Rockhampton of a university or university college, the two being interchangeable for most speakers, Alderman Pilbeam appears to have dropped the subject for a time.

When Duggan visited Rockhampton on 18 May and promised both the university college and a district abbatoir, the Mayor came back with the comment that both promises were at the same level of cynical hypocrisy. In view of Duggan's connection with Toowoomba, which city would get its university first? The Mayor contrasted his own firm advocacy for priority for Rockhampton, and compared the lack of interest in the Central Queensland University Development Association of his A.L.P. opponent, C. W. White, with his own status as a foundation member, vice-president, and member of every deputation to the State Government and University Senate, even paying his own fares. White replied that as Mayor and M.L.A., Alderman Pilbeam was in duty bound to join such a body, but asked what good had his three years as a Liberal M.L.A. done. The Morning Bulletin whilst continuing to press the case for the university college sourly referred to an abortive railway station started by the A.L.P. State government thirty years before and to a wool store never built by an A.L.P. Federal 
government, and asked whether Duggan's university college and abbatoir might not share their fate. Alderman Pilbeam answered White by asking voters to distinguish between sincere candidates and opportunists on a number of grounds, one being:

The sincere candidate is one who, when he advocates a project, has proved that he has always been interested in it by working hard for it. Such projects are the Central Queensland university, Port Alma development, alternate meat works in Rockhampton. The opportunist is one who takes no interest in these projects at all, but simply opens his mouth about them before an election. (Ibid.: 29 May 1963)

When the election was safely over, Anderson, whose vote had fallen slightly, stated to the press that he believed that the A.L.P. promise to build a university college had swung a lot of votes against him, and added: 'My Government did not do much about it until it was too late.' The Association's chairman declared that he was surprised by such a statement, for the Association had always emphasised that this was not a political struggle, even though he hoped that Anderson's remarks indicated that it had become a vital public issue. By the end of June the Darling Downs Association had almost 6,000 members, but its prospects were declining. The Telegraph (27 June 1963) reported that the State government had had unofficial advice that no new provincial university colleges would be built in the 1964-6 triennium. Pizzey denied that the A.U.C. had given such advice, and explained the difference between the A.U.C. and the Martin Committee, on whose report the future of country university colleges depended, a distinction which was frequently misunderstood during the campaign.

Members of the provincial cities panel in Toowoomba East were asked their views on the question. Their responses suggest that partisan loyalty was probably the dominant influence on their opinions.

Very few Liberals were susceptible to the A.L.P. line, whilst some Labor voters did accept the Government's explanation. It would be unwise to accept the percentages at face value, for the more partisan Labor voters might well be those who would fail to complete a mail questionnaire, and again the almost complete agreement that the issue was a real one might be challenged on the ground that the politically apathetic would not participate in an inquiry of this sort. Of the respondents, 32 per cent chose to add some comment of their own, most affirming the need for a university college, and many saw a need for continued 'pressure' to get something done, even though none saw this in terms of backing a particular party or candidate. A few argued that politics did not come into it or referred to the need for Commonwealth finance. 
Table 7.02

Opinions of voters in Toowoomba East on the university college 1963

$\%$

\begin{tabular}{lccc}
\hline & \multicolumn{3}{c}{ Voting intention: } \\
\cline { 2 - 5 } & $\begin{array}{c}A . L . P . \\
(\mathrm{n}=25)\end{array}$ & $\begin{array}{c}\text { Liberal } \\
(\mathrm{n}=54)\end{array}$ & $\begin{array}{c}\text { Q.L.P. } \\
(\mathrm{n}=7)\end{array}$ \\
\hline $\begin{array}{l}\text { I think the present State Government are doing } \\
\text { their best, and will provide a University College } \\
\text { for Toowoomba as soon as possible }\end{array}$ & 20 & 59 & 43 \\
$\begin{array}{l}\text { I think that an A.L.P. Government would probably } \\
\text { get a University College for Toowoomba more } \\
\text { quickly than the present Government }\end{array}$ & 56 & 7 & 14 \\
$\begin{array}{l}\text { I think our only hope for a University College in } \\
\text { Toowoomba is an A.L.P. Government }\end{array}$ & 24 & 0 & 14 \\
$\begin{array}{l}\text { I think that the whole question of a University } \\
\quad \begin{array}{l}\text { College for Toowoomba is a political stunt } \\
\text { I don't think that Toowoomba and this area will } \\
\text { need a University College in the immediate } \\
\text { future }\end{array}\end{array}$ & 8 & 6 & 0 \\
\hline
\end{tabular}

Note: Percentages may add to more or less than 100 because other answers might be given or more than one of the forced choice alternatives marked.

\section{Road transport regulation in Tablelands and Lockyer}

Another local issue which appeared in two widely separated electorates was the Government's handling of road transport. A convenient, and dramatic, point for beginning the story would be Boxing Day 1961 when Albert Edward Jonsson, a farmer from Kalban near Ravenshoe which in turn lies inland from Innisfail, was imprisoned for failure to pay two fines of $£ 240$ and $£ 270$ imposed under the Transport Act. Jonsson was a respected farmer who employed thirty-six men at the time of his arrest. The 1960 Transport Act permitted a farmer to drive his own produce distances up to seventy-five miles in a truck of up to four tons without incurring road tax, but as Jonsson drove his vegetables a longer distance to Townsville twice a week he was liable for $£ 24$ tax per truck. The chairman of the Herberton Shire Council called a protest meeting at Ravenshoe, and the local Country Party Member, T. V. Gilmore, at once urged a review of the application of the Act in remote areas. The meeting attended by more than 300 people passed resolutions asking the Premier whether steps could be taken to secure Jonsson's release and for the Minister for Transport to add fruit and vegetables to the substantial list of items already exempted from the provisions of the Transport Act-fresh milk and cream, meat and fish, stock and station goods, fertiliser, and 
a number of other items. Gilmore criticised the State Railways as inefficient and for failing to provide the service they should, but pointed out that hundreds of millions of pounds were invested in them, and every new carter's permit cost the railways money.

The dispute spread quickly. Nicklin, with unaccustomed severity, declared that Jonsson did not want to be helped and no special exemption could be granted him, and Chalk as the responsible Minister met criticism by stating that Jonsson had assets worth $£ 200,000$ but when offered time in which to pay his fines had replied: 'I would rather sweat it out in jail.' Eventually Cabinet rejected the Ravenshoe meeting's request to have the penalty waived on the ground that Jonsson had placed himself in the position of 'flagrantly breaking the law' and that to intervene would bring the law into disrepute. Meanwhile Duggan suggested that the Government's transport policy needed an overhaul, especially in North Queensland where distances were great and produce perished quickly; one of Jonsson's points was that slow, roundabout transport by rail ruined his produce. The president of the Country Road Transport Association also advocated Jonsson's release.

On 22 January he was released from prison upon a writ of habeas corpus. On 28 February the Minister for Transport told a meeting of the Government parties that concessions would be made to primary producers including unlimited transport in the grower's own trucks up to four tons, instead of two tons as previously. Jonsson's case was sub judice, however, and could not be affected. In May the State Supreme Court, in another case, found the 1960 Act invalid on what could be regarded as a technical point. When the Minister stated that his Department would continue to accept applications for and to issue permits under the Act, the Country Road Transport Association advised its members that the Transport Commissioner and his officers had no power to enforce provisions of the Act or regulations made under it, and complained to the Governor about the Minister's 'provocative disregard of Her Majesty's Court' (Courier-Mail: 19, 21, and 22 May 1962). A special sitting of Parliament was called for 6 June to fill the gap left by the Court's decision, but before it could meet, the Young Country Party convention at Southport gave Chalk a stormy time, and heard the Liberal M.L.A. for East Toowoomba and managing director for one of the State's largest hauliers, Anderson, attack hasty validation of the Act. The following Country Party conference was equally embarrassing for it was decided that Chalk, as a Liberal, was ineligible to address the conference and eventually the Premier promised a conference with road users.

When Parliament met, Duggan and Anderson agreed on the need for a Royal Commission into the transport industry, Anderson adding that such an inquiry might find the source of a rumour that road hauliers would donate $£ 100,000$ to the A.L.P. to fight the Government. 
However the new legislation re-enacting the old, apart from the minor provision which had led to its invalidation, was passed swiftly to protect the Government's road tax revenues, and the High Court subsequently upheld the new legislation as retrospectively validating the 1960 Act. On 1 August Jonsson was back in court for breaches committed whilst released on the writ of habeas corpus; he was fined $£ 400$, but this time the Government chose to seek a civil order to recover the fines when Jonsson was reported ready to return to jail.

The Country Road Transport Association was the only pressure group, apart from trade unions supporting the A.L.P., which chose to take an active and open part in the 1963 election. Its problem was to decide the most effective and appropriate method of intervention. One possibility was the Tablelands electorate where the Jonsson case had highlighted the oppressive possibilities of the Transport Act, but Tablelands was a marginal seat where the sitting Country Party Member, Gilmore, had additional handicaps (see pp. 256-7), and a campaign against him by the Association might be crowned with the defeat of a Government Member, whether or not the Association had caused it. It was too risky to tackle the Government in such a situation where the Government might blame the Association for Gilmore's defeat and take reprisals, and instead the Association chose to campaign against Chalk in his own electorate of Lockyer where he had polled 63.37 per cent of the vote in 1960 against three Independent opponents. Chalk was quite safe, and however much the Association might castigate him it was unlikely to do him irreparable harm. The Association wished to make a point, not seriously antagonise a Government which was likely to be returned to office, and whilst the Lockyer campaign was embarrassing to Chalk, it was not dangerous to him.

The campaign was opened with advertisements in a local newspaper, the Gatton Star, placed over the name of the Association which described itself as non-political. One advised voters to ask their candidate whether he was going to permit 'a Communistic policy attitude as shown by Mr Chalk under his present Transport Act', and others complained of police powers under the Act and inequalities of freight rates between different areas. At the same time the Independent can. didate for Lockyer, Jim Dwyer, opened his campaign at Gatton with an attack on Chalk along the same lines: the Government was building up a police state and had launched 14,000 prosecutions in five years and the man on the land was being exploited to pay railway losses in order to build up a State-owned monopoly. Both the Association and Dwyer also used the statewide press to attack powers of search and seizure under the Act and to ask: 'Could you expect worse from any of the Communist-dominated countries?' (Sunday Truth: 19 May 1963). 
Opening his own campaign at Gatton Chalk asked why was it that 'the large hauliers' association' was trying to defeat him, and answered himself that it was not out of any regard for the farmer. The Minister went on to paint a lurid picture of a conspiracy of the A.L.P. and the big hauliers to drive out the small hauliers and exert pressure on the farmers. A spokesman for the Association retorted that the Railways Department was prepared to lose large sums to crush road transport, after which the losses would be recouped with high rail charges. Large advertisements in Sunday Truth (26 May 1963) and the Queensland Times (31 May 1963) of Ipswich set out the Association case that maladministration of the Transport Department had cost the State $£ 30$ million in the previous five years and had favoured interstate hauliers, and concluded: 'Help us stamp out this menace ... Vote wisely on June 1.'

Chalk's own advertisement in the Queensland Times was only slightly smaller. It pointed out that the Australian Transport Directory indicated that not a single member of the Association lived in Lockyer, and, after repeating the points made in his Gatton speech, advised: 'Forget the outside disgruntled interests, Stay with the Country-Liberal Parties. For ... No Domination by Self Seeking Pressure Groups' (ibid.). In a speech at Crows Nest Chalk dealt with Dwyer: a vote for him was a vote against the freedom the Nicklin government had brought to the primary producers and small hauliers. Chalk reminded voters that on the last occasion Dwyer had stood as an Independent he had polled only 169 votes and lost his deposit. In 1963 Dwyer managed only 112 votes, and again lost his deposit. A postscript came in a press report of the first meeting of the government parties after the election. According to the report, Chalk bitterly attacked Anderson for an alleged association with the hauliers' campaign; Anderson denied the connection (Sunday Truth: 23 June 1963).

The campaign against Chalk in Lockyer developed too late to permit any local inquiry to be made, but members of the provincial cities panel in Toowoomba East were asked for their views on the Government's record in transport regulation. Their answers again suggest that partisanship was the principal influence at work. It does not appear that those voters intending to vote Liberal who would have preferred a Country Party candidate differed significantly in their views from those who would have voted Liberal in any event. Some 10 per cent of the respondents used the opportunity offered them to add comments of their own. Two Government supporters referred to the mess Labor had left behind, a Labor voter accused the Government of backing down under pressure from big business groups, and one somewhat alienated voter observed that both sides could be abolished with little disruption to the State. 
Table 7.03

Opinions of voters in Toowoomba East on the Government's record on transport regulation 1963

$\%$

\begin{tabular}{lccc}
\hline & \multicolumn{3}{c}{ Voting intention: } \\
\cline { 2 - 4 } & $\begin{array}{c}\text { A.L.P. } \\
(\mathrm{n}=25)\end{array}$ & $\begin{array}{c}\text { Liberal } \\
(\mathrm{n}=54)\end{array}$ & $\begin{array}{c}\text { Q.L.P. } \\
(\mathrm{n}=7)\end{array}$ \\
\hline They have done an excellent job & 0 & 9 & 14 \\
$\begin{array}{l}\text { They have done a reasonably good job } \\
\text { They have not done very well }\end{array}$ & 16 & 48 & 14 \\
$\begin{array}{l}\text { They have done a very bad job. Labor would } \\
\text { have done better }\end{array}$ & 24 & 9 & 14 \\
$\begin{array}{l}\text { They have not done very well but Labor would not } \\
\text { have done any better had they been in office }\end{array}$ & 28 & 2 & 14 \\
\hline
\end{tabular}

The tobacco industry in Burdekin and Tablelands

Only tobacco among Queensland's many crops experienced real difficulties in the months before the 1963. election. Heavy rains in two major areas and hail in a smaller district damaged the crop, and farmers' difficulties reached the State press when seventy-one of them at Clare in the Burdekin delta unsuccessfully applied to the Central Cane Prices Board for sugar cane assignments. A very limited increase in Commonwealth protection and falling prices worsened their plight, and by April the Premier announced that members of an interdepartmental committee appointed the previous year to investigate the problems of tobacco growers in the Burdekin delta would leave immediately for the area, adding that distressed farmers would be entitled to relief payments to tide them over. As reports of the plight of the farmers darkened, the State Government despatched the chairman of the inter-departmental committee, Sir James Holt-Co-ordinatorGeneral of Public Works and the State's best known public servantto join the rest of his committee. The officials met a growers' committee led by the local priest, and while its officers were still in the district the Government made three more concessions by writing off the farmers' arrears for irrigation water supplied, authorising the Agricultural Bank to defer payments save for seasonal crop advances, and lifting drainage charges on the farmers' land.

At the next round of tobacco sales the Burdekin farmers continued to experience difficulty. Because of differences in soil the Burdekin leaf is less attractive than tobacco grown at Mareeba, but the farms are too small to convert to grain growing and too far from population centres to grow vegetables. By the end of the sales Burdekin growers 
had sold barely half the leaf they offered at an average price of $104 \mathrm{~d}$. per pound while the Mareeba growers had sold 95 per cent of their leaf at an average price of 148d. Speaking at Ingham on 12 May, Nicklin promised every possible Government assistance to stabilise the tobacco industry, and although the inter-departmental committee did not report formally to the Government until the end of June most farmers appear to have been satisfied with the attention they had received, or at least remained unconvinced that an A.L.P. government would do any more for them.

Table 7.04

Votes received in Burdekin 1960 and 1963

\begin{tabular}{|c|c|c|c|c|c|c|}
\hline \multirow[b]{2}{*}{ Polling places } & \multicolumn{3}{|c|}{1960} & \multicolumn{3}{|c|}{1963} \\
\hline & Ind. & Q.L.P. & A.L.P. & Ind. & Q.L.P. & A.L.P. \\
\hline Clare & 86 & 48 & 12 & 68 & 20 & 38 \\
\hline Dalberg & 19 & 14 & 4 & 14 & 14 & 9 \\
\hline Milaroo & 38 & 62 & 11 & 44 & 8 & 55 \\
\hline & $\overline{143}$ & $\overline{124}$ & $--\overline{27}$ & $\overline{126}$ & $--\overline{42}$ & $\overline{102}$ \\
\hline Burdekin electorate & 3529 & 2063 & 1367 & 3888 & 1085 & 1949 \\
\hline
\end{tabular}

In 1960 Coburn, the pro-Government Independent, had polled approximately the same proportion of votes in the three tobacco centres as in the electorate as a whole; in 1963 he polled 10 per cent below his electorate-wide average. The total vote at the three polling places was down by twenty-four; Coburn lost seventeen of the votes, so the swing of his own supporters to other candidates was probably small. The principal influence was that whilst the Q.L.P., represented by the former member for the area which had been brought into Burdekin on the redistribution, had polled 12.5 per cent above its electorate-wide average in those three polling places in 1960 , by 1963 the new Q.L.P. candidate polled only at the electorate average. The A.L.P., which had trailed its electorate average by 10 per cent in 1960 , in 1963 was 10 per cent above it. In Burdekin as a whole the A.L.P. proportion of the vote rose sharply, but only at the expense of the Q.L.P., and Coburn's share of the electorate-wide vote rose also, suggesting that the tobacco farmers' difficulties had no impact outside the affected area.

As is noted elsewhere (pp. 160-1), the Burdekin campaign was quiet, or at least was substantially unreported in the Townsville and Ayr newspapers. The Tablelands campaign was one of the most vigorously contested in the State, but tobacco played a very small part in it. The A.L.P. candidate, E. Wallis-Smith, advocated more land and irrigation for tobacco, and a 'full inquiry into the whole tobacco industry with the aim of making this area safe and stable financially' (Cairns Post :28 
May 1963). His opponent, the Country Party Member, Gilmore, who was also chairman of the Tobacco Leaf Marketing Board, kept away from the subject except to praise the industry as a source of income and employment. Across the border in Cook, Adair was able to take equal pride in the growth of the industry at Mareeba. It is difficult to compare voting patterns in 1960, when Adair was still in the Q.L.P. and a Country Party candidate stood as well, with 1963 when there were only Adair as an Independent and Bethel standing again for the A.L.P., but in the Mareeba district the proportionate increase in the A.L.P. vote was slightly less than in the electorate as a whole, suggesting that any dissatisfaction about tobacco did not extend to Adair-but then, again, Mareeba farmers must have known that they were better off than other Queensland tobacco growers.

\section{Railway closures in Tablelands and Cairns}

After some alarming predictions of the severity of the restrictions which might result, including the possibility of the disappearance of all railway services north of Fownsville, the 1962 recommendation of an American consulting firm, Ford, Bacon and Davis, for progressive retirement of the line from Cairns to the Atherton Tableland confined concern to Tablelands and Cairns where the future of the railway workshops was at stake. The Minister for Transport, Chalk, at once explained that although passenger services on the Atherton Tableland were unprofitable they were essential and should be continued, and added that the livestock traffic would warrant keeping the Forsayth and Mungana branch-lines open as well. The report provided a tenyear plan which would permit the gradual transfer of staff and closure of some workshops as dieselisation and concentration on main lines were pursued. Union spokesmen, local government leaders, and Duggan all expressed concern at the prospect, and A.L.P. election advertisements characterised the Government as the 'Close the Workshops Gang' (ibid.: 7 May 1963). Opening his campaign, the A.L.P. candidate for Tablelands, Wallis-Smith, warned that new railway line closures were contemplated by the Government (two small lines had recently been closed before the Ford, Bacon and Davis report) and pointed to a general lack of development in the area. Government spokesmen, including the Country Party Member, Gilmore, and the two Ministers most involved, Transport and Main Roads, listed works undertaken and denied that there would be further closures. Chalk conceded that there would have to be some change in the activities of the Cairns workshops, but they would remain important. The Country Party candidate for Cairns even promised to seek expansion of the workshops, and pointed out that Duggan as Minister for Transport before 
1957 had closed railway lines. The A.L.P. stuck to its warnings that the report called for closures and the Government was pledged to its implementation, while the A.L.P. had promised not to implement it. Its slogans were 'Don't Give the Railways Away! Give the Government Awayl' and 'Don't Vote Your Railways out of the Tablelands-The A.L.P. will give you Roads-and Rails!' (ibid.: 24 and 31 May 1963).

In Cairns the A.L.P. vote increased by over 8 per cent between 1960 and 1963, but entirely at the expense of the D.L.P. Fear for loss of the workshops did not drive voters away from the Country Party. Tablelands on the other hand was the one seat which the A.L.P. managed to gain at the 1963 election. In 1960 Gilmore led WallisSmith by almost 750 votes on the returns from the polling booths within the electorate, but in 1963 he trailed him by almost 500 . The net swing from Country Party to A.L.P. was close to 10 per cent over the whole electorate, but in the larger centres was particularly pronounced. Eight polling places recorded more than 250 votes each, and at seven of these the swing to Wallis-Smith greatly exceeded the electorate average. In two special leaflets directed to the Atherton and Dimbulah districts Wallis-Smith concentrated on agriculture and irrigation rather than the railways: the swing to him at Atherton was 36 per cent and at Dimbulah 40 per cent, but these figures were exceeded by two other centres, 42 per cent at Tolga and 47 . per cent at Emerald Creek. The eighth polling place with more than 250 votes was Ravenshoe, where one might have expected a reaction to the Jonsson case; there the swing was merely 3 per cent.

\section{Local issues}

In short, then, local issues do not appear to have been readily translated into electoral swings. The prospect of economic harm to Main Beach shopkeepers or Burdekin tobacco growers does not seem to have panicked them into voting for the A.L.P., nor did the prospect of securing a local university college tempt many voters to the A.L.P.

Seventy-three Members stood for re-election in 1963. Two had been unopposed in 1960 and one was unopposed in 1963. Of the remaining seventy, forty-seven improved their share of the vote. Of the twentythree whose share of the vote diminished, twelve could point to the intervention of an additional candidate in the contest, one was faced by a Country Party candidate in place of a Q.L.P. (Dufficy for the A.L.P. in Warrego), and one was now standing as an Independent (Muller in Fassifern). Only nine sitting Members lost support, relatively speaking, in the same sort of contest as they had fought in 1960. Seven of them were Government supporters, the eighth was the Q.L.P. leader, Hilton, and the ninth was Aikens. Both Knox (Nundah) and Aikens could say that their A.L.P. opponents in 1963 were more 
effective than in 1960, the former M.L.A. and Lord Mayor, Frank Roberts, in Nundah in 1963 and Trower in place of the ailing W. F. Edmonds in Townsville South. Hilton suffered from the general decline of the Q.L.P. between 1960 and 1963. In four of the remaining six cases the loss of support was small: Hodges (Gympie) down 0.98 per cent, Anderson (Toowoomba East) 1.54 per cent, N. T. E. Hewitt (Mackenzie) 2.08 per cent, and O. O. Madsen (Warwick) 2.45 per cent, and no doubt Madsen's ill-health contributed to the Warwick situation. In Tablelands Gilmore was beset by local difficulties, and lost 9.40 per cent of the vote; whilst an independent candidate was added to the contest in 1963 , he secured only 3.21 per cent of the vote, leaving a substantial drift from Gilmore in any event. The final electorate in which the sitting Member lost support was Landsborough; the Member was Nicklin, and the loss of support 5.90 per cent. Whilst the new A.L.P. candidate, Frank Fremantle, could be given credit for some of the swing, the extent to which it was localised in the western part of the electorate suggests that a local issue, such as the by-pass road around Landsborough, might have been operating. As the Landsborough campaign was fought without benefit of press it is impossible to say with any certainty what actually happened. But looking at the whole State, one can say that between 1960 and 1963 the predominant electoral trend was towards stability in favour of the sitting Member and not many local issues were strong enough to oppose such a trend.

In 1966 there were sixty-six sitting Members standing for re-election. One had been unopposed in 1963 and two were unopposed in 1966. Of the other sixty-three, twenty-five recorded gains or losses in support of less than 2 per cent, twelve gains and thirteen losses. Another sixteen recorded gains or losses between 2 and 4 per cent, eight gains and eight losses. The gains or losses in excess of 4 per cent of another eleven sitting Members can be accounted for by changes in the field opposing them, the addition or withdrawal of third party or Independent candidates, and two more very substantial changes by the loss of A.L.P. endorsement for Baxter (Hawthorne) and the regaining of Country Party endorsement for Muller. In a comparable situation in 1966 this leaves only nine sitting Members whose share of the vote altered by more than 4 per cent. Camm for the Country Party in Whitsunday dropped to $4 \cdot 70$ per cent, the result of the difficulties of the sugar industry, but all the others gained: H. Dean (Sandgate) 7.48 per cent, F. D. Graham (Mackay) 4.83 per cent, and Wallis-Smith (Tablelands) 4:05 per cent for the A.L.P., Dr Delamothe (Bowen) 4.69 per cent for the Liberal Party, and Sullivan.(Condamine) 4.31 per cent, Lonergan (Flinders) 6.03 per cent, Rae (Gregory) 6.86 per cent, and Row (Hinchinbrook) 6.29 per cent for the Country Party. Whilst Graham's increased vote might be attributed to the Government's sugar troubles as well, there is no obvious explanation for any of the other changes 
apart from the virtues of the sitting Member or the deficiencies of his opponents. Whilst there is no clear trend in favour of sitting Members in 1966 such as there was in 1963, and indeed there are as many unfavourable movements as favourable, there are again few electorates which deviate from the statewide pattern on what can be discerned as local issues.

In times of general prosperity, a small pocket of misfortune can receive special attention. The State Government was able to promise help to tobacco growers and to keep the uneconomic Tableland railway lines open, and even to offer to spend money on the decrepit Jubilee Bridge. When big money was involved, however, as with the two university colleges, the Government's hands were tied, and the only recourse was to explain the financial limitations of the emerging system of federally-controlled tertiary education. All that the A.L.P. could then do was to claim that they would argue a Queensland case harder, and to claim that the Government had engaged in sharp practice in the past with the Townsville University College. Short of proper door-knock opinion surveys in particular electorates it is difficult to say just how many electors perceive a local issue which is being debated in the local press and on the hustings, but from what is known about issues affecting a broader area, such as a whole State or the entire country, it is probable that the tentative findings reported in the tables above would be confirmed: that partisanship influences perception of issues as much as, if not more than, the reverse. 
III: THE ELEGTORATES 


\section{Kurilpa and South Brisbane, 1963}

THE electorates of Kurilpa and South Brisbane lie immediately across the Brisbane River from the centre of the city. Both have long electoral histories. South Brisbane was a Labor seat from 1915 to 1929 and was regained in 1932 by a young railway clerk, V. C. Gair, who held it comfortably for the ensuing twenty-eight years. Kurilpa tended to be more marginal, but P. K. Copley held it for the A.L.P. from 1932 to 1949 when he was succeeded by T. Moores. Both electorates have been areas of inner-city depopulation: South Brisbane's enrolment dropped from 11,009 in 1950 to 8,826 in 1957, and Kurilpa's from 11,338 in 1950 to 9,175 in 1957 .

At the 'split' election in 1957 Gair retained South Brisbane for the Q.L.P. with 44 per cent of the vote, with the Liberal candidate second. In Kurilpa, Moores (who had succeeded to Duggan's place in the Cabinet) lost to a Liberal barrister, P. D. Connolly, who won with only 37.56 per cent of the total vote. In the redistribution which followed the change of government both electorates were considerably altered. South Brisbane gained almost 4,500 new voters in Kangaroo Point (part of the old Brisbane electorate, the rest of which lay across the Story Bridge on the north side of the river), and in the West End, Highgate Hill, and South Brisbane areas of Kurilpa. Kurilpa had a net increase of about 2,400 by incorporating Fairfield, Yeronga West, and part of Annerley from the Liberal electorate of Yeronga, plus part of Highgate Hill and Dutton Park formerly in South Brisbane. The new boundaries of South Brisbane occasioned little comment, and indeed removed the Kangaroo Point anomaly, but Kurilpa's equally convoluted boundaries following the south bank of the Brisbane River came in for some criticism on the ground that they seem designed to connect a number of marginally Liberal neighbourhoods into a more Liberal seat than any other extension might have produced, 
whilst shedding marginally Labor areas into South Brisbane. One consequence of the extension of Kurilpa's boundaries into the old Yeronga electorate was that the City Council alderman for Yeronga since 1955, Clive Hughes, contested the Liberal Party selection against Connolly. He won in a battle which occasioned some bitterness (Courier-Mail: 24 November 1959), and went on to win the seat with $49 \cdot 35$ per cent of the vote; Hughes polled just under 5,100 votes, the A.L.P. candidate 4,100 , and the Q.L.P. candidate 1,100. Similarly in South Brisbane the extension of the boundaries into Kurilpa brought the sitting A.L.P. alderman, Colin Bennett, into the field against Gair. As Brisbane City Council wards are tied to the State electoral boundaries, Bennett's seat in Kurilpa, which he had held for more than a decade with a considerable personal following, had become quite unsafe with the 1959 redistribution, and his only alternative was a pre-selection contest with the sitting South Brisbane alderman, Tom Doyle. Gair's old supporters in the eastern part of the electorate held firm, but the vote from new areas in West End and Highgate Hill reflected both the declining fortunes of the Q.L.P. throughout the State and Bennett's personal popularity as their alderman. Bennett won the seat with 43.91 per cent of the vote, polling 5,000 votes to Gair's 3,300 and a Liberal's 3,100.

In 1963 each seat had some interest. Neither sitting member had been able to win an absolute majority in 1960. Gair decided not to offer again, the better to contest the next federal election at the head of the Q.L.P. Senate team. (The decision, if standing in South Brisbane would have definitely precluded his Senate candidacy, was wise; a good A.L.P. vote forced the government candidate for the fifth Senate seat into third place, and Gair was elected with Liberal preferences.) Certainly no other Q.L.P. candidate could expect to poll as well as the former Member and Premier, and his absence would presumably put the Liberal candidate in second place with great expectations from well-disciplined Q.L.P. second preferences. In Kurilpa Hughes had come very close to an absolute majority, and had more than 1,000 Q.L.P. voters to fall back on. On the other hand, a large part of Kurilpa had been Labor before the split and was the sort of middle-class area in which a swing to Labor just might be operating. At the April 1961 City Council election the A.L.P. aldermanic candidate had been only 400 votes behind the C.M.O., with another 800 votes going to the Q.L.P. Certainly if the A.L.P. was to win a majority in the Legislative Assembly, Kurilpa was one of the seats it would have to win.

Neither of the sitting Members was opposed for pre-selection. Although Bennett was the only candidate for A.L.P. endorsement in South Brisbane, when his name came before the Q.C.E. in May 1962 a motion that he not be endorsed was carried by the Trades Hall 
group 28-27. Duggan intervened on his behalf, and the motion was recommitted, following which the Executive endorsed his candidacy 36-21 (Courier Mail: 30 May 1962). Half a dozen candidates were available to the Liberals in South Brisbane, only one of them being a resident of the electorate. Endorsement went to Mrs Gabrielle (Gabby) Horan, a resident of Holland Park in the Chatsworth electorate. Mrs Horan was a professional home economist and had conducted a television program for women, as well as being active in such groups as the Country Women's Association, the Red Cross, and Girl Guides. Prejudice against women candidates in the major parties is as pronounced in Queensland as in most States. There had been only one woman elected to the Legislative Assembly, Miss Irene Longman, who held Bulimba for the Country National Party in 1929-32, and few women had ever won endorsement for even a marginal seat. There were rumours in South Brisbane that because of her sex prominent local Liberals rested on their oars rather than support Mrs Horan, but undoubtedly she received additional publicity because she was a woman. Two reports in the Telegraph (2 and 28 May 1963) gave her more publicity than any other new candidate in the metropolitan areain 'human interest' stories about her husband's help in the campaign! The Q.L.P. chose Brian Kehoe, M.L.A. for the country electorate of Nash from 1953 to 1957 , to run in Gair's place. Kehoe, like Mrs Horan, lived outside the electorate in Hawthorne, but was fairly well known in it. Since his electoral defeat he had rejoined the Public Service and was a Court official. Each of the candidates was a Catholic, and although each doubted that the other's appeal to their coreligionists was as effective as his/her own, this presumably cancelled out any advantage it might have gained in an electorate which has a slightly higher proportion ( 29 per cent) of Catholics than the metropolitan average ( 25 per cent).

In Kurilpa there were two candidates for A.L.P. endorsement in May 1962, Mrs Bennett and Ben Dokter, a Dutch migrant and tram driver who had been active in the party's New Australian organisation. The Q.C.E., perhaps unhappy at the prospect of a Bennett dynasty spreading, endorsed only Dokter and no pre-selection ballot was held. However, Dokter lived at Inala, some distance from Kurilpa, and the Kurilpa A.L.P. branch with its long attachment to the Bennetts appears to have lost interest in the campaign at this point. The Q.L.P. candidate, M. P. Sheahan, also came from well outside the electorate, Graceville. His candidacy in Kurilpa reflects his own reluctance to stand closer to home, where the bitterness of Labor differences during the campaign would have been personally unpleasant. A Public Servant in the Motor Registry, Sheahan ran a very quiet campaign apparently unassisted by local supporters. The fourth candidate to nominate for Kurilpa was Paul Keneally for Social Credit. 


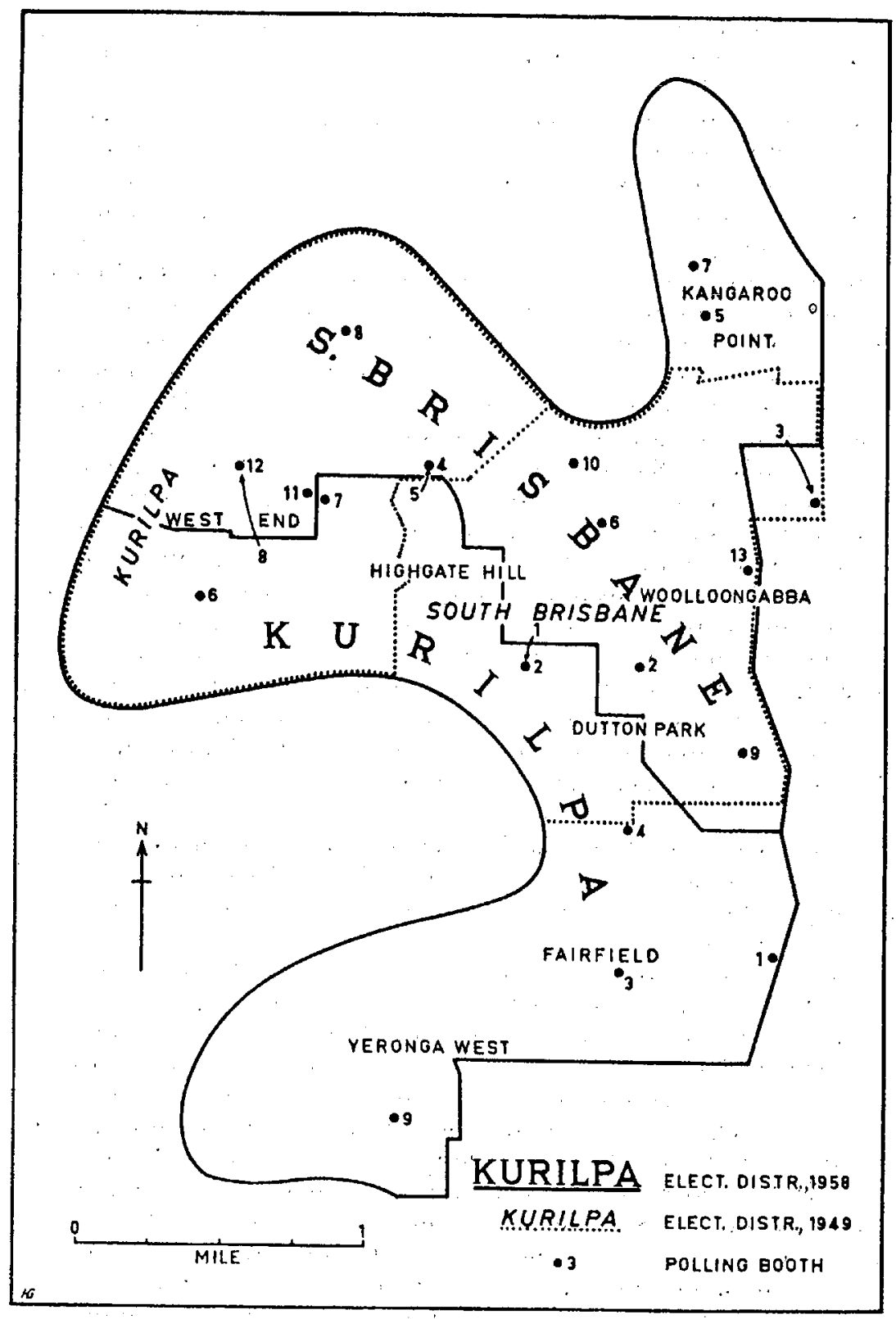

FIG. 3 KURILPA AND SOUTH BRISBANE 
VOTING AT POLLING BOOTH, 1963
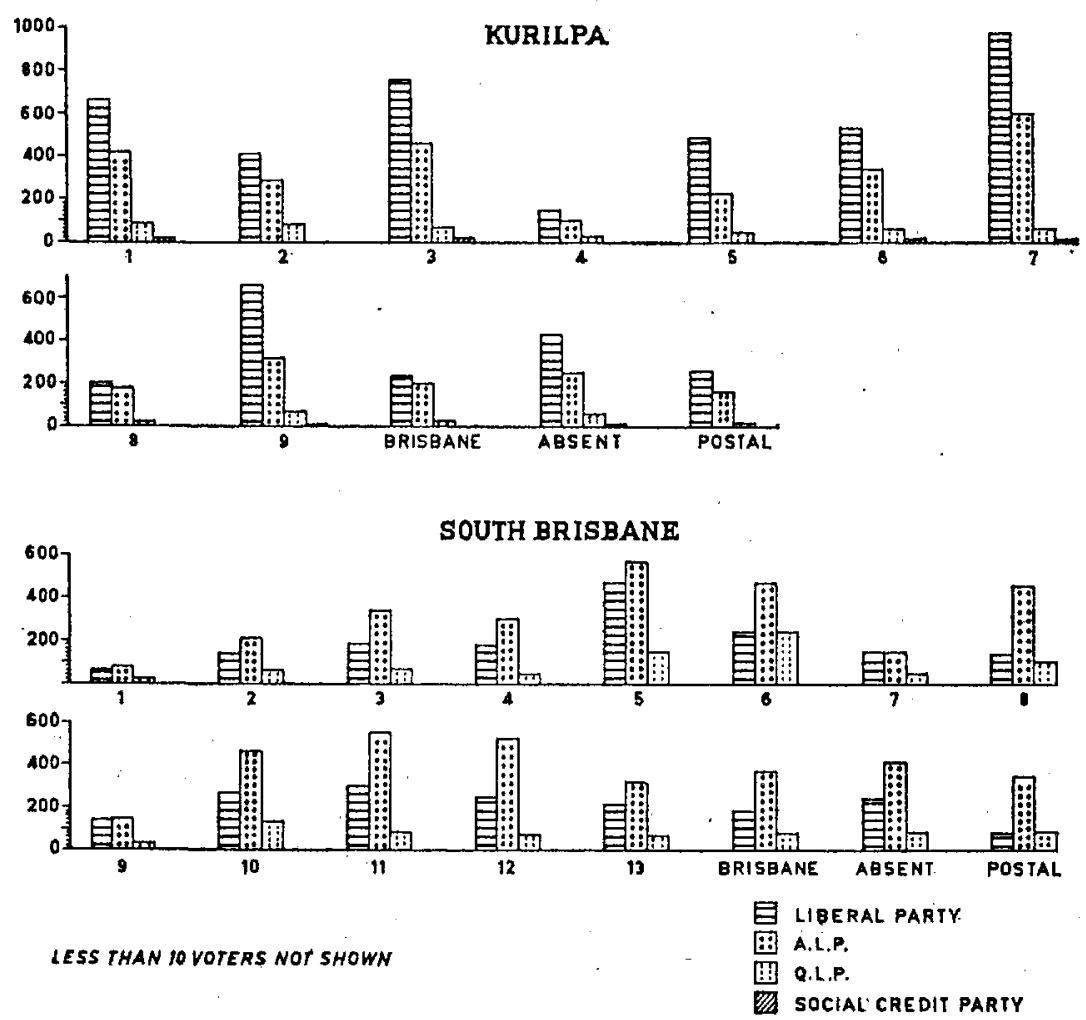

FIG. 4 VOTING IN KURILPA AND SOUTH BRISBANE

Keneally was also a non-resident; an English migrant and a window cleaner by trade he lived at Thornlands some miles away.

Kurilpa and South Brisbane are the sort of inner urban electorates where one might have expected branch organisations to be long established and strong. For various reasons, however, the party branches played a relatively minor part in the campaign. Bennett inherited two A.L.P. branches in South Brisbane, one at Kangaroo Point from the old Brisbane electorate with about thirty members, the other from the old South Brisbane electorate with about forty members, and imported his own West End branch with about sixty members. However, Bennett is also the possessor of a large family, and was able to conduct the campaign without mobilising the branches. He addressed all street-corner meetings with either Mrs Bennett or Alderman Doyle 'in the chair', and his children undertook principal responsibility for the two distributions of literature which took place. 
Mrs Horan had only one small Liberal branch to help her, although some Young Liberals were brought in to give a hand. Responsibility for the campaign rested with Mrs Horan and her campaign manager, A. A. Chresby, M.H.R. for the electorate of Griffith 1958-61. Kehoe co-operated closely with the Q.L.P. candidate for the adjacent electorate of Norman, Harry Wright, and Q.L.P. branch officers and members appeared at their street meetings and assisted with literature, but Kehoe's campaign was predominantly his own work.

In Kurilpa Hughes inherited a branch divided by his ejection of Connolly, and although he created an elaborate campaign organisation, much of its strength came from personal friends rather than the formal party structure. Hughes's Kurilpa Electorate Campaign Committee had letter-headed stationery, minutes, a committee room (the Liberal Party's rooms at 10 Annerley Road just outside the electorate), a personnel officer and a finance officer, and tremendous panache. It must have spent $£ 600$, compared with Dokter's $£ 300$ and Bennett's $£ 150$, and produced a steady flow of literature and activity during the campaign, but it was very much the creature of Hughes's personal machine and not the Liberal Party activated for the campaign. As has already been noted, Dokter was given a small donation by the local A.L.P. branch and left to his own devices; his main help came from his own branch at Inala and from his own M.L.A., Sherrington. Sheahan and Keneally conducted their own campaigns.

Although South Brisbane is a relatively small electorate, a canvass by candidates unsupported by party organisations would have been extremely difficult. Both Bennett and Kehoe were working men whose campaigning was confined to weekends and evenings. Mrs Horan started a canvass, decided that there would be insufficient time, and concentrated on street meetings. Bennett canvassed at weekends for some eight or nine weeks before the campaign really got started and managed to see, at his estimate, about 500 people. Mrs Kehoe canvassed two to three hundred homes scattered through the electorate. In Kurilpa Dokter was sufficiently hard-pressed to manage his own street-corner meetings at which he had to set up the equipment and do all the speaking, and Sheahan's campaign consisted of his Saturday morning meetings and one distribution of how-to-vote cards by a lad employed for the purpose. Keneally had canvassed some 300 homes eighteen months before the election and asked questions designed to inform electors on the iniquities of the taxation system, following it up a year later with handbills showing rates of sales taxes with spaces for individuals to work out how much tax they were paying. Only Hughes's campaign organisation was of a size sufficient to cope with a substantial campaign, and this was operated to distribute the maximum quantity of campaign literature-some 60,000 items went out in seven deliveries-and to secure the maximum postal vote. In 
January Hughes had an accident to one eye which nearly cost him its sight; a lengthy convalescence prevented him from undertaking a projected canvass, and instead a circular letter went out to all electors apologising for this and promising to maintain 'the same sincerity and sense of service' shown in the past.

Each of the candidates who undertook any sort of campaign relied on street-corner meetings and campaign literature to convey his or her message to the electors. In addition the Brisbane Telegraph made a column entitled 'Poll Points' available to candidates from metropolitan and south-eastern electorates for a very brief paragraph each; while various candidates from South Brisbane and Kurilpa availed themselves of the facility, the paragraphs were invariably snippets of general policy phrased in such a way as to have minimal local impactand suggesting that the column may have been utilised by party headquarters rather than the individual candidates. Only Bennett managed a personal note when, referring to the first of the Liberal Party's Meet-the-Cabinet meetings held at the South Brisbane Library, he claimed that his arguments had so aroused the consternation of the Government that they were sending half the Cabinet into his electorate-but were unable to answer statistics on unemployment and anomalies in the Liquor Act (Telegraph: 14 May 1963). The following paragraphs are based on the candidates' literature and attendance at certain of their meetings.

Bennett's 'personal appeal' advised voters of the circumstances in which they were entitled to a postal vote and gave a list of telephone numbers to call to obtain postal votes and promised to continue the practice of being available without appointment at his chambers in the city between the hours of 4.30 p.m. and 6.00 p.m. every day to discuss electors' problems. It asked for help in returning an A.L.P. government to eliminate unemployment, preferential treatment in State appointments, 'the housing muddle', liquor, betting and taxation anomalies, 'the hire-purchase racket', and other legislative blunders, and concluded by promising immediate implementation of three weeks' leave. Bennett's street speeches were a skilful blend of general policy and local matters. Among statewide issues he emphasised unemployment and betting and liquor taxes. He undertook personally to seek legislation to make it a criminal offence to dismiss employees to avoid their entitlement to long service leave, and complained that the proceeds of betting and liquor taxes went into general revenue instead of being used for the benefit of those who paid them. Dealing with attacks on the A.L.P.'s foreign policy, Bennett pointed out that the State Government had a very small voice in international affairs; the A.L.P. favoured a strong alliance with the United States as in Curtin's day, but Australia should not be subservient to her ally. He attacked the government's hospitalisa- 
tion record: the Premier was not game to abolish free hospitalisation, but he had indicated that his Government was not in favour of it and had proved this by the sub-intermediate ward system under which patients had to employ their own doctors. Speaking with the authority of twelve years' service on the Brisbane and North Coast Hospitals Board, Bennett claimed that the Government was using hospital areas previously used for free accommodation for other purposes, and was subjecting the free sections to overcrowding and lack of staff.

Turning to the affairs of South Brisbane and the activities of its Member, Bennett declared that he had had fifteen years as a proud and privileged representative meeting the demands of individuals and of the electorate. In his speeches in West End he spoke with particular affection of the residents, 'the finest in personality and way of life of any in Brisbane'. At Kangaroo Point he claimed credit for an underpass beneath the main road approach to the Story Bridge which he had secured with the assistance of Alderman Doyle. There was still work to be done for the elderly and mothers with prams who found it difficult to use, and he hoped further traffic rearrangements could remove this difficulty. The responsible Minister had written to him saying that anyone could cross with the traffic lights, but anyone who said this would have 'the aptitude of a well-fed bandicoot'. Warming to the subject Bennett went on to complain that he had not been invited to the opening of the underpass, an omission indicating lack of courtesy, decency, or fairness; he had been insulted by experts, and the Minister did not faze him. Another Kangaroo Point issue was the prospect that a floating restaurant would be started on its riverside; Bennett would see that its proprietor behaved himself. Petitions against the restaurant were circulated, and Bennett supported them (Sunday Truth: 5 May 1963; Sunday Mail: 2 June 1963).

Finally Bennett dealt with a subject which had gained him considerable prominence before the election-and after it-the administration of the police force. The force, said Bennett, had many good men, and he was not attacking the ordinary police officer; he would, however, attack the administration of the force, for many aspects of it did not show up in a good light. The Premier had promised in his policy speech at the previous election that a three-member commission would be placed in charge of the police, but Cabinet was not game to do it, and a writ had been issued to stifle parliamentary discussion of police matters. The Brisbane Watchhouse (a subject on which the press had campaigned) was as bad as ever; a $12^{\prime} \times 12^{\prime}$ cell would have ten to fourteen men in it, and one bed had been purchased for advertising improved conditions through press photographs.

Bennett dismissed his opponents as lacking policies. Nicklin had sneaked away to a little seaside resort to give his policy speech, which 
contained concessions designed to meet the demands of the Graziers' Association, the bosses of his party. The other half of the Government's policy had to be delivered behind closed doors to prevent questions being asked by fair-minded persons. Kehoe was circulating his yellow slips, but he had not declared any policy, and Mrs Horan had said that she opposed equal pay for women, a cause for which the A.L.P. had fought for half a century.

Mrs Horan in her speeches emphasised the neglect of development under Labor and the change the present Government had brought. In the past investment had been driven away by red tape while South Australia welcomed it with a red carpet. This year there had been $£ 300$ million invested, while there had never been more than $£ 100$ million in any previous year. The State had had an Aladdin's cave but it had been ignored. If there had been secondary industries years ago, there would be better amenities now. The Government would bring about the Queensland everyone dreamed of. With the coming of oil to Brisbane, petro-chemical works would follow. She invited listeners to ask the man down the road if he was unemployed-allegations of unemployment were tommyrot. Seasonal workers received large wages knowing they would be getting a couple of months off. The unemployment rate had been 6 per cent in 1939 .

Mrs Horan invited electors to consider all pamphlets. The A.L.P. only promised things they already had. Duggan promised more houses at lower interest, but State Insurance funds should not be used for it was 'your money'. The Government had abolished one-teacher schools because they were not good enough, and had provided transport and better schools; it had abolished the Scholarship examination so that anyone had a chance for higher education. It had kept free hospitalisation and provided more and better services than ever before; in New South Wales hospitals cost $£ 3$ a day and if Labor got in that would happen here. The Government had provided help for delinquents in a harder, faster age, by treating them in Brisbane rather than sending them to the reformatory in Westbrook.

In local affairs Mrs Horan concentrated on Bennett's performance as a provider for South Brisbane. The electorate lacked a child care centre, an aged -persons centre, and a kindergarten. Bennett had taken twelve years to get a site for a child care centre. If it took that long for the land, how long would the building take? Speaking in her support, Chresby said that half-time representation explained Bennett's failure. If he was going to play at politics, voters should not vote for him, but vote for Mrs Horan.

Kehoe's leaflet referred to his past parliamentary services and claimed that if the Gair government had not been destroyed by Duggan and his followers he would have been a Cabinet Minister. It placed him on record against outside dictation and Communist influence, and 
promised 'efficient, honest and full-time service, as he has no other profession or business interest'. In his street speeches Kehoe placed particular emphasis on the fact that the Q.L.P. was 'the old, traditional Labor Party and accepted the old policy', while the A.L.P. had a new platform with many vital changes. There would be no healing of the breach until Communists were driven out of the A.L.P. Communists had tried to take control of parliament in 1957, and Duggan backed down. He was not prepared to accept majority decisions in Caucus but he was prepared to accept dictation from Trades Hall and its Communist leaders. A vote for the A.L.P. was a vote for the Communist Party, and the Guardian advised its readers to vote for the A.L.P. The A.L.P. wanted the Chinese Communists to run Australia, and they wanted Communists in the North. They had sold out Queensland and they would sell out Australia. To restore the type of government the State had had in 1957 electors should vote for the Q.L.P. The Government was not concerned with the state of Australia and Queensland; they benefited from the split in the Labor movement and they were interested in keeping it going.

Turning to electorate matters, Kehoe charged Bennett with being a part-time representative who was interested only in pursuing his own affairs. Could any lady see her M.L.A. in the city between 4.30 and 6.00 p.m.? She should be at home fixing her husband's dinner. This was not good enough service for South Brisbane; it was not the service the electorate got during the Gair government.

Three incidents illustrate the considerable bitterness induced between the A.L.P. and Q.L.P. during the South Brisbane contest. On 18 May a Saturday afternoon Q.L.P. street-corner meeting outside a pub on the boundary between South Brisbane and Norman ended up in a fist fight which was reported to have lasted twenty minutes (Sunday Truth: 19 May 1963); Kehoe lost his shirt and got a dislocated finger and Gair had a meat pie thrown at him. On 29 May Kehoe was charged with illegally placing posters on an electric light pole; a magistrate subsequently dismissed the charge and awarded him costs (Courier Mail: 13 August 1963). On 2 December Kehoe complained that he had been assaulted by Bennett while walking in the city; the charge was subsequently dismissed when Bennett's counsel advised the magistrate that the incident had arisen when Bennett misunderstood a remark Kehoe had made on their meeting, and the Crown offered no evidence (ibid.: 8 February 1964).

In Kurilpa Hughes provided blotters backed with photographs contrasting Labor's housing barracks with a modern Housing Commission home, a Labor cottage hospital, very seedy, with the modern Chest Hospital at Chermside, and the former vacant site with the new High School at Yeronga. At street meetings Hughes's service to the community was emphasised-sitting M.L.A., former alderman, a Jus- 
tice of the Peace, war service, associated with many local organisations and charities including schools, centres for the deaf and blind and child care, the number of local causes in which he had been active proved he was 'a fair dinkum mate'. Some years before, Hughes had opposed an increase in aldermanic salaries, and when they were passed appointed a committee of constituents to distribute the additional $£ 450$ a year to local charities. While the action does not appear to have been mentioned in the campaign, it was sufficiently novel to be remembered by electors, at least in the old part of his electorate.

Hughes's own speeches were based on the Government's record. In the field of housing the legacy of the war years had continued under Labor governments, but the virility of the new Government had changed this as was evidenced in the outer suburbs. (At this point at one meeting a heckler invited Hughes to tell how the Government had put the rents up. He replied that its housing scheme had saved many people from paying rent.) The Government had provided new high schools, and if a student had the ability he should get all the education he needed through a university free from quotas. Its belief in free competition and free enterprise had produced $£ 255$ million investment. Unemployment had been caused by a sudden flood of school leavers on the market. No government could have coped at once, but the situation would resolve itself. Almost all boys were in jobs, but girls were a bit harder for they had fewer opportunities today as fewer industries employed girls. Like Mrs Horan he invited listeners to read all the papers, for the Liberal-Country Party could stand comparisons.

Dokter's leaflets, a trifle inaccurately, described Kurilpa as 'one of the most rapidly expanding and progressive areas in Brisbane', in need of vigorous representation. A Labor government would bring happiness and prosperity, a divided Conservative government would mean high unemployment and declining standards of living. One card from the Kurilpa Electoral Executive 'introducing' Dokter gave a brief biography and added: 'His ability and interest in State Parliamentary affairs is that of a man with a sense of mission and responsibility.' Another leaflet showed two schoolgirls asking their parents to vote for Ben Dokter so that they would be assured of positions on leaving school; their parents replied that they would vote for him because he was the A.L.P. candidate 'and a vote for Labor means full employment, a peak production and insures security and a high standard of living for everyone'. A card which reproduced a map of the electorate (quite useful considering the meandering boundaries) promised that Dokter would fight for jobs for all willing to work, the right of all to own their own homes, the right to receive fair wages, and would work hard on behalf of all electors and do his best for all members of the community-'impartial, sincere, but above all honest'. The last item 
to go out was a lithographed hand-written letter from Dokter 'as a friend, not a candidate', enclosing a how-to-vote card and giving figures on unemployment and complaining of high hire-purchase interest rates, increased prices of food and household goods, the import of Japanese pipes and the possibility that Americans would be brought in to lay them. In his speeches Dokter emphasised the same thingsunemployment and the lack of progress in the State, and called on voters to support the true Labor Party. Unfortunately Dokter's accent proved a serious handicap in his street meetings, and much of the effectiveness of their content was lost.

Keneally distributed a green sheet contrasting the benefits which a Social Credit government had brought to British Columbia compared with the growing debt burden of Queensland, and asking for votes 'to bring a Christian Economic System to Australia'. His how-tovote card offered alternative patterns of voting to give second preference to the A.L.P., Q.L.P., or Liberal candidate as the voter wished.

Observation of these two constituency campaigns suggests what little influence party organisations have on the results. In South Brisbane Kehoe waged as effective a campaign as any Q.L.P. candidate, but the party's vote dropped from 28.9 per cent in 1960 to 13.7 per cent in 1963; in Kurilpa Sheahan's campaign was as sotto voce as possible, and the Q.L.P. vote dropped from 10.9 per cent in 1960 to $6 \cdot 6$ per cent in 1963. Bennett's one-man band raised the A.L.P. vote considerablyfrom 43.9 per cent in 1960 to 54.9 per cent in 1963 , but Dokter's dropped it from 39.8 per cent to 35.8 per cent. One characteristic feature of the 1963 election was the increase in the sitting Member's vote, whatever his party. Whilst this factor operated in Kurilpa and South Brisbane, and explains much of the voting pattern in Kurilpa, in South Brisbane the sharp decline in the Q.L.P. vote with Gair's retirement magnified the swing. Kurilpa results also indicate that while Dokter was able to retain most of the 1960 A.L.P. vote in the southeastern part of the electorate, Annerley, Dutton Park, and Yeronga West, losing less than 1 per cent, and in Fairfield his vote dropped by less than 4 per cent, in the old Bennett territory the A.L.P. vote fell more sharply: down 4.7 per cent in Hill End, 7 per cent at West End School, 6.5 per cent at West End, 9.5 per cent at Highgate Hill. It would appear that the disaffection in the local branch spread to the electors, who reacted to Dokter as an interloper. Paradoxically the Yeronga end of the electorate, Hughes's old base, showed the smallest swings in his favour-0.4 per cent at Yeronga West and 2.5 per cent at Annerley, 4.9 per cent at Fairfield, as against 12.7 per cent at Highgate Hill or 9.5 at West End, though this may be an instance of an effective Member who has reached his 'natural maximum' in one area continuing to raise his vote in areas recently added to the electorate. In South Brisbane there was no such localised pattern. The 
15 per cent Q.L.P. lost vote divided 11 per cent to Bennett and 4 per cent to Mrs Horan, and this division was generally followed throughout the electorate; at the eastern end of the electorate Mrs Horan managed to do slightly better, at the western end slightly worse, but variations were of the 1 and 2 per cent variety. (At Peel Street Mrs Horan's vote actually dropped, but then total number of votes recorded here fell noticeably with the continuing conversion of residences into business premises.) The two constituencies show, with some qualifications in the case of Hughes's campaign, how little electoral success depends on the existence of a numerous and active party branch organisation. 


\title{
Salisbury and Sherwood, 1963
}

\author{
K. W. KNIGHT and M. N. B. CRIBB
}

THE electorates of Salisbury and Sherwood lie athwart the approaches to Brisbane from the south-west. They have a common boundary formed by the Brisbane-Toowoomba highway. Sherwood is divided lengthwise by the main railway line to Ipswich, which cuts through the outer suburbs of Chelmer, Graceville, Sherwood, Corinda, and Oxley. On the western, or river, side of the railway line the homes are of the older spacious Queensland type; on the eastern side small suburban bungalows predominate, and the electorate is one of the few areas of Brisbane in which 'the wrong side of the tracks' has some meaning. The general standard of housing tends to fall away as one approaches Oxley, and from there through to Darra, with the exception of the married quarters at Wacol Army Camp and the mental hospital at Goodna, the electorate is thinly populated. In parts of the electorate there are substantial numbers of retired or semi-retired people, living either in their own houses or in the numerous convalescent homes and establishments for the aged.

As we crossed and recrossed the Sherwood electorate in the course of the campaign we felt strongly that it looked like a Liberal seatand its past political record supported this conclusion. It had been held by the Liberal Party since 1950, although until 1960 it was not the safe seat it is now. After the split, however, the position of the Liberals in Sherwood was greatly strengthened, the 1957 results being Liberal Party 8,934, A.L.P. 5,810, and Q.L.P. 3,381. By 1960 the Sherwood electorate had grown to about 20,000 voters, and as part of the reallocation of electoral boundaries effected in 1959 a substantial area, which included the rapidly growing satellite township of Inala, was cut from it. The Inala area was joined with part of Mt Gravatt elec- 
torate to constitute the new electoral district of Salisbury. The result was that Sherwood was confirmed as a safe (63 per cent) Liberal seat, while the new electorate of Salisbury was clearly one which would be won by the Labor Party ( 56 per cent).

The history of the Sherwood electorate at the local government level was also significant. In 1961 the ward was won by a Labor candidate, Gordon Thomson, in a very close election. However, the ward was carried by the Citizens Municipal Organisation candidate for the mayoralty, and the weakness of the defeated C.M.O. alderman, B. Warner at previous elections in which she trailed her party's Lord Mayor, coupled with the possibility of pro-Labor sentiments carrying over from the credit squeeze which exploded at the federal level in Queensland later that year, suggested that particular short-term influences were at work. Discussions with local residents suggested to us that part of the credit for the A.L.P. win was due to the personal merits of Alderman Thomson, an electrical contractor by trade, and it raised the possibility that an A.L.P. candidate of similar quality could at the very least make considerable inroads into the Liberal majority in the State election. Alderman Thomson seemed to be typical of a newer type of Labor representative. He described his views to the writers as 'liberal Labor' and was obviously, both in appearance and personality, acceptable to many voters in Sherwood who normally supported the Liberal Party. In fact the pattern of voting at the 1963 and 1966 state elections and the 1964 and 1967 city council elections indicate that close to half those who vote Liberal at the state level are voting Labor at the municipal level, and on past figures it appears that the great majority of these are 'natural Liberals' won by Alderman Thomson. His knowledge of, and interest in, electoral procedures was considerable. He was widely read in this field and had made a careful study of the campaign methods of a number of successful politicians.

The electorate of Salisbury consists of four closely settled but widely separated areas: the suburb of Salisbury itself, which may be regarded as the residential section for much of the adjoining industrial area of Rocklea (lying just outside the electorate); Inala, a virtually self-contained settlement of over 3,000 houses constructed by the Housing Commission; and the suburbs of Acacia Ridge and Coopers Plains, both of which contain substantial numbers of Housing Commission houses. Between these suburbs population is thin and much of the electorate is unsettled bushland.

The assumption that the campaigns in Salisbury and Sherwood would produce no political fireworks proved to be justified. The policy speeches and the efforts of the party workers hardly created a ripple. Indeed, most voters seemed quite unconcerned about the election. Nevertheless, the situation in these two electorates did pro- 


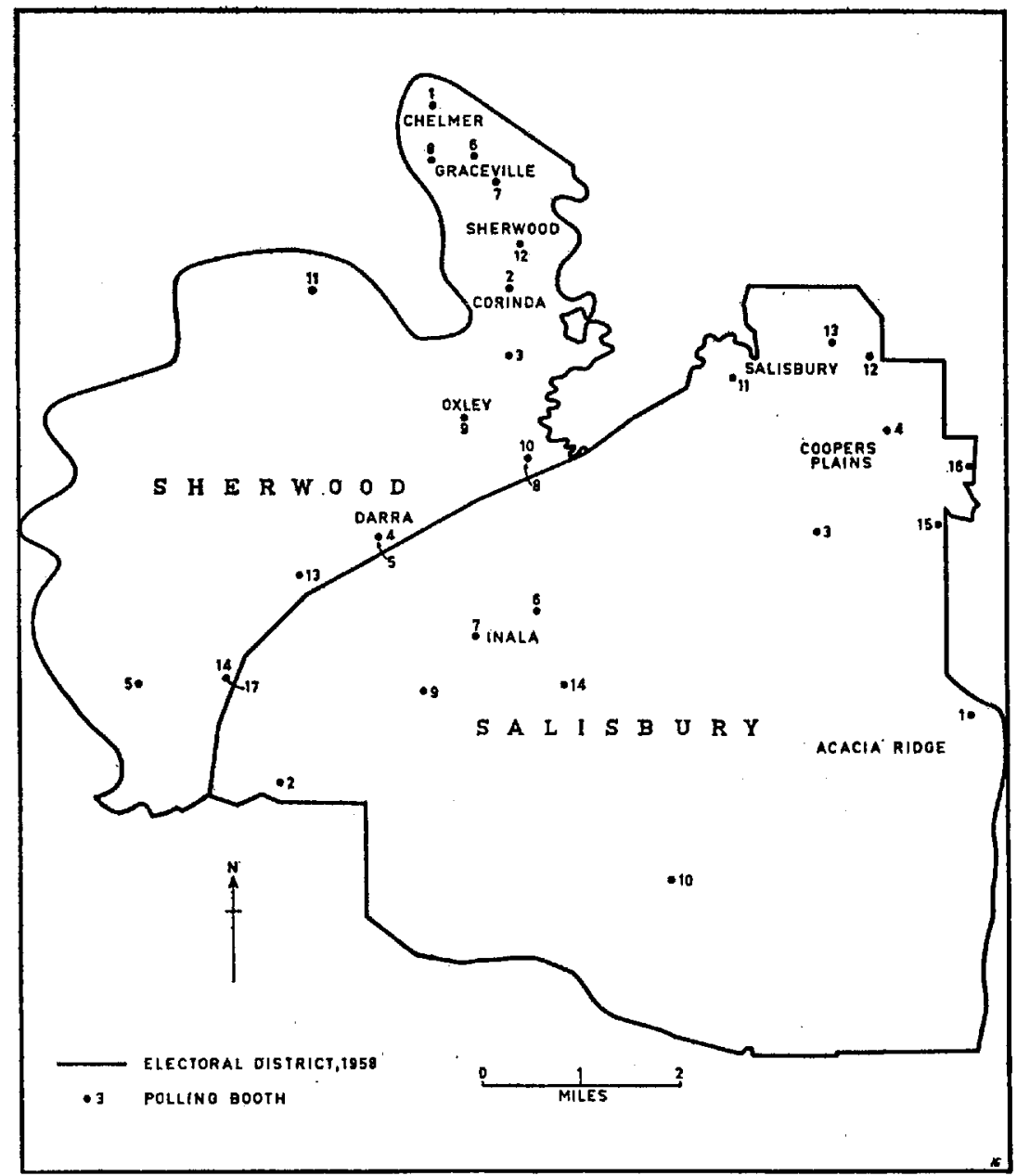

FIG. 5 SALISBURY AND SHERWOOD

vide material of interest in several ways. Firstly, although the sitting members represented different parties and had dissimiliar backgrounds, their campaign methods and their psychological approach to the elections in their own bailiwicks were of such marked similarity as to warrant further investigation of what appeared to be 'the sitting member in a safe seat mentality'. There was the question, too, of the type of candidate thrown up to contest electorates of this sort by the selection process within each party. Would the Labor candidate in Sherwood, for instance, be from the traditional Labor mould or 


\section{VOTING AT POLLING BOOTH, 1963}
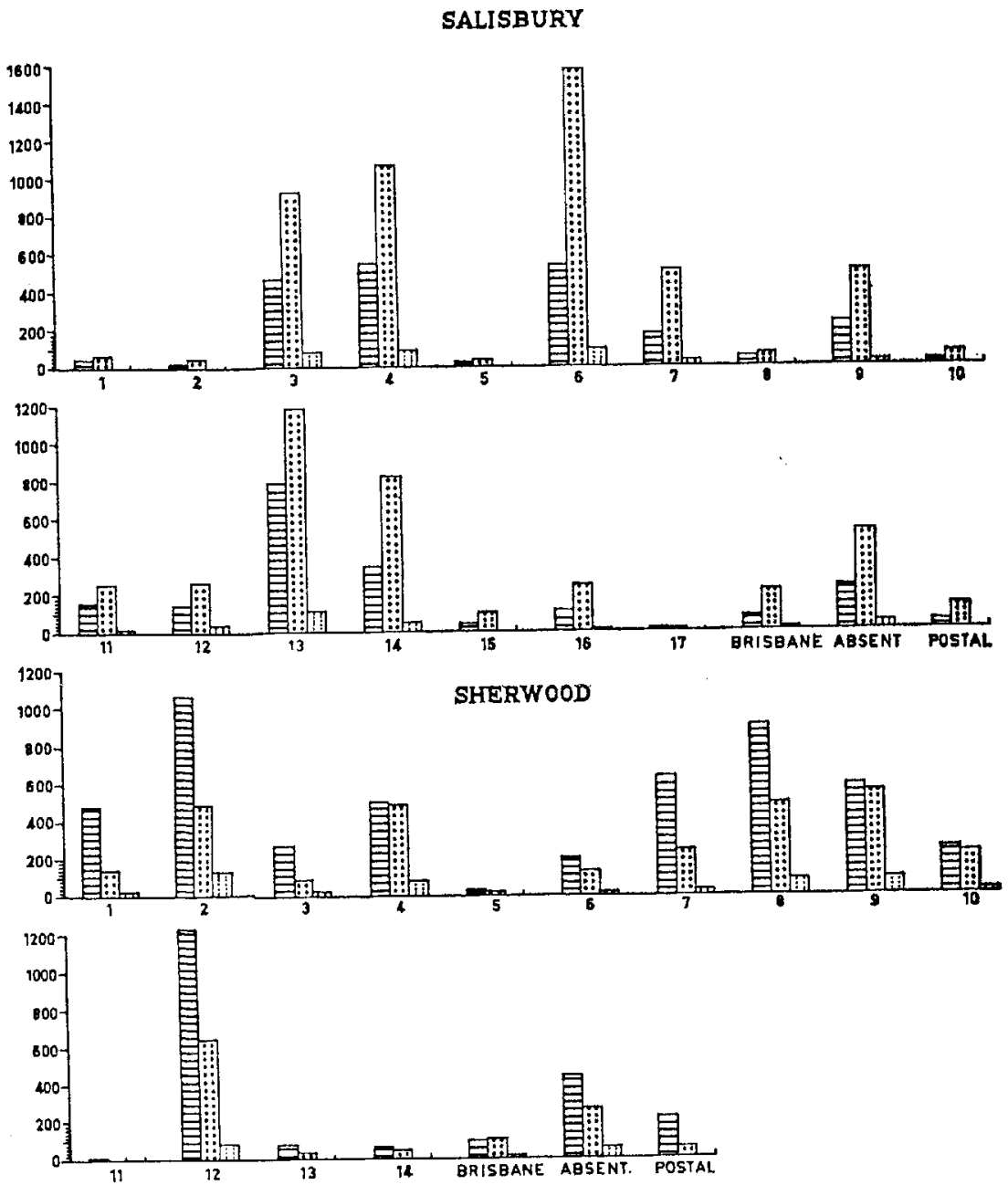

目 LIEERAL PARTY

LESS IHAN 10 VOTERS NOT SHOWN

iit A.L.P.

i. O.L.P.

FIG. 6 VOTING IN SALISBURY AND SHERWOOD 
would someone be chosen, as was earlier the case at the local government.level, who would meet comfortably the requirements of an electorate predominantly of white-collar workers? Similarly, would the Liberal Party consciously choose a candidate appropriate to the very different electorate of Salisbury?

The sitting Liberal Member for Sherwood was John Desmond Herbert, a former bank officer, then 38 years of age, married, with five sons. He had successfully held the seat for the Liberal Party since 1956 and was clearly very confident of being returned, although he stated that his majority would probably be less on this occasion. During World War II Herbert had served in the Royal Australian Navy and before his pre-selection for the Sherwood seat had been an executive member of the Sherwood sub-branch of the R.S.L. He had also been prominent in local Liberal Party affairs and was chairman of the Moreton Divisional Council. Prior to the 1956 election there were two other nominees for the Sherwood pre-selection, but both of these lived outside the electorate and neither was at the time a member of the Liberal Party. Herbert, on the other hand, was a local resident, was known to have understudied the sitting member, T. H. Kerr, and had served as Kerr's campaign director in his final campaign before retirement. His candidature was unanimously endorsed by the Area Selection Committee, and since then he had not been opposed for pre-selection. Within Parliament, Herbert was well regarded. He was secretary of the parliamentary Liberal Party and on several occasions had been mooted as a likely ministerial appointee.

Throughout his parliamentary career Herbert had concentrated on consolidating his position by active participation in a very wide range of local activities. Most parliamentarians, of course, join a variety of local bodies as one means of obtaining increased public support, but the Member for Sherwood had taken this technique to an extreme. His campaign literature stressed that he devoted almost every week night to activities in support of local organisations-and this clearly was no exaggeration. He was a member of each of the suburban Progress Associations in his electorate, school committees, Scout groups, pre-school centres, ambulance committees, church organisations, sporting bodies, and charitable institutions. He was active in local committees to support the Cancer Campaign, the Heart Foundation, the Blood Bank Building Fund, and the Freedom From Hunger Campaign. Nor were his activities confined to the electorate. He was chairman of the advisory board for the rebuilding of the Toowong Home for Delinquent Girls, a councillor of the School of Arts Association, founder and inaugural president of the Mental Health Federation of Queensland, a councillor of the National Trust Association, state president of the Father and Son Welfare Movement, vice-president of the Tarcoola district Boy Scouts Association, a member of the state 
council of the Girl Guides Association, and a member of the Air Pollution Advisory Council. These were only a few of the organisations with which he had been or was still associated.

Our discussions with prominent Liberal workers in Sherwood suggested that Herbert had been an effective Member who had not only worked hard for local bodies but had also been able to assist personally many individuals in the electorate. At the same time, there was clearly some feeling that he had been overdoing his participation in local activities and it may be asked just how deeply involved in the affairs of his electorate a Member should become, and whether, in this instance, saturation point may not have been reached. One active Liberal Party supporter complained that Herbert's guiding hand was weighing too heavily on the electorate and that it was impossible to hold a meeting of any sort without his emerging as patron or officebearer-usually president. The view was expressed that many individuals in the area were beginning to wish that local organisations could be formed without such assistance, and some nostalgic comments were made about the previous local Member, who, while helpful and interested, participated actively in local bodies only when invited to do so. At this point it must be stated that the election results did not support the view that Herbert had alienated much sympathy by his anxiety to participate in and even dominate various organisations in the electorate. Certainly his involvement in local affairs enabled him to conduct a much less intensive electoral campaign than would otherwise have been necessary. Nevertheless, he may well have been reaching a stage in which interest and assistance produced rapidly diminishing returns. There were also complaints that since his first election Herbert had become complacent, somewhat autocratic, and unwilling to accept suggestions or advice. The writers detected, too, a certain amount of resentment about the fact that he tended to run his own election campaigns where it was felt that he was 'freezing out' some of the older and previously very active Liberal Party workers. In fairness to Herbert it should be stated that comments such as these were not made by a widely representative sample of local party members and there is no way of knowing whether similar opinions were held throughout the party organisation in the electorate.

The sitting Member for Salisbury, Douglas Sherrington, had represented the electorate since its creation three years before. Previously he had been employed as an unskilled worker in the Electricity Department of the City Council. A member of the Electrical Trades Union, he had not held office in the Union which is predominantly composed of tradesmen, but he retained his membership after entering Parliament and strengthened his association with the Trades and Labour Council. In 1957 he unsuccessfully contested Sherwood; his own suburb of Coopers Plains was subsequently transferred to Salisbury, 
and he was one of six candidates for pre-selection in the new electorate. Because of the boundary changes a plebescite could not be held, and in a close ballot the Q.C.E. selected Sherrington to be the endorsed Labor candidate, perhaps on the basis of his activity at the local level.

During his brief parliamentary career he had also consolidated his position in the A.L.P. both inside and outside Parliament. Although his formal education had finished early, Sherrington had apparently quickly learned to make good use of the resources of the parliamentary Library and to prepare his speeches carefully. As a result he had developed into one of the A.L.P.'s more effective debaters. Political observers generally regarded him as being on the 'left wing' and his name had been freely canvassed in the press as a possible successor to the deputy leader of the parliamentary party (Lloyd) or even to the leader of the Opposition (Duggan). He himself denied that he had any immediate ambition to succeed to the deputy leadership or leadership of the parliamentary party and refused to accept the: description of himself as a 'left winger'. On this he adopted Duggan's position during the election campaign to the effect that there was no left or right wing of the A.L.P. Such talk, he asserted, was simply the work of Labor's political opponents. Whatever one's views on this question, it is fair to say that Sherrington's closest associations and sympathies were with the Trades Hall group within the Labor Party and he was highly regarded by all industrial leaders with whom the writers spoke. No doubts were raised about the sincerity of his beliefs or of his loyalty to the Labor Party.

The sitting Members for Sherwood and Salisbury were, then, quite different in background and manner. They did, however, have one striking feature in common-their supreme confidence in the results of the forthcoming election and in their capacity to manage their own campaigns.

The main contenders for each seat also presented some interesting contrasts and similarities. In Sherwood the A.L.P. fielded Vincent Kitson, 31 years of age and employed as a ticket clerk in the Railways Department. Kitson lived with his wife and three children in Oxley and had been a member of the party for approximately six years, and for the two years preceding his pre-selection had held office as secretary of the Oxley branch of the party. He had also been a delegate to the Electorate Executive Council and the Moreton Electorate Council and shortly before the election became secretary of the former body. Although a member of the Australian Railways Union he had held no union office. Kitson was unopposed for pre-selection and as far as could be ascertained no 'deals' were involved. There were some other members of the party interested in standing for the seat but apparently they were reluctant to contest a pre-selection ballot, particularly since Sherwood clearly could only be won if there were a swing of very sub- 
stantial proportions. Shortly after being endorsed as the candidate, Kitson also nominated as a delegate to the party's triennial convention, 'in order to gain experience'. He was, however, soundly defeated by Senator Felix Dittmer, who resides in the Sherwood electorate.

Despite his energy and vigour Kitson may have been a somewhat doubtful choice as candidate for an electorate like Sherwood. He was clearly handicapped by his youth and comparative lack of experience. But of even greater significance was his fairly low level of formal education in an electorate which contains a high proportion of voters who are both well educated and 'educationally conscious'. Here we may note the similarities in the background, education, and so on, of Kitson and his 'opposite number' in Salisbury, the Liberal candidate, Keith Brough. These similarities are significant in view of the marked differences between the two electorates. That is to say the voters of Salisbury would be very likely to favour a different type of candidate from those in Sherwood. There would have been available to the Liberal Party few candidates more appropriate to the Salisbury electorate than Brough. Aged 35 and married with three children, Brough had lived in the area for virtually his whole life. His residence, an old and modest one, was in Richlands, at present sparsely settled but quite close to the main population centre of the electorate, the Inala housing settlement. He had attended the local State school and for a number of years held the mail contract for the area and thus was known to many of the older residents. At the time of the election he was working as a sales representative.

As a Liberal candidate the most striking feature about Brough was his 'working class' background-which he emphasised throughout his campaign and in all discussions with the writers. Formally, his educational attainments were clearly not high and his appearance and manner of speech were far removed from what might be regarded as the popular image of a Liberal candidate. Indeed, in most respects, Brough closely fitted the general stereotype of a member of the A.L.P. He himself clearly realised the importance of this, but the Liberal Party organisation apparently did little to help his attempts to build up a picture of himself as a 'working man'. His personal pamphlet prepared at party headquarters, for instance, stated that he was 'a commercial representative whose main business interests are in the area'. Brough was highly indignant about this attempt, which he regarded as misguided, to portray him as a businessman.

He was unopposed for pre-selection as the Liberal candidate. We were informed that the party's field officer for the area felt it important that the election be contested in Salisbury and had asked the president of the recently formed Darra-Inala branch to see whether a candidate could be found. Most members of the branch had joined the Liberal Party only fairly recently and the chairman sounded out three 
or four members about their willingness to stand against Sherrington. These members thought the matter over for some time, discussed it amongst themselves, and eventually Brough announced that he would be prepared to stand. The other members concerned decided not to nominate and all agreed to assist the campaign to the utmost. We attended two campaign committee meetings at Brough's house and were very impressed by the co-operative spirit and by the active help given by the quite large group of branch members concerned with the various aspects of the campaign. Lack of experience was amply compensated for by the enthusiasm of Brough's supporters.

One is tempted to dispose of the two Q.L.P. candidates (L. Galligan in Sherwood and Miroslav Jansky in Salisbury) by merely stating that they 'also appeared', for neither could have succeeded in leaving the voters with more than a nebulous impression of his personality or abilities. Of the two, Galligan was by far the more experienced politically and was well known in Q.L.P. circles. Prior to the 1957 split, he had been a long-standing member of the A.L.P. and had held office as secretary of a local branch in Ipswich, where he was born and educated. In 1957 he became foundation secretary of the Bremer (later Ipswich East) branch of the Q.L.P. and subsequently had been a delegate to all regional and state conferences of the party. At the time of the election he was secretary of the Oxley Federal Executive and a member of the Central Council of the Q.L.P. A Railways Department clerk for over thirty years, he was a member of the Railways Salaried Officers' Union and at one stage had been vice-president of that union's Brisbane branch. Galligan was also an experienced campaigner -though this was hardly obvious on this occasion. In 1957 he had been campaign director in Bremer for the Q.L.P. candidate, and in 1960 was assistant campaign director in Ipswich East. He himself had also stood unsuccessfully as a Q.L.P. candidate in the Ipswich City Council elections of 1958 and 1961. Although fairly well known in Ipswich for his association with the Friendly Society Movement and as a Junior Rugby League selector, Galligan was handicapped in Sherwood because he did not live in the electorate. He resided in Goodna, just ourside the boundary of the Sherwood electorate, with his wife and two sons. Only in the suburb of Graceville, where he had once lived, did he seem likely to obtain much personal support.

In Salisbury the task of the Q.L.P. candidate, Jansky, was even more formidable. Jansky was employed as a shop assistant at the time of the election. Although he had lived in Australia for about twelve years he still had a noticeable Czech accent which was not so apparent in normal conversation but became pronounced when he was addressing meetings. In an attempt to meet this problem he had had some instruction in public speaking but still had difficulties, and members of his campaign committee found it necessary to edit his speech notes and 
to alter words which he might find difficult to pronounce. His supporters emphasised that he was 'Australian in outlook' but nevertheless much of his campaign was directed towards the New Australian vote.

In the Sherwood electorate there were four branches of the A.L.P.: Sherwood (38 members), Oxley (17), Corinda (14) and Darra (12). The Corinda branch had disappeared after the 1957 split and was not reformed for some time. It might have been expected that the strongest branches would have been those of the more working class areas of Darra and Oxley, but party strength and activity were concentrated in the suburb of Sherwood, the part of the electorate in which housing standards are highest and where white collar workers predominate. This may be partly explained by the fact that Senator Dittmer and two members of the Q.C.E. live in Sherwood and belong to that branch or the party, so that the personal interest and activity of these individuals may have done much to stimulate branch membership. This is unlikely to be the whole explanation, however, and it would be interesting to compare the situation in other electorates in which there are wide variations in class distribution to see whether such a pattern of branch membership is usual.

We also noted that the A.L.P. branches in the electorate had been much stronger when Sherwood was not represented in the City Council by a Labor alderman; at one stage membership of the Sherwood branch had reached 120. This may simply be an example of the fairly common fluctuation in membership of Labor Party branches as a result of their being built up as part of the pre-selection manoeuvrings of prospective candidates. It is often the case, too, that party branches decline in membership after an election, as Members of Parliament may well discourage, or at least not encourage, the growth of branches in their electorates, lest such growth lead to the later emergence of rivals. This is not likely to have been the case in Sherwood, however, since, given the nature of the electorate and Alderman Thomson's personal part in winning the seat, he would have been unlikely to have to face competition for pre-selection in the foreseeable future.

As a whole the A.L.P. branch organisation and membership in Sherwood was much stronger than that of the Liberal Party. This is in line with findings elsewhere, that there is an inverse relationship between a political party's branch membership and the extent of the support it receives from voters in a particular electorate. Rawson and Holtzinger (1958: 44-5) have advanced a number of reasons to explain this, and these reasons appear to fit the situation in Sherwood. There were only two Liberal Party branches in the electorate. One of these covered Sherwood and Oxley and had an active membership of not more than twenty. The other branch, Darra-Inala, included parts of both Sherwood and Salisbury electorates but it appeared that the members were predominantly from Salisbury and were more con- 
cerned to further Brough's campaign rather than Herbert's in Sherwood. In addition to the normal party branches in the electorate there was a Women's Auxiliary from 1949 until 1962. Members of the Auxiliary helped on polling day but the organisation was mainly used for fund raising, and substantial amounts were given from time to time to meet electoral expenses. Although never formally disbanded the Auxiliary seemed to have been inactive for about two years.

The branches of both the A.L.P. and the Liberal Party assisted their candidates financially during the election campaign. The Labor Party's campaign costs were estimated independently by several of those involved at approximately $f 120$. This expenditure was shared by the branches, about half being provided by Sherwood-Corinda and half by Darra-Oxley. No direct financial assistance was given by the Queensland Central Executive of the party, and we understand that financial help was provided by the Central Executive to only two of the seventy-seven Labor Party candidates contesting the election. Kitson himself met incidental expenses associated with the campaign, such as travelling costs, petrol, and so on, but made no direct cash contribution. He indicated that contributions had been sought from his trade union, the Australian Railways Union, and also from the Federal Hospital Employees' Union. The latter had no direct connection with the candidate but had apparently contributed in the past to the campaign funds of various candidates. A number of Goodna employees must live in the electorate. Donations were not solicited from businessmen or firms in the electorate because the candidate 'did not wish to be under any obligation if he were elected'. He stated, however, that he would accept such contributions if they were offered voluntarily. At a subsequent interview Alderman Thomson confirmed the claim that donations had not been sought directly from local businessmen, although he did not explain this in the same terms as the candidate. Instead he stressed that Sherwood was not an electorate that lent itself to the soliciting of campaign contributions, and felt that any such action would lose goodwill. Thus the A.L.P. campaign was modest in terms of cost, and the bulk of the finance was provided by the party branches in the electorate, either from accumulated reserves or the proceeds of various functions.

The picture regarding Liberal Party campaign expenses is less clear. The sitting Member was unwilling to give any information about this matter but from other sources it was possible to obtain some details. It is customary for each Liberal candidate to submit a preliminary campaign budget for approval, irrespective of whether or not a grant is to be made by party headquarters. For Sherwood the approved budget was apparently $£ 350$, the whole of this amount to be found locally. Part of the sum was met from accumulated branch funds but the main source of finance consisted of donations from individual 
party members and local businessmen. An appeal for donations was conducted, a letter being sent by the chairman of the Sherwood branch, $\mathrm{J}$. Broad, to all people in the electorate thought likely to assist. In midMay the writers were informed that considerable difficulty was being experienced in raising the amount required, but shortly afterwards we learned that the difficulty had been overcome following receipt of a single donation of $£ 100$. In addition to these sources of finance Herbert had previously opened a special bank account for election purposes. An amount of $£ 75$ had been placed in the fund by the Member himself, and the Women's Auxiliary had contributed an initial amount of $£ 25$. The account was to be in the nature of an emergency fund to be used for election purposes in the future, no matter whom the candidate might be. In the course of our discussions it appeared that there had been ill-feeling associated with the fund, as some members of the Women's Auxiliary apparently felt that the candidate should have drawn on the available money for part of his election expenses instead of expecting the whole of the campaign budget to be raised by local effort.

As a matter of policy the Q.L.P. aims at having only one party branch in each electorate. There was a branch supposedly operating in Sherwood, but party headquarters refused to divulge membership figures-if they knew them. From discussions with the candidate, however, it was clear that there was little branch activity; certainly no financial assistance came from that source.

In Salisbury the A.L.P. branch organisation was well developed. There were two branches in Inala, which together had approximately sixty members on the books. Both were functioning effectively. In addition, there were five branches in other parts of the electorate, providing between them about one hundred and five members. One of these branches had been newly formed at Calamvale and was stated to be growing rapidly. This was of some significance as Calamvale was one of the two booths which Sherrington did not carry in the 1960 election. Like the sitting Member for Sherwood, Sherrington was unwilling to give any information about the financing of his campaign. He was prepared to talk only in general terms and to state that the 'average cost in an electorate was about $£ 300$ '. Most of the expenses of the campaign were met by the branches, which contributed in proportion to their membership. Some of the money came from accumulated branch funds. The rest was raised in the usual ways-functions, raffles, and the like. There were a few contributions from individual party members but the amounts involved were apparently insignificant. There was no compulsory levy on branch members and donations were not sought directly from local organisations. The Q.C.E. gave no financial help, though it did meet the cost of printing a proportion of the pamphlets distributed during the campaign. 
For the Liberal Party the only really effective branch was that of Darra-Inala. There was a branch of the Liberal Party in the suburb of Salisbury but this was almost defunct, the bulk of its work being done by one or two members. A combined branch operated at Sunnybank-Mt Gravatt, but most of the members of this branch lived in the Mt Gravatt area and the branch was not of much assistance to the candidate for Salisbury. Shortly before the election an attempt was made to form a branch of the Liberal Party at Ellengrove, an area which had previously been a fairly strong Labor district. Formation of this branch had had to be held in abeyance, however, because of the inability of prospective members to pay the initial capitation fee.

Brough and members of his campaign committee were quite prepared to give full details of the financial aspects of the campaign. The approved budget of $£ 165$ was a comparatively small one, apparently because-realistically-Liberal electoral prospects in Salisbury were not regarded as good. A grant of $£ 60$ had been made by party headquarters towards this amount but the balance had to be raised locally. Assistance was received from party organisations in the electorate as follows: Sunnybank Branch $£$ 10; Sunnybank Women's Auxiliary $\ell^{20}$; Darra-Inala Branch $£ 15$; and Moreton Women's Council $£^{10}$ (with the promise of a further $£ 10$ if this were necessary). Various functions, raffles, etc., produced $£ 52$. Some ninety letters seeking donations were sent to local businessmen, but these produced only one contribution, of $£ 25$. Total receipts exceeded the approved expenditure, so that all campaign costs were covered, while the committee was also able to reimburse the candidate for incidental expenses incurred by him personally.

There was only one branch of the Q.L.P. operating in the Salisbury electorate, in the suburb of Salisbury itself. The branch had about fifteen active members although there were more members than that. There had previously been several other branches in the electorate but these were no longer active by the time of the 1963 election. Very little information could be obtained about the financial side of the Q.L.P. campaign in Salisbury. All expenses were covered from local sources. The Salisbury branch met some of the expenses but the largest part came from donations by individuals and from various functions arranged by party members.

Neither Sherwood nor Salisbury departed in any way from the statewide picture of a rather colourless election. Travelling through both electorates prior to polling day and following the contenders from one street corner meeting to the next, the writers were struck by the quietness of the election and the apathy of the electors. While the minor participants in the drama endeavoured, through hard work and enthusiasm, to inject some life into the campaign, it was obvious that their efforts were having little effect. To observers from the sidelines 
there seemed to have been a further decline in the effectiveness of the street-corner meeting technique of campaigning. Though used by all candidates, with the exception of Herbert in Sherwood, it had clearly lost most of the meaning and impact it may have had in the past. All meetings were timed to catch the crowds at suburban shopping centres on Saturday mornings, but though the meetings were short and the speakers effective, the visible impact, as far as it could be gauged, was negligible. At most, four or five persons at any meeting were seen to pause momentarily within listening range. Beyond exhausting the candidate and his vocal chords, this method of campaigning seemed to have little effect. Yet both Kitson and Thomson in Sherwood, and Sherrington in Salisbury, expressed the view that their street-corner meetings were useful, well received, and had stimulated a lot of interest.

There may, of course, be circumstances in which the street-corner meeting is appropriate. Where finance is a problem it is probably one of the cheapest means of campaigning. It might also be a way of bringing to the electors' notice a candidate not widely known in the electorate and so could perhaps be considered a valuable campaigning method for those facing the uphill task of unseating a Member in a safe electorate. Members themselves, even if they are confident of re-election, may also think it desirable to make extensive use of street-corner meetings in certain circumstances. Sherrington did so, but this could have been because he had held the seat for only three years. Moreover, the picture theatres in the electorate were poorly attended so the use of advertising slides was not warranted, nor was there any local newspaper through which he could make himself better known. At the same time it was clear that he did not look on street-corner meetings as a vital part of his overall campaign. He was absent from his own electorate for two weeks during which he assisted other candidates in country areas. He took the view, too, that as a sitting Member his campaigning had extended over the preceding three years, in the sense that he had concentrated on building up contacts through local organisations and by assisting residents with personal problems.

This was also the attitude of the sitting Member for Sherwood. He did no personal campaigning in the strict sense of the word, as he felt that his work during his seven years as a Member had constituted a continuous campaign and that it was unnecessary to step up his activities to any marked degree in the few months before the election. $\mathrm{He}$ argued that street-corner meetings should be unnecessary for a sitting Member who, if he had been fulfilling his functions adequately, would already be known to a wide range of electors. As previously. mentioned, Herbert is an active member (and usually an office bearer) of almost every public organisation within his electorate. An examina- 
tion of the local free newspaper, the Sherwood District Weekly, which is distributed widely in the electorate, showed that in each edition during the three months prior to the election Herbert's name was mentioned in five out of every seven news items or references to various associations in the area. This publicity must have been invaluable to him in keeping both his name and his activities within the electorate continuously before the voters. In addition, he had followed the practice of arranging for Ministers to visit the Sherwood electorate regularly to address members of various associations. All residents likely to be interested were invited to attend these meetings, the organisation of which was handled by the Sherwood Branch of the Liberal Party. Invitations were sent out in the name of both the branch and Herbert and the meetings were chaired by the President of the Sherwood Branch.

Essentially, Herbert's campaign consisted only of the distribution of literature, the placing of signs, and the use of space granted to candidates in the local newspaper. For some time before the election he had been purchasing and distributing reprints of election material which had appeared in the Queensland Liberal. Approximately 4,000 of these reprints were distributed monthly, so that by polling day each of the 7,000 households in the electorate had received two out of every three of these special election articles. The standard Liberal Party pamphlet was also distributed to all households. It contained a photograph, personal details of the local member, and a map of the electorate showing polling booths. This pamphlet stressed the Country Party-Liberal government's record (Moonie oil, Weipa bauxite, roads in the hinterland, brigalow land, etc.) and pointed out that Labor was 'the helpless prisoner of its extremist elements'. Though provided by party headquarters the pamphlet had to be paid for by the local electorate organisation.

To supplement this, Herbert had himself prepared a second piece of campaign literature. This gave a large amount of personal information, including a lengthy listing of local organisations with which he was associated. It also quoted the direct benefits to Sherwood which had been gained under the Nicklin-Munro government. These corresponded closely to those achievements as member for Sherwood which Herbert had been stresing in personal contacts with electors. They included a new high school at Corinda at a cost of $f 0.25$ million, giving the only Junior Agricultural course in the metropolitan area; Corinda Maternity Hospital (the only State maternity hospital with full obstetric facilities in Brisbane suburbs); and the establishment some three years previously of an Ambulance Centre. This pamphlet was mailed to all homes in the electorate. Herbert also made good use of space the Sherwood District Weekly provided over a period of months to enable him to comment on current affairs. He concen- 
trated mainly on the practical achievements of the government and the 'irresponsibility' of the Labor Party.

In the collection of postal votes the Liberal organisation was good. As we have stated, the electorate contains a number of convalescent homes and establishments for aged people, and Liberal Party workers covered these very early in the pre-election period. Herbert was confident that he had beaten his opponents to the punch, and in the final analysis his assessment was correct, as he polled 219 postal votes compared with 50 for Kitson and 9 for Galligan-75 per cent of the postal vote as against 61 per cent of the total vote.

Little use was made of the new electioneering medium-television -by any of the candidates for Salisbury and Sherwood. Herbert made only one brief appearance on 13 May, along with four other Liberal candidates. The full transmission lasted for five minutes and in that time he was asked only two questions relating to his experience. In this brief appearance he took the line that his two terms in Parliament had increased his effectiveness as a Member and justified his return on this occasion.

For the election Herbert had a campaign committee consisting of the captains of each booth, under the chairmanship of Broad. However, he acted as his own campaign director and it seemed evident that his campaign was largely a one-man show, the committee acting very much as a rubber stamp. On polling day he had available an unusually large work force said to number some 140 persons. By organising help on such a scale Herbert was able to ensure that workers were relieved at fairly short intervals. However, he does not appear to call out all the local branch members on these occasions, but draws on his immediate family, relations, personal friends from outside the electorate, a few staunch Liberal workers, and a goodly number of people who owe him favours for assistance he has given them in the past. A survey of polling booth workers in Sherwood produced only thirty-six interviews, so the estimate of 140 may be excessive. Alternately, as the interviews all took place before 1 p.m., the sample may be unrepresentative-for example working men might have come on duty in the afternoon. Subject to these reservations, 47 per cent of Herbert's booth workers were not party members, compared with a Brisbane average for the Liberal Party of 44 per cent. Only 19 per cent of his workers were under 31 compared with the Brisbane average of 35 per cent, but otherwise their social characteristics conformed fairly closely to the Brisbane average.

As the underdog, Kitson, the A.L.P. candidate, mounted a much more vigorous and intensive campaign. Had there been a prize for dogged persistence, hard work, and sheer endurance he would have won hands down. He had begun campaigning actively in November 1962, more than six months before the election, and, in order to 
reach as many people as possible in an electorate where he was not well known, he had personally conducted what may have been the most comprehensive house-to-house canvass of any candidate in the metropolitan area. By three weeks before the election he had reached 2,200 homes and felt that he had made some impression, particularly on the housewives' vote. During his door-knock campaign Kitson did not 'talk politics' unless the elector raised particular issues. His approach was merely to state that he felt candidates had a duty to let themselves be seen by as many voters as possible and to answer any question which might be put to them. At each house visited he left a small calendar, the reverse side of which featured a photograph of the candidate together with names and telephone numbers of persons from whom postal and other voting information could be obtained.

Kitson's campaign director was W. Thornton, President of the Oxley Branch of the Labor Party. Thornton was a very experienced campaigner, able to mix well with all sections of the community and very active in fund raising and other activities in the district. He did not, however, take as prominent a part in this campaign as he might have done. It was suggested to the writers that the reason may have been disappointment with the candidate. Instead Alderman Thomson acted as unofficial assistant campaign director, and his wide knowledge of electoral procedures was reflected in much of the A.L.P. campaign tactics. Though there was a campaign committee of twelve delegates from the branches (including Kitson and Thornton) Thomson appeared to be the 'brains' of the campaign, and the few errors that occurred seemed to be a result of Kitson's failure to keep to the path laid down for him. Kitson was campaign secretary as well as secretary of his local party branch and of the Electorate Executive Council. This proved something of a strain. His youth and comparative inexperience in electoral matters were also big disadvantages and it was said that it was sometimes difficult to induce him to accept advice about the campaign and to refrain from making personal attacks on Herbert. As it happened, the campaigns in both electorates were virtually free from personal clashes, although obviously there was no love lost between each Member and his opponents. In Brisbane electorates represented in the City Council by the A.L.P. it is common for the candidate at the State level to try to build up an image based on that of the municipal representative. The usual line taken is to argue that since the voters had been prepared to trust Labor at the local level and their trust had not been misplaced, they should now elect Labor's State parliamentary candidate. This was the line followed in Kitson's campaign in Sherwood, but at some risk of causingembarrassment to Alderman Thomson. As has been pointed out, Sherwood contains a high proportion of middle class voters, and while Thomson seemed to fit easily into a pattern acceptable to these people, 
Kitson did not. It was possibly to protect himself against any adverse reaction to Kitson that at street-corner meetings Thomson urged support for the Labor candidate in his capacity as a fellow member of the party, not as the local alderman.

Kitson held approximately thirty street-corner meetings on Saturday mornings in the various shopping centres throughout the electorate. Each meeting lasted about thirty minutes. They were well organised and ran to a strict timetable. In essence Kitson campaigned on the general A.L.P. issues, but he made a definite attempt to slant these according to the nature of the electorate or particular sections of it. Thus the general issue of unemployment was often related to education: 'What is going to happen to the well-educated boys and girls who cannot obtain appropriate positions when they leave school?', 'Queensland has the best educated unemployed in Australia', and so on. Sherwood also contains a high proportion of voters who invest money. Some of these had lost heavily through company failures in the months before the election. The A.L.P. campaign therefore stressed the need for the appointment of a public protector of shareholders. Similarly, the idea of a free dental health scheme and free dental care for school children was geared to an electorate which was thought to be health-conscious and which contained a considerable number of doctors. In Darra, the industrial section of the electorate which includes a cement works, the emphasis was on the need for industrial roads and for measures to minimise pollution. Kitson himself was at his best when speaking on the question of unemployment, and more particularly of underemployment and the alleged victimisation of apprentices in the Railways Department. Here he was on home ground and was able to speak effectively and with assurance. His handling of other campaign issues was, however, much less impressive. In his speeches he stressed the need for electrification of the suburban railway system, and he seemed to feel that this topic was an election winner. Both Alderman Thomson and the sitting Member, however, regarded electrification as being of little vote-catching value in most parts of the electorate.

Most of Labor's street-corner meetings were chaired by Alderman Thomson. In addition to Kitson there was always another speakerusually W. R. Walton from the Oxley Branch of the A.L.P. or F. Steer, Queensland President of the Vehicle Builders' Union. The M.L.A. for Baroona, P. J. Hanlon, spoke on one Saturday morning and Manfred Cross, M.H.R., on another. One evening meeting was held outside a local theatre, when Senator H. G. J. Cant from Western Australia was the guest speaker. The 'local' Senator, Felix Dittmer, also spoke at several Saturday morning meetings, and Kitson assured us that greater use would have been made of his services had he not unexpectedly been required to assist in other areas. In our opinion, 
however, the assistance of some Federal and State members, including Senator Dittmer, was not really welcomed by the local campaign committee, who feared that their views on various issues would not be well received in Sherwood.

During the campaign Kitson made one radio broadcast of seven minutes from the Labor station $4 \mathrm{KQ}$ and also tape-recorded a fifteenminute address in association with the Leader of the Opposition and Alderman Thomson. This tape was played on 116 occasions in various locations, a technique copied from Dittmer's campaign in Mt Gravatt some years before. Kitson and branch members also did a good deal of visiting to arrange postal votes, but in this department the Liberals obviously had the better and more successful organisation.

For some months before the election twenty-five signs had been exhibited at strategic localities throughout the electorate. Kitson had made the metal frames $\left(6^{\prime} \times 3^{\prime}\right)$ for the signs himself, and in accordance with the Central Campaign Committee's ruling, red lettering on a black background was used. The local A.L.P. committee felt that this was an unfortunate choice of colours, and Thomson was particularly conscious of the effect of colour on voters. He felt, for instance, that it was psychologically unwise to use red and white how-to-vote cards in Sherwood and it was accordingly decided to have all Kitson's election material printed in black and white. Three large paid advertisements were inserted in the Sherwood District Weekly during the campaign. These consisted of a photograph and certain personal details. The candidate was described as 'young, virile and active' and 'a man of vision, who has continued studying since his state primary and secondary school days'. This was an obvious attempt to stress two points likely to make Kitson more acceptable to Sherwood voters: the assertion about continued study as a counter to any adverse reaction to his low formal educational qualifications, and the reference to attendance at 'state' schools, so that voters would realise he was a Protestant. Kitson also used the free space provided to the candidates in the Sherwood District Weekly to write a weekly column, 'Kitson's Komments'. It was his intention to make this column one of the main methods of developing his campaign, but whether this had proved as effective as he had hoped is a moot point. Some of his supporters felt that he had been including the wrong type of material; while at least one of the articles was quite ill advised as it revealed his unfamiliarity with the particular subject. Even the title 'Kitson's Komments' was considered inappropriate for an electorate such as Sherwood.

Campaign literature, distributed through letter boxes, consisted of the general A.L.P. pamphlet provided free by the Q.C.E. This was a coloured folder stressing Labor's role as the 'People's Party' and with the name of the local candidate inserted inside. These were not placed throughout all sections of the electorate, as Alderman Thomson's 
experience suggested that residents in some areas objected to having election material thrust upon them. How-to-vote cards were also distributed beforehand in certain areas, for example Darra and Graceville West, as well as being used at booths on polling day. Thomson had noted that early distribution of how-to-vote cards had proved particularly successful during the City Council elections when used by the C.M.O. candidate to obtain the support of New Australians in the area. Lack of finance prevented the hiring of halls for meetings, and, for the same reason, no theatre slides or TV advertisements were used.

It is beyond question that Kitson mounted a comprehensive, shrewd, and energetic campaign, to which Alderman Thomson's knowledge and experience were contributions of the greatest value. Equally obviously, there was no real possibility at any stage of the Labor candidate's making substantial inroads into Herbert's majority. Perhaps a Labor candidate with a background more in keeping with that of the majority of electors in Sherwood would have left behind him at the end of the election a more satisfactory image of the A.L.P. as a whole than Kitson was able to do, and would have provided a base for future campaigns.

During the course of the campaign the confidence of the underdog candidates rose. Thomson had no illusions about the likely result of the election, and, indeed, towards the end of the campaign made, in confidence, a remarkably accurate forecast of the final result. Kitson, however, felt at the onset that his Liberal opponent had at least a $70 / 30$ chance of success, but later was assessing his own prospect at $50 / 50$. He was confident that he would obtain the votes of two-thirds of the new electors on the rolls, and that the simplicity of his preference instructions-i.e., 3.2.1. as against Herbert's 2.1.3.-would produce two informal votes from Herbert's supporters to every one from his. By the closing stages of the campaign he had been able to convince himself that the tide was running strongly for the A.L.P. in Sherwood. He based this largely on Alderman Thomson's win in the previous City Council elections and on the recent cliff-hanging struggle of the federal Member, Killen, in Moreton (of which the State electorate of Sherwood forms a large part).

The Q.L.P. candidate, Galligan, lacked both finance and branch organisation and was unable to mount an extensive campaign. Although a member of the Central Council of the Q.L.P. he had not asked the party for assistance and was meeting all his own expenses. As the Q.L.P. branch in Sherwood was almost inactive, his was very much a Do it Yourself campaign, although he did have a committee of six members to assist with planning, placing brochures in letter boxes, and so on. Galligan considered that meetings in halls and on street corners were not effective, though cost and lack of effective or- 
ganisation may have been the main reasons for his abandonment of these traditional methods of campaigning. He was, on the other hand, the only candidate to use theatre advertising. He had slides exhibited in the theatres at Darra, Oxley, Sherwood, and Graceville-two for a fortnight and two for a week. He also made use of outdoor signs-a dozen large ones $\left(30^{\prime \prime} \times 40^{\prime \prime}\right)$ and some smaller ones, facsimiles of his how-to-vote card. He ran into trouble with his signs in the Corinda district where one large and several smaller signs were removed almost as soon as they were placed in position. He was unfortunate, too, in that the Sherwood District Weekly did not accord him the same facilities as the other candidates. He inserted a paid advertisement in the issue of 29 May and at the same time an account of his career was published. without charge. However, no other space was granted by the editor, and the paper did not publish an article he submitted to it.

Galligan was a late starter in the election campaign, beginning only on 19 April. Despite this he found time to assist other Q.L.P. candidates in Kurilpa, Ipswich West, and Ipswich East. For the most part he worked alone in distributing his campaign literature. This was his main campaign effort and he managed to place quite large quantities of literature in letter boxes throughout the electorate. Q.L.P. headquarters provided 3,000 copies of a reprint of an article in the Bulletin of 29 September 1963. This article, 'QueenslandLabor's Key to Canberra?', by Peter Kelly, purported to show the extent of left-wing and Communist trade union control of the A.L.P. in Queensland. In lieu of a personal pamphlet, which he could not afford to have printed, Galligan, like most Q.L.P. candidates, purchased from party headquarters 5,000 copies of a general pamphlet called 'Why Vote Q.L.P.' On these he stamped his name and how-tovote details. This pamphlet stressed the middle of the road policy of the Q.L.P. between 'a Tory government that has failed' and 'the A.L.P. that cannot be trusted'. Into the letter boxes along with these went 3,000 of another headquarters' pamphlet headed 'What's Your Preference?' In his distribution Galligan managed to cover about half of Chelmer and Oxley, two-thirds of Graceville and Sherwood, and virtually all of Corinda. As he did not hold meetings the writers had no opportunity of hearing him expound his policy publicly. He did say, however, that in talking to voters he had concentrated on the classic Q.L.P. themes of anti-Communism and the evils of a political party's accepting 'outside direction', and had also stressed the positive role of the Q.L.P. and its 'vital programme of social justice'.

The campaigns of the candidates in Salisbury were virtually a repetition of those in Sherwood-the only notable difference being a reversal of party label. Here the confident, one might almost say relaxed, candidate was the sitting A.L.P. Member, Sherrington, while it was the Liberal candidate, Brough, who developed the most energetic 
campaign and beat the bushes in every corner of the electorate. Sherrington considered that one wins an election by selling one's name, and his campaign was directed to this end. He used forty-eight signs, each $3^{\prime} \times 3^{\prime}$ in the official A.L.P. electoral colours of red on black, placing them in well-chosen positions throughout the electorate where they would be seen by train and bus travellers.

A.L.P. branch organisation in Salisbury was both well developed and efficient, and the candidate had a large number of active members to call upon for assistance. These members distributed the campaign literature to letter boxes throughout the electorate. Here again Sherrington concentrated on getting his name across. He used the standard A.L.P. pamphlet, designed by the Central Campaign Committee, which had no personal details but displayed his name very prominently. The branch members also placed in letter boxes a calendar featuring a photograph of the candidate and listing telephone numbers which might be of importance to householders (police, fire brigade, etc.), along with those of Sherrington and Alderman Greenfield. Again, no personal details were given as Sherrington felt that this was not necessary for a sitting Member. This was in marked contrast to the attitude of Herbert, whose election pamphlet disclosed a wealth of personal detail: he appeared to work on the principle that his private life was an open book he was anxious to place before the electors for their perusal.

Thaugh he made no use of theatre slides, television, radio, or local newspapers, Sherrington did hold one meeting in a hall. This was at Calamvale, a part of the electorate too sparsely populated for effective street-corner meetings. It was also one of the only two booths he had lost at the previous election (though by only a handful of votes), and for that reason probably merited this extra attention.

He conducted a series of vigorous street-corner meetings for about six weeks, with a break of a fortnight in mid-campaign when he assisted candidates in the country. The electorate was also regularly traversed for about two weeks before polling day by car which at selected locations played a tape recording of one of Duggan's speeches.

Listening to Sherrington at his street-corner meetings one formed the opinion that, even had they been considered totally unnecessary to his campaign, he would nonetheless have held them for his own personal satisfaction. Here was a man who obviously enjoyed contact, however one-way, with the electors. A loud and forceful speaker, his approach was quite different from that of his fellow A.L.P. member, Kitson, in Sherwood-the difference between the confidence of the leading actor and the diffidence of the featured player. Kitson spoke always of the party, its policy, what it had done and would do in the future. Sherrington mentioned party policy almost in passing, and 
more by way of comment or illustration than as a basic issue. Instead, he concentrated on informing his listeners of his achievements for the electorate (housing, schools, dental clinic, etc.), and turned the big guns of his oratory upon the Country Party-Liberal government and its leaders. He accused them of personal attacks upon himself and of a smear campaign-indeed, of attempted 'character assassination'. All this he was able, however, to shrug off because, he said, his grass roots ties with churches, organisations, and groups in the electorate were so strong that the 'man in the street' knew him for what he was'a good bloke'-and would accordingly vote for him.

It was obvious from his speeches and from those of his campaign director, Alderman C. J. Greenfield, who invariably appeared with him at these meetings, that much of Sherrington's time and energy had been devoted to matters affecting the inhabitants of the satellite Housing Commission township of Inala. This area had a weekly intake of up to ten new families, and it was clearly an important section of the electorate and one that warranted nursing. For this reason Sherrington decided to distribute how-to-vote cards in Inala well before polling day to reach the new voters and some New Australians who resided there. Sherrington's campaign committee consisted of the secretary of each of the given branches in the electorate, together with himself and the campaign director, Alderman Greenfield. So far as we could ascertain this body genuinely worked as a committee and was not dominated by either Sherrington or Greenfield. All in all, the A.L.P. in Salisbury had an active and well organised campaign based on strong branch participation and a smoothly functioning local machine, and for this reason neither federal issues nor outside speakers were imported.

The Liberal candidate, Brough, had necessarily to carry on an even more energetic campaign. Indeed, it was one where the enthusiasm of the candidate and his committee had to compensate for some lack of organisation and for political inexperience. Like his counterpart, Kitson, Brough's first step in the campaign was a door-to-door canvass of the electorate, in which an introductory card was left with each householder. This was not a single-handed effort, however, a good deal of assistance being given by members of the committee, family, and friends. Again like Kitson, they did not 'talk politics' during these house calls, unless specific issues were raised, but stressed their candidate's long period of residence in the electorate and his promise to work honestly and sincerely for local residents. As a result of illness during childhood Brough is physically handicapped and wears a surgical boot. He made no reference to this during the campaign, but several of his supporters when canvassing voters emphasised his courage in overcoming such a disability. All the party workers engaged in the house-to-house canvass were confident that it had been 
effective in bringing Brough's name before a wide range of electors and in changing some votes.

The next step was to distribute to letter boxes throughout the electorate copies of Brough's personal pamphlet, together with a reprint of an election article from the May issue of the Queensland Liberal. The pamphlet was the standard Liberal Party production, previously described in some detail in the account of Herbert's campaign in Sherwood. A week before polling day, how-to-vote cards were distributed to all homes in the electorate. On polling day itself large how-to-vote placards printed in three languages were displayed on each booth, in the hope of securing the votes of New Australian families in the electorate. For the same reason the booth captain at Darra, where the concentration of New Australians was heaviest, was multilingual. Mrs Brough and seven of her friends had accepted responsibility for organising the collection of postal votes, and had apparently devoted a good deal of time and effort to this end. Their task was a difficult one, however, in view of the much superior branch organisation of the A.L.P., and in the final result Brough polled only fifty-two postal votes compared with one hundred and thirty-eight for Sherrington, while Jansky collected only one. As Sherrington had 72 per cent of the postal vote as against 65 per cent of the total vote, Mrs Brough's efforts appear to have closed the gap created by the sitting Member's natural advantages more effectively than Kitson's campaign machine had succeeded in doing. At one of Brough's campaign committee meetings which we attended we were surprised to find that the Liberal Party's Field Officer was able to produce a list of 138 women resident in the electorate who had booked in to maternity hospitals on or around polling day. He suggested that they be approached directly to see whether they required postal votes. It is disappointing to have to record that we were unable to ascertain the source of this information.

During the campaign no use was made of $\mathrm{TV}$, radio, or slides at the local picture theatres, but some thirty outdoor signs, each $5^{\prime} \times 3^{\prime}$, were erected in various parts of the electorate. The committee held two barbecues for fund-raising purposes and Brough attended two morning teas in private homes, organised so he could meet some of the women of the electorate. To stimulate interest in the campaign, and particularly to enlist active workers, several other meetings were held in private homes. Like all the other candidates, Brough's Saturday mornings were spent in a succession of street-corner meetings at shopping centres in the electorate. He was assisted at some of these by the Federal Member for Moreton, Killen, but on most occasions the speakers were himself and his campaign director. Both were obviously nervous, this being most noticeable on the occasions when they were in Killen's company. At these meetings and, indeed, 
throughout his campaign generally, Brough's approach was negative-a grave failing in what was otherwise a vigorous and well organised campaign. Essentially, he based his campaign on the assertions that he was a worker, knew the difficulties faced by workers, and was well aware of the local problems in Salisbury. Often at meetings he said no more than that, failing to elaborate the problems in any way or to give any indication that he really was aware of or understood the working man's point of view on current issues. This was a serious weakness in someone fighting a political campaign from the position of underdog in what was a staunchly Labor electorate. He was a working man-though self-employed. He looked like a working man. But he did not sound like one, at least so far as his ideas and the content of his speeches were concerned.

There was one other candidate in Salisbury-Miroslav Jansky of the Queensland Labor Party. The main-indeed almost the onlyindication the writers had that Jansky was campaigning was a rash of rather amateurish outdoor signs which sprang up all over Salisbury. Neither Jansky nor his campaign director, D. W. Malone, had telephones, and messages for them had to be left with a third party. At one stage of the campaign, in our fruitless efforts to contact him, we began to doubt Jansky's very existence. Ultimately we were able to prove to our own satisfaction that he did exist, but most of our information about his campaign had to be obtained at second hand, and such details as we could get came from the campaign director's brother, who was himself closely associated with Jansky's campaign.

As there was only one Q.L.P. branch in the electorate, at Salisbury, with at most fifteen active members, it hardly seemed possible that a campaign of the vigour attested to by Malone could have been carried out. He claimed that about seventy street-corner meetings had been held in the evenings, combined with the distribution of pamphlets in neighbourhood letter boxes, and that approximately thirty meetings had been held at shopping centres on Saturday mornings. On those infrequent occasions when we were able to extract the estimated times of these meetings from our informant we were thwarted in our attempts to hear the candidate-for the simple reason that he did not turn up-so it may be assumed that the claims for a vigorous and active campaign were gross exaggerations.

A personal pamphlet was spread throughout the electorate, but once again the estimated number distributed seemed high and we gained the impression that coverage was fairly limited. There had also been some attempts at a door-knock campaign by both the candidate and some branch members, but this, too, appeared to have been patchy and confined mainly to the Inala area. In fact, most of the campaigning, such as it was, was directed towards Inala, partly because this was the largest population centre of the electorate and partly 
because it had the heaviest concentration of New Australians. Although Jansky was described as 'Australian in outlook', he did hope for strong support from New Australians in the electorate. The main points made in his speeches were, firstly, that as a native of Czechoslovakia he had seen the troubles there in the Labour movement and did not wish the same thing to occur in his adopted country, and, secondly, his opposition to socialism. Beyond these comments he tended to confine himself to indicating his support for specific planks in the party's platform.

This brief examination of two electorates does not, of course, provide sufficient evidence to enable general conclusions to be drawn. Several points of interest do emerge, however. In each electorate the sitting Member seemed to operate under much more advantageous conditions, and in some ways more effectively, than his opponents. Both Sherrington and Herbert were better organised than the other candidates to obtain postal votes, and in the final analysis they received, both absolutely and proportionately, more such votes than the main contenders. On polling day both equipped and manned their booths more adequately and their booths tended to be located more favourably. It is difficult to suggest why this should have been so. Differences such as those mentioned cannot be explained simply in terms of the sitting Members' greater experience of campaigning or knowledge of electoral rights. The routine aspects of electioneering are known to, and can be implemented by, most candidates-particularly when they can draw on the advice and assistance of their party organisations and the experience of party workers at the local level. Perhaps an explanation in psychological terms should be sought. It may be that, except for a handful of zealots, party supporters do not give of their best unless they can feel that their candidate has at least an outside chance of success. Few of those working for the defeat of the sitting Members in these two electorates could have had any such hope.

Despite differences in background and party affiliation, the similarities of manner between the sitting Members were striking. Both were supremely confident and almost casual in their professional approach to the election. This is partly a reflection of the obvious advantages possessed by the incumbent in any seat-the means to nurse the electorate between elections, the invitations to participate in local activities which automatically come his way, the opportunities for building up goodwill by helping individuals with their problems. As both Sherrington and Herbert pointed out, all sitting Members are able, in a sense, to conduct a continuous election campaign and, unless their seats are marginal, need not greatly step up their activities in the few months preceding polling day. However, the air of confidence of the Members for Salisbury and Sherwood was perhaps 
more marked than is usual, and was probably a source of considerable inspiration to their supporters.

There were noteworthy similarities, too, between the campaign and general approach to the election of each of the main contenders. Both Brough and Kitson, realising that the task of defeating the sitting Member would be difficult, planned their campaigns in great detail. Both placed great emphasis on door-to-door canvassing. However, neither was able to weaken to any extent the position of the sitting Member. It seems unlikely that in Salisbury any Liberal candidate would have polled substantially more votes than Brough-though Brough himself may well have done somewhat better had he adopted a more positive line when addressing meetings. In Sherwood we felt that support for the A.L.P. would have been greater had a different type of candidate been chosen. Our comments on Kitson's deficiencies, for this electorate, have already been given. Although Thomson was soundly defeated when he stood against Herbert in the 1960 State elections, his stocks in the electorate had risen considerably since then and his work as local alderman was highly regarded. Had the A.L.P. on this occasion chosen him or another candidate like him, the final result would almost certainly have been much closer.

It was also interesting to observe how the confidence of both challengers rose as the campaign progressed. In the early stages they clearly realised that they had little or no chance of success. In their later predictions, however, they were much more optimistic. This was not simply a case of 'whistling in the dark'. Both genuinely came to believe that they could win. This provides an indication of how diffcult it is for those intimately involved in an election campaign to assess accurately the overall situation. One potent factor inducing overconfidence is the reluctance of voters, when visited during a doorknock campaign, to inform a candidate that they do not intend to vote for him. The fact, too, that many voters are unsure of their ultimate choice until polling day itself plays a part in increasing a candidate's optimism. Even seasoned campaigners, let alone those as inexperienced as Brough and Kitson, may be left with a sense of false security as a result of extensive door-to-door canvassing.

We were struck by the fact that political candidature, even if unsuccessful, seems to have attractions in its own right for the individual concerned. When interviewed just after the election, for instance, Brough was quite despondent about the results. Yet, very shortly afterwards, he decided to contest the City Council elections as the C.M.O. candidate for Salisbury-knowing, one assumes, that his chances of defeating the sitting A.L.P. alderman were no better than they had been for the State elections. In the landslide Labor win in 1964 he polled only 23 per cent of the vote. Undaunted, in 1966 he 
stood again for the Liberals in Salisbury, and raised his vote to 31 per cent. Clearly Brough had developed an enthusiasm for politics.

It is clear that from the point of view of a political party there are likely to be advantages in contesting even those seats in which there is little or no hope of success. The publicity gained from each separate campaign adds to the overall impact the party can make, but, quite apart from this, benefits are likely to accrue at the local level. Salisbury is a case in point. The campaign did much to consolidate the new Liberal Party branch of Darra-Inala, whose members were drawn into the election struggle from the outset. There also seems to have been, as a direct result of the election, a revival of interest and activity on the part of the party's branch members in the suburb of Salisbury.

The lack of effort put into the campaign by the Q.L.P. candidates is worth noting, particularly when we remember that it is commonly believed that that party consists largely of dedicated members-some would describe them as 'fanatics'-imbued with a sense of mission. In each of these electorates there were originally several Q.L.P. branches. Now there is only one. This is claimed to be a matter of deliberate policy, but one suspects that it simply indicates a substantial decline in party membership. For these electorates Q.L.P. election expenditure was low. They seem to have had some difficulty in obtaining candidates, and the campaigns were far less intensive than those of the other candidates. One wonders whether the contesting of Salisbury and Sherwood by the Q.L.P. represented anything more than a rather forlorn gesture, designed to cause some embarrassment-however smallto the A.L.P. 


\title{
Townsville South, 1963
}

\author{
IAN N. MOLES
}

Although to most Queenslanders it is anchored firmly in the remote and tropical 'Far North', Townsville is little more than midway along the Queensland coastline, 832 miles by rail from Brisbane. It is the major port, railhead, and distribution outlet for a vast district, almost the size of New South Wales, which is actually and potentially one of Australia's most productive areas. Its grasslands nourish a growing beef industry. Six hundred miles to the west, Mt Isa provides one of Australia's largest export industries. On the lush coastal plains a sugar industry in 1963 looked forward to a comfortable future and the largest harvest in its history.

Townsville, now the second city of Queensland (51,224 at the 1961 census), is not a very pretty place in spite of a few natural advantages. The city itself, and practically the whole of suburbia, straddle a series of mangrove swamps and salt-pans stretching between Ross Creek and Ross River, the two ugly and lifeless watercourses which roughly bisect the town. Many of Townsville's buildings instil an impression of the kind of squalid decay which Xavier Herbert has graphically evoked. Some houses were actually uprooted from the moribund gold-fields of Ravenswood and Charters Towers, and cheap and hasty construction is a good deal in evidence. Underneath the decrepitude and torpor, however, one can detect a certain restlessness, a groundswell. The Bulletin (11 May 1963) attempted to define this mood in terms of 'something entirely new in the concept of development-the coming of the "sophisticated frontier":' That was premature. The North is still a frontier with hardly a veneer of sophistication. But whereas previously a characteristic of wintering politicians was to mutter tiredly and innocuously about the potential of the 
North', in 1963 there was a sense in which the glib slogan was being turned into a social and economic reality. The opening of new industry in Townsville, the rebuilding of the Mt Isa railway, the carefully phased but steady expansion of Mt Isa mines, population growth after a century of relative stagnation, the establishment of a university college and a CSIRO laboratory, the achievement of significant breakthroughs in pasture improvement, and last but by no means least the sealing of the north-south road-all were indicative of a Northern economic renaissance. There was a feeling abroad, inchoate but widespread, that prosperity lay just around the corner. It was against this backdrop of actual economic growth and optimistic hopes for the fulfilment of a long-waited destiny that the 1963 State election in Townsville took place.

The city and its suburbs are divided into two electorates-Townsville North and Townsville South. Since there are no areas of high population density, the boundary between the two electorates divides the city of Townsville into approximately equal areas, and there is very little real difference in the character of each electorate. The city proper lies just inside the southern extremity (Ross Creek) of Townsville North, and a goodly proportion of Townsville's light industry is scattered throughout the electorate. Townsville South incorporates the fringes of downtown (from the Causeway to West End) and the other half of the city's light industrial establishments. Light industry in Townsville consists of a tin can factory, a carton factory, brick and concrete masonry works, glass works, small shipbuilding, plywood and sawmilling, paint manufacture, battery manufacture, and a small processed food industry. Large-scale industry, apart from the bulk loading of raw sugar, includes the two export meatworks at Ross River and Alligator Creek, lime and cement works, copper refining, workshops and carriage-building for the northern division of Queensland Railways, engineering works and foundries.

Although Townsville South contains all of the city's heavy, that is large-scale, industry, the electorate is not predominantly 'industrial' in character in the sense of being either densely populated or militantly working class. No town which has 80 per cent of its dwellings privately owned could ever fit into such a category. Indeed, the first absolute fact which should be recorded concerning the population of Townsville is its remarkable economic homogeneity; the second is that where differences in economic function or the vicissitudes of seasonal unemployment peculiar to the region have in fact tended towards the creation of a managerial group on the one hand and a relatively depressed labour force on the other. the tendency overall has been so slight and the geographic dispersal of both groups so pronounced that the essential 'working-class' character of both electorates has never been impaired. There is only one suburb in Towns- 
ville (North Ward) which has acquired even a faint social stigma, in working-class eyes, of 'being where the swells live'. But even so its houses are scarcely more pretentious than those in any other part of Townsville. Townsville North consistently sends an A.L.P. man to State Parliament. The Country-Liberal government's re-distribution of electoral boundaries in 1959 was obviously designed to transform this particular electorate into a non-Labor seat: the boundary between Townsville North and Townsville South veers crazily through the suburbs, excluding from the former such redoubtable Labor strongholds as West End, and including such likely 'Tory pockets' as Mysterton Estate. The attempt, however, proved a failure.

The position in Townsville South is very much the same. Suburbs like South Townsville, Railway Estate, and Hermit Park-old and staunchly working class-cluster around the railway yards and workshops. Stuart and Wulguru serve the new industrial complex based on Mt Isa Mines' copper refinery. Mundingburra and Rising Sun, once where Townsville ended, have now engendered a crop of lusty offspring in Gulliver, Pimlico, Aitkenvale, all new even if not lavish. The old Mundingburra electorate, redrawn and renamed Townsville South, had been the domain of Thomas Aikens for nineteen years. This man, 63 years of age at the 1963 election, is one of the most compelling figures ever to have stormed on to an Australian hustings. Born at Hughenden on 28 April 1900, he subsequently attended primary and secondary schools at Charters Towers until the age of 14. During this period the Aikens family came to know the poverty of a spluttering gold town. While his mother scrubbed clothes for the rich, young Tom was jarred into abrupt awareness of the viciousness and avarice of untrammelled Man; and impelled all the more by a sensitive nature, a yearning for his fellow man, a sharp intelligence and dangerously strong emotions, fed all the while on a diet of Dickens, Voltaire, Paine, and Ingersoll, Thomas Aikens responded with the classic attitudes, habits, and hatreds of the proletarian classman.

After a spell in shearing sheds, which served merely to bind him closer to the A.L.P. tradition, he joined the Railways Department in 1917, moved to Cloncurry, was elected Shire Councillor at the age of 23 , and was finally transferred to Townsville as a fireman in 1930. Somewhere along the way from Charters Towers to Townsville he got married and learned that he could speak, sing, and drink with somewhat more than average ability. During the war years, Aikens was alderman and Deputy Mayor of Townsville and continued to build on a growing reputation of personal honesty and unrestrained advocacy of anything he considered to be right and just.

In his younger days Aikens drank far too much. He was a 'bender' drinker. This, together with his other apparent and more striking 
qualities, made him enemies not only outside the party but in it. $\mathrm{He}$ was expelled from the A.L.P. in 1940, ostensibly for drunkenness, and that could easily have meant political oblivion. It was a terrible hurt to a man with his background and beliefs. It hurt even more a man who was zealous and ambitious, and who was already more than dimly aware of the charisma which exuded from him, who was frankly egotistical in the sense that only one can be who recognises his extraordinary talent for understanding people, for leading them, and for being an outstanding spokesman on their behalf. But fate, no less, came to the rescue of Aikens. Shortly afterwards, the very branch from which he had been expelled (Hermit Park) was itself proscribed by the Q.C.E. when it defied an embargo on Australia-Soviet Friendship League organisations by affiliating with the Medical Aid to Russia Committee. The prodigal was asked to return, the deregistered branch presently re-constituted itself as the North Queensland Labour Party, and Aikens, tempering gratitude perhaps with just a soupçon of opportunism, nominated for the seat of Mundingburra 'to help fight the tyranny of the Q.C.E.' In the nineteen years that he continued to represent Mundingburra and Townsville South up to 1963, Aikens has revealed himself as a politician ne plus ultra. He has also never touched another drink.

His only challenger in the 1963 election was the A.L.P. nominee, Arthur James Trower. It has been said, with some reason, that the Country-Liberal government will not contest Townsville South because it fears that the repercussions will be felt in Townsville North. Aikens has the reputation of 'training his guns impartially on Government and Opposition alike, and the explosion is often loud enough to be heard from one end of the State to the other'. Therefore, while the Government retains some hope of winning Townsville North, its policy of 'letting sleeping dogs lie' in Townsville South shrewdly brings in a bonus. Aikens is content to aim only at the A.L.P., and this has the effect not only of damaging A.L.P. chances in Townsville North but also indirectly of assisting the Liberal candidate. Born in Innisfail on 22 February 1924, Trower moved to Townsville as a child, left school at sub-Junior, and began to serve an apprenticeship as rotary printing machinist on Townsville's only daily newspaper, the morning Daily Bulletin. He enlisted in the army shortly after his eighteenth birthday and was discharged in June 1946, after serving the honourable stint of an ordinary soldier. While finishing his apprenticeship in civilian life he joined the Printing Industry Employees' Union and subsequently held all offices in his sub-branch. Since 1956 he had been Secretary-Treasurer of the Currajong branch of the A.L.P. His career, in a word, was scarcely more distinguished than that of a million other Australians, and Trower would be the first to admit it. Nevertheless he left an impression of modesty, in- 
tegrity, and dedication to family, job, and party. To his electors, Trower was 'a mighty bloke'. To his party, a submissive rather than creative intelligence was no disqualification for the immense task it had assigned him, for no man was going to defeat Tom Aikens. But the combination of an efficient machine, a faultless plan of operations, unrelenting physical hard work, and a massive barrage of propaganda might just do the trick. It is no disparagement of Trower to say that the A.L.P. campaign was infinitely more important than its candidate. He rarely attempted to project himself as anything more than the mouthpiece of a policy; and this was as much a reflection of the candidate's own self-effacing ideas about his role.in the party as it was the party's realisation of its own essential strategy. But Trower was ready to have a go at the sitting Member if only because 'no-one else had the guts to do it'. Since his own branch was part of the Townsville North electorate, he was nominated by South Townsville and received the Party's endorsement without pre-selection.

From the very beginning, the A.L.P. campaign in Townsville South was organised with the kind of thoroughness in scope and precision in detail which can only be described as military. It bore certain unique features in that, first, it was probably the most expensive campaign waged in the entire State, and second, its organisation was to be completely merged with that of the campaign in Townsville North. Candidates and campaign managers on both sides were reluctant to divulge both the amount of money spent on their respective campaigns and the sources of financial support. A large part of this reluctance may be attributable to the artful, if not wholly clandestine, methods by which some of the support was solicited. Nevertheless, the joint A.L.P. campaign for Townsville North and Townsville South cost something like $£ 2,500$, of which about half was contributed by the party branches. The cost of the N.Q.L.P. campaign in Townsville South was somewhat less than half (about $£ 1,100$ ). The A.L.P.'s joint Campaign Committee for Townsville North and Townsville South met once each month and consisted of three delegates from each of the party's branches, as well as the two candidates. There was a director and an assistant director for the campaign in each electorate. Inevitably, most of the detailed work of actual campaigning was carried out by an Executive Campaign Committee consisting of the two candidates, the two directors, the two assistant directors, and not more than one or two of the delegates to the joint committee. No effort (or even expense) was to be spared in the attempt to unseat Aikens. In the initial stages of the campaign party workers remarked jocularly to one another: 'If we don't get old Tom this time, he'll be there until he dies'. The confident ones left no one in doubt that such a contingency, because it was so ridiculously extreme, could never possibly eventuate. The first advertisement launching the A.L.P. campaign was inserted 
in the Daily Bulletin on 8 September 1962-nine months before election day. Three weeks later, on 29 September, Trower set out for his first street corner.

The operations room was 'under the house' at the candidate's home. An avid bush carpenter, Trower had partitioned off an office. Paint, placards, loud-speakers were spread about in happy confusion. A huge map of Townsville was hinged underneath the living-room floor so that it swung down at a convenient angle for concentrated plotting. It was a colourful sight, dotted with multi-coloured thumb tacks, each colour representing a particular point d'appui in the campaign to convince or seduce the voter. The red ones indicated the fences or sides of houses which displayed personal posters; the green ones located party placards; yellow tacks marked the venues of the extended Saturday morning meetings; blue, the proposed 'whistle stops'. Some selected areas were completely cordoned off for direct door-to-door canvassing by the candidate himself. Every voter in Townsville would come within sight or earshot of the party's message.

The campaign began to gather momentum in the new year. From 12 January 1963 Trower was joined by the A.L.P. incumbent in Townsville North, Percy Tucker, who was himself under strong pressure. The Saturday morning meetings were now stepped up to one in each electorate, with both candidates-and occasionally Harding, the local Labor M.H.R. for Herbert-participating. Five-minute radio broadcasts on the city's principal commercial station, 4TO, began on 19 January and continued until the end of the campaign on a regular 5.45 p.m., Saturday, timespot. Some 500 posters which had been kept on ice until the end of the 'Wet' began to appear at predetermined points all over the town at the end of February. There were 200 party placards (each $3^{\prime} \times 3^{\prime}$ ) featuring a Tucker-Trower combined appeal; and 150 personal posters for each A.L.P. candidate $\left(3^{\prime} \times 2^{\prime} 6^{\prime \prime}\right)$ bearing individual photos. The rains persisted beyond their average allotted span for the year, and many of the posters soon looked limp and forlorn, their vivid reds streaking queasily across a jet-black background, but they were quickly repaired or replaced. Simultaneously, during the first week of March, the candidates, always together now, took their loud-speakers into the suburbs at 5.15 p.m. every afternoon except Fridays. These meetings also continued until 1 June. If the voters were yet affected by the party's earnest appeals, they managed to conceal their interest effectively. The street-corner meetings were lucky to attract even a handful of self-conscious stalwarts. Usually the candidates merely directed their speakers at random to three points of the compass and spoke hopefully to the other, although it is true that a few curtains ruffled suspiciously for the trained eye and occasionally even a window was seen to open.

By 20 March the campaign had clearly begun to assume classic pro- 
portions. Ten-second slides appeared on television and cinema slides at the only Drive-in. Party literature now added to the Saturday morning litter of suburban footpaths and gutters. These consisted of a Q.C.E. dodger, with the name of the local candidate over-printed in the top right-hand corner, promising a 'destination of prosperity' for A.L.P. voters in 1963, a four-page leaflet featuring a personal appeal from Trower, with a frontispiece of himself, his wife, and their two children knocking at the door of a house and asking: 'may we come in?' Aikens's prompt and typical retort was that he preferred to be judged on his 'ability' rather than his 'fertility'. Saturday shoppers would also find a small card thrust into their hands. One side was a calendar; the obverse asked electors to 'vote A.L.P. in '63' over a small picture of the candidate, and gave the names and addresses of party insiders from whom 'all information concerning electoral matters' could be obtained. Newspaper advertisements similarly exhorted postal and absentee voters to contact certain key personnel, notably the candidate himself, who would personally assist in the completion of this formality.

During all this time Townsville was playing host to a steady stream of A.L.P. notables from the south. Frank Crean, Manfred Cross, Bill Hayden, Pat Hanlon, Senators Dittmer and McKenna, and of course John Duggan, the party leader himself-all appeared in the electorate at various times. In order to provide the visitors with an appropriate demonstration of party vigour, solidarity, and confidence, even the obsolescent and generally disdained hall meeting was resurrected on four occasions. However, the visits were usually of brief duration and calculated more to exalt the party's image than to have any direct influence on the local campaign. Indeed, simply because the campaign machinery in Townsville was so obviously well oiled, they were invariably shunted off into the neighbouring country electorates of Hinchinbrook, Flinders, and Burdekin, where the mere presence of a 'name' was likely to have a greater immediate impact. Only the party leader, John Duggan, was asked to make a five-minute television appearance.

The pace which the candidates set in the closing weeks of the campaign can only be described as killing. Every form of communication was continued; but in addition the television slides were now supplemented by the weekly talks of both candidates. Each Friday, for five weeks, Trower and Tucker enjoined a captive audience on the single television channel to elect an A.L.P. government. In the last week they added two individual appearances to a final joint appeal. For ten days, the 'whistle stops' were increased to an exhausting average of twenty-five daily. Another Q.C.E. dodger appeared, this time in technicolour, with three beaming housewives 'all agreeing on voting A.L.P. in '63' from the floor of a supermarket which was am- 
biguously, but unmistakably, abundant; inside, an equally ebullient John Duggan stood beside the over-printed name of Trower. This indefatigable candidate now modestly wound up his campaign with a door-knocking canvass in which he completely covered the two suburbs of Wulguru and West End.

Throughout the campaign, both A.L.P. candidates' speeches continually returned to the theme of unemployment. Compared with it, all other questions paled into insignificance. The usual catchcries were that unemployment in Queensland was 'higher than the national average' and that 'two out of every five unemployed were under the age of $21^{\prime}$. If unemployment were to become of substantive importance to Labor in winning the election, it had no better chance of success than in North Queensland. Seasonal unemployment is the bane of the land, particularly in the meat industry, which is a perpetual prop of Townsville's economy and a useful barometer of its day-to-day prosperity. Also, there had been no spectacular expansion of industry of a kind which could readily absorb a growing increase in the population of school-leavers. Railwaymen, too, were obviously troubled by the Nicklin government's frequently stated intention of streamlining railway operations-which was invariably interpreted in Labor quarters as a policy of 'wrapping up the railways'. Yet in spite of all this, there was to be no significant movement against the Government.

The suggestion has already been made that Trower made no attempt to project himself in any other role than representative of a party which offered a progressive and positive policy. It is for this reason that his speeches were overwhelmingly directed against the Nicklin government-not against Aikens, his actual opponent, whom he was content to represent (with circumspection and respect) as an Independent (p. 159) who had no policy and who could never be a part of any government. It is also for this reason that Trower reacted indignantly against the Government's campaign to link the A.L.P. with Communism. Normally calm and unruffled, Trower sometimes became visibly agitated in his references to the so-called 'smear'. He hit back defensively: 'Nothing makes me madder than being called a Communist'. Unfortunately, the smear had precisely the effect that the Government no doubt intended it should have. 'Unemployment' and Labor's proposals to counteract it all too often took second place to impassioned diatribes on the 'great and untarnished history' of the A.L.P., 'which always arrives at its decision through the great democratic process', and 'which has as its basic, the principle of Christianity'. Needless to say he did not take kindly to Aikens's homely aspersions in a similar vein that 'if you lie down with flea-bitten dogs, you can't blame the people if they think you've got fleas', or 'if you fly around with crows, nobody is going to think you are a canary'. Nevertheless, from Trower's side, the campaign was a scrupulously clean one. It 
could hardly have been otherwise with a man so inherently decent, who so loved his party and so respected his opponent.

While Trower fulminated, Aikens sat back in benign and disinterested amusement. His 'opening rally' took place on $17 \mathrm{May}$, a full two weeks before election day, although he had deigned to insert a few newspaper advertisements beginning on $30 \mathrm{March}$. Seven months after the commencement of the A.L.P. campaign, a mere two months before the election, Tom Aikens chose to elect the citizens of Townsville South to the Parliament of Queensland. For that is exactly what his advertisements accomplished. Beginning with the axiom that an appeal to electors goes first to the belly, second to the heart, and never to the mind, Aikens reasoned that the belly was already full. 'The worker of today is conscious of a profound struggle-the struggle "to keep up with the Jones".' Moving on to the second axiom that a citizen's loyalties move up in ascending order of priority from his belly to his family to his home to his street to his suburb to his town to his region to his State to his nation, Aikens proceeded to deal with each of these matters succinctly and conclusively. 'Townsville Honoured!' rang out his first advertisement. If one read the small print it transpired incidentally that this was because someone had written a book or something about Tom Aikens. 'Second City!' triumphed another; and this was because the people of Townsville were wise enough to know that they had a man in Parliament who was always on their side and could be relied upon not to weaken, no matter how tough the opposition or how bitter the battle'. Naturally, 'it was foolish to claim that Tom Aikens was personally responsible for all the remarkable development of our City in recent years. But the fact is . . . ' 'Tom Aikens', another said proudly,

doesn't bob up from nowhere at election time and try to ride into parliament on a 'party ticket' ... At the end of every session of Parliament he holds public meetings to tell the people to whom alone he is responsible all that went on in Parliament, and how he spoke, voted and acted on every measure, and why. He is the ONLY member of Parliament in Australia to do this.

'Man of the people', proclaimed still another, quoting 'magnificent tributes from a completely unbiassed source', and strongly implying that they were rather tributes to the very electors who had had the good sense to keep sending him back to Parliament. Another made the 'proud boast that MORE government houses had been built in Townsville than in any other city or town outside Brisbane', because Tom 'rolled up his sleeves and kept constantly on the job to get as many houses as he could for Townsville from the few that were granted to places outside Brisbane'. Surely only a fool would doubt that a man of such exceptional attainments must also have had a hand in bringing the university college to Townsville and the Burdekin bridge to North 
Queensland. Ridicule was a technique which Aikens employed effectively in the campaign. A.L.P. radio and television talks always began and ended with rhyming political commercials: 'Vote A.L.P. in '63 and you will score in '64'; 'The man of the hour-Arthur Trower'; 'For a better life in every way vote A.L.P. on election day'; 'It fits to a "T"Townsville, Tucker, Trower', etc., etc. Aikens's references to Tucker and Trower as the 'Ada and Elsie of TV', and his droll suggestions that the A.L.P.'s 'nursery rhyme mentality' was hardly suited to the 'man's world of politics', somehow made A.L.P. pretensions seem hardly serious.

There is a very real sense in which Aikens's campaign in 1963, adroit as it was, can be said to have been redundant. However, to say that people will send him back to Parliament until he dies is not perhaps to tell the truth. The truth is that people will vote for him after he dies. That much is already Townsville legend. His campaign, in comparison with Trower's, was hardly more than a token one. But he will always have one; otherwise, he says, 'the people will feel that they have been cheated'. There were no hall meetings. No literature was printed. No special efforts were made to attract or assist postal voters. There were two half-hour Sunday morning radio talks, four quarter-hour lunch time talks, and three scatter ads. daily for two weeks. There were three five-minute television talks. There were eleven street-corner meetings with audiences ranging from fifty at the 'opening rally' to zero. There were the newspaper advertisements, a dozen or so, though each one never smaller than a striking $12^{\prime \prime} \times 6^{\prime \prime}$. The North Queensland Labor Party, with an active membership of not more than thirty, is merely a group of Aikens's loyal and ageing friends who assist him with the details and formalities of campaigning. It has to recruit extra workers on election day. It will probably not survive its leader.

Aikens remains in Parliament because his political instincts are uncanny and unfailing. He identifies himself completely with the hopes and fears of his constituents. When Parliament is not in session his people always know where they can find their Member. Regularly and ritually each morning he pedals his bike from home to the city, walks up and down Flinders Street talking with anyone, and then proceeds to hold court in a corner of Jimmy Goodwin's barber shop. Each afternoon from $4 o^{\prime}$ clock he receives a steady stream of visitors on the veranda of his home. No matter how tiny or trivial their problems, Tom Aikens, M.L.A., listens patiently and sympathetically, promises to help, and sends them away smiling, secure, and proud. It has been the same for nineteen years. The N.Q.L.P. points to about forty statutory amendments 'benefitting the little man' which it attributes directly to Aikens's parliamentary representations. He has created what he calls a 'Frankenstein monster' which demands his 
constant attendance and attention, and which forces him to live a life of 'boring and almost unendurable respectability'. Whenever he goes to Parliament, which might just as well be in Canberra or Cooma, the monster frets until his return. After each parliamentary session he 'reports' to his constituents in the Regent Theatre, Hermit Park. These solo performances are mostly packed out, and Tom's good-humoured digs at the sanctity of the parliamentary institutions and the integrity of his fellow politicians always bring forth howls of delighted laughter. His actual campaign speeches are merely a restatement in broad terms of what he has achieved in the last session and what he hopes to achieve in the next. Of course everyone knows that Tom didn't exactly build the Burdekin bridge with his own hands, and he never actually claims that he did; but since it is common knowledge that he 'shames and blackmails' Ministers of the Crown, one can be forgiven for thinking that perhaps the bridge mightn't have been built if Tom Aikens had not actually been in Parliament. And even though one can't be sure that the A.L.P. is really controlled by Reds, it's hard to disagree with the proposition that its politicians are 'human yo-yos dangling at the end of a string held by someone else', particularly when he puts it that way. Aikens's rhetorical technique is deft and assured. He is, like Paine, the purveyor of common sense par excellence. Somehow, he manages to convince his listeners not only that they control him, not only that they are the only ones who really know what is going on in politics, but also that they are the most thoughtful and intelligent electors in the entire Commonwealth.

Aikens was returned to Parliament with a majority of almost 3,000 votes in a poll of almost 14,000. In 1960 he polled 8,501 (66-85 per cent) votes to Edmonds's 4,216 (33.15 per cent). In 1963 he received $8,229(60 \cdot 16$ per cent) to Trower's 5,450 (39.84 per cent). So, at first glance, it might appear that Trower had made a significant inroad into the Aikens vote, more than 6 per cent. This is not quite so. In the first place, Edmonds in 1960 had been a weak candidate, already defeated at a federal election and personally unpopular in the A.L.P., so that he had difficulty in manning his polling booths. He did not reside in the electorate. The 1960 election was a straight fight between 'Brisbane Bill' and 'Townsville Tom' in which as many as 500 A.L.P. fringe supporters voted against their candidate. Corroboration of this comes from the 1966 results when Aikens's vote rose again to 9,260 (63.21 per cent) and Trower's dropped to 5,196 (35.47. per cent), the balance of 194 (1.32 per cent) votes going to a Communist candidate.

Trower was liked by A.L.P. supporters, he fought a clean fight, and he lived in his city. Throughout the campaign there was a distinct atmosphere in the A.L.P. circles of 'we-cleaned-up-Menzies-now-we'llclean-up-Nicklin'. It is therefore probably true that the 'band wagon 
boys', the 'be-on-a-winner' fringe element in the A.L.P. which had voted against Edmonds in 1960 now wholeheartedly supported Trower in 1963. Trower's was very likely the 'true' A.L.P. State vote in Aikens's electorate. By 1966 this novelty had worn off, and some of the marginal voters were pulled back into the Aikens orbit.

The additional, though small, margin of success which Trower achieved in 1963 is probably explicable in terms of two other factors. Firstly, there was the general State-wide improvement in the A.L.P. vote. The 1960 election had been held at the peak of an economic boom. Immediately after it, the Federal Government's 'credit squeeze' and an anti-Queensland attitude which had even provoked attacks by State Country-Liberal Ministers unquestionably enhanced A.L.P. prospects. In the second place-though this consideration must weigh far less-there was some restiveness among the high concentration of industrial workers in Townsville immediately before the election. A decision of Judge Ashburner in Melbourne rankled in the bosoms of waterside workers. A pay rise to railway clerks, which meant that the lowest paid clerk earned more than the driver of the 'Sunlander', made railwaymen conscious of the ever-widening gap between the white and blue shirt workers. Industrial disturbances spluttered at the meatworks. It is perhaps worthy of mention that the three (out of fifteen) polling places where Trower led Aikens-McIlwraith Street, Oonoonba, and Stuart-were in precisely those suburbs which were contiguous to wharves, railway, and meatworks.

In Townsville South there are seven A.L.P. branches: Stuart-Wulguru (1960 active membership, 7; 1963, 40); Oonoonba (49; 33); Hermit Park (19; 19); Railway Estate $(36 ; 36)$; South Townsville (21; 41); Mundingburra (25; 39); Aitkenvale (new branch, 29). The A.L.P. candidate was to defeat Aikens in Stuart and South Townsville (McIlwraith Street), where the most pronounced increases in party membership had occurred, where branch leadership was vigorous, and where actual assistance in the campaign was most actively sustained. In Oonoonba, where Trower also beat Aikens, party membership had shown a marked decline, but branch leadership at the time of the campaign was active. Oonoonba was in fact the only branch to adopt the imaginative technique of issuing each voter in the suburb with a card bearing his name and electoral roll number. On the other hand, it should be noted that in Wulguru, which was also one of the two suburbs where the A.L.P. candidate carried out a door-to-door canvass, a majority of the electors voted for Aikens. It would therefore appear that if there is any essential relationship between either enthusiastic branch leadership or actual size of party membership and electoral success, it is the organisational virility of leadership which provides the key.

Most of the foregoing conclusions, it must be admitted, are not 


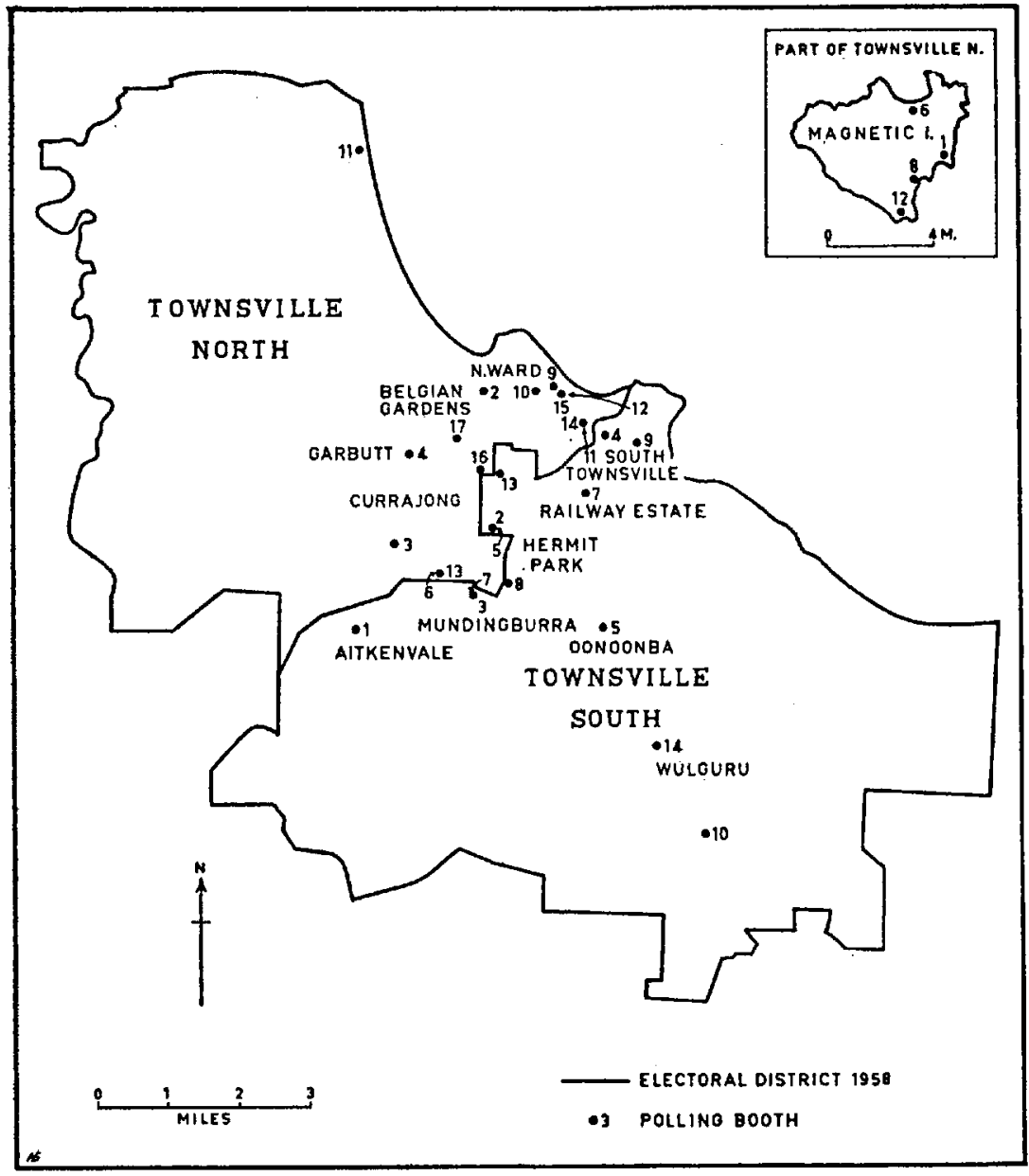

FIG. 7 TOWNSVILLE SOUTH AND TOWNSVILLE NORTH

susceptible of any proof which can properly be called scientific. In the absence of comprehensive voter surveys they cannot aspire to any higher dignity than that of the informed guess. However, there does appear to be sufficient evidence available to warrant at least one incontestable assertion. It is simply this: that formal campaigning by the A.L.P. in this election was a sheer waste of time and money. When, as the culmination of a massive campaign, a candidate's door-to-door canvass in a suburb which votes solidly A.L.P. in Federal elections elicits nothing but ingratiating promises to vote A.L.P. in the State election, and when on election day that same suburb votes solidly for his opponent, this futility is convincingly underlined. A multitude of 


\section{VOTING AT POLLING BOOTH, 1963}

TOWNSVILLE NORTH
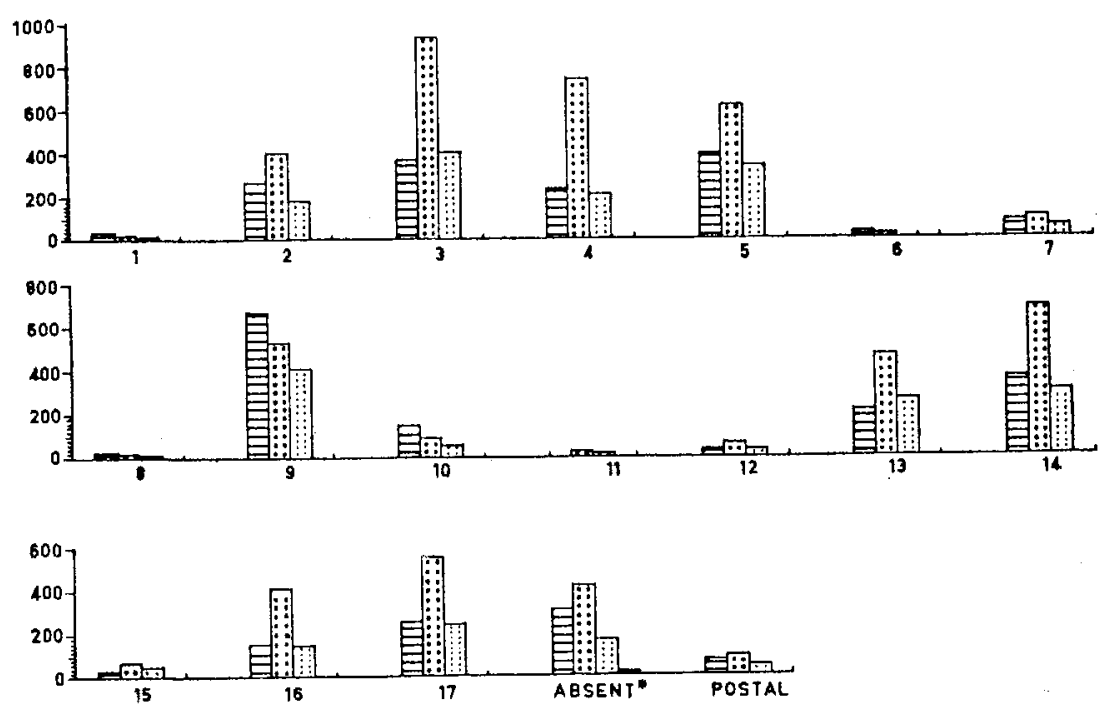

TOWNSVILLE SOUTH
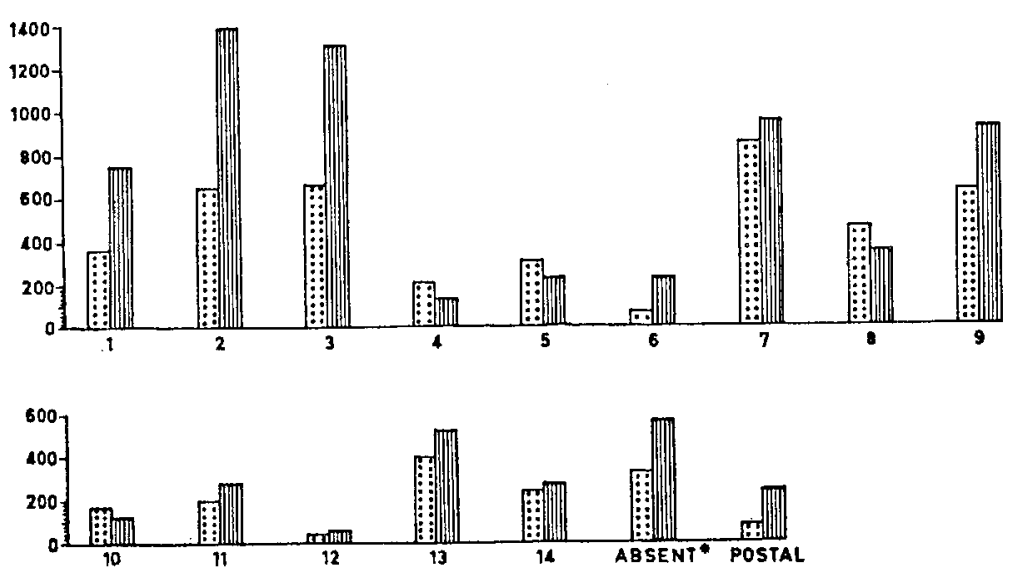

LESS THAN 10 VOTERS NOT SHOWN. - INCLUDING BRISBANE

目 LIOERALPARTY

A.t.P.

O. O.P.

IIII INDEPENDENT

FIG. 8 VOTING IN TOWNSVILLE SOUTH AND TOWNSVILLE NORTH 
questions cry out for answers. Do people who would not lie about anything lie about the way they will vote? Do they make up their minds on whether or not they will vote for the incumbent even as the campaign begins? Does any election campaign accomplish more than merely making the name of the challenger known? Are people much more interested in their own welfare than in party politics or party labels-in beating their joss in bad times and burning incense in the good? As long as they feel their welfare is secure will the man (or the Government) in power always be returned? Is hard-working representation at a grass roots' level the key to permanent political survival? Has the A.L.P. become a 'crisis' party?

The questions in themselves are not original; nor do they contribute much to an understanding of the kinds of problems which it is the chief purpose of such studies to resolve. But in throwing them into a rhetorical form the writer wishes as much to make his own predilections clear as to postulate what the campaign in Townsville South mainly disclosed. One very certain prognostication is that Tom Aikens can be beaten-but only by Tom Aikens. 


\section{Townsville North, 1963}

\section{JENNEPHER STEPHENSON}

THE electorate of Townsville North was created in 1959 by the Country-Liberal Party government's redistribution of electoral boundaries, possibly in the hope that the faint edge of respectability that Townsville North would have over Townsville South would return a Liberal candidate. The old electorate of Townsville which it replaced had been held by George Keyatta (A.L.P.) from a by-election on 27 May 1939 until his retirement at the general election on 27 May 1960. The new electorate of Townsville North then returned P. J. R. Tucker (A.L.P.).

Townsville North, with an area of fifty-eight square miles, takes in the city proper and the more exclusive suburb of North Ward, the address of most of Townsville's first families, but this is balanced at its other geographical extremity by the industrial suburb of Garbutt, which houses many Department of Civil Aviation and R.A.A.F. employees working at the city airport. The electorate extends beyond Garbutt to the Bohle River, a stretch of marshy ground that includes little but a few farms and a zoo. However, though it is possible to distinguish the social standing of a North Ward address against one in Garbutt, it would be singularly hard to point to any social or economic grouping to characterise any other suburbs within the electorate.

The campaign in Townsville North was far more exciting than in Townsville South, as the results were far less of a foregone conclusion. It was fought on a personality/party basis and State, federal, and foreign issues were all but ignored. Very little political capital was made by the Liberal-Country Party and Q.L.P. candidates of the Bundaberg Labor-in-Politics Convention, and the bandwagon possibilities 
of the widely publicised 'People the North' campaign were virtually by-passed by all of the candidates. Four candidates had nominated for Townsville North when nominations closed at noon on 26 April as against five in 1960. They were the sitting Member, P. J. R. Tucker (A.L.P.), R. N. Bonnett (Liberal-Country Party), Dr K. J. J. Dorney (Q.L.P.), and A. F. Reeves (Independent).

From the outset Reeves had no hope of winning and knew as much (see p. 177). His was a protest nomination decided on only a week before nominations closed, and he was prepared to lose his deposit for the sake of his current crusade against preferential voting. He was almost unknown within the electorate and was dismissed by his opponents (several of whom knew nothing about him) as an eccentric. His only form of campaign publicity was a series of advertisements running from 23 May to 1 June in the Townsville Daily Bulletin at a cost of $£ 60$. He stated that he had nominated as an Independent so that

the citizens of Townsville who do not believe in party politics could declare as such . . . Preferential voting demands citizens to cast votes to candidates they have absolutely no desire to support. They are compelled to vote in fear of being fined.

Reeves felt that the system of allocating second and subsequent preference votes only after a voter's first choice was defeated was undemocratic, and advocated a 'democratic preferential vote with all votes counted'-that is primary, secondary, etc. preferences all totalled together. His large advertisement on 23 May, the first to appear, also told people how to vote for the various party candidates if they preferred them, and ended with a plea that everyone uphold their right to vote, and to vote validly.

An Englishman by birth, Reeves's only other political activity had been a fretful six months as an A.L.P. branch member, during which time he stood unsuccessfully as an A.L.P. candidate for the municipal elections, and had a second independent try for the city hall on another sudden crusade, apparently about rates. After a varied life (three years with the R.N. on minesweepers during World War I, and a civilian R.A.A.F. aircraft engine instructor between wars), Reeves at 65 was working as a railway fitter, and was somewhat disgruntled about life for he felt keenly his 'inferior' social position.

The only Townsville North candidate given special coverage by the Townsoille Daily Bulletin was Dr K. J. J. Dorney, whose Q.L.P. nomination rated a full column of personal history and political ideology plus photograph. Dorney was a very well known, liked, and respected Townsville surgeon, with a fine A.I.F. Sixth and Ninth Division war service record. He later re-enlisted and served in Korea, and with this background was an active member of R.S.L. and Legacy. He was also widely known in North Queensland as the Townsville 
Branch President of the Queensland Sub-Normal Children's Association. Dorney, a Catholic, was by far the most politically literate candidate and had read widely in South-East Asian affairs. This was his first active interest in politics, although he has since twice contested Herbert in the 1963 and 1966 federal elections. He accepted nomination for Townsville North at the request of the then Townsville Branch Q.L.P. President, J. Judge, and campaigned for twelve weeks on a strong anti-Communist platform. The local Q.L.P. branch of sixteen to twenty hard-core members has been in existence since the A.L.P. split. Campaign advertising and expenses were spread over neighbouring electorates; the costs of the combined campaign were estimated to be in excess of $£ 700$. Individual contributions were solicited, and the branch Women's Committee held various fundraising functions.

The first local candidate to use television in his campaign (and television was still a novelty in Townsville in 1963), Dorney had a relaxed and very effective style, and his manner impressed far more than the other local candidates, all of whom seemed highly selfconscious. His talks were well informed, even perhaps somewhat too sophisticated for local viewers, and dealt mainly with South-East Asian trade relations, the 'Communist threat in our community', and Communist control in the A.L.P. The only incident of the campaign in Townsville North was an alleged attempt to prevent Dorney reaching the television studios in time for one of his talks. The local television station is located on Mt Stuart, and the only access is by a road, gated at the bottom. Dorney found this gate locked one evening, and thinking he had only two miles to go started jog trotting up the mountain. He had however underestimated, and ran over five miles, and although over an hour late, made his appearance. The same evening, slogans were painted on the road outside his home. Dorney made no direct accusations, and tended to pass off the affair, but it gained him statewide publicity. To a lesser extent, Dorney advertised in the Townsville Daily Bulletin with Q.L.P. candidates for nearby electorates under the slogan 'For progress, prosperity and productivity work and vote for Q.L.P. candidates on June 1st'. Q.L.P. dodgers comparing A.L.P. and Communist policies were dropped in letter boxes, and party slides were shown in cinemas.

Dorney acknowledged it would be to his own personal financial disadvantage were he to be elected, but thought the Q.L.P. could provide a good government and a good opposition. He stressed his own concern about political apathy in the community, particularly the subversive infiltrations of Communism, and considered his primary duty to the electorate to stimulate political awareness. The change to preferential voting made election forecasts hazardous (and his position on the ballot paper was unfavourable), but his personal standing in 
the community certainly placed him as a 'possible' in the fight for Townsville North. Dorney's second preferences went to the Liberal candidate, Bonnett, whom he considered 'A hard working, honest chap who could always be relied on to get a job done', while his third preferences went to Reeves (whom he did not know) and his fourth to Tucker.

The North Queensland Zone Liberal Party and Liberal Country Party Co-ordinating Committee have their headquarters in one of the main city streets, and from here their candidate 'Duke' Bonnett ran his campaign; the Liberal Party is the only party to maintain permanent local offices. Bonnett's face must have been familiar to everyone in Townsville, as a huge billboard with the candidate's photo was mounted above the office for the duration of the campaign, about seven months. He was a sales manager who had lived in Townsville for seven years, the same length of time he had been a member of the Liberal Party. Bonnett had a secondary education to Junior standard, and a five-year war service record. His work on various sporting club committees reflects his personal interests in swimming, rugby, and fishing. He had been secretary of the Co-ordinating Committee for two years (and previously secretary of the zone Liberal Party for three years) and was asked by State headquarters to stand for election. He had one unnamed rival before a selection committee.

If elected, Bonnett saw his duty as being first to the electors, second to the State, and finally to the party. He described himself as 'stable, honest and game to have a go', and emphasised that he would act independently of the party if it should be to the benefit of his electorate. He was familiar with parliamentary procedure and felt that his experience in the party branch committees would give him the background to cope with parliamentary practice. Bonnett agreed with the prevailing Liberal view that whichever party gained power in the election would be in for the next decade, as Queensland, and especially North Queensland, stood poised on the threshold of tremendous development. The State had been in the doldrums too long and was just beginning to awaken. On the local scene the first step would be to attract industry, for the establishment of new industry would bring the population the North needed. Bonnett also spoke of the need to send Queensland trade missions selling Queensland overseas, and the sending of top professional and technical men abroad to bring back the latest technical data to further State development. Commenting on the Labor-in-Politics Convention held in Bundaberg, Bonnett saw it as the culmination of a-long-range plan for left-wing union control of the A.L.P. His office distributed copies of the May 1963 issue of the Queensland Liberal headed 'Who gets elected? ... if you vote Labour', which featured an Ian Gall cartoon headed 'Here he comes to tell us what they've decided we're going to do', and showing Calwell and 
Whitlam sitting outside the A.L.P. conference room awaiting instructions from a delegate who is shown leaving the conference.

There were three Liberal Party branches in the electorate. The first was established ten years ago and has a hard-core membership of twenty-five, the second had been functioning for four years with an active membership of about forty-five, and the third with twenty-five members was established eighteen months before the election. Branch secretaries did most of the legwork and 'worrying' about the campaign, but Bonnett ran his own campaign to the extent of dealing with all election material. The general organisation was in the hands of a campaign committee, consisting of three members elected from each branch, and the executive of the Co-ordinating Committee.

With an electorate of 14,000 Bonnett estimated the 'donkey vote' to be about two hundred, and thought that his position as first on the ballot paper would be considerable help. The Liberal/Country Party did not hold hall or street meetings, but promoted their campaign through television and radio interviews, door-to-door canvassing, press advertisements, and posted campaign literature. Most of Bonnett's press advertisements started 'This is the man for Townsville North who says ...' which was followed by a criticism of Labor legislation that penalised a special group-for example

How petty can they get? When Labour was in power a blind person travelling with a 'seeing eye' dog had to pay FULL rail fare for the dog. Under the present Government these faithful animals travel free with their blind owners.

Bonnett's campaign got under way in November 1962, and, as with the other candidates in Townsville North, was considerably longer than average. Both Munro and Hiley visited the electorate to help. The campaign was estimated to have cost about $£ 600$ and contributions were solicited from local businesses to cover the cost. Private hospitals were canvassed for the postal votes (estimated at 150), and how-to-vote instructions were sent to inquirers and to those usually requiring a postal vote. During his campaign Bonnett was probably helped by the pronounced Liberal bias of the Townsville Daily Bulletin, although the Bulletin did not print any of the candidate's: speeches. While the Bulletin did not specifically support any of the local candidates, it made no bones about its Liberal bias in editorial comment and news releases. None of the local candidates' campaign speeches were reported, and the nearest editorial comment came to. touching on local aspects was:

In the seats which are in the vicinity of Townsville an unbiased opinion is that the Government candidates should hold their seats. with the prospects of adding one to the anti-ALP forces. Such a result may come about in the Townsville North contest, wherethere is a strong A.L.P. candidate in the contest. The allied strength. 
of the Queensland Labour Party and Liberals in this electorate, with the use of preferences, might well dislodge the sitting member. In the last election the A.L.P. candidate was 1612 votes short of an absolute majority, indicative that on June 1st the people of Townsville North may decide to change its representation. (27 April 1963)

The sitting A.L.P. member for Townsville North, Perc Tucker, had been a draftsman in the Titles Office before his election in 1960. He was 43 years of age in 1963, had been educated to Senior standard, and served from 1941 to 1945 with the 42nd Infantry Battalion (A.M.F.), followed by fifteen years with the C.M.F. He had lived in Townsville since 1955 , was a keen reader with an extensive history and travel library, and, with interests in football, rugby, and athletics, was an active supporter of the North Queensland Athletics Association.

Tucker was a straight A.L.P. man. In 1959 he stood before a Q.C.E. preselection committee with three rivals, two of whom later appealed against his selection to the 1960 A.L.P. Convention in Brisbane. For eleven years he had been President of the Herbert Federal Division Executive of the A.L.P. and secretary to the Hinchinbrook Electoral Committee. In private interview Tucker sidestepped personal comment on any political issue and stuck to the party line. $\mathrm{He}$ felt his public image to be that he was 'decisive, prepared to stick by his decision, not wishy-washy, fair and with the qualities of leadership'. Of his political role, Tucker thought that as Townsville North's representative he could gauge public opinion through A.L.P. branches which represent a good cross-section of the community, and these local views would then be taken to Caucus. Local feeling for the North, he considered, might be detrimental to the State as a whole, and any conflict of interests should be subject to the overall development of the State. Tucker spoke strongly in favour of the socialising of public utilities as one of his own principal political ideals. He thought the results of the Bundaberg Labor-in-Politics convention 'very good'. He denied that the unions controlled the A.L.P. and said that left-wing direction of the Q.C.E. was nonsense, pointing out that at the convention there were 136 delegates-fifty-eight union representatives and seventy-eight A.L.P. delegates from the electorates, so the balance of power remained with the party.

The A.L.P. campaign, which began in December 1962, was run jointly in Townsville North and South and the overall expenses were estimated to be in excess of $£ 2,000$. In addition Tucker expected to be an extra $£ 200$ out of pocket, mostly through travel expenses.

There are five A.L.P. branches in Townsville North, with a total hard-core membership of about 140. The oldest branch had been established twenty years before, and the most recent a year before the election. Tucker is a capable speaker, and slanted his speeches according to his audience. He held six hall meetings (attended almost exclusively by party stalwarts), street-corner meetings throughout the 
suburbs (maximum Saturday morning attendance being about fifty in the main street of Townsville), and on weekdays between 5.30 and 6.00 p.m. a loud speaker van stood at various suburban street corners to relay a talk by Tucker to housewives. These broadcasts could be heard for blocks, and Tucker was prepared to risk causing annoyance to get his message across. Radio talks were broadcast at a peak listening period, 5.45 p.m. when most Townsville people are eating their evening meal and listening to the radio.

Tucker also made somewhat self-conscious TV appearances, and put into letter boxes a Q.C.E. dodger headed 'Going somewhere? Go with A.L.P. in '63. Destination: Prosperity.' In January he distributed, again through letter boxes, a small $4 " \times 2$ " plastic calendar for 1963 with his photo on the front. His press advertisements (usually in conjunction with Trower) gave information about the times of radio broadcasts and street-corner meetings, and carried one of the many A.L.P. jingle slogans. His most effective visual publicity was the use of small posters and banners $\left(18^{\prime \prime} \times 4^{\prime \prime}\right)$ printed in bright, almost luminescent red against black reading simply 'A.L.P. Tucker'. The posters were displayed in suburban yards facing the main traffic routes throughout Townsville North, and the banners were stuck to the rear windows and sides of cars.

At the declaration of the poll Tucker was again returned. In 1960 he had polled 5,262 (43.36 per cent) votes to win with first-past-the-post voting over the Liberal candidate's 4,140 (34.11 per cent) votes; the Q.L.P. candidate had polled 1,655 (13.64 per cent), an Independent running on a 'New State' platform 871 (7.18 per cent), and a Communist 208 (1.71 per cent). By 1963 Tucker had improved his vote to 6,196 (48.42 per cent); with half Reeves's preferences and almost one-fifth of Dorney's he had 53.18 per cent on the final count. Bonnett and the Liberal Party lost ground, down to 3,639 (28.43 per cent) votes, while Dorney's 2,896 (22.63 per cent) primary votes were a remarkable personal triumph, to be topped in December when he polled 18.5 per cent in Herbert, covering not only Townsville but nearby country areas at a time when the Q.L.P. everywhere else declined. In 1966 Bonnett returned to Townsville North, and with a different Q.L.P. candidate raised the Liberal vote to 4,919 (35.97 per cent) while the Q.L.P. vote fell back to its 1960 level-1,895 (13.86 per cent) votes. However, in 1966 Tucker continued to consolidate his position, and achieved an absolute majority: 6,862 (50.18 per cent) votes. Later that year he succeeded Houston as deputy leader of the A.L.P., and still later in 1966 Bonnett won the federal seat of Herbert on Dorney's second preferences. Dorney's sharp increase in Q.L.P. votes, rather like Aikens's victories in Townsville South, show how potent personal popularity can be in Townsville, but Tucker's steady consolidation of the A.L.P. vote in Townsville North shows that there are several paths to electoral success. 


\section{APPENDIX A}

To obtain a sample of Brisbane voters in 1963,500 names were drawn with the aid of a table of random numbers from the electoral rolls of Ashgrove, Baroona, and Ithaca, three electorates in the western suburbs of Brisbane. These were the three contiguous electorates which, in combination, provided a total vote distribution closest to the metropolitan totals at the 1960 election. For the convenience of the interviewers it was thought preferable to have them contiguous. When the supplementary rolls appeared shortly before the election, names struck off the rolls were deleted from the interviewers' lists and replaced with an equivalent number shown as newly enrolled, also drawn with the assistance of a table of random numbers. Some 348 of the 500 were interviewed; the non-interviews resulted from refusals, death, illness of the party or in the family, removals from the addresses shown on the rolls, which were unsatisfactorily high given the sources used and pointed to the bad state of the rolls, absence from home after three visits by interviewers, and inadequate command of English. Lack of time prevented replacement of the 152 subjects, as interviews were conducted one to two weeks before polling day.

Interviews were undertaken by interviewers of the Australian Gallup Poll (Roy Morgan Research Centre Pty Ltd). The questionnaire administered was designed by the writer and organised in some particulars by $\mathrm{Mr}$ Roy Morgan; voting intention was secured by use of the Gallup ballot and box. Pre-testing was undertaken by mail questionnaire employing open-ended questions sent to a semi-random sample of electors in the southside suburban constituencies of Bulimba and Chatsworth; responses from these questionnaires were used to design the questions concerning party leaders' and party images. A total of 508 questionnaires were sent out in the pre-test and 63 were returned completed, 12.4 per cent. No demographic data apart from sex were secured from the pre-test sample (it was slightly overly weighted with males), but voting intention was asked, Liberals were over-represented and A.L.P. supporters under-represented by about 15 per cent of the whole sample. It is probable that the substantial skew of the sample as to voting is explained by the usual bias to white collar occupations in returns of mail questionnaires. 
In terms of voting intention the door-knock sample in 1963 appears to have been quite satisfactory: see Table A.0l.

Table A.01

Voting intention of sample compared with actual vote, 1963

\begin{tabular}{lccc}
\hline & $\begin{array}{c}\text { As \% of all } \\
\text { respondents }\end{array}$ & $\begin{array}{c}\text { As \% of those } \\
\text { who had intention }\end{array}$ & $\begin{array}{c}\text { Actual vote } \\
\text { recorded }\end{array}$ \\
\hline A.L.P. & 42.9 & 46.2 & 45.4 \\
Liberal & 43.1 & 46.5 & 44.9 \\
Q.L.P. & 6.9 & 7.4 & 8.5 \\
None $/$ refused & 7.2 & - & - \\
Communist & - & - & 0.7 \\
Social Gredit & - & - & 0.5 \\
\hline
\end{tabular}

The census divisions of Ashgrove, Enoggera, Fernberg, Ithaca, Newmarket, and Normanby constitute most of the area covered by the electorates of Ashgrove, Baroona and Ithaca, and their 1961 returns provide a rough and ready check as to age and religion: see Table A.02.

\section{Table A.02}

Age and religion of sample 1963 and area 1961 $\%$

\begin{tabular}{llll}
\multicolumn{3}{c}{ Age } \\
\hline \multicolumn{3}{c}{ Sample } & \multicolumn{2}{c}{6 census divisions } \\
\hline $21-30$ & $11 \cdot 9$ & $20-29$ & $18 \cdot 0$ \\
$31-40$ & $18 \cdot 0$ & $30-39$ & $19 \cdot 3$ \\
$41-50$ & $22 \cdot 4$ & $40-49$ & $21 \cdot 9$ \\
$51-60$ & $18 \cdot 9$ & $50-59$ & $18 \cdot 7$ \\
$61+$ & $28 \cdot 8$ & $60-79$ & $22 \cdot 1$ \\
\hline
\end{tabular}

\begin{tabular}{lcc}
\hline \multicolumn{3}{c}{ Religion } \\
\hline & Sample & 6 census divisions \\
\hline Anglicans & $34 \cdot 6$ & $28 \cdot 3$ \\
Catholics & $34 \cdot 0$ & $27 \cdot 6$ \\
Presbyterians & $13 \cdot 0$ & $10 \cdot 4$ \\
Methodists & $8 \cdot 1$ & $10 \cdot 4$ \\
Others & $6 \cdot 1$ & $10 \cdot 9$ \\
None/refused & $4 \cdot 3$ & $12 \cdot 4$ \\
\hline
\end{tabular}

As with most door-knock panels, there were somewhat too many older respondents (who tend to be at home) and too few young ones (who do not). Supposing that the much higher proportion who failed to answer the census question about their religion divided in the same proportions as those who did, it would appear that the 1963 panel contained slightly too many Anglicans, Catholics, and Presbyterians, slightly too few Methodists and the smaller denominations. In neither case, however, was the bias of a size likely to affect conclusions drawn from the data. 


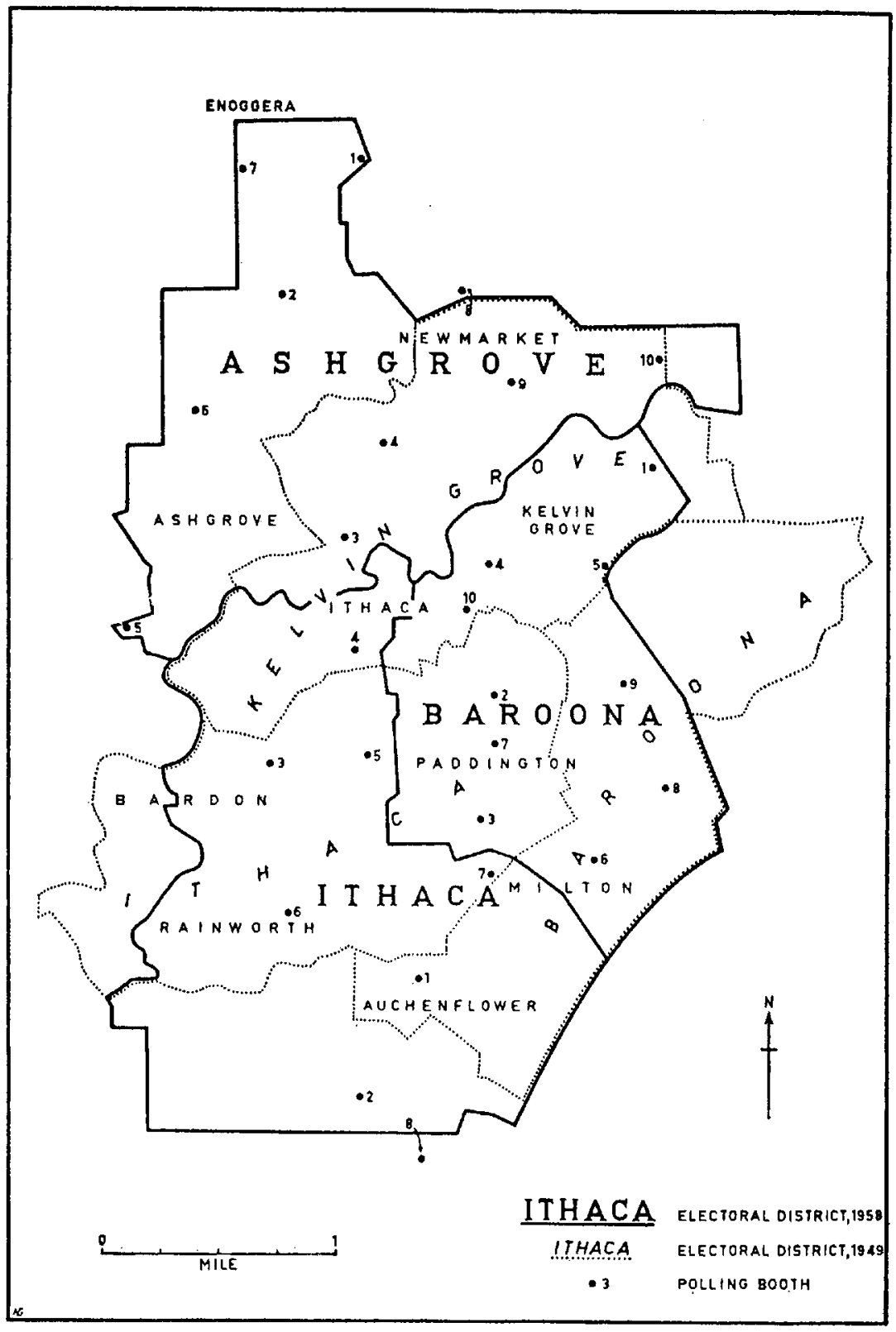

FIG. 9 ASHGROVE, BAROONA, AND ITHACA 


\section{VOTING AT POLLING BOOTH,1963}
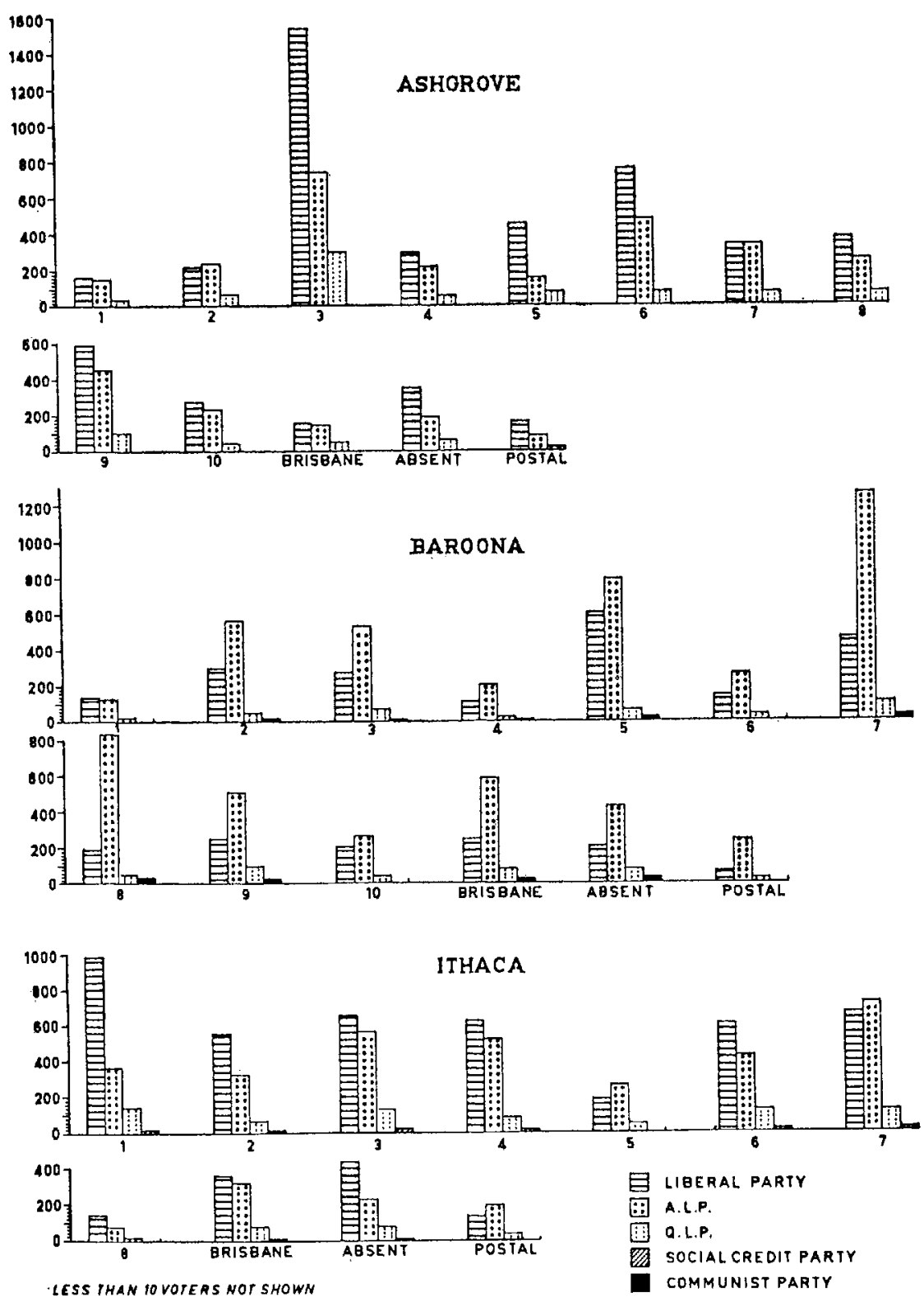

FIG. 10 VOTING IN ASHGROVE, BAROONA, AND ITHACA 
As class, represented in this study by occupation, appears to have the strongest relationship with voting intention, it might be useful to indicate the distribution of occupational groups between parties and between electorates: see Table A.03. Again, for the record, occupational sub-groups may be classified in respect of religion and age: see Table A.04.

Table A.03

Occupations of sample 1963

\begin{tabular}{|c|c|c|c|c|c|c|c|c|c|c|c|c|}
\hline \multirow[t]{3}{*}{ Occupation } & \multicolumn{12}{|c|}{ Voting intention } \\
\hline & \multicolumn{3}{|c|}{ A.L.P. } & \multicolumn{3}{|c|}{ Liberal } & \multicolumn{3}{|c|}{ Q.L.P. } & \multicolumn{3}{|c|}{$\begin{array}{c}\text { None/refused } \\
\text { to say }\end{array}$} \\
\hline & Ash. & Bar. & Ith. & Ash. & Bar. & Ith. & Ash. & Bar. & Ith. & Ash. & Bar. & Ith. \\
\hline Professionals & 1 & 5 & 1 & 11 & 6 & 7 & 1 & 0 & 1 & 4 & 0 & 0 \\
\hline \multicolumn{13}{|l|}{ Directors and } \\
\hline Office and sales & 2 & 15 & 11 & 18 & 9 & 16 & 1 & 3 & 3 & 3 & 1 & 0 \\
\hline Skilled workers & 9 & 18 & 13 & 10 & 4 & 20 & 3 & 4 & 0 & 1 & 3 & 2 \\
\hline Semi-skilled & 8 & 21 & 12 & 6 & 5 & 3 & 0 & 4 & 1 & 1 & 2 & 2 \\
\hline Unskilled workers & $\mathbf{5}$ & 12 & $\mathbf{5}$ & 0 & 3 & 4 & 1 & 0 & 1 & 1 & 1 & 1 \\
\hline \multicolumn{13}{|l|}{ Housewives, } \\
\hline Pensioners* & 0 & 1 & 1 & 0 & 1 & 0 & 0 & 0 & 1 & 0 & 0 & 0 \\
\hline
\end{tabular}

- Not otherwise classified; housewives when possible have been classified under their husbands' occupations, students under their fathers', pensioners under their last occupation before retirement.

Table A.04

Occupations and religion of sample 1963

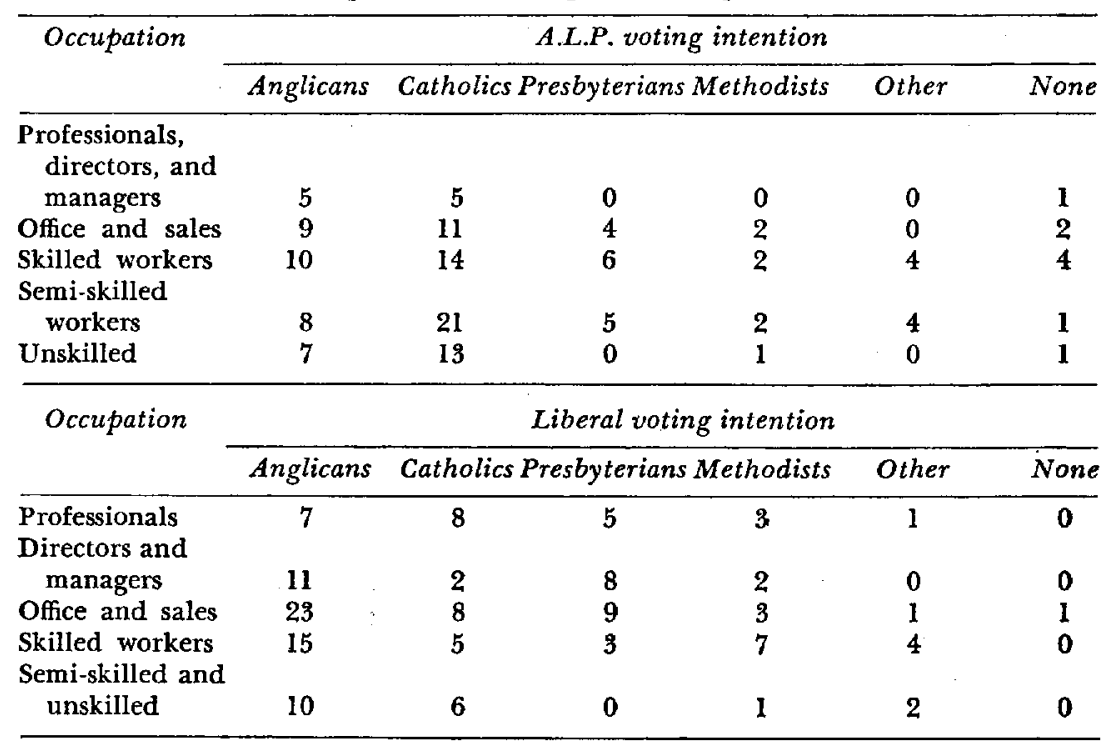


Numbers in some categories were extremely small, but it is noticeable that the A.L.P. did much better with Catholics, both white collar (= professionals, directors and managers, office and sales) and manual (= skilled, semi-skilled, and unskilled), than it did with other denominations. Whilst it had less than one-sixth of the white collar Presbyterians and a quarter of the white collar Anglicans, it had the support of almost half the white collar Catholics. Whilst it had the support of only one-third of the Methodist manual workers and half the Anglican manual workers, it had the support of four-fifths of the Catholic manual workers-and three-quarters of the Presbyterian manual workers. In so far as Presbyterianism in Australia is generally a high status denomination this last phenomenon calls for some explanation. It may be that the recent antecedents of the A.L.P. Presbyterians are to be found in Scotland or the north-east of England where the denomination is more radical than in, say, Victoria.

Table A.05

Occupations and age of sample 1963

\begin{tabular}{lcrrrrr}
\hline \multirow{2}{*}{ Occupation } & \multicolumn{5}{c}{ A.L.P. voting intention } \\
\cline { 2 - 6 } & $21-30$ & $31-40$ & $41-50$ & $51-60$ & $61+$ \\
\hline Professionals, directors, and managers & 1 & 2 & 2 & 2 & 4 \\
Offce and sales & 6 & 4 & 4 & 10 & 4 \\
Skilled workers & 2 & 2 & 14 & 8 & 14 \\
Semi-skilled workers & 5 & 11 & 7 & 9 & 9 \\
Unskilled workers & 0 & 3 & 4 & 5 & 10 \\
\hline
\end{tabular}

\begin{tabular}{lcccccc}
\multicolumn{1}{c}{ Occupation } & \multicolumn{5}{c}{ Liberal voting intention } \\
\cline { 2 - 6 } & $21-30$ & $31-40$ & $41-50$ & $51-60$ & $61+$ \\
\hline Professionals & 5 & 3 & 4 & 4 & 8 \\
Directors and managers & 1 & 5 & 8 & 2 & 7 \\
Office and sales & 6 & 11 & 9 & 5 & 14 \\
Skilled workers & 6 & 7 & 6 & 5 & 10 \\
Semi-skilled and unskilled & 1 & 3 & 3 & 8 & 4 \\
\hline
\end{tabular}

It would have been impossible in 1963 to arrange a comparable doorknock interview survey of a panel of Queenslanders outside Brisbane, but in the belief that sooner or later a start would have to be made with the nonmetropolitan Australian voters the decision was taken to employ a mail questionnaire in certain areas outside Brisbane. Albert, Bundaberg, South Coast, and Toowoomba East were the electorates selected. Three of the electorates were likely to be extremely close contests, and the fourth, South Coast, provided something of a control over one of them which it adjoins and resembles-Albert. A 1 per cent sample of electors was drawn from each electorate using a table of random numbers, and 1,205 questionnaires were sent out: see Table A.06. As with the pre-test mail questionnaire the responses 
Table A.06

Completed questionnaires returned 1963

\begin{tabular}{lcc} 
& No. & $\%$ \\
\hline Albert & 68 & 27 \\
Bundaberg & 74 & 21 \\
South Coast & 71 & 27 \\
Toowoomba East & 88 & 25 \\
\hline
\end{tabular}

were somewhat overweighted with supporters of the government parties, although not so badly: A.L.P. responses 34 per cent (vote in four electorates combined 36 per cent); government parties (three electorates only) 45 per cent (39 per cent) ; Q.L.P. (two electorates only) 4 per cent ( 2 per cent) ; independent candidates (two electorates only) 17 per cent (23 per cent). It is possible to test the class bias of the mail questionnaire by matching the occupations of the 1,205 electors to whom questionnaires were sent (as shown on the rolls) with the occupations shown on the responses, although no attempt has been made to match the two at the individual level to see whether an individual enrolled with a particular occupation still retained it: see Table A.07.

Table A.07

Occupations of persons to whom questionnaires sent and by whom questionnaires were returned 1963

$\%$

\begin{tabular}{lcc}
\hline \multicolumn{1}{c}{ Occupation } & Sent to & Returned by \\
\hline Professionals & $5 \cdot 6$ & $10 \cdot 8$ \\
Directors and managers & $6 \cdot 3$ & $17 \cdot 0$ \\
Office and sales workers & $13 \cdot 8$ & 17.4 \\
Skilled workers & $21 \cdot 6$ & $18 \cdot 4$ \\
Semi-skilled workers & $10 \cdot 8$ & $5 \cdot 6$ \\
Unskilled workers & $13 \cdot 5$ & $5 \cdot 6$ \\
Farmers and farm workers & $6 \cdot 6$ & $8 \cdot 7$ \\
Housewives* & $10 \cdot 5$ & 12.5 \\
Pensioners* & 11.3 & 4.2 \\
\hline
\end{tabular}

* Whose husbands' or previous occupations could not be identified.

If one were to make two very large assumptions, viz. that the city of Gold Coast is a microcosm of Albert and South Coast (which also contain portions of Albert Shire) and that the electorate of East Toowoomba contains onehalf of each religious denomination in the city of Toowoomba, it would appear that the mail questionnaire sample is lacking Catholics (sample 14 per cent; census $21 \cdot 1$ per cent), and has too many Anglicans (42.5 per cent; census 35.5 per cent), Presbyterians (16.3 per cent; census 13.7 per cent), and Methodists (13 per cent; census $9 \cdot 70$ per cent) .

In terms of voting intention, occupation, or religion, however, the 1963 mail-questionnaire sample was not so grossly unrepresentative as to prevent its responses from being used as a very tentative guide to what a more rigorous procedure might have revealed. 
In 1966 the original 348 individuals were sought for reinterview, first at their original addresses and then anywhere else in the City of Brisbane where they might be traced. The reinterviewing was conducted again by interviewers of Roy Morgan Research Centre Pty Ltd, supplemented by some undergraduate students of the University of Queensland who had experience of interviewing in Anthropology and Sociology courses. Again the questionnaire administered was designed by the writer and organised in some particulars by Mr Morgan. It involved also a replication of Oeser and Hammond's inquiry about social class which will be reported at a later date. Some 199 of the 348 were successfully reinterviewed, the losses including those who were known to have died, to have moved to other parts of Queensland or interstate, those who had become too aged and infirm to be interviewed, and a small group who declined to be reinterviewed. When various attributes of the group reinterviewed indicated in 1963 are compared with the attributes of the original panel of 348 , few significant variations appear to have resulted from the loss of 43 per cent of the original group: see Table A.08. The panel has aged conspicuously in three years because young people tend to move and older people tend to stay put, but age did not prove a very significant variable on any of our attitudinal measures.

Table A.08

Characteristics (1963) of original panel and group reinterviewed $\%$

\begin{tabular}{lcc} 
& Original panel & Reinterviewed group \\
\hline Voting intention & $(\mathrm{n}=348)$ & $(\mathrm{n}=199)$ \\
A.L.P. & $42 \cdot 9$ & $44 \cdot 7$ \\
Liberal & $43 \cdot 1$ & $45 \cdot 2$ \\
Q.L.P. & $6 \cdot 9$ & $5 \cdot 0$ \\
Don't know/refused & $7 \cdot 2$ & $5 \cdot 0$ \\
Ocrupation & & \\
Professionals & $10 \cdot 6$ & $11 \cdot 1$ \\
Directors and managers & $8 \cdot 0$ & $9 \cdot 5$ \\
Office and sales & $23 \cdot 6$ & $21 \cdot 1$ \\
Skilled workers & $25 \cdot 0$ & $29 \cdot 6$ \\
Semi-skilled workers & $18 \cdot 7$ & $17 \cdot 6$ \\
Unskilled & $9 \cdot 8$ & $8 \cdot 5$ \\
Miscellaneous & $4 \cdot 3$ & $2 \cdot 5$ \\
Religion & & \\
Anglican & $34 \cdot 6$ & $36 \cdot 2$ \\
Catholic & $34 \cdot 0$ & $32 \cdot 7$ \\
Presbyterian & $13 \cdot 0$ & $14 \cdot 1$ \\
Methodist & $8 \cdot 1$ & $7 \cdot 5$ \\
Other & $6 \cdot 1$ & $5 \cdot 5$ \\
None/refused & $4 \cdot 3$ & $4 \cdot 0$ \\
Ags & & \\
21-30 & $28 \cdot 3$ & $7 \cdot 5$ \\
31-40 & $27 \cdot 6$ & $19 \cdot 6$ \\
41-50 & $10 \cdot 4$ & $24 \cdot 6$ \\
51-60 & $10 \cdot 0$ & $28 \cdot 6$ \\
61+ & 12.4 & \\
\hline
\end{tabular}


Thus if we compare the 1963 party leader image scores of the whole panel and the reinterviewed group we find a significant difference only with the small group of Q.L.P. voters: see Table A.09. Lest it be thought that a sim-

Table A.09

Party leader image scores (1963) of whole panel and reinterviewed group

\begin{tabular}{lccc}
\hline & $\begin{array}{c}\text { Liberal voting } \\
\text { intention }\end{array}$ & $\begin{array}{c}\text { A.L.P. voting } \\
\text { intention }\end{array}$ & $\begin{array}{c}\text { Q.L.P. voting } \\
\text { intention }\end{array}$ \\
\hline Nicklin & +2.7 & -0.3 & +0.5 \\
Whole panel & +2.8 & -0.4 & +2.3 \\
Reinterviewed group & & & \\
Duggan & -1.3 & +2.1 & -1.5 \\
Whole panel & -1.3 & +2.3 & -1.3 \\
Reinterviewed group & & \\
\hline
\end{tabular}

plified measure such as the scores masks substantial variations in detail, Table A.10 sets out the responses to individual items in the party image. A variation of 5 per cent on any item is most exceptional. Thus, quite fortuitously, one can safely compare the responses of the original panel of 1963 and the reinterviewed group of 1966 . 


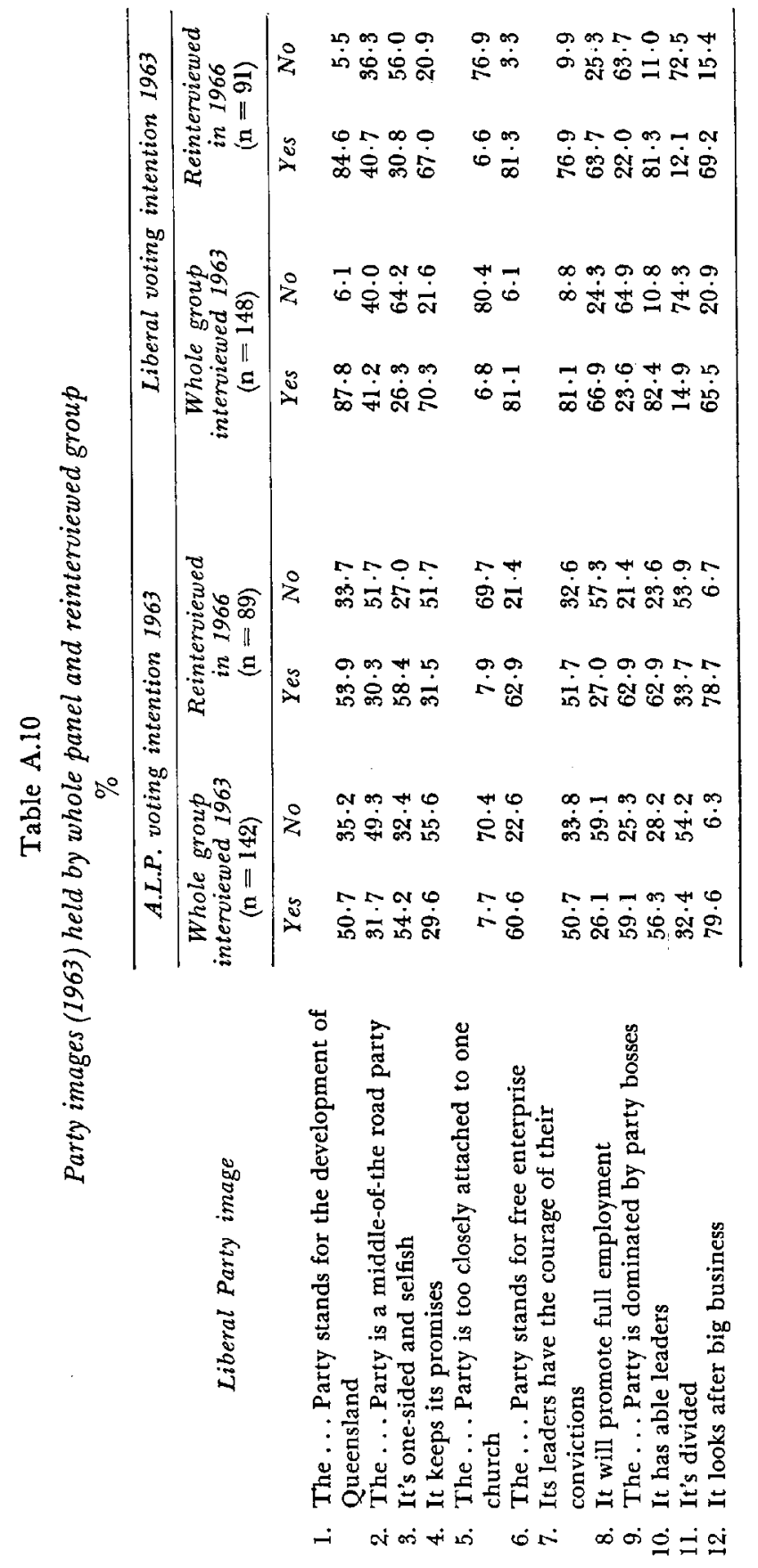




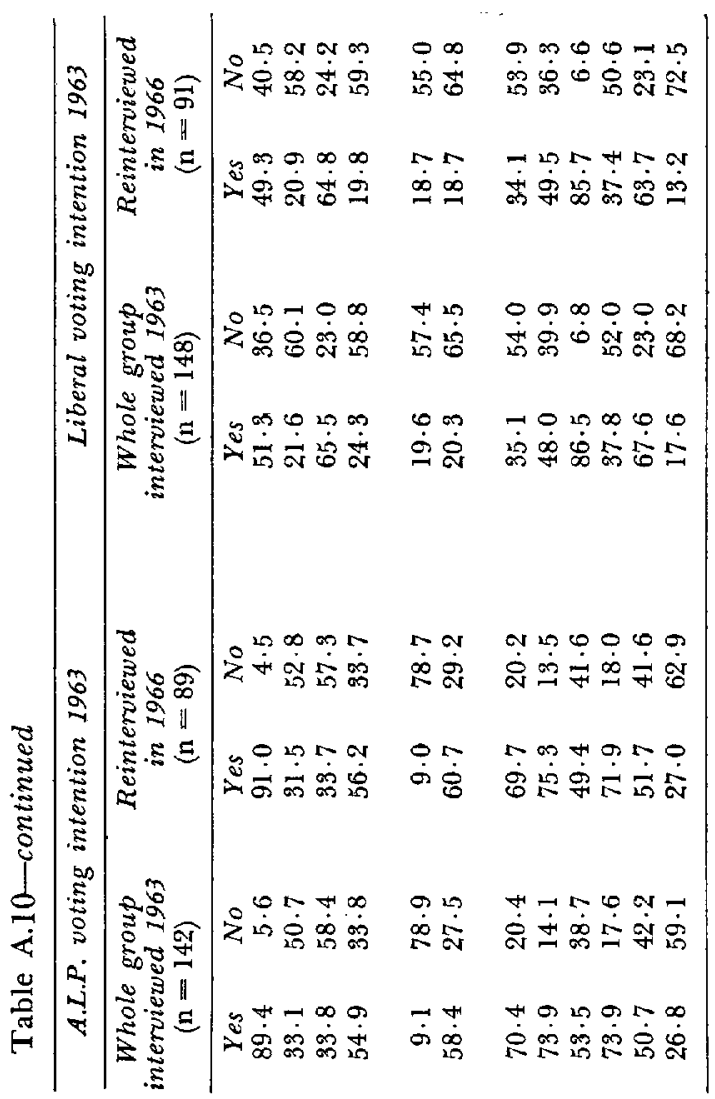

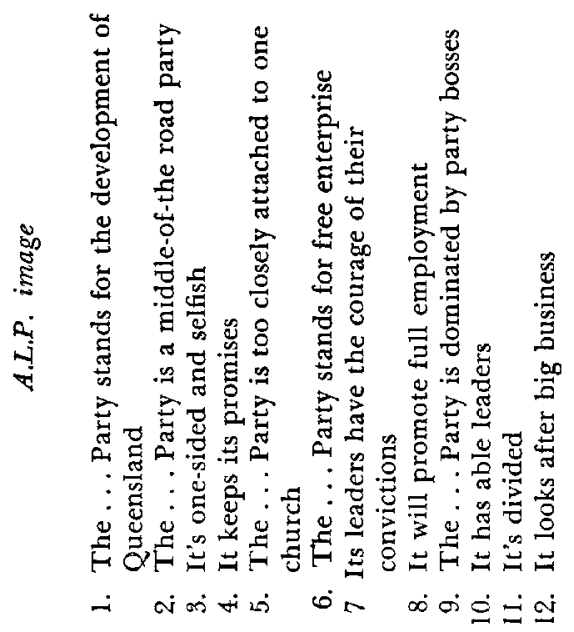




\section{APPENDIX B}

Election results, enrolments, and electorate area 1960, 1963, 1966

\begin{tabular}{|c|c|c|c|c|c|}
\hline \multicolumn{2}{|c|}{ METROPOLITAN } & ZONE & 1960 & 1963 & 1966 \\
\hline \multicolumn{2}{|c|}{ ASHGROVE } & Lib. & $\begin{array}{l}\text { Tooth } \\
50.40\end{array}$ & $\begin{array}{c}\text { Tooth } \\
54.75\end{array}$ & $\begin{array}{c}\text { Tooth } \\
53.87\end{array}$ \\
\hline 1960 & 11,136 & A.L.P. & Turner & Kearney & Gill \\
\hline 1963 & 10,870 & & $35 \cdot 30$ & 35.38 & 36.03 \\
\hline 1966 & 11,055 & Q.L.P. & & Cook & Cook \\
\hline \multicolumn{2}{|c|}{ Area: 2.8 sq. m. } & & $14 \cdot 40$ & $9 \cdot 66$ & 10.09 \\
\hline \multicolumn{2}{|c|}{ ASPLEY } & Lib. & $\begin{array}{c}\text { Campbell } \\
47 \cdot 10\end{array}$ & $\begin{array}{c}\text { Campbell } \\
50-96\end{array}$ & $\begin{array}{c}\text { Campbell } \\
52.37\end{array}$ \\
\hline 1960 & 11,355 & A.L.P. & Carver & Humbler & Purtell \\
\hline 1963 & 13,744 & & $40 \cdot 20$ & $39 \cdot 65$ & $38 \cdot 87$ \\
\hline 1966 & 17,691 & Q.L.P. & Kerr & Balaam & Judge \\
\hline Area: & $13.8 \mathrm{sq} . \mathrm{m}$ & & $12 \cdot 70$ & $9 \cdot 39$ & $8 \cdot 75$ \\
\hline \multicolumn{2}{|c|}{ BAROONA } & Lib. & $\begin{array}{l}\text { Moore } \\
28 \cdot 60\end{array}$ & $\begin{array}{r}\text { Stanton } \\
29.40\end{array}$ & $\begin{array}{r}\text { Barron } \\
31 \cdot 12\end{array}$ \\
\hline 1960 & 13,371 & A.L.P. & Hanlon & Hanlon & Hanlon \\
\hline 1963 & 12,036 & & 58.80 & $61 \cdot 40$ & 59.74 \\
\hline 1966 & 11,979 & Q.L.P. & Maule & Garsden & Machin \\
\hline \multicolumn{2}{|c|}{ Area: $2 \cdot 1$ sq. m. } & Comm. & $12 \cdot 60$ & $\begin{array}{r}7 \cdot 00 \\
\text { Englart } \\
2 \cdot 19\end{array}$ & $\begin{array}{c}7.72 \\
\text { Moynihan } \\
1.42\end{array}$ \\
\hline \multicolumn{2}{|c|}{ BELMONT } & Lib. & $\begin{array}{r}\text { Hewitt } \\
34.60\end{array}$ & $\begin{array}{c}\text { Schuurs } \\
34 \cdot 72\end{array}$ & $\begin{array}{c}\text { Brunner } \\
35 \cdot 81\end{array}$ \\
\hline 1960 & 12,268 & A.L.P. & Newton & Newton & Newton \\
\hline 1963 & 14,183 & & $54 \cdot 70$ & $59 \cdot 31$ & 57.99 \\
\hline $\begin{array}{l}1966 \\
\text { Area: }\end{array}$ & 16,595 & Q.L.P. & $\begin{array}{l}\text { Reville } \\
10.80\end{array}$ & Taylor & Taylor \\
\hline & $32 .-9$ sq. m. & & & $5 \cdot 97$ & $6 \cdot 20$ \\
\hline
\end{tabular}

Note: 1963 and 1966 first preferences only, all elections percentage of total valid vote. The successful candidate is shown in italics. 


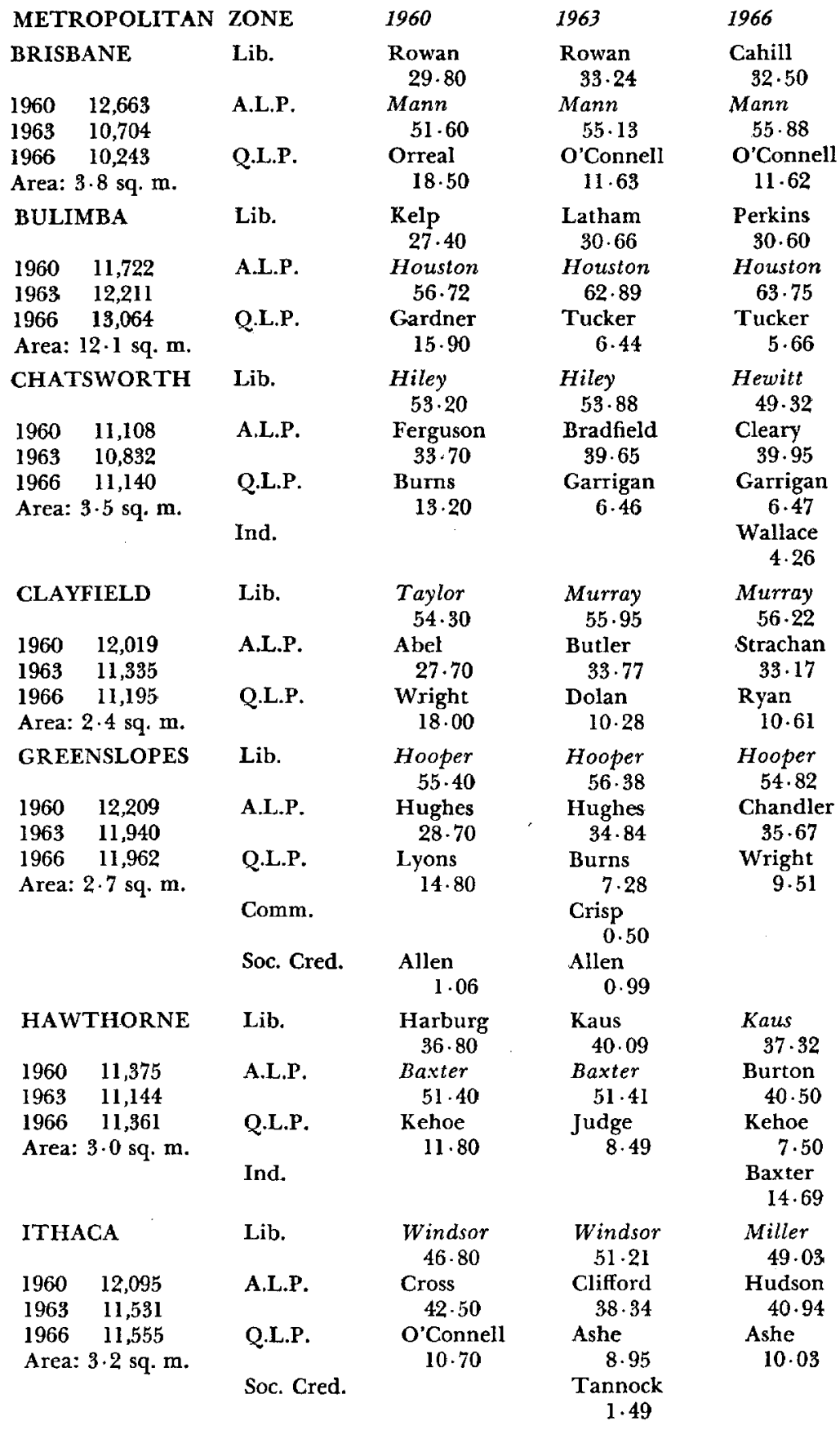




METROPOLITA
KEDRON
$\begin{array}{ll}1960 & 12,383 \\ 1963 & 12,814 \\ 1966 & 13,598\end{array}$

Area: 4.8 sq. m.

KURILPA

$1960 \quad 11,513$

$1963 \quad 10,932$

$1966 \quad 10,968$

Area: 2.9 sq. $\mathrm{m}$.

MERTHYR

$\begin{array}{ll}1960 & 12,341 \\ 1963 & 11,131 \\ 1966 & 10,532\end{array}$

Area: 2.8 sq. $\mathrm{m}$.

\section{MOUNT' \\ COOT.THA \\ $1960 \quad 11,185$ \\ $1963 \quad 12,872$ \\ $1966 \quad 15,365$ \\ Area: 94.0 sq. $\mathrm{m}$. \\ MOUNT \\ GRAVATT}

$1960 \quad 12,580$

$1963 \quad 14,345$

$1966 \quad 16,638$

Area: 48.0 sq. m.

\section{NORMAN}

$1960 \quad 11,188$

$1963 \quad 10,157$

$1966 \quad 9,944$

Area: 2.2 sq. $\mathrm{m}$.
Lib.

A.L.P.

Q.L.P.

Ind.

Whitlock

$9 \cdot 80$

Lib.

A.L.P.

Q.L.P.

Soc. Cred.

Lib. . Ramsden

$50 \cdot 10$

A.L.P.

Q.L.P.

Campbell

O'Connor

$16 \cdot 70$

Lib.

A.L.P.

Morris

$56 \cdot 80$

Davis 29.90

Q.L.P.

Hurley $13 \cdot 30$

Lib.

A.L.P. Pearson

Hart

53.96

Q.L.P. $29 \cdot 50$

Kneen

Ind. Lab. King

$$
6.93
$$

Lib.

A.L.P.

Q.L.P.

Comm.

Ryan

$36 \cdot 10$

Bromley $48 \cdot 10$

Hartnett 14.60

Crisp

$$
1.13
$$

1963

Toonen

$29 \cdot 26$

Lloyd 58.44

Doherty 7.47

Burrows 4.83

$\begin{array}{cr}\text { Hughes } & \text { Hughes } \\ 56.24 & 53.77 \\ \text { Dokter } & \text { Buckley } \\ 35.83 & 40.57 \\ \text { Sheehan } & \text { Doolan } \\ 6.58 & 4.73 \\ \text { Keneally } & \text { Smith } \\ 1.34 & 0.94\end{array}$

\section{Ramsden $53 \cdot 43$ \\ Campbell 37.03 \\ Traill} 9.54

\section{Lickiss} 59.67

Maddock 32.50

Muller $7 \cdot 83$

Chinchen
55.98

Barnes 35.79

Allingham 8.23

Ryan 33.98

Bromley 53.15

Wright 9.90

Soc. Cred,

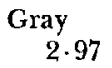

1966

Jesberg 30.71

Lloyd 60.47

Doherty 8. 82

Ramsden $51 \cdot 10$

Mellifont 40.03

Kehoe 8.87

Lickiss 59.96

Gorman 31.40

Muller 8.63

\section{Chinchen} 55.93

Rowe 35.34

Bayliss 8.73

Shawcross 34.40

Bromley

56.61

Fitz-Gibbon

$$
7.80
$$

Gray 


\begin{tabular}{|c|c|c|c|c|c|}
\hline \multicolumn{2}{|c|}{ METROPOLITAN } & ZONE & 1960 & 1963 & 1966 \\
\hline \multicolumn{2}{|c|}{ NUDGEE } & Lib. & $\begin{array}{l}\text { Banks } \\
\mathbf{3 3 . 3 0}\end{array}$ & $\begin{array}{r}\text { Hedges } \\
31 \cdot 31\end{array}$ & $\begin{array}{r}\text { Nugent } \\
34.70\end{array}$ \\
\hline \multirow{5}{*}{$\begin{array}{l}1960 \\
1963 \\
1966 \\
\text { Area: }\end{array}$} & 12,711 & A.L.P. & Melloy & Melloy & Melloy \\
\hline & 13,384 & & $53 \cdot 70$ & 60.43 & $63 \cdot 30$ \\
\hline & 14,462 & Q.L.P. & Barnes & O'Connor & \\
\hline & 26.4 sq. m. & & $12 \cdot 10$ & $8 \cdot 25$ & \\
\hline & & Comm. & $\begin{array}{l}\text { Hill } \\
\quad 0.89\end{array}$ & & $\begin{array}{l}\text { Hill } \\
\qquad 2.00\end{array}$ \\
\hline \multicolumn{2}{|c|}{ NUNDAH } & Lib. & $\begin{array}{l}\text { Knox } \\
52.00\end{array}$ & $\begin{array}{l}\text { Knox } \\
\quad 49 \cdot 80\end{array}$ & $\begin{array}{l}\text { Knox } \\
51 \cdot 73\end{array}$ \\
\hline 1960 & 12,910 & A.L.P. & Sweeney & Roberts & Carey \\
\hline 1963 & 12,562 & & $32 \cdot 20$ & $40 \cdot 48$ & 39.85 \\
\hline 1966 & 12,560 & Q.L.P. & Hadley & Cleary & Green \\
\hline \multicolumn{2}{|c|}{ Area: $9.7 \mathrm{sq} . \mathrm{m}$. } & & $15 \cdot 80$ & $9 \cdot 72$ & $8 \cdot 42$ \\
\hline \multicolumn{2}{|c|}{ SALISBURY } & Lib. & $\begin{array}{c}\text { Edwards } \\
31 \cdot 50\end{array}$ & $\begin{array}{r}\text { Brough } \\
30.67\end{array}$ & $\begin{array}{r}\text { Brough } \\
30.74\end{array}$ \\
\hline 1960 & 12,367 & A.L.P. & Sherrington & Sherrington & Sherrington \\
\hline 1963 & 14,550 & & 55.70 & 64.63 & $69 \cdot 26$ \\
\hline 1966 & 19,334 & Q.L.P. & Tresillian & Jansky & \\
\hline \multirow{2}{*}{\multicolumn{2}{|c|}{ Area: 42.6 sq. $\mathrm{m}$. }} & & $11 \cdot 60$ & 4.69 & \\
\hline & & Comm. & $\begin{array}{c}\text { Stubbins } \\
1 \cdot 26\end{array}$ & & \\
\hline \multicolumn{2}{|c|}{ SANDGATE } & Lib. & $\begin{array}{c}\text { Ahearn } \\
41.80\end{array}$ & $\begin{array}{l}\text { White } \\
37.18\end{array}$ & $\begin{array}{l}\text { Clark } \\
31.16\end{array}$ \\
\hline 1960 & 10,790 & A.L.P. & Dean & Dean & Dean \\
\hline 1963 & 11,149 & & $50 \cdot 80$ & 55.44 & 62.92 \\
\hline 1966 & 12,414 & Q.L.P. & Lokhorst & McShane & Lincoln \\
\hline \multicolumn{2}{|c|}{ Area: 15.4 sq. m. } & & $7 \cdot 40$ & $7 \cdot 38$ & $5 \cdot 91$ \\
\hline \multicolumn{2}{|c|}{ SHERWOOD } & Lib. & $\begin{array}{r}\text { Herbert } \\
62.90\end{array}$ & $\begin{array}{c}\text { Herbert } \\
60.74\end{array}$ & $\begin{array}{c}\text { Herbert } \\
66.57\end{array}$ \\
\hline 1960 & 12,231 & A.L.P. & Thomson & Kitson & Thorsen \\
\hline 1963 & 12,492 & & $37 \cdot 10$ & 33.06 & $33 \cdot 43$ \\
\hline 1966 & 13,778 & Q.L.P. & & Galligan & \\
\hline \multicolumn{2}{|c|}{ Area: 20.5 sq. m. } & & & $6 \cdot 20$ & \\
\hline \multicolumn{2}{|c|}{$\begin{array}{l}\text { SOUTH } \\
\text { BRISBANE }\end{array}$} & Lib. & $\begin{array}{r}\text { O'Brien }^{\prime} \text { 27.20 }\end{array}$ & $\begin{array}{l}\text { Horan } \\
31.38\end{array}$ & $\begin{array}{r}\text { Schuurs } \\
30.80\end{array}$ \\
\hline & & A.L.P. & Bennett & Bennett & Bennett \\
\hline 1960 & 13,203 & & $43 \cdot 90$ & $54 \cdot 88$ & $58 \cdot 24$ \\
\hline 1963 & 11,838 & Q.L.P. & Gair & Kehoe & Eunson \\
\hline 1966 & 11,522 & & $28 \cdot 90$ & $13 \cdot 74$ & $8 \cdot 35$ \\
\hline \multicolumn{2}{|c|}{ Area: $2.7 \mathrm{sq} . \mathrm{m}$. } & Comm. & & & $\begin{array}{c}\text { Bowden } \\
2 \cdot 62\end{array}$ \\
\hline \multicolumn{2}{|c|}{ TOOWONG } & Lib. & Munro & Munro & Porter \\
\hline 1960 & 11,963 & A.L.P. & & McGrath & Wallace \\
\hline 1963 & 11,812 & & & 23.95 & $25 \cdot 42$ \\
\hline 1966 & 12,176 & Q.L.P. & Judge & O'Brien & O'Brien \\
\hline Area: & 5.4 sq. m. & & $21 \cdot 30$ & 6.97 & $9 \cdot 30$ \\
\hline
\end{tabular}




\begin{tabular}{|c|c|c|c|c|c|}
\hline METF & ROPOLITAN & ZONE & 1960 & 1963 & 1966 \\
\hline WAVI & ELL & Lib. & $\begin{array}{c}\text { Dewar } \\
53 \cdot 70\end{array}$ & $\begin{array}{r}\text { Dewar } \\
53.01\end{array}$ & $\begin{array}{c}\text { Dewar } \\
50.36\end{array}$ \\
\hline 1960 & 14,152 & A.L.P. & Harriss & Harriss & Bromley \\
\hline 1963 & 14,480 & & $35 \cdot 30$ & 36.79 & $41 \cdot 18$ \\
\hline 1966 & 15,339 & Q.L.P. & O'Dea & Bedsor & Grundy \\
\hline Area: & 4.5 sq. $\mathrm{m}$. & Soc. Cred. & $11 \cdot 00$ & $\begin{array}{c}8 \cdot 85 \\
\text { Goldstiver } \\
1-35\end{array}$ & $\begin{array}{c}7.31 \\
\text { Goldstiver } \\
0.79\end{array}$ \\
\hline & & Ind. & & & $\begin{array}{l}\text { Fulton } \\
\quad 0.36\end{array}$ \\
\hline WIND & OSOR & Lib. & $\begin{array}{l}\text { Smith } \\
\quad 49.90\end{array}$ & $\begin{array}{l}\text { Smith } \\
51.04\end{array}$ & $\begin{array}{l}\text { Smith } \\
48 \cdot 79\end{array}$ \\
\hline 1960 & 11,581 & A.L.P. & Georgouras & Georgouras & Fordyce \\
\hline 1963 & 11,199 & & $35 \cdot 70$ & 39.73 & 42.99 \\
\hline 1966 & 11,196 & Q.L.P. & Hotham & O'Donoghue & Wenk \\
\hline Area: & 2.6 sq. m. & & $14 \cdot 30$ & $9 \cdot 23$ & $8 \cdot 22$ \\
\hline WYNI & NUM & Lib. & $\begin{array}{l}\text { Dodd } \\
29.97\end{array}$ & $\begin{array}{c}\text { Brunner } \\
\mathbf{3 0 . 4 8}\end{array}$ & $\begin{array}{l}\text { Beath } \\
38.33\end{array}$ \\
\hline 1960 & 13,396 & A.L.P. & Gunn & Gunn & Harris \\
\hline 1963 & 13,289 & & $63 \cdot 36$ & $68 \cdot 15$ & 54.69 \\
\hline 1966 & 13,835 & Q.L.P. & Campbell & O'Regan & Burns \\
\hline Area: & 11.5 sq. m. & & 6.66 & $4 \cdot 37$ & $\begin{array}{c}5 \cdot 36 \\
\text { Nord } \\
1 \cdot 62\end{array}$ \\
\hline YERO & DNGA & Lib. & $\begin{array}{l}\text { Noble } \\
51 \cdot 40\end{array}$ & $\begin{array}{l}\text { Noble } \\
52 \cdot 23\end{array}$ & $\begin{array}{l}\text { Lee } \\
\quad 50.99\end{array}$ \\
\hline 1960 & 11,708 & A.L.P. & O'Donnell & Cusack & Davies \\
\hline 1963 & 11,507 & & $37 \cdot 60$ & $36 \cdot 89$ & $38 \cdot 76$ \\
\hline 1966 & 11,580 & Q.L.P. & Wickings & Andrews & Lamberth \\
\hline Area: & 6.7 sq. $\mathrm{m}$ & & $11.00^{\circ}$ & $10 \cdot 12$ & $10 \cdot 25$ \\
\hline & & Soc. Cred. & & $\begin{array}{r}\text { Phipps } \\
0.75\end{array}$ & \\
\hline PROV & VINCIAL CIT & IES ZONE & 1960 & 1963 & 1966 \\
\hline BUNI & DABERG & Lib. & $\begin{array}{c}\text { Howard } \\
19.05\end{array}$ & & \\
\hline 1960 & 13,612 & A.L.P. & Saliter & Tallon & Tallon \\
\hline 1963 & 13,980 & & 40.41 & 46.54 & $46 \cdot 52$ \\
\hline 1966 & 15,071 & Q.L.P. & Walsh & & \\
\hline Area: & 17 sq. m. & & 40.54 & & \\
\hline & & Ind. & & $\begin{array}{c}\text { Walsh } \\
53.46\end{array}$ & $\begin{array}{c}\text { Walsh } \\
53.48\end{array}$ \\
\hline CAIR & NS & Country & Baggott & Joy & Franzmann \\
\hline 1960 & 13,903 & Lib. & & $29 \cdot 27$ & $\begin{array}{c}12 \cdot 54 \\
\text { De Jarlais }\end{array}$ \\
\hline 1963 & 13,751 & & & & $18 \cdot 00$ \\
\hline 1966 & 13,781 & A.L.P. & & & Jones \\
\hline Area: & 19 sq. m. & & 56.47 & 64.82 & $51 \cdot 34$ \\
\hline & & Q.L.P. & $\begin{array}{c}\text { Allendorf } \\
13 \cdot 63\end{array}$ & $\begin{array}{c}\text { Trembath } \\
5.91\end{array}$ & $\begin{array}{c}\text { Trembath } \\
1.64\end{array}$ \\
\hline & & Ind. & & & $\begin{array}{c}\text { Penridge } \\
16.48\end{array}$ \\
\hline
\end{tabular}




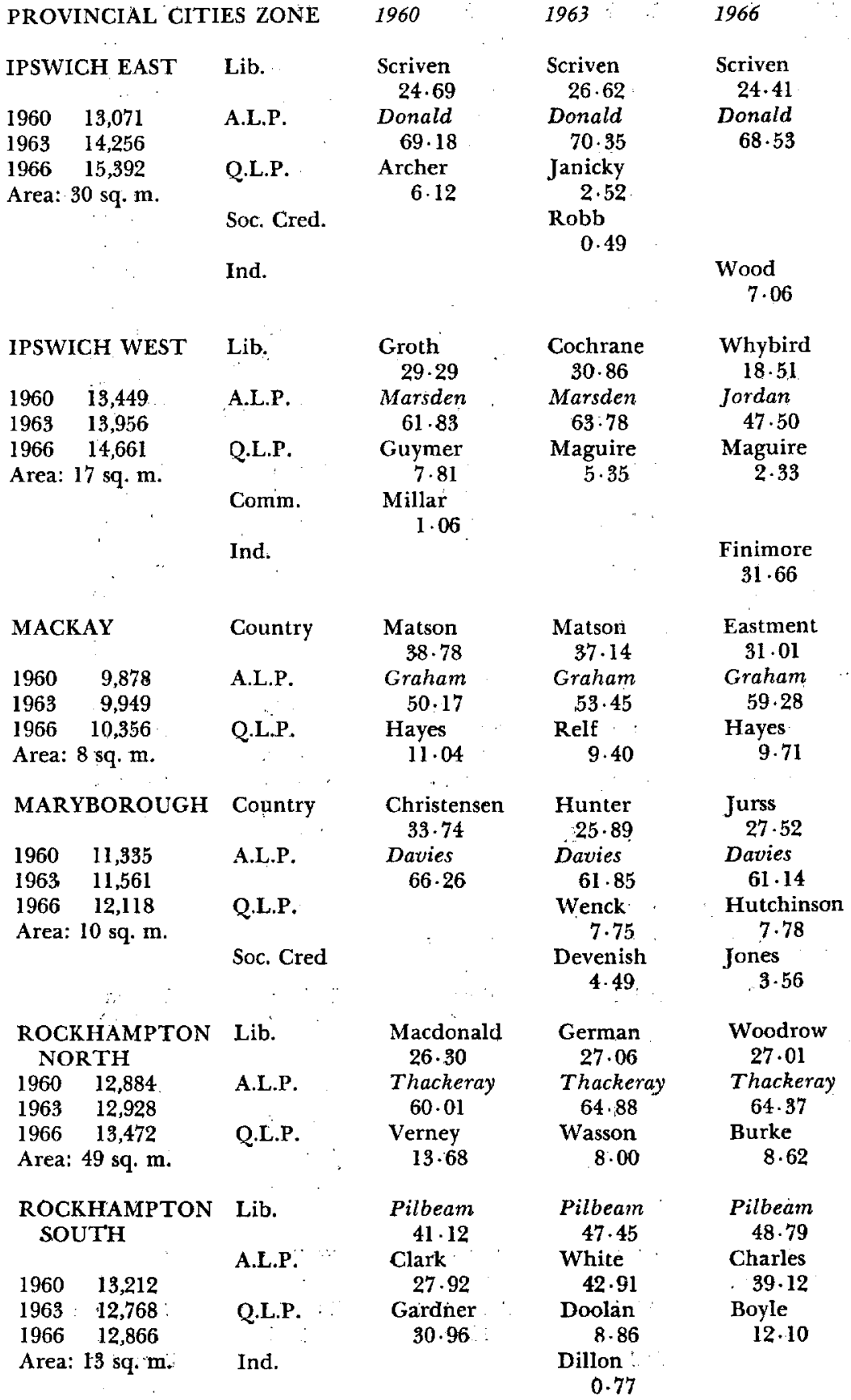




\begin{tabular}{|c|c|c|}
\hline PRIOVINCIAL & IES ZONE & 1960 \\
\hline $\begin{array}{l}\text { TOOWOOMBA } \\
\text { EAST }\end{array}$ & Country & \\
\hline $1960 \quad 13,779$ & Lib. & Anderson \\
\hline $1963 \quad 14,056$ & & $47 \cdot 17$ \\
\hline $1966 \quad 14,832$ & A.L.P. & Wood \\
\hline Area: $18 \mathrm{sq} . \mathrm{m}$. & & $46 \cdot 41$ \\
\hline & Q.L.P. & $\begin{array}{l}\text { Green } \\
6.41\end{array}$ \\
\hline
\end{tabular}

\begin{tabular}{cc}
\multicolumn{2}{c}{ TOOWOOMBA } \\
WEST \\
1960 & 14,454 \\
1963 & 14,788 \\
1966 & 15,289
\end{tabular}

Area: $26 \mathrm{sq} . \mathrm{m}$.

\section{TOWNSVILLE NORTH}

$\begin{array}{ll}1960 & 13,240 \\ 1963 & 13,842 \\ 1966 & 15,059\end{array}$

Area: $58 \mathrm{sq} . \mathrm{m}$.

$\begin{array}{lc}\text { Lib. } & \text { Storey } \\ 35 \cdot 55 \\ \text { Duggan } \\ \text { A.L.P. } & 55 \cdot 28 \\ & \text { Rawle } \\ \text { Q.L.P. } & 9 \cdot 16 \\ & \\ \text { Lib. } & \text { Annable } \\ & 34 \cdot 11 \\ \text { A.L.P. } & \text { Tucker } \\ & 43 \cdot 36 \\ \text { Q.L.P. } & \text { Comerford } \\ & 13 \cdot 64 \\ \text { Comm. } & \text { Bishop } \\ & 1.71\end{array}$

Ind.

New State Hooper

$$
7 \cdot 18
$$

\begin{tabular}{|c|c|}
\hline \multicolumn{2}{|c|}{$\begin{array}{l}\text { T,OWNSVILLE } \\
\text { SOUTH }\end{array}$} \\
\hline 1960 & 19,863 \\
\hline 1963 & 14,707 \\
\hline 1966 & 15,840 \\
\hline
\end{tabular}

Area: 51 sq. m.

GOUNTRY ZONE

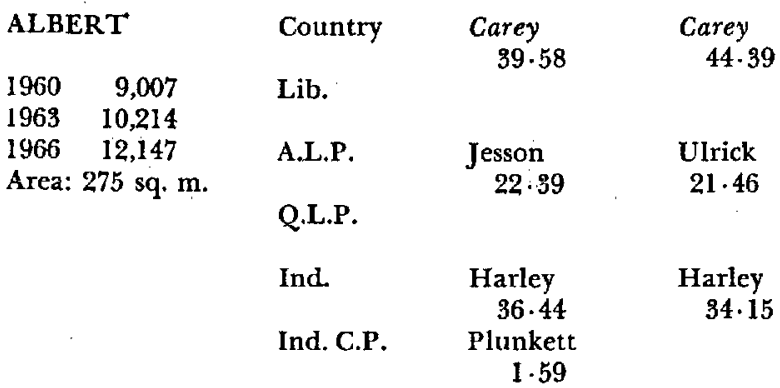

Reeves 0.51

A.L.P. $\quad$ Edmonds

Comm.

Ind.

Aikens
66.85

Aikens

$60 \cdot 16$
1963

1966

$\begin{array}{cc} & \text { McCafferty } \\ & 26.48 \\ \text { Anderson } & \text { Storey } \\ 45.63 & 15 \cdot 76 \\ \text { Wood } & \text { Wood } \\ 48.87 & 51.86 \\ \text { Mullins } & \text { Mullins } \\ 5.49 & 5 \cdot 49 \\ & \text { O'Sullivan } \\ & 0.42\end{array}$

$\begin{array}{cc}\text { Dietz } & \text { Leavy } \\ 33.53 & 28.86 \\ \text { Duggan } & \text { Duggan } \\ 58.29 & 61.80 \\ \text { Morris } & \text { Morris } \\ 8.18 & 9.34\end{array}$

$\begin{array}{cc}\text { Bonnett } & \text { Bonnett } \\ 28.43 & 35.97 \\ \text { Tucker } & \text { Tucker } \\ 48.42 & 50.18 \\ \text { Dorney } & \text { McManus } \\ 22.63 & 13.86\end{array}$
Trower 35.47
Bishop $1 \cdot 32$
Aikens $63 \cdot 21$

1966

Carey $41 \cdot 72$

Harley $33 \cdot 26$

Evans 20.97

Hallinan 4.05 
COUNTRY ZONE

AUBIGNY

$\begin{array}{ll}1960 & 9,425 \\ 1963 & 9,326 \\ 1966 & 9,656\end{array}$

Area: 1,465 sq. $\mathrm{m}$.

\begin{tabular}{lc}
\multicolumn{3}{l}{ BALONNE } \\
1960 & 7,388 \\
1963 & 7,226 \\
1966 & 7,345 \\
Area: & 30,980 sq. \\
BARAMBAH \\
1960 & 9,815 \\
1963 & 9,504 \\
1966 & 9,489
\end{tabular}

Area: 2,665 sq. m.

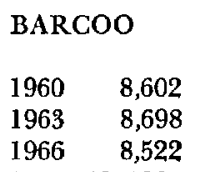

Area: 43,190 sq. m.

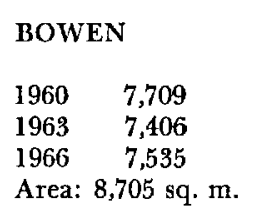

\section{BURDEKIN}

$\begin{array}{ll}1960 & 7,531 \\ 1963 & 7,438 \\ 1966 & 7,843\end{array}$

Area: 3,650 sq. m.

BURKE
$\begin{array}{lr}1960 & 8,560 \\ 1963 & 8,887 \\ 1966 & 8,862\end{array}$

Area: 51,860 sq. m.

$\begin{array}{lc} & 1960 \\ \text { Country } & \text { Sparkes } \\ & 42 \cdot 92 \\ \text { A.L.P. } & \text { Strachan } \\ & 11 \cdot 19 \\ \text { Q.L.P. } & \text { Diplock } \\ & 45 \cdot 89\end{array}$

Country

A.L.P.

Country

A.L.P.

Q.L.P.

Ind.

$\begin{array}{lc}\text { Country } & \text { Gowland } \\ & 36 \cdot 12 \\ \text { A.L.P. } & \text { Davis } \\ & 46 \cdot 84 \\ \text { Q.L.P. } & \text { Foley } \\ & 17.04\end{array}$

Lib.

A.L.P.

Q.L.P.

Comm.

Lib.

A.L.P.
Q.L.P.

Ind.

Country

A.L.P.

Q.L.P.

Soc. Cred. 64.50

Weir 21.31

Curtain

$14 \cdot 18$
Delamothe 46.05
Klaka 39.41
Berryman 9.51

Nisbet $5 \cdot 02$

Page
19.64
McCathie
29.64
Coburn
$50 \cdot 71$

Hindson
$24 \cdot 42$
Inch
$42 \cdot 25$
Smith
$33 \cdot 33$

1963

1966

Corfe 31.07

Fitzpatrick $12 \cdot 64$

Diplock $56 \cdot 29$

Beardmore 62.71

Ward $37 \cdot 29$

Bjelke-Petersen Bjelke-Petersen Bjelke-Petersen 74.20

Hasemann $25 \cdot 80$

Weir

25.40

$25 \cdot 80$

\section{Edwards} $11 \cdot 69$

$\begin{array}{cc}\text { Vandersee } & \text { Cronin } \\ 35 \cdot 80 & 35 \cdot 10 \\ \text { O'Donnell } & \text { O'Donnell } \\ 64.19 & 59.01 \\ & \text { Eshman } \\ & 5.89\end{array}$
Delamothe $46 \cdot 51$
Gralton 46.83
McCane

6.65
Delamothe 51.20
Gralton 43.42
McCane 5.38

Pearce 12.43

O'Brien
Niven
$28 \cdot 16$
Andersen
15.67
Coburn
$56 \cdot 17$

23.88

Andersen

$11 \cdot 12$

Coburn

45.56

Presley 24. 47

Inch Inch

(unopposed) $\quad 62.58$

Donaldson 12.95 
COUNTRY ZONE

BURNETT

$1960 \quad 9,734$

$1963 \quad 9,680$

$1966 \quad 9,977$

Area: 5,525 sq. m.

\section{CALLIDE}

1960

8,755

1963

8,792

$1966 \quad 9,146$

Area: 8,690 sq. $m$.

CARNARVON Country

$1960 \quad 9,650$

$1963 \quad 9,374$

19669,423

Area: 3,920 sq. m.

\section{CONDAMINE}

$1960 \quad 7,467$

$1963 \quad 7,177$

19667,244

Area: 6,075 sq. $\mathrm{m}$.

\section{COOK \\ $1960 \quad 8,798$ \\ $1963 \quad 9,613$ \\ $1966 \quad 12,290$}

Area: 49,850 sq. m.

A.L.P.

Q.L.P.

Country

A.L.P.

Ind. C.P.

1960

1963

1966

Wharton
54.94
Grace
$27 \cdot 18$
McDonnell
17.87

A.L.P.

Q.L.P.

Ind.

Country

A.L.P.

Q.L.P.

Ind.

Country

A.L.P.

$1960 \quad 9,522$

$1963 \quad 9,957$

$1966 \quad 10,284$

Area: 770 sq. m.

\section{CUNNINGHAM}

1960

8,080

1963

8,078

$1966 \quad 7,836$

Area: 3,100 sq. m.
Ind.

Country
A.L.P.
Q.L.P.

Wharton

$65 \cdot 12$

Grace

34.88

Jones

$62 \cdot 32$

Edwards

$37 \cdot 68$

Rogers
$36 \cdot 06$
Gow
$22 \cdot 66$
Hilton
$41 \cdot 27$

Sullivan

$68 \cdot 82$

Beaumont 27.22

Drabsch 3.96

Simms 25.62

Bethel $35 \cdot 21$

Adair 39. 18

Jones
$45 \cdot 45$
Coombs
$31 \cdot 82$
Green
$5 \cdot 47$
O'Rourke
$17 \cdot 26$

McKechnie $36 \cdot 37$

Gow

$28 \cdot 22$

Hilton

$35 \cdot 41$

Sullivan

$73 \cdot 03$

Keating

26.97

Wharton

63.56

Craig 36.44

Jones

53.76

Prisgrove

23.21

Lanigan

$13 \cdot 03$

McKechnie

56.82

Gow

$28 \cdot 34$

Burges

14. 84

Sullivan $77 \cdot 34$

Blundell $22 \cdot 66$

Bethel

$45 \cdot 26$

Bethel

44.81

Adair

$54 \cdot 74$

Adair $55 \cdot 19$

Low

$$
71 \cdot 04
$$

Sanderson 28. 96

Low

61.85

Low

Sanderson $31 \cdot 22$ 59.99

Kliese 40.01

Chapman 6.93

$\begin{array}{cc}\text { Fletcher } & \text { Fletcher } \\ \text { (unopposed) } & 72.84 \\ & \text { Davis } \\ & 20.91 \\ & \text { Scott } \\ & 6.25\end{array}$

Fletcher $72 \cdot 21$

Davis 16. 42

Browne $11 \cdot 37$ 
COUNTRY ZONE

FASSIFERN

\section{0}

1963

9,670

9,482

$1966 \quad 9,487$

Area: 1,680 sq. $m$.
Country

A.L.P.

Q.L.P.

Soc. Cred.

Ind.

\begin{tabular}{l|l}
\multicolumn{2}{l}{ FLINDERS } \\
1960 & 8,936 \\
1963 & 8,522 \\
1966 & 8,184
\end{tabular}

Area: 61,730 sq. m.

$$
\text { Country }
$$

A.L.P.

Q.L.P.
1960

Muller

71.84

O'Brien

$28 \cdot 16$

Ind.

Country

A.L.P.

Q.L.P.

$1963 \quad 7,859$

$1966 \quad 7,617$

Area: 159,000 sq. $\mathrm{m}$.

$$
\begin{gathered}
\text { Rae } \\
54.39 \\
\text { Laracy } \\
45 \cdot 60
\end{gathered}
$$

Country

$\begin{array}{ll}1960 & 10,187\end{array}$

$1963 \quad 10,079$

$1966 \quad 10,085$

Area: 1,015 sq. m.

Q.L.P.
A.L.P. Jamieson

30.21

HINGHINBROOK Country

$\begin{array}{lr}1960 & 7,572 \\ 1963 & 7,960 \\ 1966 & 8,650\end{array}$

Area: 7,965 sq. $\mathrm{m}$.

A.L.P.

Q.L.P.

Comm.

New State

Tanner

11.68

$$
\begin{gathered}
\text { Row } \\
44.07 \\
\text { Cavanagh } \\
39.69 \\
\text { Bodero } \\
9.97
\end{gathered}
$$

Wilson

$$
6.26
$$

ISIS

1960

$$
9,734
$$

$1963 \quad 9,572$

$1966 \quad 9,542$

Area: 4,404 sq. $\mathrm{m}$.

\section{Country}

A.L.P.

Q.L.P.

Soc. Cred.
1963

1966

Muller 63.95

O'Brien 27.79

Blain

$$
5.97
$$

Robb

$$
2 \cdot 31 \text {. }
$$

Muller 33.46

Lonergan
55.42
Rattray
40.82
Judge
$\mathbf{3 . 7 6}$

Lonergan
61.45
Mckitrick
34.49
Judge
3.06
Row
1.00

Rae

Rae

52.22

Laracy

42.58

Hutchinson

$5 \cdot 19$

59.08

Burns

$38 \cdot 15$

Parker

$2 \cdot 77$

Hodges
$57 \cdot 13$
Jamieson
33.51
Tanner
9.96

Hodges 57.27

Dower 35.81

Tanner 6.93

$\begin{array}{cc}\text { Row } & \text { Row } \\ 56.83 & 63.12 \\ \text { Cavanagh } & \text { Palanza } \\ 33.34 & 29.52 \\ \text { Williams } & \text { Williams } \\ 7.02 & 7.36\end{array}$

Bordujenko 2.80

$\begin{array}{lc}\text { Pizzey } & \text { Pizzey } \\ \text { (unopposed) } & 57 \cdot 70 \\ & \text { Hooper } \\ & 34 \cdot 59 \\ & \text { Carroll } \\ & 2 \cdot 81 \\ & \text { Jones }\end{array}$

\section{Pizzey 57.69 \\ Hooper $35 \cdot 34$ \\ Hawes \\ 6.96}




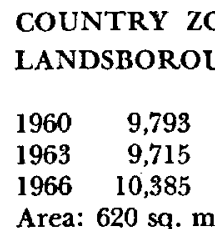

\section{LOCKYER}

$\begin{array}{ll}1960 & 8,456 \\ 1963 & 8,468 \\ 1966 & 8,571\end{array}$

Area: 1,515 sq. m.

\section{LOGAN}

$1960 \quad 9,768$

$1963 \quad 10,728$

$1966 \quad 12,269$

Area: 735 sq. m.
Lib

A.L.P.

Q.L.P.

Ind. C.P.

Ind. Lab.

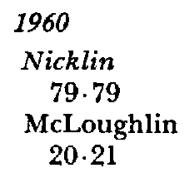

Chalk

$63 \cdot 37$

Martin

28.94

OIm

$5 \cdot 58$

Ind.

Dwyer $2 \cdot 11$

Country

Harrison

Lib.

A.L.P.

Q.L.P.

Sheppard 38.71

Ind.

Soc. Cred.

$\begin{array}{ll}\text { MACKENZIE } \\ 1960 \quad 7,276 \\ 1963 \quad 7,341 \\ 1966 \quad 7,653 \\ \text { Area: } & 15,220 \text { sq. m. }\end{array}$

\begin{tabular}{ll}
\multicolumn{2}{l}{ MIRANI } \\
1960 & 8,104 \\
1963 & 8,095 \\
1966 & 8,454
\end{tabular}

Area: 13,050 sq. m.

MOURILYAN

\begin{tabular}{ll}
1960 & 8,966 \\
1963 & 8,747 \\
1966 & 9,130 \\
\hline
\end{tabular}

Area: 610 sq. m.

MULGRAVE

$1960 \quad 7,210$

$1963 \quad 6,982$

$1966 \quad 7,092$

Area: 1,240 sq. m.

\section{Country \\ A.L.P. \\ Hewitt 64.83 \\ White $35 \cdot 16$}

Country

A.L.P.

Q.L.P.

Country

A.L.P.

Q.L.P.

Country

A.L.P.

Q.L.P.

$$
\begin{gathered}
\text { Evans } \\
62.94 \\
\text { Moody } \\
27.67 \\
\text { O'Grady } \\
9.39
\end{gathered}
$$

Webb 35.89

Byrne 54.58

Higham 9.51

Armstrong $49 \cdot 12$

Scoines $27 \cdot 19$

English 11.27
1963

Nicklin

$74 \cdot 17$

Freemantle

$25 \cdot 83$

\section{Chalk \\ $61 \cdot 95$ \\ Keim $31 \cdot 99$ \\ Hannan \\ 4. 69}

\section{Dwyer

$$
1.38
$$ \\ Harrison
$58 \cdot 17$}

Ware

38.22

Andrews

3.61

1966

Freemantle

$28 \cdot 74$

\section{Wood 31.67 \\ Dennis 19.81 \\ Ware $37 \cdot 19$ \\ Sheehan I. 77 \\ 8torey $8 \cdot 34$ \\ Keneally 1.22}

Hewitt

(unopposed)

62.75

O'Brien

$37 \cdot 24$

$\begin{array}{cc}\text { Evans } & \text { Newbery } \\ 64.78 & 51 \cdot 24 \\ \text { Moody } & \text { Creber } \\ 35 \cdot 21 & 46 \cdot 31 \\ & \text { Relf } \\ & 2.45\end{array}$

Martinuzzi 30.41

Byrne 58.73

Higham 10.86

Armstrong 57.63

Scoines 35.45

English
Martinuzzi 31 . 50

Byrne $56 \cdot 24$

Higham $12 \cdot 26$

Armstrong 58.22

Dalton 41.78 
COUNTRY ZONE

MURRUMBA

$1960 \quad 9,634$

$1963 \quad 11,109$

$1966 \quad 13,515$

Aree: 775 sq. m.
Country

Lib.

A.L.P.

Q.L.P.

Ind.

Country

Lib.

$\begin{array}{ll}1960 & 9,378 \\ 1963 & 8,907 \\ 1966 & 9,144\end{array}$

Area: $3,030 \mathrm{sq} . \mathrm{m}$.
1960

\section{Nicholson 60.51}

Kruger
$\$ 9.49$
1963

Nicholson 54.61

\section{Kruger \\ 41.49}

Carter

$3 \cdot 17$

O'Mara

0.72
1966

Nicholson $41 \cdot 33$

Cooke. 12.03

Kruger 41.84

Vlug $2 \cdot 20$

Bishop 2.59

Grant $17 \cdot 76$

McGree 12.29

Hanson 69.96
68.51

Q.L.P.

Ind.

$\begin{array}{cc}\text { Country } & \text { Gomersall } \\ 24.82\end{array}$

A.L.P.

Q.L.P.

Ind.

\section{Griffith \\ $22 \cdot 58$ \\ Dignan}

Houghton $41 \cdot 96$

Black 4.87

$\begin{array}{lc}\text { Country } & \text { Ewan } \\ & 44.46 \\ \text { A.L.P. } & \text { Taylor } \\ \text { Q.L.P. } & 31.34\end{array}$

Ind.

Country

A.L.P.

$1960 \quad 9,515$

$1963 \quad 9,328$

19669,041

Area: 3,000 sq. $\mathrm{m}$.
Condon 24.21

$$
\begin{array}{r}
\text { Richter } \\
55.08 \\
\text { Warren } \\
18.95 \\
\text { Skinner } \\
25.97
\end{array}
$$

Q.L.P.

Ind.
80.44

McClarty

$15 \cdot 16$

4.39

$\begin{array}{cc}\text { Houghton } & \text { Houghton } \\ 55.43 & 45.08 \\ & \text { Elder } \\ & 10.27 \\ \text { McInnes } & \text { Hunter } \\ 35.50 & 38.46 \\ \text { Doyle } & \text { Morrissey } \\ 5.06 & 6.19 \\ \text { Pritchard } & \\ 3.16 & \\ \text { Sykes } & \\ 0.84 & \\ \end{array}$

Ezwan

$63 \cdot 70$

$61 \cdot 50$

Williamson Thew $28 \cdot 21 \quad 36 \cdot 30$

Hurley 10.29

Richter
$60 \cdot 14$
Walters
39.85

Richter 59.92

Van der Lelie 32.37 Grulke 3.23 Rasmussen 4.49 


\section{COUNTRY ZONE}

SOUTH COAST Country

$\begin{array}{ll}1960 & 10,145 \\ 1963 & 10,720 \\ 1966 & 13,443\end{array}$

Area: 340 sq. m.

Lib.

A.L.P.

Q.L.P.

Ind.

TABLELANDS

$1960 \quad 7,595$

$1963 \quad 7,375$

$1966 \quad 7,866$

Area: 76,560 sq. m.

Ind.

$\begin{array}{cc}\text { Country } & \text { Gilmore } \\ & 52 \cdot 79 \\ \text { A.L.P. } & \text { Wallis-Smith } \\ & 40.43 \\ \text { Q.L.P. } & \text { Mottarelly } \\ & 6.79\end{array}$

Country

WARREGO

$\begin{array}{ll}1960 & 8,177 \\ 1963 & 8,154 \\ 1966 & 8,140\end{array}$

Area: 73,820 sq. m.

\section{WARWICK}

1960

1963

9,112

1966

8,867

8,618

Area: 1,440 sq. m.
A.I.P.
Q.L.P.

66.74

GIynn

$33 \cdot 26$

\section{Gaven \\ 75.94}

Darveniza
$21 \cdot 50$

Fitzgerald

$$
2.56
$$

\section{3}

1966

Gaven

$77 \cdot 47$

Hinze

30.48

Winders

37.92

Cummings 20.91

McWatters

Schwede

$3 \cdot 26$

$$
3.53
$$

Elsey $7 \cdot 17$

Gilmore 43.39

Wallis-Smith $51 \cdot 57$

McManus 1. 82

Bertoldo

$3 \cdot 21$

Turner

36.38

Dufficy

$63 \cdot 62$

Madsen

$61 \cdot 44$

Wenham

24.04

Skehan

14.51

Campbell

14.74

WHITSUNDAY

Country

Roberts

$56 \cdot 81$

$1960 \quad 8,364$

$1963 \quad 8,372$

$1966 \quad 9,626$

Area: 1,840 sq. m.
A.L.P.

Q.L.P.

Dalton 34.93

Lewis $8 \cdot 26$

\section{Camm 56.90 \\ Barry 43.09}

Dufficy

(unopposed)

Gilmore $42 \cdot 35$

Wallis-Smith 55.62

Rehbein 2.03

Cory 58.90

Barrett 33.04

Skehan 8.06

Camm $51 \cdot 20$

Kirwan 43.28

Lewis 5.52 


\section{APPENDIX C}

Independent candidates at State elections 1945-66

\begin{tabular}{|c|c|c|c|c|}
\hline Year & State & $\begin{array}{l}\text { No. of Ind. } \\
\text { candidates }\end{array}$ & $\begin{array}{c}\text { As \%of all } \\
\text { candidates }\end{array}$ & $\begin{array}{l}\text { Their vote as \% } \\
\text { of total valid vote }\end{array}$ \\
\hline 1945 & Vic. : & 23 & 15.03 & $10 \cdot 49$ \\
\hline 1946 & Tas. & 16 & $18 \cdot 60$ & $14 \cdot 79$ \\
\hline \multirow[t]{5}{*}{1947} & N.S.W. & 26 & $12 \cdot 44$ & 6.83 \\
\hline & Vic. & 18 & 12.41. & 6.91 \\
\hline & Qld. & 16 & 10.00 & 2.97 \\
\hline & S.A. & 8 & $13 \cdot 79$ & $6 \cdot 20$ \\
\hline & W.A. & 12 & $16 \cdot 00$ & $10 \cdot 24$ \\
\hline 1948 & Tas. & 16 & 19.28 & 12.65 \\
\hline \multirow[t]{6}{*}{1950} & N.S.W. & 20 & $12 \cdot 44$ & 3.00 \\
\hline & Vic. & 10 & $6 \cdot 54$ & $2 \cdot 65$ \\
\hline & Qld. & 10 & 5.92 & 1.94 \\
\hline & S.A. & 12 & 20.69 & 10.07 \\
\hline & W.A. & 12 & 12.63 & 8.68 \\
\hline & Tas. & 5 & $7 \cdot 58$ & $3 \cdot 79$ \\
\hline 1952 & Vic. & 17 & $12 \cdot 59$ & 6.90 \\
\hline \multirow[t]{4}{*}{1953} & N.S.W. & 16 & $8 \cdot 65$ & 3.58 \\
\hline & Qld. & 10 & 6.54 & 2.98 \\
\hline & S.A. & 19 & $28 \cdot 36$ & $11 \cdot 10$ \\
\hline & W.A. & 12 & $16 \cdot 90$ & 6.40 \\
\hline \multirow[t]{2}{*}{1955} & Vic. & 15 & $7 \cdot 32$ & 3.53 \\
\hline & Tas. & 3 & $4 \cdot 76$ & 2.02 \\
\hline \multirow[t]{5}{*}{.1956} & N.S.W. & 27 & $11 \cdot 95$ & $4 \cdot 10$ \\
\hline & Qld. & 9 & $5 \cdot 81$ & 1.96 \\
\hline & $\tilde{S . A .}$ & 11 & $18 \cdot 33$ & $7 \cdot 34$ \\
\hline & W.A. & 7 & $8 \cdot 23$ & 5.08 \\
\hline & Tas. & 5 & $6 \cdot 33$ & 2.59 \\
\hline \multirow[t]{2}{*}{1957} & Qld. & 20 & $9 \cdot 30$ & 4.04 \\
\hline & $\widetilde{V i c}$ & 7 & $3 \cdot 39$ & $1 \cdot 29$ \\
\hline \multirow[t]{4}{*}{1959} & N.S.W. & 24 & 10.53 & $4 \cdot 38$ \\
\hline & S.A. & 12 & 14.28 & 5.93 \\
\hline & W.A. & 9 & 8.57 & 2.91 \\
\hline & Tas. & 8 & 8.99 & 9.05 \\
\hline
\end{tabular}




\begin{tabular}{llccc}
\hline Year & State & $\begin{array}{c}\text { No. of Ind. } \\
\text { candidates }\end{array}$ & $\begin{array}{c}\text { As \% of all } \\
\text { candidates }\end{array}$ & $\begin{array}{c}\text { Their vote as } \% \\
\text { of total valid vote }\end{array}$ \\
\hline 1960 & Qld. & 18 & 7.89 & 4.16 \\
$196 \mathrm{I}$ & Vic. & 7 & 4.43 & 0.66 \\
1962 & N.S.W. & 30 & 12.24 & 5.08 \\
& S.A. & 9 & 11.54 & 3.14 \\
1963 & W.A. & 15 & 14.70 & 6.62 \\
& Qld. & 18 & 7.50 & 4.55 \\
& Vic. & 4 & 1.84 & 0.17 \\
1965 & Tas. & 11 & 9.40 & 2.48 \\
& N.S.W. & 35 & 17.07 & 4.12 \\
& S.A. & 10 & 9.43 & 1.88 \\
1966 & W.A. & 6 & 6.67 & 3.44 \\
& Qld. & 16 & 6.58 & 4.76 \\
\hline
\end{tabular}




\section{REFERENCES}

Barrett, Russell H. 1959. Promises and Performances in Australian Politics 1928-1959, New York, Institute of Pacific Relations.

Berelson, Bernard R., and others. 1954. Voting, Chicago, University of Chicago Press.

Campbell, Angus, and Cooper, H. C. 1956. Group Differences in Attitudes and Votes, Ann Arbor, Survey Research Center, University of Michigan. , and others. 1960. The American Voter, New York, Wiley.

Carboch, Dagmar. 1958. 'The Fall of the Bruce-Page Government' in Studies in Australian Politics, Melbourne, Cheshire.

Davies, A. F. 1958. Australian Democracy, Melbourne, Longmans. , and Encel, S. (eds.) . 1965. Australian Society, Melbourne, Cheshire.

Downs, Anthony. 1957. An Economic Theory of Demacracy, New York, Harper, Row.

Gough, Marian, and others. 1964. Queensland Industrial Enigma, Melbourne, Melbourne University Press.

Hughes, Colin A. 1957. 'Party and Parliament in Queensland', Parliamentary Affairs, Vol. 10, No. 4, pp. 480-94.

-, 1966. 'The Dawson By-election, 1966', The Australian Journal of Politics and History. Vol. 12, No. 1, pp. 12-23.

Lack, Clem. n.d. Three Decades of Queensland Political History, Brisbane, Government Printer.

Rawson, D. W. 1961. Australia Votes, Melbourne, Melbourne University Press for the Australian National University.

- , and Holtzinger, Susan M. 1958. Politics in Eden-Monaro, Melbourne, Heinemann.

Rokeach, Milton, 1960. The Open and Closed Mind, New York, Basic Books.

Storing, Herbert J. (ed.) . 1962. Essays on the Scientific Study of Politics, New York, Holt, Rinehart, Winston.

Trenaman, Joseph, and McQuail, Denis. 1961. Television and the Political Image, London, Methuen.

Wahlke, John C., and others. 1964. The Legislative System, New York, Wiley.

Wallas, Graham. 1948. Human Nature in Politics (4th ed.), London, Constable. 


\section{Index of Persons*}

Adair, H. A. (Q.L.P., Ind. Cook): as Independent, 121, 146, 153-5; break with Q.L.P., 145; sugar, 229; tobacco, 256

Aikens, T. (Ind. Townsville South): as Independent, 121, 130, 143, 144, $146,159-60,312-14$; campaign in Townsville South, 257, 306-7, 312 16,318

Anderson, M. J. R. (Lib. Toowoomba East): campaign in Toowoomba East, 106, 121, 127, 211, 247-9, 258; marginal electorate, $8,10,11,14$, 244; road transport, 251

Armstrong, R. A. (C.P. Mulgrave), 11, $50,51,226,235$

Ashburner, Mr Justice, 315

Ashe, J. M., 136

Bacon, E. A., 57-8

Barnes, J. F., 130, 143, 144

Barnes, L. J., 143, 144

Barrett, E. T., 109, 233, 236

Baxter, W. E. (A.L.P. Hawthorne): break with A.L.P., 146-7; campaign in Hawthorne, 167; marginal electorate, 11, 17, 18, 258; possible A.L.P. Minister, 140-1

Beardmore, E. J. (C.P. Balonne), 109
Bell, C. B. P., 43, 205, 233

Bennett, C. J. (A.L.P. South Brisbane): as local Member, 121, 270-2; campaign in South Brisbane, 264. 75 passim; marginal electorate, 11 ; possible A.L.P. Minister, 141; police, 33,270

Bertoldo, D., 178

Bethel, J. J., 153-5, 229, 256

Bishop, D. W., 19, 178

Bjelke-Petersen, J. (C.P. Barambah), campaign in Barambah, 42, 169-70; commends Diplock, 151; as Minister, 15, 139

Boland, C., 44

Bolte, Sir Henry, 32

Bonnett, R. N., 26, 47, 320, 322-5

Bordujenko, G., 58

Brimblecombe, W. J., 148

Broad, J., 287, 291

Bromley, F. P. (A.L.P. Norman), 11, $39,81,212$

Browne, W. H., 1

Brough, K., 283-4, 286, 296-303 passim

Brunner, O. W., 112

Buchan, N. L., 135, 137, 141

Bukowski, R. J. J., 6, 9

Burns, G., 110, 220

Burrows, R. W. C., 178

* Note: Not all the candidates at the 1960, 1963, and 1966 elections, contained in Appendix B, are indexed; the successful candidates are, together with their affiliation and constituency. 
Burton, T. S., 147, 167

Bury, L. E., 34

Byrne, P. (A.L.P. Mourilyan), 11, 125$6,223,227$

\section{Cairns, J. F., 141}

Calwell, A. A., 32-3, 42, 112, 203

Camm, R. E. (C.P. Whitsunday): as Minister, 115, 139; campaign in Whitsunday, 36, 109, 111, 258; preferential voting, 13; sugar, 111, $226,230,258$

Campbell, F. A. (Lib. Aspley), 11

Cant, H. G. J., 293

Carey, C. C. (C.P. Albert), campaign in Albert, 105, 126, 162-6; Jubilee Bridge, 239-43; marginal electorate, $11,14,16,18$

Chapman, T. J., 173

Chalk, G. W. (Lib. Lockyer): as Minister, 8, 115, 127, 139, 140; Burdekin dam, 161; campaign in Lockyer, $127,219,235,236,252-3$; criticises A.L.P./Duggan, 41, 45, 46, 219; dairying, 235, 236; education, 247; federal finance, 32-3, 228; image as Liberal leader; 79; policy speech (1966), 26, 30, 42, 45, 84; prices, 216, 219; relations of Country and Liberal parties, 26, 35, 79, 84; road and rail transport, 127, 251-3, 2567; seat changed to Lockyer, 4, 10; sugar, 228; unemployment, 191

Chamberlain, F. E., 44

Chifley, J. B., 46, 50, 55

Chresby, A. A., 268, 271

Clifford, L. C., 136

Coburn, A. (Ind. Burdekin): as Independent, 144, 164; campaign in Burdekin, 16, 18, 146, 160-2; sugar, 126; tobacco, 255

Connolly, P. D., 263, 268

Cook, G. E., 136, 145

Cooper, W. A., 49

Copley, P. K., 263

Corfe, J. E., 151, 236

Cory, D. W. (C.P. Warwick), 109

Coutts, W. D., 141

Craig, A. T., 33-4, 37-8, 223

Crean, F., 310
Creber, G. R. H., 226, 227

Cross, M. D., 134, 135, 141, 293, 310

Curtin, J., 46, 55, 112, 269

Daley, J., 44

Dalton, S. J., 231, 233

Daly, J., 116

Davies, H. J. (A.L.P. Maryborough), $107-8,140,141$

Davis, E. W. (A.L.P. Barcoo), 11

Dawson, A., 1

Dawson, G., 43, 44, 217, 223

Dean, H. (A.L.P. Sandgate), 11, 141, 258

Dewar, A. T. (Lib. Wavell): as Minister, 87,139 , 140; development, 28, 79, 195; marginal electorate, 11; Moonie pipes, 204; relations of Country and Liberal parties, 16; unemployment, 190, 194-6

Delamothe, P. R. (Lib. Bowen): as local Member, 106, 125; as Minister, 15, 116, 139, 140; criticises A.L.P./Duggan, 43, 46; marginal electorate, 10,11, 14, 258

Devereux, J., 191, 199

Dietz, A., 121

Dillon, B., 175-6

Diplock, L. F. (Q.L.P. Aubigny): campaign in Aubigny, 10, 122-5, 144 , 147-52, 234-5; policy speech (1966), 33, 34, 51, 56, 222

Dittmer, F. C. S.: campaign (Sherwood), 283, 293-4; (Townsville), 310; deputy leader A.L.P. (1957), 5, 7, 8; oil, 82; possible A.L.P. Minister, 141

Dokter, B., 265, 268, 273-4

Donald, J. (A.L.P. Ipswich East), 8, $111,140,141,175$

Dorney, K. J. J., 320-2, 325

Dougherty, T., 85, 112

Doyle, T. J., 264, 267, 270

Drury, N., 134, 135

Dufficy, J. J. (A.L.P. Warrego), 212, 257

Duggan, J. E. (A.L.P. Toowoomba West): Bundaberg convention (1963), 42, 87-9; calibre of candidates, 9, 81; Canberra conference 
(1963), 88; Catholic, 73; Communist/leftwing influence on A.L.P., $40-1,43,47,85,87,221,272$; criticised as 'knocker', 41, 51-2, 92, 229; criticises Government/Nicklin, 32, $34,79,87-8,213$; dairying, 234, 235; drink, 213; education, 244-9; free hospitalisation, 210, 211; image as party leader, $17,27,39,73,75,80$ 3, 87-101, 104, 334-5; Jubilee Bridge, 242; Moonie pipes, 205; Moura strike, 200-2; policy speech (1957), 210, (1960), 33, (1963), 31, $34,38,39,188,213,218$, (1966), 231 ; prices, $127,215,217,218,221$ 4; retires as leader, 90; road and rail transport, 251, 256; role of Independents, 157; South Brisbane pre-selection, 265; 1957 split, 5-8, 82; S.G.I.O., 188, 208-10; sugar, 227, 231; three weeks' leave, 198; unemployment, 193; 'wise or unwise', $7,27,42,46,83.4$

Dwyer, J. P., 175, 252-3

Eastment, R. E., 37, 114-15

Edmonds, W. F., 258, 314

Edwards, P. B., 169-70

Egerton, J.: 'A.L.P. doctrine, 117; calibre of candidates, 81-2; influence on A.L.P., 27, 43, 44, 47, 85; relations of A.W.U. and Trades Hall, 9, 81; Moonie pipes, 203, 205, 206; Moura strike, 199; unemployment, 191, 196

Elsey, B., 19, 168-9

Englart, V. J., 134, 136

Evans, E. (C. P. Mirani): as Minister, 8, 114-15, 147, 149; campaign in Mirani, 109, 118; dispute with Hulme, 34; gambling, 213; Jubilee Bridge, 238-41; Moonie pipes, 33, 202-6; Moura strike, 199-201; preferential voting, 13; road and rail transport, 256; sugar, 111 .

Evans, H. I., 162

Everingham, D. E., 206

Ewan, W. M. (C.P. Roma), 11, 120

Fahy, W., 44
Field, H., 44

Finimore, J. T., 162, 166-7, 175

Fisher, A., 112

Fitzgerald, J., 44

Fitzpatrick, P. G., 151-2, 236

Fletcher, : A. R. (C.P. Cunningham), $83,139,172,245,247$

Foley, T. A., 5, 140, 141

Fordyce, K. D., 141

Franzmann, J. W., 83

Fremantle, F. H., 258

Fulton, D. S., 178

Fulton, W. J., 155

Gair, V. C.: criticises Walsh, 145; loses seat $(1960), 10,264,272$; possible A.L.P. Minister, 140, 141; preferential voting, 12-13; Premier in 1957 split, 2, 4-8, 81, 117, 263; rightwing Labor, 54; three weeks' leave, 198

Gallagher, Mr Justice, 201-2

Galligan, L., 284, 287, 295-6, 303

Gardner, H. R., 6, 244

Garsden, D. R., 136

Gaven, E. J. (C.P. South Coast), 106, $119,166,239-43$

Georgouras, G., 120

German, P. M., 121, 248

Gibbs, Mr Justice, 225

Gill, R. I., 141

Gilmore, T. V. (C.P. Tablelands): as local Member, 114; dairying, 235; marginal electorate, 11, 258; prices, 221; road and rail transport, 250-2, 256-7; tobacco, 256

Gorman, B. M., 141

Gow, D. G. T., 152-3

Graham, F. D. (A.L.P. Mackay), 11, $108-9,118,141,258$

Gralton, J. A., 220

Green, N. H., 172, 207

Greenfield, C. J., 297, 298

Grulke, N. A., 234

Hall, A. G. V., 111-12, 118-19, 158-9

Hall, R. H., 110, 194-5, 196

Hanlon, E. M.: 1949 electoral zones, 9; free hospitalisation, 210; M.L.A. for Ithaca, 6; Premier when Dug- 
gan entered Cabinet, 81; rightwing Labor, 49, 55; sugar, 227, 291

Hanlon, P. J. (A.L.P. Baroona): as local Member, 130, 136; campaigns (Sherwood), 293, (Townsville), 310; debating ability, 104; gambling, 212; M.L.A. for Ithaca, 6; possible A.L.P. Minister, 140, 141

Hansen, E. J., 44

Hanson, M. (A.L.P. Port Curtis), 18, 141

Harch, C. W., 115

Harding, E., 309

Hart, G. L. (Lib. Mt Gravatt), 11

Harley, E. O.: as independent candidate, 162-6; Jubilee Bridge, 238-43; joins Liberals, 166; lack of rural experience, 110

Harvey, W. C. R., 141

Hasemann, N. H., 234, 236

Hatton, N. G., 49

Hayden, W. G., 310

Haylen, L. C., 135-6

Herbert, J. D. (Lib. Sherwood): as Minister, 139, 140; campaign in Sherwood, 280-2, 286-7, 289-91, 295, 301-2; prices, $51,215,216$

Hewitt, N. T. E. (C.P. Mackenzie), $128,172,258$

Higham, G. A., 111, 228-9

Hiley, Sir Thomas (Lib. Chatsworth): as Minister, 105; disagreement with federal Treasury, 34; economic prospects (1963), 51; gambling, 212 . 13; Moura housing, 202; becomes Liberal leader, 78-9; marginal electorate, 11, 18; Muller dispute, 146; preferential voting, 13; S.G.I.O., 209; unemployment, 207

Hilton, P. J. R. (Q.L.P. Garnarvon): anti-Communism, 48, 53-4; campaign in Carnarvon, 144, 152-3; criticises A.L.P./Duggan, 82; defeated, 14, 17, 257-8; policy speech (1968), 48, 53, 56; Q.L.P. joins D.L.P., 145, 152; sectarianism, 55

Hinze, R. J. (G.P. South Coast), 18, 19,168

Hitler, A., 44
Hodges, A. M. (C.P. Gympie), 50, $119,126-7,258$

Holt, Sir James, 254

Horan, G., 217, 218, 265, 268, 271, 275

Houghton, J. E. (Ind., C.P. Redcliffe), $13,26,34,173-4$

Houston, J. W. (A.L.P. Bulimba): becomes deputy leader and leader A.L.P., 90; debating ability, 104; industrial wing, 81, 90; possible A.L.P. Minister, 140, 141

Hudson, S. C., 141

Hughes, C. M. (Lib. Kurilpa), 11, $264,268-9,272-5$

Hughes, J. B., 82-3

Hulme, A., 13-14, 34, 126

Hunter, R. A., 107-8

Inch, A. J. (A.L.P. Burke), 11, 34, 141,217

James, J. R., 195, 201, 216-17, 219

James, R., 200

Jansky, M., 284-5, 288, 300-1, 303

Jones, Claude, 57

Jones, Clem, 134, 137, 223-4

Jones, R. (A.L.P. Cairns), 18, 104-5

Jones, V. E. (C.P. Callide), 15, 102 , 171.2

Jonsson, A. E., 250-2, 257

Jordan, V. (A.L.P. Ipswich West), 18, 166-7, 220

Joshua, R., 55, 145

Judge, J., 321

Kajewski, W. F., 123, 124

Kane, J. T., 48

Kaus, W. B. (Lib. Hawthorne), 17, 18,167

Kearney, T. W., 136

Kearney, V., 168

Keeffe, J., 82, 85

Kehoe, G. B., 265, 268, 271-2, 274

Keim, J. J., 111, 127, 234

Kelly, T. P., 176

Keneally, P., 265, 267, 268, 274

Kerr, T. H., 280

Keyatta, G., 319

Khrushchev, N. S., 47 
Killen, D. J., 295, 299

Kidston, W., 1, 2

Kitson, V., 282-3, 286, 291-5, 297, 302

Knox, W. E. (Lib. Nundah), 11, 13, $14,139,140,257$

Kruger, N. H., 233

Lawrie, A. G. E., 149, 172

Lawson, G., 135

Leavy, C. G., 219

Lenin, V. I., 231

Lewis, B. J., 228

Lobwein, F. M., 151, 234

Lonergan, W. H. (C.P. Flinders): campaign in Flinders, 107, 114, 119-20; gambling, 214; marginal electorate, 11, 258

Longman, I., 265

Low, D. A. (C.P. Cooroora), 173

Lloyd, E. G. (A.L.P. Kedron): becomes deputy leader A.L.P., 8; Bundaberg convention, 42; Communist influence on A.L.P., 47, 85; criticises Government, 31, 190; defeated, 90; on role of Independents, 164; possible A.L.P. Minister, 140,141 ; prices, 220, 223, 224; S.G.I.O., 208-9

McCafferty, J. F., 83, 121, 203, 246, 247

McCane, O., 53

McCormack, W., 3

Macdonald, A., 44, 45, 85, 201, 205, 205

Macdonald, F., 44

McEwen, J. E., 34, 228

McKechnie, H. A. (C.P. Carnarvon), $15,128,153,219$

McKenna, N., 310

McMahon, W., 189

Madsen, O. O. (C.P. Warwick), 11314,258

Maher, E. B., 76

Malone, D. W., 300

Mann, J. H. (A.L.P. Brisbane), 11, $17,141,210$

Mansfield, Sir Alan, 6

Marriott, G. H., 143, 144
Marsden, I. (A.L.P. Ipswich West), $17,141,166$

Marshall, H. J., 135, 137, 141

Martinuzzi, A. L., 230

Matson, J., 108-9, 111, 118

Mead, H. V., 135-7

Melloy, J. (A.L.P. Nudgee), 11

Menzies, Sir Robert: Communist threat, 53-4; federal election (1961), 188, 314; Malaya, 47; preferential voting, 12; style of leadership, 92

Millar, T., 44, 200, 201

Milliner, B., 44, 85, 112

Moore, A. E., 3

Moores, T., 263

Moody, G., 114, 118

Morgan, Sir Arthur, I

Morgan, V., 48

Morris, Sir Kenneth (Lib. Mt Coottha): free hospitalisation, 210; style as Liberal leader, 78, 79; unemployment, 26, 188-9

Morris, T. A., 31, 48, 54, 121, 214, 222

Muller, A. G. (C.P., Ind. Fassifern): campaign in Fassifern, 15, 120, 158 . 9, 221; Country Party (leaves), 34, 145-6, 257, (rejoins), 16, 17, 146, 258

Mullins, F. J., 56

Munro, - 141

Munro, Sir Alan (Lib. Toowong): becomes Liberal leader, 17, 78; Country and Liberal parties (relations between), 26, 84; drink, 21314; free hospitalisation, 210-11; housing, 207-8; photograph, 26-7; policy speech (1963), 26, 29, 84, 207-8; preferential voting, 13

Murray, J. (Lib. Clayfield), 15, 34, I21

Newbery, T. G. (G.P. Mirani), 119, 219,228

Newton, H. F. (A.L.P. Belmont), 11, $39,81,140,141$

Nicholson, D. E. (C.P. Murrumba), 19,45

Nicklin, Sir Francis (C.P. Landsborough): campaign in Lands- 
borough, 258; Country and Liberal parties (relations between), 16, 26, 27, 34, 37, 166; criticises A.L.P./ Duggan, 41-3, 49, 51, 87; dairying, 232-5; development, $15,35-6,52$, 106-7, 202; drink, 214; education, 245-6; free hospitalisation, 210; gambling, 214; Leader of Opposition (confirmed as), 8; Muller dispute, 146; party leader (image), 17, 26-7, 76-80, 83-7, 90-101, 334-5; photograph, 26-7; on role of Independents, 162; policy speech (1960), $210,214,270$, (1963), 35, 36, 42, 43, 49 , 270-1, (1966), 37; predicts results (1966), 89; Premier, 8; prices, 219-21; oil, 202, 205; road transport, 251; sectionalism, 36; S.G.I.O., 208-10; social welfare, 51; sugar, 227, 229-31; tobacco, 254-5; unemployment, 189, 191, 194, 195

Niven, T. McC., 161

Noble, H. W. (Lib. Yeronga), 11, 105, 116,192

Nolan, F., 44, 47, 82, 85, 141

O'Brien, D. M., 234

O'Donnell, E. C. (A.L.P. Barcoo), 11, 140, 141, 212, 233

O'Mara, F. X., 174-5

O'Neill, _-, 141

O'Rourke, A. W., 170-2

O'Sullivan, G. E. M., 177

Paterson, F. B., 143, 144

Patterson, R, 141, 227, 228

Pearce, S. J., I61-2

Penridge, C. G., 167-8

Petrov, V., 5

Philp, Sir Robert, I

Pilbeam, R. B. J. (Lib. Rockhampton South): abattoirs, 172; campaign in Rockhampton South, 111; education, 248-9; marginal electorate, 10 , 11, 14, 18, 244; oil, 203

Pizzey, J. C. A. (C.P. Isis): abattoirs, 172; as Minister, 105, 115, 139, 140; campaign in Isis, 111; education, 244-7; Nicklin's heir, 78, 87; on role of Independents, 157-9, 163-4; preferential voting, 13

Plant, S., 124

Playford, Sir Thomas, 92

Pluckrose, D. H., 216, 217, 222, 224

Porter, C. R. (Lib. Toowong), 24

Power, W. A., 5, 140, 141

Prisgrove, W. R., 234, 236

Pritchard, E. J., 174-5

Rae, W. (C.P. Gregory), 43-4, 121, $213,214,258$

Ramsden, S. R. (Lib. Merthyr), 11, 106

Rasmussen, J. L., 172-3

Rattray, C., 120, 121

Reeves, A. F., 176-7, 320, 325

Richter, H. H. (C.P. Somerset): as Minister, 115, 139; campaign in Somerset, 106; preferential voting, 13; unemployment, 190-1

Robb, V., 126

Roberts, F. E., 162, 258

Row, J. A. (C.P. Hinchinbrook): as Minister, 139; campaign in Hinchinbrook, 111, 258; marginal electorate, 11; sugar, 111, 226-8

Ryan, T. J., 2

Sakzewski, A., 213

Schonell, Sir Fred, 105, 245

Scott, H. J., 211

Scriven, H. J., 121

Shannon, J. N., 242

Sheahan, M. P., 265, 268, 274

Sherrington, D. J. (A.L.P. Salisbury): campaigns (Kurilpa), 268, (Salisbury), 281-2, 287, 289, 296-302; dairying, 233; industrial wing A.L.P., 81; possible A.L.P. Minister, 140,141

Sherrington, R. D., 16

Smith, P. R. (Lib. Windsor), 11, 18, 105-6, 120-1

Sparkes, W. B. J. G., 123

Spooner, Sir William, 205-6

Stanton, D. L., 136

Steer, F., 418

Storey, L. E., 29-30

Storey, L. J., 19, 173 
Strachan, B. W., 151

Sullivan, V. B. (C.P. Condamine), $83-4,126,194,196,258$

Swartz, R., 211, 247

Sykes, E. A., 174-5

Tallon, M., 39, 120, 156-7, 223, 229

Tannock, B., 134, 136

Taylor, H. B. (Lib. Clayfield), 11

Theodore, E. G., 2, 81

Thew, M. R., 110

Thomson, G., 277, 285, 286, 289, 292. 5, 302

Thorn, R., 147

Thorn, S., 37, 121-5, 147-51

Thorn, W., 147

Thornton, W., 292

Tooth, S. D. (Lib. Ashgrove), 11, 130, $136,139,140$

Trezona, L. A., 141

Trower, A. J., 159-60, 220, 258, 307 14

Tucker, P. J. R. (A.L.P. Townsville North): becomes deputy leader A.L.P., 90; campaign in Townsville North, 47, 309, 310, 313, 319, 320, 324-5; marginal electorate, 11 ; possible A.L.P. Minister, 140, 141

Turnbull, R. J. D., 148

Turner, M., 109, 194, 196

Ulrick, E. F. J., 162-5, 241

van der Lelie, J. L. S., 234

Vickers, C., 199, 200

Wade, H. W., 148
Wallace, D. J., 178

Wallis-Smith, E. (A.L.P. Tablelands), $14,141,255-8$

Walsh, E. J. (Q.L.P. Ind. Bundaberg): breaks with Q.L.P., 145; campaign in Bundaberg, 120, 144, 146, 155-8; 1957 split, 4-5; possible A.L.P. Minister, 140, 141

Walton, W. R., 293

Warner, B., 277

Waters, F., 47, 85

Weir, I. G., 242

Weir, W. A. A., 170

Wenham, R. H., 37, 38

Wharton, C. A. (G.P. Burnett): campaign in Burnett, 107, 109; marginal electorate, 11; sugar, 126, 228, 230-I; unemployment, 194, 196

Wheeler, N. J., 216

White, C. W., 248

Whitlam, E. G., 32-3, 42, 205, 219-20

Whybird, A., 167

Winders, H. G., 110, 120, 168-9

Windsor, R. L. (Lib. Ithaca), 11, 18, $130,136,137$

Wood, D. K. W., 175

Wood, E. G. W. (C.P. Logan), 19, 50, 109

Wood, L. A., 8, 81

Wood, P. (A.L.P. Toowoomba East): anti-Communism, 40; campaign in Toowoomba East, 17, 111, 112, 126; education, 244-7; free hospitalisa. tion, 211; gambling, 214; unem. ployment, 195

Wright, H. J. A., 268 


\section{Index of Subjects}

Age: and attitudes, 101; and information, 137; of sample, 333

Albert, 11, 14, 16, 18, 105, 110, 126, $162-6,237-43,343$

Ashgrove, 11, 130-1, 135-41, 328-9, 337

Aspley, 11, 89, 337

Aubigny, 10, 37, 56, 121-5, 144-52, $234,236,344$

Australian Labor Party (A.L.P.): doctrine of supremacy of extraparliamentary machine, 1, 2, 4-7, $27,38-49,82,85,89,116-18,128$. 33; geographic basis, $1-4,10$; image of (advanced by parties), 24, 25, $38-52$, (held by voters), 59-74, 3356 ; loss of experienced leaders, 7-8; origins, 1-3; split (1957), 4-8, 81, 91

Australian Labor Party conferences: Brisbane (1960), 81; Bundaberg (1963), 42, 49, 57, 82, 87-9, 213, 238, 244, 248; Canberra (federal; 1963), 88, 91; Hobart (federal; 1955), 4, 46; Mackay (1956), 5; Rockhampton (1953), 4

Australian Railway Union, 3, 85

Australian Universities Commission (A.U.C.), 246-9

Australian Workers Union (A.W.U.): influence on pre-split A.L.P., 2, 3, 28, 81-2, 204; part in 1957 split, 4-6, 9; Mt Isa strike, 15-16, 46; praised by Country Party members, $110,200,232$
Balonne, 8, 89, 109, 110, 153, 194-6, 221, 231, 344

Barambah, 169-70, 234, 236, 344

Barcoo, 11, 344

Baroona, 130-1, 134-8, 141, 328-9, 337

Bauxite, 17, 27, 28, 31, 34

Belmont, 11, 39, 337

Bowen, 10, 11, 14, 53, 89, 107, 116, $125,143-4,194,220,258,344$

Brisbane, 11, 263, 338

Brisbane City Council, 215, 223-5,

Bulimba, 104, 143-4, 338

Bundaberg, 39, 89, 104, 120, 143-6, $155-8,223,228,341$

Buranda, 8

Burdekin, 16, 18, 126, 144, 146, 1602, 254-6, 344

Burke, 11, 14, 34, 217, 344

Burnett, 11, 33-4, 37-8, 107, 109, 126, $194,223,228,230-1,345$

Business influence: on Liberal Party, 31, 38, 57, 73, 253; on Q.L.P., 57; on all parties, 60-1

Cabinet ministers, 113-16, 199-40; possible Labor, 140-I

Cairns, 16, 18, 83, 104-5, 143-4, 167-8, 256-7, 341

Callide, 15, 102, 170-2, 207, 234, 236, 345

Carnarvon, 14, 15, 56, 89, 128, 146, 152-3, 219-20, 257-8, 345

Catholic influence on Q.L.P., 52-3, 
$55,57,60-1,73$

Changes: of attitudes, $67-8$; of voting intention, 70-1

Chatsworth, 11, 18, 89, 105, 178, 2234, 398

Cheeryble syndrome, 64, 66, 69

Class: and attitudes, 71-2, 100-1, 131 3 ; and information, 137; of sample, 330-3

Clayfield, 11, 34, 121, 338

Coal, 17, 27, 31, 34, 206

Communist Party image, 57-9

Communists and Communism: influence (in Australia), 5, 54, (on A.L.P.), 9, 37, 39-49, 52-4, 58, 67, $84-6,87,90,117-18,183,199-202$, 205, 207; vote, 14,17

Condamine, 123, 126, 194, 258, 345

Cook, 89, 121, 144-6, 153-5, 228, 345

Cooroora, 89, 173, 345

Country Party: Country-National government (1929-32), 3; geographic basis, 3-4, 8, 10-11; image (advanced by parties), 35-8, (held by voters), 60, 62; relations with Liberal Party, $4,12-16,26,33-5,37-8,78-9$

Cunningham, 83, 245, 345

Dairying, $36,50,126-7,172-9,188$, 231-6,

Development (of Queensland): 17, 27-9, 33, 35-6, 38, 41, 49-51, 84; party standing for, 60-1, 335-6

Decimal currency, 215

Drink, 212-14, 269

Drought, 16, 51, 109, 172-3, 225-6

East Toowoomba, 4

Education, 30, 32, 36-8, 51, 87, 168, $188,233,244-50,259$

Election results, (1893), 1; (1901), 1; (1912), 2; (1915), 2; (1920), 3; (1929), 3; (1938), 4; (1956), 4, I1; (1957), 8, 11; (1960), 10, 11, 337-49; (1963), 13-15, 337-49; (1966), 17-19, 337.49

Electoral system: readiness to tamper with, 2-3; introduction of preferential voting, 11-14, 23; zones, 3, 9-11
Employment, see Unemployment

Fassifern, 15, 111-12, 118-20, 145-6, $158-9,221,234,257-8,346$

Federal constituencies: Brisbane, 134, 135; Herbert, 324; Parkes, 195-6; Ryan, 134, 135

Federal-State relations, $32-3,52,86$, $88,187,190,225,232,244-9$

Flinders, 8, 11, 89, 107, 111, 114, 119$21,214,258,346$

Ford, Bacon, Davis report, 256

Fortitude Valley, 8

Free hospitalisation, see Hospitalisation

Gambling, 212-14, 269

Greenslopes, 82-3, 338

Gregory, 8, 39, 43-4, 81, 89, 110, 121, $213,214,220,259,346$

Gympie, 50, 119, 126-7, 258, 346

Hawthorne, 11, 17, 18, 146-7, 167, 258,338

Hinchinbrook, 11, 58, 111, 226, 259, 346

Hospitalisation, free, $30,37,38,188$, 210-12, 270

Housing, 30, 37-8, 87, 109, 200-2, 20710 , see also State Government Insurance Office

Independent candidates, 143-78, 3501

Industrial issues, 15-16

Industrial Groups, 4, 5, 47, 48

Inebriates' Institute, 246

Images: in general, 23-5, 75-6; party images, see A.L.P., Country Party, Liberal Party, Q.L.P., Communist Party; party leader images, see Nicklin, Duggan

Ipswich East, 121, 126, 175, 342

Ipswich West, 18, 166-7, 220, 342

Isis, 105, 111, 115, 346

Issues: in general, 181-8, 237, 257-9

Ithaca, 6, 11, 18, 89, 130-1, 134-8, 141, $217,328-9,338$

Jubilee Bridge, 237-43, 259 
Kedron, 8, 178, 339

Kelvin Grove, 8,130

Kurilpa, 8, 11, 263-9, 272-4, 339

Labor-in-politics conventions, see A.L.P. conferences

Land policy, 32, 38, 188, 233, 234

Landsborough, 258, 347

Liberal Party: geographic basis, 3-4, 8, 10-11; image (advanced by parties), 24-35, (held by voters), 59-74, 335-6; relations with Country Party, $4,12-16,26,33-5,37-8,78-9$

Liberal Party conference: Brisbane (1966), 216

Leaders: images held by voters, 90101 ; ability and courage of party leaders, 60.1, 335-6, see also Nicklin, Duggan

Lockyer, 4, 10, 79, 106, 111, 115, 116, $127,175,221,234,252-3,347$

Logan: 19, 50, 89, 109, 173, 221, 347

Mackay, 11, 37, 108-11, 117-18, 221-2, 258,342

Mackenzie, 4, 17, 128, 258, 347

Martin Committee, 245, 249

Maryborough, 107-8, 214, 342

Merthyr, 8, 11, 89, 106, 339

Ministers, see Cabinet Ministers

Mirani, 8, 89, 108, 110-11, 114-15, 117. $19,219,226-8,347$

Moonie pipes, see Oil

Mt Coot-tha, 339

Mt Isa strike, 15-16, 33, 46, 221

Mt Gravatt, 8, 11, 339

Moura strike, 45, 58, 188, 198-202

Mourilyan, 11, 111, 125-6, 223, 227, 228, 230, 347

Mulgrave, 8, 11, 226, 231, 233, 235, 347

Mundingburra, 143

Murrumba, 19, 76, 89, 174-5, 178, 233, 348

Nash, 8, 265

National Civic Council, 53, 55

Norman, 11, 39, 339

North Toowoomba, 8, 81

Nudgee, 11, 340

Nundah, 8, 11, 14, 257-8, 340
Occupation, see Class

Oil, 17, 27, 28, 33, 42, 110, 188, 202-7

Parliamentary salaries, 16-17, 128, 215

Police, 33, 270 .

Port Curtis, 18, 176, 348

Prices, 30-3, 37, 67, 89, 90, 127, 188, 215-25

'Queen Street government', 2, 8, 32, 39, 246

Queensland Labor Party (Q.L.P.): creation (1957), 7; geographic basis, 10; image (advanced by parties), $31,52-7$, (held by voters), 59-74; preferential voting (use), 12-15, 1819; relations with A.L.P., 52-7

Railways, 27, 84, 188, 256-7, 259

Redcliffe, 13, 18, 26, 34, 89, 173-5, 348

Religion: and attitudes, 72-3, 101; of sample, 327, 330-2

Roads, 27, 32, 114-15, 170, 171

Road transport, 250-4

Rockhampton, 176

Rockhampton North, 121, 244-9, 342

Rockhampton South, 10, 11, 14, 18, $111,176,244-9,342$

Roma, 8, 11, 110, 120, 348

Salisbury, 276-89, 296-303, 340

Sandgate, 8, 11, 258, 340

Sectionalism: and A.L.P., 197; and Country Party, 36-7, 197; and Liberal Party, 30-2, 197; and Q.L.P., 54

Sex: and attitudes, 101, 132, 193; and information, 137

Sherwood, 276-96, 301-3, 340

Social Credit, 14, 17-18, 274

Socialism: and A.L.P., 41, 49-51, 196, 209

Social Welfare: and A.L.P., 38-9, 41; and Country Party, 51; and Liberal Party, 30-2

Somerset, 8, 106, 115, 172-3, 233, 234, 348

South Brisbane, 10, 11, 263-72, 274-5, 340 
South Coast, 18, 106, 110, 119, 120, $168-9,237-43,349$

State Government Insurance Office (S.G.I.O.), 84, 188, 207-10

Sugar, 16, 89, 110-11, 125-6, 188, 22533

Tablelands, 8, 11, 14, 114, 178, 221, $235,250-8,349$

Thirty-five hour week, 197

Three-cornered contests, 16-19

Three weeks' leave, 4-7, 197-8

Tobacco, 254-6, 259

Toowong, 340

Toowoomba, 8, 81

Toowoomba East, 10, 11, 14, 17, 29$30,56,83,89,106,111,112,121$, $126-7,177,195,211,214,244-51$, $253-4,258,343$

Toowoomba West, 31, 48, 54, 121, 211, 214, 219, 222, 244-9, 343

Townsville, 319

Townsville North, 11, 15, 26, 47, 1767, 308-10, 319-25, 343

Townsville South, 143-4, 146, 159-60, $220,257-8,304-18,324-5,343$

Torres Strait Islanders, 155

Totalisator Agency Board (T.A.B.), see Gambling
Trades and Labour Council, see Trades Hall

Trades Hall, Brisbane: influence on A.L.P., 41, 43-6, 81-2, 85-6, 117, 207, 214, 220-1, 264-5; in industrial matters, 15-16, 203-4, 223; in Mt Isa dispute, 15-16; part in 1957 split, 4-6

Trade unions, 196-7

Unemployment, 17, 26, 28, 31-3, 37-9, $58,84,87,188-96$; parties likely to promote full employment, 60-1, 196, 335-6

University colleges, see Education

Warrego, 17, 109, 194, 257, 349

Warwick, 37, 38, 48-9, 109, 113-14, $233,236,258,349$

Wavell, 11, 178, 341

Westbrook inquiry, 116

West Moreton, 4

Whitsunday, 36, 89, 109, 110-11, 115, $117-18,144,226,228,258,349$

Windsor, 8, 11, 18, 31-2, 89, 105-6, $120-1,341$

Wynnum, 112, 341

Yeronga, 11, 89, 105, 116, 263, 341 
Professor Hughes was introduced to Australian politics in Queensland in 1956, the heroic days of the great 'split', and developed a taste for Queensland's particular brand of parochial politics which survived four years in the rarified air of federal politics in Canberra whilst at the A.N.U. For most of his academic career he has been writing about elections; Images and Issues represents a wedding of his enthusiasms. He holds a B.A. and an M.A. from Columbia and a $\mathrm{Ph}$.D. from the London School of Economics. In 1965 he was appointed foundation Professor of Political Science and head of the Department of Government at the University of Queensland, the position he currently holds. 